Alena Rizi Marmo Jahn

\title{
O MUSEU QUE NUNCA FECHA: \\ a exposição virtual digital como um programa de ação educativa
}

Tese de Doutorado apresentada à Escola de Comunicações e Artes da Universidade de São Paulo para a obtenção do título de Doutora em Artes Visuais.

ÁREA DE CONCENTRAÇÃO

Teoria, ensino e aprendizagem da arte

LINHA DE PESQUISA

Fundamentos da aprendizagem da arte

ORIENTADORA

Professora Doutora Maria Christina de Souza Lima Rizzi

São Paulo, 2016. 


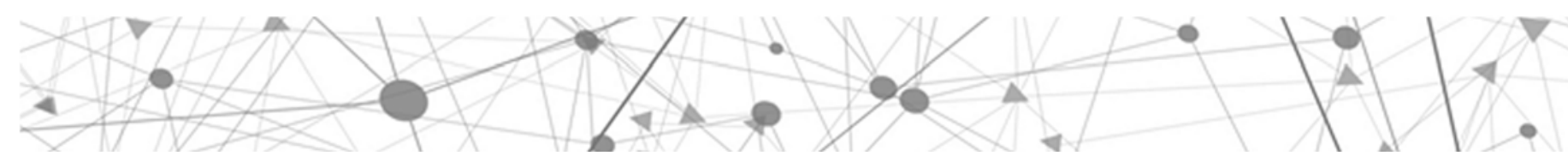

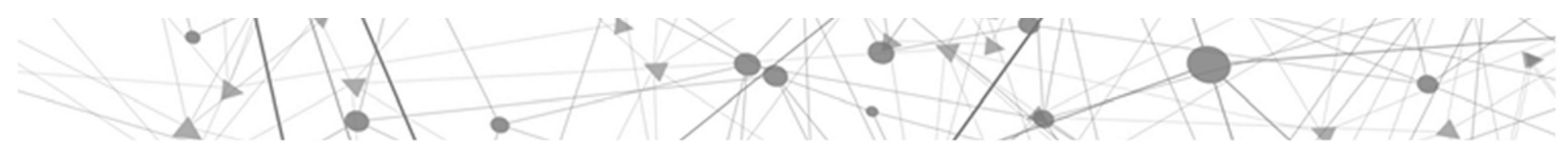




\section{FICHA DE APROVAÇÃO}

JAHN, Alena Rizi Marmo. Orientadora: RIZZI, Maria Christina de Souza Lima. 0 museu que nunca fecha: a exposição virtual digital como um programa de ação educativa. Tese apresentada à Escola de Comunicações e Artes da Universidade de São Paulo para a obtenção do título de doutora. Área de concentração: Teoria, ensino e aprendizagem da arte.

Aprovada em:

\section{BANCA EXAMINADORA}

PROFESSORA DOUTORA MARIA CHRISTINA DE SOUZA LIMA RIZZI

INSTITUIÇÃO: UNIVERSIDADE DE SÃO PAULO

ASSINATURA:

PROFESSOR DOUTOR:

INSTITUIÇÃO:

ASSINATURA:

PROFESSOR DOUTOR:

INSTITUIÇÃO:

ASSINATURA:

PROFESSOR DOUTOR:

INSTITUIÇÃO:

ASSINATURA:

PROFESSOR DOUTOR:

INSTITUIÇÃO:

ASSINATURA: 


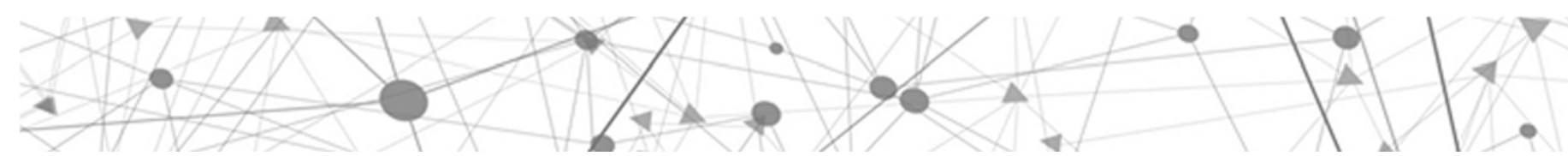

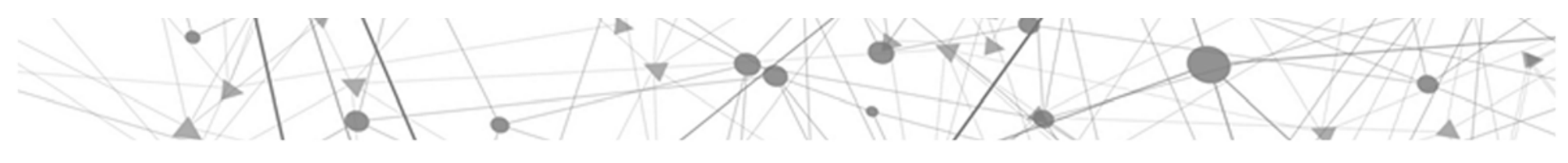




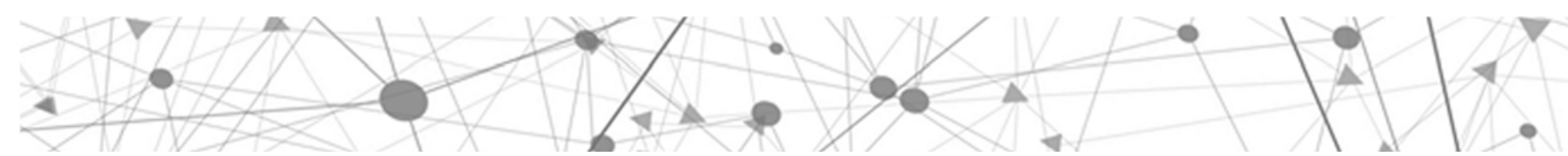

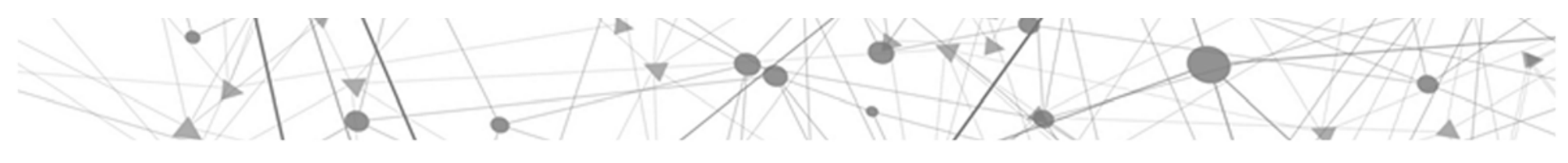




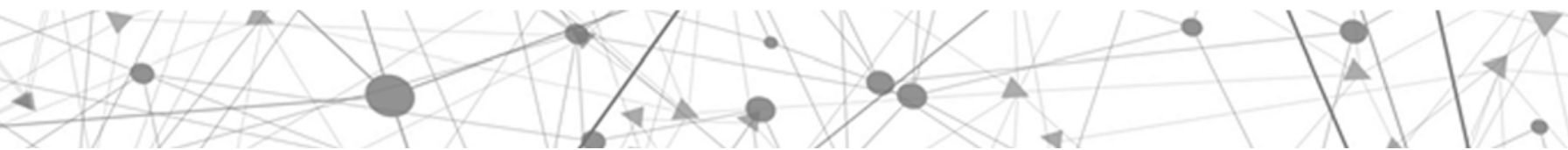

Para Juliano, Sarah (que veio ao mundo durante o processo) e Cora (que está quase chegando).

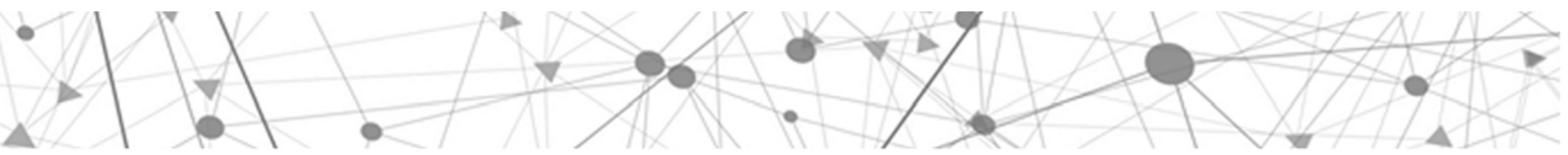




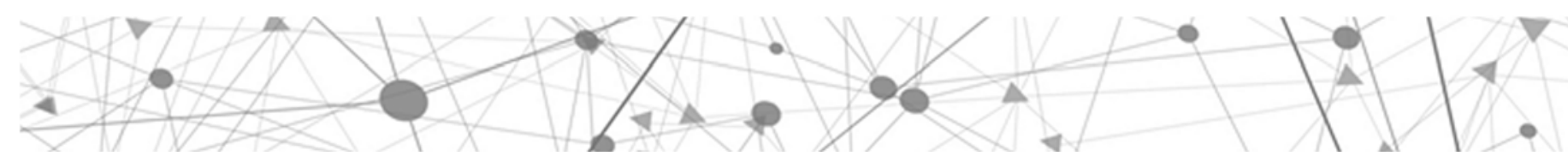

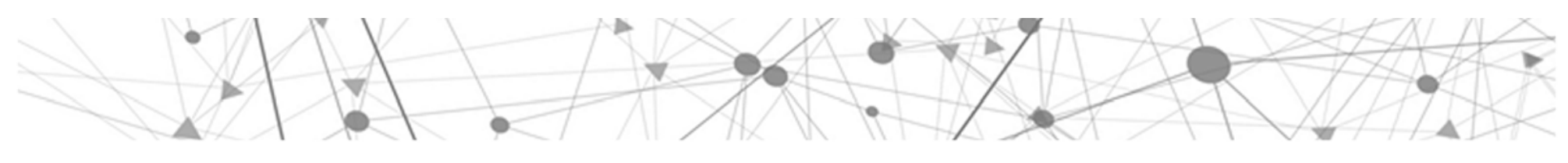




\begin{abstract}
RESUMO
Esta tese de doutorado consiste na remontagem virtual da exposição $A$ casa tomada (de Julio Cortázar) por desenhos que não deram certo. Desenhos de 1978/80. Apogeu do Claro-escuro Pós-Caravaggio, do artista joinvilense Luiz Henrique Schwanke, realizada no Museu Nacional de Belas Artes, do Rio de Janeiro (RJ), em 1980. Tal remontagem é ancorada na curadoria educativa, entendida no contexto desta pesquisa como uma forma de desenhar exposições pensadas para todos os tipos de público, por meio da qual a arte se coloca em articulação com o indivíduo e com a sociedade, de maneira a ser ativada como um instrumento de ação cultural. Essa exposição acontece no Museu de Arte Contemporânea Luiz Henrique Schwanke Virtual (MAC Schwanke Virtual), localizado no website do museu, que ainda não possui sede física, mas que já atua enquanto tal mediante seus programas e suas ações. Defende-se a existência do museu no ambiente virtual em rede, assim como a utilização desse espaço pela exploração de suas especificidades, ou seja, como um meio de ampliar as ações do museu e de pôr o seu acervo constantemente em ativação, para deleite, pesquisa e estudo, sem reproduzir os recursos utilizados na realidade física. Portanto, a versão virtual da exposição promovida está alicerçada na exploração da natureza não linear e hipermidiática no ciberespaço, e não na tentativa de reprodução do espaço e da lógica de exposições existentes na realidade física, o que aqui, conforme já dito, ocorreu por intermédio da curadoria educativa.
\end{abstract}

Palavras-chave: museu virtual; exposição virtual; curadoria educativa; arte; ensino/aprendizagem. 


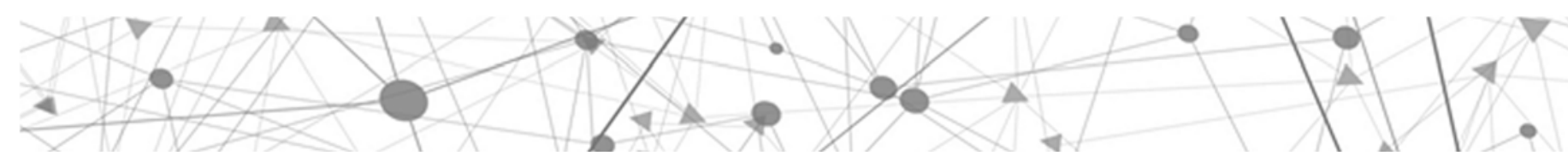

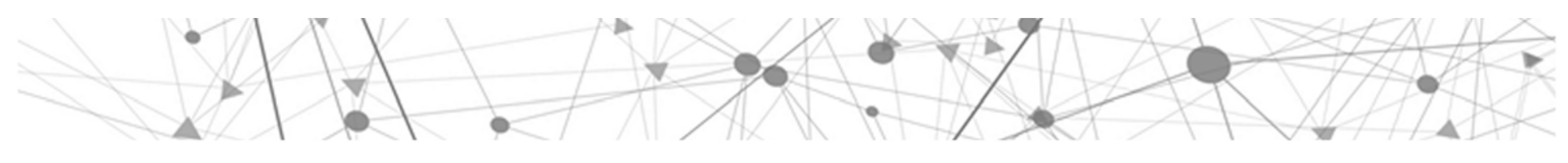




\section{ABSTRACT}

This PhD thesis consists on the virtual reinstallation of A Casa Tomada exhibition (by Julio Cortázar) with drawings that did not work. Drawings from 1978/1980. The prime of post-Caravaggio chiaroscuro, by Joinville-born artist Luiz Henrique Schwanke, at the National Fine Arts Museum, of Rio de Janeiro, in 1980. Such reinstallation is anchored on educational curating, understood in the context of this research as a way to plan exhibitions for all kinds of public, through the means of which art is articulated with the individual and with society, so that it is activated as an instrument of cultural action. This exhibition is at Schwanke Virtual Museum of Contemporary Art, located in the website of the museum, which does not have a physical headquarters yet, but is already active through its programs and actions. We defend the existence of the museum in the virtual network environment, just as utilizing this space from the exploration of its specificities, that is, as a means to enlarge the actions of the museum and activate its collection, for delight, research and studies, without reproducing the resources of the physical reality. Thus, the virtual version of the exhibition is based on the exploration of non-linear and hypermediatic nature of cyberspace, and not in the attempt to reproduce the space and the logic of exhibitions that exist in physical reality, which, as said, was achieved by the means of educational curating.

Keywords: virtual museum; virtual exhibition; educational curating; art; teaching/learning. 


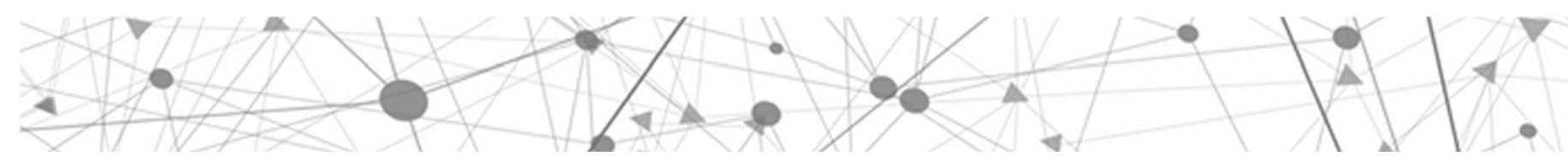

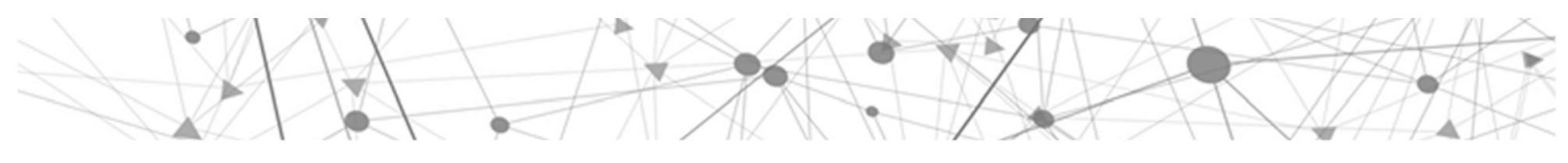




\section{SUMÁRIO}

INTRODUÇÃO 17

1. Museus, virtualidades e ciberespaço 25

$\begin{array}{ll}1.1 & 0 \text { museu na contemporaneidade } \quad 27\end{array}$

1.20 museu e o ciberespaço $\quad 34$

1.30 museu virtual e a web $\quad 39$

1.4 As experiências de museus virtuais na web 57

1.5 Mapeamento de experiências de museus virtuais disponíveis na web.

1.6 A exposição no ambiente virtual em rede. 110

2. A curadoria, a curadoria educativa e a exposição virtual na web $\quad 119$

$\begin{array}{lll}2.1 & \text { A curadoria e a história da exposição } & 121\end{array}$

2.2 A curadoria como curadoria educativa 146

2.3 A exposição virtual na web e a curadoria educativa $\quad 154$

3. A trama poética de Luiz Henrique Schwanke $\quad 171$

3.1 Schwanke: arte e vida 173

3.2 Exposição $A$ casa tomada (de Julio Cortázar) por desenhos que não deram certo. Desenhos de 1978/80. Apogeu do claro-escuro pósCaravaggio

3.2.1 A casa tomada (de Julio Cortázar) por desenhos que não deram certo 212

3.2.2 Desenhos de 1978/80 214

3.2.3 Apogeu do claro-escuro pós-Caravaggio 225

3.3 O Museu de Arte Contemporânea Luiz Henrique Schwanke _ _ $\quad 228$

3.4 0 website do MAC Schwanke e o MAC Schwanke virtual $\quad 229$

4. Exposição Virtual Digital no MAC Schwanke virtual, a partir da curadoria educativa

233

4.10 desenho da exposição $\quad 235$

4.1.1 A remontagem virtual $\quad 242$

4.1.2 Montagem de $1980 \quad 248$

4.1.3 A montagem de $1999 \quad 249$

4.1.4 Organize a sua própria mostra $\quad 250$

4.1.5 Para o professor 251

5. Conclusão 255

Referências $\quad 261$

Apêndices $\quad 271$

Anexos $\quad 285$ 


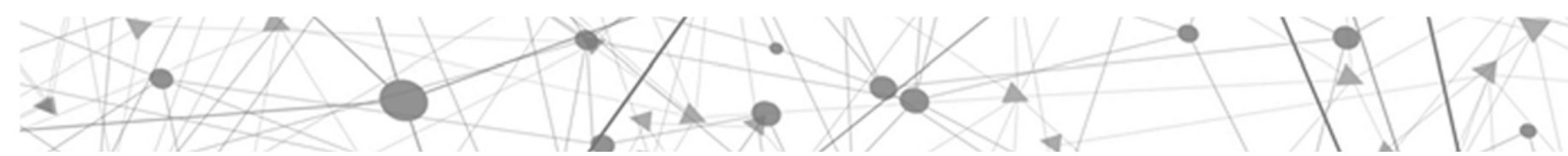

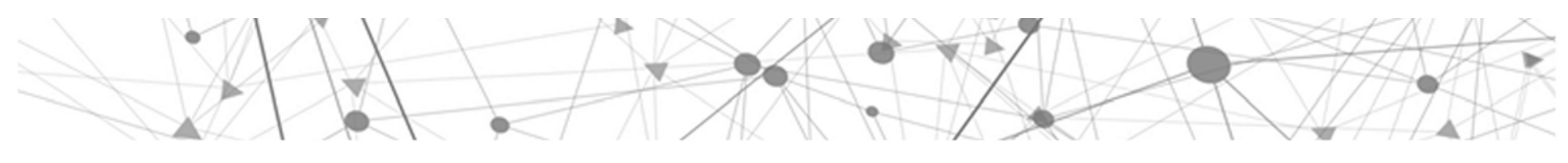


1. b.

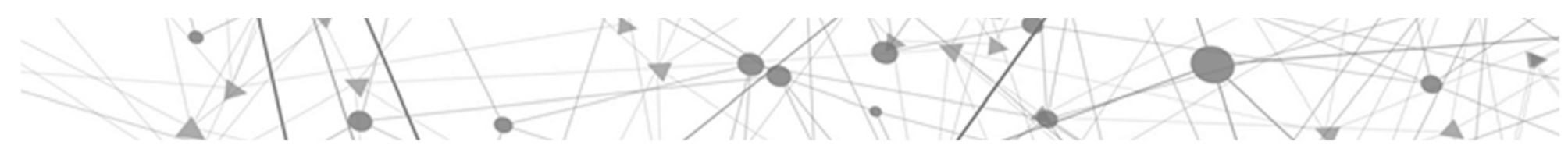




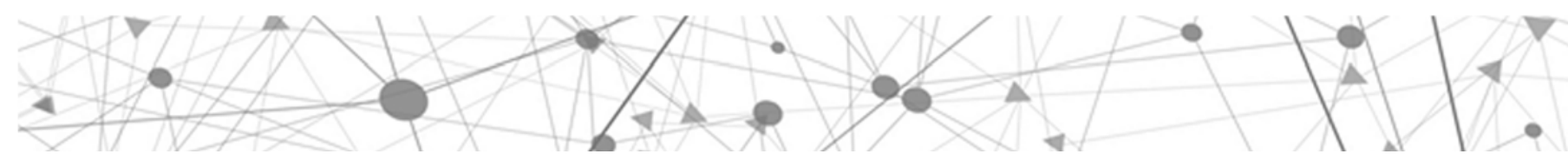

\section{INTRODUÇÃO}

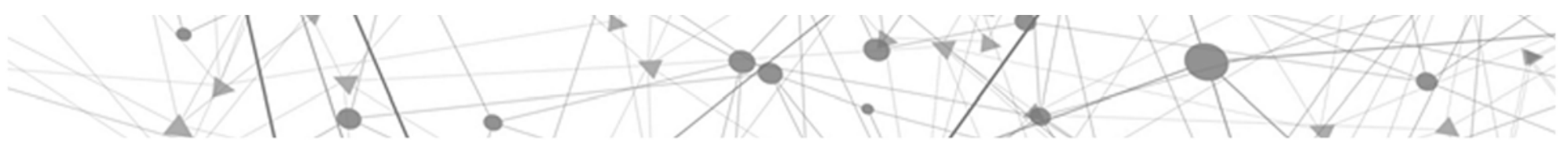


1. b.

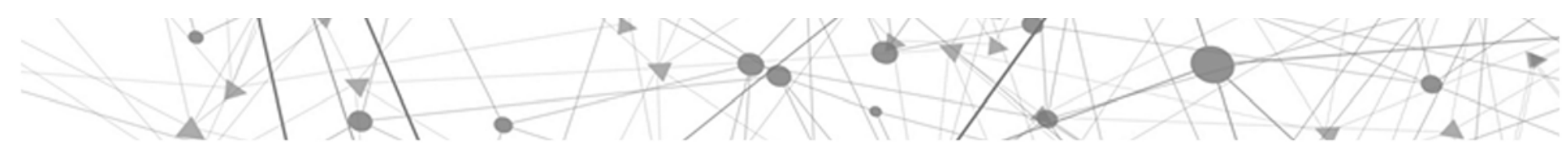




\section{Introdução}

0 interesse inicial para o desenvolvimento desta tese estava alicerçado na investigação acerca da presença do museu de arte no ciberespaço e na tentativa de construção de um possível conceito para o que pode ser entendido como museu virtual. A partir daí, seria então projetado o Museu de Arte Contemporânea Luiz Henrique Schwanke Virtual (MAC Schwanke Virtual).

Luiz Henrique Schwanke (1951-1992), artista joinvilense, foi um dos representantes de Santa Catarina na cena artística nacional dos nos 1980, chegando a participar da 21. ․ Bienal Internacional de São Paulo (SP), em 1991. Em 1980, realizou uma importante exposição no Museu Nacional Belas Artes, do Rio de Janeiro (RJ), a qual será remontada virtualmente no contexto desta tese.

O MAC Schwanke consiste no primeiro museu de arte contemporânea do estado de Santa Catarina. Foi criado no dia 11 de junho, com o Decreto Municipal n. 10.632/2012. Embora ainda não possua sede física, vem atuando como museu na realização de inúmeros programas e ações, tais como seminários, palestras, oficinas, workshops e exposições. 0 MAC Schwanke e as suas ações, assim como a trajetória artística de Schwanke, serão mais bem tratados no capítulo 3, "A rede poética de Luiz Henrique Schwanke".

Como ponto de partida para a construção do MAC Schwanke Virtual, foi feito um estudo bibliográfico sobre o tema e um mapeamento das experiências de museu disponíveis na internet, o que aconteceu no período de janeiro de 2013 a junho de 2016. Com base nesse levantamento, foi construída uma tabela resultante do agrupamento por afinidade, tanto no que diz respeito à estrutura, como também em relação aos conteúdos e ferramentas disponibilizadas, o que contribuiu para que se tivesse uma visão ampla e geral de como os museus vêm fazendo uso do ambiente virtual em rede.

Desde a década de 1990, o desenvolvimento tecnológico permite com que se possa acessar os conteúdos e o acervo dos principais museus do mundo, a qualquer momento do dia ou da noite, mediante uma tela de computador conectado à internet. Entretanto questiona-se se todos esses sites encontrados no ciberespaço podem de fato ser referenciados como museu virtual. 
Por meio do mapeamento realizado, foram identificadas diversas experiências de museus que se intitulam dessa forma, contudo não existe uma unidade de comportamento a respeito delas, o que dificulta o entendimento do que de fato é compreendido como esse tipo de museu.

Nesse sentido, o que se pretendia, a princípio, era analisar essas experiências mapeadas, organizar uma tabela com base nas principais características, o que foi feito, e confrontá-las com o entendimento de museu estabelecido no contexto contemporâneo, para então traçar uma definição possível de museu virtual. Todavia, quando se fala em ciberespaço, entendido como "o espaço de comunicação aberto pela interconexão mundial dos computadores e das memórias dos computadores" (LÉVY, 1999, p. 92), as transformações não cessam, e a velocidade com que as experiências de museus no contexto virtual se modificam acaba dificultando a construção de uma definição fixa, se é que é necessária uma, o que até mesmo iria contra a ideia de museu como processo, muito discutida na atualidade. Segundo Scheiner (2015) ${ }^{1}$,

nunca é demais relembrar que, se o Museu é fenômeno, sua verdadeira essência é intangível, é em si mesma fluida, cambiante, é da ordem do movimento - e portanto é plena de atualidade. 0 Museu se dá na relação entre indivíduo e fato social (ou museal, para usarmos a nomenclatura do campo), entre indivíduo e a parcela de real que está musealizada. Prescinde, assim, na origem, de artifícios comunicacionais que apenas agregam a essa experiência (a da relação) uma carapaça polifônica, multisensorial, que tende a misturar os sentidos e a impedir a experiência irrepetível do verdadeiro conhecimento.

Sendo assim, em lugar de construir uma definição fechada para o que é museu virtual, ação deveras redutora, esta investigação gira em torno de identificar e pensar as formas por meio das quais os museus e as instituições culturais fazem uso do ciberespaço, bem como a maneira tal qual disponibilizam a arte para o espectador.

Logo, foram estudadas diferentes concepções de museu virtual, entre as quais se destacam a de Deloche $(2004 ; 2005)$ e a de Scheiner (1998; 2004). Para

\footnotetext{
${ }^{1}$ Disponível em: <http://www.revistamuseu.com.br/18demaio/artigos.asp?id=32832> Acesso em: 1.으. 2015 .
} 
entender as diferentes experiências de museu existentes no espaço cibernético, além da tabela construída, a qual foi revisada, ampliada e aprofundada, foram cruzadas as tipologias organizadas por Gant (2001), Piacente (1996 apud THEATER, 1998), Ascott (1996) e Schweibenz (2004).

Para o desenvolvimento desta tese, parte-se do pressuposto de que a instituição museu encontra as suas bases na formação de uma coleção, em sua preservação, no estudo, na pesquisa e na extroversão (BRASIL, 2009), e defende-se a afirmativa de que o museu pode e deve existir também no ciberespaço. Essa existência, porém, não se dá como a de um substituto do museu físico, por meio do qual se tem a experiência estética diante do "original", mas como outro, dotado de novas possibilidades de vivência e que cumpre um papel social de extrema importância, na medida em que pensa e exercita a arte como uma possibilidade de ação cultural, sendo a exposição um de seus mais importantes programas.

Nessa perspectiva, consideram-se relevantes para o desenvolvimento da pesquisa tanto o estudo dos conceitos que giram em torno do museu na contemporaneidade como 0 de sua existência cibernética. 0 museu na contemporaneidade, o processo de mapeamento, a análise das tipologias, bem como a inserção do museu e de exposições no ambiente virtual em rede serão temas tratados no capítulo 1, "Museus, virtualidades e ciberespaço".

Quando se fala em exposição de arte, seja ela virtual, seja física, acredita-se que sua realização esteja fundamentada em uma proposta curatorial. Sabe-se que existem inúmeras posturas curatoriais, desde aquela em que o curador autor defende sua tese focando mais na exposição do que na individualidade dos trabalhos, muitas vezes acessível à minoria iniciada, até aquela conhecida como curadoria educativa (VERGARA, 1996). Tal conceito será aqui entendido como a realização de uma curadoria que objetiva promover a arte como um instrumento de ação cultural, valorizando assim a experiência do espectador, sendo ele iniciado ou não, e não como um meio artificial de valorizar o educativo, conforme afirmado por Barbosa (2008).

Vê-se ainda nesta tese a ideia da curadoria educativa como um dos importantes programas do museu e que pode ser concretizada na concepção de exposições para o ambiente virtual. É possível resgatar da história das exposições inúmeras experiências de curadorias que cumpriram papel educativo, tais como as 
mostras realizadas nos anos 1960 por curadores como Seth Siegelaub, Harald Szeemann, Pontus Hultén, entre outros, os quais apresentaram para o público a arte de seu tempo (RUGG; SEDGWICK, 2007).

No caso brasileiro, destaca-se a curadoria do 31. Panorama da Arte Brasileira, por Adriano Pedrosa, no Museu de Arte Moderna (MAM), de São Paulo, em 2009. Intitulado de Mamoyguara opá mamo pupé (Estrangeiros em Todo o Lugar), a mostra não exibiu sequer uma obra nacional, mas produções estrangeiras que beberam na fonte dos artistas brasileiros, mostrando ao público, por meio da exposição, que a arte produzida no Brasil é também fonte e referência para a arte estrangeira.

Para discutir a curadoria educativa, serão tomadas como foco de investigação e estudo as experiências de exposição, assim como alguns escritos de Jacob, Brenson e Olson (1995) e Jacob e Baas (2007), que pensam e discutem a experiência da arte, a qual entendem como uma forma de pensamento, principalmente no que diz respeito à arte pública. Jacob e Baas (2007) explicam que, quando a arte está nas ruas, está acessível às pessoas que frequentam ocasionalmente museus ou mesmo não os frequentam. Tomando por exemplo 0 trabalho Cloud Gate, de Anish Kapoor (Chicago, Estados Unidos, 2006), os autores asseguram que, ao encontrar-se nos espaços da cidade, as pessoas podem visitá-lo quando, quantas vezes e pelo tempo que quiserem, estabelecendo com a obra inúmeras relações e fazendo com que ela se torne memória de uma multidão de pessoas.

Nessa ótica, tendo em vista que as individualidades se articulam na construção de uma experiência coletiva, pode-se entender que muitos dos trabalhos urbanos, a exemplo de Cloud Gate, configuram-se em uma experiência relacional de arte. 0 interesse em organizar exposições acessíveis a um ilimitado número de pessoas, cuja maioria nunca frequentou ou mesmo não tem interesse em frequentar museus de arte, consiste em uma forma fecunda de aproximar as pessoas da produção artística e cultural de seu tempo, de modo que o trabalho de arte acaba por ter existência e razão de ser com base na relação construída com o visitante, relação essa que aproxima as pessoas de seu patrimônio artístico, bem como conduz o desenvolvimento do sentimento de pertencimento. É nesse sentido que se entende uma curadoria como educativa, o que aqui será exercitado no 
ambiente virtual em rede e discutido no capítulo 2, "Curadoria, curadoria educativa e exposição virtual na web".

Existem inúmeras diferenças entre uma curadoria realizada em um espaço físico e uma realizada em ambiente virtual. Por meio desta investigação, serão observadas essas diferenças com o intuito de conhecer e perceber as possibilidades de desenhar exposições no ambiente virtual objetivando a promoção da experiência estética por parte do observador. Cabe ressaltar que o foco deste trabalho não está na web art, nem na produção em arte construída digitalmente, mas na produção artística instaurada na realidade física que é digitalizada e disponibilizada via internet, uma vez que esta será a natureza da exposição a ser construída.

Ao final, no capítulo 4, “A exposição virtual digital "A casa tomada (de Julio Cortázar) por Desenhos que não Deram Certo. Desenhos de 1978/80. O Apogeu do Claro-escuro Pós-Caravaggio'", será então apresentada e analisada a exposição virtual digital construída, que, conforme já dito, consiste na remontagem de uma mostra promovida por Luiz Henrique Schwanke em 1980. Essa remontagem será disponibilizada no MAC Schwanke Virtual com base nos pressupostas da curadoria educativa. Por meio dela, serão explorados as possibilidades e os recursos oferecidos pelo ambiente virtual em rede, na disponibilização de diferentes camadas de aprofundamento para o visitante e de ferramentas participativas, com o propósito de exercitar a atuação social de museu.

Assim, espera-se que, por esta tese, seja comprovada a importância do museu virtual e da inserção do museu no ciberespaço, assim como a relevância da utilização desse espaço para a realização de exposições. Sendo a exposição entendida como uma das mais importantes ferramentas relacionais do museu, por intermédio de seu exercício no ciberespaço estar-se-á ativando seu acervo de forma ampliada e colocando-o disponível para um ilimitado número de visitantes, sem ter as barreiras geográficas como empecilho. Defende-se ainda a realização de exposições mediante a curadoria educativa e de forma independente das mostras ocorridas em sua sede física como um dos programas do museu. 

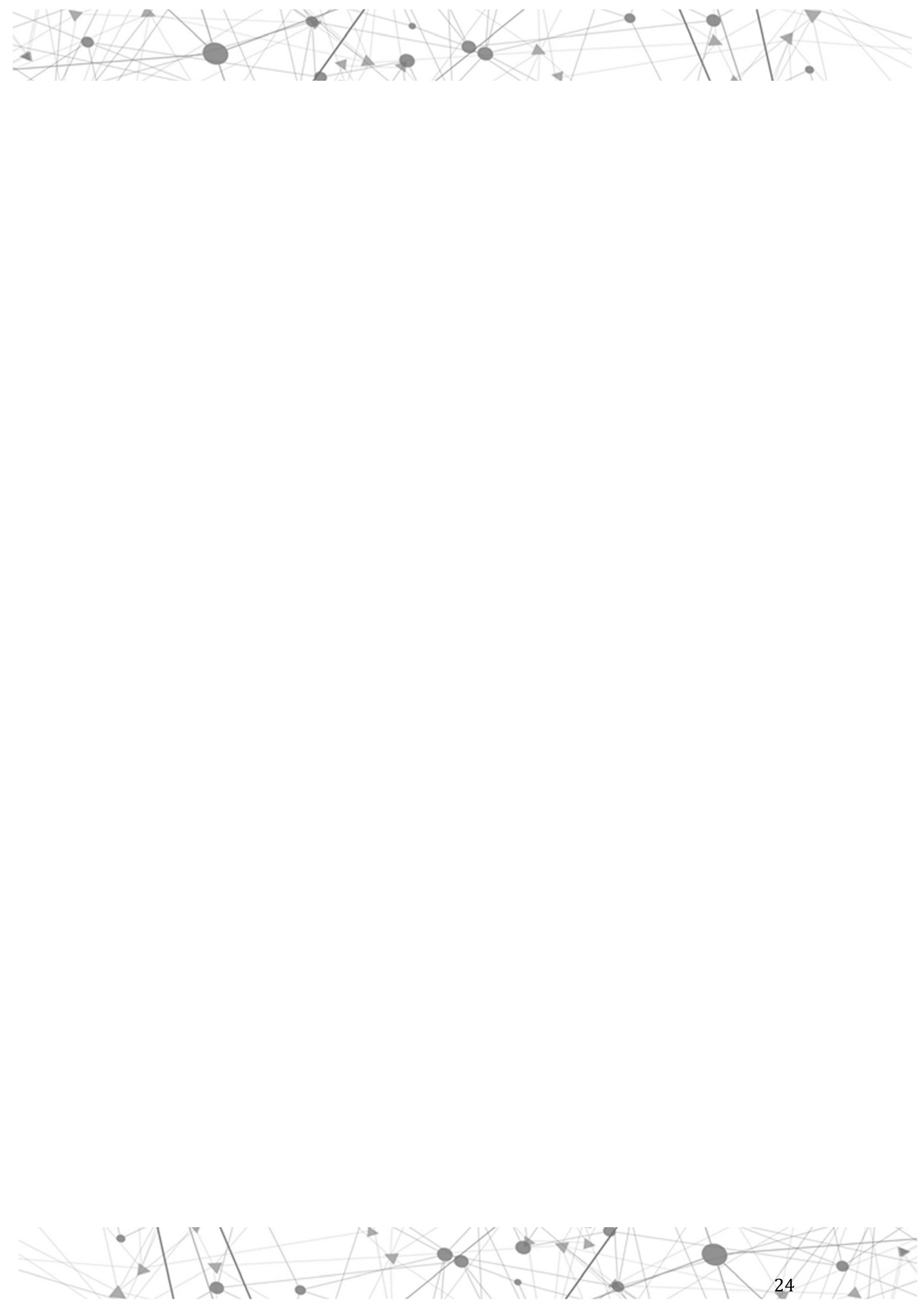


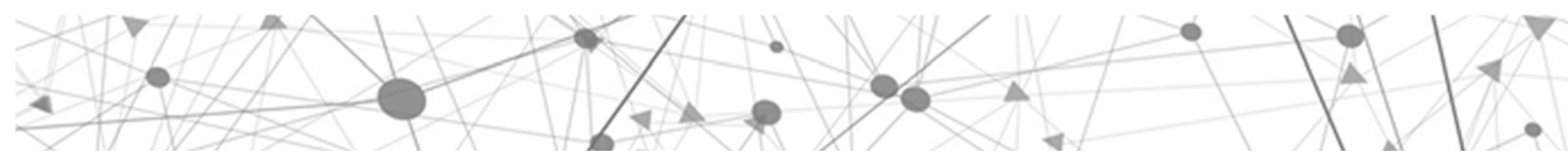

CAPÍTULO 1

MUSEUS, VIRTUALIDADES E CIBERESPAÇO

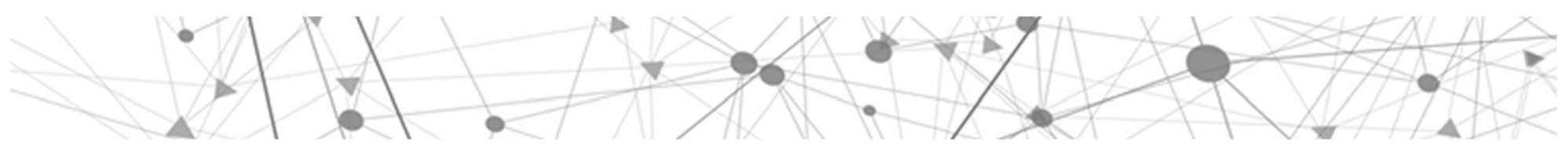




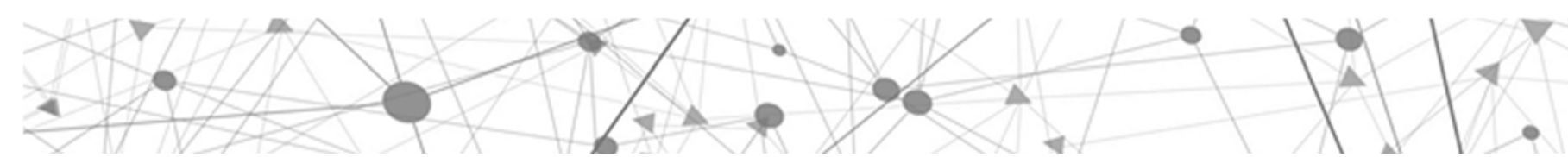

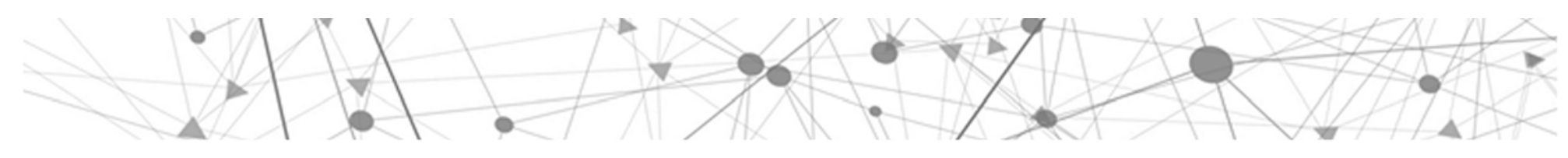




\subsection{0 museu na contemporaneidade}

0 século XIX viveu dos museus; ainda vivemos deles, e esquecemos que impuseram ao espectador uma relação totalmente nova com a obra de arte (MALRAUX, 2011, p. 9).

0 objetivo central desta tese gira em torno da realização de uma exposição virtual de base digital que é a remontagem de uma exposição física feita em 1980 pelo artista joinvilense Luiz Henrique Schwanke, a acontecer no Museu de Arte Contemporânea (MAC) Schwanke Virtual. Ressalta-se que essa remontagem vai explorar as possibilidades oferecidas pelo ambiente virtual em rede. A exposição, entendida como a maior instância relacional do museu, será projetada pelo prisma da curadoria educativa, na defesa de que o ambiente virtual pode funcionar como um instrumento eficaz para a construção de conhecimento em arte e para a formação de público. Cabe ressaltar que o Museu de Arte Contemporânea Schwanke existe apenas em decreto e não possui, ainda, sede física. Mesmo assim, defendese a existência dessa instituição enquanto museu por meio de seus programas e de suas ações, já que, além de salvaguardar, de pesquisar e de estudar a produção de Schwanke, promove cursos, palestras, oficinas, exposições e publicações tanto sobre arte em geral como também a respeito do artista, mantendo assim seu acervo, formado inicialmente pela produção de Schwanke, ativo.

Nesse sentido, por intermédio da experiência virtual digital, é possível potencializar o alcance de suas ações, como também tornar acessível, conhecido e estudado um acervo material que ainda fisicamente não pode ser exposto nesse museu. Como parte do processo, considera-se importante tomar conhecimento das questões que orbitam o museu na contemporaneidade e, por conseguinte, defender e justificar a sua existência no contexto da virtualidade. Para tal, será adotada uma concepção de museu. É desse modo que se desdobrará a primeira parte deste texto. Não se pretende a invenção da roda, mas a sistematização de ideias e de conceitos que ancorem a crença de que é possível a existência do museu no ciberespaço, independentemente de ele estar vinculado a uma construção existente no mundo físico.

Por ciberespaço, entende-se um "espaço de comunicação aberto pela interconexão mundial dos computadores e das memórias dos computadores" (LÉVY, 
1999, p. 92, grifo meu) que, conforme fora previsto por Lévy em 1999, se configura hoje como o mais relevante canal de comunicação e de suporte de memória do mundo. Trata-se de um mundo virtual global (SANTAELLA, 2004) pelo qual a distância e a falta de tempo não são mais empecilhos para aqueles que querem conhecer e se comunicar. Por esse motivo, o ciberespaço tem sido muito explorado, e de diversas maneiras, por museus e instituições culturais do mundo todo e será ele, mediante o MAC Schwanke Virtual, o suporte que sustentará a exposição que na perspectiva desta tese se pretende construir.

Para a discussão tanto no que tange a museu como a museologia, vista aqui como "um campo interdisciplinar específico, independente, de caráter científicofilosófico, tendo o museu (fenômeno) e a musealidade (valor) como objetos de estudo" (SCHEINER, 2013, p. 359), foram adotados alguns autores. Um deles é Scheiner (1998; 2009; 2013). A autora pensa o museu enquanto fenômeno, levando em conta a sua multiplicidade de manifestações nas diferentes esferas de percepção do real, e compreende a museologia como um campo que inicialmente se desenvolve nas ciências humanas. Já Rússio (1990), de extrema importância na discussão e na investigação acerca da museologia (falecida precocemente, em 1990), localiza a essência do museu nas relações humanas, no campo do social, inferindo a museologia das ciências sociais. Ela defendia a museologia enquanto ciência em processo, sendo o fato museal (objeto da museologia) pautado na relação entre o homem (sujeito conhecedor) e o objeto (parte da realidade do homem e sobre a qual ele tem o poder de agir), no espaço do museu.

Logo, enquanto Scheiner (1998; 2009; 2013) segue uma abordagem de natureza filosófica e vê o museu como um fenômeno de múltiplas naturezas, abrindo, assim, espaço para se pensar essa instituição no contexto da virtualidade, Rússio defende tal espaço como algo que existe nas relações humanas, enfatizando a função social de museu, função essa entendida, no desenvolvimento desta tese, como uma das mais importantes e exercitada sobretudo por meio de exposições. Segundo a autora, "a tarefa do museu contemporâneo é a de permitir a leitura clara do mundo através do despertar de uma consciência crítica, de forma que a informação veiculada conduza a uma ação transformadora por parte do homem" (RÚSSIO, 1990, p. 8). Trata-se de duas visões que, apesar de oriundas de diferentes 
tempos e contextos, resultam em um diálogo rico para se pensar a experiência de museu no ambiente virtual.

Entre os teóricos que também refletem a respeito de museu enquanto fenômeno e que fundamentam este texto, mesmo que indiretamente, estão Mário Chagas (2011), Mário Chagas et al. (2010), Anna Gregorová (1980), Peter van Mensch (1994; 2009), Peter van Mensch, Suminas e Gudinavicius (2015), Peter van Mensch, Pouw e Schouten (1990) e Tomislav Sola (1990). Ainda no que se refere a museu e pmuseologia, serão utilizados escritos de Dominique Poulot (2013), Marília Xavier Cury (2005) e André Desvallées e François Mairesse (2013).

0 museu, desde suas origens, que remontam à Grécia Clássica, permanece em constante processo de atualização, estando a preservação do passado não mais entre as suas prioridades e, em muitos casos, nem mesmo como parte de sua natureza. Pensar o museu enquanto "locus absoluto de preservação" "representa e reatualiza um mundo que já não existe mais, um sistema de valores não mais possível no contemporâneo, uma forma de perceber o real que já não é a do homem dos dias de hoje" (SCHEINER, 1998, p. 2).

Nota-se que, na atualidade e cada vez mais, se amplia a ideia de que museu vem assumindo novas funções e diferentes formatos, estabelecendo-se como uma instituição que coloca em primeiro plano a experiência, tanto do artista como do espectador. Essa experiência muitas vezes é mediada pelo uso da tecnologia, cuja emergência e cujo rápido desenvolvimento talvez estejam entre os maiores desafios dos museus no século XXI. Preservar? Como? Como mostrar? Nessa ótica, pode-se entender o museu hoje não mais como lugar, "templo das musas", que acabou por originar a ideia de museu como depósito, mas sim como um espaço que pensa o sentido das coisas no mundo e na vida e reelabora incessantemente a sua missão poética (CURY, 2005, p. 22).

Scheiner (1998) propõe um novo ponto de partida para se pensar a origem do museu, fazendo com que a sua definição tradicional, construída com base no propósito de servir ao estatuto da burguesia (SCHEINER, 2008), seja revista e ampliada. Segundo a autora, entender que a origem do museu está na palavra grega mouseion implica conceber museu como "templo das musas", ou seja, como o lugar que abriga tais musas e no qual elas vivem e falam por intermédio das Pitonisas (SCHEINER, 1998). A pitonisa, a exemplo da que vivia no templo de Apolo, 
em Delfos, era uma sacerdotisa e, como tal, responsável por fazer a mediação entre dois mundos, o espiritual e o físico, assim como entre o passado e o futuro. Nesse sentido, tanto o Templo de Delfos como o Museu de Alexandria (século III a.C.) podem ser entendidos como templo das musas, lugar onde comumente se acredita que estejam os primórdios do museu, espaço de mediação e presentificação por natureza. Tal concepção, de acordo com a autora, sugere uma origem pautada no sistema filosófico da Grécia Clássica, em que e quando houve o predomínio da razão:

Como experiência oracular, ao Museu caberia a função de agente da Verdade: assim como a pitonisas, ele poderia recontar o passado, narrar o presente e prever, pela palavra, os acontecimentos. Como espaço físico, o templo das musas estaria irremediavelmente vinculado à ideia de preservação: um templo é um relicário, um local de guarda das coisas sagradas, acessível apenas a poucos; é solene, é o espaço do ritual - um espaço de reprodução devotado muito mais à permanência do que à criação. Não é possível imaginar a dessacralização do templo: sua própria existência se justifica pela mística do ritual. 0 templo é um local de reverência, de ocultação do novo, de repetição do já experimentado. Aberto ao culto público, é também um espaço impessoal, onde os "sacra" (objetos sagrados, símbolos religiosos) [...] transformam-se em espetáculo. Não há lugar para as Musas num lugar assim (SCHEINER, 1998, p. 11, grifos do original).

Assim sendo, Sheiner (1998; 2004) propõe então que as origens do museu não sejam resgatadas da ideia de "templo" (mouseion), mas da de "musas" (mousáon, ou mousaion, que significa "pelas musas"). Para Teogonia, de Hesíodo (1991, p. 22), as musas, filhas de Zeus de Olimpo e da Memória, "têm grande e divino o monte Hélicon". 0 verbo têr, de raiz grega ékhousin, significa tanto "terocupar-habitar" como "ter-manter-suster" (HESÍODO, 2015, p. 22). Conforme afirma Hesíodo (2015, p. 22):

Como as Deusas o têm por habitação, elas o mantêm na grandeza e sacralidade em que ele se mostra. É pela presença delas que ele, o Hélicon, se dá em sua presença imponente e sagrada. Mantendo o Hélicon como sua habitação, elas o mantêm como hierofania como mantêm no encanto do canto o poder de presentificar o que sem elas é ausente.

Logo, as musas, presentificação da palavra cantada (HESíODO, 2015), não possuem o Hélicon, mas o mantém, trazendo por intermédio de sua manifestação 
aquele espaço grego à memória e, assim, tornando-o vivo e presente. Nesse sentido, o único espaço que possuem é o seu espaço de manifestação, abstrato, imaterial. Conforme questiona Sheiner (2008, p. 61), "o que poderia ser, então, o 'templo das musas', senão o espaço possível de presentificação das ideias, de manifestação da memória?". Dessa forma, em lugar de pensar o museu como templo, estático, como um lugar que abriga a produção da humanidade para preservação, estudo e deleite, ele pode ser encarado como um espaço no qual as ideias do homem se avivam e se presentificam. Assim, a autora pergunta:

Não seria este, portanto, o verdadeiro Museu - o Mousáon, espaço de expressão das Musas, de (re)criação da natureza e do mundo das ideias, contido na ideia mesma enquanto criação? 0 verdadeiro Museu, que não está sujeito a um lugar específico, mas que é fato dinâmico, eternamente a conjugar memória, tempo e poder, recriando-se continuamente para seduzir o ouvinte pela sua voz? (SCHEINER, 1998, p. 18).

Dessa maneira, entende-se e defende-se aqui o museu enquanto um fenômeno cultural em si mesmo, independentemente do espaço que o abriga e de possuir ou não espaço físico. Contudo, ao pesquisar acerca das definições contemporâneas de museu, percebe-se que a maioria delas ainda mantém como base a proposição do International Council of Museums (ou, em português, Conselho Internacional de Museus, Icom) construída em 1974:

0 museu é uma instituição permanente, sem fins lucrativos, a serviço da sociedade e de seu desenvolvimento, aberta ao público, e que faz pesquisas relacionadas com os testemunhos materiais do ser humano e de seu ambiente, tendo em vista a aquisição, conservação, transmissão e, principalmente, exposição desse acervo com a finalidade de estudo e deleite (POULOT, 2013, p. 18).

Em 2007, na 22. a Conferência Geral do Icom, em Viena, Áustria, atualizou-se a definição de museu, lugar internacionalmente entendido desde então como

non-profit, permanent institution in the service of society and its development, open to the public, which acquires, conserves, researches, communicates and exhibits the tangible and 
intangible heritage of humanity and its environment for the purposes of education, study and enjoyment ${ }^{2}$ (ICOM, 2010).

Ou seja, o museu ainda é visto por muitos como uma coisa única, de natureza permanente, que se modifica ao longo do tempo sem que seja levada em conta a sua pluralidade. Trata-se de uma concepção deveras fechada e dura de algo que é complexo e múltiplo. Assim como escreve Scheiner (1998, p. 2),

museu é, pois, um nome genérico que se dá a um conjunto de manifestações simbólicas do homem e da sociedade. Não um espaço que se moderniza, nem um território que se protege. Não é um edifício escuro cujo destino seja transformar-se em centro cultural - proposta impossivelmente "alquímica", que pressupõe seja possível, em nome da contemporaneidade, transformar água em vinho.

A variedade de formatos de museus existentes na contemporaneidade atesta a dificuldade, e até a impossibilidade, de se traçar uma definição de museu que dê conta de toda a sua complexidade e de sua natureza fenomênica. Diversos estudos realizados no âmbito da museologia estabeleceram uma tipologia de maneira a tentar abranger o fenômeno museu em suas inúmeras formas de existência. Para tal, foi organizada a tipologia: museu tradicional, museu de território, museu interior e museu virtual (SCHEINER, 1998).

0 museu dito tradicional é contemplado pelo museu ortodoxo, pelo museu exploratório e pelo museu com coleções vivas. 0 museu tradicional ortodoxo é abrigado em uma construção edificada, formado por uma coleção específica e aberto ao público. Segundo Scheiner (2009), esse tipo de museu fundamenta-se no objeto, ressaltado como um produto cultural tanto em sua unicidade (técnica conceitual) como também enquanto coleção (técnicas de ambientação e reconstituição). As exposições são desenhadas com base num circuito definido e organizadas em núcleos integrados dispostos em espaços delimitados. No museu tradicional exploratório, por sua vez, a ênfase está na percepção e no tempo do espectador, que percorre um ambiente não mais delimitado nem dotado de um percurso definido. Agora, a prioridade está na participação do público visitante, que

\footnotetext{
${ }^{2}$ Instituição permanente, sem fins lucrativos, a serviço da sociedade e de seu desenvolvimento, aberta ao público e que adquire, conserva, pesquisa, comunica e expõe o patrimônio material e imaterial da humanidade e seu ambiente para fins de educação, estudo e deleite (livre tradução).
} 
encontra os objetos no museu destacados como conjunto. Já o museu tradicional com coleções vivas, que são os jardins botânicos, os zoológicos, os aquários, entre outros, cujo realce está nos espécimes vivos, a organização das exposições acontece pelos diferentes núcleos, os quais são definidos mediante critérios científicos ou ecológicos (SCHEINER, 1998).

Já o museu de território é dividido em museus comunitários, ecomuseus, parques nacionais ou outros sítios naturais musealizados, cidades-monumento, sítios históricos, arqueológicos, paleontológicos, entre outros similares. Enquanto os museus comunitários e os ecomuseus encontram as suas bases na musealização de um território específico, dando ênfase a processos naturais e culturais na valorização da relação entre o ser humano e o seu território, os parques nacionais e os sítios naturais musealizados enfatizam as relações entre os elementos integrantes do ecossistema, musealizando espaços geográficos e ressaltando aspectos importantes do patrimônio natural. As exposições realizadas pelos museus comunitários e ecomuseus podem ser tradicionais, pela mostra de objetos exibidos balizada pelo tempo social de uma dada comunidade. Já as exposições dos parques naturais e de outros sítios naturais musealizados ocorrem tendo em vista 0 tempo biológico, podendo até mesmo mostrar espécies e objetos diversos. As cidades-monumento, os sítios históricos, arqueológicos e similares, por sua vez, têm sua fundamentação na musealização de um território, sendo a exposição todo 0 conjunto com base no qual é destacada a presença do homem. A exposições por esses tipos de museu podem ser de natureza tradicional, com a exibição de objetos e diferentes espécimes, como também, no caso das cidades-monumento, contemplar os demais tipos de museu anteriormente referenciados (SCHEINER, 1998).

0 outro item da classificação, chamado de museu interior, existe somente no interior de cada indivíduo socialmente marginalizado, tais como os loucos, os infradotados, os superdotados etc. Mas, conforme Scheiner (1998), trata-se de um museu que

se dá no cruzamento entre o plano consciente e o plano da inconsciência, naquele exato momento em que o indivíduo, ao perceber-se vivo no mundo, se reconhece a si mesmo. Esta seria a sua origem absoluta - o Museu em potência, que habita cada um de nós (SCHEINER, 1998, p.41). 
Um exemplo desse tipo de museu é o Museu de Imagens do Inconsciente, cuja maioria do acervo é formada por trabalhos produzidos por pessoas residentes no Centro Psiquiátrico Nacional, no Rio de Janeiro (DIONÍSIO, 2001).

0 museu virtual, categoria de museu que é foco no desenvolvimento desta tese, consiste em um museu que, dada a sua ausência de materialidade, não tem público, mas visitantes que o acessam individualmente, de qualquer lugar do planeta, desde que diante de um dispositivo conectado à internet. Existente no meio cibernético, em função da natureza transitória e processual do referido espaço, cada visitante tem o potencial de alterar a exposição em um processo constante de recriação que se dá pelos cliques do mouse (SCHEINER, 1998). Por meio de uma simples investigação em um site de busca, é possível constatar hoje que muitas e diversas experiências de museu no ciberespaço são denominadas, muitas vezes e em muitos casos, de museu virtual. Por outro lado, vê-se também que diferentes autores apresentam concepções distintas acerca desse tipo de museu, o que atesta a relevância de cruzar essas diferenças na tentativa de construção de um entendimento do que de fato é um museu virtual.

Os tipos de museu citados são modelos e conceitos oriundos de diferentes contextos e realidades e que enfatizam o museu como fenômeno e como processo, já que atestam as transformações sofridas por essa instituição levando em conta as mudanças sociais e as necessidades de cada momento histórico. Conceber o museu como um fenômeno, como um espaço de manifestação, e não propriamente como um locus, abre espaço para que ele exista também no contexto do ciberespaço.

\subsection{0 museu e o ciberespaço}

0 museu tradicional não é o único museu possível [...]. Existem outras dimensões do Museu. [...] 0 Museu deve ser pensado agora já não mais como coisa única (portanto estática), mas como fenômeno, e portanto coisa dinâmica, independente de um local e de um tempo específicos, podendo estar simultaneamente em muitos lugares, sob as mais diversas formas e manifestações (SCHEINER, 1998, p. 89).

A partir da década de 1990, os avanços da tecnologia muito têm contribuído para a transformação da forma de viver, conviver e relacionar-se com o mundo. Segundo Castells $(2000$, p. 21$)$, “uma revolução tecnológica concentrada nas 
tecnologias da informação está remodelando a base material da sociedade em ritmo acelerado", de maneira que podemos afirmar estar vivendo na era da informação ou, ainda, na era digital. Assim como o surgimento da fotografia afetou ideologicamente o comportamento pictórico do início do século XIX (BOURRIAUD, 2009), os adventos do ciberespaço e da internet influenciaram a produção artística e, consequentemente, apareceram novas formas de produzir e de exibir arte, inclusive no ambiente físico. Mesmo que de modo indireto, com a disseminação da internet como uma ferramenta de comunicação, hoje muito presente na vida cotidiana de grande parte da população mundial, o jeito de olhar para o mundo e para a arte mudou, abrindo espaço para o rompimento de inúmeros paradigmas, muitos deles envolvendo o museu.

Por meio da estética relacional, teoria que pode ser localizada na tradição materialista, com base no materialismo aleatório de Louis Althusser, partindo assim do princípio da contingência do mundo, sem uma origem, sem razão e sem sentido que ampare o seu objetivo e mesmo a sua existência, Bourriaud (2009) entende as manifestações da arte contemporânea como um processo de trabalho, processo esse que se estende ao público, tornando-se resultado da coletividade, e, assim como Karl Marx, considera a essência da humanidade como o conjunto das relações sociais.

Esse regime de encontro casual intensivo, elevado à potência de uma regra absoluta de civilização, acabou criando práticas correspondentes, isto é, uma forma de arte cujo substrato é dado pela intersubjetividade e tem como tema central o estar-juntos, 0 "encontro" entre observador e quadro, a elaboração coletiva de sentido (BOURRIAUD, 2009, p. 21).

Portanto, não há mais espaço entre o trabalho de arte e o espectador, o qual de fato já não é mais espectador, mas parte essencial do processo para que o trabalho aconteça ou não. Conforme o teórico, "não se pode considerar a arte contemporânea como um espaço a ser percorrido [...] agora ela se apresenta como uma duração a ser experimentada, como uma abertura para a discussão ilimitada" (BOURRIAUD, 2009, p. 20-21). Assim como arte sempre foi de natureza relacional, ou seja, um fator de sociabilidade e fundadora de diálogo (BOURRIAUD, 2009), defende-se a ideia de que, ao disponibilizá-la na internet, a sua natureza relacional é potencializada à medida que é acessada pelo visitante de qualquer lugar e em qualquer horário, desde que ele tenha um dispositivo eletrônico conectado à 
internet. Por conseguinte, o ciberespaço pode ser entendido como um espaço relacional por excelência, tendo em vista que o conteúdo disponibilizado só existe em potência, no âmbito da virtualidade, e acontece no exercício do visitante.

Pode-se dizer que o primeiro passo dado pelas instituições culturais e museológicas em direção ao ciberespaço é a inserção de sistemas de multimídia e de hipermídia nos museus tradicionais, por meio dos quais o público já é conduzido a sair de seu papel passivo de observador para assumir uma postura mais dinâmica e participativa. Entre os pioneiros no uso dessas tecnologias estão o Museu da Ciência e Indústria ${ }^{3}$, de Chicago (1933), Estados Unidos, e o Palácio da Descoberta ${ }^{4}$, de Paris (1937), França (GANT, 2001). Conforme Bourriaud (2009, p. 96-97),

a tecnologia que domina a cultura de nossa época é, sem dúvida, a informática, que pode ser dividida em dois aspectos: de um lado, o computador em si, as modificações que ele acarreta em nosso modo de apreender a tratar a informação. De outro lado, o avanço rápido das tecnologias de convívio, do celular à internet, passando pelas telas táteis e videogames interativos.

Nesse contexto, o sistema tecnológico computacional torna-se mediador das ações sociais de maneira que o celular, o notebook, o tablet, entre "outras formas de extensão humana" (SANTAELLA, 2003, p. 15), se tornaram essenciais à vida cotidiana.

Assim sendo, a presença dos museus no ambiente virtual é cada vez mais frequente, já que instituições culturais e museológicas têm feito da rede um instrumento de divulgação, tanto de seu espaço físico e de sua coleção como também de seus programas e de suas ações. Trata-se de uma forma dinâmica e acessível de informação que, apesar de não ser nova, está em estado emergente. Como assegura Schweibenz (1998), tal experiência de museu, muitas vezes referenciada como um banco de informações digitalizadas, tem recebido diferentes nomenclaturas, entre as quais estão: museu online, cibermuseu, museu eletrônico, museu digital e web museu. Todos os termos citados envolvem a ideia de um museu que disponibiliza informação em meio virtual, tornando desse modo a sua coleção acessível em formato imaterial. Ainda segundo Schweibenz (2004), "regardless of

\footnotetext{
${ }^{3}$ Mais informações em: <http://www.msichicago.org/>.

${ }^{4}$ Mais informações em: <http://www.palais-decouverte.fr/fr/accueil/>.
} 
the name, the idea behind this phenomenon is to build a digital extension of the museum on the internet, a museum without walls" 5 .

Desde a década de 1990, muitos pesquisadores, tanto das ciências da comunicação como da museologia, desenvolvem pesquisas acerca do museu no contexto da cibercultura, o que tem resultado em diversos artigos, dissertações de mestrado e teses de doutorado que muito contribuem para pensar as experiências de museus no âmbito do ambiente virtual. Nesse sentido, não se pretende, com este estudo, a construção de uma nova concepção de museu virtual, porém, conforme já dito anteriormente, objetiva-se entender os conceitos que giram em torno dessa experiência a fim de melhor conceituar e defender o museu virtual de fato como museu, museu esse que também pode abrigar exposições e cumprir um papel tão importante no que tange ao incentivo à experiência estética em arte e à construção de conhecimento quanto o museu físico.

Como já é sabido, a origem do museu como instituição pública está calcada no desejo de posse, responsável pela formação das primeiras coleções particulares, que mais tarde deram forma aos primeiros museus, a exemplo do Museu Ashmolean de Arte e Arqueologia ${ }^{6}$, considerado o primeiro museu público, concebido com base na coleção de John Tradescant (1570-1638), doada por Elias Ashmole (1617-1692) à Universidade de 0xford, Inglaterra, no fim do século XVII (BLOM, 2003). 0 Museu Britânico ${ }^{7}$ é o segundo museu público, criado em 1759 pelo parlamento inglês, com a aquisição da coleção de Hans Sloane (1660-1753). 0 Museu do Louvre ${ }^{8}$, por sua vez, criado pelo governo revolucionário em 1793 , constitui o primeiro museu público francês, cujo objetivo foi tornar as coleções particulares acessíveis à população (POULOT, 2013).

Já no Brasil, o primeiro museu foi criado em 1862. Trata-se do Museu do Instituto Arqueológico, Histórico e Geográfico de Pernambuco ${ }^{9}$. Contudo vale ressaltar que o Museu Nacional ${ }^{10}$, da Universidade Federal do Rio de Janeiro (UFRJ), criado por D. João VI em 1818 (MACHADO, 2013), tendo como primeira sede o Campo de Santana, originalmente atendia aos interesses de promoção do

\footnotetext{
5 “Independentemente do nome, a ideia por trás desse fenômeno é construir uma extensão digital do museu na internet, um museu sem paredes" (livre tradução).

${ }^{6}$ Mais informações em: <http://www.ashmolean.org/>.

${ }^{7}$ Mais informações em: <http://www.britishmuseum.org/>.

${ }^{8}$ Mais informações em: <http://www.louvre.fr/>.

${ }^{9}$ Mais informações em: <https://www.facebook.com/institutoarqueologico>.

${ }^{10}$ Mais informações em: <http://www.museunacional.ufrj.br/>.
} 
progresso tanto cultural como econômico do país. Inicialmente denominado de Museu Real, passou a integrar a Universidade do Brasil em 1946 e hoje faz parte da UFRJ. Vinculado ao Ministério da Educação, esse museu é tido como a instituição científica mais antiga do Brasil, assim como o maior museu de história natural e antropológica da América Latina.

É interessante observar que todos os museus citados experienciam o ciberespaço, seja por intermédio de sites ou de redes sociais.

Com o surgimento da instituição museu, a forma de olhar para a história e para a produção cultural modificou-se. Segundo Malraux (2011), no começo de sua obra Le musée imaginaire, publicada originalmente em 1965, "um crucifixo românico não era, de início, uma escultura; a Madona de Cimabue não era, de início, um quadro; nem sequer a Atena de Fídias era, de início, uma estátua" (MALRAUX, 2011, p. 9).

0 autor afirma que, ao integrar o acervo de um museu, o significado primeiro de uma obra de arte transforma-se. Os retratos, por exemplo, deixam de ser "retratos de alguém" e passam a ser Rubens ou Velázquez. Espadas, capacetes e armaduras, bem como vestes e objetos de uso pessoal de alguém, passam a ser artefatos de importância histórica, ficando a sua função originária em segundo plano. Além disso, as coleções dos museus tornaram-se tão extensas que dificilmente podem ser expostas integralmente, de maneira que o espectador possa ter acesso, por vez, apenas a uma parte limitada de determinado acervo. Entretanto, com a reprodução de imagens mediante a fotografia, um acervo inteiro pode se apresentar disponível à visualização do público, completamente e ao mesmo tempo. “Criou-se um Museu Imaginário, que vai aprofundar ao máximo o incompleto confronto imposto pelos verdadeiros museus: respondendo ao apelo por estes lançado, as artes plásticas inventaram a sua imprensa" (MALRAUX, 2011, p. 13).

Na contemporaneidade, ao conjunto que envolve livros, catálogos e revistas, podem ser acrescidos imagens e documentos digitais disponibilizados na web. Nesse sentido, além do musée imaginaire (MALRAUX, 2011), fruto de um processo de virtualização, surgem também as experiências virtuais de museu encontradas na internet. 


\subsection{0 museu virtual e a web}

No contexto desta tese, a experiência de museu virtual que interessa é aquela exercitada no ciberespaço, tendo em vista que o que se pretende é a construção de uma exposição virtual digital disponibilizada na internet, como um dos programas educativos do museu, o que será realizado no espaço do MAC Schwanke Virtual, contudo é interessante observar que a relação entre o museu e o virtual ${ }^{11}$ não se dá apenas no espaço cibernético e é até mesmo, conforme será discutido mais adiante, anterior ao surgimento do ciberespaço.

Com o desenvolvimento da tecnologia de base microeletrônica, novas possibilidades apresentaram-se e, assim como afirma Ascott, "any discussion of the museum of the future must necessarily respond to the computer-mediated practices which define the canon of late 20th century art"12 (ASCOTT, 1996).

De fato, os museus muito têm utilizado computadores, seja dentro de seu espaço físico, nas exposições, ou, conforme citado anteriormente, como um meio de disponibilizar e ativar o seu acervo no contexto da web. Todas essas experiências, sejam no ambiente físico, sejam na internet, têm sido frequentemente nomeadas de museu virtual.

Talvez um dos exemplos mais interessantes de museu que fazem uso da virtualidade no espaço físico de suas exposições seja o ZKM National Media Museum $^{13}$, criado em 1997, em Karlsruhe, Alemanha. Trata-se de um museu de concepção interativa que coloca em exposição e diálogo os trabalhos de natureza multimídia, tais como filmes interativos, simulações no ciberespaço e softwares projetados para a internet, com trabalhos de arte contemporânea realizados em suporte tradicional. Nesse sentido, o ZKM apresenta a produção de arte das últimas décadas, de maneira que nem os tipos de suporte nem as técnicas empregadas sejam critérios excludentes (GANT, 2001), já que em seu espaço expositivo a realidade física e a realidade virtual coexistem e conversam.

\footnotetext{
${ }^{11}$ Cabe observar aqui que o termo virtual, cuja origem está no latim medieval virtualis, palavra derivada de virtus, que significa força, potência, será entendido, nesta tese, como aquilo que existe em potência, em um constante vir $a$ ser que tende a atualizar-se. Nesse sentido, o virtual não se opõe ao real, mas ao atual, sendo a virtualidade também uma realidade, mas em potência (LÉVY, 2011).

12 “Qualquer discussão sobre o museu do futuro terá necessariamente que responder às práticas mediadas por computadores, as quais definem o cânone da arte tardia do século XX" (livre tradução).

${ }^{13}$ Mais informações em: <http://on1.zkm.de/zkm/e/institute/medienmuseum>.
} 
Outro exemplo acerca de um museu físico também entendido como virtual, afinal oferece experiências nesse âmbito, consiste no coreano Leeum, Samsung Museum of $\mathrm{Art}^{14}$. De acordo com o vídeo disponível em seu website, para acompanhar as exposições feitas em suas dependências físicas, o museu oferece ao espectador um guia digital, o qual equivale a um "professor em suas mãos". Tal guia oferece inúmeros recursos que funcionam como um complemento à exposição e que possibilitam ao espectador o acesso a procedimentos não permitidos fisicamente em um museu tradicional. 0 guia digital disponibiliza reproduções das peças em exposição em alta resolução, as quais podem ser ampliadas e rotacionadas, de forma que sejam percebidas em um grau de detalhamento e em posições impossíveis à realidade física, em função do impedimento de aproximação e de manipulação. Também pelo guia digital, os manuscritos, acondicionados em expositores com tampa de vidro, podem ser folheados, assim como os textos em chinês tradicional que compõem as pinturas são traduzidos com o recurso da realidade aumentada. Ao final da visita, o espectador pode rever os trabalhos mediante o guia e fazer o download das imagens visualizadas diretamente em seu smartphone. Tal como afirma Gant (2001, p. 248), "la realidad virtual nos conduce a transformar, dentro del ámbito museístico, nuestra manera tradicional de acercarnos a los objetos dentro del museo"15, e isso diz respeito tanto ao museu físico, a exemplo do ZKM, como ao museu virtual, mesmo quando existente também fora do espaço da virtualidade, tal como o Museu Temporário da Mudança Permanente.

Situado na cidade de Salt Lake, em Utah, nos Estados Unidos, e projetado pelo artista, urbanista e professor Stephen Goldsmith, o Museu Temporário da Mudança Permanente ${ }^{16}$ é um museu que coleciona a mudança. Ele não tem endereço específico; existe enquanto uma construção de ideias em relação às transformações sofridas pela cidade ao longo da história até o tempo presente, assim como pelos projetos de transformação pelos quais passará no futuro.

Com base no museu, são propostas ações com a finalidade colaborativa diretamente à população, que contribui para que Salt Lake seja vista por meio de

\footnotetext{
${ }^{14}$ Mais informações em: <http://leeum.samsungfoundation.org>.

15 "A realidade virtual leva-nos a transformar, dentro do campo museal, a nossa forma tradicional de se aproximar de objetos dentro do museu" (livre tradução).

${ }^{16}$ Mais informações em: <http://www.museumofchange.org/>.
} 
um novo olhar, aquele que tanto aceita quanto provoca a mudança. Conforme consta de seu website, o espaço do museu, embora não possua endereço fixo, é dotado de alcance geográfico e localiza-se no centro histórico da cidade, tendo um limite flexível que se estende a oeste, até a Estação Central, a leste, até a Catedral de Madeleine, a norte, até o City Creek Park, e ao sul, pela Praça da Biblioteca. A sua página virtual funciona como uma extensão do museu para web, o qual explora a estrutura para promover exposições colaborativas com a população ou qualquer pessoa que passe pela cidade - que, conforme dito, é entendida como o espaço do museu. Por meio do link Permanent Collection, por exemplo, o visitante pode ter acesso a Temporary Street Collection. Ao acessar tal mostra temporária, aparece o convite para uma exposição colaborativa a ser realizada naquela página. A mostra em cartaz nesse momento é a Treasures of the Broadway Wing e acompanha o seguinte texto explicativo:

The Museum's Temporary Street Collection is an assemblage of authentic elements found as we observe, listen, taste, touch and breathe in the life of the city. Sometimes a passing voice, sometimes the historic artifact or remarkable personality, all that occurs within the museum can be collected as memory, or as muse (THE TEMPORARY MUSEUM OF PERMANENT CHANGE, 2015) ${ }^{17}$.

Logo depois, o visitante do site é convidado a enviar para a curadoria, pelo endereço de e-mail indicado, uma imagem ou descrição de algum tesouro que porventura tenha sido descoberto dentro do museu (cidade) e que gostaria que fosse incluído na exposição. As imagens e os textos selecionados são inseridos na exposição virtual dessa página no site. Por meio de tal proposta, as pessoas são conduzidas a exercitar não somente o olhar, mas todos os sentidos no exercício de perceber a cidade, que é um museu permanentemente aberto e em constante transformação. Seu acervo é formado tanto por objetos diversos encontrados em sua área de abrangência, como por sons, aromas, sensações, sentimentos e questionamentos, frutos da vivência e convivência de todos e de cada um naquele lugar.

\footnotetext{
17 “A Coleção de Rua do Museu Temporário é uma montagem de elementos autênticos encontrados quando nós observamos, escutamos, provamos, tocamos e respiramos na vida da cidade. Algumas vezes uma voz passageira, algumas vezes um artefato histórico ou uma personalidade marcante, todas as ocorrências dentro do museu podem ser colecionadas como memória, ou como musa" (livre tradução).
} 
Apesar de ser existente em meio físico, e por isso possível de ser entendido também como um museu de território (conceito trabalhado no início deste texto), sua natureza é essencialmente virtual, tendo em vista a definição de Lévy (2001), já que existe enquanto acontece, sendo, portanto, um constante vir a ser. Sua estrutura é não linear e segue um fluxo de natureza rizomática, sem raízes fixas, solto no tempo e no espaço. Embora muitas de suas ações sejam fruto de propostas pensadas, o museu não tem controle nem domínio sobre seu acervo, na medida em que tais propostas são desenvolvidas pelo público autor, que constantemente exercita a cidade e produz transformações.

Cabe observar que o Museu Temporário da Mudança Permanente possui e abriga também uma coleção de natureza física, formada por artefatos de importância histórica coletados na cidade, contudo o principal item de seu acervo é a mudança.

Tanto o ZKM como o Museu Temporário da Mudança Permanente podem ser entendidos como museus virtuais. Isso se dá pelo fato de que o primeiro utiliza meios digitais e o ambiente virtual para apresentar trabalhos em seu espaço físico, e o segundo existe sob o aspecto de potência na exploração, do ambiente virtual como parte de sua experiência de museu e também de outros espaços de virtualidade, tais como as propostas de mudança no contexto da cidade. Ambos existem somente pelo exercício do visitante, responsável por ativar a coleção.

Todavia, quando se fala em museus virtuais, o primeiro suporte que vem à mente é a internet. Embora tenha sido a web que tenha tornado o museu virtual flexível e dinâmico, é possível afirmar que, originalmente, a ideia de museu virtual ganhou corpo, primeiramente em formato de CD-ROM e de DVD-ROM, e o catálogo impresso, museu imaginário de Malraux (2011), pode ser compreendido como o seu ponto de partida.

Logo, uma das propostas pioneiras é o Museu Virtual da Apple, em formato de CD-ROM, produzido nos anos 1990. Trata-se de uma exposição portátil, por meio da qual o espectador poderia explorar, mediante uma visita em três dimensões, três galerias interligadas. Tal como o catálogo, era uma forma de o público levar para casa uma parte do museu para compartilhá-lo ou visitá-lo quando bem quisesse.

Ainda naquela década, diferentes museus produziram a sua versão virtual e portátil nesse mesmo formato, a exemplo do Museu do Louvre e do Museu 
Hermitage ${ }^{18}$, em São Petersburgo, Rússia. É importante ressaltar que tal mídia era encarada mais como souvenir, memória da visita ou forma de suprir o desejo de "possuir" do que como uma nova versão ou substituto (HUHTAMO, 2002). Todavia, já estavam ali as ideias de rede e de acessibilidade que hoje perpassam o conceito do museu disponível no ciberespaço.

É sabido que a transformação da world wide web (www) em um ambiente multimídia, por meio do navegador Mosaic (1993), foi uma das grandes contribuições como estrutura para o surgimento do museu no ciberespaço, entretanto não é aí que está a sua origem, mas sim na invenção do hipertexto, o que se deu na década de 1960.

A gênese da ideia de hipertexto já está no artigo "As we may think", escrito em 1945, pelo matemático e físico norte-americano Vannevar Bush (LÉVY, 1995). Nesse artigo, Bush critica o sistema de indexação e ordenação de informação utilizado pela comunidade científica da época por ser de natureza linear e limitada, alegando que a mente humana não funciona dessa maneira, mas por associações. Ele propõe então a criação de um dispositivo, o Memex, cuja função é mecanizar a classificação e a seleção de informações (textos, sons e imagens) por associação, de forma paralela aos princípios clássicos de indexação.

Já o termo hipertexto foi cunhado pelo filósofo e sociólogo norte-americano Theodor Nelson e expressava a ideia de um processo de escrita e de leitura não linear em um sistema de informática. A ideia de Nelson girava em torno de produzir uma rede imensa e acessível em tempo real, na qual estivessem contemplados todos os tesouros literários e científicos já produzidos pela humanidade, o qual denominou de "xanadu". Por essa rede, as pessoas poderiam escrever, interagir, interconectar-se, tecer comentários sobre filmes, textos, imagens ou qualquer tipo de informação ali disponível (LÉVY, 1995). Sendo assim, “xanadu, enquanto horizonte ideal ou absoluto do hipertexto, seria uma espécie de materialização do diálogo incessante e múltiplo que a humanidade mantém consigo mesma e com seu passado" (LÉVY, 1995, p. 17).

Foi somente com base nessas ideias de então que se tornou possível pensar uma arquitetura não linear de informação (HUHTAMO, 2002), assim como escreve Sheiner (2004, p. 216):

\footnotetext{
${ }^{18}$ Mais informações em: <http://hermitagemuseum.org/wps/portal/hermitage/>.
} 
Nesse processo, a internet é o fenômeno que mais tem contribuído para a globalização dos comportamentos (GANT, 2001).

Bajo la metáfora de la aldeã global se consolidó un esquema nuevo de relaciones sociales y culturales en el que el mistizage, el sincretismo y el cosmopolitismo se han instalado definitivamente, dando passo a outra metáfora, más urbana, la ciudad de Internet ${ }^{20}$ (GANT, 2001, p. 237).

É nesse novo contexto da "ciberdemocracia" (MATHIAS, 1998) que surgem as experiências virtuais de museus disponíveis no ciberespaço. Ou seja, por um computador ou dispositivo móvel conectado à internet, é possível acessar a produção artística e cultural de diversos lugares do planeta. A vivência da arte torna-se uma experiência cotidiana que está disponível a qualquer pessoa que tenha acesso a essa tecnologia, seja por meio de um aparelho celular, tablet, notebook, seja pelo computador de um cibercafé qualquer. Essas experiências cibernéticas de museu acabam por quebrar com a ideia de templo e propiciam ao visitante até mesmo organizar a sua própria coleção.

Como citado anteriormente, os museus institucionais têm a sua origem no desejo de posse, já que as primeiras coleções públicas são fruto de diferentes coleções particulares, antes restritas a um reduzido número de pessoas.

Praticamente desde o seu surgimento, o museu tem sido alvo de críticas, sobretudo no período modernista, quando a sua função social foi questionada de maneira mais intensa (GANT, 2001). Como exemplo, pode-se tomar o Manifesto futurista, escrito por Filippo Tommaso Marinetti (1909), que propõe até a destruição dos museus (LYNTON, 2000).

No contexto das vanguardas históricas, destaca-se também a figura de Marcel Duchamp (1887-1968), cuja produção é marcada por gestos que dessacralizam tanto a arte, a figura do artista, como a instituição museu. Chegou a criar um museu imaginário de seus próprios trabalhos, gesto que foi apressado, dada a iminência de uma guerra europeia, já que poderia funcionar como uma maneira de preservar a sua produção (TOMKINS, 2013). Para tal, produziu cópias e miniaturas de seus principais trabalhos, os quais abrigou em uma maleta. Além das

\footnotetext{
20 "Sob a metáfora de aldeia global um novo esquema de relações sociais e culturais em que a mestiçagem, o sincretismo e o cosmopolitismo foram permanentemente instalados definitivamente, em direção a outra metáfora, mais urbana, a cidade da internet" (livre tradução).
} 
300 edições dessa maleta, confeccionadas no período de 1936 a 1941, que pode ser entendida como um museu pessoal e portátil, Duchamp fez uma tiragem luxuosa de 20 exemplares revestidos em couro e mais quatro, que não seriam comercializados.

Foi essa versão de luxo que ficou conhecida como boîte-en-valise (caixa-valise).

Cada caixa-valise de couro continha 69 itens "de ou por Duchamp ou Rose Sélavy", como está informado na tampa, e mais uma obra original - nas doze primeiras, o original é uma das impressões coloridas que Duchamp fez para orientar os impressores. Aberta a valise de couro, suspensa a tampa da caixa interna até que ficasse em posição vertical e puxados os compartimentos corrediços nos dois lados, estariam, engenhosamente expostas as pinturas mais importantes de Duchamp (TOMKINS, 2013, p. 355).

É interessante observar que na boîte-en-valise as diferenças entre o original e a cópia se diluem, tendo em vista que em algumas dessas malas o artista fazia constantes melhorias. Por esse motivo, pode cada uma delas ser considerada única. Duchamp inseriu, em meio às reproduções, também trabalhos originais (TOMKINS, 2013).

Por meio dessa experiência, já são colocadas em pauta perguntas que permeiam a ideia de um museu existente no ciberespaço. Além de não possuir lugar fixo e de questionar a importância da originalidade, de suprir o desejo de posse, a exposição virtual de Duchamp está em constante movimento, na medida em que pode ser exercitada pelo espectador, que, ao mesmo tempo em que é espectador, também é dono. Segundo Gant (2001, p. 241),

estas dos ideas, la posesión de obras de arte propia del ser humano y la creación de un museo imaginario que albergue todas las creaciones artísticas y no imponga unos discursos sesgados al espectador, se conjugan en los museos virtuales. Para hacer realidad esta idea ya hace algunos años se han comenzado a digitalizar obras de numerosos museos ${ }^{21}$.

Diferentemente do processo fotográfico, por meio do qual as imagens nascem como índices, ou seja, pela relação direta, de contiguidade, com a realidade física, a imagem de natureza digital surge enquanto dado. 0 processo de

\footnotetext{
21 “Essas duas ideias, a posse de obras de arte própria do ser humano e a criação de um museu imaginário que abrigue todas as criações artísticas e não imponha discursos tendenciosos ao espectador, combinam-se nos museus virtuais. Para fazer dessa ideia realidade, há muitos anos se começaram a digitalizar obras de numerosos museus" (livre tradução).
} 
digitalização implica a numeralização, e, ao se tornar código, a digitalização pode facilmente ser inserida no ambiente cibernético. Entretanto observa-se que, para Lévy (2001), o digital é dotado de natureza potencial, e não virtual, pois

o virtual só eclode com a entrada da subjetividade humana no circuito, quando num mesmo movimento surgem a indeterminação do sentido e a propensão do texto a significar, tensão que uma atualização, ou seja, uma interpretação, resolverá na leitura (LÉVY, 2001, p. 40).

Nessa perspectiva, o museu virtual, que também pode ser virtual digital, só existe no tempo presente, e o surgimento da imagem digital contribui como uma importante ferramenta de acessibilidade para as experiências virtuais de museus, que podem disponibilizar potencialmente todo o seu acervo.

Segundo Deloche (2005), por meio do uso da imagem de natureza digital, o museu cumpre pelo menos três de suas funções mais importantes:

- preservação ${ }^{22}$, tendo em vista que pode ter todo o seu acervo digitalizado e armazenado em um banco de dados;

- exposição, que pode ser realizada tanto pelo destaque e problematização de determinado recorte, como também por meio da disponibilização das imagens do seu acervo para que os visitantes as visualizem;

- estudo, mediante a apresentação de informações, análises críticas e históricas sobre cada objeto do acervo, além de colocar todos esses dados disponíveis para estudiosos e pesquisadores continuarem a construir conhecimento.

É importante constatar também que o processo de digitalização contém as mesmas vantagens da fotografia, porém acrescido da possibilidade de trabalhar diretamente sobre os pixels. Ao ter a sua imagem digitalizada, uma pintura, por exemplo, ela pode ser reprocessada e modificada facilmente, de maneira que sua cor, seu tamanho e sua textura possam ser desviados substancialmente do original (LÉVY, 1995). Esse recurso, ao mesmo tempo em que representa um perigo quando se trata da reprodução de uma obra ou de um documento, consiste em uma

\footnotetext{
${ }^{22}$ Ressalta-se aqui que a ideia de preservação é no sentido de manter um registro do original enquanto dado para a memória, e não no sentido de manter a perenidade e integridade da peça física.
} 
ferramenta fértil quando utilizada por um artista, sem contar que a imagem digital serve de suporte para a imagem de síntese, aplicada para a criação de obras e cenários fictícios (DELOCHE, 2004). Ou seja, possibilita a recriação em meio cibernético de lugares, construções e monumentos existentes no mundo físico, a exemplo da Abadia de Cluny, na França, ou dos aquedutos romanos (SCHEINER, 2004), assim como também para que sejam concebidos ambientes pensados especialmente para o espaço virtual, a exemplo do Museu Virtual de Artes El País, o Muva.

Existente somente no ciberespaço, o Muva simula a experiência física de museu tanto no que diz respeito à construção arquitetônica como também na lógica de percurso pelo site proporcionada ao público. Possui duas versões: o Muva I, construído em duas dimensões, e o Muva II, realizado dez anos após o primeiro e que consiste em uma atualização da primeira versão para três dimensões. Ele foi concebido, segundo sua idealizadora e diretora Alicia Haber, como um espaço social e educativo especialmente projetado para a produção artística uruguaia, já que o Uruguai não possui espaços adequados para a exposição de $\operatorname{arte}^{23}$.

Por meio do Muva, são promovidas exposições temporárias e permanentes que podem ser visitadas por qualquer pessoa com acesso à internet. Em função de sua natureza digital, é possível ter contato com produções pertencentes a diferentes coleções particulares e que dificilmente seriam visualizadas em um mesmo espaço. Tais mostras, organizadas com base em critérios estabelecidos pela curadoria, envolvem tanto trabalhos realizados em meios de expressão tradicionais e que foram digitalizados como por aqueles de natureza multimídia e interativa, como, por exemplo, a webart. Ao clicar no trabalho escolhido, o público tem a oportunidade de visualizá-lo em uma janela de forma isolada, assim como tem acesso às informações escritas acerca do trabalho em questão e do artista que o fez. Entretanto, embora faça uso das possibilidades de visualização oferecidas pelo ciberespaço, o Muva apresenta algumas limitações técnicas, dadas a lentidão do programa e a dificuldade de controle no processo de "circulação" por seus corredores, bem como questões de ordem estética, pois o desenho do museu reproduz a estrutura arquitetônica do mundo físico e de um museu tradicional, não

\footnotetext{
${ }^{23}$ Mais informações em: <http://muva.elpais.com.uy/flash/muva.htm?\&lang=sp>.
} 
explorando os recursos próprios da realidade virtual, tal como o Museu Temporário da Mudança Permanente.

Acredita-se que a reprodução de uma estrutura arquitetônica existente na realidade física ${ }^{24}$ contribua para que o Muva funcione quase que como um manifesto à falta de incentivo do governo uruguaio para a construção de museus, além de reforçar a relevância de ter uma instituição museológica que cumpra, também no mundo físico, o papel social e educativo que só vem sendo concretizado no contexto cibernético. Todavia, questionam-se os motivos pelos quais a grande maioria das experiências virtuais de museu não tem explorado as especificidades da arquitetura não linear para a realização de exposições ou propostas participativas. Por que manter como referência o espaço físico para a realização de museus virtuais, o qual, em muitos casos, é reproduzido fielmente, diante das possibilidades que esse espaço proporciona?

Deloche (2004) discute o museu virtual de um ponto de vista filosófico e entende a arte como dotada de uma tripla reciprocidade: o estético, ligado ao sentir; o museal, que diz respeito ao expor; e, por sua vez, o virtual, que implica o substituir:

Contrariamente a lo que frequentemente cremos, explorar las formas del museo virtual no es hacer ciência ficción, sino má bien todo lo contrario, ya que se trata, en certa manera, de arqueologia museal, puesto que el museo virtual ha precedido al museo institucional ${ }^{25}$ (DELOCHE, 2004, p. 17).

Nesse sentido, pela ótica de Deloche (2004), pode-se entender o museu virtual como um museu que existe em potência, para suprir as questões que envolvem a memória coletiva. Hoje, a solução padrão utilizada para resolver essas questões é um museu institucional, que cumpre três principais papéis: reunir testemunhos do passado; preservar; e gerir esses testemunhos. Tais papéis são realizados com base na articulação de três pilares: a coleção, a construção e a instituição (DELOCHE, 2005). Contudo, assim como afirma o autor, não é necessário que os três pilares estejam potencializados de forma atualizada para que cumpram

\footnotetext{
${ }^{24} \mathrm{~A}$ fachada principal do museu está até mesmo de frente para uma praça que é a reprodução de uma existente em Montevidéu, capital uruguaia.

25 “De forma contrária ao que frequentemente acreditamos, explorar as formas do museu virtual não é fazer ficção científica, mas sim o oposto, já que se trata, de certa maneira, de arqueologia museal, tendo em vista que o museu virtual precede o museu institucional" (livre tradução).
} 
as suas funções, já que estas podem ser exercidas de outras formas, como, por exemplo, simbolicamente.

Para Deloche (2004), entram em atuação as várias formas de museu virtual na ausência de um desses pilares. Uma coleção particular, por exemplo, constitui um museu sem instituição (pilar virtual). Um monumento histórico, ao qual 0 público vai, nas ruas, por não poder ser transportado, é um museu sem construção (pilar virtual). Ou mesmo o museu imaginário de Malraux (2011), que possui os três pilares apenas em potência, já que indica um museu que existe tendo o papel como suporte, afinal não é dotado, a não ser potencialmente, nem de um prédio, nem de uma coleção, nem mesmo da instituição. Assim, para Deloche (2005), o museu virtual consiste em um museu paralelo, sem lugar e sem paredes, um substituto não institucional do museu físico, diferente de cibermuseu:

En cualquier caso, el museo virtual no ha de confundirse con el cibermuseo, aunque se puede considerar que lo cubre con su tutela teórica. Se dirá que el cibermuseo no es más que una actualización contemporánea y particularmente es particular del museo virtual, el la medida en que pone en juego resortes que caracterizan "lo museal" tal y como ha sido definido anteriormente: su principal función es mostrar e intercambiar y, además, lo hace gracias a artefactos, haciendo malabarismos con los substitutos (la pantalla, el sonido, lo digital, los recorridos, las direcciones, etc.) ${ }^{26}$ (DELOCHE, 2002, p. 31-32).

Assim, o museu virtual, conforme Deloche (2004; 2005), é uma experiência não institucional de museu que existe em potência para suprir as necessidades do museu físico no que diz respeito à memória coletiva. Pode-se entender então que, para o autor, quando atua no espaço cibernético para exercitar uma das funções do museu, seja ela a acessibilidade do acervo, seja a divulgação dos seus programas e ações, ou mesmo a realização de exposições e a disponibilização de informações no cumprimento de seu papel educativo, trata-se de uma ferramenta do museu institucional, e não um museu por si só.

\footnotetext{
26 “Em qualquer caso, o museu virtual não deve ser confundido com o cibermuseu, embora se possa considerar que o envolva com sua tutela teórica. Pode ser dito que o cibermuseu não é mais do que uma atualização contemporânea e particurlamente é particular do museu virtual, na medida em que coloca em jogo recortes que caracterizam "o museal" tal como foi definido anteriormente: sua principal função é mostrar e intercambiar e, também, o faz graças a artefatos, fazendo malabarismos com os substitutos (a tela, o som, o digital, rotas, instruções, etc.)" (livre tradução).
} 
produzidos em meio virtual como aos mais variados produtos de hipermídia (CD, DVD, videotextos etc.) e aos terminais interativos ${ }^{29}$ inseridos no espaço físico dos museus tradicionais. Ressalta ainda que se deve diferenciar, no contexto do ciberespaço, a linha divisória que separa os museus virtuais dos bancos de dados dos museus existentes em espaço físico.

Nesse sentido, e de forma diversa à concepção de Deloche (2002; 2005), para a autora, o museu virtual é essencialmente um cibermuseu (SCHEINER, 2004, p. 263, grifo do original):

Conceitualmente, o cibermuseu não teria similar no mundo real: seria continuamente recriado, pela vontade de seus criadores, a partir de movimentos articulados do mouse ou de pincéis digitais. Poderia ainda existir nos pequenos aparatos individualizados da realidade virtual - que, colocados sobre os olhos de um indivíduo, literalmente o projetam para dentro da imagem.

Como exemplo de museu virtual, além do Muva, já citado anteriormente, Scheiner (1998) aponta o Museu da Pessoa ${ }^{30}$. Formado por um acervo que hoje possui mais de 17 mil depoimentos disponibilizados em formato de áudio, vídeo e texto e cerca de 60 mil documentos e fotos digitalizados, trata-se de um museu virtual colaborativo fundado em $1991^{31}$ por um grupo de pesquisadores, com base em um projeto de registro de história oral, na cidade de São Paulo.

0 objetivo do Museu da Pessoa, cujo site foi criado em 1997, é "registrar, preservar e transformar em informação histórias de vida de toda e qualquer pessoa da sociedade", assumindo como principal missão "ser um museu aberto, colaborativo que transforme as histórias de vida [...] em fonte de conhecimento,

\footnotetext{
${ }^{29}$ Entende-se por experiência interativa aquela que envolve a relação entre duas ou mais inteligências, mesmo sendo uma ou mais delas de natureza artificial.

${ }^{30}$ Mais informações em: <http://www.museudapessoa.net/pt/home>.

31 “Desde a sua criação, o Museu da Pessoa teve como objetivo estabelecer uma rede virtual de histórias de vida. A ideia de construir um museu de histórias de vida levou-nos a reconsiderar a noção de 'espaço', pois as pessoas são inúmeras e as histórias intangíveis. No início, pensamos que poderíamos estabelecer um banco de dados multimídia e divulgar informações em CD-ROM. À medida que a internet se tornou cada vez mais popular, o nosso projeto expandiu-se. Além de garantir o acesso à coleção, a internet é hoje a ferramenta que permite que as pessoas sejam não apenas receptores de informação, mas também para se tornarem agentes de sua própria história. Pela internet, os indivíduos e grupos tornam-se parte de uma comunidade maior. Suas histórias não são mais exclusivamente delas e tornam-se parte da memória coletiva. Uma memória permeada por múltiplas vozes, inclusive, histórias de pessoas de todos os setores da sociedade" (WORCMAN, 2004).
} 
compreensão e conexão entre pessoas e povos" para, assim, "construir uma rede internacional de histórias de vida capaz de contribuir para a mudança social"32.

Criado antes mesmo da internet, sua coleção era mantida em base digital por meio de bancos de dados multimídia e divulgada por intermédio de CD-ROM. Segundo Karen Worcman, uma das pesquisadoras fundadoras, o Museu da Pessoa já nasceu virtual e é fruto de uma ideia inovadora, tanto no que tange ao fato de reunir a história de vida das pessoas em um acervo como patrimônio como também pelo uso feito da internet. Diferentemente do que acontece em geral com os registros de história oral, que são arquivados em bibliotecas públicas ou em espaços acadêmicos, os arquivos do Museu da Pessoa estão disponíveis, em tempo integral, tanto para quem quiser acessá-los como também para aqueles que queiram ampliá-lo contando suas próprias histórias de vida. Conforme afirma,

From its inception, the Museum of the Person aimed to establish a virtual network of life stories. The idea of building a museum of life stories led us to reconsider the notion of "space", since people are innumerable and stories intangible. At first, we thought we would establish a multimedia databank and disseminate information on CD-ROM. As the Internet became increasingly popular, our project expanded. Besides guaranteeing access to the collection, the Internet is now the tool that allows people to be not only receivers of information, but also to become agents of their own history. Through the Internet, individuals and groups become part of a larger community. Their histories are no longer solely theirs and become part of collective memory. A memory pervaded by multiple voices, including histories of people from all sectors of society (WORCMAN, 2004) ${ }^{33}$.

Nos seus 25 anos de existência, já aprovou e executou 252 projetos, recebeu 18 prêmios nacionais e internacionais, realizou 74 exposições, 68 publicações e possui oito exposições permanentes em diferentes centros de memória.

\footnotetext{
${ }^{32}$ Mais informações em: <http://www.museudapessoa.net/pt/entenda/o-museu-da-pessoa>.

33 "Desde a sua criação, o Museu da Pessoa teve como objetivo estabelecer uma rede virtual de histórias de vida. A ideia de construir um museu de histórias de vida levou-nos a reconsiderar a noção de espaço, pois as pessoas são inúmeras e as histórias intangiveis. De início, pensamos que poderíamos estabelecer um banco de dados multimídia e divulgar as informações em CD-ROM. À medida que a internet se tornou cada vez mais popular, nosso projeto expandiu-se. Além de garantir o acesso à coleção, a internet é agora a ferramenta que permite que as pessoas não sejam apenas receptores de informação, mas que também se tornem agentes de sua própria história. Pela internet, indivíduos e grupos tornam-se parte de uma comunidade maior. Suas histórias não são mais exclusivamente suas; tornaram-se parte da memória coletiva. Uma memória permeada por múltiplas vozes, incluindo histórias de pessoas de todas as camadas da sociedade" (livre tradução).
} 
0 Museu da Pessoa está em constante movimento e renovação permanente, o que se dá por meio de diferentes vertentes de produção de conteúdo. Fazendo uso da estrutura e de possibilidades oferecidas pelo ciberespaço, o museu oferece um espaço no próprio site para que o internauta possa enviar a sua história de vida ou a de outras pessoas que conheça e também organizar as suas coleções pessoais por meio das histórias, dos vídeos e das imagens que ali se fazem disponíveis. 0 museu também desenvolve ações educativas objetivando com que os jovens possam, baseados em seu acervo, construir uma percepção tanto sobre o passado como também a respeito do tempo presente, pelos depoimentos de diferentes pessoas que viveram esses tempos. No espaço educativo do museu ${ }^{34}$, podem ser acessados publicações e roteiros em PDF, assim como as coleções virtuais em formato de podcasts, o que permite com que os arquivos sejam disponibilizados em MP3 para download gratuito.

Trata-se de um museu includente, de participação potencial de qualquer membro da sociedade (SCHEINER, 2004), já que utiliza sua natureza desterritorializada, imaterial e mutante para se fazer e refazer por intermédio da interação e contribuição das pessoas e cujo acervo pode ser acessado e exercitado por qualquer um que tenha acesso à internet. É um museu que, embora não exista exclusivamente no ciberespaço, é essencialmente virtual, existente apenas em potência, mas vivo, e que cumpre uma das mais importantes funções do museu, a social, na medida em que contribui para a construção de uma identidade coletiva, para o incentivo à alteridade e para a valorização do patrimônio imaterial, que são as pessoas e as suas histórias.

Com o desenvolvimento de experiências de museus virtuais no espaço cibernético, tais como o Muva e o Museu da Pessoa, constata-se que a visita ao espaço físico e o consequente contato com o original não são a única maneira e, em muitos casos, nem mesmo a melhor de estabelecer relação com o acervo de uma determinada coleção. As possibilidades apresentadas pelas experiências de museu no ambiente virtual permitem com que o público se relacione com 0 patrimônio artístico e cultural de modos jamais possíveis no espaço físico e tão profundas quanto, já que, como afirma Scheiner (1998), o museu virtual configura-se como uma

\footnotetext{
${ }^{34}$ Mais informações em: <http://www.museudapessoa.net/pt/educativo/area-educativa>.
} 
manifestação imagética das novas tecnologias da informação e da comunicação. Desterritorializado, existe apenas em processo, na memória do computador ou nos aparatos de realidade virtual. Recria-se continuamente, e não tem limites. No museu virtual, o homem tem uma relação inusitada com o tempo, o espaço, a matéria e com sua própria capacidade de criar e de penetrar-se (SCHEINER, 1998, anexo 1).

Cabe observar que não está sendo proposto aqui que a experiência de arte diante do original, no espaço físico do museu, possa ser substituída pela tecnologia. Defende-se sim a ideia de que as imagens digitalizadas dos originais, disponibilizadas pelos museus e instituições culturais na internet, dependendo de como e por intermédio de quais recursos, podem proporcionar ao visitante uma experiência estética tão aprofundada como aquela vivenciada no museu físico, assim como também a construção de conhecimento. Ou seja, trata-se de outro tipo de vivência e que muitas vezes funciona até como forma preparatória à visita ao museu, ou mesmo complementar, após a visita. Assim como afirma Scheiner (1998, p. 108), o museu virtual

é o museu que se institui no contemporâneo, e que dele herda a face: impessoal, pode ser o museu de um autor só ou o resultado de uma colagem; intemporal, existe apenas no presente; imaterial, independente da existência prévia de testemunhos, podendo surgir pela presentificação imagética das imagens e sensações do museu interior. Desterritorializado, é o museu do não-lugar - e simultaneamente de todos os lugares, pois entra em rede $e$ alcança o mundo em tempo real. E embora potencialmente alcance o mundo, é a antítese da cultura de massa - pois acessar 0 museu virtual é um ato isolado, que depende dos tempos e espaços perceptuais de cada indivíduo (SCHEINER, 1998, p. 108, grifo do original).

Nesse sentido, mesmo como fenômeno, o museu virtual pode ser entendido como uma instituição que tanto mantém preservada a memória dos objetos como aquela que coloca esses objetos ativos em contato com o público (DELOCHE, 2002).

As experiências de museu no ciberespaço têm cumprido muito bem esse papel, tanto de aproximação do público com seu patrimônio artístico e cultural como também o de preservação da memória pela digitalização de diferentes acervos. E tem feito ainda mais, na medida em que disponibiliza ferramentas e atividades participativas por meio das quais o público não apenas observa, mas 
exercita a coleção. Não existem mais possibilidades de negar a importância da inserção dos museus no ambiente virtual, entretanto, conforme pôde ser observado durante a organização do mapeamento de experiências de museus disponíveis na internet, o qual será discutido mais à frente, parece que a ideia de um museu virtual na web ainda está em estado de desenvolvimento, tendo em vista que na maioria dos casos a estrutura do museu físico ainda permanece como modelo, o que impede com que as da internet sejam exploradas em suas inúmeras possibilidades. De acordo com Menezes (2006, p. 59),

\begin{abstract}
cada vez mais encontro fundamentos para acreditar que o museu deveria ser o lugar de perguntas, muito mais do que das respostas. Sua principal função educacional seria ensinar a fazer perguntas. 0 mundo virtual está plenamente capacitado para esta função. Entretanto, não é o que vem acontecendo na prática. Antes de mais nada, também no museu virtual tem dominado o paradigma do conhecimento observacional, em detrimento do discursivo. E as "experiências" que ele propõe são predominantemente instrumentais. Dessa forma, o museu exerce um papel homologatório, abastecido na maior parte de respostas prontas. De novo, sob a aparência da interatividade, continua-se a propor enganosamente que ver é o melhor caminho do conhecer.
\end{abstract}

Nesse sentido, pode-se entender que a construção do conhecimento em detrimento do simples entretenimento e da absorção de informação talvez seja um dos maiores desafios do museu virtual existente no espaço cibernético. Esse desafio também está sendo enfrentado pelas figuras do curador e do educador, cujos papéis têm de ser revistos e cujas atuações poderão contribuir para que a experiência em um museu no ambiente virtual em rede não se resuma no abrir e fechar janelas.

0 museu físico está para o objeto assim como o museu no ciberespaço está para a informação. Ao transformar a arte em informação e torná-la acessível a um público diversificado, o que deve ser feito com recursos e ferramentas que façam com que que essa informação se torne conhecimento, o museu virtual em rede torna-a ativa culturalmente. Logo, pode-se entender essa experiência virtual de museu como um agente cultural, já que possibilita a dinamização entre a arte, 0 indivíduo e a sociedade. E possivelmente esse será o futuro do museu. 
0 museu virtual pode ser concebido como o conjunto de museus possíveis, ou o conjunto de soluções possíveis aplicada às problemáticas às quais responde, notadamente, o museu clássico. Assim, o museu virtual, em uma acepção que não é a do cibermuseu, pode ser definido como um "conceito que designa globalmente o campo problemático do museal, isto é os efeitos do processo de descontextualização/recontextualização. Tanto uma coleção de substitutos quanto uma base de dados informatizada constituem um museu virtual. Trata-se do museu em seus teatros de operações exteriores" (Deloche, 2001). 0 museu virtual, ao se constituir como uma gama de soluções possíveis para a questão do museu, inclui naturalmente o cibermuseu, mas, nessa perspectiva, não se reduz a ele (DESVALLÉES; MARIESSE, 2013, p. 67 , grifos do original).

Existem, na atualidade, inúmeras e diferentes experiências de museus virtuais nos contextos do ciberespaço, sendo o cibermuseu, já discutido neste texto, apenas uma delas.

\subsection{As experiências de museus virtuais na web}

Por meio de pesquisa na internet realizada no período de quatro anos (2012 a 2016) tomando-se por base o termo museu virtual (e virtual museum), foi constatado que sites de museus, de instituições culturais ${ }^{35}$, assim como aqueles organizados e geridos por artistas, curadores e estudiosos de várias áreas, em variados formatos, com distintas propostas e conteúdos, são apresentados como tal, apesar de a maioria deles funcionar como um instrumento do museu em exercício no ambiente virtual em rede. Foram então mapeados, de início, 198 desses sites, produzidos em diferentes continentes. Tendo por objetivo identificar as experiências virtuais de museu disponíveis no ciberespaço, na primeira análise do mapeamento foram levados em consideração, como critérios de escolha, os seguintes aspectos:

1. reunir informações e imagens acerca do patrimônio artístico e cultural, ou então ser vinculado a um museu ou instituição cultural;

2. ter sido criado e ser gerenciado por alguma instituição ou por artistas, curadores e pesquisadores;

\footnotetext{
${ }^{35} \mathrm{Na} 20$. a Assembleia Geral do Icom, realizada em Barcelona no ano de 2001, aprovaram emendas ao artigo 2 dos estatutos de órgão que define o museu. A partir desse momento, centros culturais e entidades em geral voltadas à preservação, manutenção e gestão de bens patrimoniais tangíveis e intangíveis foram oficialmente inseridos na categoria de museu (LOUREIRO, 2004).
} 
3. ter seu conteúdo acessível ao visitante em geral, ou seja, não necessitar de senha para acesso.

Sendo assim, alguns websites que não atendiam aos critérios foram suprimidos, e outros, acrescentados, ou porque foram referenciados na bibliografia estudada, ou porque eram de instituições culturais de renome que não tinham aparecido no processo de busca. Ao final, a lista do mapeamento somou 155 websites. 0 conjunto foi então estudado e, tomando-se por base as afinidades entre as experiências observadas, na busca pela construção de um entendimento acerca delas, foi construída uma tabela (apêndice 1).

A princípio e de forma geral, foram observadas cinco experiências de museu no ambiente virtual em rede:

1. website de museu ou instituição cultural física composto apenas por informações;

2. website de museu ou instituição cultural física que disponibiliza banco de dados com imagens do acervo;

3. website de museu que apresenta a reprodução de espaço físico (edifícios de museus e de instituições culturais, de espaços expositivos, de lugares históricos etc.) com simulação de visita em três dimensões;

4. reunião de endereços eletrônicos de museus e instituições, de informações culturais e de imagens, sem possuir acervo próprio;

5. website de arte existente apenas no ciberespaço, com acervo próprio ou que disponibiliza imagens de trabalhos de outros acervos.

Durante o processo de investigação e estudo dessas experiências, foi também verificado quais delas se intitulam como museu virtual, quais disponibilizam ferramentas que promovem a participação do visitante e quais incluem exposições desenhadas especialmente para o ambiente virtual, tendo em vista que o gesto de expor pode ser entendido, conforme já dito anteriormente, como a instância relacional mais significativa do museu, além de o objetivo central desta tese girar em torno da construção de uma exposição virtual digital fundamentada na curadoria educativa. Por fim, viu-se também quais dessas experiências de museu possuem sede física.

No intuito de obter referências para melhor desenvolvimento e estudo das experiências mapeadas, foi realizada uma investigação acerca de tipologias 
construídas por diferentes autores: Ascott (1996), Gant (2001), Schweibenz (2004) e Piacente (1996 apud THEATER, 1998). Observa-se que Gant (2001) e Schweibenz (2004), antes mesmo da análise e organização de sua tipologia, já apresentam uma concepção de museu virtual formada e que até mesmo nomeia um dos tipos de museu por eles definidos. Já Ascott (1996) parte da afirmativa de que todas as experiências de museu existentes na internet são denominadas de WebMuseu, o qual, segundo ele, possui três tipos, sendo apenas o terceiro o museu virtual. Piacente ${ }^{36}$, por sua vez, identifica o que, para Theater (1998), chama de três tipos de websites de museu, sendo o segundo deles nomeado de museus no mundo virtual.

Valendo-se de diferentes autores, Gant (2001) faz um levantamento acerca de definições já existentes de museu virtual. De Sergio Talens-Oliag e José Hernández-Orallo, a autora compartilha o entendimento do museu virtual como uma réplica dos museus tradicionais inserida em suporte eletrônico. Segundo Talens-Oliag e Hernández-Orallo (1997 apud GANT, 2001, p. 249),

Los museos virtuales reciben fundamentalmente esta denominación porque suelen copiar los contenidos de algún otro museo real, siguen la obra de algún artista o tratan un tema especial. Aunque los museos virtuales no reemplazarán nunca las visitas físicas para ver los originales de obras históricas para la humanidad, cuando la distancia o las posibilidades económicas no permiten ir, siempre pueden ser una opción muy válida para un primer acercamiento, de una forma más próxima (virtual) a lo que sería la verdadera visita ${ }^{37}$.

Já em concordância com Arturo Colorado, autor do CD-ROM do Museu Thyssen-Bornemisza, em Madri, Espanha, Gant entende que o museu virtual consiste em um meio de facilitar o acesso ao público, que, além de ter contato com acervos de diferentes museus que possuem a sua coleção digitalizada, possibilita a

\footnotetext{
${ }^{36}$ Não foi possível ter acesso ao material original escrito por Piacente. Seu texto Surf's up: museums and the world wide web, fruto da pesquisa por meio da qual obteve o título de Master of Museum Studies, está localizado na Universidade de Toronto. Por esse motivo, a autora foi estudada com base em Theater.

37 "Os museus virtuais recebem fundamentalmente esta denominação porque costumam copiar os conteúdos de algum outro museu real, seguem a obra de algum artista ou tratam um tema especial. Ainda que os museus virtuais nunca substituam as visitas físicas para ver as obras originais de valor histórico para a humanidade, quando a distância ou as possibilidades econômicas não permitem ir a um museu real, sempre podem ser uma opção muito válida para um primeiro contato, de uma forma mais próxima (virtual) do que seria a verdadeira visita" (livre tradução).
} 
esse público organizar a sua própria coleção (COLORADO, 1997 apud GANT, 2001). De Antonio Cerveira Pinto, crítico de arte, escritor e artista português, um dos criadores do Museu Virtual de Alentejo ${ }^{38}$, Gant apropria-se da ideia de que o museu do futuro deverá se abrir para as possibilidades culturais. Segundo Pinto, tal museu pode ser imaginado como um parque ou um santuário da experiência estética e vai configurar-se em uma extensa rede interativa de base de dados multimídia, disponibilizada em meio eletrônico, de forma a possibilitar o intercâmbio entre as pessoas, enriquecido pela liberdade própria do ciberespaço (PINTO, 1997 apud GANT, 2001). Fundamentada nessas definições, com as quais a autora deste texto concorda, Gant (2001, p. 249-250) conclui:

Estas tecnologías son capaces de aprovechar esos avances para crear unos sistemas que permiten la interconexión entre comunicaciones electrónicas en red, sistemas de búsqueda y gestión de la información, procesos de digitalización, organización de bases de datos, hipertexto, interactividad, multimedia, realidad virtual, etc. Al servicio del goce estético y del conocimiento de las manifestaciones artísticas ${ }^{39}$.

Nesse sentido, percebe-se que o entendimento da autora acerca do que é um museu virtual, estabelecido com base nos autores citados, envolve tanto a reprodução do museu físico como também um espaço de interação com o público, por meio do qual este pode vivenciar experiências estéticas e ter contato com informações e imagens de acervos de um banco de dados multimídia, de forma a facilitar o acesso às informações. A partir daí, Gant (2001) estabelece então a sua tipologia, composta de três espécies de museus.

A primeira delas, segundo a autora, está fora do que se entende por museu virtual, pois engloba websites que apenas contêm informações incipientes sobre museus.

Se trata de una digitalización de los folletos informativos tradicionales, sin ningún tipo de enlace, jerarquización de la información ni actualización alguna. Son páginas de museos que

\footnotetext{
${ }^{38}$ Mais informações em: <http://elpais.com/diario/1997/09/09/cultura/873756005_850215.html>.

39 “Essas tecnologias são capazes de tirar proveito desses avanços para criar sistemas que permitem a interligação entre a rede de comunicações, sistemas eletrônicos de pesquisa e gestão da informação, digitalização, organização de bases de dados, hipertexto, interatividade, multimídia, realidade virtual etc., ao serviço do prazer estético e do conhecimento das manifestações artísticas" (livre tradução).
} 
no han entendido las posibilidades reales que tiene la red y se han conformado con el nivel más bajo de la difusión. Estos museos corren el riesgo de potenciar un efecto contrario en el posible visitante, pues ante una presencia tan pobre en Internet, pueden desistir de realizar una visita real ${ }^{40}$ (GANT, 2001, p. 250).

Mediante o processo de investigação e de análise dos sites mapeados, notase que hoje, 15 anos mais tarde, não foram mais encontrados exemplos dessa tipologia descrita pela autora, o que conduz ao entendimento de que o ambiente virtual em rede tem sido inesgotável foco de investimento e de exploração por parte dos museus e das instituições.

0 segundo tipo, já concernente ao que Gant (2001) define como museu virtual, engloba aqueles que, juntamente com as informações básicas, incluem a história da sede física e da coleção, informação dos serviços, das exposições em cartaz, das atividades complementares e, em alguns casos, possibilita 0 acesso ao catálogo da biblioteca, além de apresentar ligação com outros museus e instituições culturais. Conforme suas palavras, "son páginas interactivas y estructuradas a partir de enlances hipertextuais"41 (GANT, 2001, p. 250).

A terceira tipologia, por sua vez, diz respeito aos museus virtuais, que, segundo a autora, são de nível mais avançado, os quais incluem recriações do prédio ou de salas do museu e que permitem

auténticas inmersiones en la realidad virtual puesta al servicio del museo. Esta tipología, mucho más cara y sofisticada, no es por el momento la más habitual, aunque los importantes avances tecnológicos y su abaratamiento nos permiten pensar que se convertirá en la más empleada en un tempo de cercano ${ }^{42}$ (GANT, 2001, p. 250).

Observa-se que no mapeamento realizado no contexto desta tese, apenas 36 experiências de museu oferecem visitas virtuais com base na reprodução em

\footnotetext{
40 "Trata-se da digitalização dos folhetos informativos tradicionais, sem nenhum tipo de link, hierarquização da informação, nem nenhuma atualização. São páginas de museus que não compreenderam as possibilidades reais que a rede oferece e se conformam com o nível mais baixo da difusão. Esses museus correm o risco de potencializar um efeito contrário no possível visitante, pois, diante de uma presença tão pobre na internet, acabam desistindo de realizar uma visita real" (livre tradução).

41 "São páginas interativas e estruturadas a partir de links hipertextuais" (livre tradução).

42 “Autênticas imersões na realidade virtual posta a serviço do museu. Essa tipologia, muito mais cara e sofisticada, não é por enquanto a mais habitual, ainda que os importantes avanços tecnológicos e seus barateamentos nos permitam pensar que se tornará, em breve, a mais usada" (livre tradução).
} 
três dimensões de suas dependências físicas, o que significa que, ao contrário do previsto por Gant (2001), esse recurso não tem sido muito adotado. Entretanto fazse necessário ressaltar a existência do Google Art Project ${ }^{43}$, que pelo trabalho de parceria com museus e instituições culturais e da tecnologia oferecida pelo recurso Street View, desde 2011, disponibiliza visitas virtuais a galerias e espaços expositivos de instituições culturais do mundo todo. Por meio dessa ferramenta, além de visualizar em três dimensões as dependências dessas instituições, o público tem contato com imagens de peças do acervo em alta resolução e pode selecioná-las a fim de formar a sua própria galeria, acessível a todos os usuários cadastrados.

Durante o processo de mapeamento, embora essa informação não tenha sido apontada na tabela (apêndice 1), identificou-se que mais de dez dos sites mapeados apresentam link para o Google Arte Project. Apesar de se tratar de uma experiência que possibilita ao público conhecer as dependências físicas da instituição, seja na impossibilidade de estar lá fisicamente, seja na falta de interesse de estar presente no local, questionam-se os motivos pelos quais não são exploradas, pela maioria dos websites mapeados, também as potencialidades próprias do ambiente virtual em rede, na criação de novas experiências de exposição que não sejam a tentativa de reprodução da vivência física.

Por sua vez, Schweibenz (2004) estabelece quatro tipos de experiência, organizados mediante o processo de desenvolvimento do museu na internet: museu brochura, museu conteúdo, museu de aprendizagem e museu virtual.

0 museu brochura, o qual dialoga com a primeira tipologia estabelecida por Gant (2001), sendo, contudo, mais completa, é composto pelas informações básicas a respeito do museu, tais como a natureza da coleção, informações para contato, entre outras. 0 autor ressalta que o objetivo desse tipo é fornecer informações aos visitantes em potencial, o que hoje é adotado por 130 das 155 experiências de museu que foram mapeados, embora apenas 25 se restrinjam a isso.

Já o museu conteúdo, conforme explica, disponibiliza a sua coleção online e convida o visitante a explorá-la pelo site. 0 conteúdo é apresentado de forma orientada e quase idêntica à base de dados da coleção. Assim como afirma o autor, "it is more useful for experts than for laymen because the content is not didactically

\footnotetext{
${ }^{43}$ Mais informações em: <http://www.google.com/culturalinstitute/project/art-project>.
} 
enhanced"44 (SCHWEIBENZ, 2004), sendo o objetivo desse formato oferecer um retrato detalhado da coleção. Observa-se que, com o mapeamento (apêndice 1), foram identificadas 94 experiências de museu que disponibilizam banco de dados de imagens do acervo, contudo as vias de acesso são muitas, por título, por autor, por linguagem ou por mosaico de imagens.

0 museu de aprendizagem, por outro lado, é aquele que disponibiliza diferentes pontos de acesso à coleção, o que se dá pela idade, pelo background e pelo conteúdo do visitante. Conforme Schweibenz (2004), esse website "is didactically enhanced and linked to additional information that motivates the virtual visitor to learn more about the subject they are interested in and revisit the site" ${ }^{45}$. Portanto, 0 autor conclui que o objetivo desse tipo de museu é fazer tanto com que o visitante estabeleça uma relação pessoal com a coleção online, e assim volte ao website, como também com que se interesse por visitar o museu para ter contato com o objeto físico.

Considera-se o formato do museu de aprendizagem um dos propósitos primordiais da inserção do museu no ambiente virtual em rede. 0 que se observa é que a maioria dos sites mapeados possui um ambiente específico para o setor educativo dos museus apenas para disponibilizar informações sobre os programas oferecidos pela instituição. Alguns deles disponibilizam para download propostas educativas para serem realizadas na exposição, no espaço do museu. Apenas 40 oferecem jogos e atividades participativas para serem feitos no próprio website, ou aplicativos que servem como guia, trazendo informações complementares sobre os itens em exposição. Ou seja, mesmo tratando-se do ambiente virtual e de um conteúdo disponibilizado virtualmente, enriquecido por todo um universo de informações e possibilidades como pano de fundo, já que seu suporte é a internet, ainda é mais valorizada a experiência física como educativa em detrimento das possibilidades proporcionadas pela estrutura do espaço cibernético, que ainda não são exploradas pela grande maioria das instituições.

0 museu virtual, quarta e última tipologia estabelecida por Schweibenz (2004), configura-se, segundo o autor, no passo seguinte do museu de

\footnotetext{
44 “É mais útil para especialistas do que para leigos porque o conteúdo não é melhorado didaticamente" (livre tradução).

45 “É melhorado didaticamente e ligado a informações adicionais que motivam o visitante virtual a aprender mais a respeito do tema no qual está interessado e revisita o site" (livre tradução).
} 
aprendizagem, já que possibilita que se estabeleçam links com outras coleções digitais. Nessa perspectiva, conclui: "Digital collections are created which have no counterparts in the real world. This is the implementation of André Malraux's vision of the 'museum without walls"'46 (SCHWEIBENZ, 2004).

Essa ferramenta elencada pelo autor consiste em uma das especificidades a ser explorada no ambiente virtual em rede. Apesar de, conforme o mapeamento, 15 experiências de museus apresentarem links para websites de outras instituições, somente seis oferecem ao visitante a possibilidade apontada pelo autor. Ao organizar a sua própria galeria, o visitante não apenas absorve informação, mas constrói conhecimento na medida em que estabelece diferentes relações por meio de uma organização particular e do exercício do aprofundamento do olhar. Sendo assim, em concordância com Schweibenz (2004), os avanços ocasionados pelo desenvolvimento da tecnologia, que fazem com que a herança cultural seja digitalizada, e as coleções se tornem então mais acessíveis,

will blur the differences between cultural heritage institutions, and in the long run these institutions will merge into one memory institution. A memory institution combines digital surrogates of the collections of archives, libraries and museums in rich interactive environments and allows access to the content regardless of the nature of the institution. The goal of the memory institution is to preserve this content for future generations and support its use and management over time ${ }^{47}$ (SCHWEIBENZ, 2004).

Com essa afirmativa, o autor ressalta mais uma das virtudes ocasionadas pelo museu no contexto do ciberespaço. Nesse sentido, pode-se concluir que 0 museu virtual não representa ameaças ao museu físico, já que lida com substitutos (DELOCHE, 2005), sendo um deles a disponibilização de reproduções digitais de peças do acervo do museu, o que, independentemente da qualidade da imagem, não comuta jamais o contato com o original, mas configura-se em outro,

\footnotetext{
46 “Coleções digitais que não possuem contrapartidas no mundo real são criadas. Essa é a implementação da visão de André Malraux a respeito do museu sem fronteiras" (livre tradução).

47 "Vão mesclar as diferenças entre instituições de herança cultural, e a longo prazo essas instituições vão fundir-se numa instituição de memória. Uma instituição de memória combina substitutos digitais de coleções de arquivos, livrarias e museus em ricos ambientes interativos e permite acesso ao conteúdo independentemente da natureza da instituição. 0 objetivo da instituição de memória é preservar o conteúdo para futuras gerações e apoiar seu uso e gerenciamento ao longo do tempo" (livre tradução).
} 
oferecendo uma experiência diferenciada e até complementar. Ainda segundo Schweibenz (2004), o museu virtual "can extend the ideas and concepts of collections into the digital space and in this way revel the essential nature of the museum"48, já que o contato e a participação do público, o conhecimento construído e a experiência por ele vivenciada passam a assumir o primeiro plano. 0 desenvolvimento da tecnologia não possibilita apenas o acesso e a interpretação da produção artística e cultural, mas também permite com que se estabeleça uma relação entre a memória histórica e a memória coletiva, sem que a memória seja dissociada de seu dono (MENSCH, 2009).

0 britânico Ascott (1996), por sua vez, artista e teórico que pesquisa e trabalha com a cibernética e com a telemática, organizou as experiências de museus encontradas no ciberespaço, as quais, conforme já citado, denomina de WebMuseus, em três tipos: museus de primeiro tipo, museus de segundo tipo e museus de terceiro tipo.

Os museus de primeiro tipo são aqueles que correspondem aos websites de museus físicos, por meio dos quais são disponibilizados catálogos online e informações diversas sobre o museu, contudo por meio de uma página estática que não provoca o exercício do espectador com a coleção. Corresponde à segunda categoria de museu organizada por Gant (2001) e ao museu conteúdo de Schweibenz (2004).

Já os museus de segundo tipo são aqueles pensados para disponibilizar uma produção de arte que "is not originated in pigment, canvas, or steel, but which is composed of pixels from its inception, digitally destined from the start for the computer screen, which slips easily into the net for instant world wide consumption"49 (ASCOTT, 1996). Ou seja, trata da experiência de museu que lida com trabalhos construídos digitalmente com base em softwares e que são disponibilizados no ambiente virtual, tal como um terminal de computador que funciona apenas como um meio de passar informação. Os demais autores estudados não possuem categorias correspondentes a essa.

\footnotetext{
48 "Pode ampliar as ideias e os conceitos de coleções em espaço digital e, desse modo, revelar a essencial natureza do museu" (livre tradução).

49 "Que não tem origem em pigmentos, tela ou aço, mas que é composta de pixels desde seu princípio, digitalmente destinada para a tela do computador que facilmente desliza para dentro da net para consumo do mundo inteiro" (livre tradução).
} 
0 museu de terceiro tipo, por sua vez, é aquele do qual faz parte uma produção de arte que, segundo Ascott (1996), foi criada na rede, para a rede e existe somente nela. Trata-se de um ambiente cibernético com obras digitais que foram concebidas mediante programas e que não são disponibilizadas apenas para a visualização, mas para a interação com o visitante. Conforme afirma, o museu de terceiro tipo não faz uso do computador

as a video terminal, through which you view objects of art, a kind of digital carousel projector, but as a screen of operations, an interface, which enables you to enter into a process of manipulation and transformation of images, texts and sound. It deals not so much with the behavior of forms, the aesthetic of appearance, as with forms of behavior, the aesthetic of apparition, of coming-into-being. Your interaction is with its multi-mediated form and its many layered meanings. It is about the viewer being active in the creation of art, actually with the creation of meaning ${ }^{50}$ (ASCOTT, 1996).

Nessa perspectiva, pode-se entender o museu de terceiro tipo proposto por Ascott (1996) como um museu puramente relacional, no sentido de Bourriaud (2009), na medida em que encontra sua razão de ser e existência no exercício do visitante. Essa categoria é correspondente ao museu virtual de Schweibenz (2004).

Assim como Ascott (1996) e Gant (2001), Piacente (1996 apud THEATER, 1998) estabelece três categorias para as experiências de museu encontradas no ciberespaço. A primeira delas denomina de brochura eletrônica e engloba os websites de museu cuja preocupação está na apresentação visual e nas informações de ordem prática que por esse meio são transmitidas, tal como acontece com um folheto informativo impresso. Alguns desses sites são mais elaborados do que outros, contudo, ao acessá-los, o visitante não achará nada mais do que informações sobre a história da instituição, o corpo técnico, o perfil do acervo e os horários de funcionamento. Essa categoria é equivalente ao museu brochura de Schweibenz (2004) e ao museu de primeiro tipo proposto por Ascott (1996) e funciona como um meio de divulgação e de incentivo à visita física.

\footnotetext{
50 “Como um terminal de vídeo, pelo qual você pode visualizar objetos de arte, um tipo de carrossel de projetor digital, mas como uma tela de operações, uma interface, o que permite com que você entre em um processo de manipulação e transformação de imagens, textos e sons. Não lida tanto com o comportamento das formas, a estética da aparência, como com as formas de comportamento, a estética do vir-a-ser. Sua interação é com sua forma multimediada e seus muitos significados. É sobre o observador ser ativo na criação da arte, na verdade com a criação de significado" (livre tradução).
} 
Já a segunda categoria Piacente chama de museus no mundo virtual, por se tratar de experiências de museu que, segundo a autora, se projetam no âmbito da virtualidade. Consistem em websites que disponibilizam informações mais aprofundadas acerca do acervo e, em alguns casos, são disponibilizadas visitas virtuais. Fazendo uso das possibilidades oferecidas pelo ciberespaço, os museus dessa categoria mantêm, em alguns casos, segundo a autora, exposições temporárias que já foram desmontadas no museu físico, como se a internet fosse uma espécie de reserva técnica de exposições.

Como exemplo, a autora cita o Museu Peabody de Arqueologia e Etnologia ${ }^{51}$. Esse museu, além de manter as informações a respeito de exposições passadas feitas em seu espaço físico, o que se dá por textos, imagens e vídeos, disponibiliza por meio de sua experiência virtual em rede exposições online formadas por textos e imagens e articuladas por uma estrutura de hyperlink, de forma que não reproduz a lógica espacial de exposições físicas. Afirma Piacente (1996 apud THEATER, 1998) que consiste na recriação online do museu físico, contudo cabe observar que no desenvolvimento do mapeamento realizado nesta tese não foram verificadas experiências de museus em que exposições promovidas no espaço físico do museu também acontecem em seu ambiente virtual, nem como reprodução do espaço físico, nem na exploração da estrutura da web. 0 que se verificou foram algumas imagens de trabalhos que compuseram mostras ocorridas no prédio do museu, assim como, por vezes, imagens mais gerais mostrando o espaço expositivo, e vídeos, para que o visitante possa visualizar, de forma mais geral, a exposição em cartaz no momento, acompanhados por texto informativo, crítico ou curatorial. Ainda segundo Piacente (1996 apud THEATER, 1998), muitos dos museus no mundo virtual também disponibilizam uma base de dados com obras do acervo de modo que o visitante possa ter acesso a trabalhos que não estão em exposição naquele momento. Essa categoria é equivalente ao museu de segundo tipo de Ascott (1996) e ao museu de conteúdo de Schweibenz (2004).

Já os museus realmente interativos correspondem ao terceiro tipo de museu proposto por Piacente (1996 apud THEATER, 1998), e que, conforme sugere o próprio nome, engloba aqueles websites que disponibilizam ao visitante elementos de interatividade. Podem tanto reproduzir os conteúdos de seu espaço físico como

\footnotetext{
${ }^{51}$ Mais informações em: <https://www.peabody.harvard.edu/node/877>.
} 
também apresentar-se completamente diferentes. 0 mote das experiências de museus presentes nessa categoria é a interatividade. Como já citado, no mapeamento realizado nesta pesquisa, foram identificadas apenas 40 experiências de museus que oferecem ferramentas para participação do visitante, algumas interativas e outras não, entre elas a organização de uma galeria pessoal, espaço de opinião, jogos e atividades educativas, além de aplicativos para smartphones e tablets. Dialogam com esse tipo de museu proposto por Piacente (1996 apud THEATER, 1998) a segunda categoria de Gant (2001) e o museu de aprendizagem de Schweibenz (1996).

Com base no estudo das tipologias de Ascott (1996), Schweibenz (2004), Gant (2001) e Piacente (1996 apud THEATER, 1998) (tabela 1), pode-se perceber que elas não dão conta das experiências contemporâneas em sua totalidade, já que consistem em caixas em que não cabem perfeitamente, seja pelo tamanho, seja pelo formato.

\begin{tabular}{|c|c|c|c|c|c|}
\hline Autor & $\begin{array}{l}\text { Experiências } \\
\text { de museus na }\end{array}$ & \multicolumn{4}{|c|}{ Tipologia } \\
\hline $\begin{array}{l}\text { Schweibenz } \\
\text { (2004) }\end{array}$ & $\begin{array}{l}\text { Categorias de } \\
\text { museu na } \\
\text { internet }\end{array}$ & $\begin{array}{c}\text { Museu } \\
\text { brochura: site } \\
\text { de informações }\end{array}$ & $\begin{array}{l}\text { Museu de conteúdo: } \\
\text { base de dados que, } \\
\text { dada a sua } \\
\text { complexidade, é } \\
\text { acessível apenas por } \\
\text { especialistas }\end{array}$ & $\begin{array}{c}\text { Museu de } \\
\text { aprendizagem: mais } \\
\text { didáticos no que tange } \\
\text { ao acesso à informação, } \\
\text { incentivo para o visitante } \\
\text { conhecer o acervo do } \\
\text { museu e visitar o espaço } \\
\text { físico }\end{array}$ & $\begin{array}{c}\text { Museu } \\
\text { virtual: links } \\
\text { com outras } \\
\text { coleções } \\
\text { online; museu } \\
\text { sem paredes } \\
\text { (MALRAUX, } \\
\text { 2011) }\end{array}$ \\
\hline Gant (2001) & Museu virtual & $\begin{array}{c}\text { Primeira } \\
\text { categoria: não } \\
\text { considera } \\
\text { museu virtual; } \\
\text { site de } \\
\text { informações }\end{array}$ & $\begin{array}{l}\text { Segunda categoria: } \\
\text { informações mais } \\
\text { aprofundadas; links } \\
\text { com sites de outros } \\
\text { museus; } \\
\text { instrumentos de } \\
\text { interação com o } \\
\text { visitante } \\
\end{array}$ & $\begin{array}{l}\text { Terceira categoria: } \\
\text { recriação de prédios ou } \\
\text { salas de museus }\end{array}$ & \\
\hline Ascott (1996) & WebMuseus & $\begin{array}{l}\text { Museus de } \\
\text { primeiro tipo: } \\
\text { site de } \\
\text { informações }\end{array}$ & $\begin{array}{l}\text { Museus de segundo } \\
\text { tipo: base de dados } \\
\text { digital formada por } \\
\text { trabalhos que já } \\
\text { foram concebidos; } \\
\text { sem equivalente no } \\
\text { mundo físico, mas } \\
\text { estáticas; sem } \\
\text { oferecer interação } \\
\text { com o visitante }\end{array}$ & $\begin{array}{l}\text { Museus de terceiro tipo: } \\
\text { museu cibernético } \\
\text { formado por obras } \\
\text { digitais concebidas por } \\
\text { programas. Foi criado na } \\
\text { rede e só existe nela. } \\
\text { Disponibiliza } \\
\text { ferramentas interativas }\end{array}$ & \\
\hline $\begin{array}{l}\text { Piacente } \\
\text { (1996 apud } \\
\text { THEATER, } \\
\text { 1998) }\end{array}$ & $\begin{array}{l}\text { Website de } \\
\text { museus }\end{array}$ & $\begin{array}{c}\text { Brochura } \\
\text { eletrônica: site } \\
\text { de informações }\end{array}$ & $\begin{array}{l}\text { Museu no mundo } \\
\text { virtual: informações } \\
\text { mais aprofundadas, } \\
\text { consulta a banco de } \\
\text { dados com imagens }\end{array}$ & $\begin{array}{c}\text { Museus realmente } \\
\text { interativos: atividades } \\
\text { de interaçãa com o } \\
\text { visitante }\end{array}$ & \\
\hline
\end{tabular}

Tabela 1 - Tipologias dos autores estudados

Fonte: Primária 
Observa-se também que as experiências de museus disponíveis no ambiente virtual em rede estão em constante transformação, de forma que essas tipologias, com exceção daquela proposta por Piacente (1996 apud THEATER, 1998), já não englobam algumas ferramentas que estão sendo exploradas hoje, tais como jogos, atividades educativas e aplicativos para tablets e smartphones.

\subsection{Mapeamento de experiências de museus virtuais disponíveis na web}

Conforme citado anteriormente, o ponto de partida para o estudo das experiências de museu no ciberespaço foi a investigação empírica, o que resultou na construção de um mapeamento organizado em forma de tabela, e com base nisso tais experiências puderam ser mais bem analisadas (apêndice 1).

$\mathrm{Na}$ intenção de fugir da construção de uma tipologia, tendo em vista que isso já foi feito por diversos autores - entre eles quatro já aqui tratados -, foram então selecionadas, por meio da tabela do mapeamento, 15 experiências de museus, e elas serão discutidas considerando as características enfatizadas na sua construção. Sendo assim, tais experiências não serão enquadradas mediante uma tipologia, mas estudadas, levando-se em conta as características pontuadas no mapeamento, mas sem deixar de valorizar as suas especificidades.

0 objetivo deste estudo é conhecer o que os museus no ambiente virtual em rede têm explorado, especialmente de que maneira o seu acervo tem sido mostrado e exercitado, para que assim se tenham mais referências e subsídios para a construção da exposição que será realizada no MAC Schwanke Virtual.

Durante o processo de investigação, constatou-se que 130 das 155 experiências de museus mapeadas utilizam o website como um meio de divulgar a sua história, o perfil de seu acervo, seus programas e suas ações. Quase todos os importantes museus e instituições culturais do mundo possuem um website. Tratase de um espaço eficaz para a disponibilização de informações, tanto acerca dos horários de funcionamento, das exposições em cartaz e da coleção como das atividades e dos programas desenvolvidos no espaço do museu. Ou seja, pode funcionar como um instrumento de informação útil no que tange à divulgação da instituição e à preparação da visita in loco. Como afirma Gant (2001, p. 231-232): 
Los museos han convertido Internet en un substituto de las páginas tradicionales de sus boletines y publicaciones periódicas, folletos y catálogos, pero con la gran ventaja de posibilitar uno difusión de ámbito global. [...] Los boletines electrónicos están a disposición de cualquier usuario, no exigen costes de impresión y distribución u permiten su actualización al ritmo con que se producen las noticias ${ }^{52}$.

Pela natureza abrangente e acessivel da internet, é lógico que se faça uso dela como um instrumento de divulgação e difusão de informação, e, como já citado, isso já faz parte da rotina de boa parte das instituições culturais do mundo todo. Contudo, na atualidade, esse é apenas um dos propósitos da maioria das instituições quando inseridas no ciberespaço. Das 130 experiências de museu aqui mapeadas que disponibilizam informações, apenas 26 fazem uso do ambiente virtual em rede exclusivamente com essa finalidade, aos moldes dos museus de primeiro tipo de Ascott (1996), do museu brochura estabelecido por Schweibenz (2004) e do brochura eletrônica de Piacente (1996 apud THEATER, 1998) - eles já ultrapassam os limites da primeira categoria de Gant (2001). Desses 26 websites que não disponibilizam nada mais do que informações, nenhum se afirma como museu virtual. Ou seja, todos funcionam como uma ferramenta de divulgação do museu e auxílio para o visitante.

Diferentemente da primeira tipologia estabelecida por Gant (2001), que já naquela época não era entendida pela autora como museu virtual, todos os sites mapeados possuem estrutura hipertextual, o que possibilita a organização dinâmica, clara e objetiva de uma grande quantidade de informação. Destaca-se, nesse sentido, a experiência da Kunsthalle ${ }^{53}$, de Hamburgo, Alemanha. Além de disponibilizar todas as informações necessárias à visita - sobre a história da instituição, suas ações e seus programas -, informa o público acerca das exposições em cartaz, das que estão por vir e ainda mantém um banco de dados no qual há informações das exposições que já aconteceram. Além de textos a respeito das mostras, produzidos por curadores e estudiosos, são disponibilizadas inúmeras

\footnotetext{
52 " 0 s museus converteram a internet em um substituto das páginas tradicionais de seus boletins e publicações periódicas, folhetos e catálogos, mas com a grande vantagem de possibilitar difusão em âmbito global. [...] 0s boletins eletrônicos estão à disposição de qualquer um na rede, não possuem custo de impressão e distribuição e permitem sua atualização no mesmo ritmo com que se produzem as notícias" (livre tradução).

${ }^{53}$ Mais informações em: <http://hamburger-kunsthalle.de/index.php>.
} 
imagens de trabalhos que as compõem, acompanhadas de todos os dados, e disponíveis para serem visualizadas, em boa definição, em uma janela separada. Tais informações podem ser usadas tanto para a preparação como para a memória da visita. Apesar de o museu não disponibilizar pesquisa online à sua coleção, apresenta em seu website um excelente retrato do acervo, o que se dá por intermédio de textos e de imagens de alguns dos trabalhos de sua coleção.

Salienta-se também a experiência cibernética do Museu de Orsay ${ }^{54}$, de Paris. A instituição, além de possibilitar a consulta online ao acervo, deixa disponível ferramentas para a participação do visitante. Pelo acesso ao link My Selection, são apresentadas ao público, fora a possibilidade de consulta online, mais seis: 0 álbum, por meio do qual podem ser reunidas as imagens do acervo pelo banco de dados online; os e-cards, que consistem em cartões-postais virtuais disponibilizados pelo museu para que possam ser enviados por e-mail a quem quiser; os wallpapers, que são imagens do museu disponibilizadas para serem aplicadas como pano de fundo de telas de computador; saved searchs, recurso que faz com que se salve a pesquisa de conteúdo realizada no site; Planning your visit, tornando possível localizar no mapa do museu as obras do acervo em exposição, com a opção de impressão, para que se possa organizar melhor a visita ao espaço físico; e a ferramenta RSS feed, que possibilita com que o usuário receba as atualizações do site sem ter de visitá-lo.

São ferramentas bastante ricas que, ao mesmo tempo em que trazem o visitante virtualmente para dentro do museu, fazem com que o museu entre na vida do visitante. Nesse sentido, mais do que conhecer o perfil do museu e absorver informações, o visitante participa do site e trabalha a coleção tornando-a ativa, exercitando até mesmo o seu olhar e deixando para o museu, por meio da organização de sua própria mostra em My Selection, as suas próprias relações estabelecidas entre as obras da coleção.

Já o Museu de Arte Gibbes ${ }^{55}$, nos Estados Unidos, tem essa mesma ferramenta, que em seu site é nomeada de Criate Your Own Gallery, no espaço Learning, o que pressupõe que o museu a entenda como específica do setor educativo. Questiona-se, contudo, se a disponibilização desse recurso não deveria acontecer em um espaço de acesso mais fácil pelo público em geral, o que incentivaria tal exercício a um maior número de pessoas, tendo em vista que o

\footnotetext{
${ }^{54}$ Mais informações em: <http://www.musee-orsay.fr/en/home.html>.

${ }^{55}$ Mais informações em: <http://www.gibbesmuseum.org/>.
} 
educativo não precisa, nem deve, ser voltado apenas a professores e estudantes. Para que o público possa então criar a sua própria galeria, é necessário preencher um cadastro no site, o que por si só já acaba provocando uma relação de proximidade com o museu, já que como isso é possível ter um espaço pessoal, acessível somente por senha. Ainda no ambiente Learning, é possível tomar conhecimento dos programas educativos e de mediação oferecidos pelo museu, além dos guias de visita específicos para famílias e professores, disponíveis para download e possíveis de ser levados em mãos para a visita no espaço físico.

Embora essas duas experiências de museu estejam ainda aquém das possibilidades oferecidas pela estrutura do ciberespaço, cumprem muito bem a função de divulgação das instituições, tanto de suas coleções como das atividades por elas desenvolvidas, tornando-as conhecidas a um ilimitado número de pessoas, que por meio delas podem desenvolver interesse em visitar a instituição física. No entanto, apesar de terem sido mapeadas mediante a busca pelo termo museu virtual, acredita-se que tais entidades não se configuram como museus virtuais, tendo em vista que funcionam mais como convite e memória da visita física do que como suprimento das necessidades de um dos pilares do museu (DELOCHE, 2005). Afinal, não exercitam a coleção por intermédio de exposições, não disponibilizam atividades educativas e não oferecem espaços de troca com o público, funcionando mais como fonte de informação do que como um meio de construção de conhecimento.

Entre as experiências mapeadas, 95 disponibilizam ao visitante, além de informações sobre o museu, a exemplo do Museu de Arte Gibbes e do Museu de Orsay, pesquisa à sua coleção digitalizada por um banco de dados disponível online.

É uma difícil tarefa encontrar uma instituição que consiga colocar a sua coleção em sua totalidade em exposição no espaço físico de uma só vez (a não ser que se trate de um acervo pequeno), de forma que de tempos em tempos são feitos diferentes recortes, que, por sua vez, são fruto do olhar de curadores e estudiosos que põem em voga, na mostra, algumas problemáticas provocadas por aquele determinado conjunto de obras. Cabe ao público visitar essas mostras e acessar o seu museu imaginário (MALRAUX, 2011), formado com base em experiências anteriores, para estabelecer diferentes relações tendo como sustentáculo outros 
trabalhos que até podem integrar a coleção, mas que naquele momento não estão ali presentes.

Ao disponibilizar a reprodução de seu acervo online, o museu possibilita ao visitante suprir o seu desejo de visualizar outros trabalhos e estabelecer suas próprias relações com as peças da coleção, a qual está integralmente disponível. Todavia, observa-se que essa ferramenta é mais utilizada por estudantes, estudiosos e pesquisadores do que pelo visitante em geral, já que consiste em um banco de dados acessado principalmente por quem está em busca de alguma imagem específica. Ou seja, a ferramenta por si só não promove a ativação do acervo. Para tal, é necessário que seja oferecida alguma atividade, pautada em um objetivo específico, que incentive o visitante a realizar a pesquisa.

Assim, essa experiência, entre outras mapeadas, enquadra-se no museu de conteúdo de Schweibenz (2004), cujo acervo é acessível apenas para quem já conhece a coleção e sabe o que procura. Como mais um exemplo, pode-se citar também o Museu J. Paul Getty ${ }^{56}$, nos Estados Unidos, que, com exceção das aquisições recentes, que podem ser visualizadas facilmente em uma barra de rolagem, como ferramenta de pesquisa ao acervo digital se oferece somente um sistema de busca com base na inserção de dados, o que só pode ser feito por quem já conhece a coleção e tem o que procura em mente.

Já o Museu Hermitage oferecia em 2014 uma ferramenta diferenciada, denominada de Query by Image Content (QBIC). Por meio dela, a busca no banco de dados do acervo poderia ser realizada de duas maneiras: por cor (QBIC Color Search) e por tipo de composição (QBIC Layout Search). Mediante a pesquisa por cor, por intermédio de uma ferramenta de escolha de matiz e de tonalidade, o visitante podia pesquisar no acervo digital trabalhos equivalentes à composição de cores selecionadas (figuras 1 e 2 ).

${ }^{56}$ Mais informações em: <http://www.getty.edu/art/>. 

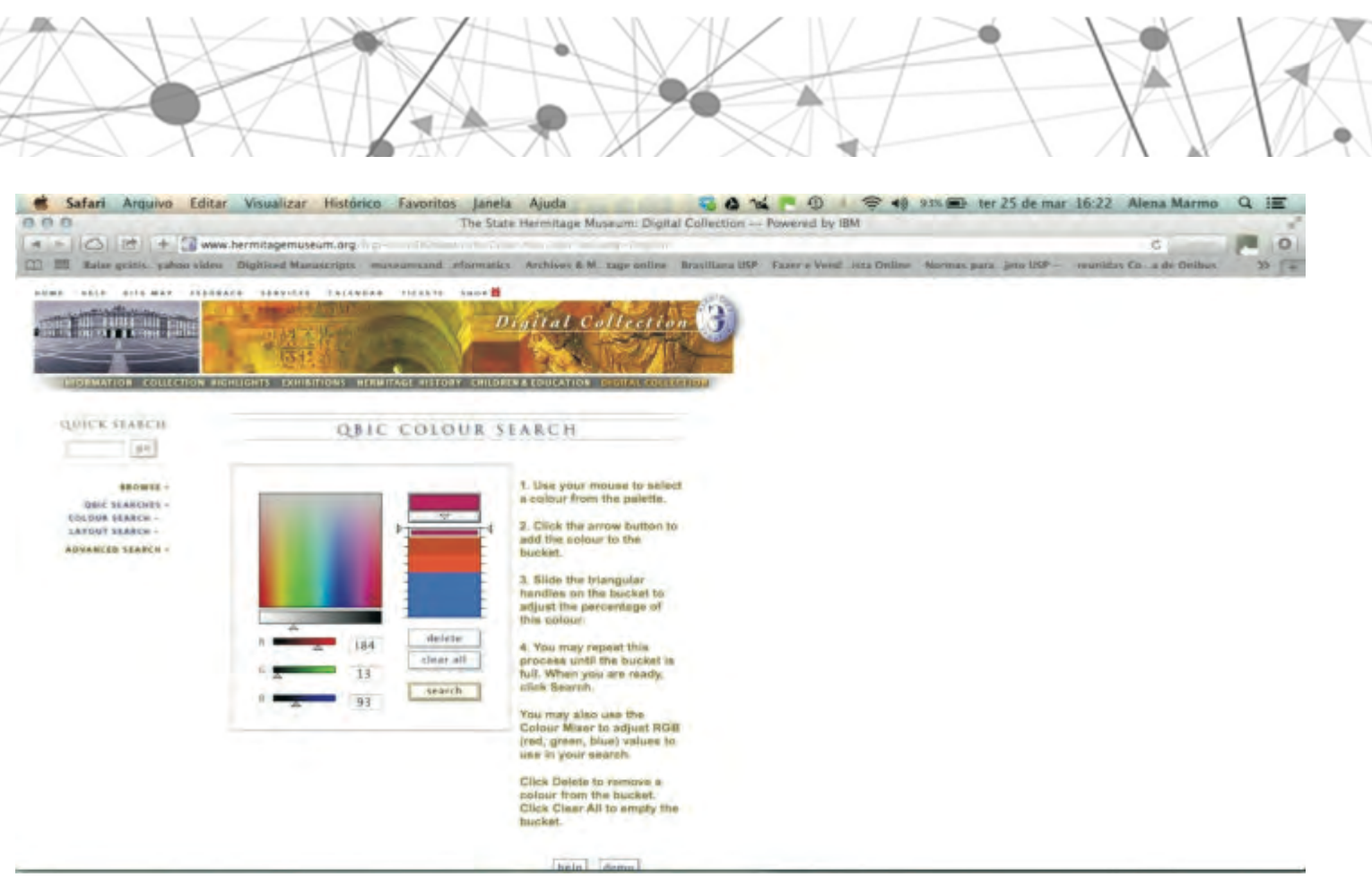

Figura 1 - Captura de imagem do site do Museu Hermitage mostrando a página da ferramenta de busca Query by Image Content Fonte: Primária

A imagem resultado da busca vinha acompanhada por seus dados técnicos, e, ao clicar no nome do artista, outra janela se abria com informações sobre ele. $\mathrm{Na}$ parte inferior da página, era oferecida ao público, por meio de uma nova ferramenta de busca, View Similar Artwork in the Digital Collection, a possibilidade de continuar a sua pesquisa por meio de outros trabalhos disponíveis no acervo online.

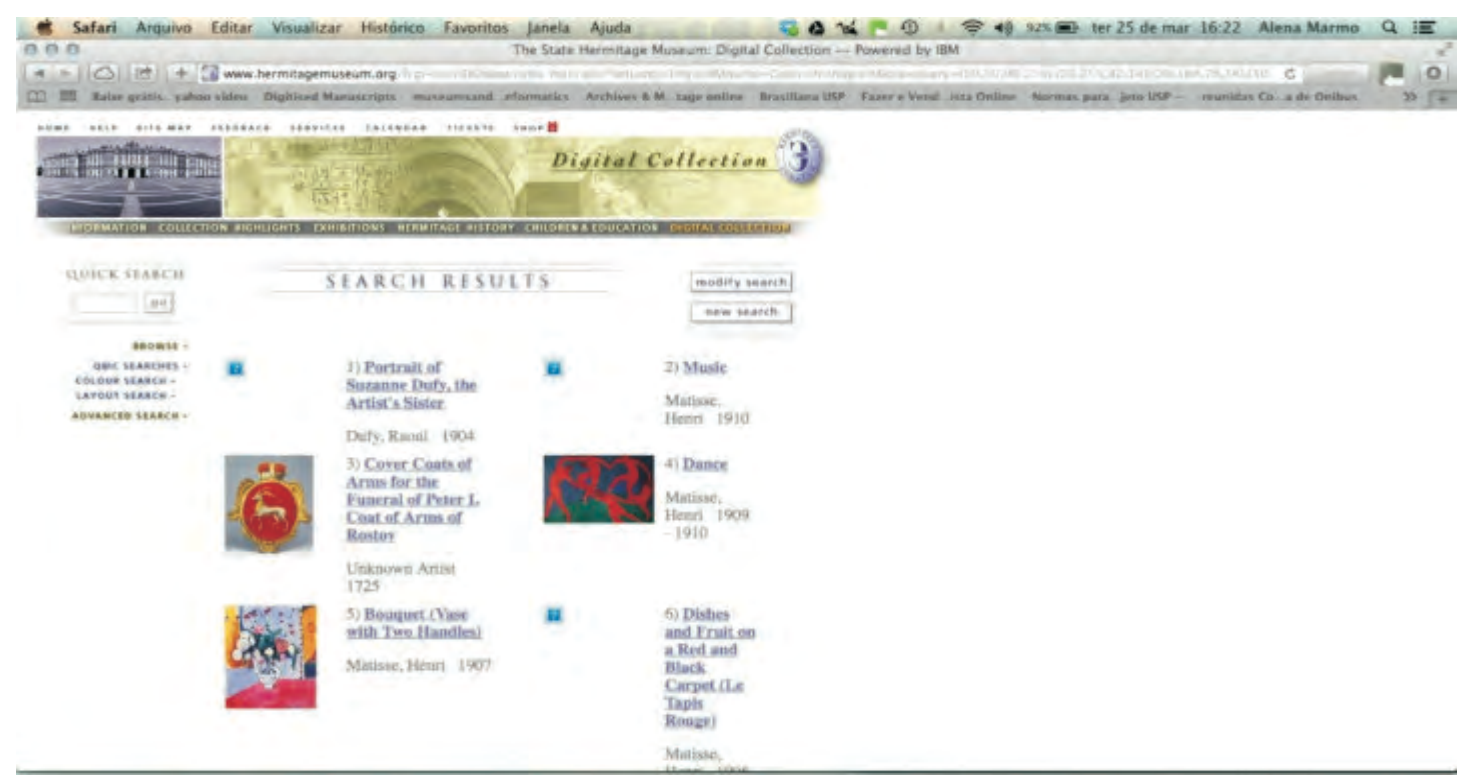

Figura 2 - Captura de imagem do site do Museu Hermitage mostrando a página do resultado de busca por meio da ferramenta Query by Image Content Fonte: Primária

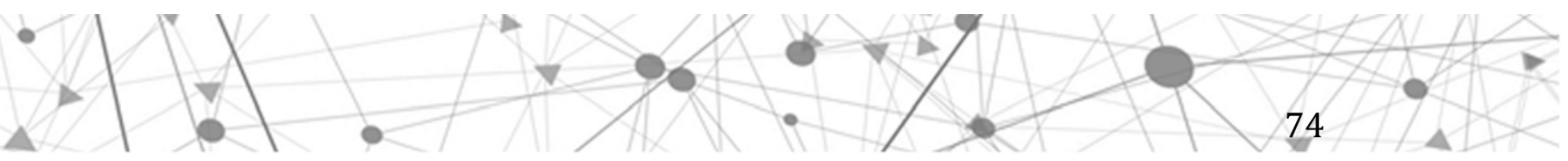


do Louvre do que no espaço físico do museu. Isso não se dá apenas pela proteção que envolve a obra nem pela grande distância que a separa do público, mas também pelos recursos hoje oferecidos pela tecnologia. No website do Google Art Project, por exemplo, a reprodução da pintura, assim como de inúmeros outros trabalhos, é disponibilizada em gigapixel. Com essa ferramenta, é possível verificar os craquelamentos ocasionados pela ação do tempo, o que dificilmente pode ser visto em detalhes a olho nu. Com a tecnologia da imagem, pode-se também enxergar os pormenores das pinceladas e de elementos da composição, os quais, diante do original, no espaço de exposição, passariam desapercebidos. A visualização acontece de forma isolada das demais imagens que compõem a sala, sendo as interferências de outra ordem, como a moldura da tela do computador, por exemplo. Ou seja, não substitui, mas possibilita outro tipo de experiência, que também deve ser valorizada e explorada.

Entre as 95 experiências de museus que disponibilizam consulta ao acervo digitalizado e online, apenas 17 oferecem jogos e atividades para serem desenvolvidos no próprio ambiente virtual, por meio de computador, tablet ou smartphone, e interação com as redes sociais.

Dessas experiências, destaca-se o Museu Nacional do Prado ${ }^{57}$, na Espanha. $\mathrm{Na}$ investigação iniciada em 2014, a experiência cibernética desse museu oferecia um ambiente denominado de Prado Media. Por ele, o público encontrava-se diante de quatro possibilidades de acesso a informações e atividades que exploravam a coleção por inúmeros recursos:

- Exposiciones: era possível ter acesso a informações gravadas em audiovisual acerca de exposições passadas e atuais, assim como também de mostras que estavam acontecendo em outras instituições;

- Colección: com conteúdos em áudio sobre imagens do acervo em exposição no museu físico, os quais poderiam ser utilizados tanto como áudio guia como também uma forma de obter informação online, já que as imagens estavam disponíveis no site;

- Educación: registros audiovisuais das conferências realizadas pelo museu, de itinerários online pelos espaços expositivos mediante

\footnotetext{
${ }^{57}$ Mais informações em: <http://www.museodelprado.es>.
} 
diferentes temas, de encontros com professores e de atividades educativas feitas com as crianças. Também estavam disponíveis por meio desse link as edições do Projeto Otros Ojos para ver el Prado, pelo qual vários estudiosos de diferentes áreas, acompanhados pelos restauradores do museu, analisaram os principais trabalhos do acervo que integravam a mostra permanente. 0 espaço educativo não apenas informava as atividades e os programas promovidos pelo museu como também permitia ao visitante impossibilitado de se fazer presente a vivência da exposição, ainda que por meio de gravações;

- Juegos: 11 jogos a serem realizados online eram disponibilizados. Um deles era nomeado de puzzle. Conforme sugere o próprio nome, tratava-se de um quebra-cabeça construído com base na imagem de uma das obras que compõem o acervo. No primeiro momento, a reprodução da pintura El vino de la fiesta de San Martín (1565-1568), de Peter Bruegel, estava disponível para contemplação de maneira que ocupava boa parte da tela e em alta resolução, possibilitando a sua observação em detalhes. Essa imagem aparecia acompanhada do título e do nome do autor, assim como também de um breve histórico de quando foi incorporada ao acervo do museu. Também apareciam nessa tela as instruções do jogo, colocadas de forma clara e objetiva (figura 4). 

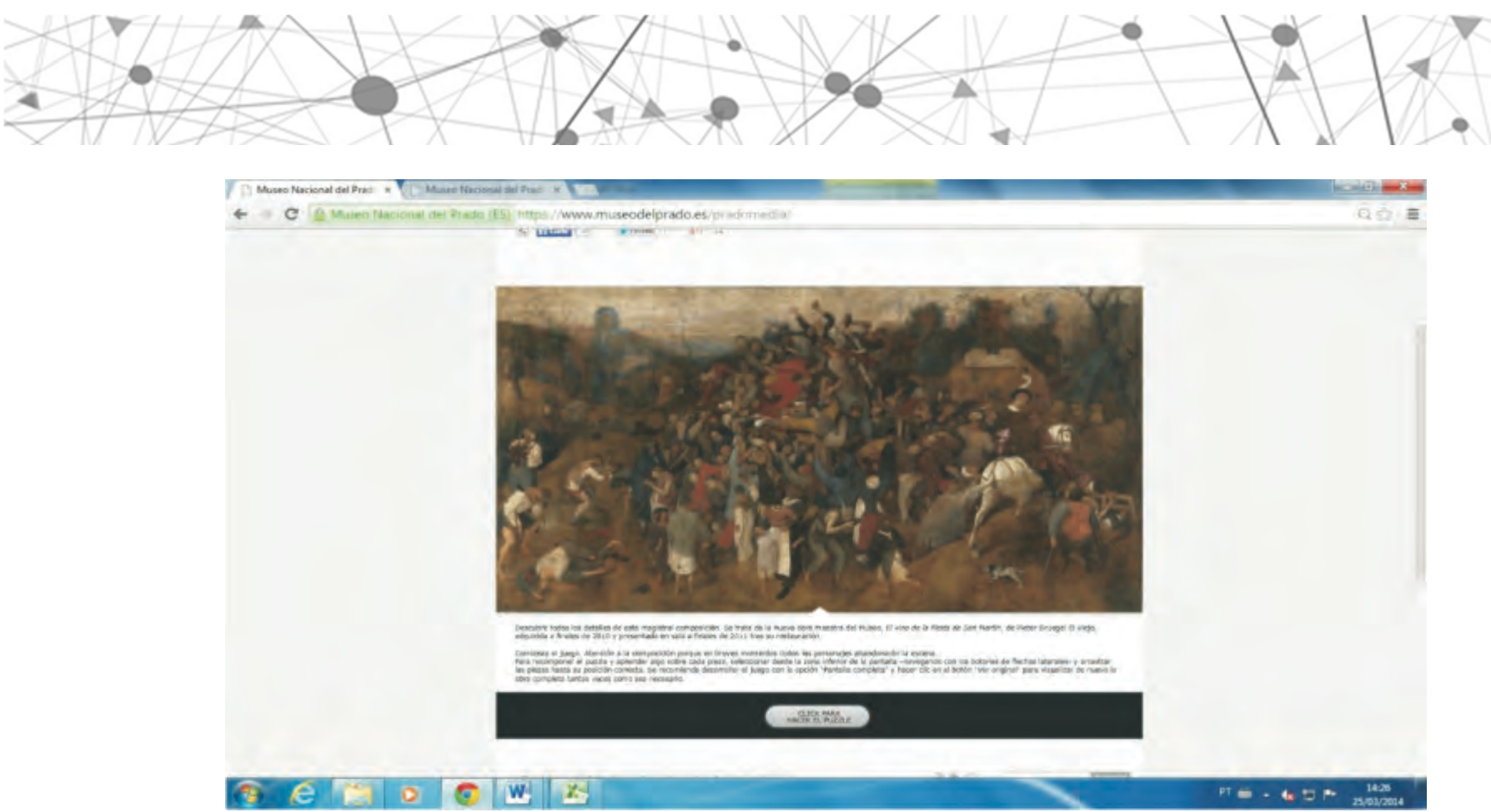

Figura 4 - Captura de imagem do site do Museu Nacional do Prado com a pintura de Peter Bruegel antes de começar o quebra-cabeça

Fonte: Primária

Ao clicar na instrução Click para hacer el puzzle, as figuras humanas que compõem a imagem sumiam gradativamente, deixando um espaço preto na formação do jogo, o qual deveria ser preenchido pelo visitante com as figuras disponibilizadas na parte inferior da tela, em uma barra de rolagem (figura 5).

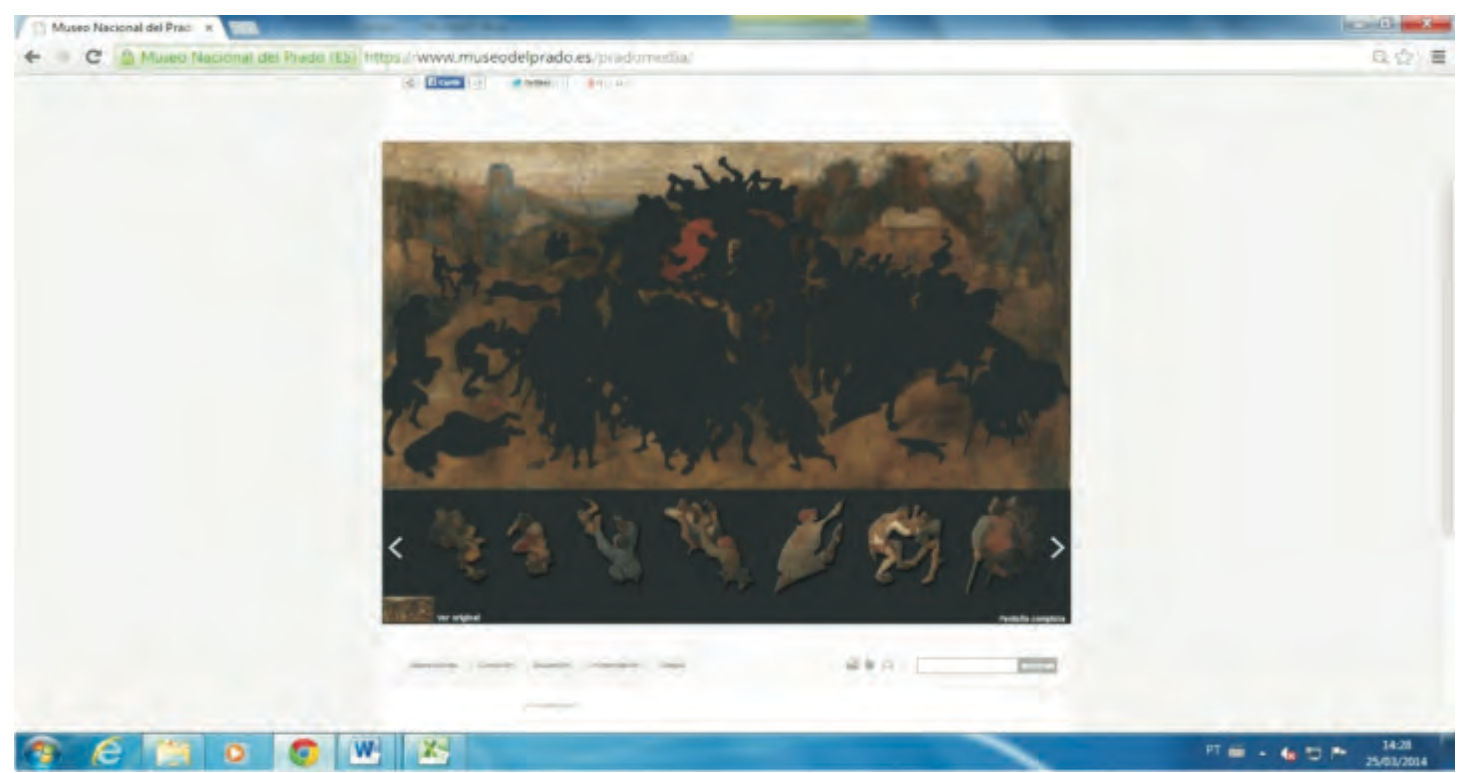

Figura 5 - Captura de imagem do site do Museu Nacional do Prado com o quebra-cabeça formado após o desaparecimento das figuras

Fonte: Primária

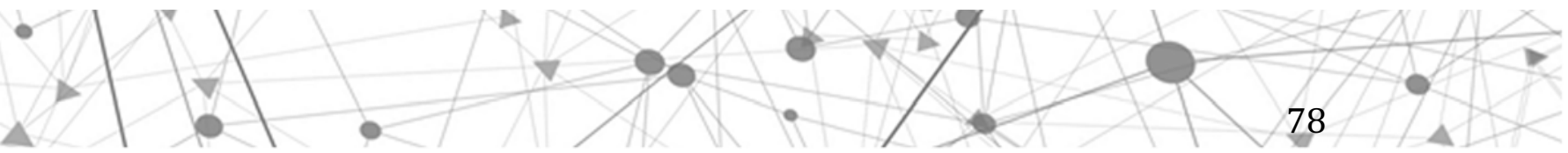


Ao inserir a figura em seu lugar correto, aparecia um pequeno texto informativo sobre ela apontando a sua importância para a composição (figura 6).

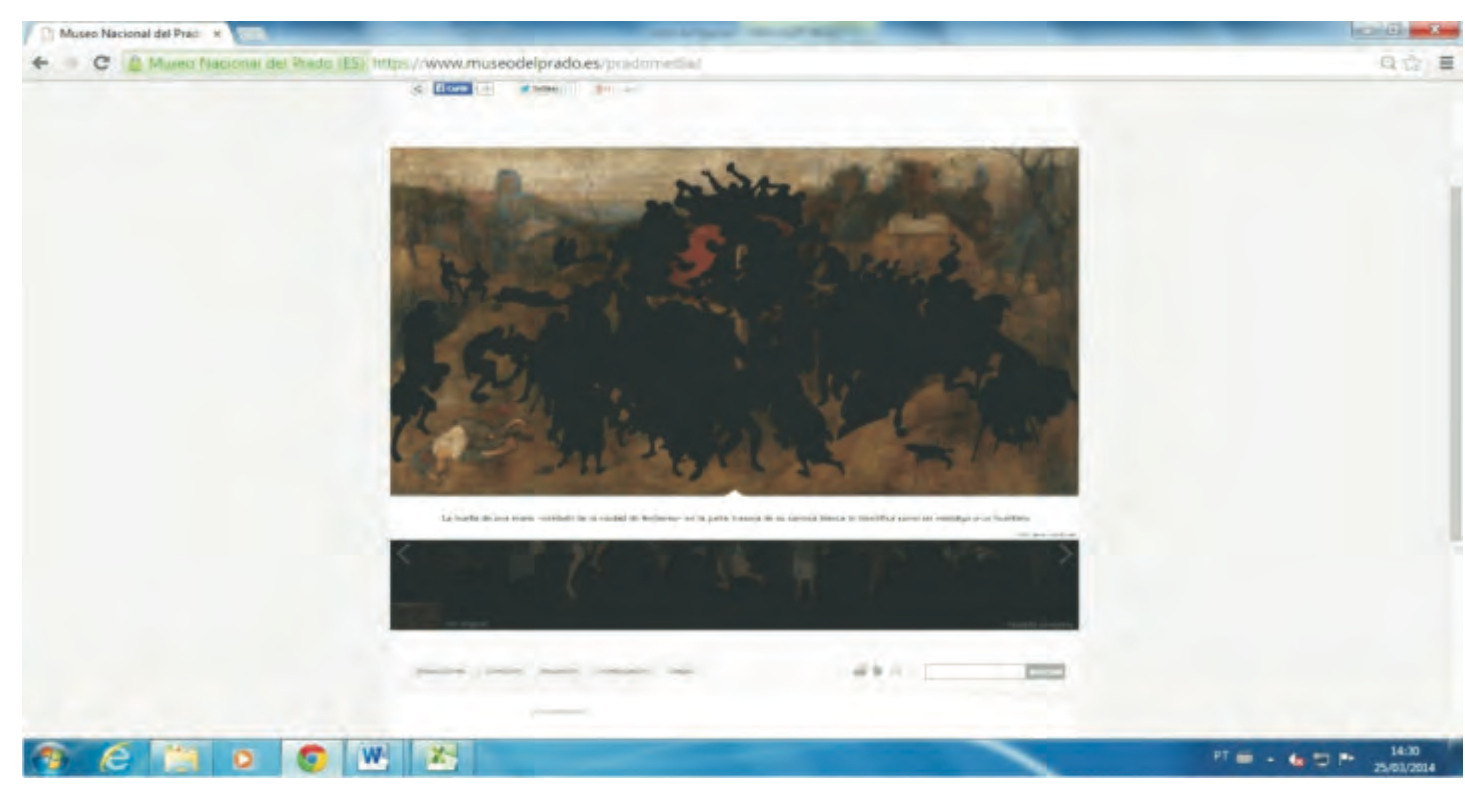

Figura 6 - Captura de imagem do site do Museu Nacional do Prado com a figura inserida em seu lugar correto e o texto referente a ela Fonte: Primária

Com essa experiência, antes oferecida pela experiência virtual do Museu Nacional do Prado, é possível perceber como os recursos próprios do ciberespaço podem proporcionar experiências educativas por intermédio de atividades lúdicas. Tratavase de uma forma extremamente rica e única de vivência diante de um trabalho de arte, mesmo sendo uma reprodução. Por essa experiência, o visitante poderia desenvolver interesse em visitar o museu para ter contato com o trabalho original, e, se o fizesse, a sua experiência estética seria mais profunda do que se tivesse observado o trabalho pela primeira vez. Caso isso não acontecesse, a experiência do jogo ainda não perderia a sua importância nem o seu caráter educativo, já que por meio dela seria possível o exercício de aprofundamento do olhar.

Entretanto, conforme já dito anteriormente, as mudanças no contexto da web acontecem depressa, tão depressa que antes mesmo de finalizar esta pesquisa a experiência cibernética do Museu Nacional do Prado, assim como aconteceu com o Museu Hermitage, mudou. Agora, em 2016, não existe mais a página Prado Media.

Na versão atual, ao acessar o website, o visitante depara com uma das imagens das obras que estão em exposição no museu como pano de fundo. Sobre ela aparece o título da mostra e o período de exposição. No lado direito inferior,

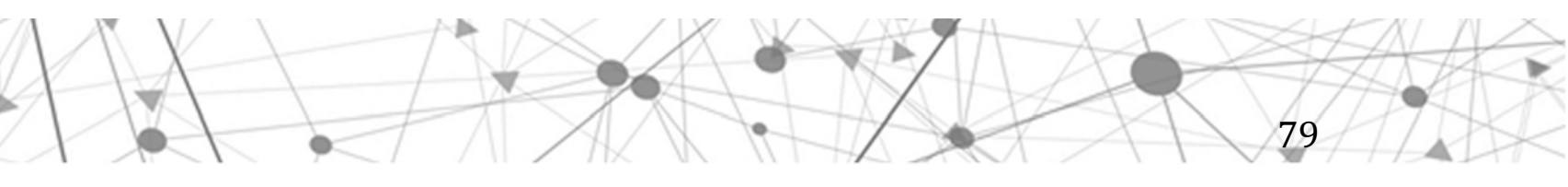


consta a ficha técnica do trabalho em destaque. Ao rolar a página, surgem novas imagens de outras exposições em cartaz no museu. No fim da página, são disponibilizadas informações de ordem prática sobre o museu, tais como 0 endereço, os telefones para contato, o e-mail e os horários de funcionamento. Ou seja, já na página de apresentação do website é dado destaque ao acervo.

Já na barra horizontal superior, o visitante encontra-se diante de nove possibilidades de acesso. As seis primeiras são Collection, Whats-on, Visit, Learn, Museum e Shop, as quais são separadas delicadamente por uma linha vertical do hiperlink My Prado, separado por uma linha da ferramenta de escolha da língua do website, que, por sua vez, é separada por uma linha da ferramenta de busca.

Em Collection, o visitante tem acesso a uma imagem centralizada, em destaque, de uma das principais obras do museu. Ao clicar sobre a figura, ela é disponibilizada em alta qualidade por uma ferramenta que permite a sua ampliação, de forma que a imagem pode ser percorrida pelo uso do mouse e visualizada em detalhes. Logo abaixo dela, do lado direito, aparece a ficha técnica. No centro constam informações textuais sobre a sua história e seu conteúdo e, do lado direito, são disponibilizados hiperlinks para que a imagem seja compartilhada nas redes sociais, ou enviada por e-mail, assim como também tags que conduzem o visitante a outras imagens do acervo do museu que tenham alguma relação com a então analisada, tal como linguagem, conteúdo ou momento histórico. Logo abaixo da imagem, em uma barra de rolagem horizontal, há, em menor tamanho e dispostas lado a lado, imagens de outras importantes obras do acervo do museu. 0 visitante pode optar por fazer a sua pesquisa e seleção pela barra de rolagem, ou clicar em See all Works, opção que conduz a uma nova página, intitulada de Explora la Colección, com mais de 11 mil resultados, que podem ser visualizados de diferentes formas, como em mosaico, lista ou uma a uma, ou por ordem cronológica, tema, nome de artista ou linguagem. Todos os resultados são acompanhados de informações textuais e, às vezes, de vídeos.

Em Whats-on o visitante encontra informações completas sobre as exposições que estão em cartaz, bem como comentários de pessoas, disponibilizados por meio das redes sociais, com base nas imagens selecionadas do acervo online. 
Por meio de Visit são disponibilizadas todas as informações necessárias para a realização da visita ao prédio do museu, e há também uma ferramenta para que seja feita a compra online da entrada ao espaço físico do espaço.

Ao acessar Learn, podem ser encontradas informações sobre a biblioteca do museu, tanto a física como a digital, a qual disponibiliza, em espanhol, o acesso a diversos livros e documentos de importância histórica, tais como manuscritos e inventários. Também estão aqui os catálogos online das exposições e arquivos sobre pesquisa e restaurações realizadas pela instituição. Ou seja, trata-se de um espaço utilizado para fornecer informações a aqueles que querem não somente pesquisar, mas também estudar a coleção.

Já em Museum, o visitante encontra informações a respeito da história da arquitetura do museu, da Associação de Amigos do Museu, além de ter contato com aplicativos para download, link para redes sociais e notícias.

Se assim for de seu interesse, em Shop o visitante pode comprar produtos vendidos pelo museu, desde catálogos, jogos e agendas a objetos diversos.

Por sua vez, pelo My Prado, o visitante tem acesso ao ambiente interativo do museu, por meio do qual ele pode criar a sua própria conta. Isso o possibilita criar o seu próprio itinerário com base na coleção online, itinerário esse que pode ser compartilhado nas redes sociais, além de ficar disponível no próprio site do museu para a visualização dos demais visitantes.

Com as mudanças realizadas, percebe-se que o website ficou mais dinâmico e que explora melhor a natureza rizomática da web, pois propicia ao visitante 0 exercício da coleção e o seu compartilhamento nas redes sociais. Por meio dessa experiência de museu, a sua instância relacional (BOURRIAUD, 2009) é colocada em primeiro plano, de forma que se trata de mais uma experiência em que o museu entra na vida das pessoas, o que faz com que a sua coleção fique viva e em movimento. Os jogos que estavam disponíveis na página virtual do museu em 2014, entre os quais se destacou o quebra-cabeça, exploravam possibilidades oferecidas pelo ambiente virtual no que tange aos recursos técnicos e também aos estruturais, contudo não se renovava; bastava ser jogado uma vez para esgotar as suas possibilidades, não sendo convidativo para que o visitante retornasse ao jogo uma vez mais. Talvez tenha sido esse o motivo pelo qual esse e os demais jogos tenham sido suprimidos do website, por já terem cumprido seu papel ao serem 
disponibilizados por um tempo, e por agora conflitarem com a atmosfera dinâmica das experiências de museu existente em rede.

Embora a maioria das experiências de museus que disponibiliza acervo para consulta online não ofereça ferramentas para o exercício da coleção no próprio ambiente cibernético, cumpre papel importante no auxílio do visitante para a preparação da visita, assim como também do professor, tanto na organização de atividades no prédio do museu como também em sala de aula. Sem contar que, conforme já citado anteriormente, pode funcionar como um incentivo à visita para a contemplação do original.

Por meio da disponibilização de sua coleção na internet, mesmo que seja reprodução, o museu torna-a mundialmente acessível e conhecida, de modo que as barreiras físicas não são mais empecilhos para que se tome conhecimento acerca do patrimônio artístico e cultural mundial, nem para que se vivencie a experiência estética ou para que se construa conhecimento mediante o exercício desse patrimônio. As experiências de museu mencionadas não apenas fornecem informações a respeito dos programas e das ações dos museus e de instituições culturais físicas, mas atuam como uma extensão desses espaços.

Alguns museus têm feito uso do ciberespaço para a reprodução não somente dos itens da coleção, mas também de seu espaço arquitetônico. Conforme já dito, foram mapeadas 36 experiências de museus que contêm visitas virtuais em três dimensões às suas dependências físicas. Segundo a tipologia estabelecida por Gant (2001), esse tipo de site configura-se na experiência mais avançada de museu virtual, entretanto o fato de se tratar da disponibilização de um acervo digitalizado, ou seja, composto por imagens numeralizadas ${ }^{58}$, não faz dessas imagens mais virtuais do que uma fotografia, uma pintura, um desenho ou uma imagem de qualquer espécie exposta no museu físico. De acordo com Lévy (2011), e assim como afirma Deloche (2002, p. 130), "lo virtual no se opone a lo real, como lo posible, sino que se opone a lo actual: es el estado de que todavia no se ha actualizado" ${ }^{59}$.

\footnotetext{
58 “Trata-se da imagem que passou pelo processo de digitalização e que, segundo Quéau (1999, p. 91, grifos do original), graças a sua natureza numérica e simbólica (no sentido matemático do termo), torna possivel todos os tipos de mediação entre linguagens formais e representações sensiveis".

59 “ 0 virtual não se opõe ao real, como o possível, mas se opõe ao atual: é o estado de que ainda não foi atualizado" (livre tradução)
} 
Entre a fotografia de uma paisagem, por exemplo, e a paisagem ela mesma, existe um processo de virtualização. Nesse sentido, pode-se entender o processo de virtualização como algo que muda de dimensão por uma espécie de deslocamento, o que acaba por resultar na produção de um equivalente de si mesmo, mas que é outro. Ainda segundo Deloche (2002, p. 132, grifo do original),

disociar los afectos de un sujeto afectado y los perceptos de un objeto percibido, sentir o hacer sentir la sensación por sí misma, es lo que se ha llamado el momento patico de la sensación, es decir, aquel momento en el que lo sensible se torna virtual ${ }^{60}$.

Tal momento patico, descrito por Deloche (2002), pode ser vivenciado tanto no museu físico, diante do original, como perante sua versão digitalizada disponível na internet. A experiência estética no museu virtual não é mais virtual do que uma experiência no museu físico; é apenas diferente.

A maioria dos museus na web que se afirmam virtuais não tem explorado essa diferença, mas a ideia de um duplo. Um dos sites que podem ser tomados como exemplo nessa tipologia é o do Museu Ashmolean de Arte e Arqueologia, que disponibiliza o que nomeia como Tour Virtual. 0 público pode escolher se quer ter a visão geral dos espaços da exposição, ou então percorrer os corredores e as salas do museu fazendo uso do mouse e dos comandos do teclado. Para tal, deve selecionar, em um mapa, o local que gostaria de visitar. Conforme se desloca o cursor pelo mapa, aparece o tema corresponde à sala (figura 7).

\footnotetext{
60 “Dissociar os afetos de um sujeito afetado e os perceptos de um objeto percebido, sentir ou fazer sentir a sensação por si mesma, é o que se tem chamado de momento patico da sensação, ou seja, aquele momento em que o sensível se torna virtual" (livre tradução).
} 

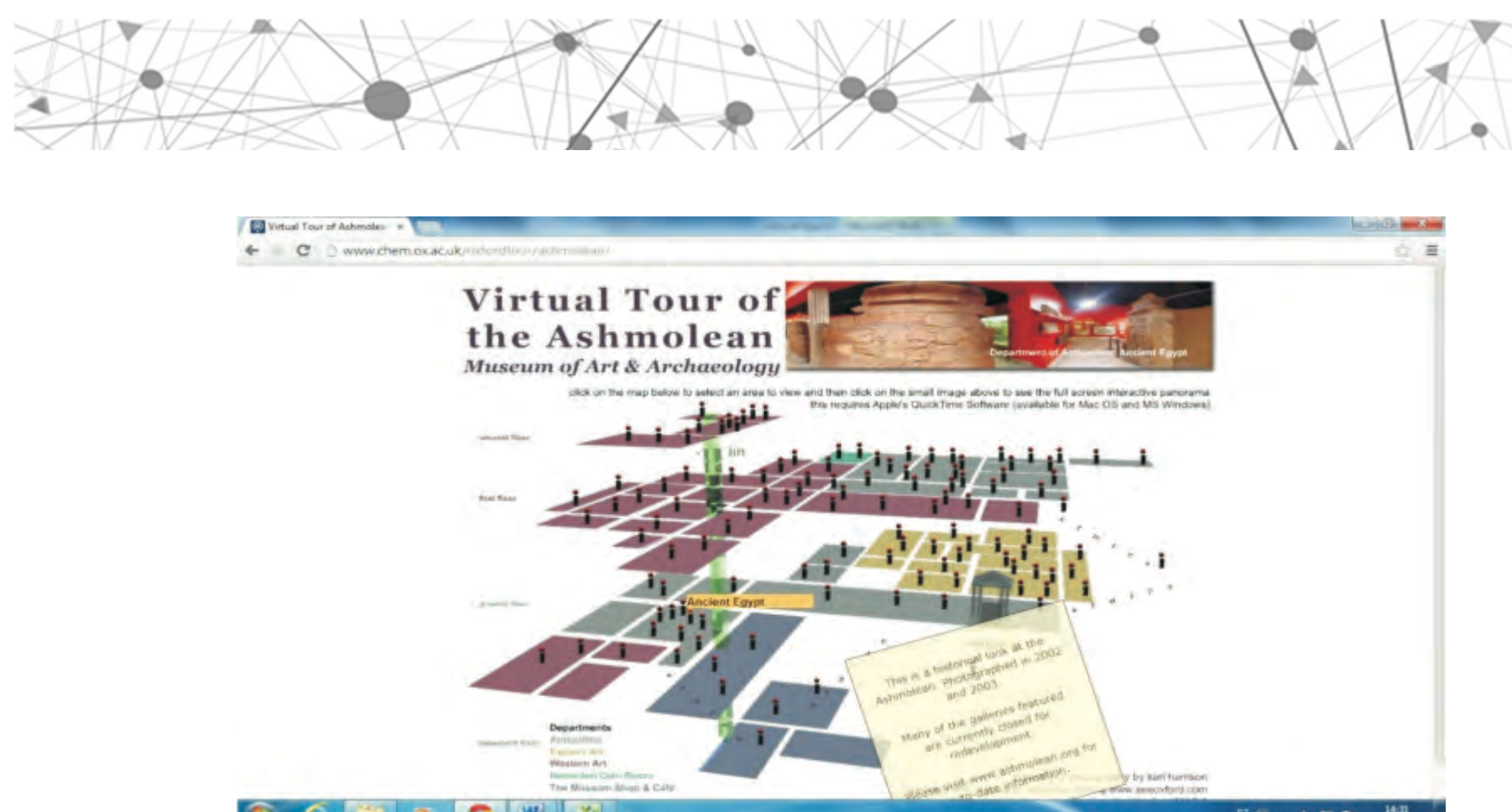

Figura 7 - Captura de imagem do site do Museu Ashmolean de Arte e Arqueologia com o mapa do museu para a escolha do local a ser visitado virtualmente. Nessa imagem a sala mostrada é a do Egito Antigo

Fonte: Primária

Além do tema da sala, com o deslocamento do cursor, na parte superior da página, aparece a imagem da vista panorâmica do ambiente interno no qual a coleção relacionada está. Ao pressionar o botão do mouse nessa imagem, uma nova janela abre-se, disponibilizando então a visita em três dimensões àquele ambiente (figura 8).

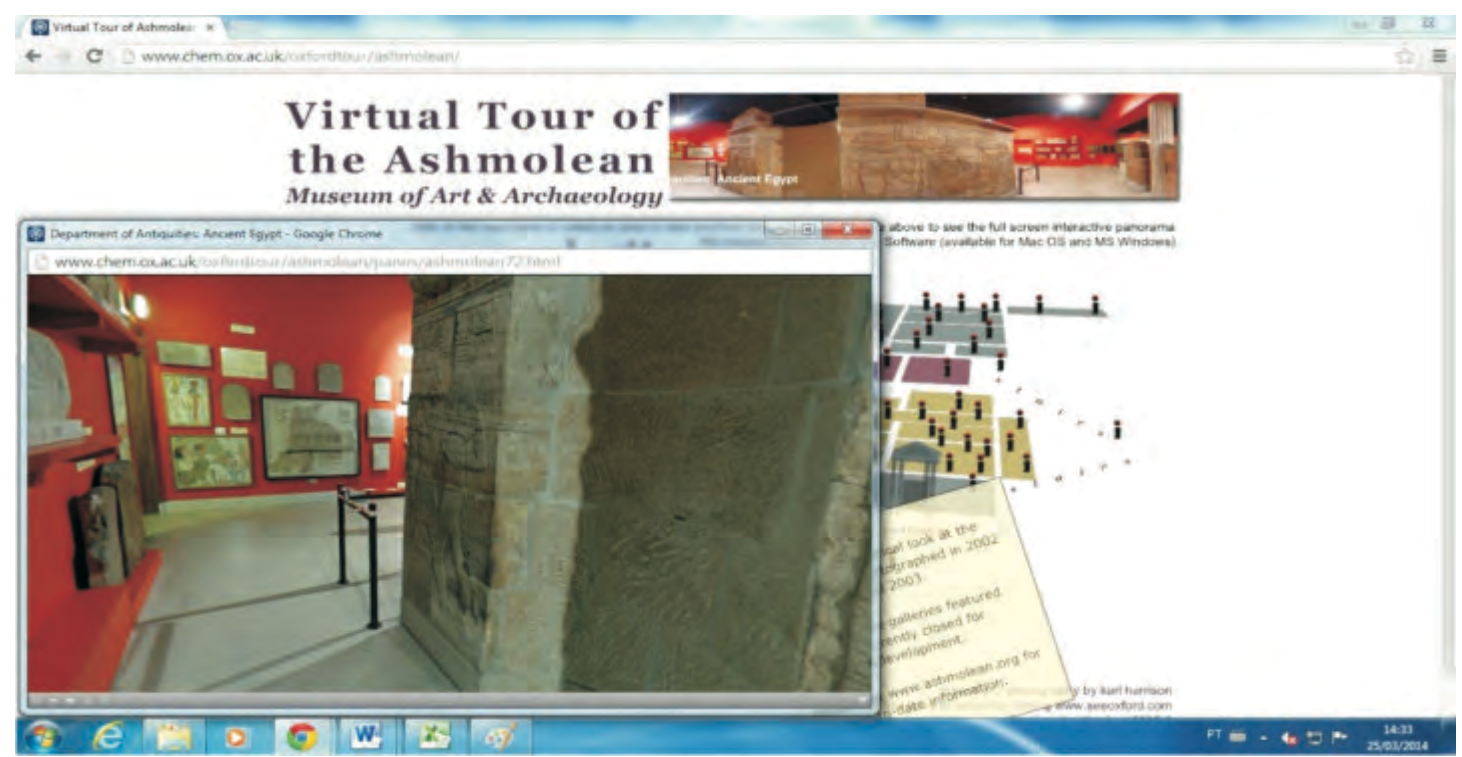

Figura 8 - Captura de imagem do site do Museu Ashmolean de Arte e Arqueologia com a janela pela qual é possível visitar virtualmente a sala do Egito Antigo por meio da tecnologia de três dimensões

Fonte: Primária

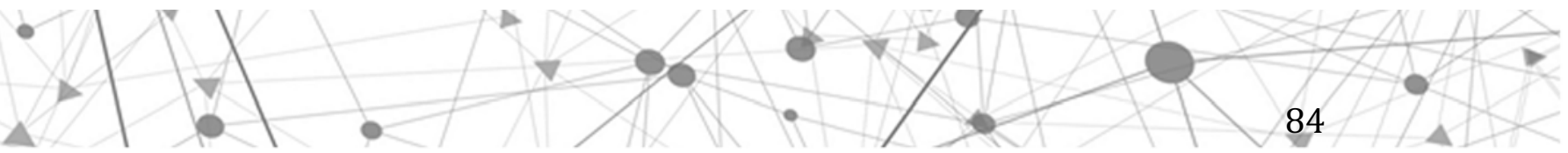


Embora a visita seja realizada em três dimensões, resultado de um processo de digitalização de imagens, ela não difere da visita ao museu físico pela virtualidade da experiência, porém pela vivência da espacialidade e da natureza da experiência estética, funcionando mais como uma referência do que como uma visita ao museu. Nessa perspectiva, cabe questionar a relevância da utilização da reprodução do espaço físico como estrutura para que o público realize sua experiência diante das peças do museu presentes na web. Com essa experiência, questionam-se uma vez mais os motivos pelos quais não explorar as novas possibilidades que a arquitetura não linear do site pode oferecer.

Conforme já escrito anteriormente, por meio do Google Art Project, muitas instituições culturais e museológicas têm digitalizado peças do acervo e seus espaços expositivos. Entre as experiências de museus que disponibilizam a visita virtual em três dimensões, assim como também link para o Google Art Project, está o Museu Thyssen-Bornemisza.

Apesar de oferecer visita virtual em seu próprio site, o Museu ThyssenBornemisza disponibiliza link para o Google Art Project, o que é muito interessante, já que este se configura como um espaço de troca entre museus e possibilita, dada a grande visibilidade alcançada pelo Google e ocasionada pela rede, que os seus espaços e a sua coleção sejam difundidos mundialmente. Logo, 27 obras de seu acervo estão disponíveis no site do link para o Google Art Project, as quais podem ser visualizadas em detalhes por meio da tecnologia de gigapixel.

No site do museu, tanto a visita virtual como o link para o Google Art Project estão disponíveis no espaço Coleciones, em que o público tem acesso ao catálogo digital e às imagens das principais obras do acervo. Todas essas imagens podem ser visualizadas em janelas separadas e acompanham texto informativo, cujo conteúdo também pode ser escutado por meio de arquivo de áudio. Ainda nesse espaço, o público tem acesso a vídeos de profissionais falando sobre diferentes momentos históricos, estilos diversos e obras do acervo. Já no espaço Educathyssen, são apresentados os programas e cursos educativos voltados a diferentes públicos e faixas etárias, além de ser disponibilizados materiais de apoio e propostas educativas para professores e jogos online, construídos com base em obras do acervo. Aqui também são disponibilizados aplicativos para tablets e smartphones. 
Cabe observar uma vez mais que, embora a visita virtual em três dimensões tenha a sua relevância, pois permite com que os impossibilitados de deslocamento possam, de alguma forma, ter contato com as dependências do museu, se acredita que ela não faça daquele site um museu, afinal a grande importância desses espaços virtuais está na ativação da coleção, nas experiências de educação e de participação proporcionadas ao público, o que se dá por meio das atividades online, da disponibilização de audiovisuais e dos conteúdos oferecidos, tais como textos críticos e um banco de dados com imagens do acervo, a exemplo de diversos sites que aqui já foram analisados. Todavia, no processo de mapeamento, foram identificadas experiências de museus que oferecem a visita virtual em três dimensões ao seu espaço físico, mas não disponibilizam imagens do acervo. Entre eles está o Museu Oscar Niemeyer ${ }^{61}$, de Curitiba.

Já o projeto da Google World Wonders ${ }^{62}$, por meio de três diferentes recursos - fotos, vídeos e visualização em três dimensões -, proporciona ao público o acesso e o conhecimento acerca dos lugares e construções dos mundos moderno e antigo que são considerados patrimônio mundial. A situação aqui é diferente do site que reproduz o espaço da instituição, tendo em vista que a visualização em três dimensões se dá diretamente do próprio lugar, que por si só é tido como patrimônio. Por meio do website do projeto, é possível conhecer, por exemplo, os sítios arqueológicos da cidade de Pompeia, Itália. Esse pode ser um instrumento de altíssima importância, para visitantes interessados em conhecer esses lugares, e também um recurso educativo para ser trabalhado em sala de aula, na escola.

Acredita-se que uma das funções mais importantes dos museus e das instituições culturais, a qual tem sido plenamente realizada no ambiente virtual em rede, é tornar a sua coleção ativa, ou seja, estudar, disponibilizar, problematizar e exercitar esse patrimônio com o público, a exemplo das experiências virtuais do Museu Thyssen-Bornemisza e do Museu Nacional do Prado. Não que o prédio das instituições e as suas histórias não sejam importantes, mas pensa-se que não é a construção que faz dessa instituição um museu, e o mesmo pode ser afirmado em relação a um website. Ressalta-se uma vez mais que não é a reprodução virtual do edifício nem a dos espaços expositivos de um museu, permitindo ao público a visita

\footnotetext{
${ }^{61}$ Mais informações em: <http://museuoscarniemeyer.org.br>.

${ }^{62}$ Mais informações em: <http://www.google.com/culturalinstitute/project/world-wonders>.
} 
em três dimensões, que farão desse site um museu virtual - ele pode até ser virtual, mas não será um museu.

A partir daí, questiona-se: no que consiste uma experiência de "museu" virtual? Andar pelos corredores ou estabelecer diálogos com a coleção na construção de conhecimento?

Por meio da internet, é deveras difícil visitar virtualmente os espaços e estabelecer, ao mesmo tempo, relações com a coleção exposta, dados os limites que a tecnologia ainda possui, a exemplo das dificuldades de manuseio para realizar o percurso no já citado Muva, por exemplo, ou mesmo na visita às dependências do Museu Ashmolean de Arte e Arqueologia - a importância de ambas as experiências está na visualização, no estudo e no exercício da coleção, não no percurso feito por seus corredores virtuais. Nesse sentido, a experiência da visita virtual acaba caindo no puro passeio de entretenimento. Como afirma Schweibenz (1998, p. 1),

the virtual museum is defined as a means to establish access, context, and outreach by using information technology. The internet opens the virtual museum to an interactive dialog with virtual visitors and invites them to make a virtual museum experience that is related to a real museum experience ${ }^{63}$.

Portanto, questiona-se a tipologia de Gant (2001), que define que a terceira categoria de museu virtual é aquela que implica a reconstrução do espaço físico do museu. Afinal, conforme citado, embora tal construção seja entendida como virtual, dificilmente pode ser entendida como museu.

Em 2012, o Instituto Itaú Cultural realizou em seu espaço físico a exposição temporária denominada Lygia Clark: uma retrospectiva ${ }^{64}$. Como complemento à mostra, a instituição produziu um website que nomeou de museu virtual ${ }^{65}$ e no qual disponibilizou a reconstrução virtual de trabalhos da artista para que o público pudesse, mesmo apenas pelo mouse e comandos do teclado, manipulá-los. Entre os trabalhos expostos, o que se dá no interior de uma construção (figura 9), que

\footnotetext{
63 “0 museu virtual é definido como um meio de estabelecer acesso, contexto e extensão por intermédio do uso da tecnologia. A internet abre o 'museu virtual' a um diálogo interativo com visitantes virtuais e convida-os a realizar uma experiência virtual de museu que é relacionada com a experiência de museu de verdade" (livre tradução).

${ }^{64}$ Embora tenha sido mapeada, essa experiência de museu não se enquadra em nenhuma das tipologias estabelecidas.

${ }^{65}$ Mais informações em: <http://novo.itaucultural.org.br/museu-virtual/>.
} 
consiste na recriação do espaço físico, encontra-se a reconstrução digital do trabalho Trepantes (obra mole), de 1977, que diferentemente dos originais físicos construídos pela artista, os quais não podem mais ser tocados pelo público, no ambiente virtual podem ser manipulados pelo visitante.

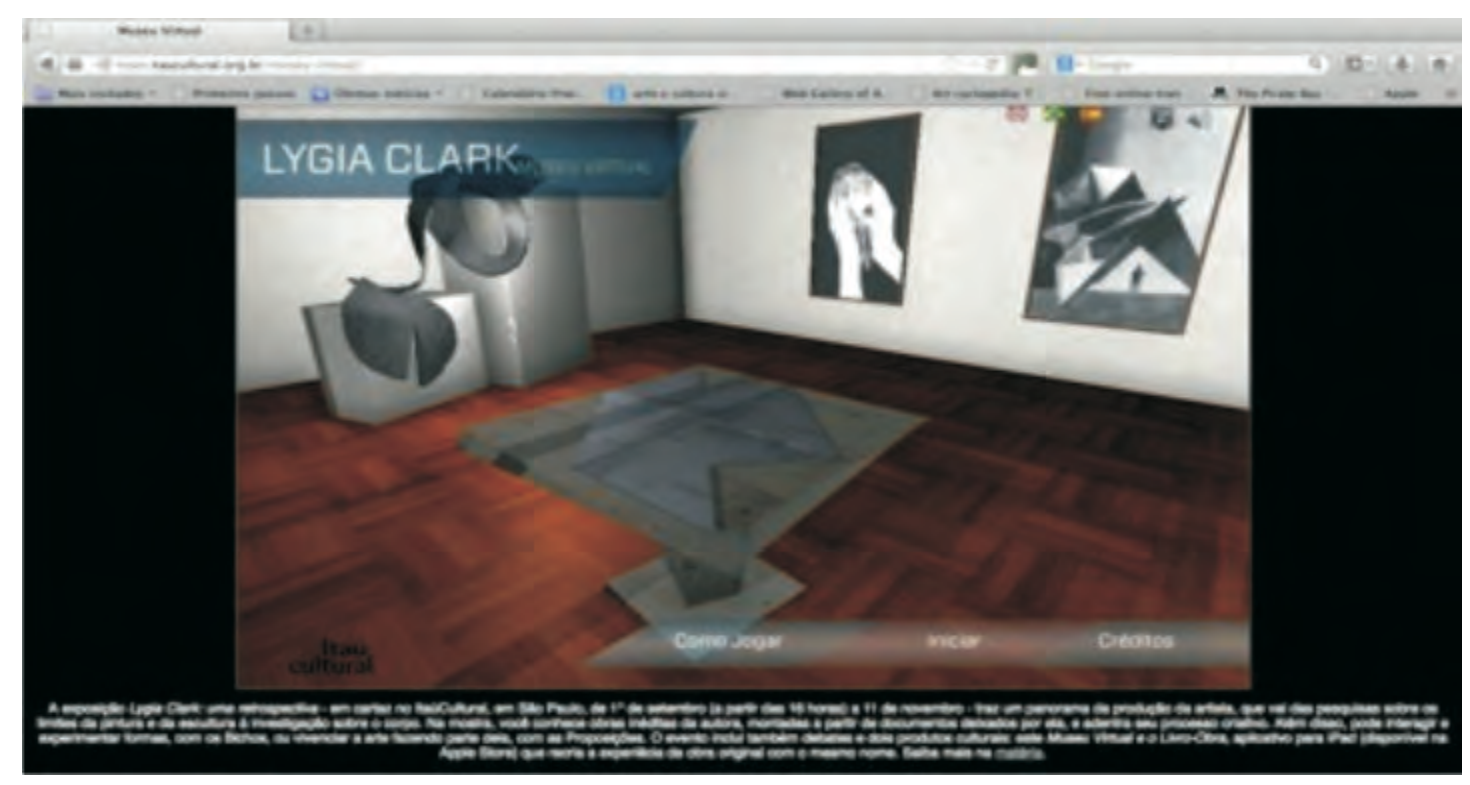

Figura 9 - Captura de imagem do site Museu Virtual: exposição Lygia Clark: uma retrospectiva, com a galeria interna e reconstruções dos trabalhos da artista Fonte: Primária

Embora seja uma experiência interessante, deve-se levar em consideração que os originais físicos possuem peso, textura, temperatura, resistência, características que não podem ser percebidas tendo-se apenas o mouse e o teclado como instrumentos. A experiência proporcionada pelo website está longe de funcionar como um substituto, e mesmo como uma referência, já que se distancia sobremaneira da experiência física. Pode, até mesmo, prejudicar a impressão do visitante que não teve a oportunidade de manipular o trabalho físico. Também mediante comandos, é possível navegar, com dificuldade, por um espaço expositivo composto por salas em que constam reproduções de fotografias e outras peças de Clark. 0 site também disponibiliza um tour virtual à parte externa do museu, que é por onde a visita começa, com barreiras físicas e placas indicativas (figura 10). Até os sons da realidade física são reproduzidos. 


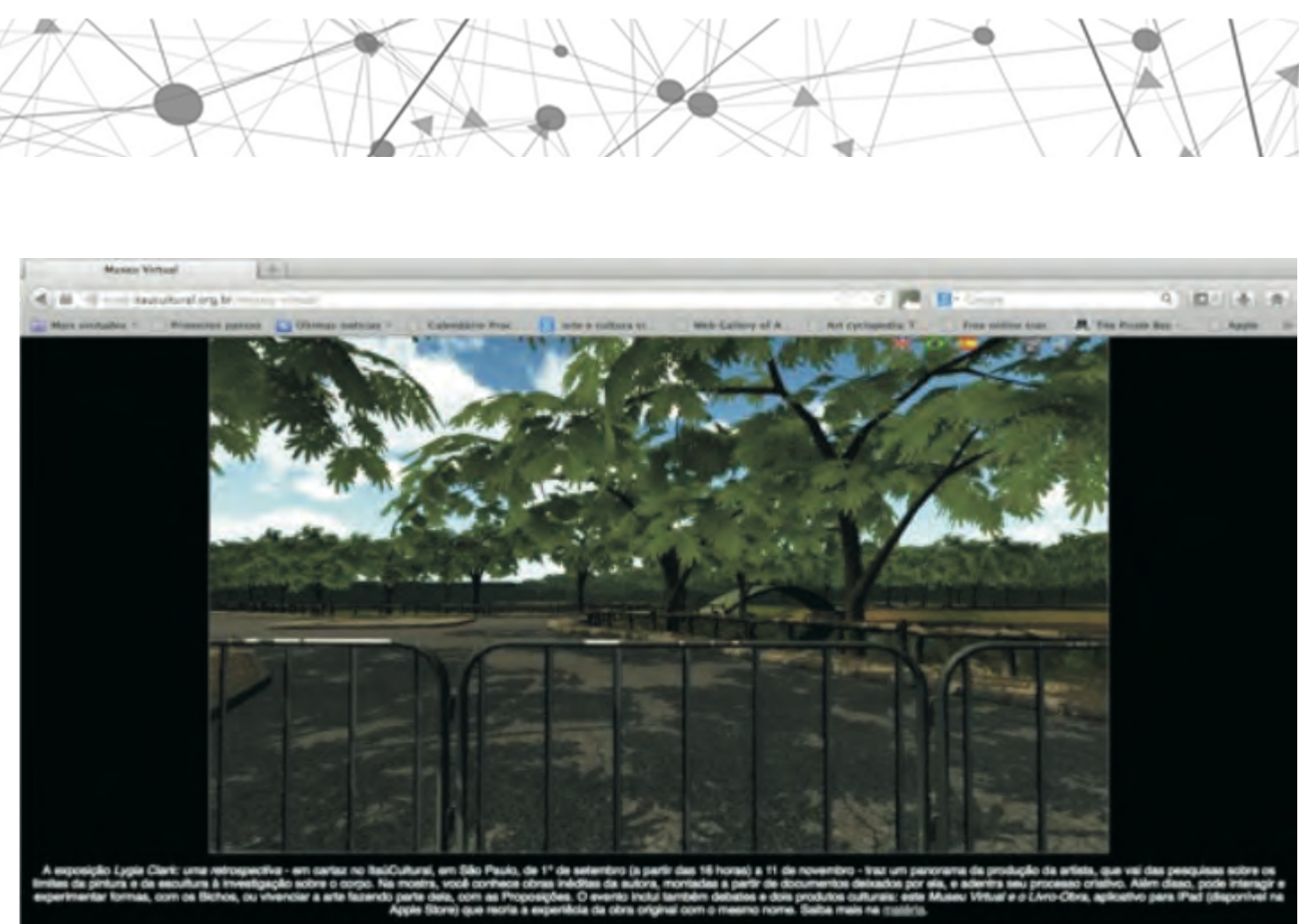

Figura 10 - Captura de imagem do site Museu Virtual: exposição Lygia Clark: uma retrospectiva, com a reprodução da realidade física

Fonte: Primária

A visita em três dimensões proporcionada pelo museu virtual, que tenta reproduzir a lógica espacial e os ambientes da realidade física, acaba tirando o foco da obra da artista em questão. É até mesmo difícil encontrar a galeria na qual os trabalhos de Clark estão expostos, dadas as dificuldades de controle proporcionadas pelos comandos e pelas barreiras que se encontram no percurso.

Sendo assim, considera-se questionável a utilização do termo museu virtual para esse tipo de experiência, já que, conforme afirmado anteriormente, a reprodução de um ambiente físico em meio virtual para disponibilizar reproduções dos trabalhos originais não faz desse espaço um museu, mas o vínculo com uma coleção que é estudada, pesquisada e colocada em exercício. Essa experiência proporcionada pelo Itaú Cultural, apesar de pôr em discussão a produção da artista, na medida em que promove uma exposição, prejudica o entendimento da obra, correndo o risco de mesmo afastar o visitante.

Também são referenciados como museu virtual websites que reúnem informações acerca de arte e de cultura, a exemplo do Museu Virtual do Canadá $(V M C)^{66}$. Consiste em um espaço por meio do qual é possível ter acesso a diversas informações concernentes ao contexto histórico e cultural do Canadá, mediante imagens e conteúdos multimídia disponibilizados por museus e galerias do país.

${ }^{66}$ Mais informações em: <http://www.virtualmuseum.ca/>. 
Podem ser visualizadas imagens de exposições por meio de ferramentas que não simulam o mundo físico, mas que fazem uso da estrutura do próprio ambiente, tais como hiperlinks, hipertextos e audiovisuais.

Ainda, integra o website uma lista de museus canadenses, que também podem ser vistos em um mapa. Ao clicar no museu escolhido, tem-se acesso às informações relativas aos horários de funcionamento, aos programas, à coleção e às exposições. Além disso, o site possui um espaço dedicado especialmente aos professores, o Teacher's Centre. Por ele, professores podem ter acesso a inúmeras informações de reforço relativas a exposições e artistas, pertinentes tanto para a preparação da visita aos museus e às instituições como para a construção de aulas na escola, já que disponibiliza imagens, conteúdos e sugestões para atividades a ser realizadas em aula.

0 VMC também disponibiliza o Virtual Exhibits. Ao acessar o hiperlink, o visitante seleciona exposições virtuais de diferentes museus e instituições culturais do Canadá, com um clique em uma das imagens capa da mostra, acompanhadas pelo título e nome da instituição realizadora, ou pela ferramenta de busca. As exposições disponibilizadas não seguem um padrão, ou seja, cada um faz uso do layout e das ferramentas necessárias dos trabalhos que a compõem. Ao clicar sobre a mostra escolhida, como a Artwork Awaiting Discovery ${ }^{67}$, por exemplo, o visitante é conduzido à página inicial da exposição. Nessa página, além do título e do nome da instituição realizadora, que nesse caso é o Maison Saint-Gabriel, cuja sede física está localizada em Pointe-Saint-Charles, Quebec, tem-se um texto introdutório. No caso específico dessa exposição, a porta de entrada é a imagem acima do texto. Ao clicar nela, uma nova página abre-se, na qual são dadas ao visitante quatro opções de acesso:

- The Exhibition: há um texto introdutório explicativo sobre a exposição, de maneira que o visitante pode obter as informações necessárias acerca do conteúdo a ser vivenciado, bem como as diferentes maneiras, tendo em vista que se trata de uma exposição que, por respeitar a estrutura do ambiente virtual, foge da lógica do espaço físico;

\footnotetext{
${ }^{67}$ Mais informações em: <http://www.virtualmuseum.ca/virtual-exhibits/exhibit/artwork-awaitingdiscovery/>.
} 
- The Artists: ao acessar a seção, o visitante depara com um novo texto acerca do que será encontrado nesse espaço, assim como toma conhecimento de como pode usufruí-lo. Ao fechar a aba desse texto, tem-se uma lista com os nomes dos artistas que integram a exposição, e por tais nomes se pode optar por onde começar e pela ordem a seguir no processo de visualização. Ao clicar no nome do artista escolhido, são encontradas informações sobre a vida, a trajetória e a produção dele, além de um retrato para que seja conhecida a sua fisionomia. No corpo do texto, alguns nomes de pessoas que fizeram parte da trajetória do artista constituem links pop-up, de forma que ao clicar nesses links se abre um pequeno texto explicativo no tocante a quem foi aquela pessoa;

- The Paintings: um novo texto introdutório explica os critérios de seleção utilizados pela curadoria, a importância daquele conjunto de imagens e como usar as ferramentas disponibilizadas para a vivência dos trabalhos da mostra. Ao fechar a aba da introdução, são visualizados retângulos emoldurados tal como pinturas clássicas, dispostos lado a lado e organizados em duas fileiras horizontais e paralelas, encaixados como um mosaico. Cada um deles traz o nome de um dos artistas que fazem parte da exposição. Aqui também se pode escolher por onde começar, assim como a ordem de visualização. Ao clicar no nome escolhido, surge um texto sobre os trabalhos desenvolvidos por aquele artista, incluindo os gêneros trabalhados, procedimentos empregados e informações relevantes a respeito do conjunto que será visualizado. Fechando-se a aba, as imagens das pinturas podem ser visualizadas enfileiradas, lado a lado, em uma barra de rolagem. Ao selecionar uma delas e clicar na imagem, uma nova janelinha abre-se com a imagem em maior tamanho, acompanhada por seus dados técnicos. Se o visitante quiser informações específicas daquele trabalho, basta fechar essa janelinha e clicar no pequeno retângulo localizado logo abaixo da imagem da pintura, na barra de rolagem, para se abrir uma nova janela com essas informações; 
- The Studios: aqui o visitante pode ter contato, passo a passo, com o processo de restauração das pinturas.

Ressalta-se, no contexto dessa exposição virtual, a ferramenta The Directory, que se encontra disponível no espaço The Paintings. Por meio dela, o visitante pode selecionar duas imagens de trabalhos de um mesmo artista ou de artistas distintos para que sejam visualizadas lado a lado, separadamente, a fim de ser comparadas e problematizadas. Ao clicar e arrastar a imagem escolhida, uma nova janela de fundo preto abre-se, de maneira que a imagem possa ser visualizada sozinha, sem interferência das outras imagens ou de textos.

0 VMC pode ser entendido como um museu de terceiro tipo, com base na tipologia de Ascott (1996), já que existe apenas no ambiente virtual, sendo formado por um conjunto de exposições compostas por obras digitalizadas e que só podem ser vivenciadas daquela maneira pela experiência do museu virtual. Mas também pode ser englobado nos museus realmente interativos de Piacente (1996 apud THEATER, 1998), pois o visitante possui papel ativo em todo o processo de vivência da mostra.

Embora não seja o caso da exposição agora descrita, que não apresenta muitas ferramentas de natureza participativa, a exposição virtual ArtPad: $A$ Collection. A Connection ${ }^{68}$, realizada pelo Museu Glenbow, por exemplo, e que também integra o VMC, disponibiliza ferramentas para jogar, explorar e interagir com os trabalhos da mostra. Pelo Interact, por exemplo, o visitante pode fazer perguntas ao curador da exposição, assim como deixar a sua opinião sobre ela.

Destaca-se, em Play, o jogo The players. Ele oferece uma atividade denominada de Choose a Perspective. 0 visitante pode escolher entre a imagem de cinco trabalhos de arte contemporânea do Canadá, que fazem parte da mostra, para conhecer o ponto de vista de quatro diferentes players: o curador, o marchand, o restaurador e o artista. Ao optar por conhecer primeiramente a opinião do curador, por exemplo, o visitante depara com cinco perguntas a serem respondidas sobre 0 trabalho em questão. Pode-se escolher entre responder a elas ou em ouvir as respostas elaboradas por aquele profissional. Essas mesmas perguntas são respondidas pelos demais profissionais, de maneira que o visitante tem acesso a

${ }^{68}$ Mais informações em: <http://www.glenbow.org/artpad/en/home.html>. 
quatro pontos de vista distintos sobre o trabalho em questão, cada qual proferido por um profissional que fala de um lugar diferente no contexto da arte.

Trata-se de uma atividade extremamente rica e de natureza educativa que não somente atinge o estudante e o professor, mas também o público em geral. Por ela, trabalhos em exposição são exercitados pelo visitante, que passa a vivenciar uma experiência aprofundada em relação à mostra, assim como exercita o olhar para a arte. É interessante observar que tal atividade, que pode ser entendida como educativa, não se encontra intitulada dessa forma, sendo então convidativa a qualquer visitante, independentemente de ter ou não interesse por arte/educação.

Ressalta-se que essa exposição virtual de maneira nenhuma substitui o contato com o original, porém a exposição física tampouco oferece esse tipo de vivência. Percebe-se com essas experiências que o museu no ambiente virtual pode ser entendido também como um espaço especialmente pensado para facilitar 0 acesso a variadas informações e à construção de conhecimento, mas que não necessariamente possui uma coleção física específica que pesquisa, estuda, expõe e preserva. Ou seja, coloca em exercício outras coleções. Assim, afirma Scheiner (2004, p. 262, grifo do original):

0 museu torna-se, mais que objeto informacional: ele é também um espaço experimental absoluto - uma obra aberta, capaz de comportar simultaneamente o registro existente e o advento do novo - e de oferecer, ao logos e aos sentidos, as mais diversas experiências.

Assim como o VMC, há outras experiências de museus que lidam com a reunião de sites e de informações. Conforme já dito, nesse mapeamento foram identificadas 15 , entre as quais está o Videomuseum ${ }^{69}$, associação sem fins lucrativos formada por museus e organizações. Por meio dele, foram reunidas 60 coleções de arte moderna e contemporânea presentes em diferentes museus e acervos da França, totalizando 29 mil artistas, 315 mil obras e 235 mil imagens. Contudo, por questões de custos envolvendo os direitos autorais, a coleção em sua totalidade está disponível em um banco de dados acessível apenas à pesquisa profissional e no centro de documentação do Videomuseum, existente em algumas das instituições que possuem o software.

${ }^{69}$ Mais informações em: <http://www.videomuseum.fr>. 
Para a pesquisa online, aberta ao público em geral, estão disponíveis 35 coleções que podem ser acessadas pelo website do projeto. Para tal, basta selecionar a instituição que contém a coleção desejada, o que pode ser feito por uma lista exibida já na página de abertura. Ao selecionar a instituição desejada, uma nova janela abre-se, possibilitando o acesso à coleção, cuja consulta pode ser realizada de diferentes maneiras, seja por nome de artista, título de trabalho e linguagem, seja pela seleção do nome desejado contido numa lista, facilitando assim a pesquisa.

Ao acessar o Museu de Arte Contemporânea de Lyon, França, por exemplo, e selecionar o nome de Marina Abramovic da lista de artistas, mais uma janela abrese, com imagens e informações de trabalhos da artista que compõem a referida coleção. A partir daí, pode ser selecionado o trabalho desejado, tanto para ser visualizado, em boa resolução, em janela separada, com a opção de impressão da imagem na parte inferior da página, como para passar para a visualização da próxima imagem. Nesse caso específico, por se tratar de um registro audiovisual de performance, é disponibilizado apenas um frame. Essa forma de visualização é própria do ambiente virtual e permite que cada uma das imagens, selecionadas conforme o interesse do público, seja contemplada isoladamente do restante da coleção, de maneira que sejam evidenciadas as suas especificidades, que não sofrem influências nem de outros trabalhos nem de um discurso curatorial ou de elementos da arquitetura, apenas da moldura da tela do computador.

Outro exemplo interessante de experiências de museu virtual que não possuem acervo próprio é o Museum With No Frontiers ${ }^{70}$, organização da qual participam diferentes profissionais como professores, cientistas, fotógrafos, agentes de turismo, entre outros e que tem por objetivo organizar um museu transnacional a partir do qual a arquitetura, a arqueologia e a obra de arte são acessadas em seu contexto de origem. Assim, por meio do link Museu Virtual, disponível na página principal do website, são disponibilizadas exposições organizadas sem que as peças sejam deslocadas de seu acervo ou local original, de maneira que o museu atua como uma porta de entrada às diferentes instituições culturais e lugares históricos que compreendem a Europa, o norte da África e o Oriente Médio.

\footnotetext{
${ }^{70}$ Disponível em: <http://www.museumwnf.org/>
} 
Pelo link Discover Islamic Art, por exemplo, na página principal desse Museu Virtual, tem-se acesso a outra página na qual são oferecidas maneiras de explorar as várias coleções islâmicas das instituições que fazem parte do museu, o que pode ser feito por diversas portas de entrada. Ao optar por Permanent Collections, é apresentada a possibilidade de escolher a coleção islâmica por país ou por período. Ao selecionar o Egito, por exemplo, aparecem algumas imagens de obras islâmicas e, ao clicar em uma delas, uma nova janela é aberta, com informações sobre a obra, até mesmo especificações da instituição egípcia da qual ela faz parte. São apresentados também objetos e monumentos que a ela podem ser relacionados, assim como também propostas de passeios turísticos pelo Egito, sendo o turismo cultural outro foco do site. Ao clicar na imagem, esta surge em outra janela, de forma ampliada e em alta resolução, podendo ser aproximada, proporcionando ao público a sua contemplação em detalhes. Conforme já comentado, tal aproximação dificilmente é possível no museu físico, já que esses objetos em geral são expostos em vitrines ou protegidos por cúpulas de vidro ou acrílico, recursos que, embora sejam de proteção, prejudicam a visualização.

Já o link Database conduz a uma página de busca mais direcionada aos especialistas, pois para a consulta devem ser inseridas informações conhecidas por aqueles que já sabem o que querem encontrar. Contudo o hiperlink Exhibition oferece a escolha por diversas exposições virtuais por diferentes focos da arte islâmica, excelente para quem quer aprender. 0 tema geral é "A Descoberta da Arte Islâmica no Mediterrâneo". Ressalta-se que os textos são oferecidos também em português (figura 11). 

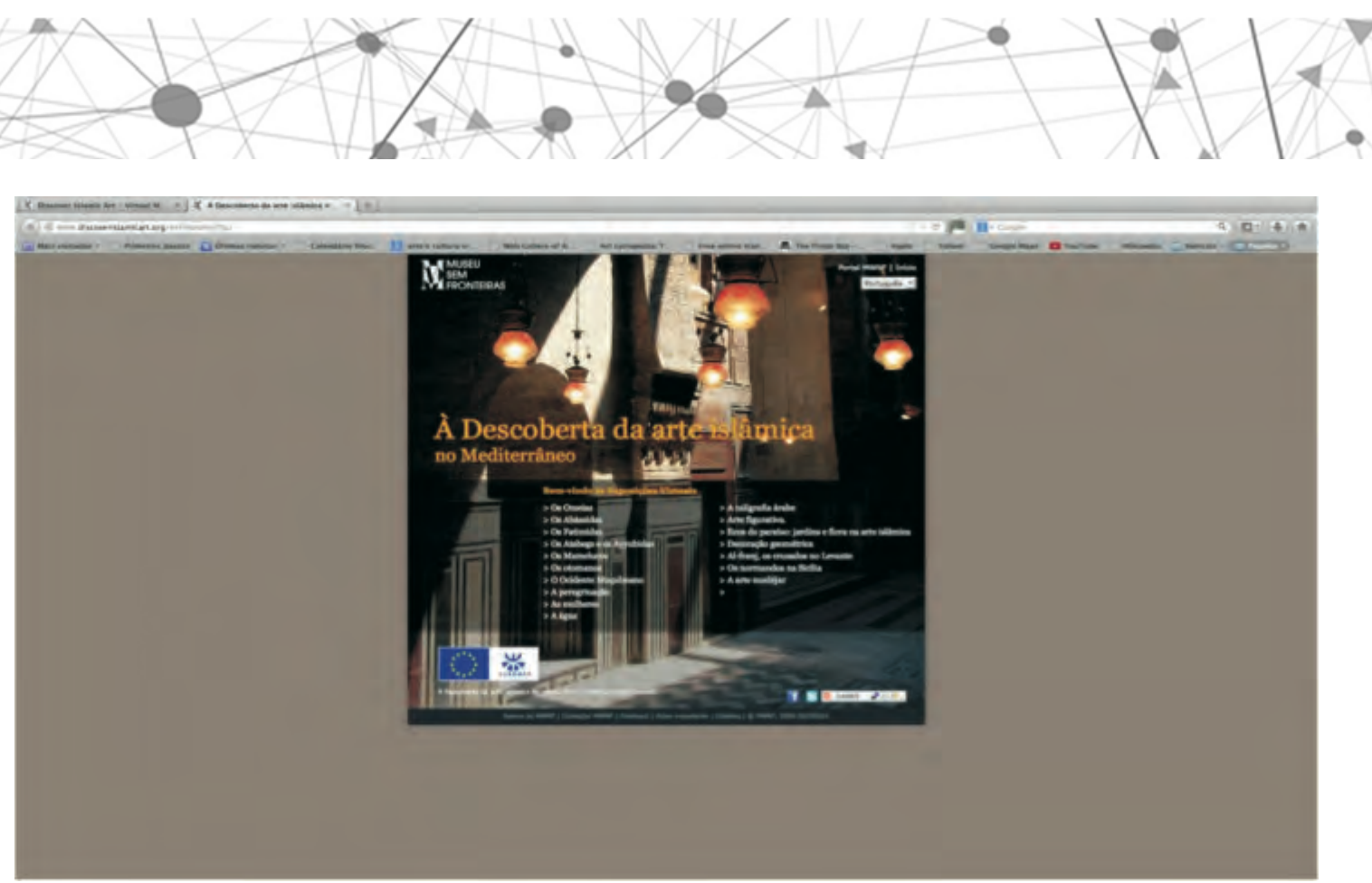

Figura 11 - Captura de imagem da página acessada por meio de Exhibitions mostrando as diversas exposições virtuais oferecidas sob o tema geral "A Descoberta da Arte Islâmica no Mediterrâneo"

Fonte: Primária

As exposições virtuais organizadas por esse museu foram pensadas especialmente para o ambiente virtual e exploram os recursos próprios do ciberespaço, fugindo da tentativa de reproduzir a lógica das exposições da realidade física. Entre as oferecidas sob o tema "A Descoberta da Arte Islâmica no Mediterrâneo", foi escolhida a exposição Arte Figurativa. Na página inicial da mostra, que pode ser entendida como a sua porta de entrada, consta um pequeno texto sobre a figura na arte e na arquitetura islâmica e três opções de assunto: “Introdução", “A representação humana” e “A representação de animais”. 0 público percorre a exposição de página em página, pela leitura de textos e visualização das imagens, que são acompanhadas pelos seus dados técnicos, entre eles a indicação da coleção da qual faz parte, já que inclui peças de inúmeros acervos distintos e que só puderam ser reunidas em uma mesma exposição pela mediação da tecnologia. Cada uma das imagens pode ser ampliada e visualizada em alta resolução em uma janela separada, proporcionando ao público mais proximidade com a peça do que seria possível no espaço físico.

Ao acessar o hiperlink Art Introduction, a Islamic Art in Mediterranean, podese conhecer as principais características da arte e da arquitetura islâmica do Mediterrâneo com base em textos e imagens de acervos e de lugares históricos 
distintos, propiciando uma excelente fundamentação sobre o assunto, ao mesmo tempo em que se tem contato com o contexto no qual essa cultura se desenvolveu.

Ainda na página Discover Islamic Art, podem ser acessados outros hiperlinks que complementam as informações disponibilizadas até o momento. Por meio de Partners, o museu informa que instituições parceiras possuem peças da produção islâmica em seu acervo. Com Mission Statement, é apresentado um breve texto a respeito da cultura e da arte islâmica, informando os países e as instituições envolvidos, bem como os objetivos do Museum With No Frontiers na organização dessa coleção. Já em Learn with MWNF, são disponibilizadas atividades online que provocam o visitante, de maneira lúdica, a exercitar o olhar e a buscar conhecimentos acerca da cultura islâmica, configurando-se em instrumentos de aprendizado. Ao acessar o hiperlink, são oferecidas nove atividades (figura 12).

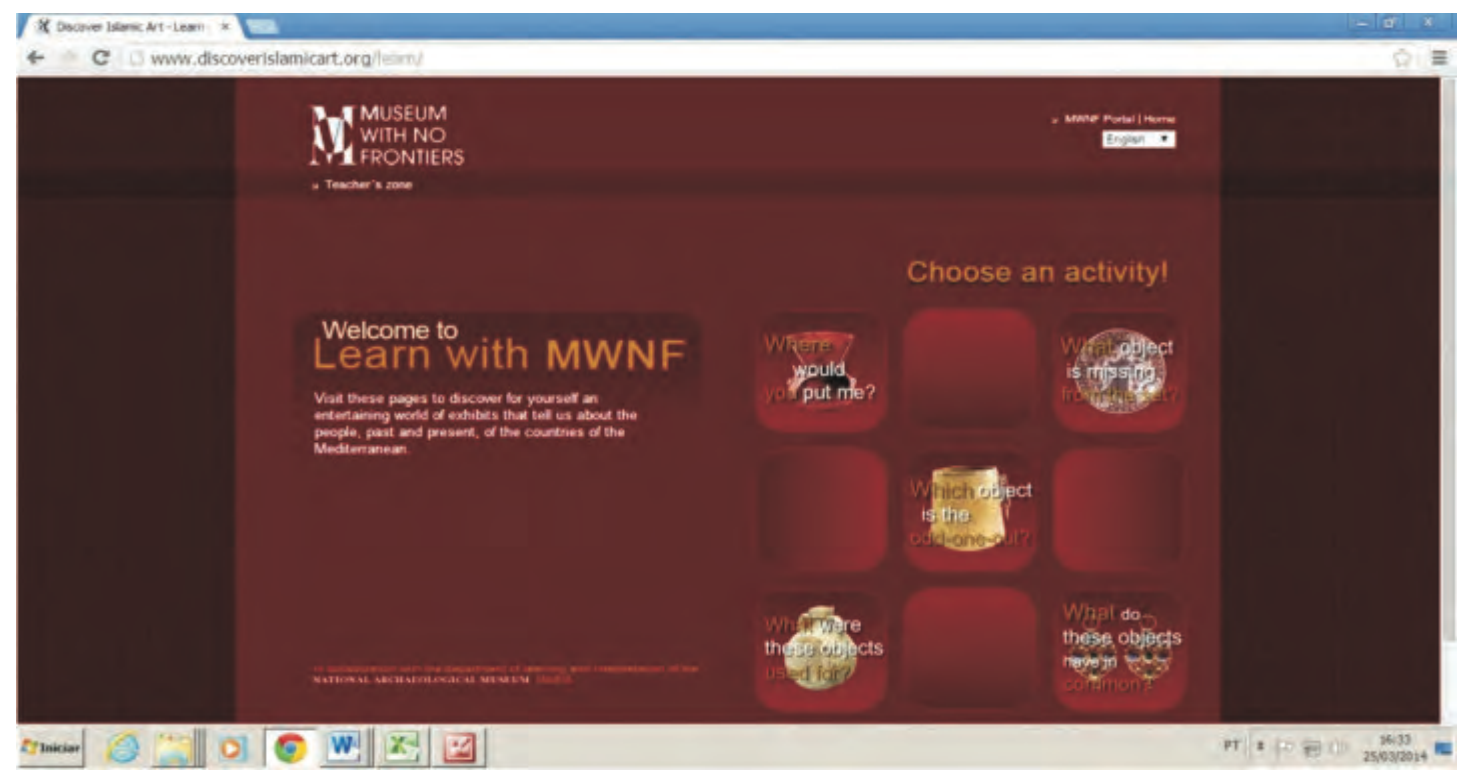

Figura 12 - Captura de imagem da página Learn With MWNF com as nove opções de atividade que podem ser escolhidas

Fonte: Primária

As atividades foram pensadas como um meio de explorar os recursos e conteúdos disponíveis pelo próprio site, a exemplo da intitulada Learning to Contextualize: A place for Everything. As atividades são desenvolvidas em etapas, e a subsequente consiste no aprofundamento do conteúdo trabalhado na anterior. $\mathrm{A}$ primeira etapa, por exemplo, consiste em identificar os objetos islâmicos apresentados numa lista. Deve-se então selecionar o nome desejado e, com 0 mouse, deslocá-lo até o espaço vazio abaixo da imagem do objeto ao qual se refere. 
Como se trata de imagens pequenas, ao pressionar o sinal + , a imagem aparece ampliada, possibilitando assim a sua visualização em detalhes. Se mesmo com a ampliação da imagem não for possível a identificação do objeto por desconhecimento, pode-se acessar o hiperlink ?, que direciona o visitante para a página do acervo do qual o objeto faz parte e na qual constam todas as informações sobre ele, tais como nome, ano, dimensões, materiais, período histórico, procedência, além de uma minuciosa descrição.

Percebe-se então que, com a atividade, o público é levado a exercitar os inúmeros recursos oferecidos pelo website e, assim, acaba por aprofundar o seu olhar e os seus conhecimentos acerca da cultura islâmica, o que se dá pelo contato, consulta e articulação entre diferentes acervos. Ao finalizar essa etapa da atividade, uma nova apresenta-se dando continuidade ao assunto. Após identificar os objetos, deve-se agora localizá-los em seus grupos conforme o local a que geograficamente pertencem. Desse modo a atividade vai sendo desenvolvida, e a etapa seguinte consiste em especificar quem utiliza o objeto e com qual finalidade.

Por fim, ao acessar o hiperlink My Museum, mediante registro, o website possibilita que se organize a sua própria coleção, o que pode ser feito por qualquer um dos acervos que integram o Museum With No Frontiers. Nesse sentido, constata-se que este pertence à tipologia museu virtual estabelecida por Schweibenz (2004), já que, além da gama de experiências e interações proporcionadas, permite com que sejam formadas coleções únicas, jamais pensadas como possíveis por conta das limitações da realidade física.

Em vez de reproduzir o espaço arquitetônico no qual as coleções estão abrigadas, tanto o Videomuseum como o Museum With No Frontiers exploram outras formas de relacionamento com o patrimônio artístico e cultural que, no contexto do ciberespaço, são denominadas de museu. Museus esses cujo acervo é constituído por acervos de diferentes instituições e por meio dos quais são possíveis experiências exclusivas do ambiente virtual em rede. As reproduções não estão apenas em exposição, mas disponíveis para serem exercitadas. Por intermédio de experiências de museus virtuais como essas, pode-se pensar na ideia de um museu global (LÉVY, 2001), na medida em que reúne, em uma mesma base de dados, coleções e informações de fontes diversas, tratando-se do alargamento 
da ideia de museu, entendido como fenômeno, na medida em que se transforma no exercício da coleção.

Apesar de tanto o Videomusem como o Museum With no Frontiers exercitarem coleções baseadas em propostas pensadas para o ciberespaço, ambos possuem sede física que funcionam mais como prédios administrativos. No processo de mapeamento, foram identificadas 15 experiências de museus que existem apenas no ciberespaço, formadas, todas, por coleções de trabalhos digitalizados. A exceção é a International New Media Gallery ${ }^{71}$, cujo acervo é composto por imagens em movimento, as quais já nasceram em formato digital. Por meio desses websites, coleções que estão impossibilitadas de serem mostradas se tornam acessíveis, como é o caso do Museu Virtual Hampson ${ }^{72}$, ou então edifícios que não podem ser construídos pela falta de financiamento passam a existir, como é a situação do Muva, já discutido anteriormente.

A International New Media Gallery foi fundada em 2012 e, como antes afirmado, é especializada em mostrar imagens em movimento, mais especificamente a produção de arte contemporânea produzida para ser exibida em tela. Nesse sentido, ao disponibilizar esses trabalhos na internet, estes não sofrem alterações em relação ao seu suporte original de visualização, diferentemente de quando se trata de uma pintura ou de uma escultura digitalizada, que passam a assumir um novo formato. 0 acesso aos trabalhos dá-se por meio do weblink Current, pelo qual são disponibilizadas exposições de dois artistas. Ao escolher uma delas, o que é feito por uma imagem convite com o nome do artista, o título da mostra e o período de exposição, o público é conduzido à página na qual consta 0 trabalho da exposição escolhida. Logo abaixo do trabalho, são apresentadas todas as informações técnicas, além de um texto explicativo. Na parte superior da página, aparecem três opções de acesso: Catalogue, Discussion e Events.

Em Catalogue, é disponibilizado o catálogo da exposição, composto por frames do vídeo e por textos de diferentes estudiosos, também disponíveis para download. Cabe ressaltar que não se trata de um catálogo pronto para ser baixado em PDF, mas de textos do catálogo virtual que podem ser eventualmente baixados, ou seja, projetado de maneira especial para o ambiente virtual.

\footnotetext{
${ }^{71}$ Mais informações em: <http://www.inmg.org/>.

72 Mais informações em: <hampson.cast.uark.edu/>.
} 
Já o link Discussion leva a uma página com perguntas direcionadas ao visitante, que pode participar mediante a inserção de sua opinião. Tais perguntas podem ser respondidas apenas durante o tempo estipulado para durar a mostra; depois disso, o espaço é fechado e as respostas permanecem arquivadas na página e disponíveis para visualização.

Na primeira exposição realizada pelo Videomusem, da artista Corinne Silva, em 2013, os questionamentos pontuados foram os seguintes: What do visitors think about the online gallery platform? Is it a good way to experience artworks? Our first exhibition is a film, is this the best medium to exhibit online? ${ }^{73}$. Essas perguntas refletem a preocupação dos curadores e gestores do espaço em relação à vivência do público, o que demonstra que o interesse não é apenas exibir, mas contribuir para que se tenha uma boa experiência diante de um trabalho de arte, o que, conforme foi visto até agora, é perfeitamente possível. Além da exposição e do espaço de discussão online, são dadas informações a respeito da projeção do filme e uma conversa com a artista realizada em espaços físicos, disponíveis pelo hiperlink Events, também na página da exposição.

Todavia, por meio de Participate, é oferecida uma proposta denominada de Collective Curating, um programa que objetiva reduzir as diferenças entre 0 curador, 0 artista e o público e pela qual o visitante é convidado a participar. 0 conceito da exposição proposta pode ser enviado por e-mail em formato de esboço. Quando online, a exposição poderá ser modificada pelo visitante, que envia trabalhos, por exemplo. A primeira experiência de exposição nesse formato foi a Between Self and Selfie ${ }^{74}$ (2013), ainda em cartaz, que investiga a política de autorrepresentação online. As pessoas interessadas em participar podem enviar as suas fotos por e-mail ou pelas redes sociais.

Já o Museu Virtual Hampson foi desenvolvido com a intenção de tornar conhecida e acessível a produção indígena americana. A instituição é reconhecida, de acordo com o próprio website, por disponibilizar a maior fonte de informação acerca da vida e história dos povos pré-colombianos do Vale do Rio Mississipi. Foi

\footnotetext{
73 “ 0 que os visitantes pensam sobre a plataforma da galeria online? É um bom meio de experenciar trabalhos de arte? Nossa primeira exposição foi um vídeo, é a melhor maneira de exibir online?" (livre tradução).

${ }^{74}$ Mais informações em: <http://www.inmg.org/cc/selfie/>.
} 
finalizado em 2010 pelo Center for Advanced Spatial Technologies ${ }^{75}$ e contou com 0 apoio financeiro do Arkansas Natural and Cultural Resources Council, do Arkansas Department of Parks and Tourism, do Arkansas Department of Heritage e do Arkansas Archeological Survey. Trata-se de um espaço virtual online que disponibiliza objetos para a visualização em três dimensões, selecionados da coleção do Hampson Archeological Museum State Park ${ }^{76}$, localizado na cidade de Wilson, no Arkansas, Estados Unidos.

As peças da coleção, de 350 a 600 anos atrás, passaram por um processo de digitalização por meio de um scanner três dimensões a laser, processo descrito em detalhes no website. Ao acessar o hiperlink Browse the Collection, a coleção é disponibilizada em três formas de pesquisa. Ao clicar em Browse the Entire Collection, todas as peças da coleção aparecem dispostas em prateleiras, aos moldes do que poderia ser feito no espaço físico de um museu (figura 13).

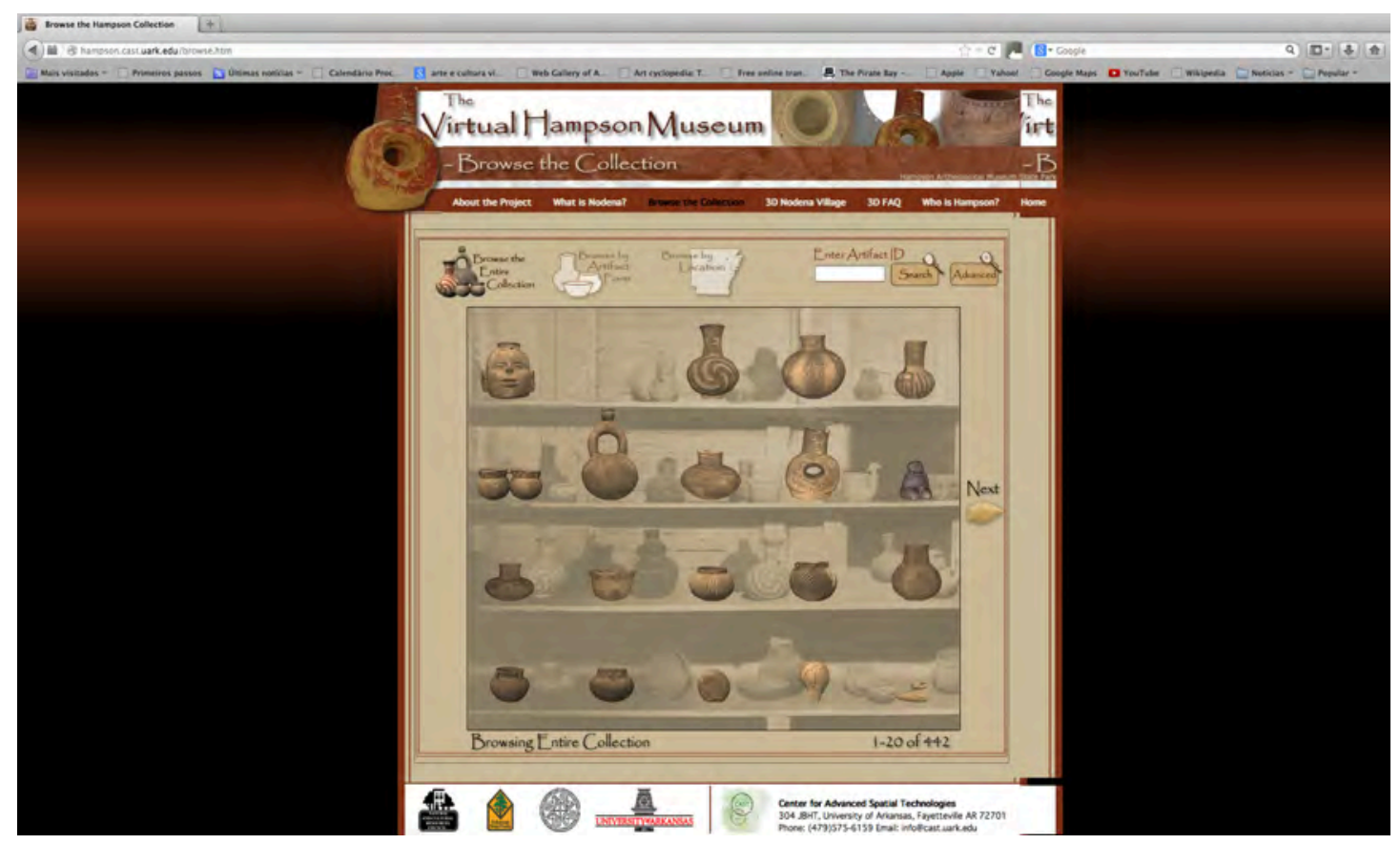

Figura 13 - Captura de imagem da página Browse the Entire Collection, mostrando as peças das coleções disponíveis para visualização conforme a escolha do público Fonte: Primária

Ao selecionar uma imagem, uma nova janela é aberta indicando diferentes formas de visualização: um vídeo, por meio do qual a peça aparece em rotação,

\footnotetext{
${ }^{75}$ Mais informações em: <http://cast.uark.edu/>.

${ }^{76}$ Mais informações em: <http://www.arkansasstateparks.com/hampsonmuseum/\#.UyqA_V6tVrw>.
} 


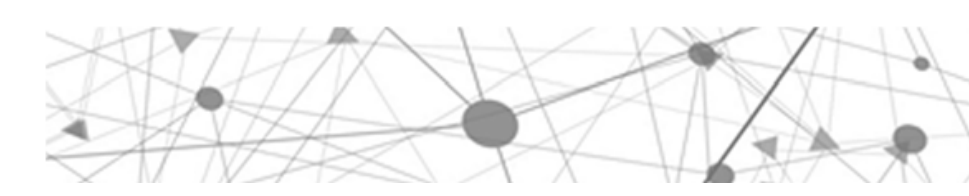

possibilitando assim com que seja contemplada de todos os lados; uma barra de rolagem, na qual constam imagens da peça em diferentes lados e ângulos que podem ser ampliadas; a opção de visualizá-la em três dimensões; e quatro formatos para download (figura 14).

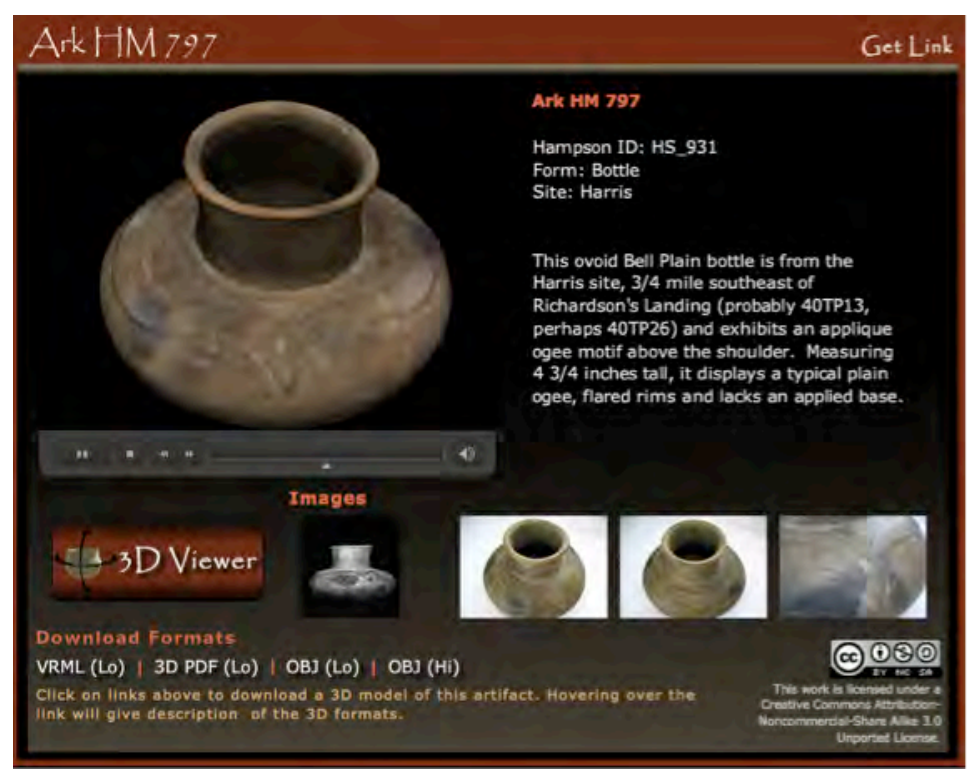

Figura 14 - Captura de imagem da janela que apresenta diferentes opções de visualização da peça

Fonte: Primária

É interessante observar que, além das opções de visualização da peça em sua cor natural, é disponibilizada a versão em preto e branco (figura 15), a qual permite com que as características mascaradas pela cor sejam evidenciadas e que as suas formas sejam percebidas de maneira diversa do original físico. São possibilidades de visualização e de estudos que só podem ser realizadas com a reprodução. 

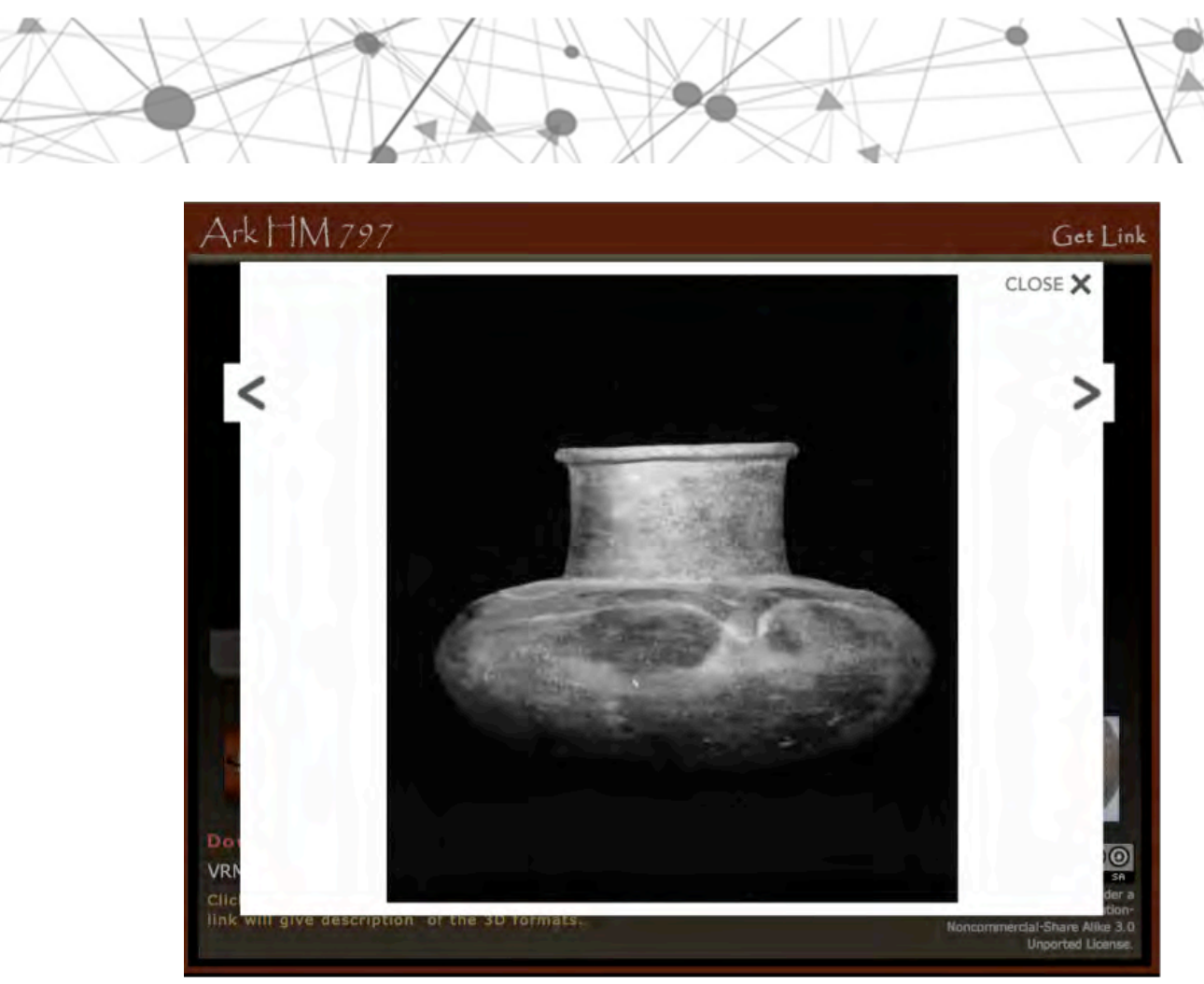

Figura 15 - Captura de imagem da janela mostrando versão da peça em preto e branco. Fonte: Primária

Já a visualização em três dimensões possibilita ao visitante perceber a peça de maneira mais próxima da realidade e, ao mesmo tempo, mais minuciosa, já que ela pode ser observada de todos os ângulos que se tenha interesse (figura 16). 0 website oferece ainda ferramentas que permitem com que a imagem em três dimensões possa ser aproximada, ajustada à página ou visualizada em tamanho natural, impressa ou salva por meio de download. 


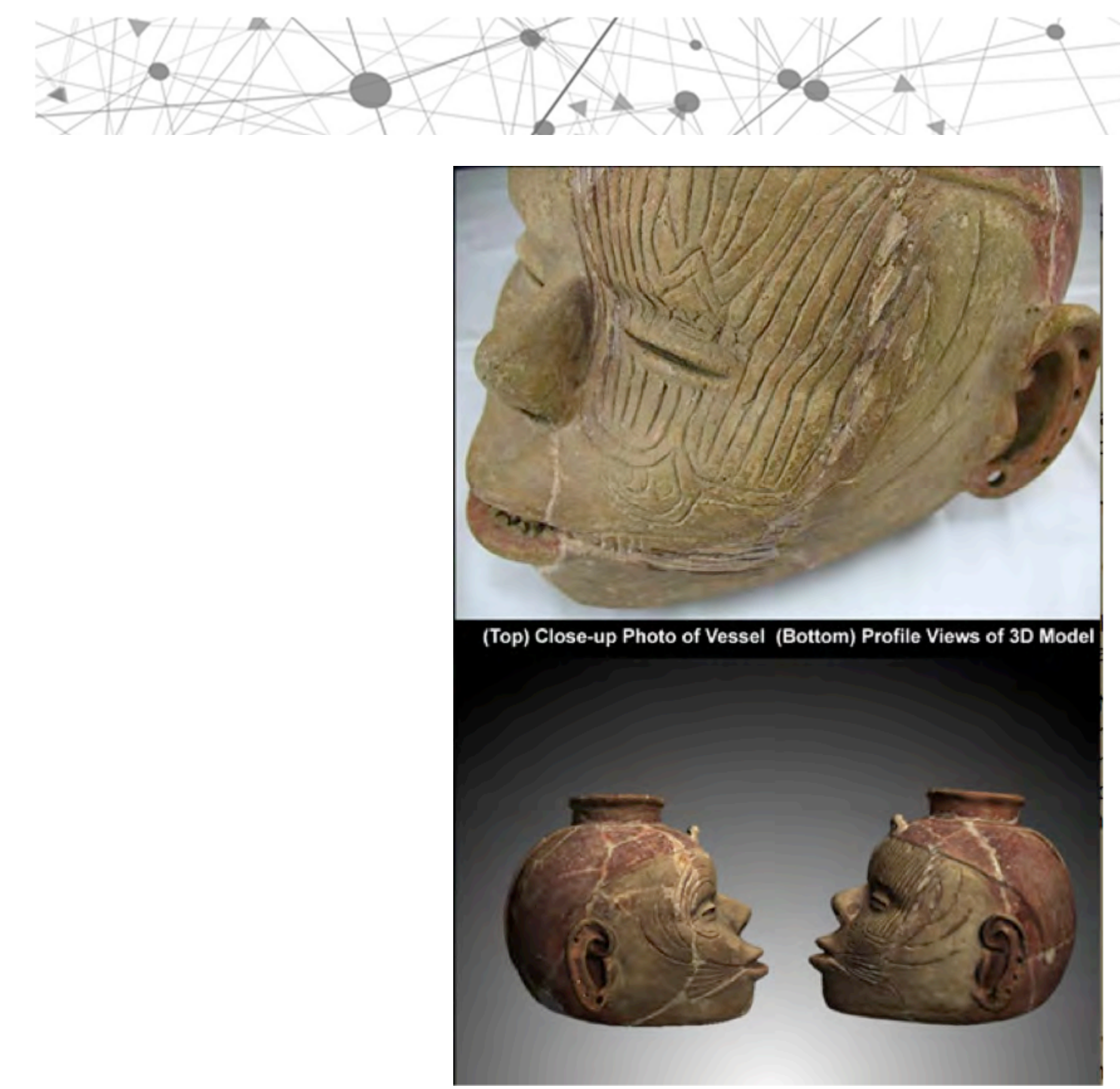

Figura 16 - Captura de imagem da janela mostrando a visualização aproximada do vaso (acima) e a peça em perfil no formado três dimensões

Fonte: Primária

Pelo hiperlink Browse by Artifact Form, é permitida a busca de peças considerando o desenho de sua forma. Ao selecionar um desenho de forma, são então visualizadas todas as peças da coleção que possuem aquele formato ou que estão próximas dele. Já por meio de Browse by Location, pode-se selecionar um local em um mapa da Vila de Nadena e são disponibilizadas para visualização as peças que nele foram produzidas. Trata-se de um recurso de busca que aproxima 0 objeto do seu contexto de origem.

Para que se tenha conhecimento acerca da região, foi realizada a reconstrução da Vila de Nadena em três dimensões, além da disponibilização de texto sobre o lugar, sobre o período histórico das peças e sobre as pessoas que lá viveram e que produziram os artefatos.

Por meio do Museu Virtual Hampson, é possível entrar em contato com a cultura indígena americana do Vale do Rio Mississipi e conhecer a sua produção pela

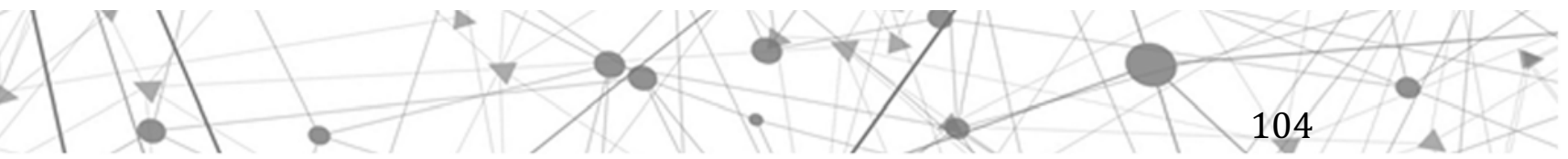


visualização em detalhes, sem as barreiras visuais que os sistemas de proteção dos museus acabam impondo ao público. Assim, foi tornada pública e conhecida uma coleção de peças de que muitos sequer imaginavam a existência, o que pode ter despertado o interesse de alguns que possivelmente buscarão o contato com os originais. É interessante observar que, após a experiência proporcionada pelo museu, a sensação a partir da memória da vivência que se teve é bem parecida com aquela que se tem no museu físico: nunca se sai da mesma maneira como se entra.

Conforme pode ser observado na tabela do mapeamento (apêndice 1), das 155 experiências de museu existentes no ciberespaço que foram aqui mapeadas, apenas 22 se denominam de museu virtual. Uma intitula-se webmuseu e outra museu online, termos que também têm sido utilizados por alguns autores em referência às experiências de museus disponíveis no ambiente da web. Dessas 22, 9 existem exclusivamente no ciberespaço, e somente uma disponibiliza a visita em três dimensões.

Essa última é o Museu Virtual de Ouro Preto ${ }^{77}$, que, além de disponibilizar um tour virtual em três dimensões a seis igrejas da cidade, traz informações textuais sobre a cidade colonial, sobre a religião e sobre as artes e os ofícios.

Assim sendo, pode-se constatar que a previsão de Gant (2001) de que a terceira categoria de museus no ambiente virtual por ela estabelecida viria a ser a mais adotada no futuro estava equivocada. Segundo afirma, essa categoria consiste em um nível mais avançado, que incorpora recriações virtuais, seja do edifício, seja de seu espaço interno. Entre as 155 experiências mapeadas, de maneira geral e sem levar em conta se elas se autodenominam de museu virtual, mas também englobando as que assim o fazem, ressalta-se novamente que apenas 36 disponibilizam recriações de seus ambientes físicos em três dimensões. Talvez isso se dê por questões financeiras, ou então pelo fato de essa ferramenta não despertar o interesse da instituição, já que o ambiente virtual cibernético apresenta inúmeras possibilidades que podem ser exploradas, não havendo necessidade de manter relações de similaridade com o mundo físico.

Pela análise do mapeamento e no cruzamento com as tipologias organizadas por Schweibenz (2004), Gant (2001), Ascott (1996) e Piacente (1996

\footnotetext{
77 Mais informações eram possíveis em: <http://www.museuvirtualdeouropreto.com.br/tourvirtual.html>, mas o site não está mais no ar.
} 
apud THEATER, 1998), percebe-se a complexidade da tarefa da sistematização das experiências de museus disponíveis no ciberespaço, bem como o equívoco em generalizá-las como museu virtual. Embora todas elas lidem com a virtualidade, esse termo não dá conta de suas especificidades. Além do mais, e conforme já tratado aqui, um museu pode ser virtual sem estar na web, já que se trata de um fenômeno e não de um espaço (SCHEINER, 1998), e a virtualidade implica um estado de potência (LÉVY, 2001; DELOCHE, 2005) que, embora possa existir na web, não depende dela.

Tal qual afirma Deloche (2004; 2005), a face virtual do museu exerce o seu papel na ausência de um de seus principais pilares. Nesse sentido, muitas experiências de museu presentes no mapeamento podem ser entendidas como virtuais nessa perspectiva, a exemplo do Muva, que é instituição, mas que não possui prédio nem coleção. Ou então o Museu Virtual do Canadá, que não possui coleção nem prédio. Contudo, apesar de faltar a essas instituições pelo menos um de seus principais pilares para atuar como museu, virtualmente essas funções são cumpridas e, nesses casos, pela experiência de museu disponibilizada na internet. Contudo, esclarece Scheiner (2004, p. 263, grifos do original):

Ainda que possamos reconhecer que todo museu "real" pode ter, hoje, uma "face virtual" - já anunciada pelas experiências da fotografia, do cinema e do vídeo, e plenamente realizada nas múltiplas experiências de captura do real para o ciberespaço, acreditamos que museu virtual é uma criação exclusiva do cibermeio, que ganha corpo e forma na tela do computador. $\dot{E}$ essencialmente, um cibermuseu.

Nessa perspectiva, considera-se que o termo mais apropriado para o Videomuseum, por exemplo, seja cibermuseu, já que, embora se configure em uma experiência virtual de museu, ele existe apenas no ciberespaço e dele depende enquanto estrutura, mas pode ser vivenciada também no museu físico, por uma tela de computador dotado de software específico, não dependendo necessariamente da estrutura da internet.

0 termo cibermuseu encontra a sua origem na palavra cibernética, que implica a ciência que estuda as comunicações e os sistemas de controle tanto nos organismos vivos como nas máquinas. 0 ciberespaço pode ser entendido como um domínio operacional para o armazenamento e trocas de informações composto por 
chips de silício, fios de cobre, cabos de fibra ótica e demais componentes que estruturam o funcionamento dos computadores, que, por sua vez, se configuram como meios de armazenamento e disponibilização de redes que armazenam, transmitem e manipulam bits (KOEPSELL, 2005). Entre essas redes, está a internet. Logo, pode-se entender o cibermuseu como aquela experiência de museu que existe na internet, ou que se manifesta no espaço cibernético, seja mediante um aparato tecnológico, seja por intermédio de um computador por outro tipo de rede. Isto é, resumidamente, são sites que possuem interface presencial, estão disponíveis online e funcionam apenas na web. Ainda, segundo Scheiner (2004, p. 263):

Conceitualmente, o cibermuseu não teria similar no mundo real: seria continuamente recriado, pela vontade de seus criadores, a partir de movimentos articulados do "mouse" ou de pincéis digitais. Poderia ainda existir nos pequenos aparatos individualizados da "realidade virtual" - que, colocamos sobre os olhos de um indivíduo, literalmente o projetam para dentro da imagem.

Assim sendo, é possível afirmar que o museu virtual consiste em um termo mais amplo que engloba diferentes experiências de museus que exercitam a virtualidade, a exemplo também dos webmuseus e dos museus online.

Da mesma forma que os cibermuseus, os webmuseus também existem somente no ciberespaço e não possuem correspondentes no mundo físico. Trata-se de websites que reúnem e disponibilizam virtualmente trabalhos concebidos ou por processos de síntese, ou por meio da digitalização dos originais produzidos no mundo físico. Para Loureiro (2004),

As características da internet the conferem configuração hipertextual, propiciando a conectividade e ampliando as possibilidades de interação com a obra, cuja (s) abertura (s) é (são) evidenciada (s) e/ou potencializada (s), além de condições peculiares de acesso, eliminando empecilhos espaciais e temporais e impondo, por outro lado, restrições de ordem cognitiva e tecnológica, assim como barreiras linguísticas. Diferem do dos museus físicos, ainda, por seu caráter provisório e não necessariamente institucional, bem como pela imaterialidade inerente à imagem digital. Suas finalidades abrangem e, eventualmente, ultrapassam a educação e o lazer, podendo incluir propostas de participação em processos criativos. Compartilham com os museus de arte construídos no espaço físico 
características e funções que os equiparam como aparatos informacionais: destinam-se a produzir, processar e transferir informações e mantêm interface com a sociedade de modo a propiciar viabilidade/acesso a suas coleções e informações.

Por conseguinte, os webmuseus podem ser entendidos como experiências de museu disponíveis na internet dotadas de natureza hipermidiática. Ou seja, além de disponibilizar textos, imagens, áudios e vídeos, possibilitam conexões com outros documentos também disponíveis na web. Conforme já discutido, Ascott (1996) estabelece em sua tipologia três formatos de webmuseus - os de primeiro tipo, os de segundo tipo e os de terceiro tipo-, contudo apenas os de segundo e os de terceiro tipo condizem à definição de webmuseu defendida por Loureiro (2004), já que o de primeiro tipo consiste apenas em um website que fornece informações e não disponibiliza acervo online.

Desse modo, compreende-se o webmuseu como uma experiência de museu constituída por reproduções digitais de obras de arte, e sua principal característica é possibilitar a reunião de trabalhos de arte em um mesmo ambiente virtual em rede, digitalizados ou de síntese, que estão dispersos no espaço e no tempo (LOUREIRO, 2004), tais como o Museu Virtual do Canadá, o Muva e o Museu de Arte Moderna Grand-Duc Jean ${ }^{78}$, especialmente na versão que esteve disponível no período de 2001 a 2009, sobre o que será tratado mais adiante.

Já o museu online pode ser entendido, conforme sugere o próprio termo, como uma experiência de museu que se encontra disponível em rede, estruturada por um sistema de conexão. Nessa visão, o webmuseu e o cibermuseu também podem ser compreendidos como museus online. Da mesma forma, os websites de museus físicos também podem ser vistos como museus online, na medida em que exercitam o espaço da internet tanto para divulgação como para tornar a sua coleção mais acessível. Ou seja, são museus que também estão disponíveis no ambiente virtual da web, tais quais o Museu de Orsay, o Museu do Prado e o Museu de Arte de São Paulo Assis Chateaubriand, por exemplo. Há também experiências de museus virtuais físicos que possuem a sua versão virtual online, como o Museu Temporário da Mudança Permanente e o Museu da Pessoa, ambos já tratados no contexto desta tese.

\footnotetext{
${ }^{78}$ Mais informações em: <http://archive.mudam.lu/?article=657>.
} 
Assim, conforme pode ser constatado, tanto pelo mapeamento como também pelo estudo dos autores (tabela 2), existem hoje disponíveis na internet inúmeras experiências virtuais de museus. A maioria delas é entendida como extensão do museu físico, e outras como exercício de um dos principais pilares necessários à existência do museu enquanto instituição. Ainda, têm-se aquelas que só podem ser encontradas em rede, como os cibermuseus e os webmuseus. Salienta-se também que, nessa lista de termos usados para nomear experiências de museus advindas do desenvolvimento da tecnologia de base microeletrônica, podem ser acrescentados muitos outros, os quais não serão tratados aqui por não serem considerados como relevantes para esta pesquisa. Entre eles, estão o hipermuseu e o museu eletrônico.

\begin{tabular}{|l|l|}
\hline Cibermuseu & $\begin{array}{l}\text { Existente somente na web; } \\
\text { Manifesta-se por meio de computador ou dispositivos } \\
\text { móveis; } \\
\text { Interface presencial; } \\
\text { Pode existir em aparatos informacionais da realidade } \\
\text { virtual. }\end{array}$ \\
\hline Webmuseu & $\begin{array}{l}\text { Existente somente na web; } \\
\text { Hipertextual; } \\
\text { Disponibiliza propostas participativas; } \\
\text { Produz, processa e transfere informações. }\end{array}$ \\
\hline Museu online & $\begin{array}{l}\text { Disponível em rede; } \\
\text { Baseado em um sistema de conexão; } \\
\text { Pode ser a extensão de um museu físico. }\end{array}$ \\
\hline Museu virtual & $\begin{array}{l}\text { Não é exclusivo da web; } \\
\text { Existente também na realidade física; } \\
\text { Existe enquanto potência; } \\
\text { Engloba o museu físico, o cibermuseu, o webmuseu e o } \\
\text { museu online. }\end{array}$ \\
\hline
\end{tabular}

Tabela $\mathbf{2}$ - Síntese dos termos que nomeiam experiências de museus virtuais Fonte: Primária

Também a partir do mapeamento (Apêndice 2), foi investigado que experiências de museu disponíveis na web disponibilizam exposições virtuais projetadas especificamente para aquela realidade. Entre elas, foram identificadas apenas 19. Dessas exposições, 11 são disponibilizadas por intermédio de experiências virtuais que se afirmam museu, ou seja, pouco mais da metade. Sendo a exposição, conforme já citado, considerada a instância relacional do museu de maior importância, questiona-se a relevância de disponibilizar um acervo se este 
não é problematizado, exercitado nem estudado. Conforme assegura Cauquelin (2008, p. 130):

\begin{abstract}
Falar de obra virtual ou de galeria virtual quando se expõem na internet obras já realizadas é um abuso de linguagem. Aliás, a maior parte dos museus chamados virtuais nada tem de virtual: eles apenas permitem visualizar uma sequência de fotografias e de visões panorâmicas; nesse caso, o que se chama de "virtual" é a possibilidade que tem o visitante de escolher o que ver clicando um nome em um menu.
\end{abstract}

Observa-se ainda que, dessas experiências que se intitulam museu virtual, apenas seis contêm atividades participativas. Embora seja interessante que acervos estejam disponíveis online, pelos diversos motivos já tratados ao longo do desenvolvimento deste texto, questiona-se se o apenas disponibilizar implica tornar 0 acervo de fato acessível.

\title{
1.6 A exposição no ambiente virtual em rede
}

Constata-se que 133 das experiências de museu mapeadas possuem sede também na realidade física. Delas, 35 disponibilizam visita em três dimensões a suas dependências físicas, e 94, acervo para consulta online. Isso significa que o espaço virtual disponível em rede já vem sendo explorado em suas possibilidades, contudo ainda é a minoria que o aproveita como um meio de colocar o acervo em exercício, tendo em vista que somente 40 oferecem atividades participativas e apenas sete realizam exposições no ambiente virtual.

Entre todas as experiências mapeadas, destaca-se como exemplo de exploração das possibilidades oferecidas pelo ambiente virtual em rede a experiência de museu realizada por Claude Closky para o Museu de Arte Moderna Grand-Duc Jean, que permaneceu online no período de 2001 a $2009^{79}$ e que agora integra os arquivos do website museu. Das 135 experiências analisadas, trata-se da única experiência mapeada que, além de informações e banco de dados com imagens do acervo para consulta, oferece ferramentas para participação do visitante, assim como promove exposições virtuais. Esse museu virtual, assim denominado pela própria instituição, criado e coordenado pelo artista Closky,

\footnotetext{
${ }^{79}$ Mais informações em: <http://archive.mudam.lu/?article=657>.
} 
buscou romper com relações de similaridade com a realidade física na exploração das possibilidade e especificidades encontradas no ambiente virtual da web.

Ao acessar o website, o visitante depara com um menu horizontal, na parte superior da tela, por meio do qual pode escolher, além da língua, inglesa ou francesa, a opção de navegação desejada. A primeira delas é Mudam in Pictures, por meio da qual o visitante opta por visitar o museu mediante textos ou imagens. Assim, ao clicar em Mudam in Pictures, somem os textos e é oferecida navegação exclusivamente visual, permanecendo apenas o menu na parte superior. Ao clicar em Hide Menu, no canto inferior esquerdo, o menu desaparece, ficando somente a imagem, a qual ocupa a tela inteira. Automaticamente começa a ser disponibilizada uma imagem após a outra, com legenda sobreposta (e que também pode ser escondida), mostrando vistas de trabalhos e exposições feitas na sede do museu físico. Ainda na opção Mudam in Pictures, ao clicar em Menu para voltar a ele e selecionar About this Site, por exemplo, um novo conjunto de imagens aparece, todas mostrando as pessoas trabalhando, envolvidas na construção e na manutenção do website, bem como fotos de crianças, adolescentes e adultos visitando $o$ website pelo computador. Ao clicar em The Museum, têm-se então imagens da fachada e da arquitetura em diferentes ângulos mostrando detalhes diversos.

Ressalta-se aqui a forma como a consulta ao acervo é disponibilizada. Ao clicar em The Collection, imagens de obras do acervo passam a aparecer aleatoriamente. Ao selecionar novamente Hide Menu, a informação textual volta, e uma lista de nomes de artistas presentes no acervo é disponibilizada de forma sobreposta à imagem, e cada nome é um link. Ao clicar no nome desejado, a imagem de fundo muda, e imagens de obras do artista selecionado mostram-se como um novo fundo, uma a uma, acompanhadas pela legenda, a qual pode ser escondida, caso o visitante desejar.

As ferramentas até agora descritas proporcionam ao visitante o contato com o museu físico e a sua coleção, contudo pela exploração das possibilidades oferecidas pelo ambiente virtual. Conforme consta no próprio website, em About this Site: 
It seems to us that a museum should not confine itself to giving information without offering a reflection on the nature and medium of this information. We do not see the web site as a space for reproduction, a paper publication or even less as an art book. Its aim is to complement the work of the museum, not to duplicate its contents. The image of a work should not be a substitute for experiencing the work itself. That is why we use reproductions on the Mudam site as clues. The visuals relating to the same subject are displayed full screen, one after another, randomly or not, like a slideshow. The proportions are adjusted to those of the window of the navigator of the internaut ${ }^{80}$ (MUSEU DE ARTE MODERNA..., 2016).

Já em iGallery, o visitante pode escolher entre inúmeras experiências de webart disponibilizadas não por um menu, mas por imagens de capa acompanhadas pelo nome do artista e título do trabalho, organizadas uma após a outra em duas fileiras, entre as quais pode selecionar qual delas deseja vivenciar. Ao escolher, uma nova janela abre-se, e o trabalho pode ser vivenciado. Alguns deles necessitam de plugin específico, o qual pode ser baixado e instalado. Cauquelin (2008) cita essa experiência como a de um museu de fato virtual, já que, além de explorar as particularidades do ambiente virtual, torna disponível uma produção artística projetada exclusivamente para um espaço dessa natureza.

A experiência de exposição proporcionada pela iGallery consiste em disponibilizar para vivência trabalhos que já nasceram digitais, o que é diferente de realizar exposições com trabalhos pensados para a realidade física. Contudo, já que os museus passaram a ocupar também o espaço virtual da web, é interessante que esse espaço seja explorado considerando as suas especificidades, não como uma reprodução do mundo físico. Conforme já dito, no processo de mapeamento foram encontradas 22 experiências de museus que disponibilizam exposições virtuais, das quais 14 são feitas por museus que só existem no âmbito da virtualidade e 6 (apêndice 2) acontecem por aqueles que também possuem sede física.

Além do Mudam, apenas mais duas experiências de museus mapeadas promovem exposições de webart e de arte digital: o Muva e o Museum of Computer

\footnotetext{
80 “Parece-nos que um museu não deveria limitar-se a dar informações sem oferecer a reflexão da natureza e dos meios dessas informações. Nós não vemos o website como um espaço para uma reprodução, uma publicação de relatórios nem muito menos como um livro de arte. Seu objetivo é complementar o trabalho do museu, não duplicar seus conteúdos. A imagem de uma obra não poderia ser um substituto para experimentar a obra em si. Por isso nós utilizamos, como dicas, reproduções no site de Mudam. Os relatos visuais para o mesmo tema são mostrados em tela cheia, um após o outro, aleatoriamente ou não, como uma apresentação de slides. As proporções são ajustadas às proporções da janela do navegador do internauta" (livre tradução).
} 
$\mathrm{Art}^{81}$, o Moca. Criado em 1993 pelos artistas Don Archer e Bob Dotson, o Moca configura-se em um museu existente apenas na web, com o intuito de promover arte digital nas suas mais diversas formas e manifestações, desde vídeos digitais, em três dimensões, a produções em áudio. 0 visitante pode escolher entre visualizar trabalhos de artistas específicos, da seleção por nomes disponíveis em Scrolling for Art, ou então acessar as Main Galleries, organizadas por diferentes propostas, temas e técnicas. Além das exposições virtuais, recentes e passadas (realizadas a partir de 2010), o museu também contém ensaios sobre arte digital escritos por diferentes autores e um espaço para submissão de trabalhos, que, se selecionados pela equipe curatorial, podem integrar uma das galerias. É interessante observar que esse museu possui a mesma natureza dos trabalhos que o integram e, ao aproveitar a estrutura da web para abrir espaço para novos artistas, contribui tanto para a difusão de novos trabalhos como permanece em constante processo de transformação.

Das experiências de museu que realizam exposições virtuais (apêndice 2), 17 são contempladas por trabalhos físicos que foram digitalizados, ou reproduzidos digitalmente, como é o caso da mostra de Lygia Clark realizada pelo Itaú Cultural, já analisada no início deste capítulo. Delas, destacam-se, além das já tratadas no desenvolvimento deste texto, as feitas pelo Museu Casa de Portinari ${ }^{82}$, no interior de São Paulo. No corpo da página principal do website do museu, ao acessar Exposições Virtuais, o visitante pode escolher entre: Futebol e Arte, Novos Talentos e 0 Carnaval na Paleta de Portinari. Cada uma dessas exposições possui formato distinto, tendo em vista as suas especificidades.

Para discutir aqui, foi selecionado o item 0 Carnaval na Paleta de Portinari ${ }^{83}$, pelo fato de ele envolver as obras do artista e ter mais afinidade com a proposta de exposição a ser desenvolvida no âmbito desta tese. Ao clicar no título da exposição, na página principal do site, uma nova janela abre-se para a exposição (figura 17).

\footnotetext{
81 Mais informações em: <http://moca.virtual.museum/>.

${ }^{82}$ Mais informações em: <http://museucasadeportinari.org.br/>.

${ }^{83}$ Mais informações em: <http://www.museucasadeportinari.org.br/exposicao-carnaval-paletaportinari/>.
} 

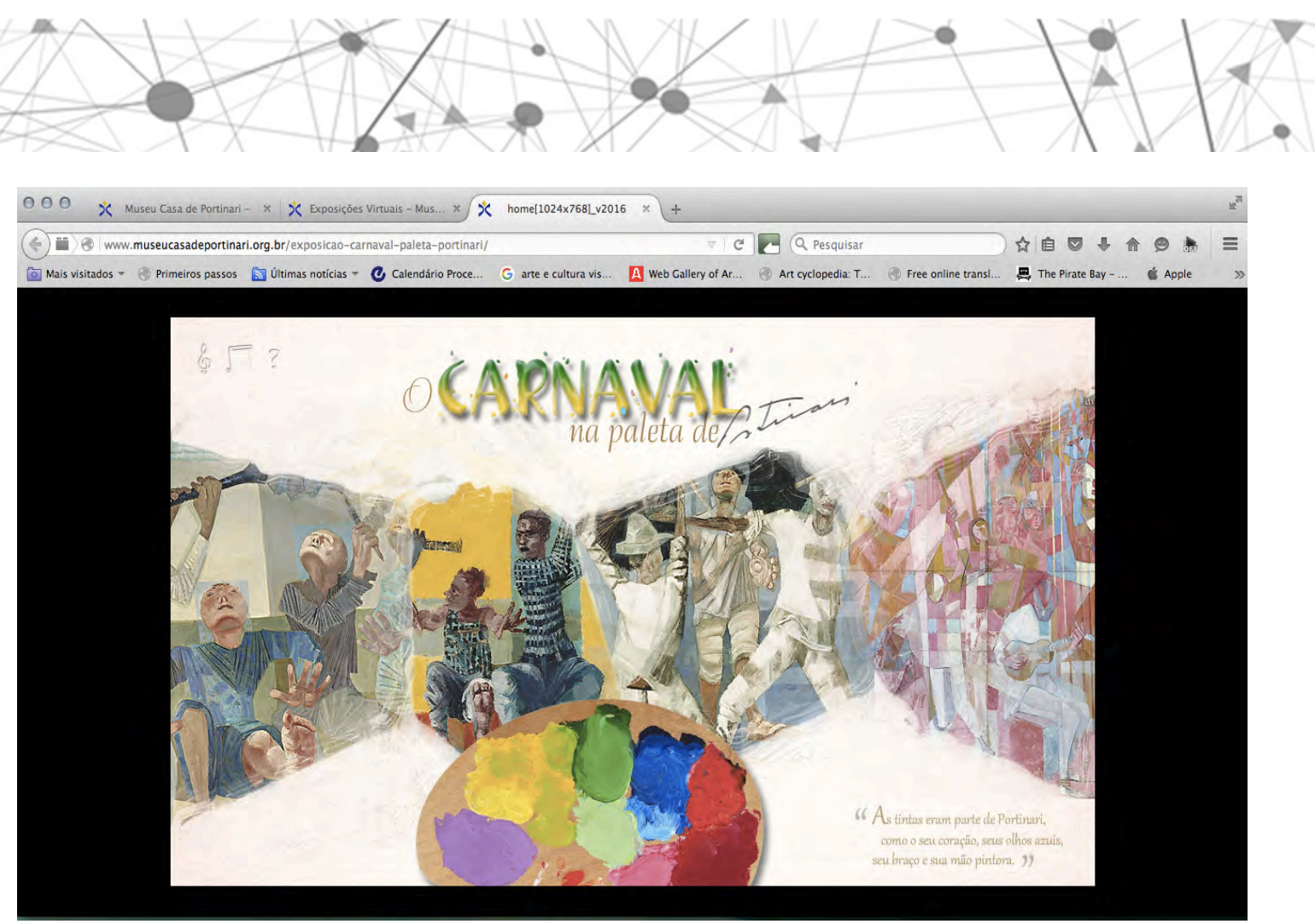

Figura 17 - Captura de tela mostrando a página de abertura da exposição virtual 0 Carnaval na Paleta de Portinari

Fonte: Primária

Além do título e de fragmentos de imagens das pinturas que compõem a mostra, consta da capa a imagem de uma paleta de tintas, e cada uma das cores é um link para um dos caminhos possíveis de percurso pela exposição. No canto superior esquerdo, há três ícones. 0 primeiro, que uma clave de sol, dá acesso a uma lista de músicas de frevo. 0 segundo, que representa um pergaminho aberto, disponibiliza os dados técnicos sobre a exposição, informando as equipes e instituições envolvidas, assim como os realizadores. Já no terceiro (figura 18) o visitante tem contato com um menu explicativo para realizar o percurso da exposição. 

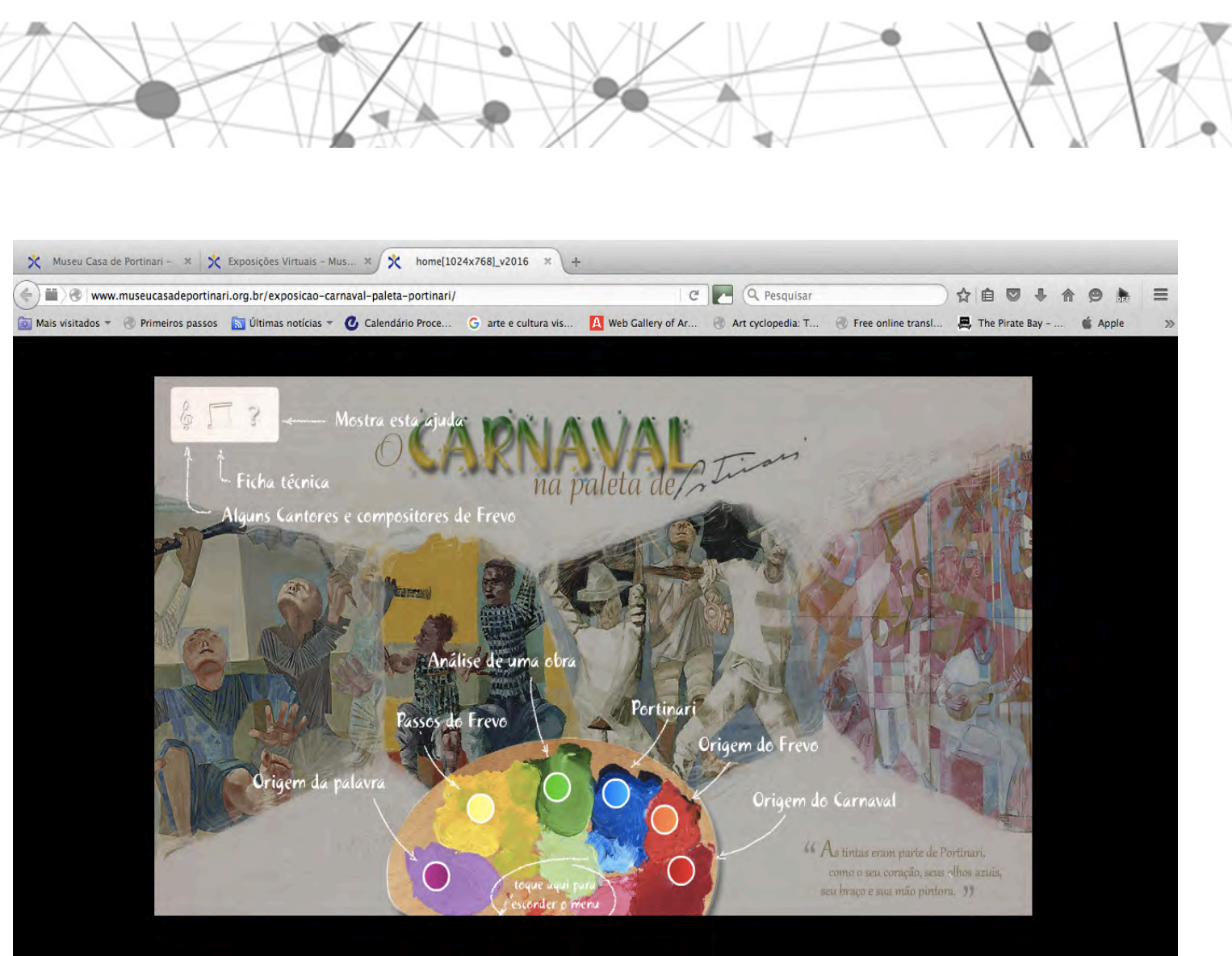

Figura 18 - Captura de imagem mostrando menu explicativo para percurso da exposição Fonte: Primária

Ao escolher iniciar a visita à exposição pela cor lilás, por exemplo, o clique conduz a uma página que trata do frevo (figura 19).

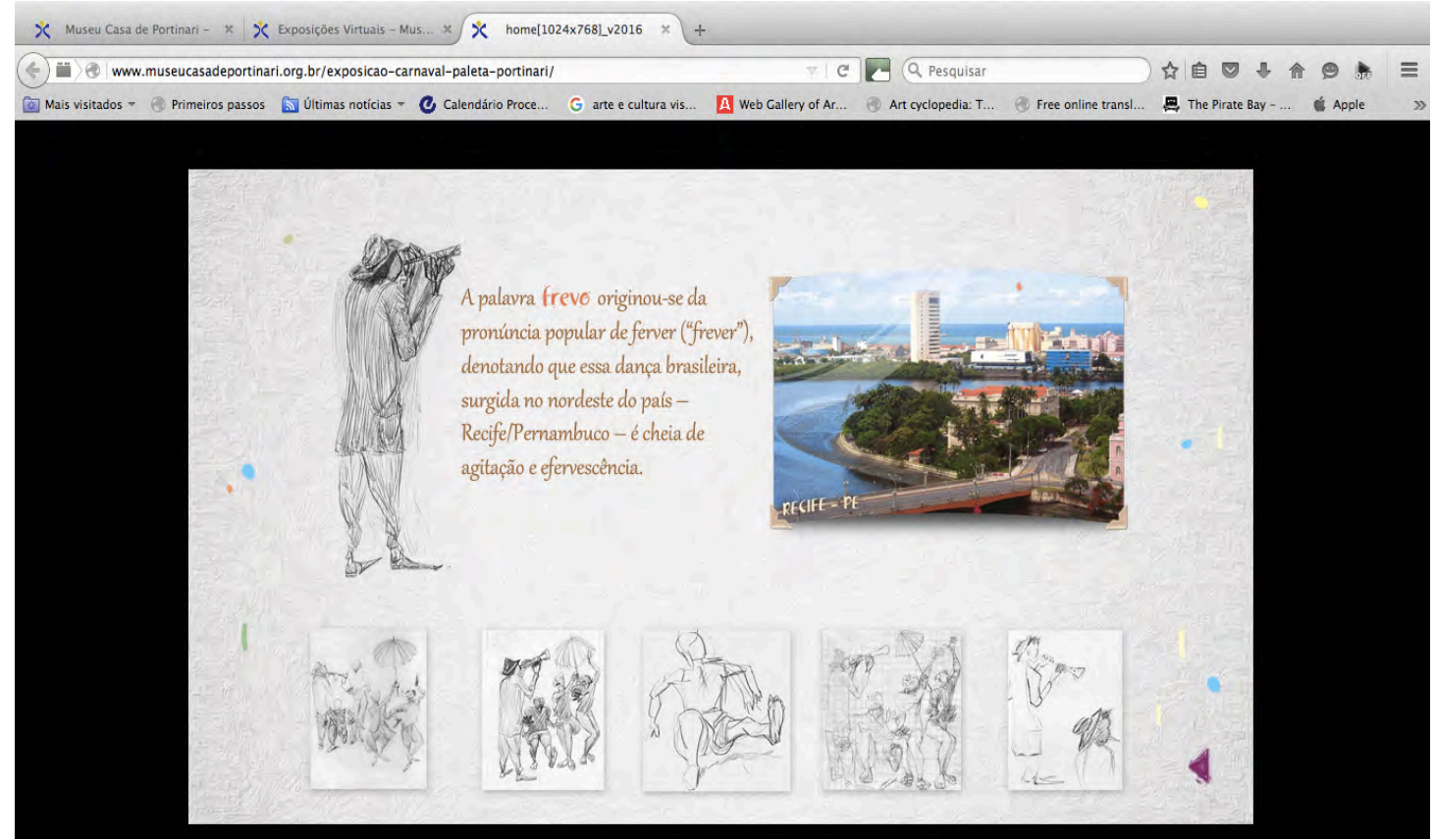

Figura 19 - Captura de tela mostrando a página da exposição que trata do frevo Fonte: Primária

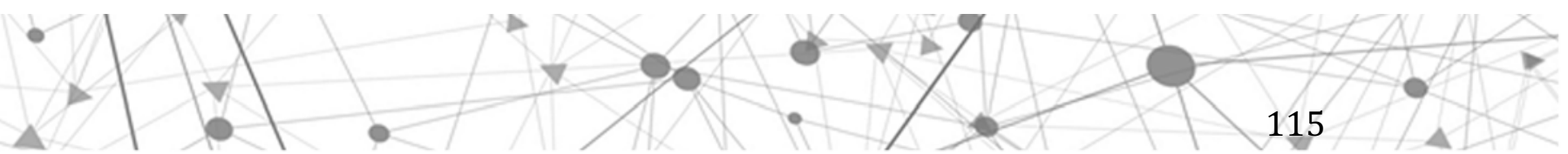




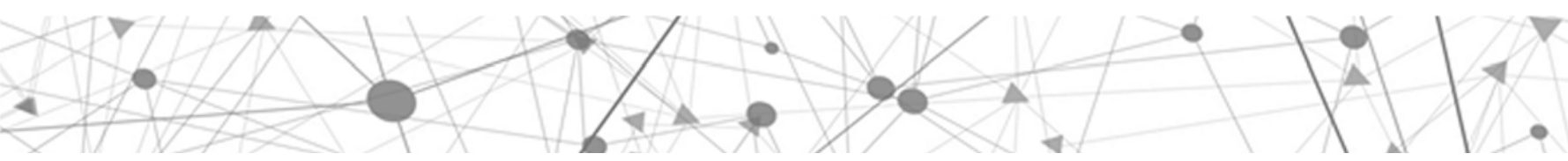

Ao clicar no texto, uma nova tela abre-se com a reprodução da pintura Frevo, do artista Cândido Portinari, em alta qualidade, acompanhada por legenda contendo o título e o ano (figura 20). Não são informadas as dimensões dessa pintura original nem de nenhuma outra que compõe a exposição, o que se considera um problema, tendo em vista que por meio da visualização na tela do computador se perde a referência de tamanho. No caso de uma reprodução, essa informação faz-se necessária, a não ser que seja a intenção o rompimento com o original construído na realidade física, o que não parece ser o caso aqui.

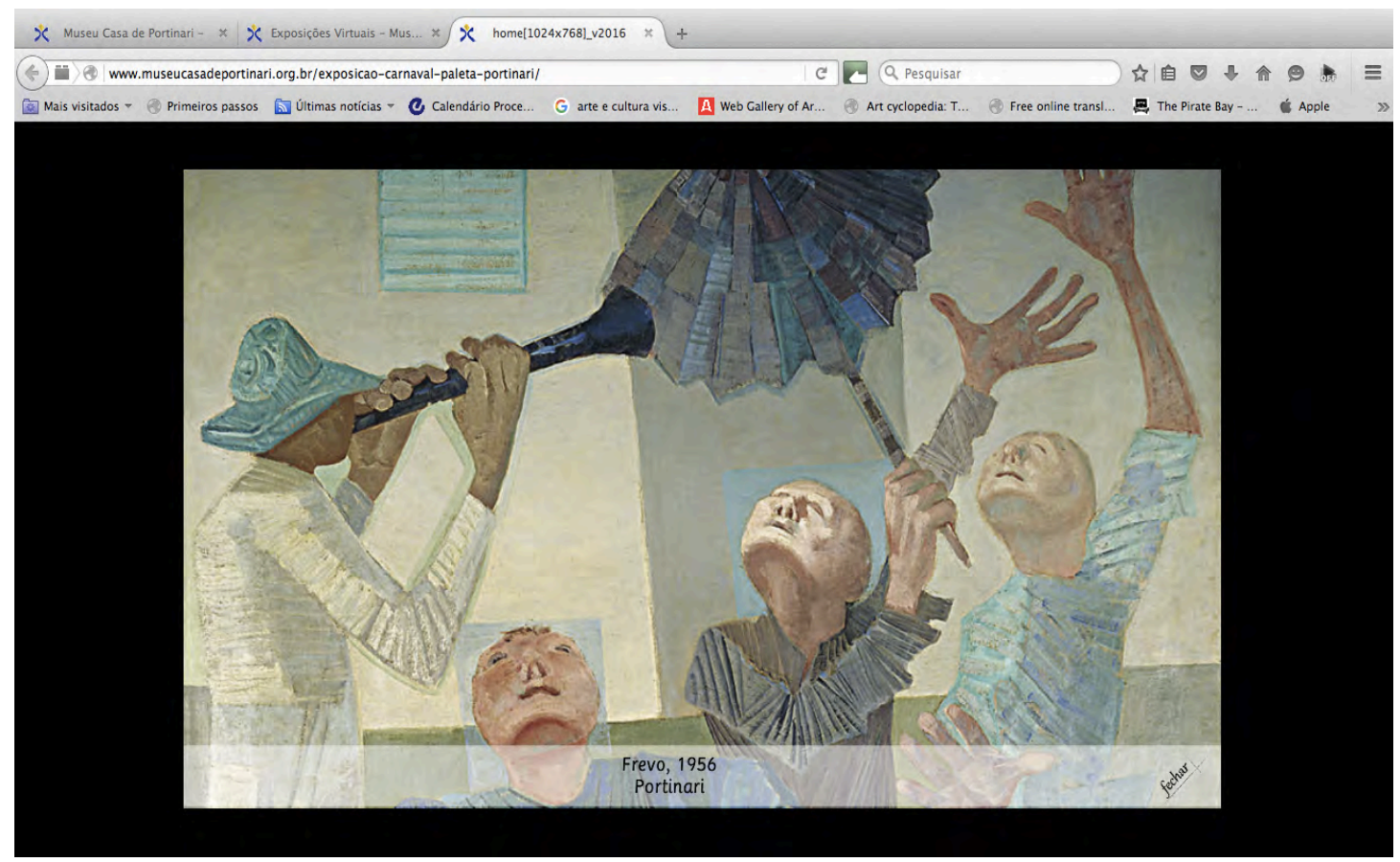

Figura 20 - Captura de tela mostrando a reprodução da pintura Frevo, de Cândido Portinari, que não pode ser visualizada por inteiro Fonte: Primária

$\mathrm{Na}$ parte inferior da tela, estão disponíveis cinco reproduções de estudos realizados pelo artista sobre o tema. Ao clicar em cada uma delas, aos moldes da primeira imagem, elas também podem ser visualizadas em alta qualidade. Já ao lado direito superior, há a imagem de uma vista da cidade do Recife, berço do frevo, a qual também pode ser ampliada. Para retornar à página principal da exposição, após ter contemplado a quantidade que se quis das imagens disponíveis e por quanto tempo se tenha tido vontade, basta que o visitante clique na seta lilás que aponta para a direção esquerda, indicando o caminho de retorno. 
Ao clicar na cor amarela da paleta, a página referente aos principais passos do trevo é aberta, e o visitante pode visualizar três imagens de obras de Portinari que representam esses passos. Da mesma forma como acontece com as demais imagens que compõem a exposição, basta clicar nelas para que sejam visualizadas individualmente. Na parte inferior da página, constam o nome de quatro dos principais passos do frevo. Ao clicar em cada um dos nomes, uma nova página com um esboço de Portinari relativo àquele passo é visualizada.

Já a cor vermelha conduz a uma página acerca da história do carnaval. À direita da página, um texto trata brevemente do carnaval e, do lado esquerdo, são disponibilizadas três imagens, Luta entre Carnaval e Quaresma, de Pieter Bruegel; Um Desfile de Carnaval com Figuras Mascaradas, de P. Bergaine; e Procissão do Rei dos Pulcinelli durante o Carnaval Romano, de Johann Heinrich Stuermer.

0 vermelho mais escuro da paleta, por sua vez, direciona a uma página a respeito da história do frevo, acompanhada de três imagens de trabalhos de Portinari sobre o tema. Palavras-chave do texto são links para imagens do artista, também sobre o tema. Ao visitar essas duas páginas, o visitante tem contato com texto e imagens que se complementam na discussão das origens, das influências e do desenvolvimento do carnaval e do frevo, conteúdos que contribuem para o aprofundamento das leituras das imagens de Portinari.

Sem seguir a ordem linear para acessar as páginas da exposição, ao clicar no verde, a imagem da pintura Frevo é visualizada, seguida por um fragmento de texto que a analisa. Embora tenham sido informadas as referências da citação no texto, elas não estão completas, de maneira que o visitante fica sem conhecer a fonte. Já a cor azul conduz à página sobre o artista, contemplada por um autorretrato e por um breve texto explicativo, dando destaque para o frevo como tema na sua produção concernente ao carnaval.

Percebe-se que a exposição virtual 0 Carnaval na Paleta de Portinari explora a estrutura de hiperlinks no desenho de uma exposição dinâmica. Observa-se também a escolha por textos curtos e objetivos, que por vezes até se mostram incipientes. Em contraste com as exposições realizadas pelo Mudam, a lógica da organização da exposição ainda segue à da estrutura de salas, tal como acontece no espaço físico. Ressalta-se também que não é disponibilizada nenhuma ferramenta para participação do visitante, que, assim como no museu físico, percorre cada uma 
das salas vendo obras e lendo textos. A diferença é que a exposição virtual pode ser realizada sem precisar sair de casa, a qualquer hora do dia ou da noite, tendo facilmente ao alcance um universo inteiro para ser pesquisado e relacionado com 0 que está sendo exposto. É uma pena que, a exemplo dessa mostra de Portinari, nem todas as exposições tirem partido dessa estrutura e que nem todas as experiências de museu disponíveis no ciberespaço utilizam esse meio para realizar exposições.

No contexto desta tese, conforme será visto nos capítulos posteriores, defende-se a exposição virtual como uma das mais importantes ferramentas relacionais do museu. Acredita-se que ela possa existir no ambiente virtual independentemente de possuir versão no espaço físico e que, por meio dela, sejam exploradas as especificidades do ambiente virtual em rede. Assim, a curadoria de uma exposição virtual vai lidar com desafios distintos daqueles enfrentados na construção do desenho de uma mostra física, já que se trata de uma exposição em potência, contemplada por versões digitalizadas de trabalhos físicos que podem ter as suas referências perdidas, ou até causar impressões ao visitante que distanciem as obras do que esses trabalhos de fato são.

Isso se dá sobretudo quando se tenta reproduzir a realidade física, como, por exemplo, disponibilizar uma imagem construída digitalmente de uma escultura que, no mundo físico, possui peso, volume, temperatura e dificuldade de controle. É impossível perceber tais atributos da peça mediante a manipulação do mouse e dos comandos do teclado, a exemplo da mostra de Lygia Clark produzida pelo Instituto Itaú Cultural, já discutida neste texto.

Assim sendo, tendo-se como base a curadoria educativa, a qual será tratada no próximo capítulo, entendida como um meio de desenhar exposições por diferentes camadas de aprofundamento, de forma a atender a tipos distintos de visitantes e de promover a arte como um veículo de ação cultural, será projetada a exposição fruto desta tese. Tal exposição consistirá na remontagem virtual de uma mostra importante realizada por Luiz Henrique Schwanke, em 1980, no Museu Nacional de Belas Artes, do Rio de Janeiro, por meio da qual serão exploradas as estruturas e as ferramentas específicas da realidade virtual, sem qualquer tentativa de reprodução de uma exposição promovida em ambiente físico. 


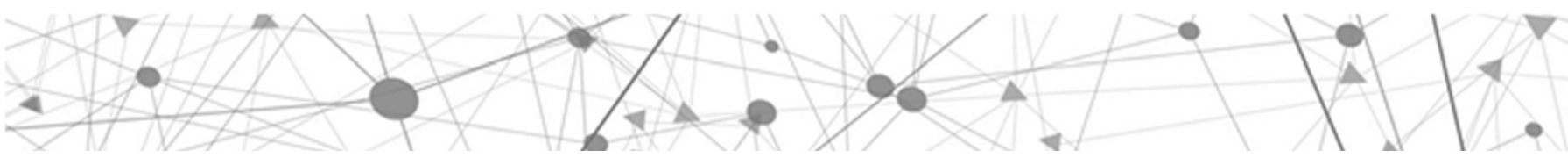

CAPÍTULO 2

CURADORIA, CURADORIA EDUCATIVA E EXPOSIÇÃO VIRTUAL NA WEB

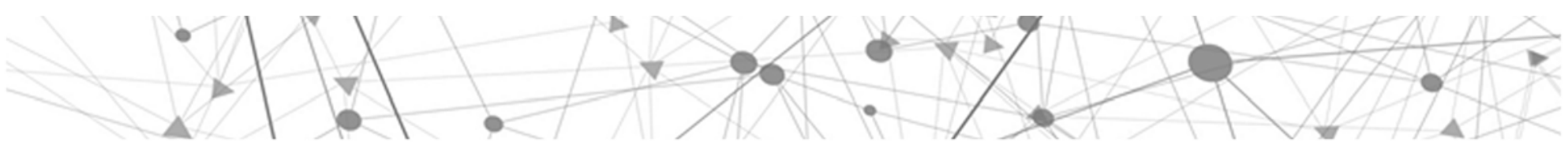




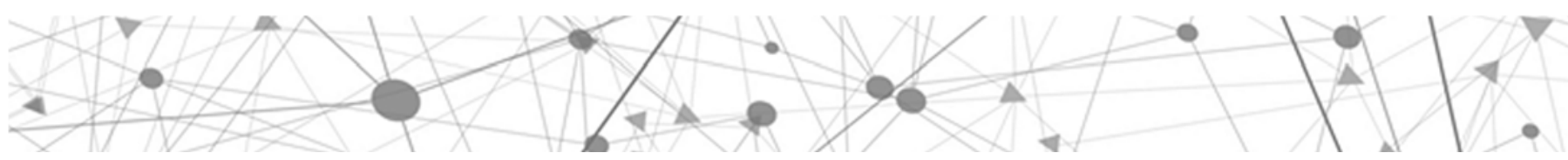

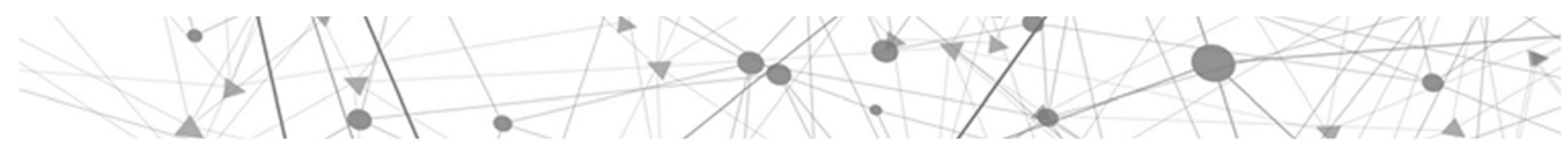




\subsection{A curadoria e a história das exposições}

Não se pode dissociar a história da arte da história das exposições nem do desenvolvimento da curadoria. A arte só tem razão de ser quando é vista, vivenciada, e somente o é quando mostrada. Apesar disso, afirma-se que a gênese das exposições está nas coleções particulares que deram forma, no primeiro momento, aos gabinetes de curiosidades (kunstkammer ou wunderkammer), cujos itens ficavam restritos à contemplação de seus donos e convidados. Surgidos no século XVI, com as primeiras experiências de colecionismo, consistiam em ambientes ou mesmo móveis nos quais eram guardados objetos considerados interessantes, curiosos e até mesmo estranhos, tais como moedas, lápides, inscrições antigas, animais empalhados, fósseis, pinturas, esculturas, entre outros (CIPINIUK, 2003). Além de pensar a disposição dos itens da coleção no espaço, alguns colecionadores chegaram a catalogar as suas peças, separando-as por categorias estabelecidas com base em critérios pessoais, como assim o fez 0 colecionador francês Pierre Borel, que organizou a sua coleção da seguinte forma:

Raridades humanas incluindo ossos de um gigante e um monstro de duas cabeças); animais de quatro patas; peixes e criaturas do mar; outros objetos marinhos; insetos e cobras; plantas; flores; [...] sementes e grãos; frutas raras; outras frutas e sementes; fósseis; outros minerais; antiguidades; coisas artificiais. As duas últimas categorias são as primeiras a incluir trabalhos de arte: urnas, vasos, moedas, medalhas, assim como "450 miniaturas raras a partir de grandes mestres como Michelangelo, Rafael, Luvas e Albert montadas em um álbum muito grande". A categoria final de "coisas artificiais" incluía "espelhos, porcelanas, lentes, 50 retratos a óleo de Roma, Flandres e Paris" (CROW, 1985, p. 29).

Organizar as peças que integram a coleção, assim como pensar a forma de colocá-las à mostra, é uma atividade que, a partir do século XIX, passou a fazer parte das atividades exercidas pelo curador.

Contudo, até o fim do século XVIII, a produção artística e cultural era acessível sobretudo à nobreza e ao clero. Inicialmente, isso se deu com os gabinetes de curiosidades e, a partir do século XVII, com a formação das primeiras coleções que se tornaram públicas, a exemplo de Frederico I di Médici, que doou a sua coleção para a Galeria dos Ofícios, em Florença, Itália, na qual as pinturas e as 


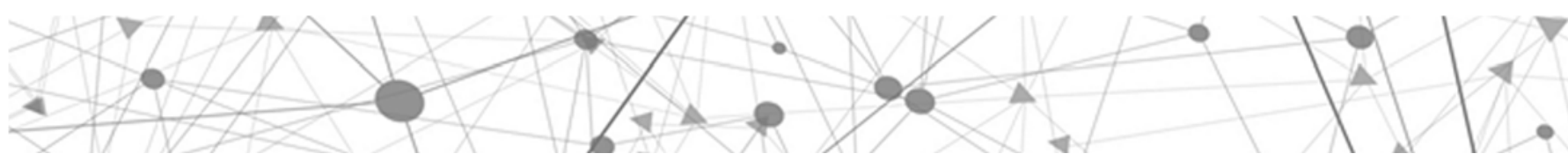

esculturas foram colocadas em destaque na sala hoje conhecida como Tribuna de Mármore. Paulatinamente, a tradição dos gabinetes de curiosidades foi perdendo a força, e as coleções foram se especializando e passaram a ser colocadas à visitação pública com a criação dos primeiros museus, conforme já tratado no capítulo 1 .

No século XVII, surgiram os primeiros salões, que podem ser considerados como as primeiras exposições temporárias abertas ao público (GONÇALVES, 2004). Na França, por exemplo, em 1697, foi realizado o Salão da Academia Real de Pintura, na Grande Galeria do Museu do Louvre, o qual, a partir de 1725, passou a acontecer no Salão Carré, desse mesmo museu (GONÇALVES, 2004). 0 pilar que serviu de modelo para a organização das obras que integravam os salões foi a forma de mostrar adotada nos kunstkammers. Tal qual pode ser observado no gabinete de curiosidades de Cornelis van der Geest (Figura 21), por exemplo, as pinturas eram dispostas lado a lado, sem espaçamento entre elas, como um mosaico, cabendo à moldura a função de separá-las, tanto uma das outras como da realidade.

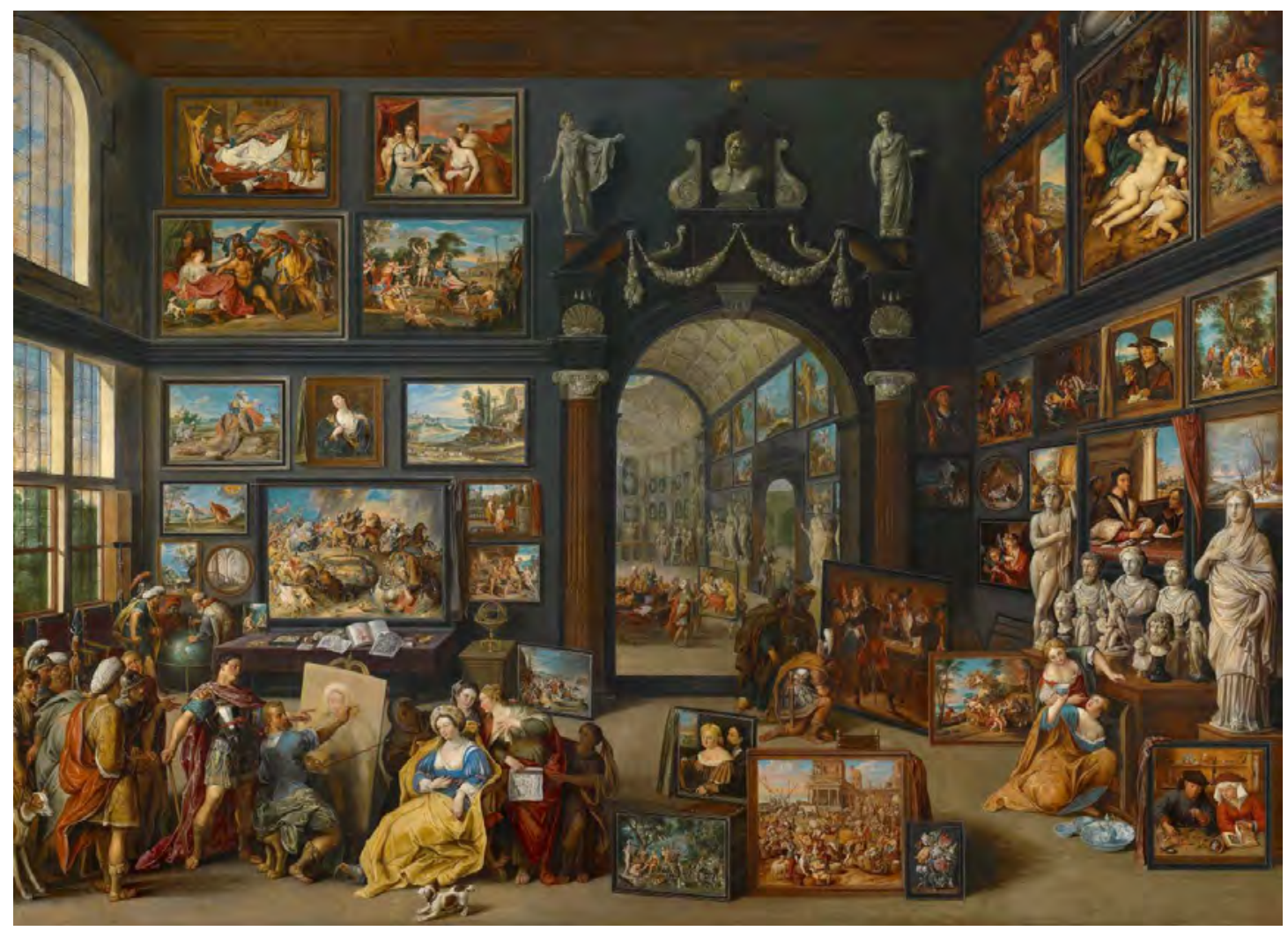

Figura 21 - Kunstkammer Cornelis van der Geest, de Willem van Haecht, c. 1630. Óleo sobre tela. $105 \times 149 \mathrm{~cm}$. Mauritshuis, The Hague

Fonte: disponível em: <http://www.wga.hu/support/viewer/z.html>. Acesso em: 22 maio 2016

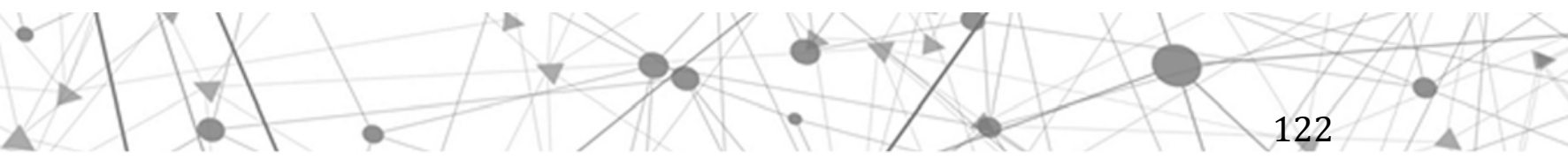




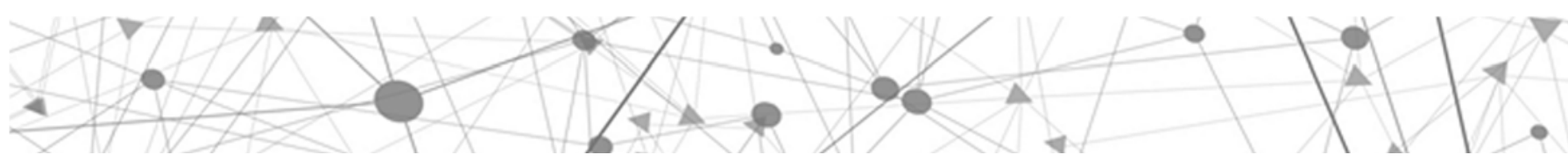

Ao visualizar a vista de uma exposição promovida no Salão Carré no século XIX (figura 22), constata-se que a disposição das pinturas, que ocupam toda a extensão da parede, segue a mesma lógica dos gabinetes de curiosidades (figura 21). Conforme 0'Dohert (2002) em relação a uma exposição realizada na Galeria de Exposição do Louvre, observada em uma pintura de Samuel B. Morse, também do século XIX:

0 trabalho perfeito de pendurar quadros resulta num mosaico engenhoso de molduras sem que se veja uma nesga de parede desperdiçada. [...] Cada quadro era encarado como uma entidade independente, totalmente isolado de seu reles vizinho por uma moldura pesada ao seu redor e todo um sistema de perspectiva em seu interior. 0 recinto era descontínuo e dividido em categorias, do mesmo que as casas em que se penduravam esses quadros tinham salas diferentes para fins diferentes. A mentalidade do século XIX era taxonômica, e o olhar do século XIX reconhecia as hierarquias de gênero e o prestígio da moldura (0'DOHERT, 2002, p. 6).

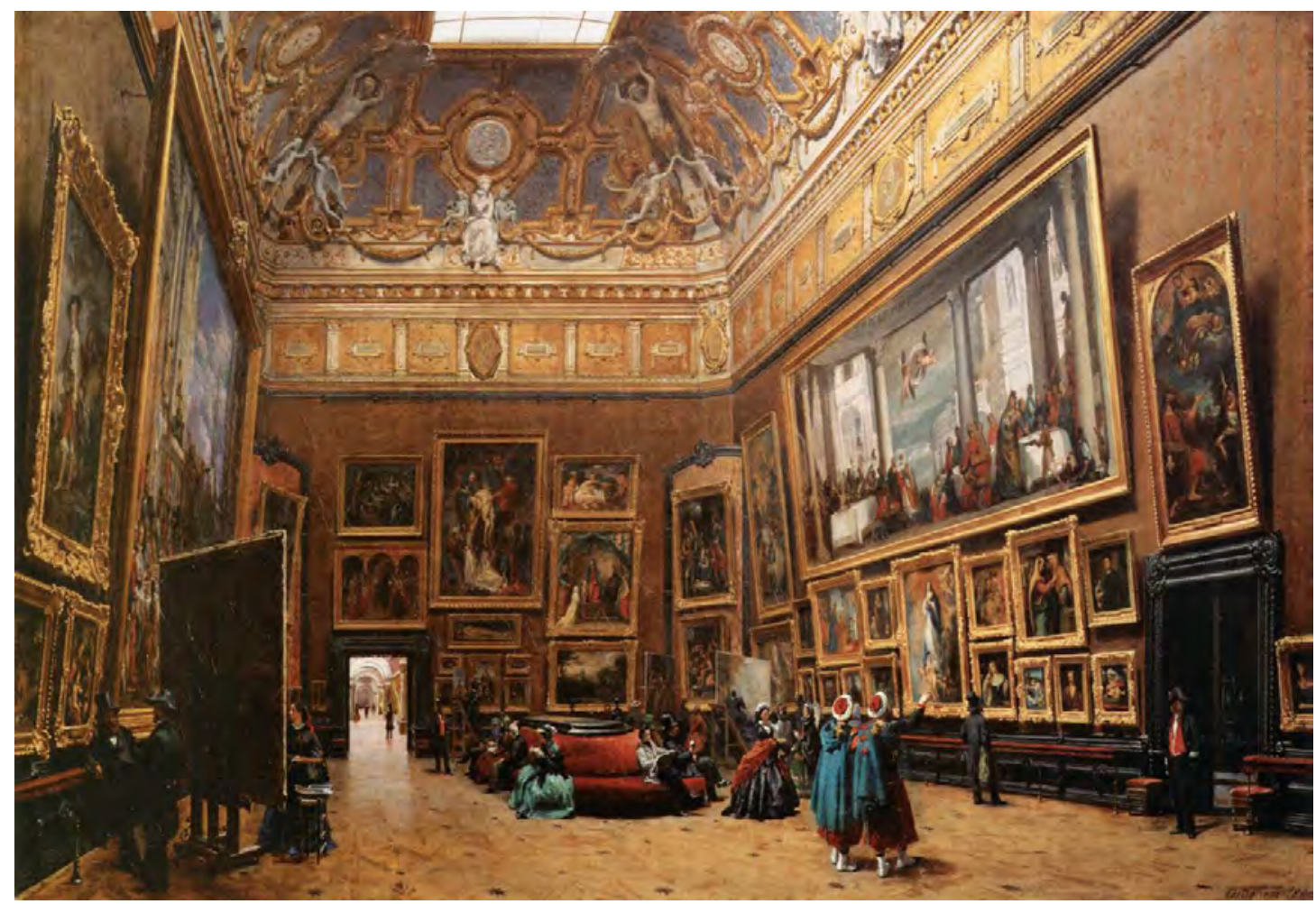

Figura 22 - Vista do Grand Salon Carré no Louvre, de Giuseppe Castiglione, 1861. Óleo sobre tela. $69 \times 103 \mathrm{~cm}$. Museu do Louvre, Paris

Fonte: disponivel em: <http://www.wga.hu/support/viewer/z.html>. Acesso em: 22 maio 2016

Embora ainda não se falasse em curadoria de arte, a montagem dessas exposições seguia critérios tanto para a seleção das obras que comporiam a mostra

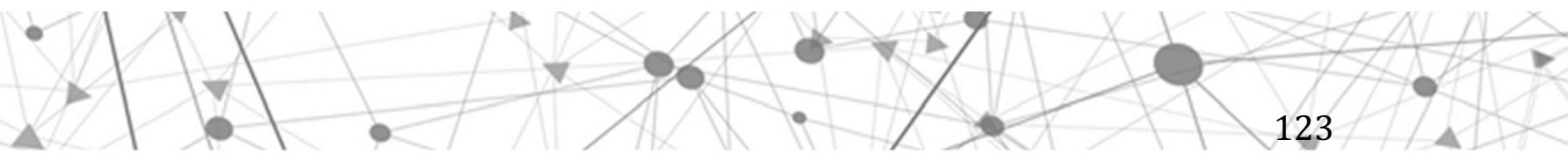


como também para a ordem da disposição delas no espaço. Geralmente, a distribuição das pinturas pela parede era feita com base numa hierarquia de gênero. Em primeiro grau de importância, vinham as pinturas históricas, as quais envolviam cenas bíblicas, mitológicas e grandes conquistas históricas. Depois, tinham-se os retratos, seguidos pelas pinturas de gênero, pelas naturezas-mortas e, finalmente, pelas paisagens (COUTINHO apud CINTRÃO, 2010).

Assim sendo, o século XVIII foi marcado pelo surgimento do salão de arte e da crítica de arte, no intuito de possibilitar a fruição estética à nova classe burguesa, economicamente estável. A relação de consumo estético entre o público e a obra de arte iniciou-se com os movimentos de arte moderna, mesmo que o último tenha sido resultado da ruptura com o academicismo até então vigente. Com esses movimentos de vanguarda, que colocava o novo em pauta em detrimento de todas as conquistas da arte do passado, agora negadas, surgiram novas propostas de leitura da arte. Com o objetivo de estabelecer um diálogo com o espectador, os movimentos de vanguarda provocaram situações encaradas como obstáculos conceituais. Nesse sentido, exposições foram organizadas com o propósito de ajudar o público a se familiarizar com o novo e dessa maneira modificar a sua forma de olhar para a arte (BINI, 2005).

0 termo curador tem sua raiz etimológica no grego curare, que significa cuidar de. No período romano, os curatores eram aqueles que tinham por função a supervisão de obras públicas, tais como os aquedutos, os encanamentos de esgoto e as casas de banho. Já na Idade Média, o curatus era o padre responsável por cuidar das almas de uma determinada paróquia (OBRIST, 2014). Foi somente no século XVIII que a atividade de curar passou a se referir aos cuidados do acervo de um museu.

Nesse sentido, pode-se considerar o linguista e egiptólogo francês JeanFrançois Champollion um dos primeiros curadores de arte da história. Foi Champollion que, em 1822, decifrou, fundamentado na Pedra de Roseta, como ler hieróglifos, além de ter ajudado a criar o Museu de Antiguidades Egípcias de Turim $^{84}$, o qual possui uma das mais importantes coleções egípcias do mundo. Em 15 de maio de 1826, por decreto real, foi nomeado curador do Departamento de Arte Egípcia do Museu do Louvre, inaugurado em 15 de dezembro de 1827 (MUSEU

${ }^{84}$ Mais informações em: <http://www.museoegizio.it/>. 


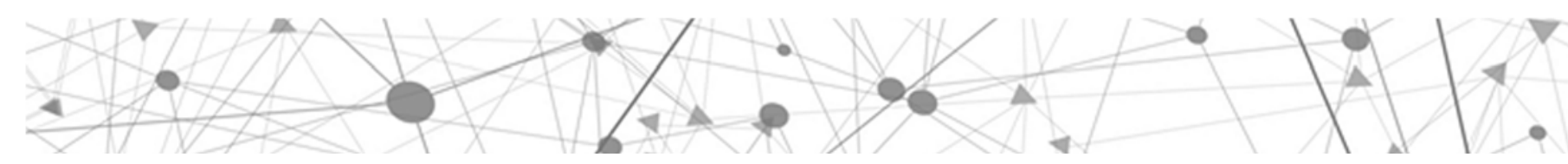

DO LOUVRE, 2010). Como tal, cabia a Champollion zelar, pesquisar, preencher lacunas e pensar formas diferentes de expor a coleção egípcia daquele museu.

Logo, observa-se que desde a sua origem, na Antiguidade Clássica, a atividade de curadoria envolvia as ideias de cuidado e de zelo. Segundo Obrist (2014, p. 25):

Different kinds of caretaking have sprung from this root word over the centuries, but the work of the contemporary curator remains surprisingly close to the sense in curare of cultivating, growing, pruning and trying to help people and their a hared contexts to thrive ${ }^{85}$.

Todavia, mesmo já havendo a função de curador, por muito tempo a disposição das pinturas na ocupação de toda a parede, e sem espaçamento, prevaleceu como modelo de montagem, conforme pode ser observado no Salon des Indépendants, de Paris (figura 23).

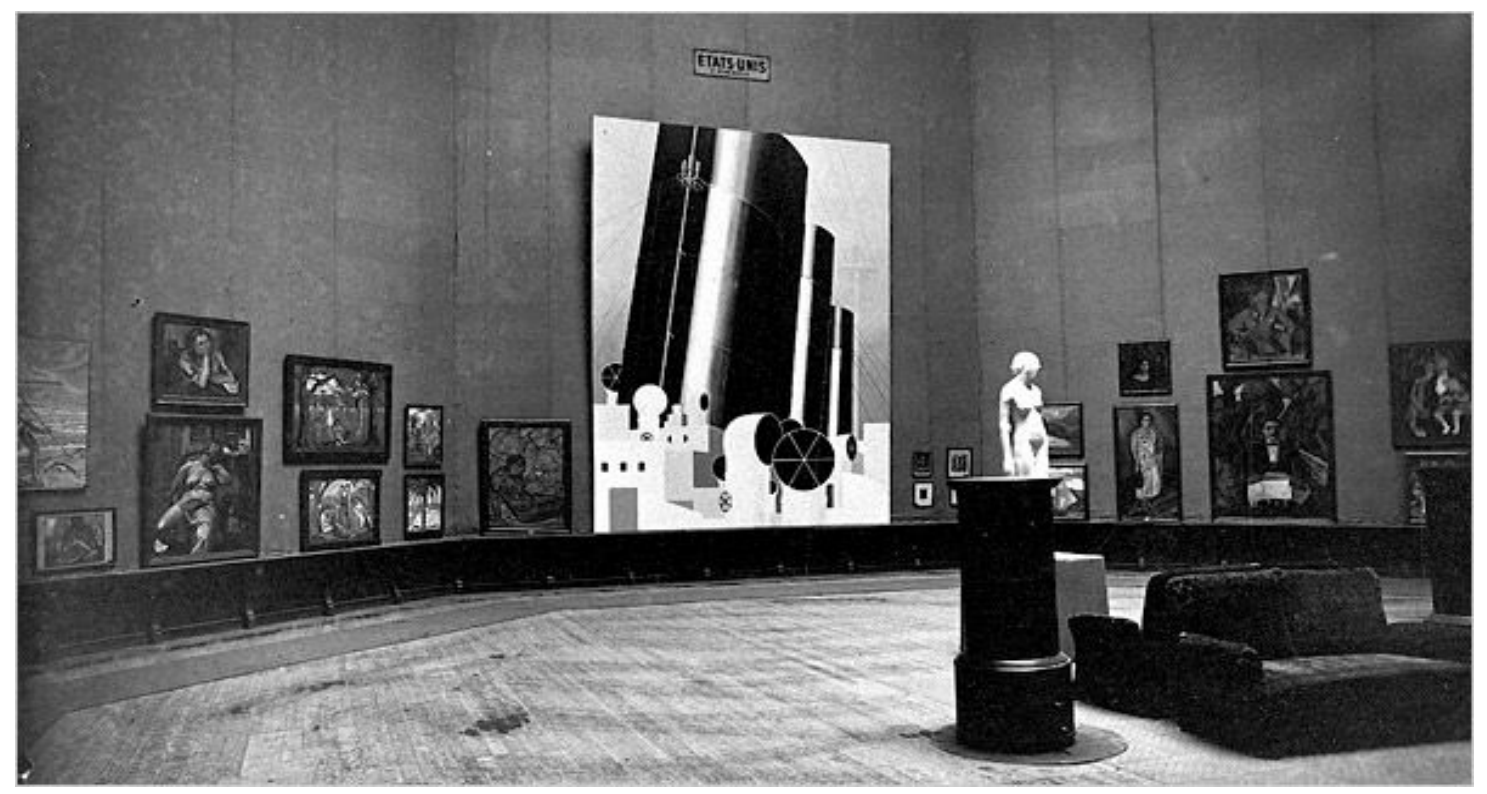

Figura 23 - Salon des Indépendants, seção norte-americana, 1924. Grand Palais, Paris Fonte: disponivel em: <https://s-media-cacheak0.pinimg.com/736x/6f/04/1a/6f041a191af953 9c6e87eb64ca7a3f8f.jpg>. Acesso em: 22 maio 2016

Observa-se na figura 23 que, apesar de a parede já não ser toda ocupada, pinturas ainda são penduradas uma acima das outras, com exceção da pintura maior, Boatdeck, de Gerald Murphy (COUTINHO apud CINTRÃO, 2010).

85 "Diferentes tipos de cuidado surgiram da raiz dessa palavra no decorrer dos séculos, mas 0 trabalho do curador contemporâneo continua supreendentemente perto do sentido de curare, de cultivar, podar e tentar ajudar as pessoas e seus contextos compartilhados a se desenvolver" (livre tradução).

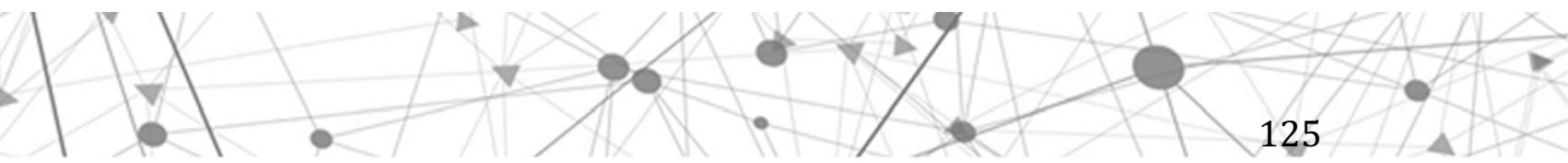


Assim como afirma Coutinho (apud CINTRÃ0, 2010), os artistas brasileiros, ao viajar para Paris para aprender a produzir arte segundo os preceitos da academia, traziam também para sua terra natal as formas de expor. "Por essa razão, era comum a utilização de aniagem para a forração de paredes, de painéis como alternativa para locais onde não havia paredes e a acumulação de obras por toda a superfície" (COUTINHO apud CINTRÃO, 2010, p. 27).

Apenas no fim da década de 1920, com a vinda do marchand bávaro Theodor Heuberger para o Brasil, houve uma mudança no modo de expor. A convite do pintor Navarro da Costa, cônsul-geral do Brasil em Munique, Alemanha, Heuberger trouxe para o Museu Nacional de Belas Artes, no Rio de Janeiro, em 1924, a Exposição de Arte e Artesanato Alemã (LACOMBE, 2009). A importância dessa mostra para a época não estava em seu conteúdo, tendo em vista que se tratava de uma exposição de arte tradicional e de artesanato, realizada pouco tempo depois da Semana de Arte Moderna, em 1922, mas sim na maneira como foi montada. Ela apresentava um espaçamento maior entre os trabalhos, organizados linearmente, lado a lado na parede, na horizontal, mudando, portanto, a forma como o espectador percebia os trabalhos, o que agora se dava também individualmente.

Também inovadora foi a atuação de Alexander Dorner, que está entre os curadores pioneiros, no Landesmuseum, em Hanover, Alemanha, um dos museus mais tradicionais da época. As exposições feitas naquele museu seguiam os padrões franceses. Ou seja, as pinturas ocupavam quase toda a superfície da parede. Com a entrada de Dorner, que lá atuou de 1922 a 1937, a forma de expor mudou. Conforme Coutinho (apud CINTRÃO, 2010, p. 34),

Dorner passou a reunir as obras visando seu contexto original, criando salas especiais com unidade narrativa e acompanhadas de um guia impresso por meio do qual o visitante podia obter mais informações sobre as obras e o roteiro da exposição - buscando uma ambientação especial para cada época. As salas medievais, por exemplo, eram escuras, enquanto as do Renascimento, brancas com elementos estruturais de arquitetura.

Foi na Alemanha que surgiram novas formas de expor. Dorner foi um dos primeiros curadores a pensar o desenho da exposição como um meio de contribuir com o aprofundamento da experiência estética, já que as cores das paredes e a ordem de disposição das obras no espaço influenciam diretamente a percepção do 
espectador. A partir de então, inúmeras exposições montadas preservando um espaço maior entre os trabalhos, organizados linearmente, foram realizadas, tanto na Europa e nos Estados Unidos como também no Brasil (COUTINHO apud CINTRÃO, 2010).

Conforme já citado, não é possível separar a história das exposições do desenvolvimento da atividade da curadoria. Afinal, como um dos interesses desta tese gira em torno da curadoria educativa voltada para exposições realizadas no ambiente virtual em rede, foram selecionadas para estudo e análise exposições cuja proposta coloque a arte em exercício do espectador por intermédio de diferentes recursos, alguns deles de natureza participativa.

Já no início do século XX, quando aconteceram as primeiras exposições de vanguarda organizadas por artistas, entre os quais estavam László Moholy-Nagy, El Lissitzky, Herbert Bayer e Frederick Kiesler, sob influência do desenvolvimento das novas tecnologias de mídia, tais como a fotografia, o cinema e a gravação de áudio, a relação entre público, exposição e arte passou a ser repensada. Para Huhtamo (2010, p. 124), "as a consequence, an essential part of the avant-gard activity was the search for new ways of displaying art" ${ }^{\prime 86}$.

Com a recém-formada Associação de Pintores e Escultores Americanos (Association of American Painters and Sculptors), organizada por conta do desejo dos artistas de conquistar melhores condições para realizar exposições, já que poucas galerias norte-americanas tinham interesse em expor arte moderna, ocorreu o Armory Show, primeira exposição de arte moderna dos Estados Unidos. A Mostra Internacional de Arte Moderna (International Exhibition of Modern Art), em função do prédio que a abrigou, mais tarde conhecida como Armory Show, foi realizada na cidade de Nova York, Estados Unidos, em 1913, no 69th Regiment Armory.

Após entrar em contato com o catálogo da Mostra Internacional de Sonderbund, em Colônia, na Alemanha, Arthur B. Davies, então presidente da Associação de Pintores e Escultores Americanos, incumbiu o artista Walt Kuhn a visitar aquela exposição e reunir trabalhos para a exposição de Nova York. Impactados com o que vira na Sonderbund, tais como os 125 trabalhos de Vincent Van Gogh, alguns trabalhos de Paul Gauguin, de Paul Cézanne, de Edvard Munch e

86 “Como consequência, uma das principais atividades de vanguarda foi procurar novas formas de expor arte" (livre tradução). 


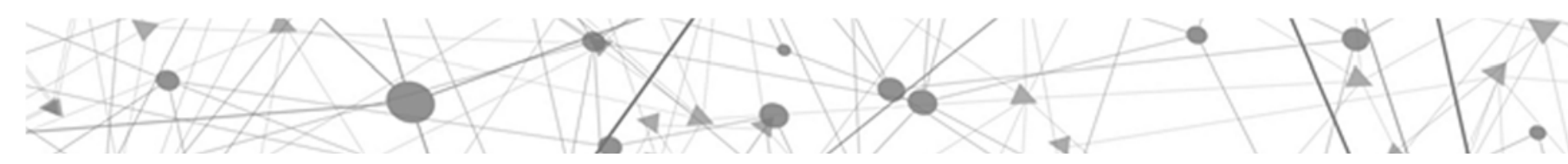

de Pablo Picasso ao lado de Davies, Kuhn e Davies começaram a viajar pela Europa a captar trabalhos com o intuito de organizar a exposição norte-americana (BROWN, 1998).

Como visto na figura 24, as paredes do espaço foram revestidas com tecidos, e utilizaram-se guirlandas para a decoração, além das plantas. A exposição foi composta por pinturas emolduradas, algumas sobrepostas, quase sem espaçamento, e por esculturas em pedestais, dispostas pelo espaço conforme a maneira tradicional de expor, ainda resquícios dos gabinetes de curiosidades.

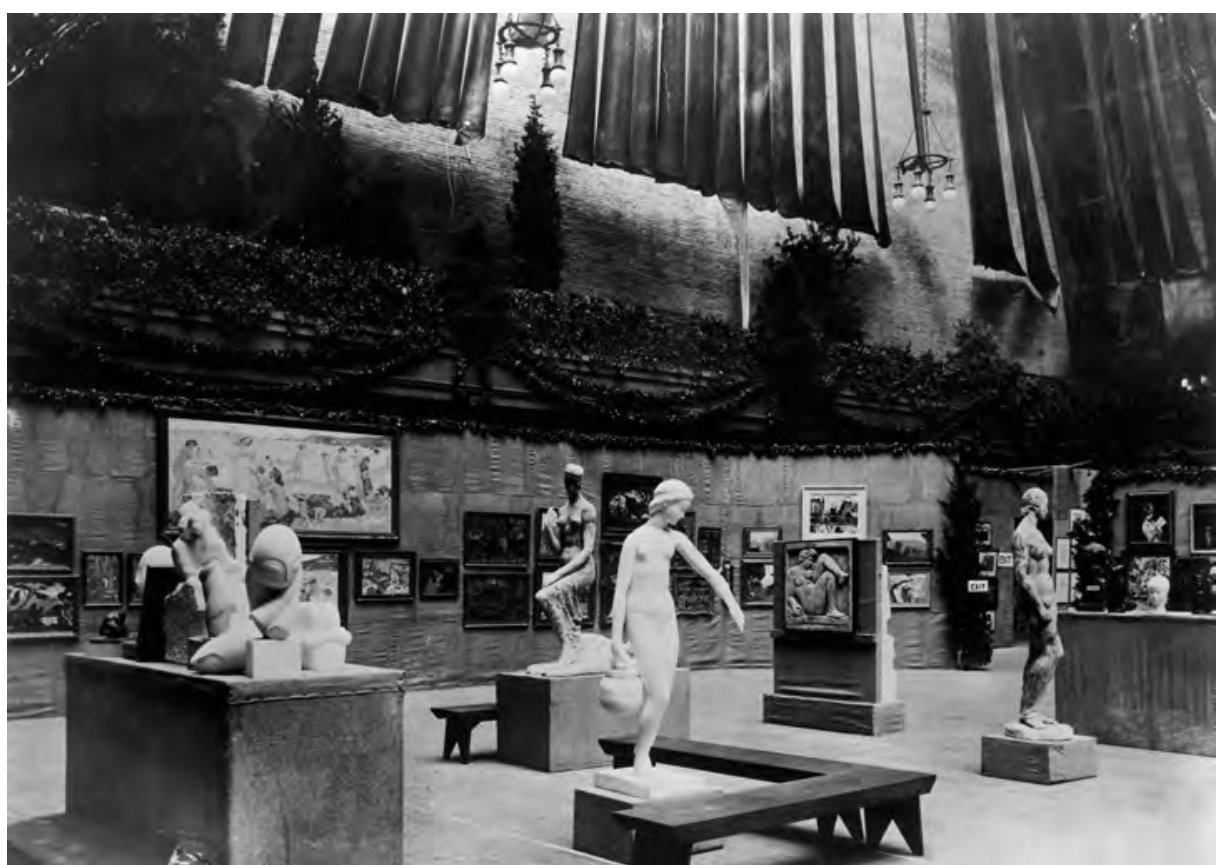

Figura 24 - Vista do Armory Show, 1913

Fonte: disponivel em: <https://static01.nyt.com/images/2012/10/28/arts/JP-ARMORY1/JPARMORY1-superJumbo.jpg>. Acesso em: 24 maio 2016

Contudo, diferentemente dos desenhos das exposições realizadas até então, de acordo com Brown (1998, p. 93),

l'immense hall vide avait été transformé en un labyrinthe de salles; les cloisons de séparations avaient été cachées avec de la toile de jute et décorées de feuillage, le tout était baigné de lumière et couronné d'une coupole de bandes de tissu ${ }^{87}$.

\footnotetext{
87 “ 0 imenso hall vazio havia sido transformado num labirinto de salas; os painéis de separação haviam sido forrados com juta e decorados com folhagens, e tudo era banhado de luz e coroado por uma cúpula de faixas de tecido" (livre tradução).
}

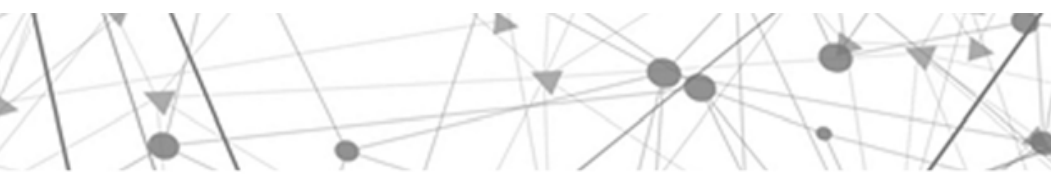


A exposição foi organizada com os propósitos de introduzir, esclarecer e educar o espectador acerca da produção de arte moderna e, ao mesmo tempo, encontrar novos rumos para a arte norte-americana. Para tal, um dos recursos utilizados, além de agrupar e organizar os trabalhos que estavam na mostra, foram os cenógrafos, talvez pensados como um meio de atrair e até de deixar o visitante mais confortável com a novidade. Entretanto, apesar de a produção artística norteamericana contemplar a maioria da exposição em relação à produção europeia, em comparação à última aparentava ser tímida e ultrapassada (BROWN, 1998).

Como consequência não intencional, o Armory Show contribuiu tanto para a criação de uma consciência nacional como para um mercado específico para a arte moderna (ALTSHULER, 2008), além de poder ser considerado a primeira grande exposição do século XX que se tornou efeito de mídia (BROWN, 1998). Em função da divulgação, das polêmicas e dos escândalos provocados pelos jornais, sendo 0 maior deles por conta da obra Nu descendo uma escada, $n .^{\circ} 2$, de Marcel Duchamp, a mostra foi visitada, somente em Nova York, por cerca de 80 mil pessoas.

L'Armory Show avait voulu réveiller l'art américain de sa léthargie, lui redonner vie, offrir de nouvelles perspectives aux artistes et ouvrir les collectionneurs à l'art moderne. Tout cela fut fait. Il va sans dire que l'art moderne serait arrivé aux Etats-Unis d'une façon ou d'une autre, mais c'est l'Armory show qui l'a fait entrer dans la conscience publique, et elle l'a fait avec une telle intensité dramatique qu'il n'y eut pas besoin de répétition. Put-être que sans cette exposition, le développement ultérieur de l'art américain eut été presque le même, mais l'Armory show avait eu des effets si bouleversants qu'aujourd'hui encore, elle reste cette contrée symbolique dans laquelle une nouvelle ère de l'art américain est née ${ }^{88}$ (BROWN, 1998, p. 104-105).

Observa-se que a galeria, diferentemente do que acontecia na Idade Moderna, quando era considerada um espaço de legitimação da arte, nessa mostra foi tratada apenas como fundo, sendo o espaço preenchido pelo significado dos trabalhos, estes sim colocados em primeiro plano (ALTSHULER, 2008; HUHTAMO,

\footnotetext{
88 “ 0 Armory Show queria despertar a arte americana de sua letargia, reanimá-lo, oferecer novas perspectivas abertas para artistas e colecionadores de arte moderna. Tudo isso foi feito. Equivocado será dizer que a arte moderna teria acontecido nos Estados Unidos, de uma forma ou de outra, mas é o show arsenal quem o fez entrar na consciência pública, e o fez com tal intensidade dramática que não havia necessidade de repetir. Talvez sem esta exposição, o desenvolvimento da arte americana teria sido quase o mesmo, mas o Armory Show teve um impacto tão avassalador que, ainda hoje, continua a ser o país simbólico no qual uma nova era da arte americana nasceu" (livre tradução).
} 
2010). Assim como afirma Huptamo (2010), talvez um dos maiores desafios da arte de vanguarda tenha sido camuflar o espaço de exposição.

É interessante notar que ainda em 1913, mesmo ano do Armory Show, Duchamp construiu a primeira peça que, dois anos mais tarde, seria conhecida como ready-made, a Roue de Bicyclette. Por meio deste e de seus demais ready-mades, o artista levou para dentro do espaço sagrado de exposição, mas não sem relutância, a exemplo da recusa de Fountain, no Salon des Indépendants, objetos triviais de uso cotidiano. Ao fazê-lo, o artista interferiu na forma como o público lidava com tais objetos, que, no contexto da exposição, não eram mais encarados nem como objeto, nem como arte.

Pode-se afirmar então que, a partir do momento em que objetos utilitários, de fabricação industrial, ocuparam um espaço entendido como especificamente de arte "produzida" por artistas, houve uma mudança tanto na maneira de encarar a arte como também no espaço de exposição, espaço esse cuja produção à mostra deveria ser contemplada a certa distância, compreendida como essencial à experiência estética. Paulatinamente, tal distanciamento foi sendo reduzido, na medida em que os desenhos das exposições de arte moderna cada vez mais visavam à aproximação física e à participação por parte do espectador.

Têm-se como exemplo dessa mudança as exposições Mostra Internacional de Novas Técnicas Teatrais, realizada em 1924, na cidade de Viena, Áustria, e a Abstract Cabinet, de 1927, no Landesmuseum. A primeira foi projetada por Frederick Kiesler, que, influenciado pelo construtivismo, fugiu do desenho convencional de exposição, o qual pressupõe quadros dispostos nas paredes, optando por ignorá-las, deixando-as em branco. Projetou então estruturas em formato de $L$ e $T$ sobre as quais foram inseridas grades que serviram de suportes verticais, horizontais e diagonais em que os trabalhos foram dispostos (HUHTAMO, 2010). A ideia era a de que o visitante mergulhasse na exposição ao transitar por entre as estruturas. Cada espectador poderia escolher o percurso a ser seguido; não havia ordem certa para que os trabalhos fossem vivenciados. Dessa forma, a exposição acabou por configurar-se em um espaço não linear de informações.

Já na exposição Abstract Cabinet, projetada por El Lissitzky, algumas pinturas estavam sustentadas por painéis deslizantes, que poderiam ser manipulados pelo visitante. Outras, por sua vez, tinham por suporte tambores 
rotativos, que, igualmente, provocavam o público a sair de seu papel de simples fruidor, passivo, para interferir na mostra, modificando a disposição dos trabalhos (HUHTAMO, 2010).

Observa-se também que, aos poucos, as novas mídias passaram a ser utilizadas, tanto na produção dos artistas como nas exposições. A exposição The Room of Our Time, realizada em 1930, no Landesmuseum, consiste numa das primeiras mostras de natureza multimídia já realizadas. Projetada pelo artista húngaro Moholy-Nagy, mediante convite do então diretor do museu Dorner, a exposição era formada por diferentes mídias, tais como a fotografia, o filme, o teatro, maquetes arquitetônicas e objetos de design. No centro do espaço expositivo, Moholy-Nagy apresentou o Prop Light, máquina por ele projetada que, ao ter um botão pressionado pelo espectador, era colocada em funcionamento, produzindo no espaço variações de luz e sombra. Também integraram a mostra projetores de slides e filmes que somente entravam em funcionamento com a ativação por parte do público (HUHTAMO, 2010). Com exceção do Prop Light, não havia na mostra trabalhos originais; todas as peças em exposição eram reproduções.

Dessa exposição, ocorrida no início do século XX, em diante, passaram a ser colocadas em pauta questões que giram em torno dos conceitos de originalidade e de autenticidade, antes mesmo de Walter Benjamin ter escrito o ensaio $A$ obra de arte em sua época de reprodutibilidade técnica, o que se deu somente em 1936 (HUHTAMO, 2010). Tais conceitos também foram postos em xeque pelos próprios artistas, a exemplo da Boîte-en-Valise, de Duchamp, produzida de 1936 a 1941, já tratada no capítulo 1, e são de extrema importância para se pensar as exposições de trabalhos digitalizados promovidas no ambiente virtual em rede.

Outra exposição que aconteceu nos Estados Unidos e que teve grande repercussão foi a de inauguração da galeria Art of This Century, de Peggy Guggenheim, em 1942, em Nova York. 0 espaço interno da galeria foi projetado pelo artista, teórico, cenógrafo e arquiteto Kiesler, que, por solicitação de Guggenheim, projetou quatro espaços para as exposições: Abstract Gallery, Surrealist Gallery, Kinect Gallery e Daylight Gallery. 


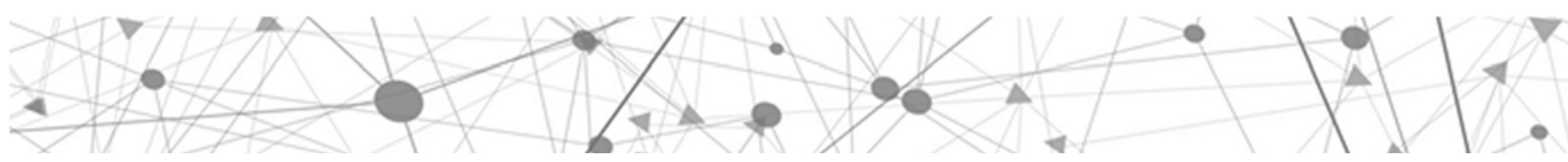

Para as paredes da Surrealist Gallery, Kiesler projetou suportes horizontais em formato de hastes móveis, os quais sustentavam as pinturas, sem molduras, que, por sua vez, podiam ser movidas pelo espectador (figura 25 ).

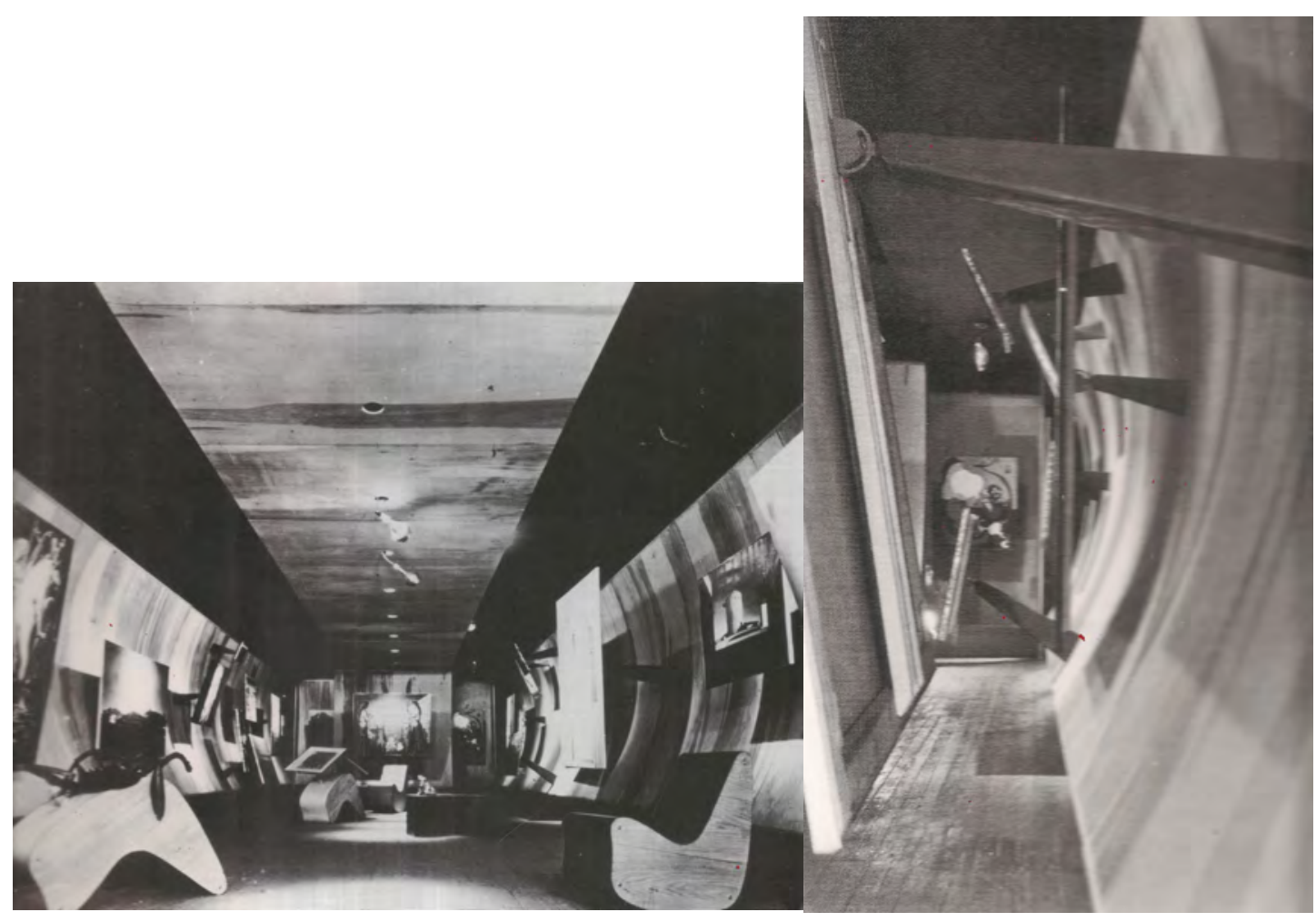

A

B

Figura 25 - A e B) Vistas da Surrealist Gallery, projetada por Frederick Kiesler, em Nova York

Fonte: ALTSHULER, 2008, p. 318

As luzes da galeria ficavam ligando e desligando e, ao fundo, ouvia-se constantemente a projeção de som de ruídos.

Já na Abstract Gallery as pinturas eram sustentadas por feixes de cordas esticadas, presas no chão e no teto, de forma que o espectador pudesse deslocá-las de cima para baixo ou de baixo para cima, modificando, conforme a sua vontade, 0 distanciamento entre a pintura e o chão (figura 26). 


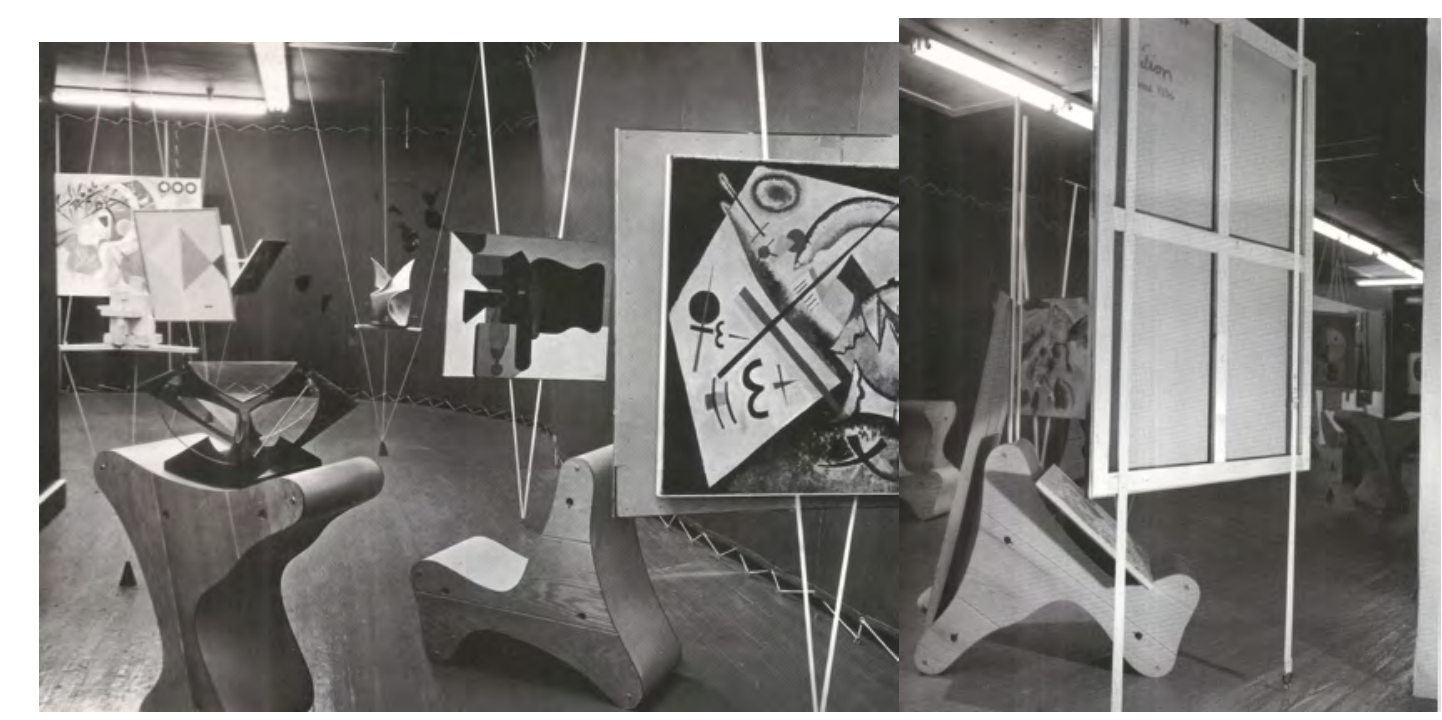

A

B

Figura 26 - Vistas de Abstract Gallery, galeria projetada por Kiesler, em Nova York Fonte: ALTSHULER, 2008, p. 317

Constata-se que a exposição não é apenas vista pelo espectador, ela é vivenciada (ALTSHULER, 2008).

Na Kinetic Gallery, por sua vez, os trabalhos de Duchamp, de André Breton e de Paul Klee poderiam ser vistos em dispositivos de peep show. Para essa mesma galeria, Kiesler criou uma máquina de visualização para a Boîte-en-Valise, de Duchamp, que funcionava por meio da manipulação do espectador (ALTSHULER, 2008).

Já a Daylight Gallery, assim nomeada pelo fato de possuir duas salas com janelas panorâmicas, era composta por paredes brancas e retas e abrigou inúmeras exposições temporárias. Dela, fazia parte a biblioteca de pinturas móveis de Kiesler (ALTSHULER, 2008). Huptamo (2010, p. 126) ressalta: “All the four galleries, although dedicated to different tendencies in modern art, emphasized the active role of the spectator. The designs refused to retreat to the background, enveloping both the artworks and the visitors" 89 .

Trata-se de exposições que demonstram como a relação entre a galeria, a arte e o espectador havia sido modificada, o que abriu espaço para repensar tanto a forma de produzir e de expor como também a de vivenciar os trabalhos de arte. Tais mostras apontam para o desenvolvimento de uma cultura da participação e da

89 “Todas as quatro galerias, apesar de dedicadas a tendências diferentes em arte moderna, enfatizaram o papel ativo do espectador. 0 s desenhos recusaram-se a recuar para o plano de fundo, envolvendo tanto as obras de arte quando os visitantes" (livre tradução).

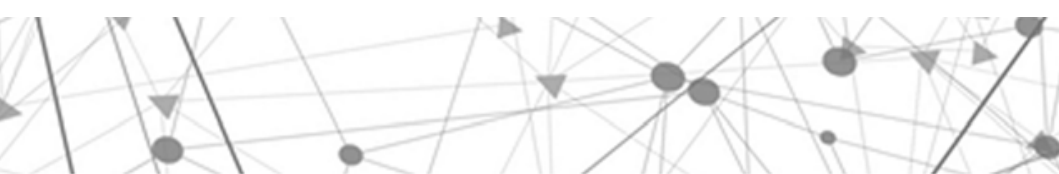


interatividade, colocando em xeque a ideia da arte em exposição como algo estático e intocável, já abrindo espaço e preparando o contexto da arte para que, algumas décadas mais tarde, as exposições fossem realizadas na web. Segundo Huhtamo (2010, p. 127), artistas como Duchamp e Kiesler tinham por objetivo trazer a dimensão perdida da tatilidade, o que poderia ser alcançado com mudanças da natureza do objeto de arte e das condições como tais objetos são percebidos e consumidos.

As exposições analisadas, apesar de terem acontecido na realidade física, colocam em pauta pontos importantes para pensar historicamente o surgimento da exposição no ambiente virtual em rede, que pode contemplar um banco de dados navegável de forma não linear, a convergência de diferentes mídias, a participação e a interação por parte do público e o questionamento acerca da ideia de originalidade.

Entretanto, até o fim do século XX, o cubo branco ou a sala vazia modernista permaneceu como o espaço ideal para exposições de arte, já que possuía as condições necessárias para a boa visualização dos trabalhos. Os novos princípios para montagem de mostras artísticas, fundamentados na participação por parte do público, assim como no uso de sistemas multimídia e hipermídia, demoraram a ser totalmente aceitos e ter sua consolidação fora dos espaços de arte, mas em feiras comerciais, parques de diversão e centros de ciência. Entre as primeiras exposições dessa natureza, estão as realizadas pelos museus de ciência e tecnologia, como o Palácio da Descoberta, inaugurado em Paris no ano de 1937; o Museu da Ciência e Indústria, de Chicago, criado por conta da exposição Universal Exhibition, de 1933; e o Exploratorium de São Francisco, de 1969 (HUHTAMO, 2010; GANT, 2001).

Somente na década de 1960 a atividade de curadoria independente de coleções museológicas começou a se desenvolver, contudo o termo curador ainda não era utilizado com frequência, sendo esse profissional chamado de organizador ou de coordenador geral (CHIARELLI, 2008). Teóricos, colecionadores, patronos e diretores de museus, impulsionados pelo desenvolvimento da arte conceitual e do experimentalismo, num contexto que aspirava por mudanças, direcionaram a atividade curatorial para fora dos espaços dos museus, na organização de exposições temporárias. Estas, muitas vezes, promovidas em espaços experimentais, aconteciam em função de uma ação colaborativa com os artistas. As 
exposições começaram a assumir, como um todo, o mesmo grau de importância que os trabalhos que delas faziam parte. No transcorrer do século XX,

\begin{abstract}
exhibitions have become the medium through which most art becomes known. Not only have the number and range of exhibitions increased dramatically in recent years but museums and art galleries such as the Tate in London and the Whitney in New York now display their permanent collections as a series of temporary exhibitions. Exhibitions are the primary site of exchange in the political economy of art, where signification is constructed, maintained and occasionally deconstructed. Part spectacle, part socio-historical event, part structuring device, exhibitions - especially exhibitions of contemporary art establish and administer the cultural meanings of art ${ }^{90}$ (GREENBERG; FERGUSON; NAIRNE, 1996, p. 2).
\end{abstract}

Ao mesmo tempo em que a curadoria ganhava independência, foi por meio da atuação desses primeiros curadores, muitas vezes associados a grupos de artistas, que a arte moderna se tornou conhecida e que surgiram as primeiras coleções dos museus de arte dessa natureza. Como exemplo pode-se citar a Sociedade Anônima, criada ainda em 1920 na França, pela patrona e artista Katherine Dreier, ao lado de Duchamp e de Man Ray (OBRIST, 2014). Este foi o primeiro museu de arte moderna da América. Já Werner Hoffmann, que também está entre os primeiros curadores independentes, fundou o Museum des 20, de Viena.

Portanto, desde o início, antes mesmo de falar em curadoria independente, os curadores exerceram importante papel, não apenas no desenvolvimento da história das exposições, mas também na documentação, na disseminação e na reflexão acerca da arte de seu tempo, ocupando então um campo que antes era restrito à crítica e que, mais tarde, também seria ocupado pelo artista e pelo educador.

Sendo assim, em meados de 1960, pesquisadores, teóricos e historiadores, entre os quais Seth Siegelaub e Harald Szeemann, por meio de sua atuação,

\footnotetext{
90 “Exposições tornaram-se o meio pelo qual a maioria da arte se torna conhecida. Não somente o número e a variedade de exposições aumentaram dramaticamente nos últimos anos, mas os museus e as galerias de arte, como a Tate, em Londres, e o Whitney, em Nova York, agora expõem sua coleção permanente como séries de coleções temporárias. Exposições são o primeiro lugar de troca na economia política da arte, em que o significado é construído, mantido e ocasionalmente descontruído. Parte espetáculo, parte evento sócio-histórico, parte dispositivo estruturante de exposições - espacialmente exposições de arte contemporânea - estabelecem e administram os significados culturais da arte" (livre tradução).
} 
provocaram a mudança de rumo acerca do papel do curador em direção a uma atividade independente.

Siegelaub, um dos principais responsáveis pela disseminação da arte conceitual em Nova York nas décadas de 1960 e 70, realizou inúmeras exposições que, além de provocarem o questionamento acerca da arte contemporânea e da sua relação com o espaço, apresentou para o público a produção de arte conceitual. Entre 1964 e 1966, foi dono da galeria Arte Contemporânea Seth Siegelaub, na qual promoveu diversas exposições com curadoria autoral que romperam com a relação tradicional entre a obra de arte e o espaço de exposição.

Após o fechamento de sua galeria, começou a atuar de forma independente envolvendo-se em projetos de diversos artistas conceituais, entre eles Carl Andre, Robert Barry, Douglas Heubler, Joseph Kosuth e Lawrence Weiner. As exposições que organizou exercitavam novas maneiras de pensar o espaço de exposição e a exploração de novos espaços para a realização de exposições, assim como problematizavam e colocavam em discussão as novas questões apresentadas pela arte conceitual. Entre as exposições que organizou, destacam-se a Xeroxbook, de 1968, e The January Show, um ano depois. Em ambas, Siegelaub experimentou a publicação como um espaço de exposição. A primeira consiste numa mostra coletiva em formato de livro, contemplando trabalhos de sete artistas. Conforme afirma o curador:

Was perhaps one of the more interesting because it was the first where I proposed a series of "requirements" for the project, concerning the use of a standard size paper and the amount of pages, the "container" within which the artist was asked to work. What I was trying to do was standardize the conditions of exhibition with the idea that the resulting differences in each artist's Project or work would be precisely what the artist's work was about. It was an attempt to consciously standardize, in term of an exhibition, book or project, the conditions of production underlying the exhibition process. In fact it was the first exhibition where I asked the artists to do something, and it was probably somewhat less collaborative than I am now making it sound. But I do have the impression that the close working relationship with the artist was an important factor in all the projects, even when I was not particularly close to an artist ${ }^{91}$ (apud OBRIST, 2011, p. 121-122).

\footnotetext{
91 “Foi, talvez um dos projetos mais interessantes, porque foi o primeiro em que propus uma série de 'requisitos' quanto ao uso de um tamanho de papel padrão e à quantidade de páginas, à 'embalagem' na qual o artista foi convidado a trabalhar. 0 que eu estava tentando fazer era
} 
Assim, conforme orientação do curador, cada um deles desenvolveu o seu trabalho mediante fotocópias, no formato de $20 \times 28 \mathrm{~cm}$. Embora os trabalhos já tenham sido concebidos em um meio de reprodução, a questão acerca da originalidade da obra de arte vem à tona, tendo em vista que a exposição foi produzida em série.

Já para a realização de The January Show, Siegelaub alugou um espaço para a montagem dos trabalhos, que foram fotografados e, em seguida, desmontados. A exposição só aconteceu (e acontece até hoje, mesmo em formato PDF disponibilizado na internet ${ }^{92}$ ) enquanto catálogo, ou seja, enquanto espaço de informação. Logo, por intermédio da exposição, é colocada em discussão a relação entre os trabalhos, o espaço de exposição e o catálogo da mostra. É uma das primeiras situações em que o público não vai até a exposição para ter contato com a arte, mas a exposição vai até ele.

Com essas duas exposições, Siegelaub provoca a reflexão acerca da relação entre a arte e a instituição, demonstrando que o conteúdo é mais importante do que o continente (CAUQUELIN, 2005), ao contrário do que fazia Duchamp 50 anos mais cedo. É interessante observar que, quando são referenciadas ambas as mostras, o foco de discussão é voltado mais para as exposições em si e para os seus formatos do que para os trabalhos que fizeram parte delas.

Outra exposição que se destaca por sua proposta curatorial e por ter tido importante papel na assimilação da arte conceitual por parte do público é When Attitudes Become Form (Works - Concepts - Processes - Situations - Information), de curadoria de Szeemann, realizada na Kunsthalle Bern ${ }^{93}$, na Suiça, em 1969. Foi a primeira vez que artistas minimalistas e conceituais expuseram em um mesmo espaço (OBRIST, 2014). Com essa exposição, Szeemann, além de aproximar trabalhos, colocou em discussão o processo como obra de arte em um contexto

padronizar as condições de exibição com a ideia de que as diferenças resultantes em cada projeto ou trabalho seria precisamente aquilo de que tratava a obra do artista. Era uma tentativa de padronizar conscientemente, em termos de exposição, livro ou projeto, as condições de produção subjacentes ao processo de exposição. Foi, na verdade, a primeira exposição na qual eu pedi que os artistas fizessem algo e foi provavelmente um pouco menos colaborativa do que eu faço parecer. Mas tenho a impressão de que a relação íntima de trabalho com o artista foi um fator importante em todos os projetos, mesmo quando eu não estava particularmente próximo a um artista" (livre tradução).

92 Mais informações em: <http://www.primaryinformation.org/files/january1969.pdf>.

${ }^{93}$ Observa-se que esse espaço institucional surgiu em 1918, sem acervo, apenas para a realização de exposições temporárias. 
marcado pelo experimentalismo. Afirma Szeemann no ensaio escrito para o catálogo da mostra About the Ehxibition:

A large group of artists, like the "Earth Artists", are not represented by Works, but with information; and the "Conceptual Artists" are represented by working plans, which no longer require further realization. This Conceptual art readily makes use of existing systems (telephone, post, press, cartography) to create its "works", and these eventually lead to new systems, which prevent all discussion of their starting-points ${ }^{94}$ (apud RATTEMEYER, 2010).

Entre os artistas que participaram da exposição, estavam Lawrence Weiner e Walter De Maria. 0 trabalho de Weiner intitulado A 36" × 36" Removal to the Lathing or Support Wall of Plaster or Wallboard from a Wall (figura 27) consiste em remover um quadrado de $36 \mathrm{~cm}$ do material que compõe a parede do espaço da mostra. Nesse sentido, ao contrário de inserir um trabalho no espaço, o artista removeu parte do espaço, sendo a ação de remover o foco do trabalho, e não o resultado da ação.

\footnotetext{
94 “Um grande grupo de artistas, como o 'Artistas da Terra', não são representados por trabalhos, mas com informação; e os 'Artistas Conceituais' são representados por planos de trabalhos que já não requerem maior realização. Essa arte conceitual prontamente faz uso de sistemas já existentes (telefone, correio, imprensa, cartografia) para criar seus 'trabalhos', e estes eventualmente conduzem a novos sistemas, que impedem toda a discussão de seus pontos de partida" (livre tradução).
} 


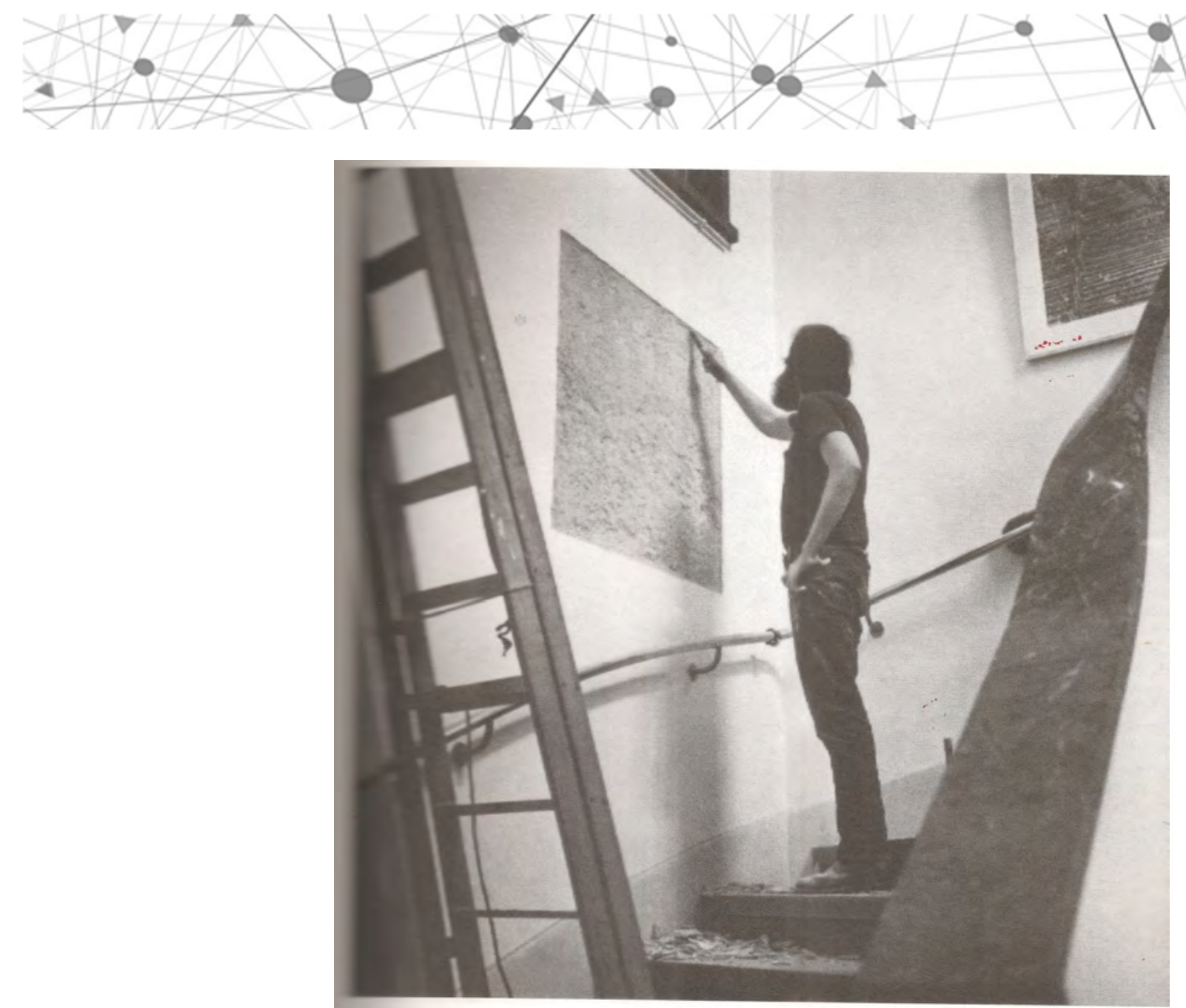

Figura 27 -A 36" × 36" Removal to the Lathing or Support Wall of Plaster or Wallboard from a Wall, de Lawrence Weiner, 1968

Fonte: RATTEMEYER, 2010, p. 161

Já De Maria inseriu no espaço de exposição o trabalho Art by Telephone (figura 28), ou seja, um aparelho de telefone acomodado diretamente no chão e acompanhado por uma mensagem escrita "If this telephone rings, you may answer it. Walter De Maria is on the line and would like to talk to you"95. Com esse trabalho, De Maria faz uso do telefone como um meio de comunicação direto entre o artista, que está fora da exposição, e o público, que está dentro dela. Apesar disso, diferentemente do que acontece normalmente, quando o artista telefona e um espectador o atende, acontece um processo síncrono de comunicação entre público e artista.

\footnotetext{
95 “Se o telefone tocar, você deve atendê-lo. Walter De Maria está na linha e gostaria de falar com
} você" (livre tradução). 


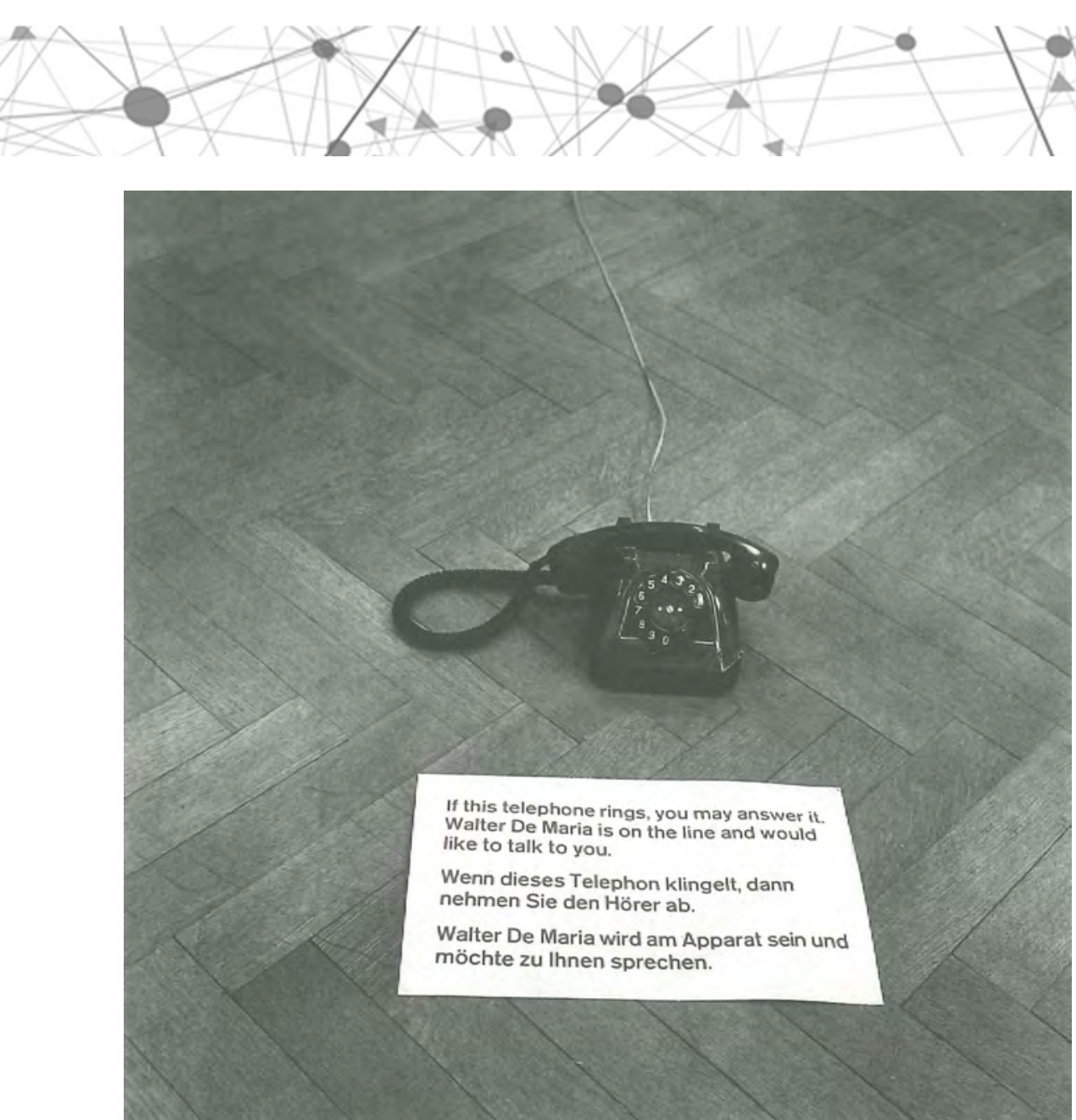

Figura 28 - Art by telephone, Walter De Maria, 1967-1969

Fonte: RATTEMEYER, 2010, p. 146

Conforme afirma Szeemann, ao realizar a exposição na Kunsthalle, o artista fez daquele local mais do que um espaço para abrigar trabalhos, mas "a mental space" (apud OBRIST, 2011, p. 83). Por meio dessa exposição, Szeemann apresentou e colocou em discussão a arte de seu tempo. Assim, embora ainda não se falasse em curadoria educativa, os curadores europeus foram "revolucionários por seus métodos de construir exposições e explicar a arte contemporânea (GONÇALVEZ, 2004, p. 48).

Com base nas curadorias tratadas, pode-se pensar na importância inicial do papel do curador não apenas no que tange à proposição, à organização, à realização e à documentação das exposições, conforme já citado, porém também no que se refere à mediação da arte e à formação de público. Siegelaub e Szeemann estão entre os primeiros curadores independentes da história e acabaram por intermediar os artistas e a sociedade. Nessa perspectiva, antes mesmo de se falar em setor educativo e em curadoria educativa, a atuação desses primeiros curadores, de certa maneira, já cumprira esse papel. A partir daí, constata-se também que o foco do discurso crítico mudou, passando de uma crítica voltada para os trabalhos de arte 
para a crítica da curadoria, estando em primeiro plano não mais os trabalhos à mostra, mas as formas de mostrar os trabalhos.

Com algumas exceções, tais como experiências de Siegelaub, Szeemann, Pontus Hultén, Walter Hopps, Lucy Lippard, entre outros, até a década de 1970, 0 trabalho do curador, geralmente com formação em História, estava vinculado a um determinado acervo museológico. Assegura Chiarelli (2008, p. 13):

Se a instituição possui um acervo reduzido, conta com apenas um curador geral [...]. À medida que a coleção é ampliada, surge a necessidade de ampliar o corpo curatorial da instituição, visando ao aprofundamento do estudo sobre as obras, melhorias nas condições de preservação, e na maneira de exibi-las no quadro geral da programação. É nessa situação que surgem os curadores específicos para cada modalidade artística presente na coleção: curadores de pintura, escultura, desenho, etc.

Pouco a pouco, a curadoria independente foi conquistando cada vez mais espaço, fosse diante das grandes exposições e eventos, tais como as bienais e os panoramas, fosse em exposições temporárias realizadas em museus e instituições culturais, que, muitas vezes, convidam um profissional de fora para realizar 0 trabalho. Muitas dessas exposições são encaradas como grandes espetáculos, de forma que a atuação do curador passou a sobressair em relação aos trabalhos dos artistas (CHIARELLI, 2008).

Assim sendo, com a valorização do papel do curador, que, por meio das mostras organizadas, muitas vezes apresentava e discutia uma tese por intermédio dos trabalhos expostos, com base nestes ou utilizando-os como exemplo, em muitos casos profissionais de outras áreas, como filósofos, psicólogos, historiadores e antropólogos, realizavam curadorias. Tratava-se de um exercício de expor novas abordagens fundamentados em um tema específico, bem como aproximar esse tema à produção de arte.

Em 1985, a convite do Centro Georges Pompidou, em Paris, Jean-François Lyotard, por exemplo, filósofo na época no auge de sua influência, ao lado de Thierry Chaput, diretor do Centro de Criação Industrial, também em Paris, organizou a exposição Les Immatériaux. Para Lyotard (1985 apud GREENBERG; FERGUSON; NAIRNE, 2006, p. 159), na tradição moderna, 
the relationship between human beings and materials is fixed by the Cartesian programme of matering and possessing nature. A free will imposes it own aims on given elements by diverting them from their natural course. These aims are determined by means of language which enables the will to articulate what is possible (a project) and to impose it on what is real (matter).

The ambition of the exhibition entitled Les Immatériaux is to make the visitor realise how far this relationship is altered by the existence of "new materials". New materials, in a wide meaning of the term, are not merely materials which are new. They question the idea of Man as a being who Works, who plans and who remembers: the idea of an author ${ }^{96}$.

Percebe-se assim que a concepção da exposição está pautada em discussões de ordem filosófica, tendo como ponto de partida questionamentos, os quais desencadeiam novos questionamentos por parte dos visitantes acerca dos materiais e dos imateriais.

É importante observar que foi a primeira vez que o computador integrou uma exposição de arte, tendo como objetivo colocar em foco a inquietude provocada pela fluidez da informação, sendo o visitante, que nele poderia inserir informação, também autor, o responsável pela construção de significado. Segundo Lyotard (1985 apud GREENBERG; FERGUSON; NAIRNE, 2006), por meio da telecomunicação e da informática, informações imateriais poderiam ser armazenadas e processadas simplesmente pelo fluxo de pensamento, o que acarretaria uma profunda mudança na relação entre o homem e o mundo.

De acordo com Lyotard (1985 apud GREENBERG; FERGUSON; NAIRNE, 2006, p. 165), "the 'target' of the exhibition is a precise one: to arouse the visitor's reflection and his anxiety about the postmodern condition"97.

A partir desse ponto de partida, a mostra foi estruturada, sendo composta por trabalhos dos artistas convidados - Dan Flavin, Dan Graham, Lucio Fontana,

\footnotetext{
96 “Na tradição da modernidade, a relação entre os seres humanos e os materiais é fixado pelo programa cartesiano de dominar e possuir a natureza. A vontade livre impõe seus próprios objetivos em dar elementos para desviá-los de seu curso natural. Esses objetivos são determinados por meio da linguagem que capacita o desejo de articular o que é possível (um projeto) e o impõe sobre o que é real (o problema). A ambição da exposição intitulada Les Immatériaux é fazer o visitante perceber quão distante esse relacionamento é alterado pela existência dos 'novos materiais'. Novos materiais em um sentido amplo do termo, não apenas materiais que são novos. Eles questionam a ideia de homem como um ser que trabalha, que planeja, que possui memórias: a ideia de um autor" (livre tradução).

97 “ 0 'alvo' da exposição é preciso: despertar as ansiedades e reflexões sobre a condição pósmoderna" (livre tradução).
} 
Moholy-Nagy e Joseph Kosuth - e pela participação de teóricos como Edmond Couchot e físicos, fotógrafos, astrônomos e arquitetos.

Ao entrar no corredor que abria caminho para a exposição, o visitante deveria escolher entre cinco percursos independentes. Cada um deles conduzia a um tipo de zona, cada qual com uma trilha sonora de fundo, que era ouvida por meio de fones de ouvido distribuídos na entrada, com instalações e um terminal de computador (DÉOTTE, 2015). As trilhas sonoras, escolhidas por Lyotard, eram formadas por fragmentos tanto de jingles publicitários como de textos de diversos autores de áreas distintas, entre os quais Maurice Blanchot e Samuel Beckett. Cada uma das zonas era dividida em sites. Entre os sites, estava o intitulado Nu Vain, projetado pelo cenógrafo Martine Moinot e composto por 12 manequins assexuados. Como fundo sonoro, ouvia-se a voz de Antonin Artaud recitando um poema. Durante seu percurso pela exposição, conforme já citado, o visitante poderia deixar registrado no terminal de computador as suas impressões e seus comentários sobre a mostra. Nesse sentido, tal ferramenta, de natureza participativa, permitia com que as informações inseridas pelos visitantes passassem a integrar a mostra.

No Brasil, a primeira exposição que trabalhou com a curadoria independente foi a Bienal Internacional de São Paulo de 1981, cujo curador contratado foi Walter Zanini. Com formação em História da Arte e 15 anos de direção do Museu de Arte Contemporânea da Universidade de São Paulo (USP) (1963-1978), foi convidado para exercer essa função também na edição de 1983.

Em seu desenho da bienal, Zanini quebrou com a representação da mostra por países, dando corpo à exposição sob o tema Analogias de Linguagem (CHIARELLI, 2008). A forma como organizou a exposição trouxe à discussão a multiplicidade de linguagens e a exploração das novas mídias, comportamentos frequentes no contexto artístico da época. Assim, os trabalhos passaram a ser vivenciados e analisados com base em suas especificidades em detrimento de questões geográficas. Ou seja, o artista e a sua produção foram colocados em foco.

Entre as conquistas de Zanini também está o resgate da importância da bienal, que havia perdido interesse por parte do público pelas constantes censuras sofridas durante o período da ditadura militar no Brasil. Tendo como ponto de partida o interesse em reconstruir a imagem da mostra diante dos artistas e da 
crítica internacional, o curador tirou partido do processo de abertura política e criou uma comissão formada por críticos do Chile, dos Estados Unidos, da Itália, do Japão e do México. Sob sua coordenação, como curador geral, caberia a essa comissão decidir como as obras, indicadas pelos países convidados, fundamentados em um regulamento, deveriam ser expostas, rompendo totalmente com as representações nacionais. Ou seja, todos os trabalhos expostos seriam selecionados tendo em vista critérios estabelecidos pela curadoria, e não mais os países definiriam quais artistas os representariam na bienal. Conforme palavras de Zanini (apud OBRIST, 2011, p. 163-164):

The crucial change consisted of eliminating national representations and organizing the installation of the Works by means of the criteria of analogies in language, closeness, and confrontation with what the countries' submissions had in common. So we tried to influence the choices of the countries' commissioners by a regulation that gave some guidance on what we had in mind. Thus, for the first time in the Biennial was able to adopt an attitude of critical responsibility ${ }^{98}$.

Assim sendo, por intermédio do pensamento curatorial, a bienal passou então a de fato reunir e colocar em discussão questões importantes para a arte de seu tempo.

Outra curadoria que se destacou em âmbito nacional foi a de Sheila Leirner para a 18. a Bienal Internacional de São Paulo, em 1985. Realizada na década conhecida como a Geração 80, rótulo, de acordo com Basbaum (2001), construído pelo discurso da crítica, a curadora deu forma, no segundo pavilhão do prédio da bienal, a Grande Tela. 0 evento ficou conhecido como a bienal da música experimental, pela marcante presença de John Cage. Leirner, a então crítica de arte do jornal Folha de S.Paulo, trouxe à discussão o retorno da pintura, já muito discutido tanto na Bienal de Veneza, Itália, de 1980, como também na Documenta, de Kassel, Alemanha, de 1982.

A expografia de $A$ Grande Tela foi realizada pelo arquiteto Haron Cohen e era formada por três corredores de $100 \mathrm{~m}$ de comprimento $\times 5 \mathrm{~m}$ de altura cada, tendo

\footnotetext{
98 “A mudança decisiva consistia em eliminar as representações nacionais e organizar as instalações dos trabalhos usando critérios de analogia, quanto à linguagem, à proximidade e ao confronto com o que os trabalhos de outros países tinham em comum. Tentamos, portanto, influenciar as escolhas dos comissários por intermédio de um regulamento que daria orientação sobre a nossa ideia. Então, pela primeira vez, a bienal pôde adotar uma atitude de responsabilidade crítica" (livre tradução).
} 
$6 \mathrm{~m}$ de espaçamento entre eles. Nesses corredores, Leirner dispôs, quase sem espaçamento nem identificação de países, telas de pintores brasileiros, alemães e italianos que seguiam tendência abstrato-expressionista (GONÇALVES, 2004). Assim sendo, os trabalhos não eram vistos pela sua individualidade, mas como uma obra única, já que uma pintura interferia visualmente na outra. Conforme Farias (2001, p. 208-209),

a ideia de solicitar ao arquiteto responsável uma museografia dessa natureza decorreu do compromisso do curador de oferecer ao público ambientes críticos, subvertendo a sintaxe habitual da montagem. No caso em questão o desejo de Leirner era transpor para a arquitetura um comentário sobre a profusão de pinturas que estavam chegando ao prédio da Bienal, obras que confirmavam o que ela já suspeitava: que a cena artística mundial estava tomada pela síndrome de uma modalidade muito particular de pintura; que em todos os lugares, acompanhando a vaga do neo-expressionismo alemão e da transvanguarda alemã, produzia-se coisa muito semelhante: pinturas de grandes dimensões, de tônica fortemente expressiva, "selvagem" ou "violenta", como eram denominados seus protagonistas alemães, ou ainda aquelas, como a da escola italiana, que efetuavam releituras de pinturas das vanguardas modernas.

Muitos artistas participantes não gostaram da montagem pelo fato de não identificar nem valorizar individualidades, contudo isso já vinha sendo feito pelo discurso da crítica nacional, que nomeou uma geração antes mesmo de ela chegar à metade de seu desenvolvimento (BASBAUM, 2001). Nesse sentido, a Grande Tela pode ser encarada como uma crítica à rotulação de toda uma geração por parte da crítica e soou tão forte e contundente quanto um texto escrito.

Observa-se que, enquanto Zanini fez da curadoria uma forma de resgatar a importância da bienal, assim como de valorizar as individualidades no levantamento e na discussão de questões importantes à produção de arte da época, Leirner desenhou uma sala na criação de uma obra única, anulando as individualidades, o que pode ser entendido como uma crítica à generalização da geração de artistas dos anos 1980. Apesar de se tratar de curadorias extremamente importantes e fundamentadas, que objetivaram provocar a reflexão e o estudo acerca da produção de arte, fosse por meio do desenho da mostra, fosse por uma crítica no formato de mostra, mais de 20 anos depois os nomes desses curadores e 
as suas curadorias são o que estão em destaque, muito mais comentados do que os trabalhos que estiveram em exposição. Chiarelli $(2008$, p. 13) afiança que o curador

foi aos poucos ganhando destaque, em alguns casos chegando a ofuscar as obras e os artistas participantes das mostras. A partir daí a "grife" do curador - seus conceitos genéricos e bombásticos, as peculiaridades cenográficas de suas montagens etc. - tornouse em muitos casos, mais comentada do que propriamente as obras exibidas.

Nota-se que, a partir da década de 1990, o crescimento da atuação da curadoria acabou assumindo um papel no discurso cultural que antes era restrito à crítica. Verifica-se também a presença de curadorias pensadas e produzidas como autorais, colaborativas ou mediadoras. Embora muitas vezes, conforme já citado, muitas delas tenham ocupado um lugar de importância antes reservado aos artistas, funcionaram como uma maneira de apresentar e mesmo de ensinar 0 público a ver e a aceitar a arte de seu tempo.

$\mathrm{Na}$ contemporaneidade, os espaços institucionais de arte multiplicaram-se, as exposições temporárias são uma constante, e a figura do curador cada vez está mais em destaque, não apenas institucionalmente, mas também em termos independentes de qualquer instituição.

\subsection{Curadoria como curadoria educativa}

A partir da segunda metade dos anos 1990, nasceu uma tendência na arte contemporânea denominada de educational turn, que se refere à adoção de abordagens educativas e métodos pedagógicos alternativos nas práticas artísticas e curatoriais. Embora tal comportamento tenha sido mais forte na Europa e nos Estados Unidos, também teve repercussão aqui no Brasil. Vários exemplos de escolas de arte, trabalhos de artistas e propostas curatoriais com esse mote podem ser apontados.

Em 1985, por exemplo, surgiu o Institut des Hautes Études en Arts Plastiques ${ }^{99}$, fundado pelo curador Pontus Hultén a convite do então prefeito de Paris Jacques Chirac, cujo objetivo era promover a pesquisa contemporânea em criação artística. Desde o início dos anos 1990, Janet Cardiff desenvolve trabalhos

\footnotetext{
${ }^{99}$ Mais informações em: <http://iheap.fr/en/>.
} 
em formato de audio walk, que funcionam como áudio guia projetado para ajudar as pessoas a perceberem o mundo ao seu redor. Afirma a artista:

I am interested in how audio affects our perception of the physical world. We understand three-dimensional space by using our vision, but also by the character of sounds we hear. If these sounds are manipulated and changed, then our perception of reality can be drastically affected ${ }^{100}$ (JANET CARDIFF'S..., 2011).

Em 1992 e 1993, a curadora norte-americana Mary Jane Jacob desenvolveu o Projeto Culture in Action, que consistiu na realização de um grande programa de site specifics em espaços públicos na cidade de Chicago, nos Estados Unidos. Por meio de seu projeto, pelo qual os artistas se engajaram diretamente com a comunidade, a curadora propôs a redefinição da função da arte pública: "Renewing the physical environment to that of improving society, from promoting aesthetic quality to contributing to the quality of life, from enriching lives to saving lives ${ }^{101 "}$ (JACOB; BRENSON; OLSON, 1995, p. 56). Trata-se de um dos projetos curatoriais que contribuíram para o estreitamento da relação entre arte e sociedade e que permitem pensar a atuação da arte como um instrumento de ação cultural.

Em 2006, Pablo Helguera seguiu de van um percurso do Alasca à Patagônia, atravessando assim o continente americano, carregando uma estrutura arquitetônica dobrável em forma de escola e munido de vídeos e publicações, para um projeto denominado de Escuela Panamericana del Desasosiego. Conforme consta do site do projeto, o objetivo foi estabelecer diálogo com diferentes tipos de público acerca de formas alternativas para entender a história, a ideologia e as linhas de pensamento que exerceram impacto sobre os acontecimentos de natureza política, cultural e social das Américas. Segundo o artista,

A pedagogia se dedica a sintetizar ambos os impulsos - tanto o da sociabilidade quanto o do sentido crítico. Por isso, tanto para mim como para outros artistas de minha geração, a busca de estruturas pedagógicas ao se fazer obras é uma maneira de gerar

\footnotetext{
100 “Estou interessada em saber como o áudio afeta a nossa percepção do mundo físico. Entendemos o espaço tridimensional usando nossa visão, mas também pelo caráter de sons que ouvimos. Se esses sons são manipulados e alterados, então a nossa percepção da realidade pode ser drasticamente afetada" (livre tradução).

101 “Renovação do ambiente físico para aquele que promove o aperfeiçoamento da sociedade, de promover a qualidade estética para contribuir com a qualidade de vida, de enriquecer vidas para salvar vidas" (livre tradução).
} 
um contexto que possa ser lúdico, ter elementos performáticos e abertos, mas que ao mesmo tempo exija um pouco mais do espectador, convertendo-o em verdadeiro interlocutor e, em alguns casos, em colaborador na investigação coletiva de um tema. Essa aproximação, sendo o caso de se estabelecer uma relação construtiva de comunicação com um público, é o mais lógico para mim, ainda que também admita que é um impulso mais idealista, que propõe a transformação do interlocutor, bem como a de si mesmo no processo (PABLO HELGUERA, 2012).

É interessante verificar que, por meio deste trabalho, que é a respeito de arte, se cruzam as fronteiras entre educação, arte e política.

0 curador chileno Gonzalo Pedraza, por sua vez, iniciou em 2008, com base em um estudo e numa investigação dos gabinetes de curiosidades, um projeto que intitulou de Colección Vecinal. Pedraza visitou os arredores da Galeria Metropolitana, em Santiago, no Chile, pedindo emprestado à vizinhança obras de arte para realizar uma exposição. Assim, por conta do pedido do curador, as pessoas foram imbuídas a pensar acerca do que é uma obra de arte para, então, atender ao pedido. Os 300 objetos emprestados integraram a exposição em uma espécie de recriação dos gabinetes de curiosidades do século XVII. Essa mesma ação também foi realizada em Porto Alegre, na VII Bienal do Mercosul, mediante a arrecadação de 350 objetos de pessoas da região.

No ano de 2004, o artista pesquisador Jorge Menna Barreto desenvolveu o Projeto Matéria no Centro Cultural São Paulo, por meio do qual instalou uma sala de aula no espaço expositivo em que ocorreu uma oficina sobre arte contemporânea para 15 pessoas, organizada em oito encontros ao longo do período de exposição (figura 29). Em cada encontro havia a participação de um crítico ou artista cuja atuação dialogava com o tema daquela aula, e os registros realizados nas paredes, que funcionavam como quadro-negro, não eram apagados até a aula seguinte, ficando disponíveis para o público como parte integrante da exposição.

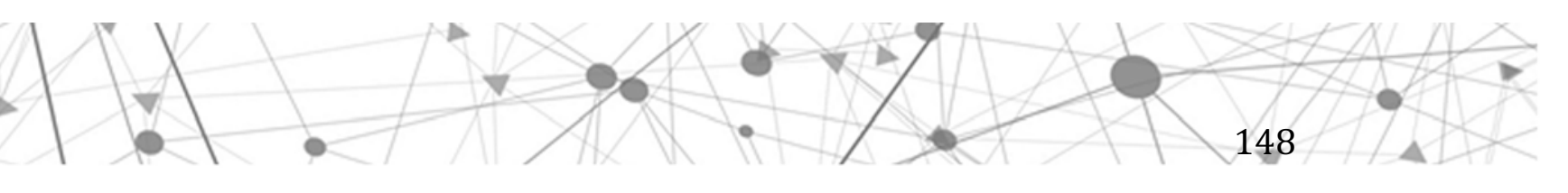




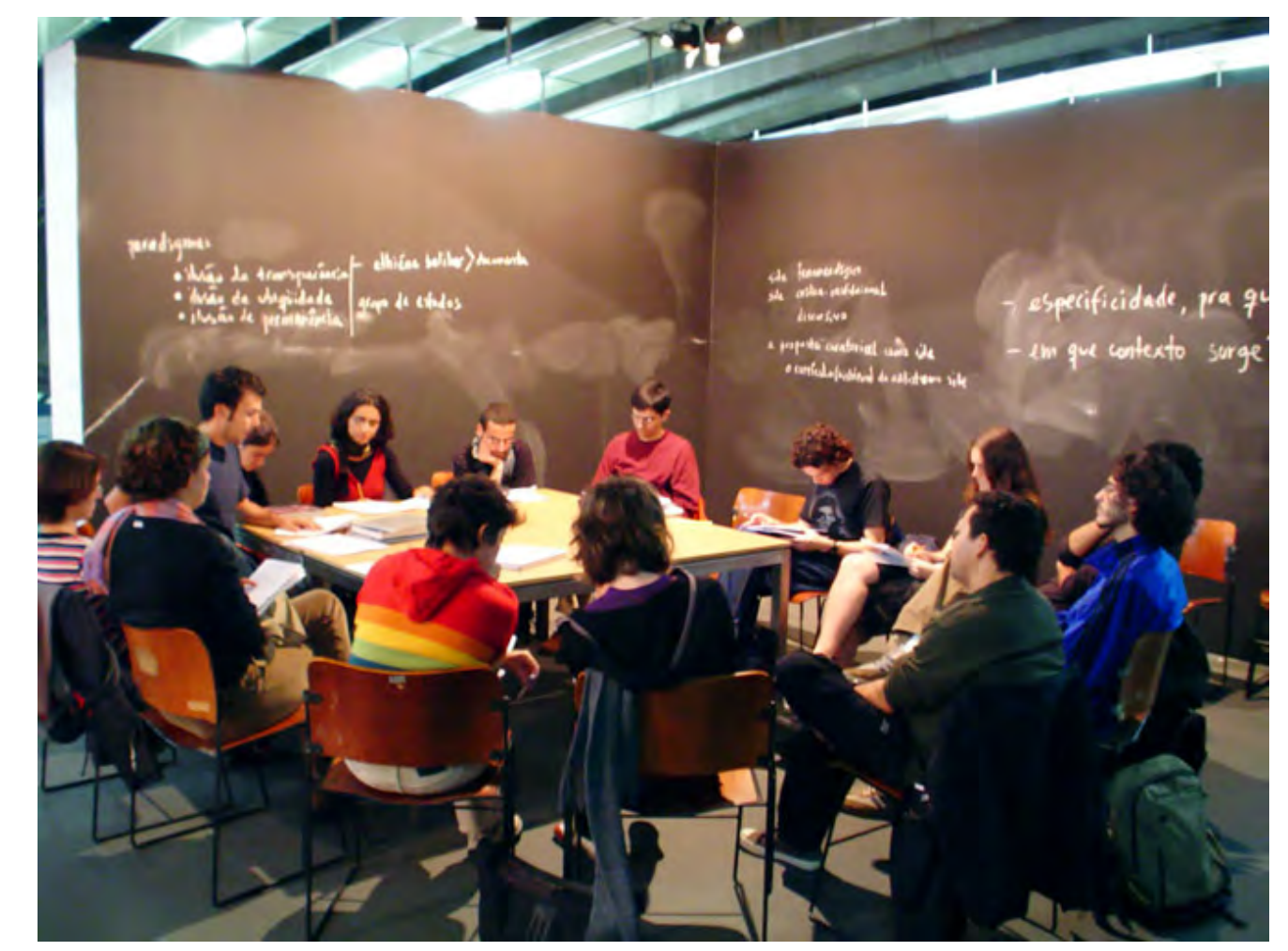

Figura 29 - Vista do Projeto Matéria, de Jorge Menna Barreto, Centro Cultural São Paulo, 2004

Fonte: disponível em: <http://payload320.cargocollective.com/1/17/556035/8714237/ sm_DSC00013-blur.jpg>. Acesso em: 10 jun. 2016

Com essa ação, todos os papéis se confundem: o de aluno com o de integrante de uma obra de arte, o de professor com o de artista, o de espaço de exposição com o de espaço de ensino, e o de uma obra de arte com o de um instrumento de arte/educação.

Três anos mais tarde, em 2007, Menna Barreto projetou, por meio do Grupo de Educação Colaborativa do Paço das Artes, em São Paulo, o Café Educativo, hoje parte integrante do acervo do Museu de Arte Moderna de São Paulo (MAM) ${ }^{102}$. 0 trabalho consiste na instalação de um café no espaço de exposição que funciona como um ambiente relacional no qual o público pode refletir acerca da exposição visitada e trocar ideias com os membros do setor educativo.

Ainda em 2007, a assessora e pesquisadora do programa educativo da Documenta 12 Carmen Mörsch propôs ações que visavam ao envolvimento do público local com a exposição e a promoção da educação crítica, sendo a primeira

\footnotetext{
${ }_{102}$ Mais informações em: <http://mam.org.br/acervo/2012-018-barreto-jorge-menna/>. Acesso em: 10 jul. 2016.
} 
vez que a mostra destacou o setor educativo ${ }^{103}$.

Nesse mesmo ano, a 6. ${ }^{\text {a }}$ Bienal do Mercosul, inspirada no conto de Guimarães Rosa A Terceira Margem do Rio, com curadoria geral de Gabriel PérezBarreiro, sobressaiu como a Bienal Pedagógica, pioneira por lançar a figura do curador pedagógico. Afirma Camnitzer, nomeado curador pedagógico dessa edição da bienal:

0 curador pedagógico é alguém que não influi na seleção dos artistas. É alguém que atua como um embaixador do público e observa o evento com os olhos do visitante. Foram justamente esses olhos do visitante que nos levaram à conclusão de que é fundamental dar maior permanência e extensão à ação educativa (apud CAMNITZER; PÉREZ-BARREIRO, 2009, p. 15).

Assim, a curadoria pedagógica desenvolveu-se de forma integrada ao projeto curatorial, e as ações educativas foram antecipadas e organizadas em função do calendário escolar. Realizaram-se também formações de professores em mais de 40 cidades do Rio Grande do Sul e de Santa Catarina, além de dois simpósios de arte e educação que alcançaram público total de 1.600 educadores.

A 7. a edição da Bienal do Mercosul, Vento e Escuta, com curadoria geral de Victória Noorthoorn e Camil Yàñez, teve seu projeto selecionado em um concurso público internacional, por meio do qual artistas atuaram como curadores e desenvolveram o projeto expositivo e pedagógico, além de coordenar e conceituar o projeto editorial, as publicações e o projeto de comunicação da bienal. Nessa edição, o artista foi entendido como um agente social e produtor do sentido crítico importante ao entendimento do mundo.

Conforme consta em seu site ${ }^{104}$, o projeto pedagógico, criado pela artista/curadora Marina De Caro, foi concebido com os propósitos de descentralizar e multiplicar as ações concretizadas, atendendo 90 mil estudantes de escolas públicas e particulares. Durante o período da mostra, foi desenvolvido, por exemplo, o Projeto Mapas Práticos - Espaços em Disponibilidade, que consistiu em uma ação realizada com 26 ateliês educativos da cidade e que contou com a participação de 40 artistas locais, que, durante o período da bienal, receberam

\footnotetext{
${ }^{103} 0$ programa educativo da Documenta 12 pode ser conhecido em detalhes por meio da entrevista concedida por Carmen Mörsch ao Fórum Permanente: <http://iptv.usp.br/portal/video.action?idltem=2856>.

${ }^{104}$ Mais informações em: <http://www.fundacaobienal.art.br/site/pt/bienais/7-bienal>.
} 
grupos, ministraram oficinas gratuitas e atenderam cerca de 1.400 pessoas.

Pode-se afirmar que, assim como no trabalho de Jorge Menna Barreto, no desenvolvimento dessa edição da Bienal os papéis se confundiram: o artista foi curador, o artista foi professor e o público aluno. Contudo, independentemente dos papéis ocupados nas propostas no âmbito da virada educacional, são a experiência, a reflexão, a discussão e a construção de conhecimento por meio da arte e em arte que estão em foco.

A partir do fim do século $X X$, diferentes procedimentos de natureza educacional tornaram-se constantes, tanto no pensamento como na prática artística e curatorial. No contexto da arte, surgiram inúmeras organizações e escolas coordenadas por artistas, bem como projetos educativos, cursos, oficinas, palestras, fóruns e seminários projetados e entendidos como trabalhos de arte. Também nesse sentido, museus e instituições culturais passaram a valorizar, a ampliar e a investir em seus programas educativos. Muitas exposições passaram a ter também como membro da equipe realizadora a figura do curador educativo. Afirmam 0'Neill e Wilson (2010, p. 12):

Contemporary curating is marked by a turn to education. Educational formats, methods, programmes, models, terms, processes and procedures have become pervasive in the praxes of both curating and the production of contemporary art and in their attendant critical frameworks. This is not simply to propose that curatorial projects have increasingly adopted education as a theme; it is, rather, to assert that curating increasingly operates as an expanded educational praxis. It is this proposition - that curating, and art production more broadly, have produced, undergone or otherwise manifested an educational turn ${ }^{105}$.

Com base nos exemplos citados, percebe-se que algumas das experiências de arte desenvolvidas no âmbito da virada educacional, fundamentadas na crítica institucional, abandonam o espaço de exposição tradicional, tais quais o museu e a galeria, e passam a exercitar as ruas, as escolas, os espaços comunitários, colocando em discussão muitas vezes questões sociais construídas pela comunidade tendo em vista especificidades locais. Verifica-se também que muitas

\footnotetext{
105 “A curadoria contemporânea é marcada por um retorno à educação. Formatos, métodos, programas, modelos, termos, processos e procedimentos educacionais tornaram-se generalizados nas práxis de ambos, curadoria e produção de arte contemporânea, e nos seus quadros críticos inerentes. Isso não é simplesmente propor que os projetos de curadoria têm adotado cada vez mais a educação como tema; é, pelo contrário, afirmar que a curadoria opera cada vez mais como uma práxis educativa expandida. É essa a proposição - que a curadoria e a produção de arte forma mais ampla, têm produzido, sofrido ou então manifestado a virada educacional" (livre tradução).
} 
das experiências da virada educacional são realizadas em escolas experimentais, assim como no contexto das bienais. Ao mesmo tempo, muitos artistas exploram, no âmbito da arte nos espaços de exposição, as formas públicas de instituição, tais como a biblioteca, a escola e o café, sendo a prática curatorial uma "expanded educational práxis"106 (0’NEILL; WILSON, 2010, p. 12).

Na proposta de exposição desenvolvida nesta tese, entende-se a curadoria educativa não apenas como uma prática educacional expandida, mas também como uma prática curatorial expandida. Isso se dá pelo fato de o propósito da ação curatorial aqui desenvolvida não girar apenas em torno do pensar a melhor maneira de apresentar determinado recorte ao público, organizado em um espaço específico, seja ele a rua, seja uma galeria, uma escola ou um espaço de conveniência. 0 que se pretende é provocar o exercício da arte como um instrumento de ação cultural (JACOB; BRENSON; OLSON, 1995), o que será feito por intermédio de diferentes recursos que darão forma a uma exposição virtual digital disponibilizada em rede, sem perder como foco o objeto de arte.

A curadoria educativa, nessa perspectiva, envolve a arte, a exposição e a educação, no entanto não a educação pensada somente ou especificamente para as escolas, para os estudantes, para os professores, ou mesmo para aquele visitante com interesse nesse sentido, mas para o público como um todo. Em geral, nas instituições do Brasil, a curadoria é responsável pela concepção e realização das exposições, e o setor educativo, muitas vezes sob a coordenação da curadoria educativa, por pensar programas de mediação. Afirma o curador dinamarquês Simon Sheikh:

The museum and the practice of exhibition making is always already a pedagogical endeavor [...]. The exhibitionary complex with its myriad disciplines and functions and curatorial techniques - is, by definition, pedagogic; the pedagogical function is not just something belonging in the education department (of large scale public institutions). Indeed, the existence of education departments can be seen as a later development and specialization of the museum alongside the establishment of curatorial departments and public programming divisions. [...] Perhaps this division of labour, and this temporal division between production and reception (as outlined with respect to the role of the docent and the separation of curatorship from mediation), indicates that a pivotal connection between the exhibitionary and

106 “Práxis educativa expandida” (livre tradução). 

the pedagogical has been severed
2010, (ap. 65).

Em grande parte dos museus e das instituições culturais, a curadoria e o educativo constituem atividades que, embora interligadas, funcionam separadamente, sendo a curadoria educativa responsável por explicar, ou mesmo traduzir, para o público o trabalho da curadoria, visto como a autoridade possessora do discurso sobre a arte. Ao ser questionado a respeito dos processos de recepção de uma obra de arte por parte do público, e se ela deve ou não ser explicada, e acerca da hierarquia estabelecida entre quem fala (artista e curador) e quem aprende (público), o artista e curador colombiano Nicolás Paris esclarece:

Refletir sobre didática fica mais próximo de pensar processos de "aprendizagem" e nem tanto de "ensino". Trabalhar no âmbito cultural pressupõe, inevitavelmente, uma pedagogia instável, como diria Irit Rogoff, onde o significado não é inerente aos espectadores/participantes, nem imposto por uma autoridade, mas ganha vida no momento mesmo da atualização. Temos estado e ainda estamos, inevitavelmente, num processo de aprendizagem, onde não podemos distinguir entre início e final, Norte ou Sul, visões corretas ou incorretas. Todos nós estamos aprendendo. Cito Buckminster Fuller e seu Dymaxion Map, onde os continentes são uma só ilha, são um só sistema, todos conectados entre si. Os pontos mais longínquos de uma linha estão um ao lado do outro (apud RITH-MAGNI, 2011).

Nesse sentido, em concordância com Paris, acredita-se em uma curadoria que já nasça como um processo educativo, e é essa curadoria que se defende, entendendo a educação como um processo humanizante, social, político, ético, histórico e cultural (FREIRE, 2009) e que pode ser viabilizado por meio das experiências de arte (DEWEY, 2010).

\footnotetext{
107 “Simplesmente, o museu e a prática curatorial são sempre um esforço pedagógico [...]. 0 complexo de exposição - com sua variedade de disciplinas e funções e técnicas curatoriais - é, por definição, pedagógico; a função pedagógica não é algo pertencente somente ao departamento de educação (da larga escala de instituições públicas). Com efeito, a existência de departamentos de educação pode ser vista como um desenvolvimento posterior e especialização do museu juntamente com a criação de departamentos de curatoriais e divisões de programas públicos. [...]. Talvez, a divisão do trabalho e a histórica divisão entre produção e recepção (conforme descrito com relação ao papel docente e à separação da curadoria da mediação) indiquem que a conexão fundamental entre o expositivo e o pedagógico tenha sido cortada" (livre tradução).
} 


\subsection{A exposição virtual na web e a curadoria educativa}

Ao observar as grandes exposições, tais como a Bienal Internacional de São Paulo, a Bienal do Mercosul e a Documental de Kassel, constata-se que a curadoria educativa, conforme já citado, é entendida como o setor responsável por criar na exposição um ambiente que estimule a experimentação por meio de ações tais como cursos, oficinas, palestras e materiais educativos, geralmente voltadas aos professores e estudantes. Por intermédio das ações desenvolvidas pela curadoria educativa, o público será provocado a estabelecer relações com os trabalhos fundamentados em seu próprio repertório, além de ter acesso a informações e saberes que contribuirão para o exercício e o aprofundamento do olhar.

Parte-se do pressuposto, contudo, de que existem outras práticas educativas que podem ser desenvolvidas pelo museu fora as visitas dialogadas, bem como se acredita que os projetos educativos não necessariamente precisam ser construídos de maneira independente, ou mesmo de forma dialogada com a curadoria. Propõe-se aqui que o desenho da exposição já seja pensado pelo curador, e/ou pela equipe curatorial, tendo em vista o propósito educativo. Ou seja, que os princípios da curadoria educativa já estejam presentes desde o início da concepção da mostra por parte da curadoria, mas não como um programa à parte, e sim como a própria exposição.

Nesse sentido, defende-se como fruto da curadoria educativa uma exposição que possibilite já em seu desenho que o espectador consuma plenamente o produto cultural. Assim, vê-se aqui a prática educativa como ponto de partida para o desenvolvimento de um processo curatorial, compreendido como um programa educativo, o que se chamou de "curadoria educativa", termo criado por Luiz Guilherme Vergara (1996) e que dele foi apropriado. Cabe observar que Martins (2006) e seu grupo de pesquisa também se apropriaram desse termo, porém a pesquisa por eles desenvolvida e o conhecimento que foi construído giraram em torno das escolhas do professor para a elaboração e realização de suas aulas na escola; por esse motivo, não será utilizada no contexto desta tese.

No caso do ciberespaço, os recursos para tal podem ser diversos, e de natureza hipermidiática, diferentemente do processo da mediação conduzida por terceiros, como acontece na maioria das exposições realizadas em espaços físicos. Pensar a exposição virtual como uma ferramenta de curadoria educativa pode 
funcionar tanto como complemento à exposição como incentivo à visita, ou mesmo ser independente de uma exposição física, tendo por objetivo ativar um determinado recorte do acervo, problematizá-lo e colocá-lo disponível para o público na web. E, mais importante, a exposição virtual pode ser desenhada com 0 intuito de provocar a vivência de uma experiência distinta daquela que acontece no espaço físico, na exploração das especificidades do ambiente virtual em rede.

Conforme já citado no capítulo 1, das 155 experiências de museus no ambiente virtual que foram mapeadas (apêndice 1), apenas 22 oferecem exposições virtuais. Dessas, apenas sete instituições possuem sede física, ou seja, a grande minoria faz uso do ambiente virtual em rede para exercitar o seu acervo físico digitalizado, ou mesmo para promover mostras temporárias, seja de seu acervo, seja de outras coleções. Pelo fato de o MAC Schwanke Virtual possuir acervo físico, e futuramente, uma sede física, são essas sete experiências que interessam no contexto desta tese, entretanto é interessante observar que, das 22 experiências de museus que se afirmam como museu virtual (20 delas), como museu online (1 delas), ou como webmuseu (1 delas), apenas 12 promovem exposições em seu ambiente virtual (apêndice 1). Mas isso não será discutido aqui, já que o foco da tese está na investigação de instituições físicas que exercitam o espaço virtual, e não em museus que existem apenas na internet.

Entre as exposições disponibilizadas no ambiente virtual por museus que também possuem sede física, apenas quatro foram desenhadas para colocar 0 acervo digitalizado em exercício, especialmente para a web. São elas: o Carnamah Historical Society \& Museum, o Palácio de Versalhes, a Galeria Nacional do Canadá e o Museu Casa de Portinari - uma das exposições realizadas por este último, 0 carnaval na paleta de Portinari, já foi analisada no capítulo 1.

Na webpage do Carnamah Historical Society \& Museum, intitulada de Virtual Museum, o visitante pode selecionar a exposição que quer visitar por um mosaico de imagens, cada imagem representando uma coleção que compõe o acervo do museu. Ao selecionar a coleção Toys!, por exemplo, o visitante é conduzido a uma nova página, a qual pode ser percorrida verticalmente pela barra de rolagem. Nela, constam imagens das peças que compõem essa coleção acompanhadas por textos explicativos e dados técnicos (figura 30). 


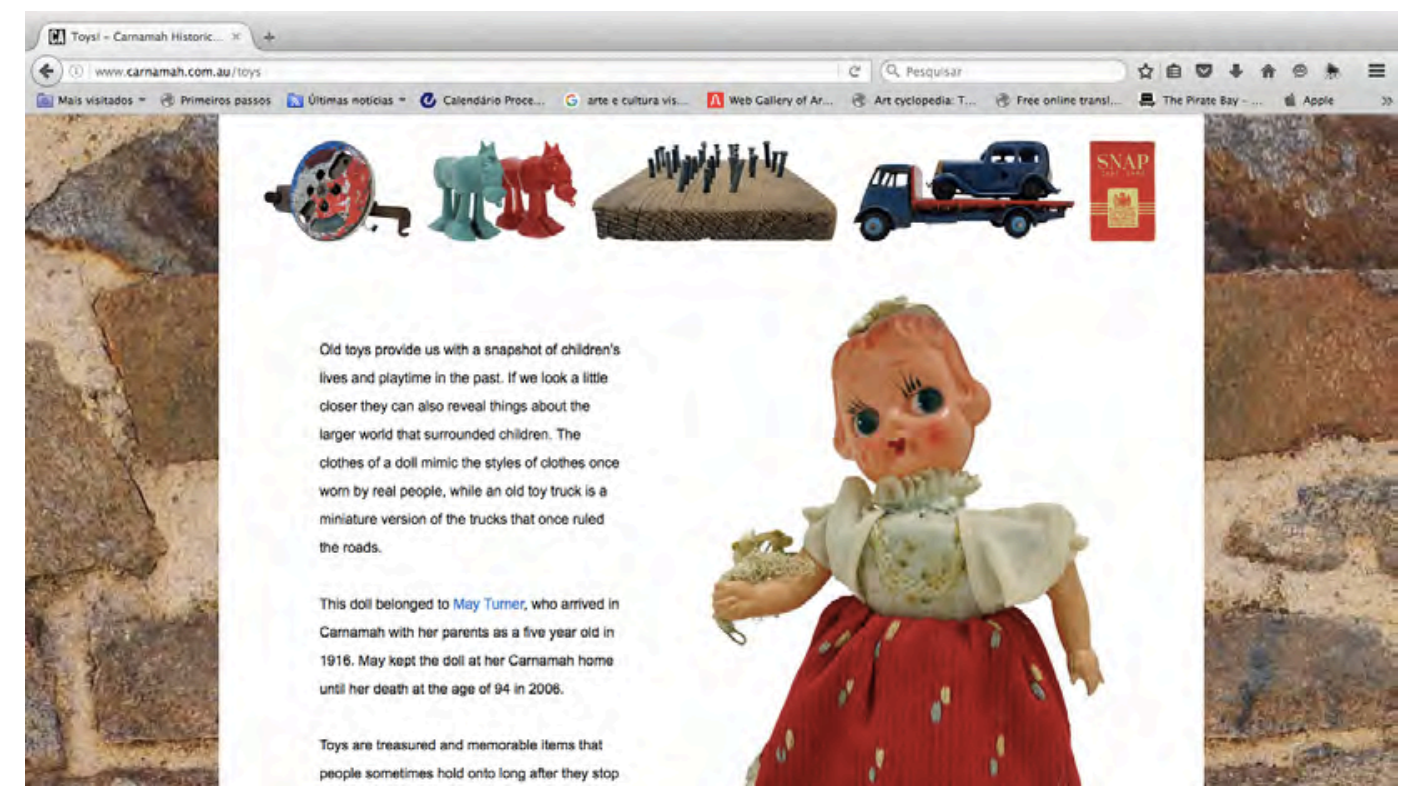

Figura 30 - Captura de imagem da página da exposição Toys!, do Carnamah Historical Society \& Museum

Fonte: disponível em: <http://www.carnamah.com.au/toys>. Acesso em: 23 jun. 2016

É uma forma interessante de conhecer a coleção, mas a exposição acaba se tornando monótona, já que cabe ao visitante apenas descer a página, visualizar as imagens e ler os textos. Não fazem parte da mostra ferramentas participativas, nem é disponibilizado um espaço para se obter retorno sobre a mostra por parte do visitante. Ou seja, a exposição ainda segue a lógica daquelas realizadas no espaço físico, já que não explora nenhuma das especificidades do ambiente virtual.

Já as exposições disponibilizadas no ambiente virtual do Palácio de Versalhes ${ }^{108}$ são promovidas em parceria com o Instituto Cultural do Google e com o Castelo de Vaux-le-Vicomte, em Maincy, França. São exposições concebidas especialmente para a web, formadas por trabalhos selecionados pela equipe de curadores e que exploram diferentes ferramentas oferecidas pela tecnologia de base microeletrônica.

Uma dessas exposições é: Louis XIV / Nicolas Fouquet: a Certain History of Taste $^{109}$, formada por obras digitalizadas do acervo do Palácio de Versalhes e do Castelo de Vaux-le-Vicomte. A mostra é organizada em seções: Architecture; Interior Decoration; Art of Gardens; e Artists. Todas essas seções estão na mesma página, que pode ser percorrida pela barra de rolagem. Entretanto, diferentemente

108 Mais informações em: <http://en.chateauversailles.fr/multimedia-/multimedia-en/googlepartnership>.

${ }_{109}$ Mais informações em: <https://www.google.com/culturalinstitute/beta/u/0/exhibit/louis-xivnicolas-fouquet-une-certaine-histoire-du-go\%C3\%BBt/eQKSvlgHkBpSLg?hl=en>.

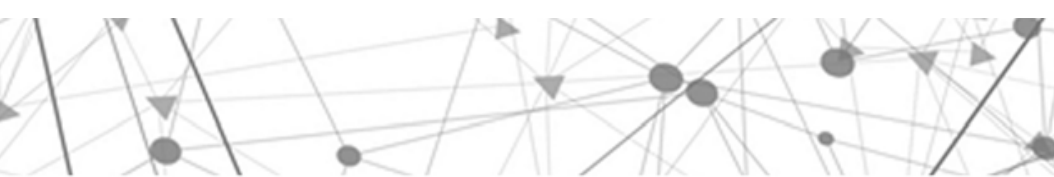


das exposições virtuais do Carnamah Museum, o visitante pode fazer uso de diversos recursos e formas de visualização.

Logo no início da exposição, há um pequeno texto introdutório (é interessante observar que tanto esse como os demais textos que compõem a exposição são curtos e objetivos), e logo abaixo consta um fragmento da pintura Allegory of Louis XIV, Protector of the Arts and the Sciences (1670-1672), de Jean Garnier e Claude Lefèbvre. Ao clicar na imagem, uma nova página abre-se com a imagem completa, com todos os seus dados técnicos, a qual pode ser ampliada e visualizada em alta resolução. A ferramenta disponibilizada pelo Google, que digitalizou a obra original em gigapixel, permite com que o visitante percorra toda a superfície da pintura e visualize seus pormenores, muitas vezes invisíveis quando se está diante do original. Além de um pequeno texto explicativo sobre a pintura, constam mais duas imagens de pinturas que possuem relação com a que está sendo visualizada. Se o visitante tiver interesse, elas também podem ser ampliadas.

Assim, percebe-se que o desenho dessa exposição explora na natureza rizomática o ambiente virtual em rede. Ao retornar para a página principal da exposição e descer mais um pouco a barra de rolagem, é visualizado um arquivo de áudio (figura 31), com informações pertinentes ao conteúdo da obra, e o visitante pode escolher entre escutar ou não. 

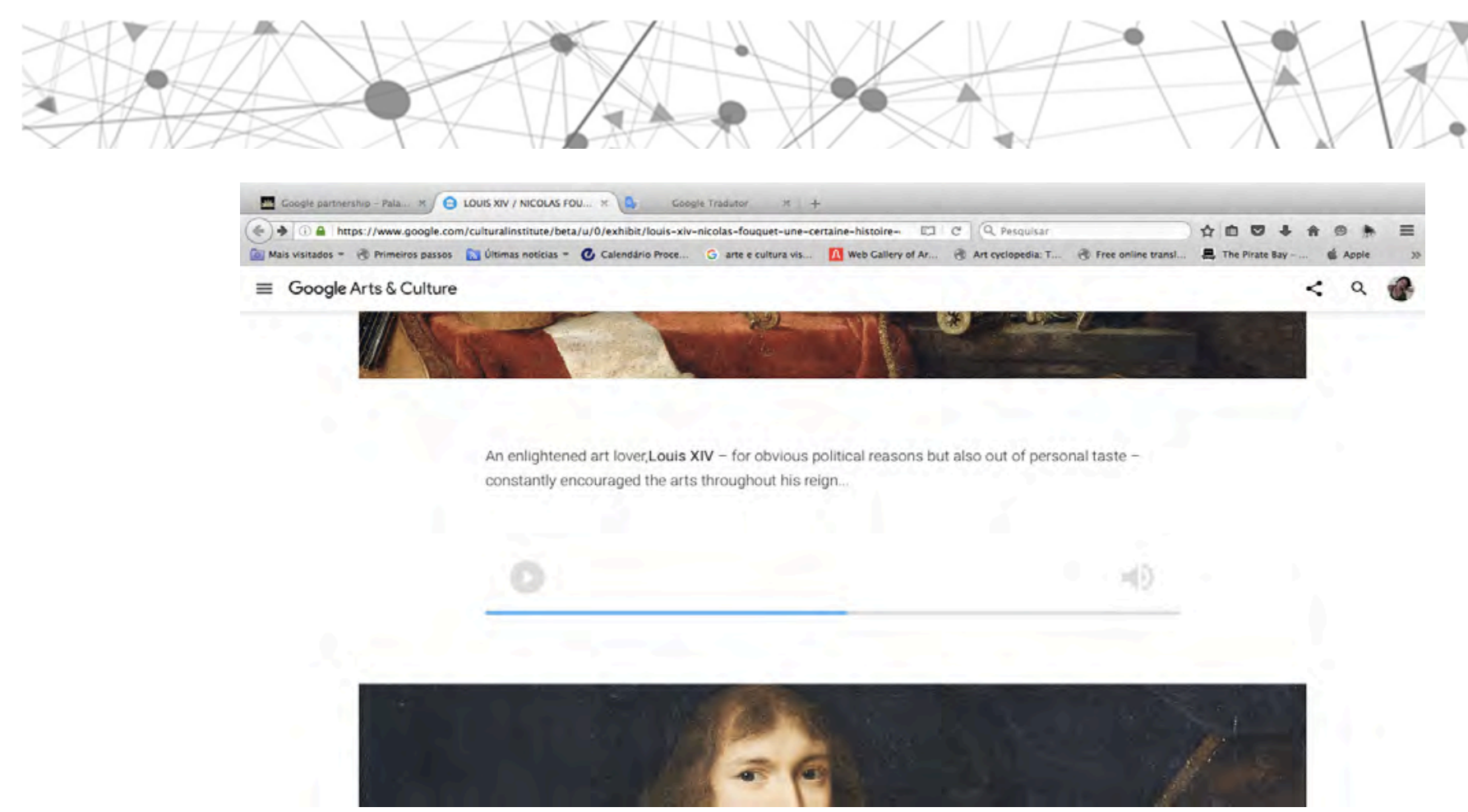

Figura 31 - Captura de imagem da exposição virtual Louis XIV / Nicolas Fouquet: A Certain History of Taste mostrando arquivo de áudio

Fonte: disponivel em: <https://www.google.com/culturalinstitute/beta/u/0/exhibit/louis-xivnicolas-fouquet-une-certaine-histoire-du-go\%C3\%BBt/eQKSvlgHkBpSLg?hl=en>. Acesso em: 15 set. 2016

Já na seção Architecture, logo no início, o visitante depara com um arquivo de vídeo (figura 32), o qual traz imagens móveis do Castelo de Vaux-le-Vicomte retratado na pintura, acrescentando uma vivência enriquecedora à contemplação da imagem e ao entendimento do conteúdo de texto que a acompanha.

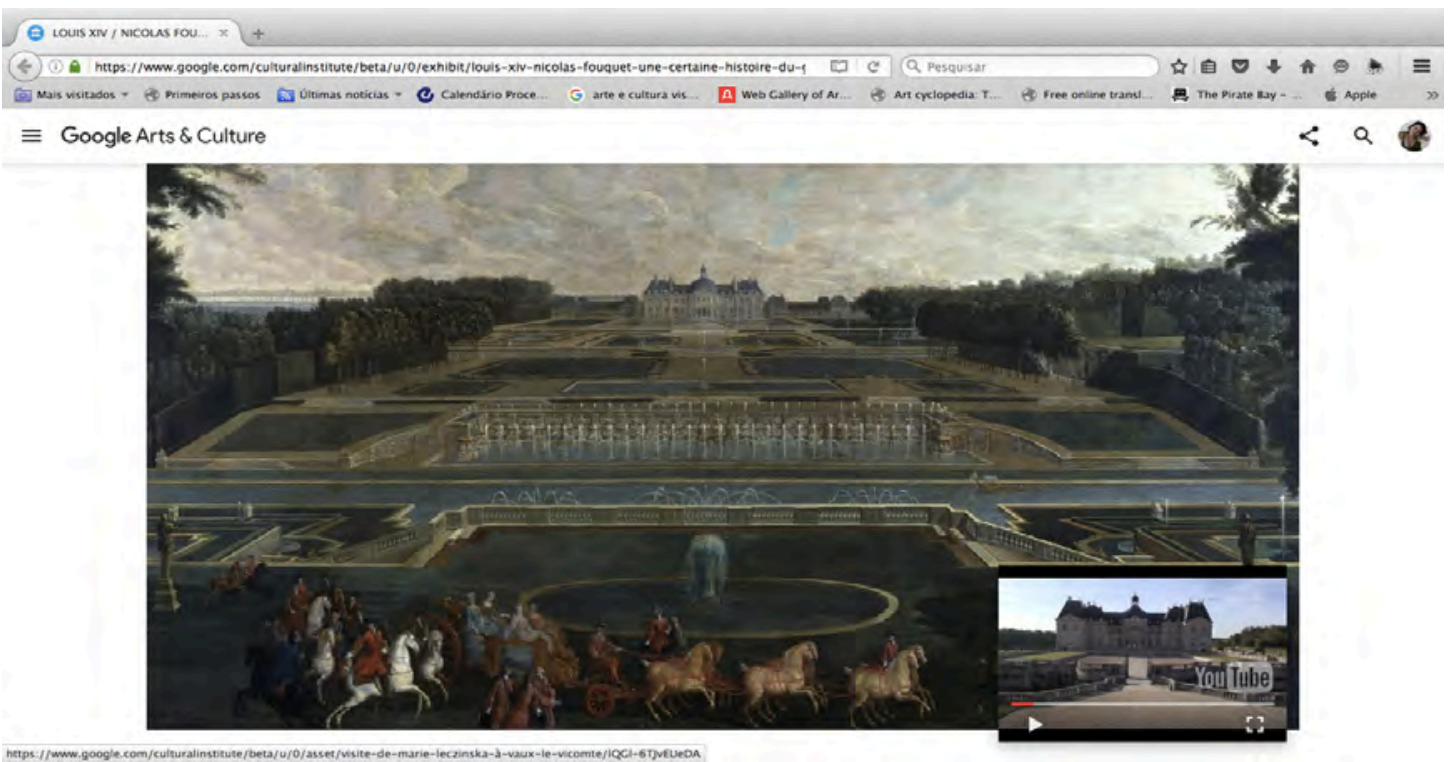

Figura 32 - Captura de imagem da exposição virtual Louis XIV / Nicolas Fouquet: A Certain History of Taste mostrando a imagem da pintura Visite de Marie Leczinska à Vaux le Vicomte, 1728 , de Jean-Baptiste Martin, acompanhada de arquivo de vídeo

Fonte: disponível em: <https://www.google.com/culturalinstitute/beta/u/0/asset/visite-de-marieleczinska-\%C3\%A0-vaux-le-vicomte/IQGl-6TJvEUeDA?hl=en>. Acesso em: 24 jun. 2016

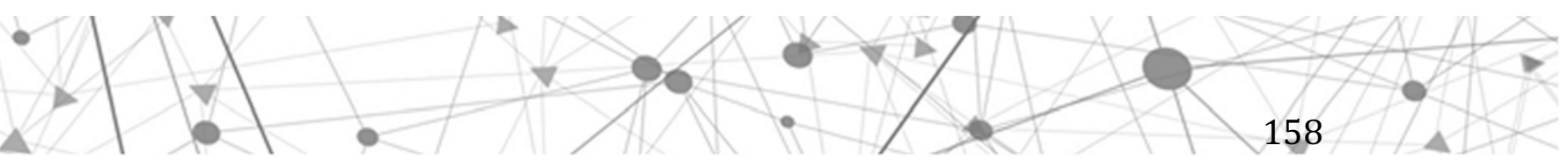




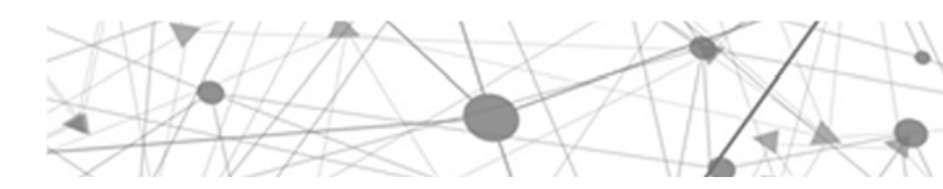

Mais para baixo, ao clicar na imagem do quarto de Luís XIV, presente na seção Interior Decoration, o visitante pode visualizá-la e percorrê-la em três dimensões com o mouse ou comandos do teclado (figura 33). Conforme já citado no capítulo 1, tal recurso não substitui a visita física no espaço e, muitas vezes, dada a dificuldade de controle da ferramenta, acaba prejudicando a relação do público com a instituição. Entretanto, no contexto dessa exposição, e pelo fato de o foco da experiência girar em torno do próprio espaço, e não de objetos de arte nele expostos, a vivência funciona como um complemento à exposição, tornando-a até mesmo mais ativa.

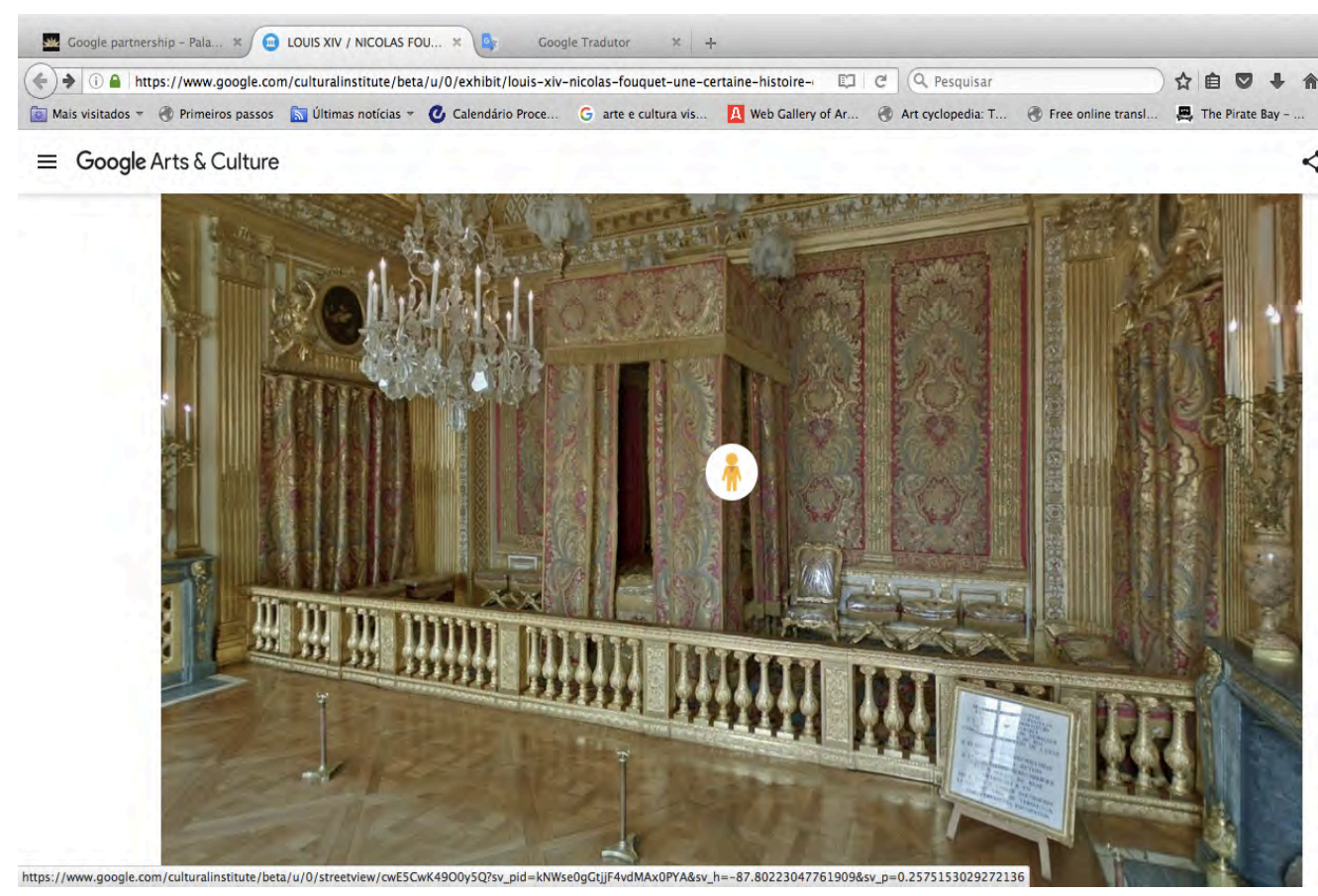

Figura 33 - Captura de imagem da exposição virtual Louis XIV / Nicolas Fouquet: A Certain History of Taste mostrando ferramenta que permite a visualização em três dimensões do quarto de Luís XIV no Palácio de Versalhes

Fonte: disponivel em: <https://www.google.com/culturalinstitute/beta/u/0/streetview/ cwE5CwK4900y5Q?sv_pid=kNWse0gGtjjF4vdMAxOPYA\&sv_h $=-87.80223047761909 \& s v \_p=0.2575$ 153029272136\&hl=en>. Acesso em: 24 jun. 2016

Assim, trata-se de uma exposição rica e dinâmica, que explora a natureza hipermidiática do ambiente virtual em rede, fazendo uso de diferentes recursos para complementar a vivência das imagens presentes na exposição.

A Galeria Nacional do Canadá, por sua vez, oferece diversas exposições virtuais denominadas de Online Showcases, organizadas em dois grupos: Artists e 
Themes. Em Artists estão as exposições virtuais individuais, cujo foco são a trajetória e a produção de diferentes artistas. Em Themes há exposições temáticas que trazem diferentes produções. Para ser analisada aqui foi escolhido o showcase de M. C. Escher - Mindscapes, localizado em Artists, pelo fato de a exposição a ser construída no contexto desta tese também envolver a produção de um único artista.

Na página principal da exposição, além do título, consta um pequeno texto introdutório, localizado do lado esquerdo da tela. No lado direito, há uma imagem de um dos trabalhos do artista, acompanhada pelos dados técnicos. Essa imagem pode ser ampliada e contemplada em uma resolução maior. Logo abaixo do título, há uma barra com seis opções: Introduction, Chronology, Themes, Techniques, Gallery e Share This (figura 34). Assim, o visitante pode escolher entre visualizar as opções da barra de rolagem na ordem sugerida, ou estabelecer a sua própria sequência de visita da exposição.

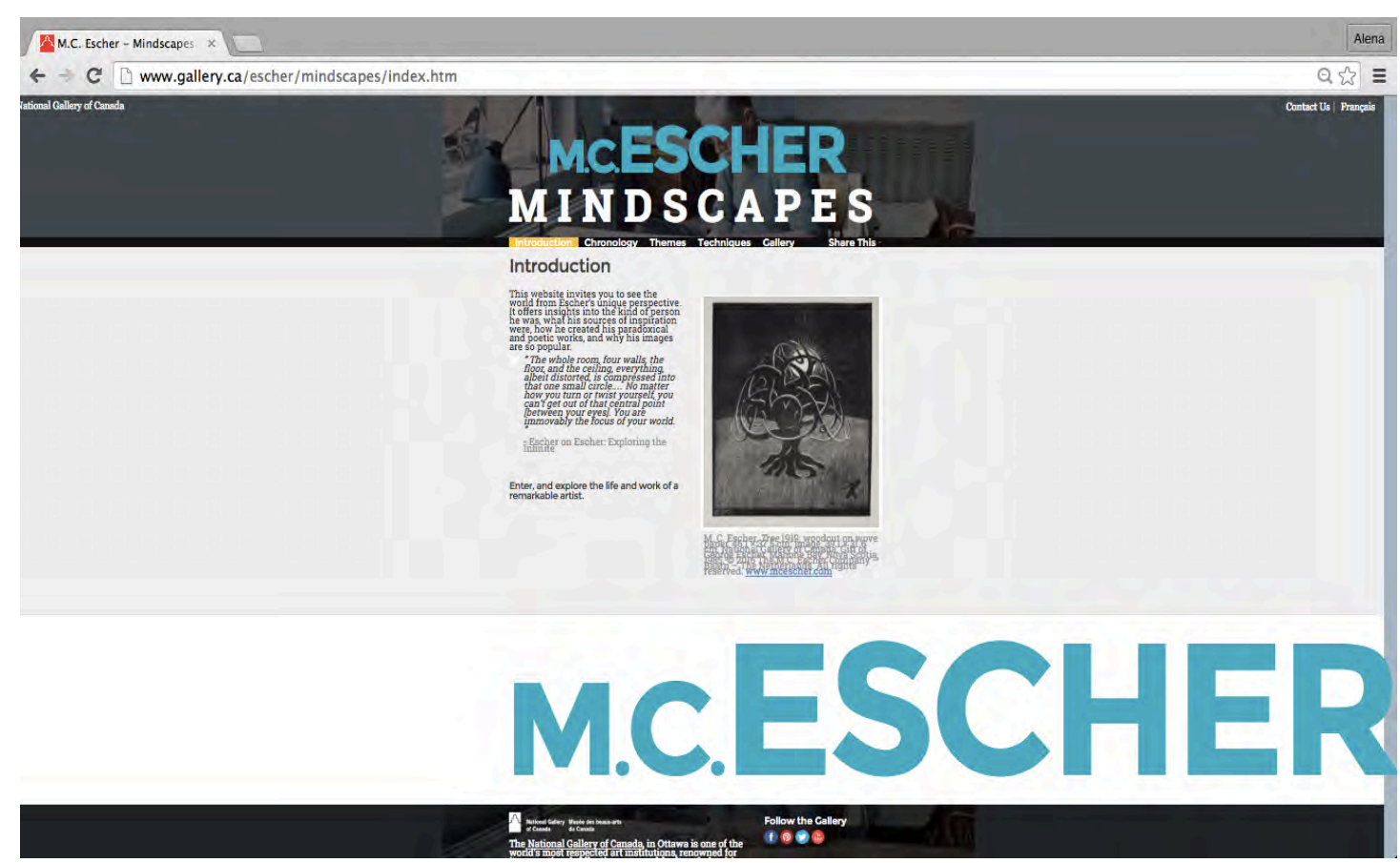

Figura 34 - Captura de imagem da exposição virtual M. C. Escher-Mindscapes, mostrando a página inicial com a barra de opções

Fonte: disponível em: <http://www.gallery.ca/escher/mindscapes>. Acesso em: 25 jun. 2016

0 título da mostra, atrás do qual consta um fragmento de uma foto do artista trabalhando, e a barra de opções são fixos na página. Conforme uma das 
opções é selecionada, ela é destacada em amarelo, de forma a ajudar o visitante a se localizar (figura 35).

Na opção Chronology, a linha do tempo da vida do artista é organizada verticalmente e pode ser visualizada pouco a pouco com o deslize da página pela barra de rolagem. Ela é formada pelos momentos de destaque, exaltados por intermédio de pequenos textos informativos, por vezes acompanhados de imagens. Em alguns momentos, o visitante pode acessar depoimentos do filho do artista, George Escher, falando sobre aquele determinado período da vida do pai, seja em formato de texto, seja em formato de vídeo, o que demonstra por parte da curadoria preocupação em relação à acessibilidade e também com o perfil do visitante (figura 35).

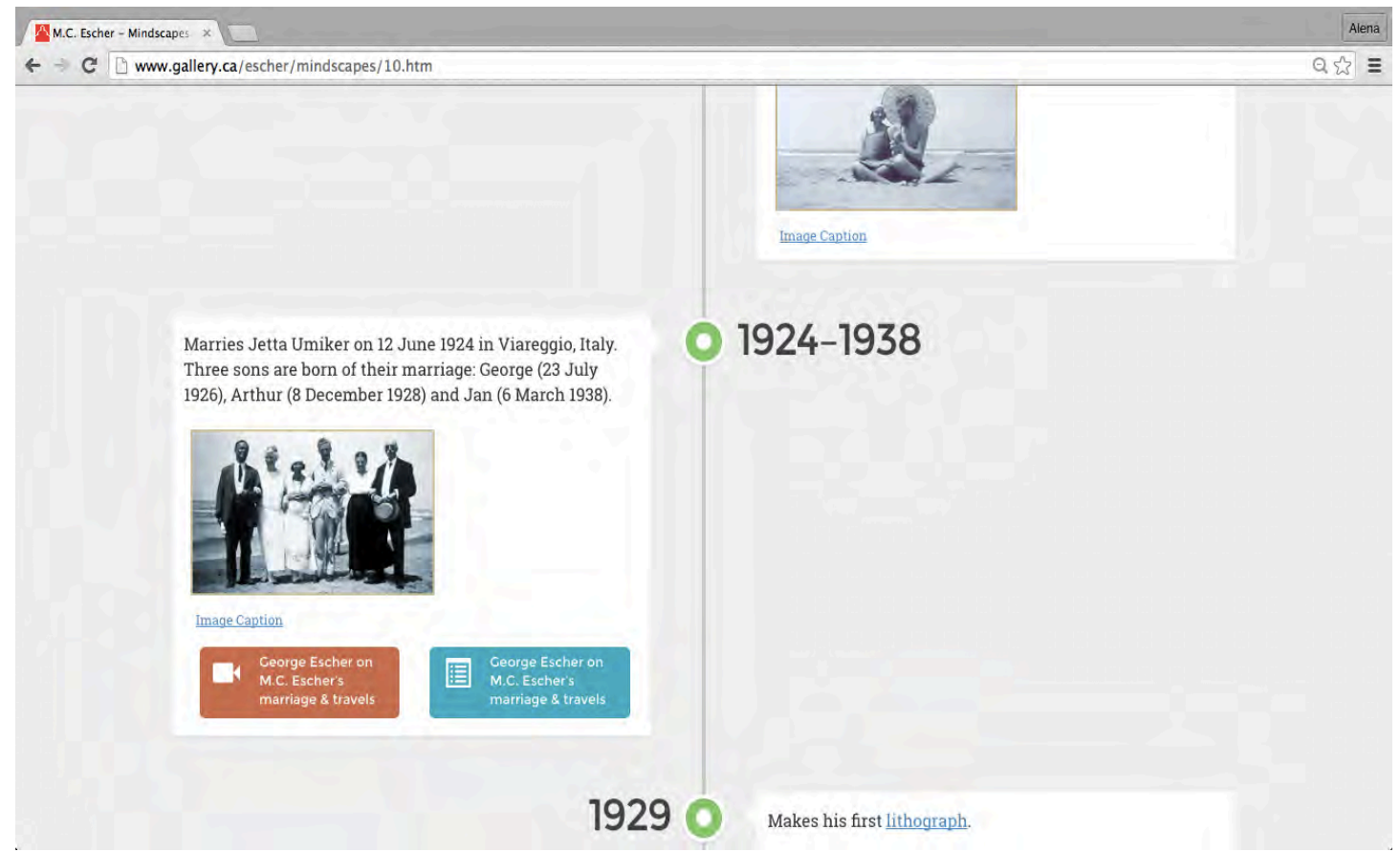

Figura 35 - Captura de imagem da exposição virtual M. C. Escher - Mindscapes, mostrando um fragmento de Chronology, na qual consta imagem acompanhada por arquivo de vídeo e arquivo de texto, ambos depoimentos do filho do artista

Fonte: disponivel em: <http://www.gallery.ca/escher/mindscapes/10.htm>. Acesso em: 26 jun. 2016

Na opção Themes, o visitante tem como opção de acesso três temas importantes da produção de Escher: Italian Landscapes, Art and Geometry e Art and Perception. Antes de selecionar qual tema será visualizado, pode-se ler o pequeno texto introdutório, nessa mesma página, assim como uma citação do próprio artista (figura 36). 


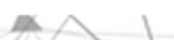

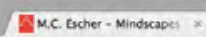

$\leftarrow \rightarrow C D$ www.gallery.ca/escher/mindscapes/20.htrm

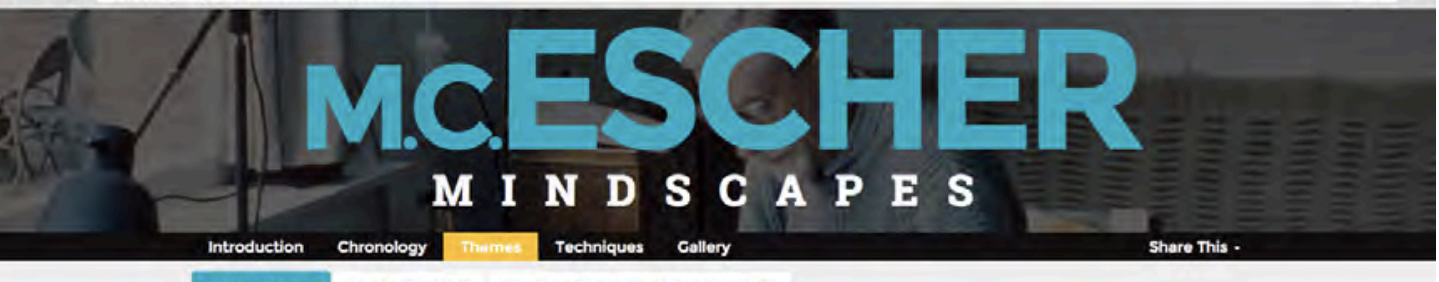

Fechersthement

Escher's Themes

Interestingly enough, Escher's name is mentioned more often in introductory mathematics and psychology texts than in introductions to art history. Escher did not conside aesthetic value as an end in itself, but rather as the outcome

of meticulous cutting or engraving of wood and a rigorous application of his far-reaching studies in geometry and perception.

Mathematics and geometry teachers often use his prints to demonstrate to their students how science can be a source of poetry and beauty. Peychology textbooks present them as proof of the claim

Whoever wants to portray something that does not exist has to obey certain rules. Those rules are more or less the same as for the teller of fairy tales he has to apply the function of contrasts; he has to cause a shock. That is why such a game can be played and understood only by those who are prepared to penetrate the surface, those who agree to use their brains just as in the solving of a riddle. It is thus not a motter for the senses but ratheracerebralmatter Profintis not at all hecessary but ain hrotente

Figura 36 - Captura de imagem da exposição virtual M. C. Escher-Mindscapes, mostrando a página principal de Themes, na qual se opta por conhecer um dos conjuntos temáticos organizados com base na obra de Escher

Fonte: disponivel em: <http://www.gallery.ca/escher/mindscapes/20.htm>. Acesso em: 25 jun. 2016

Em Italian Landscapes, conforme está na introdução da página, o visitante tem informações e visualiza alguns trabalhos da primeira parte da vida do artista, instaurada com base nas paisagens da Itália, onde ele viveu de 1923 a 1935. Juntamente com a parte introdutória, há a imagem de um de seus trabalhos dessa fase, a qual pode ser ampliada, assim como arquivos de texto e vídeo com depoimentos de George Escher acerca do interesse do artista pelas paisagens italianas (figura 37). 

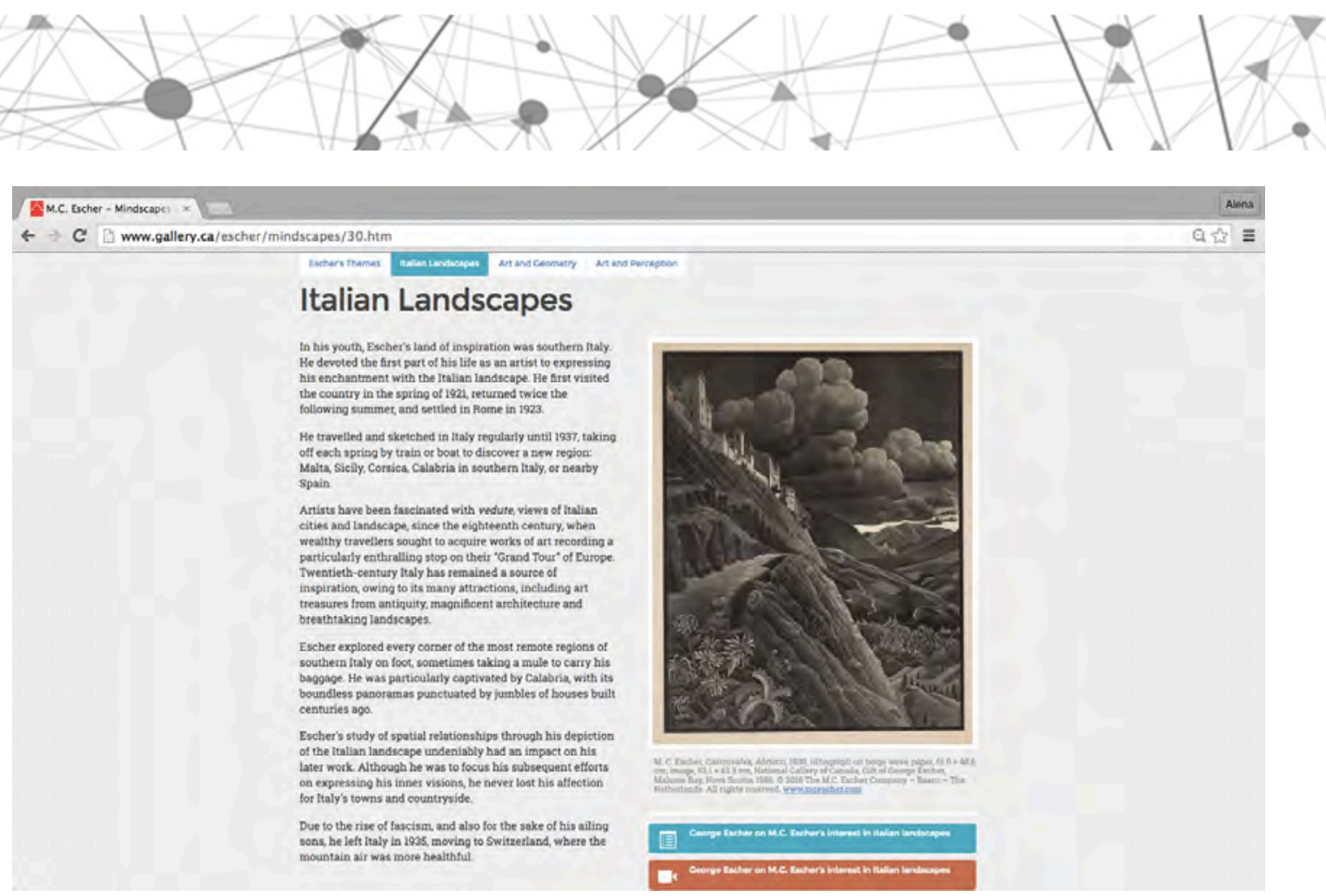

Figura 37 - Captura de imagem da exposição virtual M. C. Escher - Mindscapes, com a página Italian Landscapes, seção de Themes, na qual constam texto introdutório, uma imagem de um de seus trabalhos e a opção entre texto e vídeo de um depoimento do filho de Escher

0 tema Italian Landscapes é dividido em duas seções, separadas apenas por uma linha branca, leve e discreta. A primeira delas é intitulada de Calabria, e, assim como consta do texto explicativo dessa seção, trata da produção do artista fruto de uma viagem feita à Calábria, Itália, em 1930, com mais três amigos. Além de três imagem de obras produzidas nesse período, as quais podem ser ampliadas, há uma citação do diretor da M. C. Escher Company, Mark Veldhuysen, que em 1989 realizou uma viagem para aquela cidade em busca dos temas de Escher. Embora em tamanho reduzido, tem-se nessa página uma das fotos captadas por Veldhuysen, ao lado do desenho de Escher, com base nessa mesma paisagem, o que permite com que o visitante faça uma comparação (figura 38). 

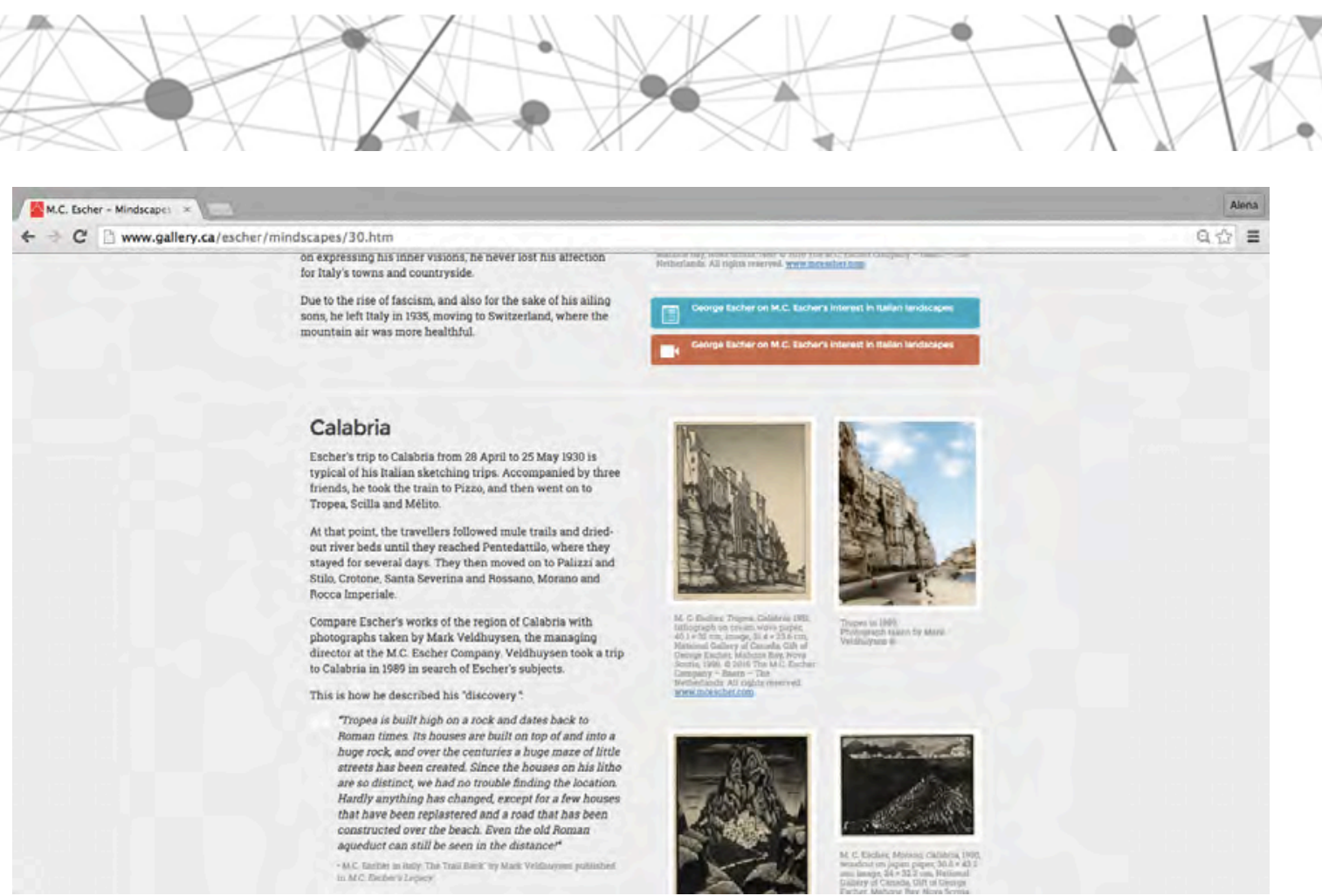

Figura 38 - Captura de imagem da exposição virtual M. C. Escher - Mindscapes, com a seção Calabria, na página Italian Landscapes. Vê-se a linha branca, a qual marca a divisão entre a introdução da seção, o texto explicativo e a citação de Veldhuysen, e também o desenho de Escher ao lado da foto tirada pelo diretor

Fonte: disponivel em: <http://www.gallery.ca/escher/mindscapes/30.htm>. Acesso em: 26 jun. 2016

A seção seguinte, ainda em Italian Landscapes, também separada da seção anterior por uma linha branca, é a Real and Imaginary Landscapes. Conforme sugere o título, trata da produção do artista que não representa fielmente as cenas do mundo, mas que toma emprestado alguns elementos na combinação do real e do imaginário. Também faz parte dessa seção um texto explicativo, uma citação de Veldhuysen, duas imagens de trabalhos do artista e uma foto de Veldhuysen captada da mesma paisagem representada por Escher, cuja comparação evidencia a relação entre o real e o imaginário nos desenhos do artista.

0 segundo tema que compõe Themes é Art and Geometry. Ele já começa com uma citação do artista assegurando que não são apenas os matemáticos que se detêm ao estudo dos caleidociclos. Em seguida, há o texto explicativo e um depoimento de George Escher, que pode ser acessado em formato de texto ou de vídeo, sobre o interesse do artista pela geometria. Igualmente, faz parte da introdução desse tema a imagem de um dos desenhos de Escher, que, assim como todas as imagens que fazem parte da exposição, também pode ser ampliada.

Observa-se que inúmeras das imagens que integram a mostra, como é o caso dessa, fazem parte do site oficial do artista, que pode ser acessado por meio do link que acompanha essas imagens. 
Esse tema é dividido em três seções, também separadas visualmente por uma fina linha branca. A primeira delas é The Moorish and Crystallographer's influence, composta por um texto explicativo e por duas imagens, a respeito da influência dos desenhos mouriscos e da cristalografia em sua produção. A segunda é The Poetry of Symmetry. Regular Division of the Plane. Essa seção é formada por três imagens que são acompanhadas por vídeos de animações inspiradas no esquema geométrico de Escher e que funcionam como um complemento interessante à visualização dos desenhos, contribuindo para o seu entendimento, na medida em que refazem os passos de construção dos esquemas geométricos do artista (figura 39).

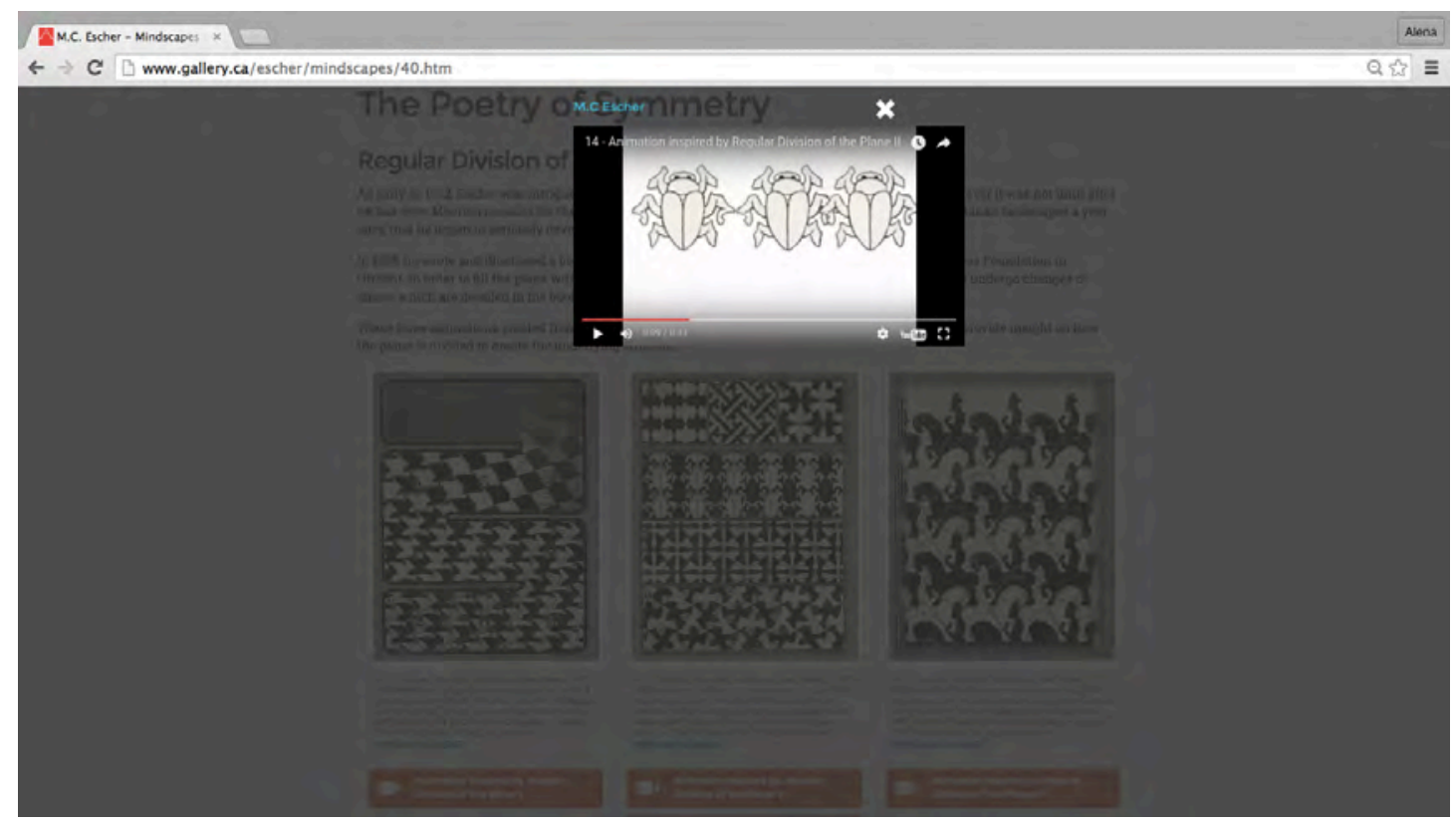

Figura 39 - Captura de imagem da exposição virtual M. C. Escher - Mindscapes, da seção The Poetry of Symmetry. Regular Division of the Plane, no tema Art and Geometry, mostrando um dos vídeos de animação que acompanha a segunda imagem

Fonte: disponível em: <http://www.gallery.ca/escher/mindscapes/40.htm>. acesso em: 15 set. 2016

A terceira seção é H. S. M. Coxeter's System, a qual trata das mudanças que a produção de Escher sofreu ao ter contato com o artigo sobre geometria hiperbólica do matemático canadense H. S. M. Coxeter, a partir de quando o artista começou a explorar a lógica de infinito na construção de seus desenhos. Além do texto explicativo, essa seção é composta pela imagem de uma obra representativa dessa fase.

0 terceiro tema disponível em Themes é Art and Perception. Assim como nos demais temas, logo no início da página, há um texto explicativo com as principais

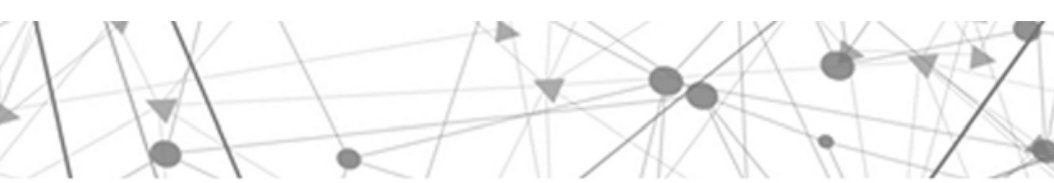


características dessa fase do artista, além de uma citação dele. Dois de seus mais conhecidos trabalhos aparecem representados nas imagens já nesse primeiro momento, e uma animação explora um deles, a obra Relativity, de 1953.

Tal qual nos demais, esse tema é dividido em mais duas seções demarcadas por uma linha branca, são elas: A Meeting of Mathematical Minds e The Visible World as Construct. Na primeira, que fala da relação do artista com a matemática na exploração de objetos impossíveis, além de duas citações do artista, aparecem imagens de três de seus trabalhos. A segunda discute a importância do campo da psicologia para o artista, tendo em vista que, conforme o texto explicativo, a percepção humana está no centro das ilusões ópticas. Além de uma citação do artista, constam aqui duas interpretações da obra de Escher em formato de animação realizadas por Claude Lamontagne, professor na Escola de Psicologia da Universidade de Ottawa, Canadá.

Dando continuidade ao trajeto pela exposição, seguindo a ordem sugerida pelo desenho do site, tem-se a opção Techniques. Aqui há um texto sobre as técnicas utilizadas por Escher no desenvolvimento de sua produção, exaltando o artista como um gravador. Além de uma citação dele, são também disponibilizados um arquivo de vídeo mostrando Escher trabalhando em sua última obra e o depoimento de seu filho, em formato de vídeo e de texto, no qual descreve o estúdio de Escher em Roma, Itália. Ainda em Techniques, o visitante pode acessar mais três opções, cada qual explicando uma das principais técnicas utilizadas pelo artista: Mezzotint, Relief Technique e Lithography. Em cada um desses links, é disponibilizado um texto sobre cada técnica, acompanhado por imagens. No caso de Relief Technique, constam também um arquivo de vídeo contendo explicação de George Escher acerca da técnica usada pelo pai e um arquivo de texto no qual explicita um dos trabalhos.

Por último, em Gallery, podem ser visualizados inúmeros trabalhos do artista organizados por períodos de tempo. Se o visitante preferir, pode também clicar em Show all, para visualizar, em mosaico, todos os trabalhos que integram a galeria. Os dados técnicos de cada trabalho não aparecem com as imagens; para visualizá-los, basta clicar em Image Caption, abaixo de cada uma delas, que uma pequena janelinha se abre contendo as informações (figura 40). 

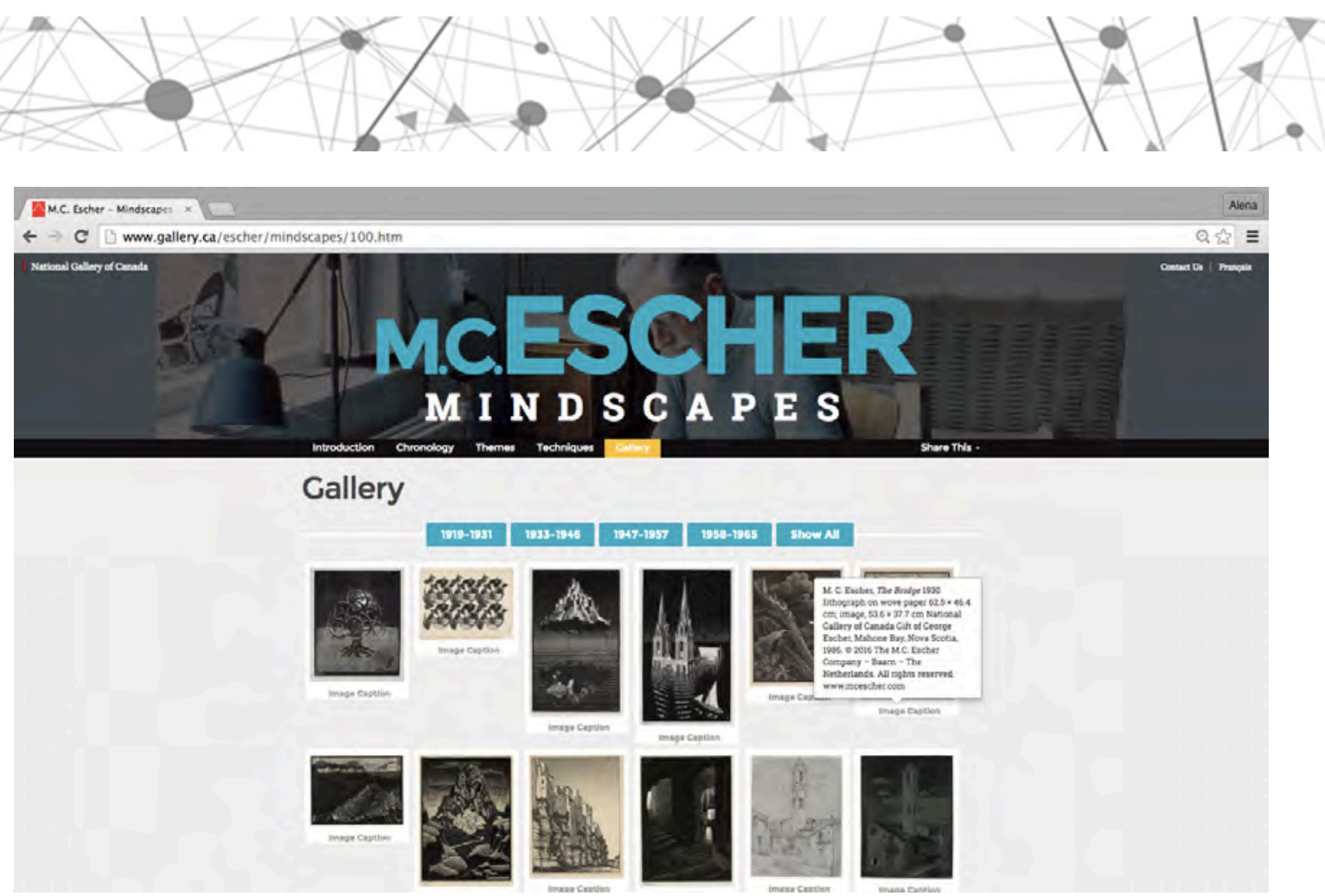

Figura 40 - Captura de imagem da exposição virtual M. C. Escher-Mindscapes, com a opção Gallery, na qual todas as imagens são visualizadas lado a lado com um clique em Show all, e a informação da imagem escolhida é disponibilizada em Image Caption

Fonte: disponivel em: <http://www.gallery.ca/escher/mindscapes/100.htm>. Acesso em: 27 jul. 2016

Observa-se que essa exposição faz uso da estrutura não linear da web, na medida em que trabalha com hiperlinks, assim como utiliza sua natureza hipermidiática na disponibilização de arquivos de vídeo e texto complementares. A forma como ela está organizada faz com que o visitante não se perca nessa estrutura, tendo em vista que todos os itens de acesso sempre podem ser visualizados no topo da página, havendo destaque na opção que está sendo visualizada no momento. Vê-se ainda, agora como pontos negativos, o fato de a exposição não fornecer ferramentas participativas para o visitante nem permitir que as imagens sejam vistas em detalhes, o que enriqueceria sobremaneira a experiência, dada a natureza minuciosa da produção de Escher. Embora não haja espaço de participação para o visitante, este pode compartilhar a exposição virtual visitada nas redes sociais, com o clique em Share This.

Conforme já dito, das sete instituições que, além do ambiente virtual, possuem espaço físico, essas quatro exposições virtuais analisadas (uma delas, a de Portinari, no capítulo 1) fizeram delas uma forma de colocar o seu acervo em exercício. As outras três instituições que também realizam exposições por meio de sua experiência virtual não o fazem por seu acervo, ou então apenas expõem a web art. 


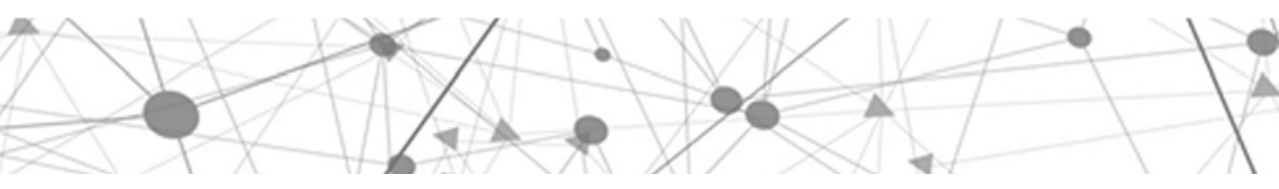

0 Museu de Arte Moderna Grand-Duc Jean, por exemplo, possui sede física, entretanto as exposições virtuais da página intitulada iGallery são apenas de web art. Já o Instituto Itaú Cultural disponibiliza duas exposições virtuais de artistas brasileiros, uma de Lygia Clark (analisada no capítulo 1) e uma de Waldemar Cordeiro, mas com base em peças digitalizadas de diferentes acervos. A instituição Coleção Frick ${ }^{110}$, em Nova York, por sua vez, tem apenas uma exposição virtual, intitulada Bruegel the Elder, feita em parceria com o Instituto Cultural do Google, e consiste na exploração de um único trabalho, a pintura The Three Soldiers, 1568, de Bruegel. Conforme o visitante avança pelo clique na seta, detalhes da pintura, acompanhados por textos explicativos, são enfatizados, de forma a percorrer toda a superfície da obra. Caso o visitante tenha interesse em se aprofundar, pode acessar o link para a página do Google Art Project, em que constam três exposições virtuais formadas por obras do artista por intermédio de diferentes acervos.

Pode-se afirmar que, mediante a curadoria, são colocados em discussão possíveis sentidos construídos pelo curador com base nos trabalhos em exposição, tanto individualmente como em conjunto, porém desde que seja dada abertura para que outros novos possam surgir por parte do visitante. Diz-se sobre o contexto do ambiente virtual em rede:

As curatorial practices evolve, curators are providing resources to enable audiences to engage in cocreation of content. This does not mean that the primary role of the curator as agent between technology and content, patrimony and program, will cease. Indeed, this role could be strengthened by an audience-focused approach as it will move beyond inclusive policy decisions and provide models of collaboration which allow multiple points of view to coexist. When communities engage with cultural institutions to preserve cultural identity, each party can contribute to the sharing of cultural knowledge and distribution of this knowledge to a wider audience ${ }^{111}$ (RUSSO; WATKINS, 2007, p. 152153).

\footnotetext{
${ }^{110}$ Mais informações em: <http://www.frick.org/>.

111 “Conforme a prática curatorial se desenvolve, curadores estão provendo recursos para possibilitar o público a engajar-se na cocriação de conteúdo. Isso não significa que o papel primário do curador como agente entre tecnologia e conteúdo, patrimônio e programa, vá cessar. Na verdade, esse papel pode ser reforçado por uma aproximação focada no público, como uma decisão de política inclusiva, provendo modelos de colaboração que permitem que múltiplos pontos de vista coexistam. Quando comunidades se unem a instituições culturais para preservar sua identidade cultural, cada parte pode contribuir partilhando conhecimento cultural e distribuindo esse conhecimento para um público maior" (livre tradução).
} 
Assim, é importante que a exposição ofereça possibilidades para que esses novos sentidos sejam compartilhados e colocados em discussão em um espaço de troca, entre os próprios visitantes e também entre os visitantes e a instituição. Como visto, embora algumas das exposições virtuais analisadas explorem a natureza rizomática e hipermidiática do ambiente virtual em rede, infelizmente em nenhuma delas esse espaço é explorado.

É importante ter em mente que o resultado de uma curadoria é sempre fruto do olhar do curador para aquela determinada produção, seja ela uma exposição individual, seja uma mostra coletiva. Todo trabalho de curadoria implica uma forma pessoal de ver, expressada em uma exposição. A exposição, tal qual dito no capítulo 1, é a principal ferramenta relacional do museu, tendo em vista que é por meio dela que o espectador estabelece contato com a produção artística e cultural e, portanto, toma conhecimento dela, de seu tempo ou de tempos passados.

Conforme pode ser constatado por inúmeras das exposições analisadas neste capítulo, apesar de o foco da maioria não ser a educação e de nenhuma delas falar em curadoria educativa, elas acabam por apresentar, aproximar e por vezes até a ensinar o público a olhar para a arte de seu tempo. Nesse sentido, a exposição pode ser entendida como um dos principais meios de estar com a arte, e o desenho da exposição interfere diretamente na maneira como a relação entre a arte e o espectador é estabelecida. Ela pode tanto aproximar esse espectador quanto o afastar, influenciando positiva ou negativamente essa relação. Como acredita Bini, a curadoria

exige responsabilidades cada vez maiores; o público deve ser visto não como consumidor (da arte moderna) mas como receptor de informação, o curador deve provocar leituras, das mais fáceis para um público leigo até as mais difíceis e deixar claro que essa é uma formulação possível, mas que existem outras (BINI, 2005, p. 98).

Com base nessa lógica, é possível constatar a importância e a responsabilidade da atuação do curador, que, além de expressar um ponto de vista e de problematizar questões instituídas por ele, deve pensar a melhor maneira de fazer com que o espectador não apenas perceba e entenda o que está posto em discussão, mas que vivencie e estabeleça as suas próprias relações com os trabalhos que estão em exposição. Caso contrário, a exposição vai reduzir-se ao 
ponto de vista do curador e não tornará a arte ativa, já que não abrirá espaço para a percepção nem para a construção de conhecimento por parte do público.

Logo, por meio desta tese, mais do que uma forma de ver uma determinada produção, defende-se a curadoria como uma alternativa de problematizar que, aqui, será pensada pela curadoria educativa. Em relação ao termo, Barbosa (2008, p. 30-32) afirma:

Curadoria Educativa não é propriamente preconceituoso, mas é usado para dissimular o preconceito. É só um meio artificial de tentar conferir a mesma importância da educação à curadoria de obras de arte. Para mim, a importância é a mesma, mas não é assim que a elite que comanda os museus pensa [...]. Curadoria Educativa é mais um artifício para nominalmente esconder que devemos tratar em museus de EDUCAÇÃO. Considero o termo curadoria educativa pedante, revelando falta de coragem de se enfrentar o que importa: EDUCAÇÃO. É patética a tentativa de se aliar a um termo de prestígio nos museus para fazer a EDUCAÇÃO ser engolida goela abaixo pelos capitalistas. É tentativa de enganação da EDUCAÇÃO.

Tomando como um desafio a fala de Barbosa (2008), por meio da qual ressalta o preconceito existente em torno do educativo e das propostas de arte/educação, defende-se a utilização do termo curadoria educativa, mas não como uma forma de mascarar uma proposta educativa, e sim como uma maneira de afirmar que a curadoria pode ser pensada e exercitada como um programa educativo. Assim, a curadoria educativa será entendida como aquela que objetiva disponibilizar a arte mediante uma exposição desenhada com o objetivo de colocála em movimento e em discussão, para então promover a construção de conhecimento. A exposição, com base nesse prisma, será encarada como uma experiência, compreendida como "a arte em estado germinal" (DEWEY, 2010, p. 84), e o conhecimento como uma construção de sentidos, o que enriquecerá a existência história do visitante (DEWEY, 2010).

A exposição digital projetada no contexto desta tese está disponível no MAC Schwanke Virtual. 0 joinvilense Luiz Henrique Schwanke foi um dos artistas que representou Santa Catarina nacionalmente no circuito das artes na década de 1980, chegando a participar da Bienal Internacional de São Paulo em 1991. Sua produção, assim como o instituto e o MAC Schwanke Virtual, será apresentada no capítulo 3.

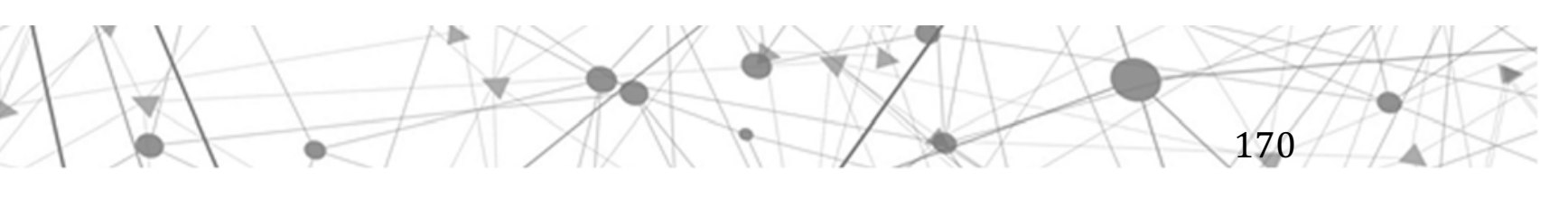




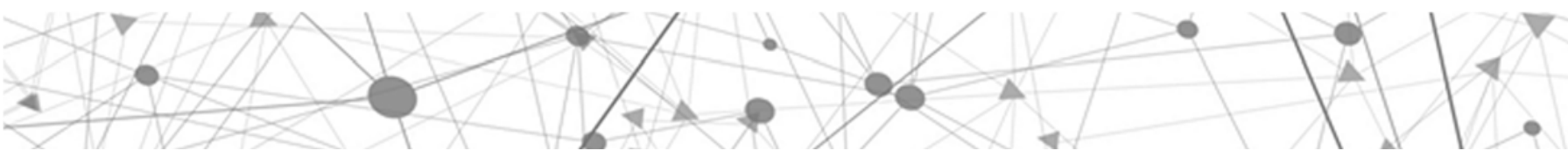

CAPÍTULO 3

\section{A TRAMA POÉTICA DE LUIZ HENRIQUE SCHWANKE}

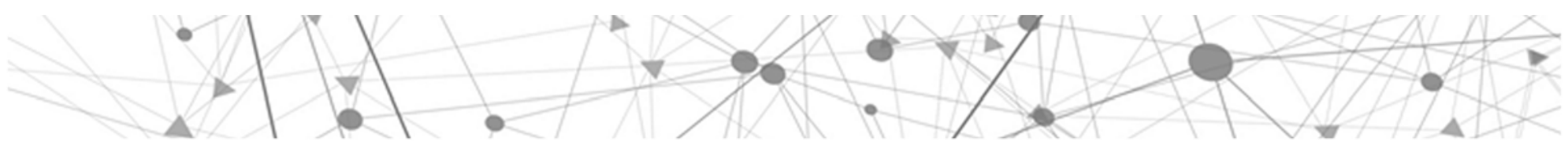




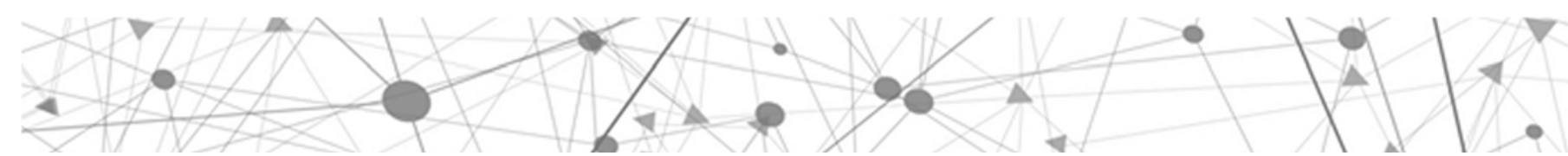

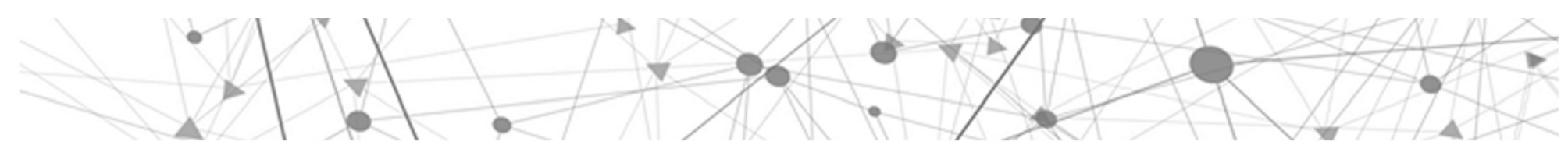




\subsection{Schwanke: arte e vida}

0 objetivo deste capítulo é apresentar, mesmo que de forma resumida, a produção de Luiz Henrique Schwanke. Ressalta-se aqui que o que será tratado está longe de contemplar a sua produção como um todo, mas possibilita se ter uma ideia acerca da riqueza e da complexidade de sua obra, produzida num período de pouco mais de 20 anos.

Joinvilense, Luiz Henrique Schwanke nasceu em 15 de junho de 1951 e faleceu, também em Joinville, em 27 de maio de 1992, aos 40 anos de idade. Apesar de sua passagem por aqui ter sido breve, foi autor de uma produção extensa e intensa, totalizando um conjunto de obras que até hoje não pôde ser contado, já que se encontra espalhado por museus e coleções particulares, somando mais de cinco mil peças. Só em artes visuais, são desenhos, pinturas, esculturas, colagens, objetos e instalações, o que evidencia a versatilidade de seu comportamento artístico, assim como a amplitude de sua pesquisa plástica. Contudo, apesar de vivenciar inúmeras linguagens e técnicas distintas, pode-se dizer que as suas diferentes seriações de trabalho dialogam entre si por, principalmente, três fios condutores: a luz, o gesto e a apropriação da história da arte, com base em discussões de momentos históricos variados, frutos do desdobramento do pensamento clássico.

0 interesse pela história da arte já apareceu na infância, sobretudo no que se refere à Grécia Antiga. Sua irmã, Regina Schwanke Schroeder (2016), relata que os deuses gregos, mas também personagens históricas, tal como a Cleópatra, estavam presentes nas brincadeiras propostas por Schwanke. Quando tinha cerca de 15 anos, o artista escreveu histórias, contos, crônicas e peças de teatro usando como meio cadernos e uma máquina de escrever.

No intitulado Livro de contos, composto por sete contos criados pelo artista, o último deles, "Confusão de amor dos deuses gregos", permite com que esse interesse pela Grécia Antiga seja comprovado. Nesse texto, em uma conversa com Zeus, Schwanke conta a história de vários deuses, a qual termina quando ganha a permissão de Zeus para escrever a sua própria história. Schwanke responde a Zeus que não criará uma história, mas que escreverá apenas sobre aquilo que viu. No processo de desenvolvimento do texto, Schwanke realizou três ilustrações. A 


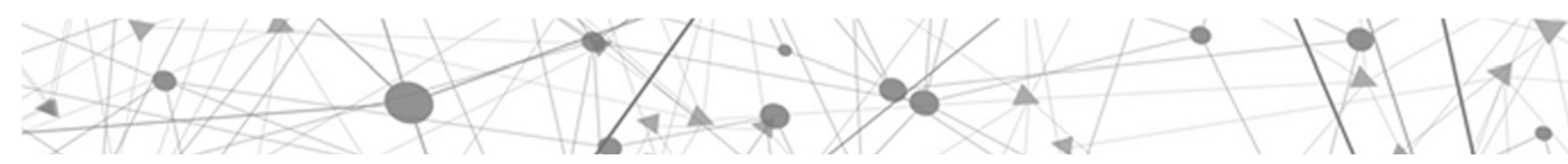

primeira é uma tabela do alfabeto grego; a segunda, o mapa da Grécia Antiga; e a terceira, o Partenon (figura 41).

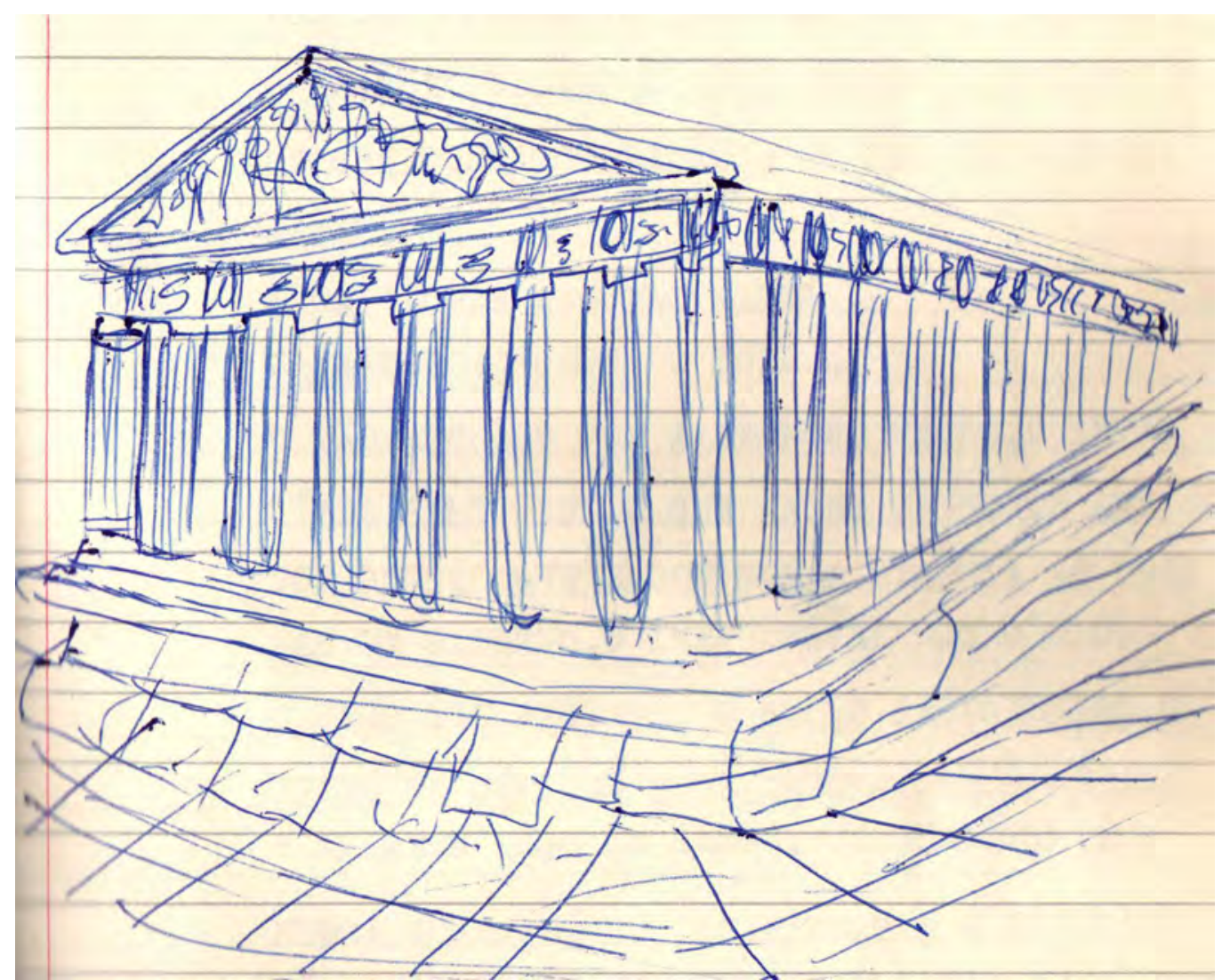

Figura 41 -llustração à caneta como parte do conto "Confusão de amor dos deuses gregos" (detalhe), de Luiz Henrique Schwanke, sem data Fonte: acervo da família Schwanke

Já em “Desespero", primeiro conto desse mesmo caderno, Schwanke conta o drama existencial de um médico, Cícero Derey, que assassina uma moça. $\mathrm{Na}$ história, tal moça é chamada de "moça do papel", pelo fato de a personagem do médico viver seu drama mediante a visualização e manipulação de uma foto da moça. Na ilustração, vemos uma mão sobre a imagem de uma mulher, de forma que o lado superior direito se encontra rasgado (figura 42). 


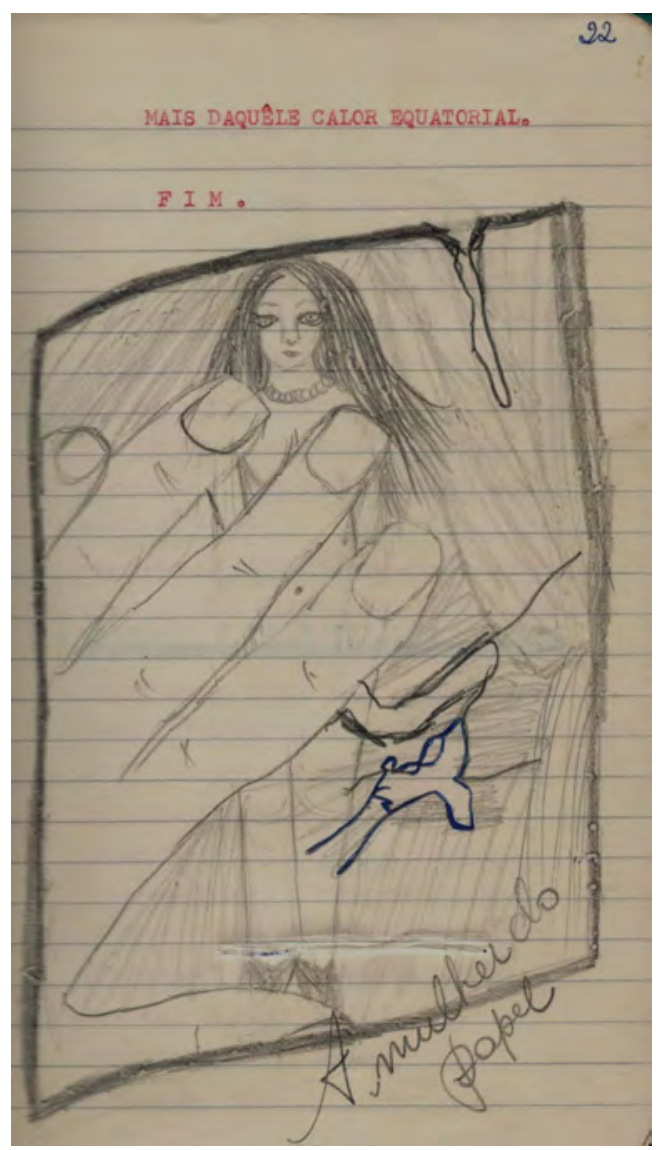

Figura 42 - Ilustração à caneta como parte da história "Desespero", de Luiz Henrique Schwanke, sem data

Fonte: acervo da família Schwanke

É interessante observar que em outra história, escrita pelo artista em outro livro, intitulado Sou só Cândida, e tu?, Schwanke também realiza uma ilustração, na qual consta a figura de uma mulher e de uma mão agindo sobre ela (figura 43). 


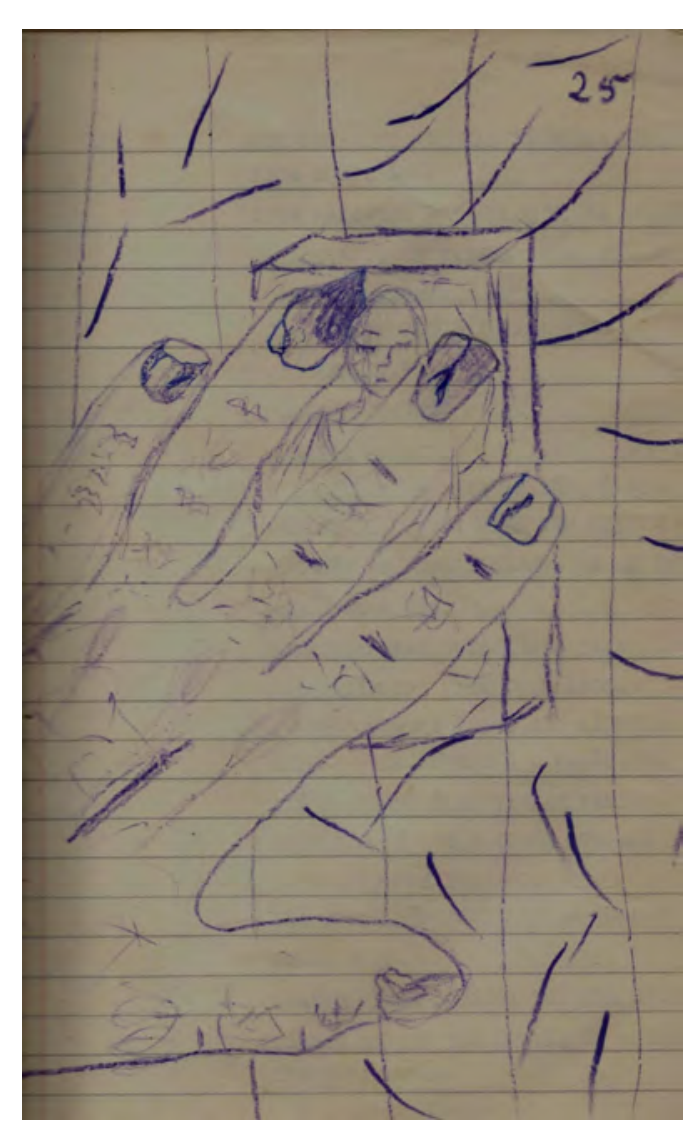

Figura 43 - Ilustração à caneta como parte da história Sou só Cândida, e tu?, de Luiz Henrique Schwanke, sem data.

Fonte: acervo da família Schwanke

Tanto a figura 42 quanto a figura 43 contemplam a figura da mão, que age sobre uma figura humana feminina. Embora se trate de uma produção infantil, percebe-se que a personagem que age, nas duas situações, é representada por uma mão sobre o alvo de sua ação. E a figura da mão, às vezes a do dedo, aparece nesse sentido também anos mais tarde, em diversas outras produções ao longo da trajetória artística de Schwanke.

0 artista começou a sua produção em pintura por intermédio da vertente naïfy, fruto da influência de pintores locais, na representação de paisagens catarinenses pela técnica do pontilhismo (figura 44). Com essa produção inicial, promoveu exposições e vendeu quase tudo o que produziu. 

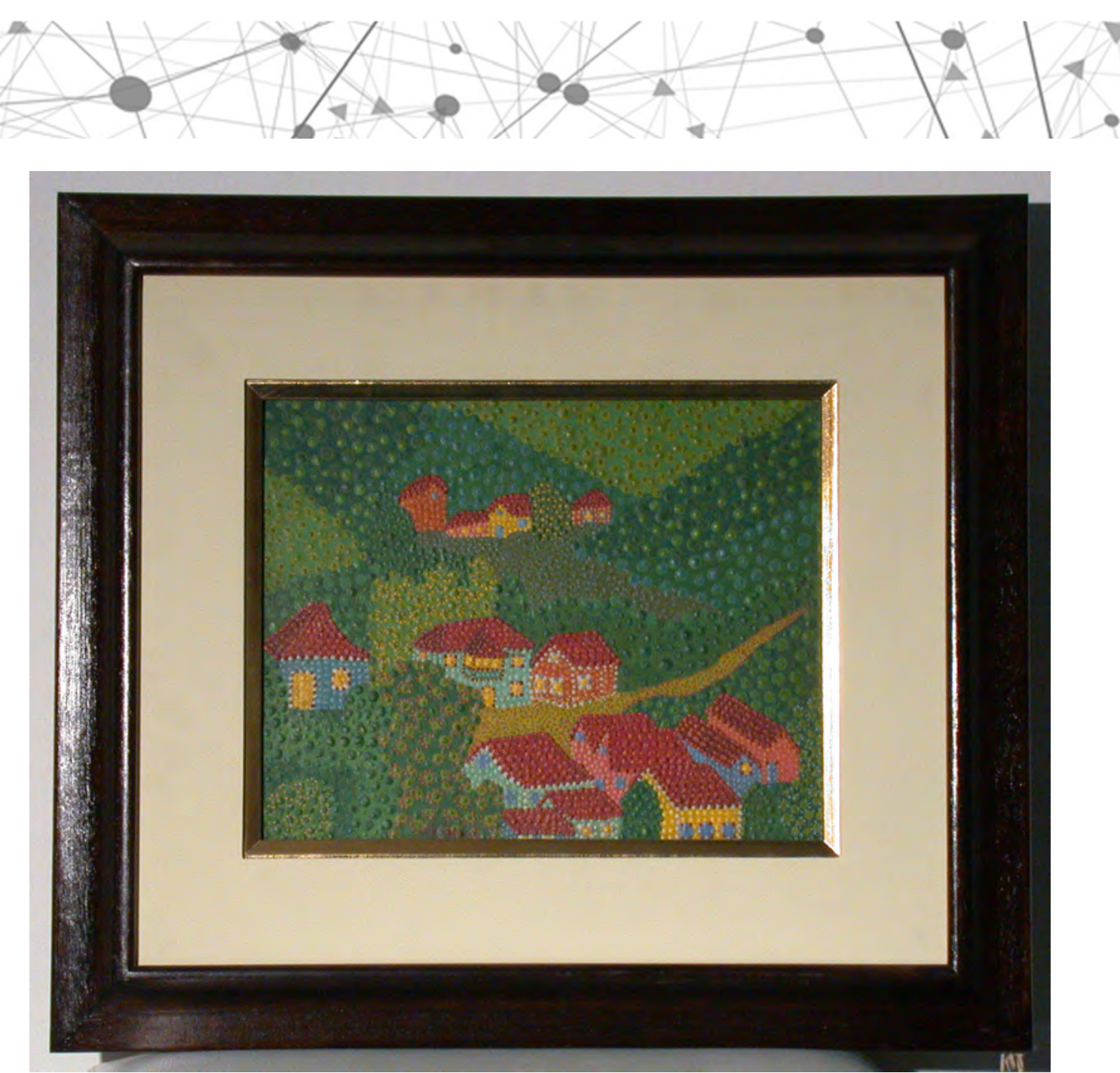

Figura 44 - Paisagem de Luiz Alves (SC), Luiz Henrique Schwanke, 1972. Pintura, óleo sobre tela. $23,4 \times 30 \mathrm{~cm}$..

Fonte: acervo do Museu Metropolitano de Arte de Curitiba (MuMa)

Mudou-se para Curitiba e, em 1970, ingressou no curso de Comunicação Social na Universidade Federal do Paraná (UFPR), onde iniciou seus estudos em história da arte com Adalice Araújo ${ }^{112}$. Por esse contato, pode-se afirmar que aprofundou a sua pesquisa plástica, assim como teórica. Em entrevista feita por Adalice Araújo (1986), Schwanke fala sobre o começo de sua trajetória (anexo 1):

Eu tinha eu acho que dezenove anos e me disseram assim em Joinville, eu tenho um monte de trabalhos, eu vou fazer uma exposição, quero fazer uma exposição. Eu já tinha tirado quando era criança um prêmio na Folha de S.Paulo de desenho [...]. Tirei também o primeiro prêmio de desenho infantil em Florianópolis e depois surgiu um movimento em Joinville com Antonio Mir, Delai etc. Todo mundo expunha todo ano na Exposição das Flores, eu disse eu vou fazer, então fiz um monte de trabalhos de diversas linhas e o pessoal disse assim: Ah! Você podia caminhar para esse

\footnotetext{
${ }^{112}$ Adalice Araújo (1931-2012) foi artista, escritora, poeta, historiadora e crítica de arte brasileira. Recebeu o Prêmio Mário de Andrade (2003), pela Associação Brasileira de Críticos de Arte, e foi ganhadora do Prêmio Gonzaga Duque (2007).
} 
estilo primitivo. Nunca tinha ouvido falar em estilo, não sabia que as pessoas deviam pintar num mesmo estilo, não tinha visto uma exposição, nada. Passei a pintar e desenvolvi um estilo assim que me foi sugerido. Daí eu via coisas primitivas, trabalhei em cima daquilo, afinal ficou uma coisa rococó, decorativa e me davam dinheiro grande. Eu fazia um teatro assim de ultravanguarda paralelo e tal, e depois vi que não aguentava mais, que não dava mais para continuar pintando aquilo.

Também em Curitiba, e de forma paralela ao curso de graduação, Schwanke começou um percurso no teatro e passou a integrar o Grupo Momento, sob a direção de Oraci Gemba, na montagem de peças importantes. É curioso notar que, entre elas, está a tragédia Electra, estreada em 1973 no Centro Cultural Teatro Guaíra, em Curitiba, na qual o joinvilense atuou como preceptor e autor do cenário. Trata-se de uma peça escrita pelo dramaturgo grego Sófocles, no século $V$ a.C., o que revela que o interesse e as pesquisas de Schwanke acerca da Grécia Antiga também se estenderam ao universo da dramaturgia. Como ator, participou de Antígona, também grega, da Via Crucis, de Maria Bueno, entre outras montagens, todas realizadas no início dos anos 1970.

Em 1974, formou-se na faculdade e de 1977 a 1980 trabalhou como publicitário, ainda na cidade de Curitiba, onde residiu até 1984. Afirma:

Trabalhei uns três anos, acho, em publicidade. Inclusive a publicidade naquela época foi até boa porque aprendia muitas técnicas que eu não tinha porque não fiz escola de belas artes e a publicidade me ensinou a ver um monte de técnicas (ARAÚJO, 1986).

Ainda conforme suas palavras, "fiz cenários de teatro e tudo, mas resolvi ficar com a pintura. Talvez até como ator eu tivesse tido um campo mais fácil, não sei" (ARAÚJO, 1986). Assim sendo, Schwanke mergulhou de cabeça nas artes visuais.

Schwanke muito escreveu, tanto cartas endereçadas a críticos de arte e curadores como também reflexões a respeito de seus próprios trabalhos. Além de profundo conhecimento da história da arte, seus escritos revelam não só o interesse pela luz, imaterial, como o interesse pelo plástico, matéria. A antinomia é uma constante em sua produção: presença e ausência, real e virtual, verso e anverso, desejo e contenção, sagrado e profano, luz e sombra. Artista e 
pesquisador erudito, também aparecem em seus textos referências e nomes de artistas, escritores e filósofos, tais como Caravaggio, Guido Reni, Antonello da Messina, Carl Andre, Jeff Koons, Dan Flavin, Ezra Pound, Julio Cortazár, Martin Heidegger e Gaston Bachelar, assim como constam referências ao barroco, ao neoplasticismo, à pop arte, à arte povera, ao minimalismo, a land art, aos acionistas de Viena, ao novo realismo e ao concretismo latino-americano.

Entre as suas primeiras produções dos anos de 1970, está um projeto de esculturas concebido para um concurso promovido por uma empresa de Joinville, a Tupy Fundições. 0 trabalho consistia na construção de um monumento formado por 120 colunas de aço inoxidável, de 1,70 $\mathrm{m} \times 3 \mathrm{~m}$ de altura, dispostas dentro de um espelho d'água, o qual seria construído dentro do parque industrial daquela empresa (figura 45). Embora tenha tirado o primeiro lugar no concurso e sido premiado, o projeto nunca foi executado. Contudo percebe-se que já no início de sua trajetória como artista visual Schwanke explorou a coluna clássica, monumento pelo qual já tinha interesse na infância e que só surgiu novamente em sua produção no fim da década de 1980. 


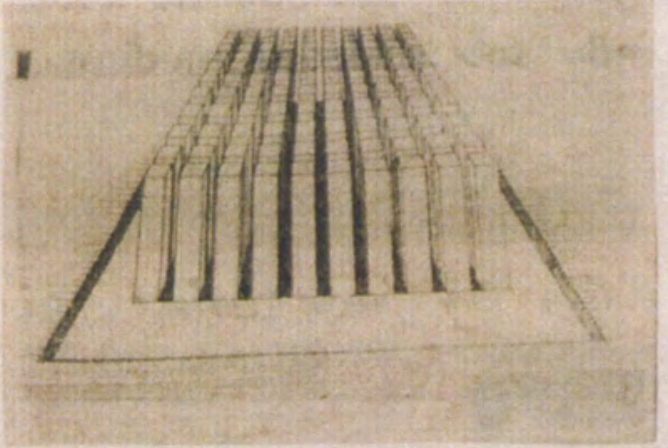

Figura 45 - Projeto realizado por Schwanke para o concurso de esculturas da Tupy Fundições, Joinville, 1976

Fonte: acervo da família Schwanke

Ao ter contato com a história da arte na graduação, interessou-se logo de início pelo elemento luz, principalmente por conta da obra de Caravaggio, e pela forma como tal elemento é trabalhado, tanto pelo último como por diferentes artistas e em períodos distintos. Interessou-se pelo neoplasticismo de Mondrian, assim como também por Andy Warhol e pelo resultado das técnicas de reprodução.

Os gestos de repetição e seriação empregados pelo artista norte-americano também seriam uma constante em sua produção. Esses interesses e gestos, apropriados, já estão presentes em seus trabalhos produzidos no fim dos anos

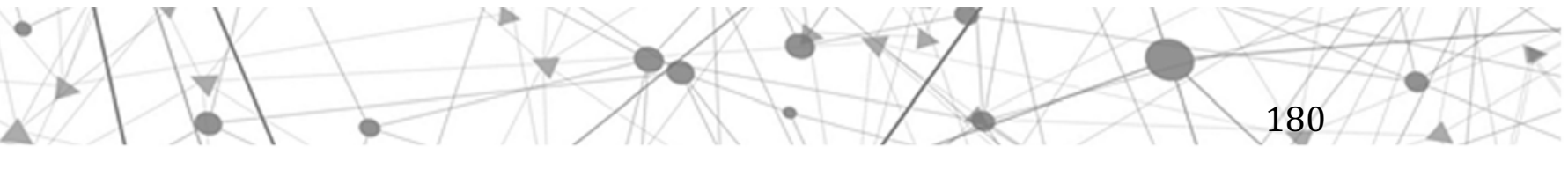




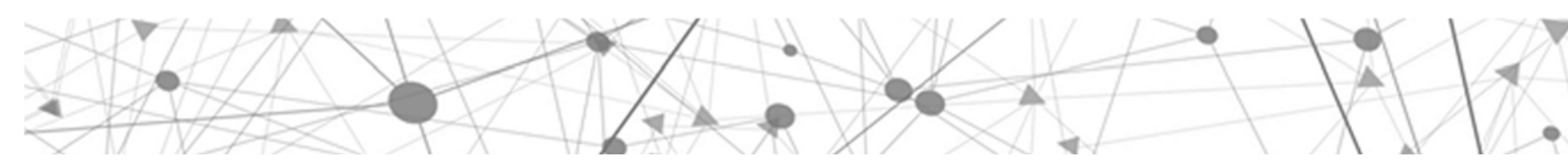

1970 e permeariam toda a sua trajetória, por meio da qual discute a história da arte por um olhar contemporâneo provocado no espectador no mesmo sentido empregado por Agambem (209, p. 69): “A contemporaneidade se inscreve no presente assinalando-o antes de tudo como arcaico, e somente quem percebe no mais moderno e recente os índices e as assinaturas do arcaico pode dele ser contemporâneo".

Como exemplo, pode-se tomar o trabalho Delimitação do espaço, de 1978 (figura 46). Em um contexto no qual a decalcomania estava na moda, Schwanke construiu um desenho, limpo e objetivo, por uma linha formada pela seriação do decalque, representando a figura de uma rosa. A linha desenhada pelo artista, mediante a apropriação de uma imagem fruto da reprodução industrial, provoca 0 espectador, que mentalmente se sente impelido a completar o desenho ali iniciado.

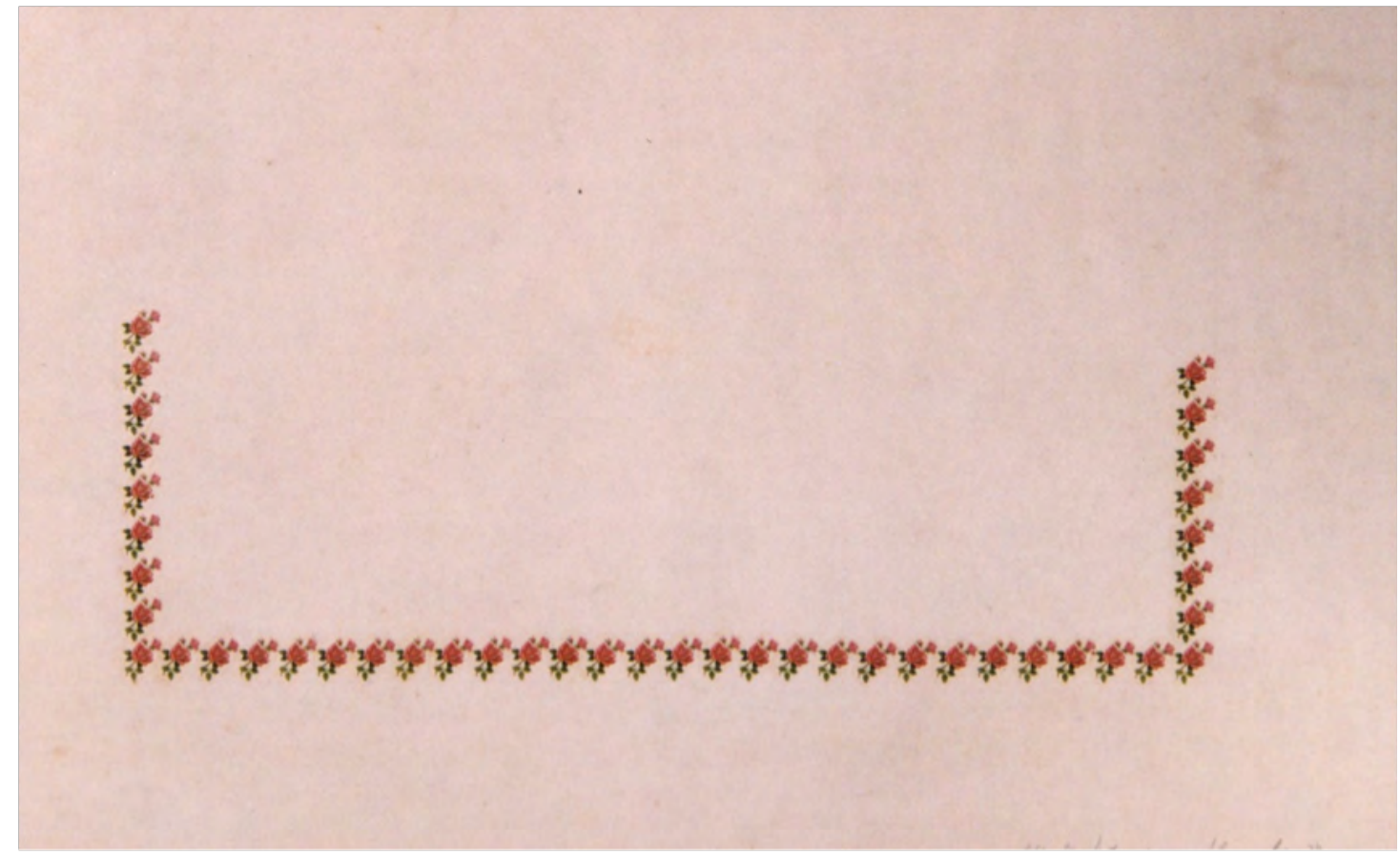

Figura 46 - Delimitação do espaço, 1978. Decalcomania sobre papel. $70 \mathrm{~cm} \times 50 \mathrm{~cm}$ Fonte: foto de Rui Arsego. Acervo da família Schwanke

Conforme escreve Schwanke (1992) (anexo 2),

A linha caminha procurando no papel um lugar certo para se situar, como se tivesse um mapa nas mãos. Em relação ao receptor, no plano metal, a forma adquirida pelo desenho passa à condição única de referencia. A partir daí o espectador inicia o processo próprio de desenvolvimento da obra. (A referência é semelhante ao método de apresentação desenvolvido por Warhol

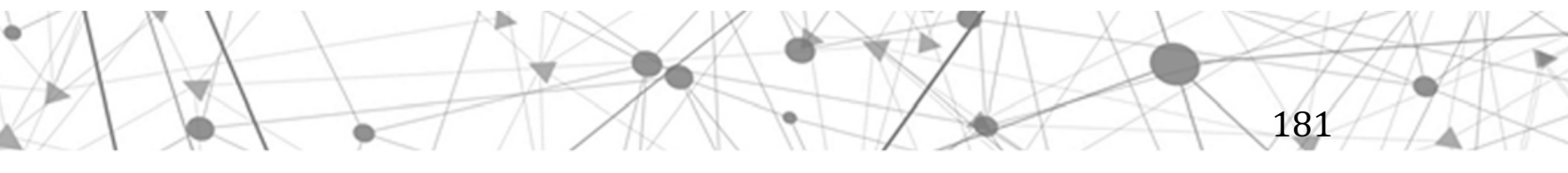


em do it yourself, mas o desenvolvimento da proposta se desemparelha de Warhol justamente no momento em que o espectador passa a fazer a obra e não somente contemplá-la.

Por meio da série Do it yourself ${ }^{13}$, Andy Warhol iniciou uma composição, deixando-a incompleta, e numerou o restante para que o espectador a "finalizasse" (figura 47). Observa-se também que, mesmo que de forma virtual (no sentido de potência, segundo Lévy, 2011), o gesto de realizar o desenho é colocado em destaque, já que, mesmo que não haja essa possibilidade, o espectador, quando diante dos trabalhos, seja do de Warhol, seja do de Schwanke, sente-se provocado a realizar aquela ação, em Warhol fisicamente, em Schwanke mentalmente.

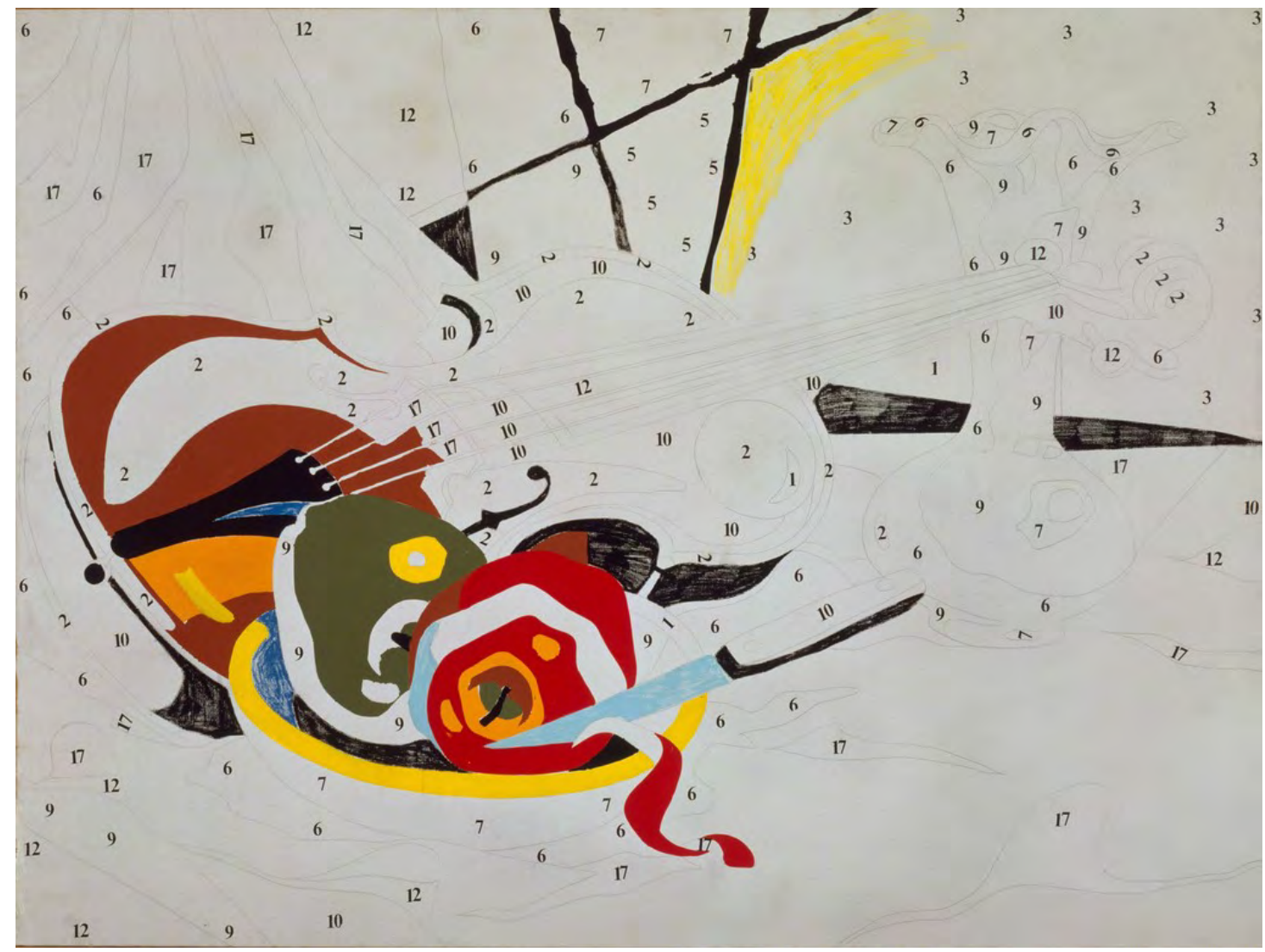

Figura 47 - Do it Yourself (Violin), Andy Warhol, 1962. Tinta sintética sobre tela. $137,2 \mathrm{~cm} \times$ $182,9 \mathrm{~cm}$

Fonte: disponivel em: <https://www.artsy.net/artwork/andy-warhol-do-it-yourself-violin>. Acesso em: 1.. jul. 2016

Outra seriação produzida no fim dos anos 1970 que explora o gesto, mas também envolve a apropriação da história da arte, o interesse do artista pela luz e

\footnotetext{
${ }^{113}$ Esse trabalho integrou a exposição Unfinished: thoughts left visible, realizada no Museu Metropolitano de Arte, Nova York, Estados Unidos.
} 
uma discussão acerca das técnicas de reprodução, é a Série Sinistra Heliográfica. Esse conjunto de trabalhos é resultado da apropriação de imagens de pinturas clássicas, do renascimento e do barroco. Schwanke tirava cópias em acetato das imagens escolhidas, invertia-as e tirava novas cópias usando a técnica da heliografia, por meio da qual nomeou a série. É interessante observar que o termo que denomina essa técnica, criada por Joseph-Nicéphore Niépce, tem origem grega e significa gravar com sol, e é o sol o astro responsável pela luz.

Pode-se então notar a profundidade da pesquisa do artista acerca da luz e o cuidado com as minúcias na exploração desse elemento. Como resultado desse procedimento, há a obtenção de uma cópia invertida do trabalho apropriado, a qual denomina de virtual. Aquele que não conhece os trabalhos originais dos quais as imagens foram apropriadas por Schwanke não vai se dar conta de que elas estão invertidas, perdendo a referência do original, já que a nova imagem passa a ser a original. Assim, por exemplo, na reprodução de Schwanke (figura 48) o menino retratado por Caravaggio toca bandolim com a mão esquerda, enquanto na pintura original ele o faz com a direita. 

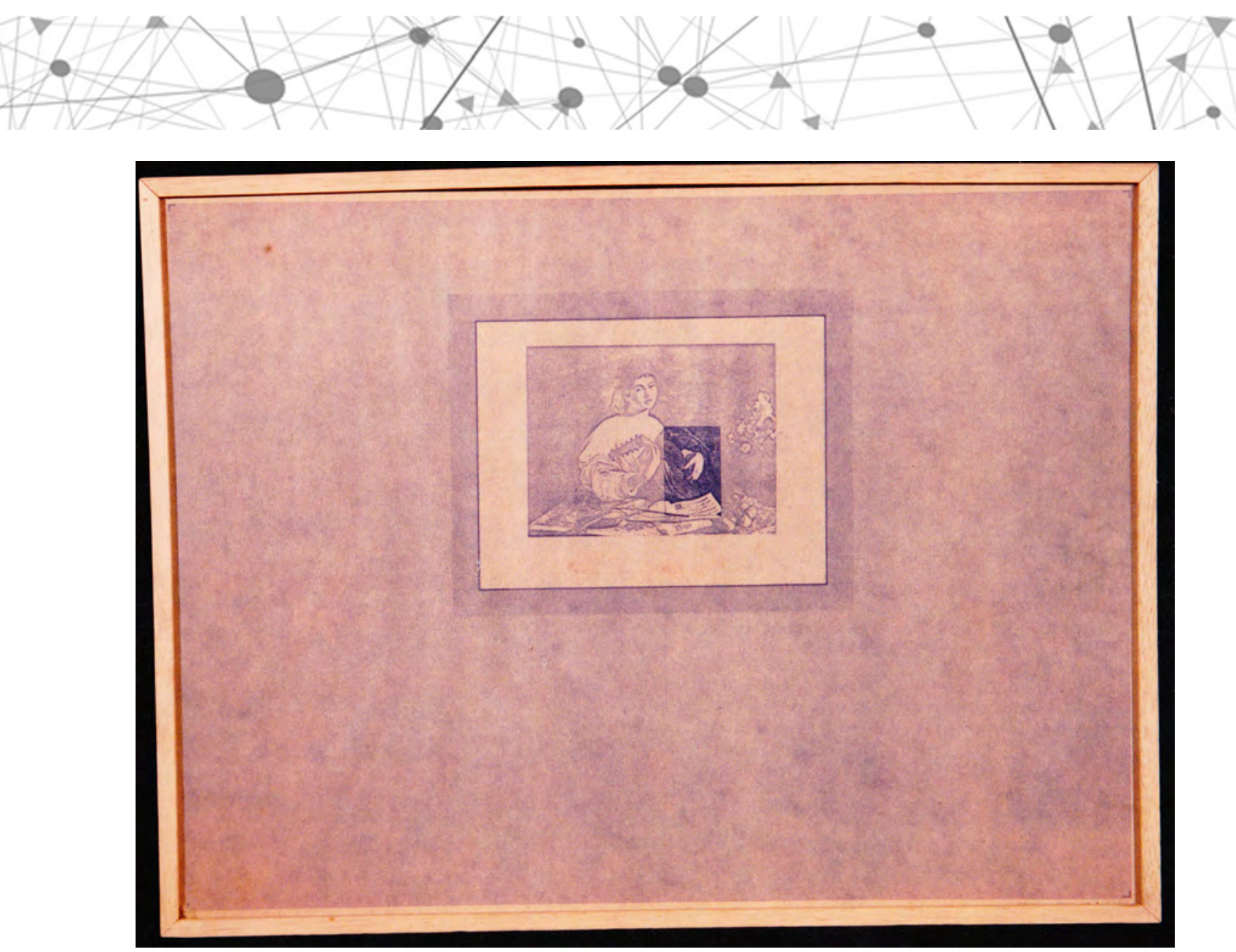

Figura 48 - Caravaggio: Menino com Bandolim, Luiz Henrique Schwanke, 1976. Cópia heliográfica (cópia impressa de acetado invertido), margem de papel vegetal e letraset. 67 $\mathrm{cm} \times 51 \mathrm{~cm}$

Fonte: foto de Rui Arsego. acervo da família Schwanke

Em cada um dos cinco trabalhos que compõem essa série, Schwanke reforçou a grafite a figura da mão responsável pela ação principal, colocando não somente a mão, mas também o gesto em destaque. Assim, na pintura de Caravaggio, a mão destacada é aquela que toca o bandolim. Conforme suas palavras:

Continua a cópia (o impresso é copiado através do desenho), mas agora a característica de maior importância não é o ato de recopiar o impresso com suas possibilidades, porém utilizar o grafite como um comentário acerca das possibilidades que permitem o desenho no processo mental a ser desenvolvido pelo receptor, tendo por referência a obra primeira (por obra primeira entenda-se o que 0 artista mostra ao receptor). (SCHWANKE, 1992).

A interferência com desenho em uma reprodução de obra de arte já havia sido empregada anteriormente por Marcel Duchamp em L. H. O. O. Q., de 1919. Trata-se de um ready-made retificado realizado pela apropriação de uma 
reprodução de La Gioconda (1503-1505), de Leonardo da Vinci, e da inserção, em desenho à caneta, de uma barba e de um bigode. Pelo título, L. H. O. O. Q., Duchamp brinca com o som e com o significado da palavra. A sonoridade da pronúncia das letras resulta na frase ele a chaud au cul, que significa ela tem calor do rabo (CABANNE, 1987). A ideia de Duchamp não estava pautada na maculação da imagem, mas no questionamento e até na ironização acerca da idolatria exacerbada sofrida por aquela pintura, assim como na interferência exercida no olhar do público, que não sabe mais distinguir o original da reprodução, uma vez que a última não possui carisma e facilmente pode ser manipulada (ARGAN, 1992).

Assim como Duchamp, Schwanke brinca com o título dado à série, na medida em que é dúbio. Ao mesmo tempo em que o termo sinistra pode remeter a sinistro, sendo entendido como aquilo que é maligno e obscuro, significa mão esquerda, tratando-se de uma pista dada ao público da interferência por ele realizada.

Assim sendo, além de uma discussão em torno do original e da cópia, nesse conjunto de trabalhos, podem ser identificadas as três vertentes que permeiam toda a produção de Schwanke: a apropriação da história da arte e de imagens que são desdobramentos do pensamento clássico; o interesse pela luz, evidenciado pela técnica de reprodução utilizada (heliografia, ou seja, gravar com sol) e nas obras apropriadas; e o gesto, que aparece não somente na escolha das obras reproduzidas, no entanto também no reforço da figura da mão em cada uma delas.

Ainda, é da década de 1970 uma série de 30 desenhos criados pela apropriação, transformação e ressignificação de obras de arte produzidas em diferentes momentos da história, escolhidas por desdobramentos da vertente clássica. São desenhos executados com técnica e acabamento impecáveis. Sobre a produção dessa série, realizada de 1978 a 1980, Schwanke (1986) afirma:

0 trabalho tinha assim um cuidado enorme de estética visual e de acabamento inclusive [...] e agora eu considero muito sincero e muito meu todo o trabalho conceitual, a série do "São Sebastião", a série das cadeiras [...] foi assim uma fase assim que eu fiz muito poucos trabalhos porque eles eram, eu levava um mês ou mais fazendo um trabalho, trabalhando todo o dia com lápis de cor, as margens eram recortadas com durex. [...] Por isso aquelas margens são perfeitas, as pessoas inclusive perguntam se não é fotografia, duvidam até. 
Esses revisitamentos ${ }^{114}$ são fruto do estudo acerca da história que os envolve e não deixa de lado nem o tratamento de luz e de sombra empregado pelo artista nem o gesto principal que envolve a composição. Foi no momento em que começou a aprofundar os seus estudos acerca do elemento luz que Schwanke iniciou os trabalhos que compuseram essa série. Conforme escreve:

Nas aulas de história da arte da UFPR, o assunto claro-escuro se tornou uma ideia constante. A luz na quantidade máxima de requinte de representação. Comparava Caravaggio a Guido Reni, onde Reni inundado de luz - mas todo claro e sem contrastes. Nessa época meu trabalho era em cima do Renascimento (isto é, reproduzia por exemplo "São José Carpinteiro" de La Tour como uma poltrona sisuda (desenhada, mas copiada de revista de design) e ao lado uma mão acendendo um palito de fósforo (também desenhada e copiada de anúncio) (SCHWANKE, s.d.) (anexo 3).

Em alguns dos desenhos dessa série, o artista substitui o gesto da personagem principal pela figura do dedo. Isso se dá quando a obra apropriada foi produzida pelo artista que a executou com base em uma determinada cena, cuja situação foi escolhida para ser representada por se tratar especificamente daquela ação. Como exemplo, pode-se ter o desenho São José O Carpinteiro, de La Tour", 1979 (figura 49), referenciado por Schwanke em seu texto (anexo 3).

\footnotetext{
${ }^{114} 0$ termo revisitamento foi utilizado por Nadja de Carvalho Lamas em sua tese de doutorado Revisitamento 'na' e 'da' obra de Luiz Henrique Schwanke, defendida em 2005, como referência ao gesto de apropriação, de transformação e de ressignificação de obras de arte do passado.
} 


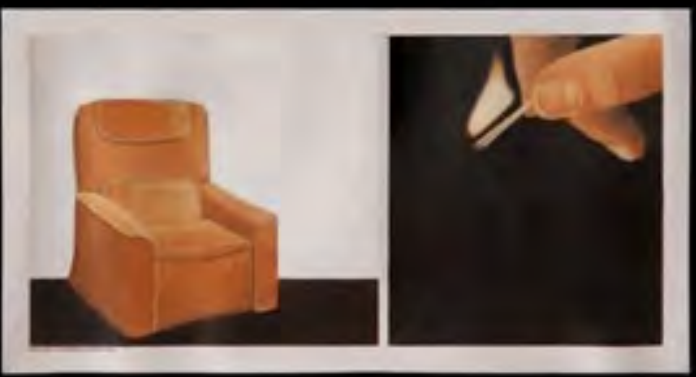

Figura 49 - São José 0 Carpinteiro, de La Tour, Luiz Henrique Schwanke, 1979. Ecoline, lápis de cor, letraset sobre papel schoeller encerado. $62 \mathrm{~cm} \times 35 \mathrm{~cm}$. Prêmio I Salão Brasileiro de Desenho

Fonte: foto de Luiz Carlos Hille. Acervo da família Schwanke

Conforme o próprio título aponta, o trabalho é resultado da apropriação da pintura São José 0 Carpinteiro, de 1642, realizada pelo artista do barroco francês Georges de La Tour, artista que em muitas de suas composições fazia uso de apenas uma vela como foco de luz. 0 ponto de partida para a realização da pintura de La Tour, assim como indicado pelo título, é a profissão de carpinteiro exercida por São José, materializada, como pode ser observado na imagem (figura 50), pelo exercício do ofício. Contudo o trabalho em meio à escuridão só é possível pela iluminação empreendida pelo menino Jesus. Assim sendo, entende-se que a ação principal presente na pintura é a do menino, caso contrário o trabalho do pai não seria possível. 

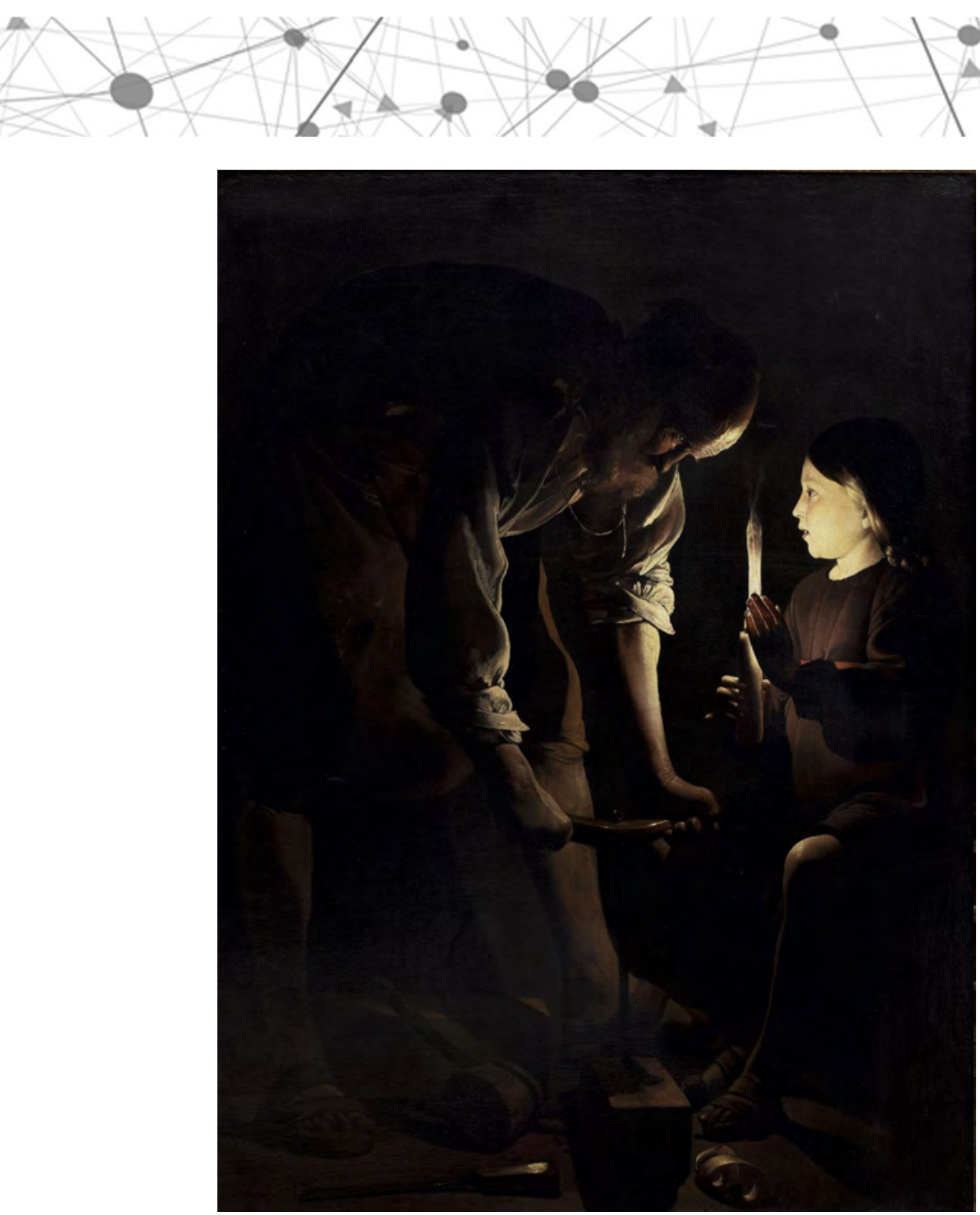

Figura 50 - São José O Carpinteiro, Georges de La Tour, $1642.137 \mathrm{~cm} \times 102 \mathrm{~cm}$. Tinta óleo sobre tela. Acervo: Museu do Louvre

Fonte: disponivel em: <http://www.panoramadelart.com/SaintJosephcharpentier>. Acesso em: 3 jul. 2016

Portanto, em sua revisitação Schwanke substitui a figura de São José, submetido pelo gesto de ser iluminado, pela representação de uma poltrona alaranjada, que ocupa a mesma posição que o carpinteiro na composição. Já o menino, autor do gesto principal, é substituído por dedos que seguram um palito de fósforos em chamas. Observa-se ainda que, além da lógica da ação e da posição, Schwanke também reproduz o mesmo esquema de iluminação.

Outro trabalho dessa série em que o gesto é representado pela figura do dedo é Anunciação, de Leonardo (figura 51). Assim como o título sugere, o desenho é resultado da apropriação e do estudo da pintura $A$ Anunciação, de Leonardo da Vinci (figura 52). 


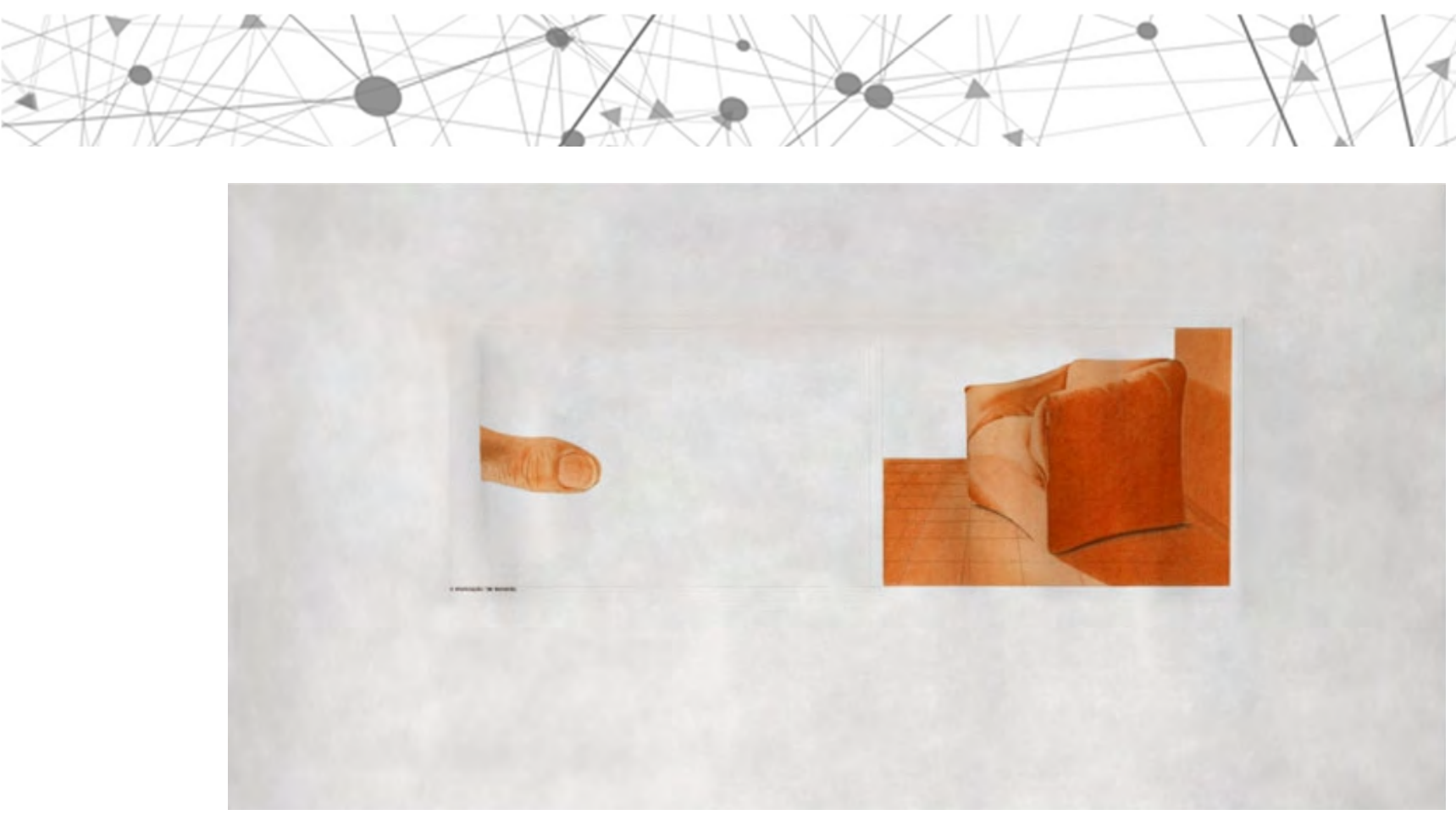

Figura 51 - Anunciação, de Leonardo, Luiz Henrique Schwanke, 1979. Ecoline, lápis de cor, letraset sobre papel schoeller encerado. $62 \mathrm{~cm} \times 35 \mathrm{~cm}$

Fonte: foto de Luiz Carlos Hille. Acervo da família Schwanke

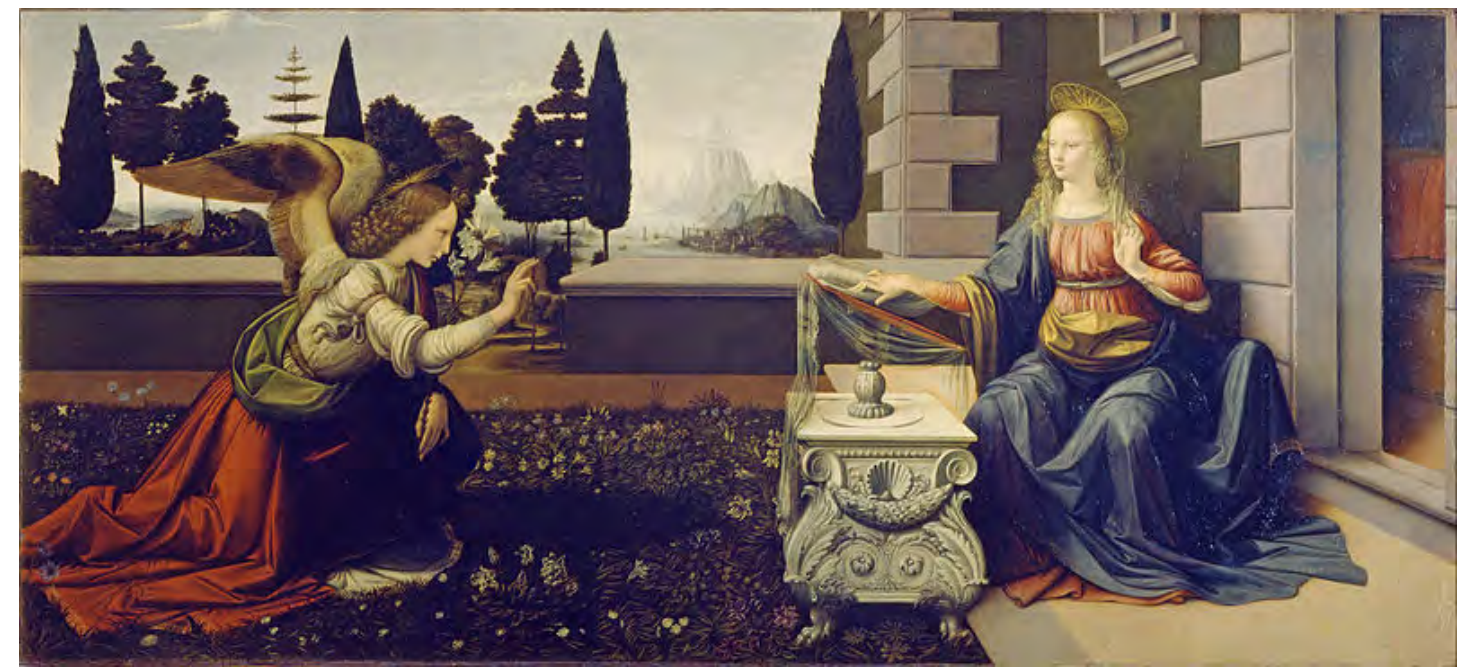

Figura 52 - A Anunciação, Leonardo da Vinci, 1472-1474. Óleo e têmpera sobre papel. 98 $\mathrm{cm} \times 217 \mathrm{~cm}$

Fonte: disponível em: <http://www.wga.hu/support/viewer/z.html>. Acesso em: 3 jul. 2016

0 que motivou a execução da pintura por parte de da Vinci, assim como consta no título, foi o anúncio do anjo Gabriel à Virgem Maria de que ela seria a mãe de Jesus. Schwanke substitui a figura de Maria por uma poltrona, inserida na mesma posição, e com o mesmo tom alaranjado da parte superior do vestido. Já o gesto do anjo é substituído pela representação de um dedo apontando para a poltrona. Nota-se também que o quadriculado do piso da pintura de da Vinci é

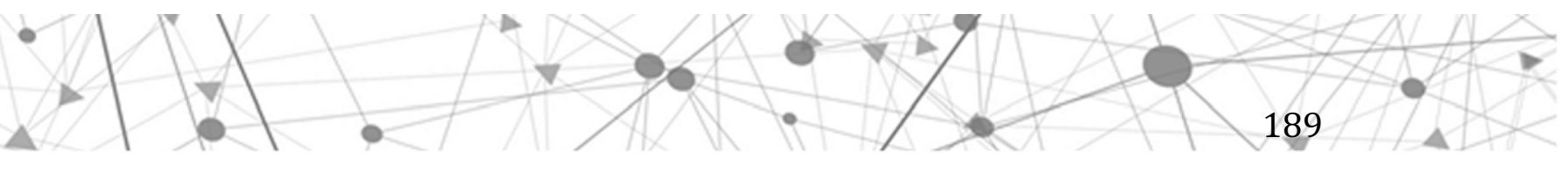


também representado no desenho de Schwanke, que leva em conta o esquema de iluminação.

Em outros desenhos, Schwanke substitui as personagens apenas por poltronas. Isso se dá quando o trabalho apropriado consiste em um retrato, ou seja, quando a motivação para a realização da pintura por parte do artista não está propriamente em um gesto, mas na representação da figura em si. Contudo, em todos os desenhos de Schwanke dessa série que são conhecidos (quatro deles não se sabe como são nem onde estão), as figuras retratadas exercem algum tipo de gesto, representado por Schwanke por intermédio de algum elemento componente do móvel.

É interessante ressaltar que a ideia do artista de substituir por cadeiras e poltronas as figuras das obras apropriadas também é resultado de uma apropriação, só que de uma peça de teatro. Em 1975, Schwanke assistiu a uma montagem de A Casa de Bernarda Alba, de Federico García Lorca, feita pelo Grupo Momento de Teatro, do qual participou até 1974. Nessa montagem, cada personagem possuía a sua própria cadeira, como se aquele fosse o seu lugar dentro da casa e como se as formas das cadeiras materializassem as personalidades fortes das mulheres que viviam ali (figura 53). Como afirma Schwanke em uma entrevista concedida à Adalice Araújo (1986):

A cadeira é intuitiva, psicológica, inclusive se eu quisesse intelectualizar eu diria que nós tomamos a borda de uma cadeira, mas eu passo a maior parte do dia em uma cadeira, eu não conhecia... E vi uma série de trabalhos dele, assim de cadeiras sozinhas, que tem muita coisa ligada a elas, se eu fosse intelectualizar, eu diria que a maioria dos homens passa a maioria do tempo trabalhando em seus empregos, sentados em cadeiras, ela é um dos objetos que mais convive conosco, eu acho muito ligada ao sexo, tem muita sensualidade, e uma carga assim, uma estimativa muito grande e eu acho muito fácil de desenhar. 


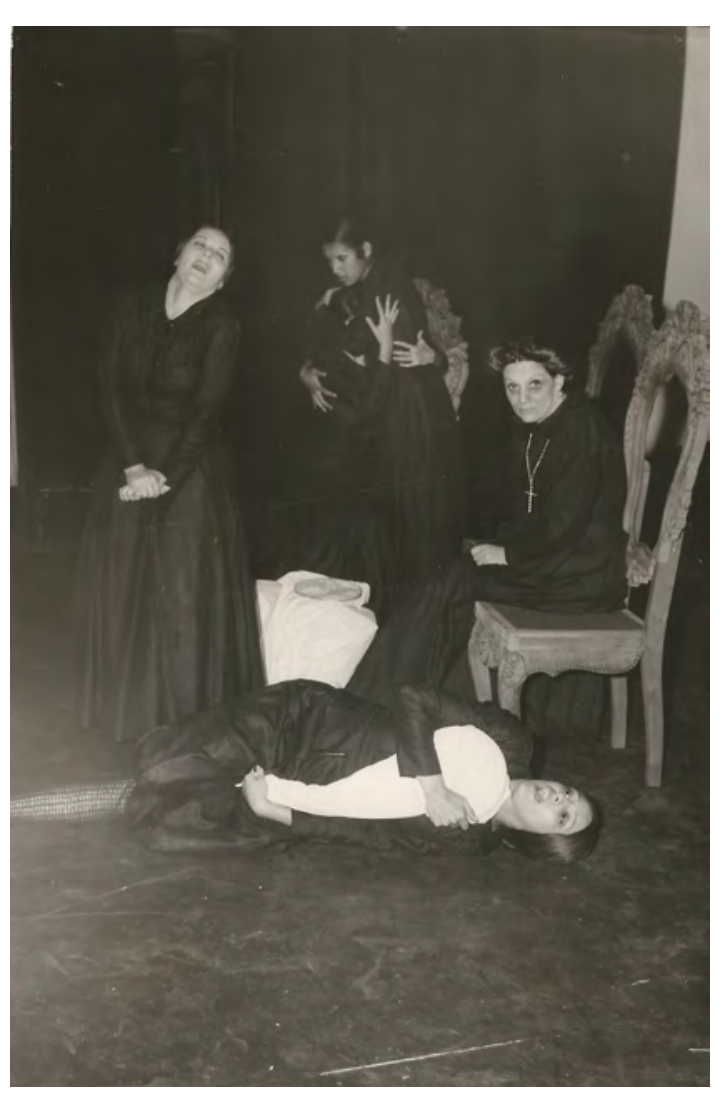

Figura 53 - Montagem de $A$ Casa de Bernarda Alba, realizada pelo Grupo Momento de Teatro, 1975. Teatro Guaíra, Curitiba

Fonte: acervo do Departamento Estadual de Arquivo Público do Paraná

Fundamentado em pesquisas realizadas em catálogos de mobiliário escandinavo, acervo da Biblioteca Pública do Paraná, Schwanke pesquisava imagens de cadeiras e poltronas que dialogassem em cor e posição com as obras que the interessavam. Ressalta-se que todas as cadeiras e poltronas que aparecem em seus desenhos são fruto da cópia literal das fotos originais. Logo, constata-se a complexidade do pensamento do artista na construção dessa série, fruto de experiências de vida e referências de áreas distintas, cruzadas tendo em vista seus interesses plásticos e conceituais.

Faz parte dessa série o desenho A Madona da Serpente, de Caravaggio" (figura 54), de 1978. Nele, Schwanke destaca o gesto da Virgem Maria, que na pintura Madonna dei Palafrenieri (figura 55), de Caravaggio, tem um dos pés do menino Jesus sobre o seu, no auxílio à criança para que pise na cabeça da serpente, enquanto Santa Ana os observa. 


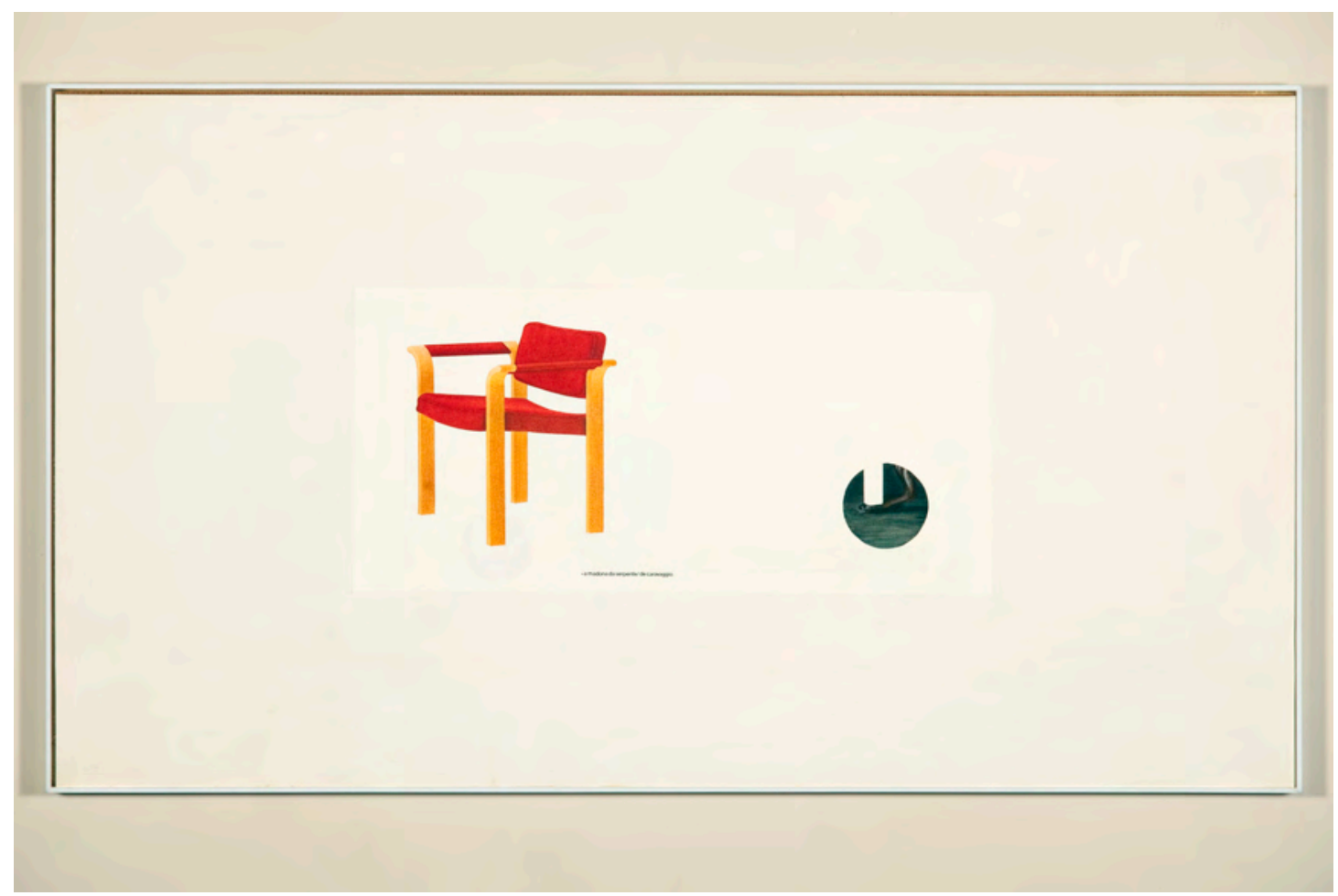

Figura 54 - A Madona da Serpente, de Caravaggio, Luiz Henrique Schwanke, 1978. Lápis de cor e ecoline sobre papel. Acervo de Bruno Musatti

Fonte: foto de Peninha Machado. Arquivo do Instituto Luiz Henrique Schwanke

Biblicamente, a serpente representa o demônio, e, tal qual consta da Bíblia Sagrada, Deus castigou a serpente por ter enganado Eva, que acabou por desobedecê-lo: "Por causa do que você fez você será castigada. Eu farei com que você e a mulher sejam inimigas uma da outra [...]. Esta esmagará sua cabeça e você picará o calcanhar da descendência dela" (BÍBLIA SAGRADA, 1977, p. 3). 


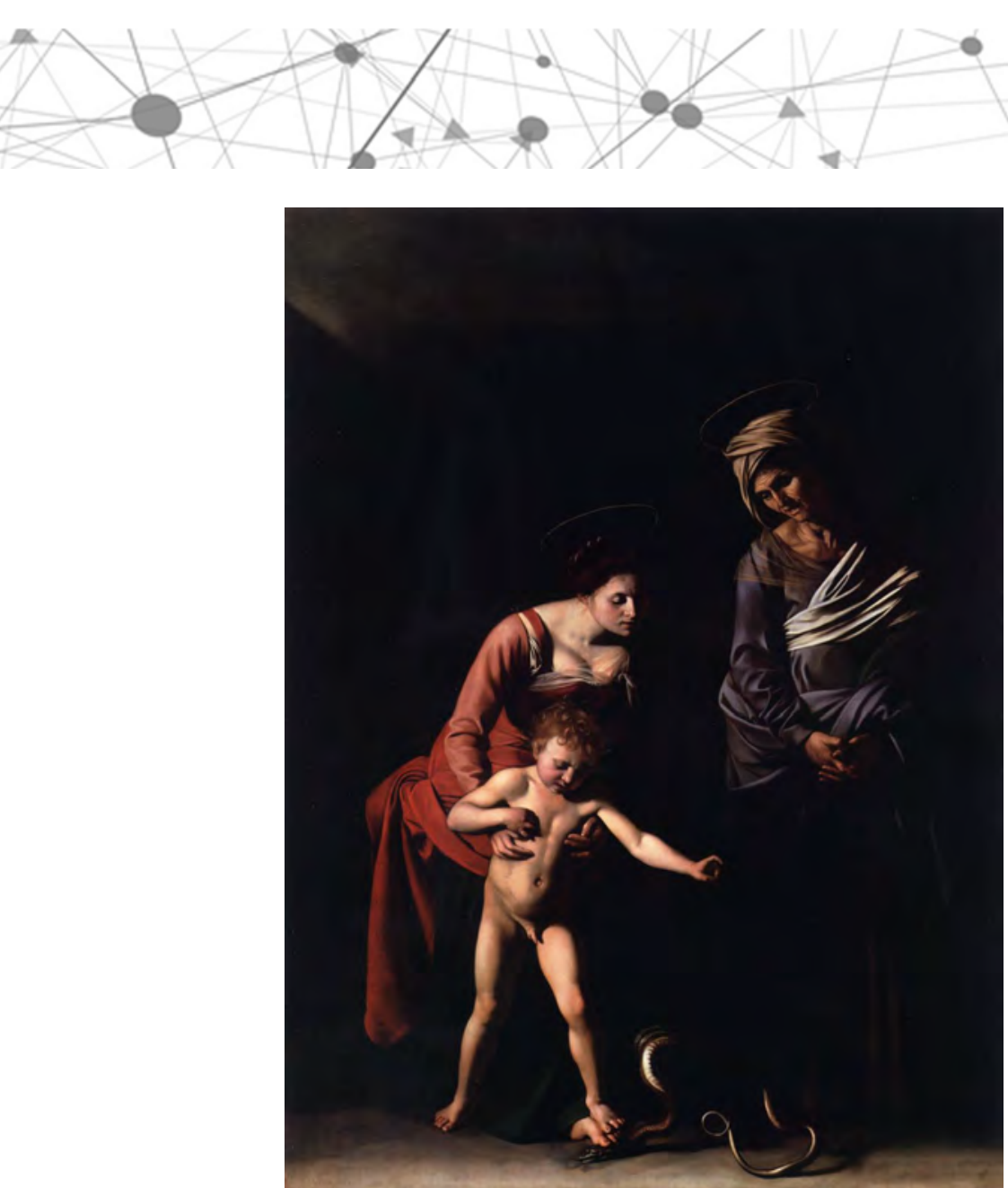

Figura 55 - Madonna dei Palafrenieri, Caravaggio, 1606. Óleo sobre tela. $292 \mathrm{~cm} \times 211 \mathrm{~cm}$. Acervo da Galleria Borghese, Roma, Itália

Disponível em: <http://www.wga.hu/frames-e.html?/html/r/raphael/index.html>. Acesso em: 11 jul. 2016

Schwanke substitui as figuras da Virgem Maria e do menino, que estão do lado esquerdo da composição, por uma poltrona com estofamento avermelhado, da mesma tonalidade de vermelho do vestido da virgem, e cujas pernas estão na mesma angulação das pernas da mãe e da criança. Do lado direito, o artista representa a cabeça da serpente, copiada fidedignamente da composição, dentro de um círculo, o qual sofre a interferência de um recorte retangular equivalente à perna da cadeira sobre a cabeça da serpente, sintetizando assim a ação que o animal sofreu. Vê-se que, embora o principal gesto realizado na pintura de Caravaggio tenha sido exercido pelos pés, a Virgem Maria faz uso de suas mãos para suspender o menino Jesus e auxiliá-lo.

Outro desenho dessa série é Rosa e Azul, de Renoir (figura 56), fruto da apropriação de pintura de natureza impressionista, que também possui forte relação com o barroco, já que, segundo Argan (2004), foi o barroco que inventou a modernidade, contexto do qual a arte moderna é fruto. Foi a partir do século XVII que a modernidade passou a ser entendida como essencial na produção cultural e

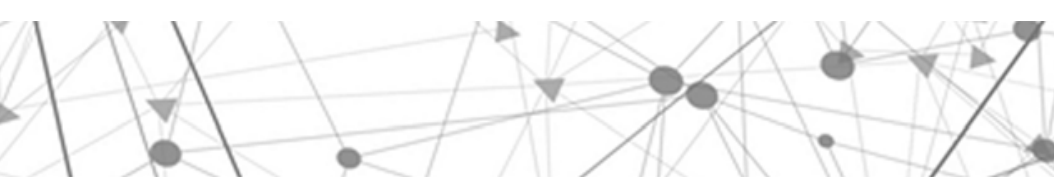


artística. Foi também no século XVII que a demanda do público passou a ser atendida pelos artistas, os quais deveriam estar atualizados em relação aos gostos e às tendências de seu tempo. Foram os artistas do barroco os pioneiros na compreensão da arte como "cultura, nada mais que cultura" (ARGAN, 2004, p. 8). Portanto, mesmo fazendo uso de um movimento moderno, Schwanke continuou seguindo os desdobramentos da vertente clássica, iniciada na Grécia Antiga. Esse trabalho, conforme sugerido pelo título, grafado no lado esquerdo inferior no próprio desenho, consiste no revisitamento à pintura Rosa e Azul, de Pierre August Renoir (figura 57).

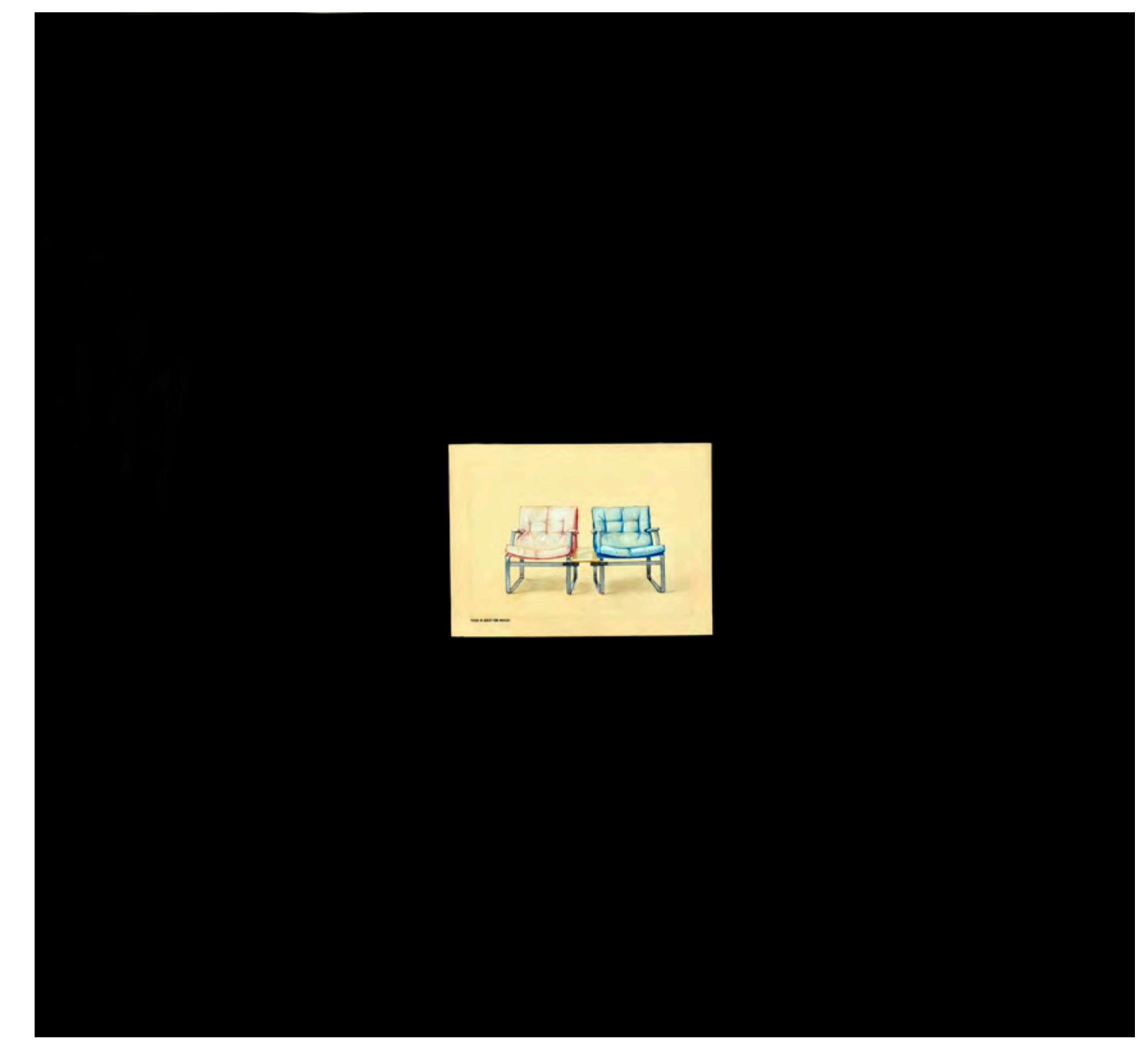

Figura 56 - Rosa e Azul, de Renoir, Luiz Henrique Schwanke, 1979. Ecoline, lápis de cor, letraset sobre papel schoeller encerado. $67,5 \mathrm{~cm} \times 73 \mathrm{~cm}$

Fonte: foto de Peninha Machado. Acervo da família Schwanke 

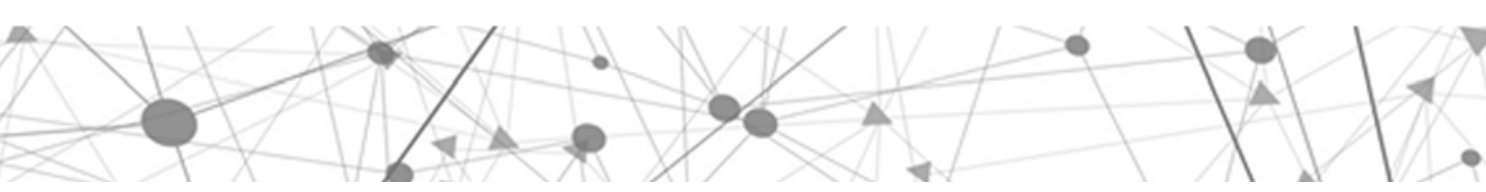

Nessa pintura, Renoir retrata duas irmãs, que estão de mãos dadas, vestidas uma de rosa e outra de azul. A iluminação da composição está concentrada nas meninas, de forma que o fundo aparece mais escurecido. Por se tratar de um retrato, embora não seja um retrato qualquer, mas um em que, conforme já citado, as figuras estão de mãos dadas, as meninas são substituídas por duas poltronas no desenho de Schwanke. 0 capitonê das poltronas dialoga com o rebuscamento do vestido das meninas e as cores, rosa e azul, possuem exatamente o mesmo tom.

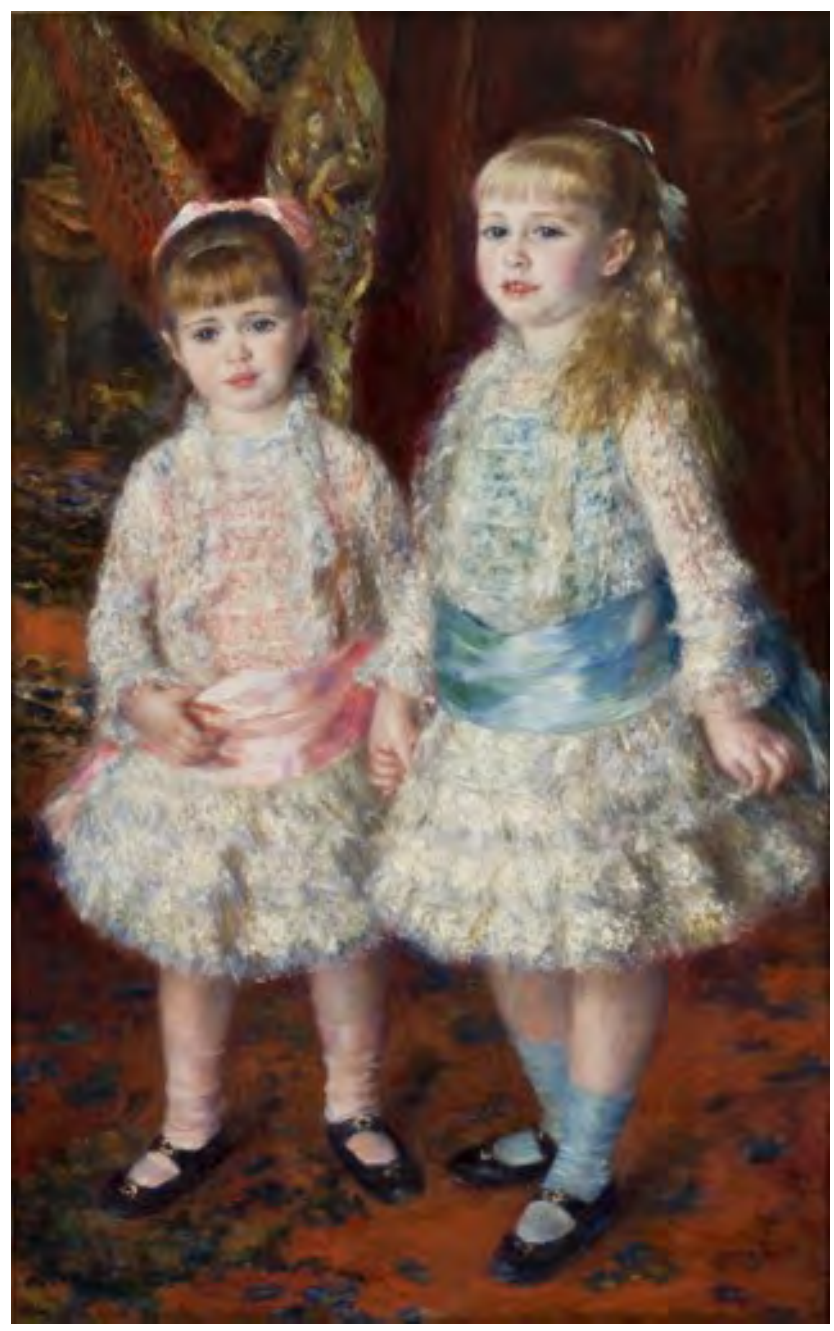

Figura 57 -Rosa e Azul, Pierre August Renoir, 1881. Óleo sobre tela. $119 \mathrm{~cm} \times 74 \mathrm{~cm}$. Acervo do Museu de Arte de São Paulo

Fonte: disponível em: <http://masp.art.br/masp2010/acervo_detalheobra.php?id=272>. Acesso em: 3 jul. 2016

0 gesto de dar as mãos, empregado pelas meninas, é representado por Schwanke por meio da mesa que interliga as poltronas. Ressalta-se, uma vez mais, que as poltronas não foram inventadas, mas copiadas fidedignamente de um 
catálogo publicitário. Observa-se ainda que a iluminação do desenho de Schwanke também está em diálogo com a pintura impressionista de Renoir.

Pode-se afirmar que o barroco foi consolidado como arte da Igreja romana no sentido de suprir uma necessidade dogmática, assim como na sistematização e na apresentação da história e dos princípios cristãos aos fiéis, mediante exemplos instrutivos. Nessa perspectiva, e conforme palavras de Argan (2004, p. 60), a produção da arte no século XII “é animada por um espírito de propaganda”, tendo em vista que a alegoria sintetiza os conceitos por meio das imagens na desconstrução didática de ideias que atingem a percepção sensível do espectador. 0 principal objetivo do uso da imagem pela Igreja romana é “induzir no fiel o estado de ânimo e a atitude modesta e humilde que ele deve assumir para dirigir-se a Deus (ARGAN, 2004, p. 103).

Nessa série de Schwanke, entende-se que o comportamento barroco também está presente não apenas quando coloca em discussão pinturas produzidas naquele período, mas na forma didática como recria a composição de todos os trabalhos que são apropriados e ressignificados. Schwanke reconfigura-os de maneira simplificada, na exaltação da relação entre luz e sombra, do gesto e da história da arte, referenciando, no próprio título, o nome do artista e do trabalho que está sendo apropriado, e com base no qual, por meio de seu desenho, constrói um comentário. Ao substituir as personagens por cadeiras e poltronas, peças de mobiliário copiadas diretamente de catálogos publicitários e que fazem parte do dia a dia do espectador, tal como Caravaggio, que humaniza as personagens bíblicas e as aproxima dos fiéis, Schwanke aproxima as personagens do espectador. Ele olhava para a arte como uma forma de descoberta e, por intermédio desses desenhos, faz com que o espectador a descubra e por ela se interesse.

No início dos anos 1980, ao contrário da produção de cunho conceitual que teve forma na década anterior, e em consonância com o momento artístico da época, marcado pelo retorno da pintura gestual, figurativa e em grandes formatos, fruto do contexto da recém-conquistada liberdade de expressão por meio das Diretas Já, após um período de 21 anos de ditadura militar no Brasil, Schwanke produziu pintura. São inúmeras seriações com base nas quais, ao contrário do que aconteceu com a produção da década anterior, nada se escreveu. Talvez porque a 
produção desse período, ao que parece, de natureza catártica, tenha sido feita para ser vivenciada, e não racionalizada.

Schwanke produziu em grande quantidade. Conforme afirma em uma carta escrita ao amigo, escritor e crítico de arte Harry Laus (anexo 4):

Esse ano eu pintei muito, muito mesmo, mais de cinco mil. Sem pretensões, preocupações. Mandei para o Salão Paulista, que foi super rigoroso, entrei lá, mandei trabalhos pequenos, modestos. Depois fui premiado no Salão Paranaense. Depois fui premiado no Salão de Pernambuco. Depois tirei o primeiro lugar no Salão de Goiânia, depois fui incluído no Salão Nacional e agora tirei $01^{\circ}$ prêmio no Salão Nacional de Belo Horizonte, nem acredito (SCHWANKE, 1985).

Conforme pode ser constatado, o ano de 1985 foi fértil para Schwanke, tanto quanto ao número de trabalhos produzidos como em relação à quantidade de prêmios conquistados - cinco em salões nacionais importantes ${ }^{115}$. Entre as inúmeras seriações de pinturas produzidas nesse período, destaca-se, como a mais numerosa e mais premiada, a série Perfis, iniciada em 1982 e produzida até o fim da década. Trata-se da representação de rostos humanos, sempre de perfil, parcial ou totalmente voltados à esquerda de quem os observa (figura 58). Boca aberta, fechada, quase fechada. Vomitando. Uma cruz no lugar da língua, às vezes mostrando os dentes. Contudo a grande maioria é representada com a língua para fora, o que levou esse conjunto de pinturas a ficar conhecido como Linguarudos. Entretanto, quando em exposição, Schwanke colocava-os como sem título.

\footnotetext{
115 Prêmios do 3. ${ }^{\circ}$ Salão Nacional de Goiânia; $13 .^{\circ}$ Salão Paranaense, realizado pelo Museu de Arte Contemporânea do Paraná; Prêmio Aquisição no 38. ${ }^{\circ}$ Salão de Pernambuco; Grande Prêmio Cidade de Belo Horizonte no $17 .^{\circ}$ Salão Nacional de Arte; Prêmio nominal D. J. Oliveira no 2.ํ Salão de Artes Plásticas de Goiânia.
} 


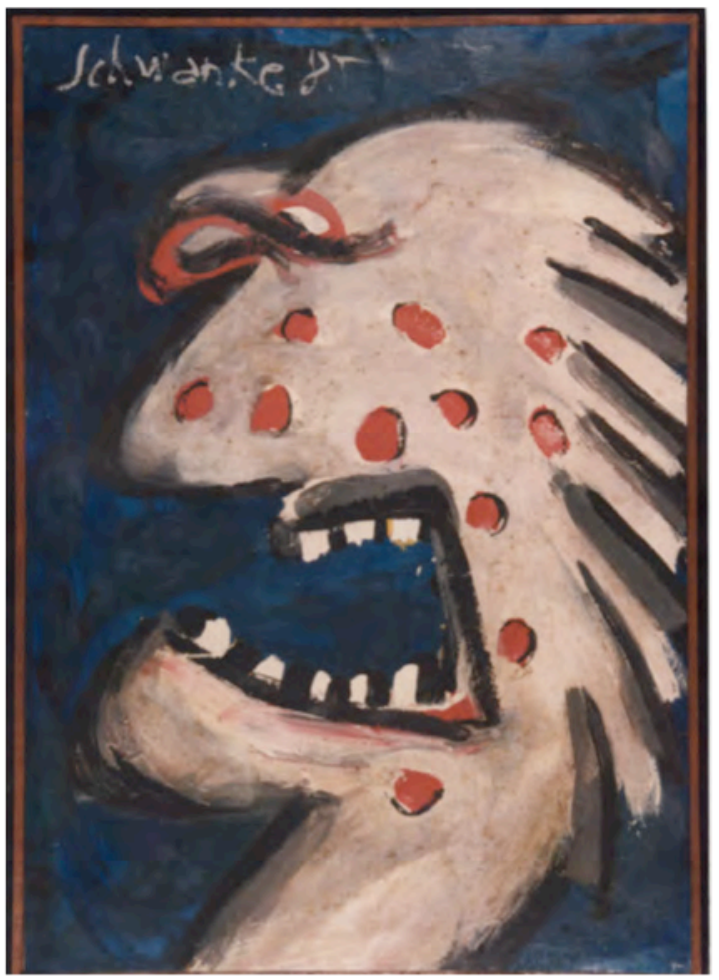

Figura 58 - Sem título, Luiz Henrique Schwanke, 1985. Guache sobre eucatex. $96 \mathrm{~cm} \times 66$ $\mathrm{cm}$

Fonte: Acervo: Família Schwanke. Foto: Rui Arsego

Esses perfis pinturas foram concebidos por meio de pinceladas carregadas, marcadas, dando forma a fisionomias de expressão exacerbada. Por vezes fálicos, deformados, alguns exprimem certa violência, outros, ironia. Em entrevista realizada por Adalice Araújo, Schwanke fala sobre o processo de concepção dos perfis:

Eu fazia vindo de dentro aquilo, tinha vontade, fazia rápido, produzia mesmo com garra, com vontade, com gesto, com emoção, sofrendo ao mesmo tempo pensando até de uma forma masoquista, em coisas ruins para tirar uma coisa forte de dentro, assim como se fosse força, habilidade, essa coisa toda terrível do mundo que eu vivo, que existe agora (SCHWANKE, 1986).

Para a produção desses trabalhos, o artista utilizava como suporte desde telas, em tamanhos diversos, até materiais simplórios, tais como folhas de jornais velhos, páginas de livros e dicionários rasgados, e folhas de livros de contabilidade que pertenceram ao seu pai, que exercia o ofício de contador. Em relação aos 
suportes usados para a execução de um conjunto de Perfis, produzidos para uma exposição individual na Sala Miguel Bakun, em Curitiba, Schwanke explica:

Todos os trabalhos, quase todos eles são pintados em páginas de livros velhos, corroídos, alguns rasgados, livros contábeis com selos, de páginas assim, de livros velhos mesmo, de coisa descartável. É um suporte pobre de lixo. Alguns livros são inclusive juntados do lixo e pintados em cima. Inclusive eu utilizo essa coisa velha, borrada e tal, até dá para ter associação com a arte pobre (SCHWANKE, 1986).

Ao utilizar suportes materiais "pobres", alheios ao contexto da arte, pode-se estabelecer uma relação com a arte povera, cuja produção não se refere ao "ser pobre", mas à pobreza moral da sociedade (DEMPSEY, 2003, p. 268). Para Schwanke, os Perfis configuram-se em uma tradução dos acontecimentos do mundo de um ponto de vista muito mais interno do que externo. Ao ser questionado por Araújo se os Perfis refletem algum tipo de tensão, responde:

Isso, essa coisa do mundo, do dia a dia que eu sinto de energia das pessoas. Nesse dia a dia das cidades grandes, dos problemas, de abrir o jornal e saber aquela carga, aquela batelada de coisas, nossa, muito mais tenebrosas e difíceis de enfrentar, do que fáceis (SCHWANKE, 1986).

Schwanke organizou a maioria dessas pinturas (figura 59), produzidas uma a uma, em formato de painel, por meio das quais dá uma feição neoexpressionista ao comportamento de repetição e seriação da pop arte produzida por Warhol. 0 artista norte-americano apropriava-se da imagem de personalidades e reproduzia-as diversas vezes, colocando-as uma ao lado da outra, provocando o espectador a contemplar a mesma figura repetidas vezes, ou a observar apenas uma delas, já que por serem iguais não despertam o interesse de que sejam contempladas individualmente. 


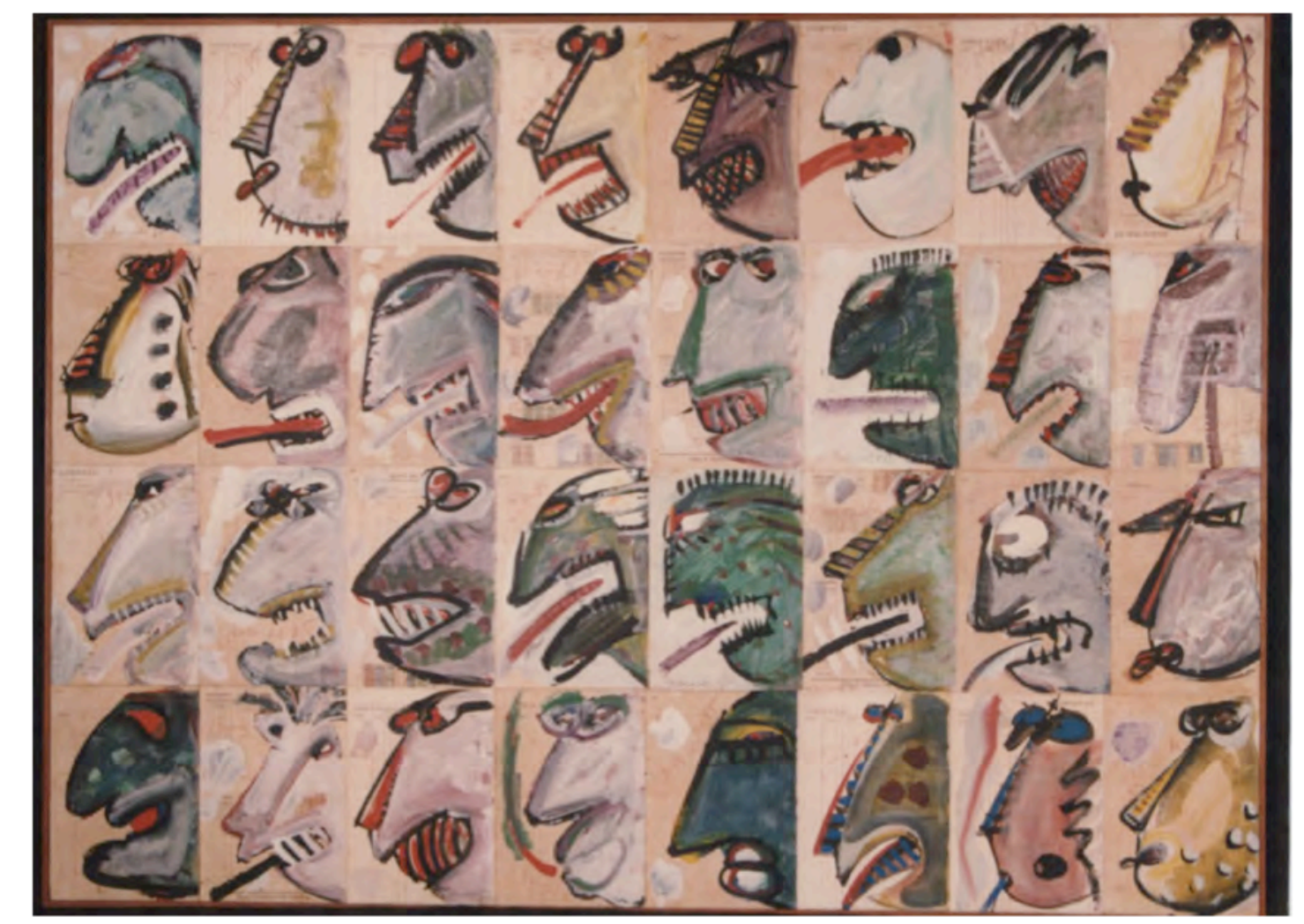

Figura 59 - Sem título, Luiz Henrique Schwanke, 1985. Guache sobre folha de livro de

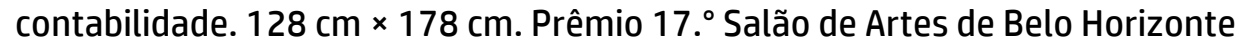
Fonte: foto de Rui Arsego. Acervo da família Schwanke

Em Schwanke, acontece o contrário. Pelo fato de cada uma das imagens possuir as suas especificidades, isso acaba prendendo o olhar do público, que se sente convidado a observar e a sentir uma por uma. Pode-se afirmar que a língua, e por vezes o nariz ou o queixo, é detentora da ação nessa série de Schwanke (figura 59), fazendo o mesmo papel que a mão e o dedo faziam na década anterior. A língua, criadora do verbo, por sua forma e mobilidade, tem o poder de uma chama; ela pode destruir ou purificar, criar ou aniquilar. Ela julga, podendo ser justa ou perversa, arrogante, mentirosa e má. Ela aponta num gesto de acusação e denúncia, condenando o espectador, que, ao contemplá-la, assume o papel de submissão à sua ação (MARMO, 2005). Nota-se que, embora os Perfis tenham sido concebidos quase que compulsivamente, em contraposição, a montagem dos painéis era racional. Schwanke ordenava-os e numerava-os no verso, indicando assim como o painel deveria ser montado.

Ainda nos anos 1980, fundamentado no conto Cefaleia, de Julio Cortázar, Schwanke dá formato a Mancúspias. Nesse conto, por meio de um sujeito plural, Cortázar parece retratar diferentes eus de uma mesma pessoa, que se revelam em

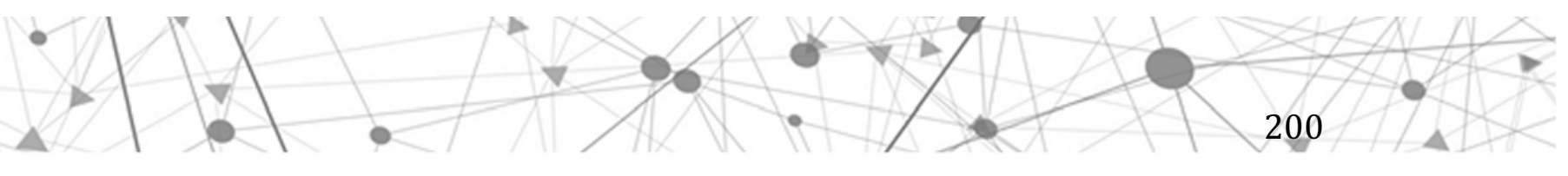




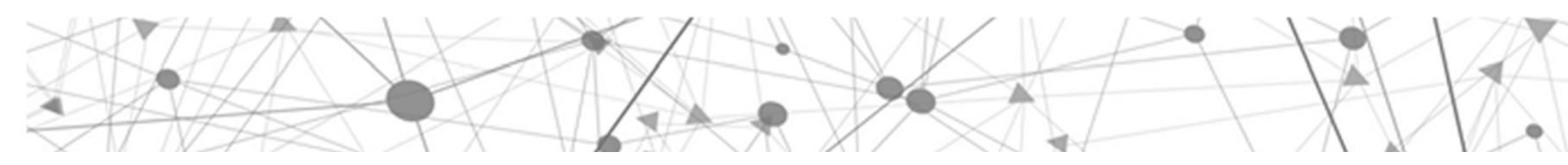

alguns momentos femininos e em outros masculinos. Esse sujeito múltiplo cuida de seres chamados mancúspias, os quais têm pelos, se alimentam de aveia maltada e requerem cuidados especiais. Conforme o conto:

Cuidamos das mancúspias até bastante tarde, agora com o calor do verão enchem-se de caprichos e inconstâncias, as mais fracas reclamam alimentação especial e que lhe levemos aveia maltada em grandes travessas de louça; as maiores estão mudando o pelo do lombo, de modo que é preciso pô-las de lado, vestir-lhes uma manta de abrigo e cuidar para que não se juntem à noite com as mancúspias que dormem em gaiolas e recebem alimento a cada oito horas (CORTÁZAR, 1951, p. 55).

As mancúspias de Schwanke configuram-se como seres híbridos, meio machos, meio fêmeas e que possuem pelos no lombo. No conto, Cortázar descreve uma situação em que o sujeito escuta "um roçar na janela do banheiro", o que pode ter sido causado por "uma mancúspia que fugiu e vem como todas para a luz" (CORTÁZAR, 1951, p. 62). Tal passagem sugere que esses seres, assim como Schwanke, gostam de luz. Talvez seja esse um dos motivos que levou Schwanke a dar forma a diversas mancúspias. Uma delas aparece apontando o dedo (figura 60), marcando a presença do gesto também nessa série.

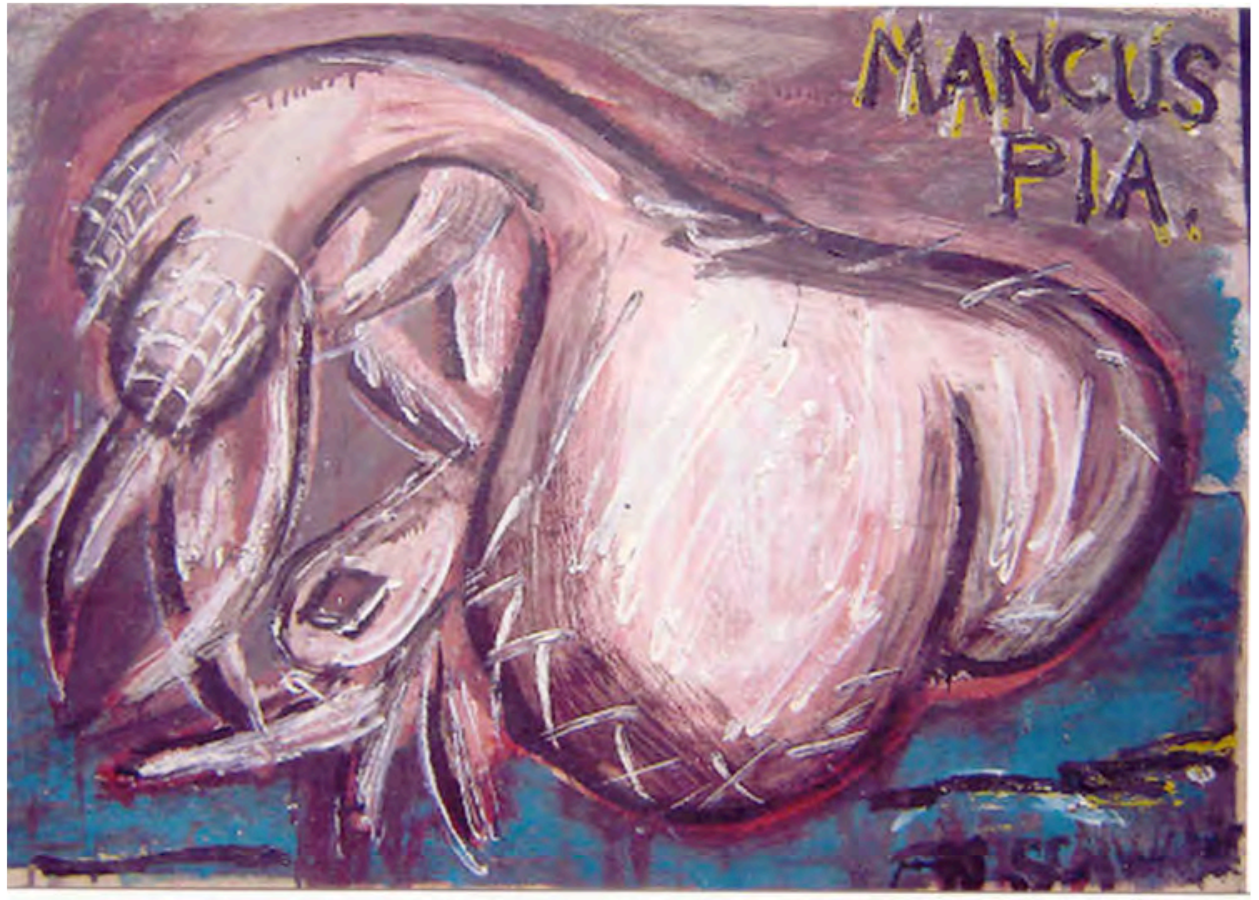

Figura 60 - Mancúspia, Luiz Henrique Schwanke, s.d. Guache sobre papel. $66,2 \mathrm{~cm} \times 96 \mathrm{~cm}$ Fonte: foto de Rui Arsego. Acervo da família Schwanke 
No fim da década de 1980, em diálogo com o minimalismo, com o construtivismo e com o concretismo latino-americano, Schwanke passou a explorar o tridimensional por meio da criação de esculturas e objetos de plástico, resultado da apropriação de materiais de produção industrial. Também nessas séries, muitas peças são produzidas diretamente no chão da fábrica, e estão presentes ali a repetição e a seriação apropriadas de Warhol, assim como o diálogo com a história da arte e a exploração do gesto. A luz também se faz presente na escolha da cor, nunca arbitrária, sempre em diálogo com a forma e, no caso das instalações, com o local onde seria colocada. Destacam-se dessas séries as colunas de baldes e bacias, resultado de seu interesse pela Antiguidade Clássica, e por pesquisas sobre colunas, tal qual é constatado tanto pelos seus desenhos e escritos da infância como mediante os inúmeros textos que sua biblioteca pessoal possui sobre o assunto.

É interessante observar mais uma vez que a ideia de trabalhar com colunas já estava presente em sua trajetória desde os anos 1970, quando propôs a realização de um monumento formado por 20 colunas de aço inoxidável no concurso de esculturas realizado pela Tupy Fundições (figura 45), já referenciado no início deste capítulo. Afirma Argan (2004, p. 387): “Da Renascença em diante, quase até nosso tempo, os arquitetos usaram as mesmas formas básicas - colunas, pilastras, cornijas, entablamento e molduras -, todas inspiradas originalmente em ruínas clássicas". Nesse sentido, pode-se dizer que Schwanke seguiu essa lógica, mas atualizando as colunas, construídas no fim dos anos 1980 e início dos 90 de plástico, material que estava em voga na época.

Assim sendo, em 1989, Schwanke realizou a primeira intervenção urbana da cidade de Joinville por meio de colunas de plástico, instaladas em três pontos. No jardim do terminal rodoviário, o artista inseriu nove colunas formadas, no total, por 180 bacias brancas, na ocupação de uma área de $21 \mathrm{~m}$ de comprimento $\times 5 \mathrm{~m}$ de altura. Já no cruzamento da Avenida Beira-Rio com a Rua 9 de março, ele instalou sete colunas de $4 \mathrm{~m}$ de altura por intermédio de 231 baldes, entre vermelhos e brancos. Na Praça da Bandeira (figura 61), por sua vez, colocou nove colunas de $4 \mathrm{~m}$ de altura cada, formadas por 237 bacias vermelhas, na ocupação de um espaço de $21 \mathrm{~m}$ de comprimento. Há quem referencie as colunas de Schwanke como “monumentais". Contudo, embora o artista tenha homenageado Joinville, industrial, produtora de objetos de plástico, com a criação de colunas que 
referenciam às ordens clássicas, muitos caras à Antiguidade Clássica, ao mesmo tempo há ironia em decorrência do emprego de um material "pobre", que é o plástico ${ }^{116}$. A contraposição, mais uma vez, faz-se presente. Em relação à escolha do material, Schwanke explica: “A textura dele é belíssima, ele é um material vulgar, você encontra hoje na sociedade de consumo, em todo canto, todos os dias, nas coisas mais chulas possíveis" (MARQUESINI, 1992) (anexo 5).

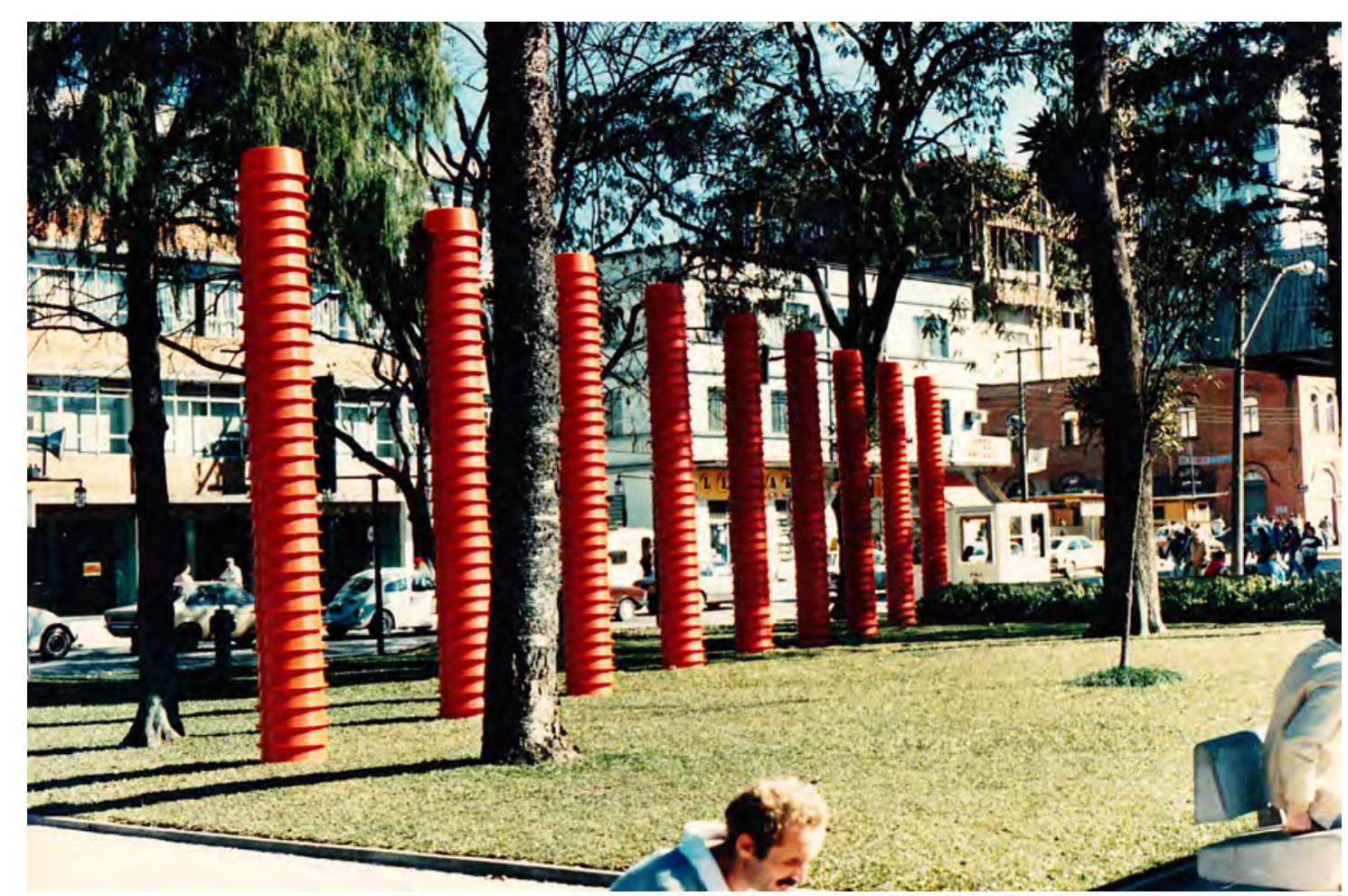

Figura 61 - Sem título, Luiz Henrique Schwanke, 1989. Plástico, ferro e madeira. $21 \mathrm{~m} \times 4$ m. Praça da Bandeira, Joinville, Santa Catarina

Fonte: foto de Rui Arsego. Acervo da família Schwanke

Ao observar a foto (figura 61), percebe-se o cuidado na escolha do local no qual as colunas foram instaladas, tanto no que tange à escolha da cor vermelha, que entra em contraste com o verde das árvores e do gramado, como também ao diálogo estabelecido entre a verticalidade das árvores e a verticalidade das colunas. Aqui, mais uma antinomia é exaltada: o natural e o artificial.

No século V, na Grécia Antiga, foram deixadas de lado as concepções religiosas (mythos) que deram lugar ao homem (logos), de forma que o homem grego voltaria a sua atenção ao humano e à arquitetura, sendo a última considerada

\footnotetext{
${ }^{116}$ Todos os seus trabalhos de plástico foram produzidos no chão de fábrica da Cipla Indústria de Materiais de Construção S.A., empresa de Joinville.
} 


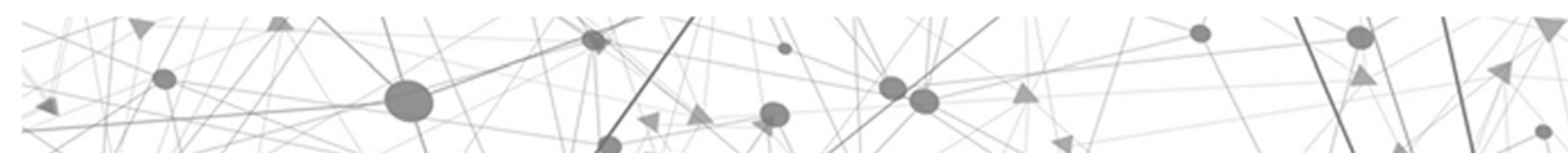

Em 1990, Schwanke promoveu uma exposição individual no Parque Lage, no Rio de Janeiro. Nessa exposição instalou colunas de bacias vermelhas em meio às colunas neoclássicas do prédio, tal qual pode ser visto no registro fotográfico feito pelo próprio artista (figura 63). 0 enquadramento da foto exalta a relação estabelecida por Schwanke entre as colunas de plástico e as colunas neoclássicas, estilo surgido no século VIII, resultante do resgate dos elementos clássicos, pelos quais, como já citado, demonstrava interesse desde a infância.

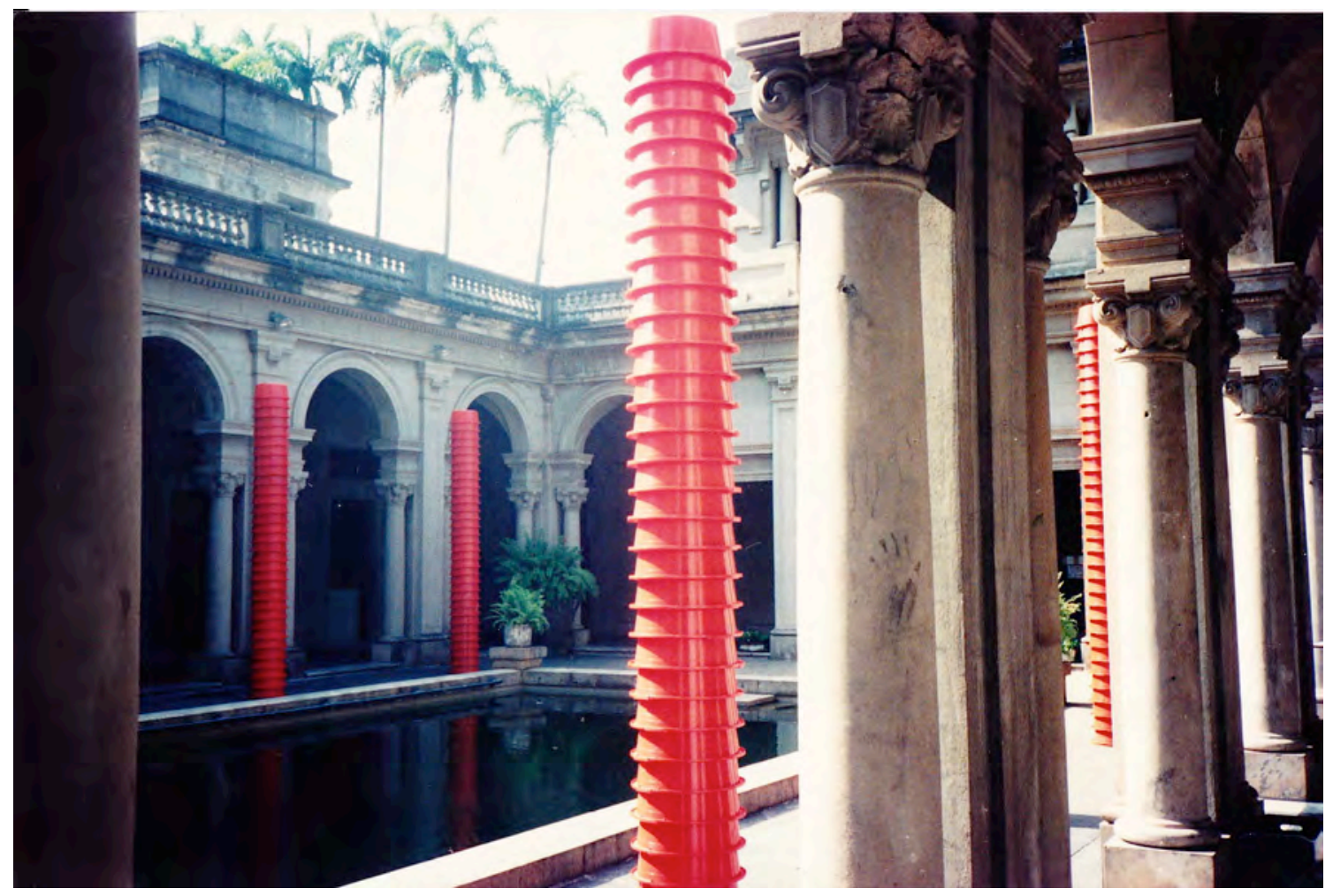

Figura 63 - Sem título, Luiz Henrique Schwanke, 1990. Baldes de plástico, barras de ferro. Parque Lage, Rio de Janeiro

Fonte: acervo da família Schwanke

É interessante verificar que as colunas direcionam o espectador a olhar para cima, como se apontassem para o céu, onde se pode ver luz, mas também escuridão, num gesto que, mais uma vez, remete ao dedo.

São desse período inúmeros outros trabalhos construídos com objetos de plástico, os quais Schwanke relaciona tanto com o barroco, estilo considerado por alguns teóricos uma continuidade do Renascimento, ou seja, um desdobramento dos princípios clássicos, como também com o minimalismo, comportamento artístico dos anos 1960. Entre eles, destaca-se Mandala (figura 64), de 1989, 

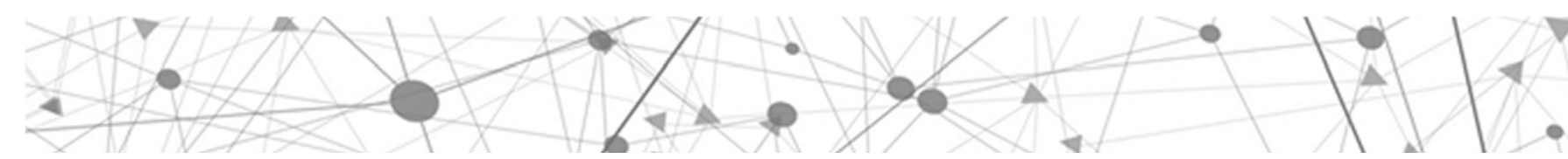

construída com $500 \mathrm{~m}$ de mangueira azul produzida pela Cipla Indústria de Materiais de Construção S.A. Escreve Schwanke (1992):

0 trabalho atual ele tem uma ligação grande com o barroco, ele é, ele entra dentro dos princípios do barroco, quer dizer, principalmente nos trabalhos das mangueiras, né, é claro que envolve todo o trabalho das escolas minimalistas de serialismo. Mas os artistas serialistas eles geralmente tendem a uma simplicidade distante do barroco, por exemplo, o Carl Andre [....] Ele tem $500 \mathrm{~m}$ de mangueira enrolada né, então ele tem um rebuscamento barroco muito grande, e, eu acho que existe na arte, na supercontemporânea, no mundo, hoje, uma tendência, não é exclusiva, pois as tendências são múltiplas e são várias, né, e existe a tendência de alguns artistas trabalharem com esse mundo do barroco [...] um dos artistas que tem essa característica é o Jeff Koons (anexo 5).

Trata-se de uma peça de parede cuja forma se remete diretamente à mandala, elemento místico e hipnótico que atrai o olhar demorado do espectador, que, por vezes, nem se dá conta de que a matéria-prima consiste em mangueiras de plástico, embora sua cor e matéria, tal como no minimalismo, estejam em destaque.

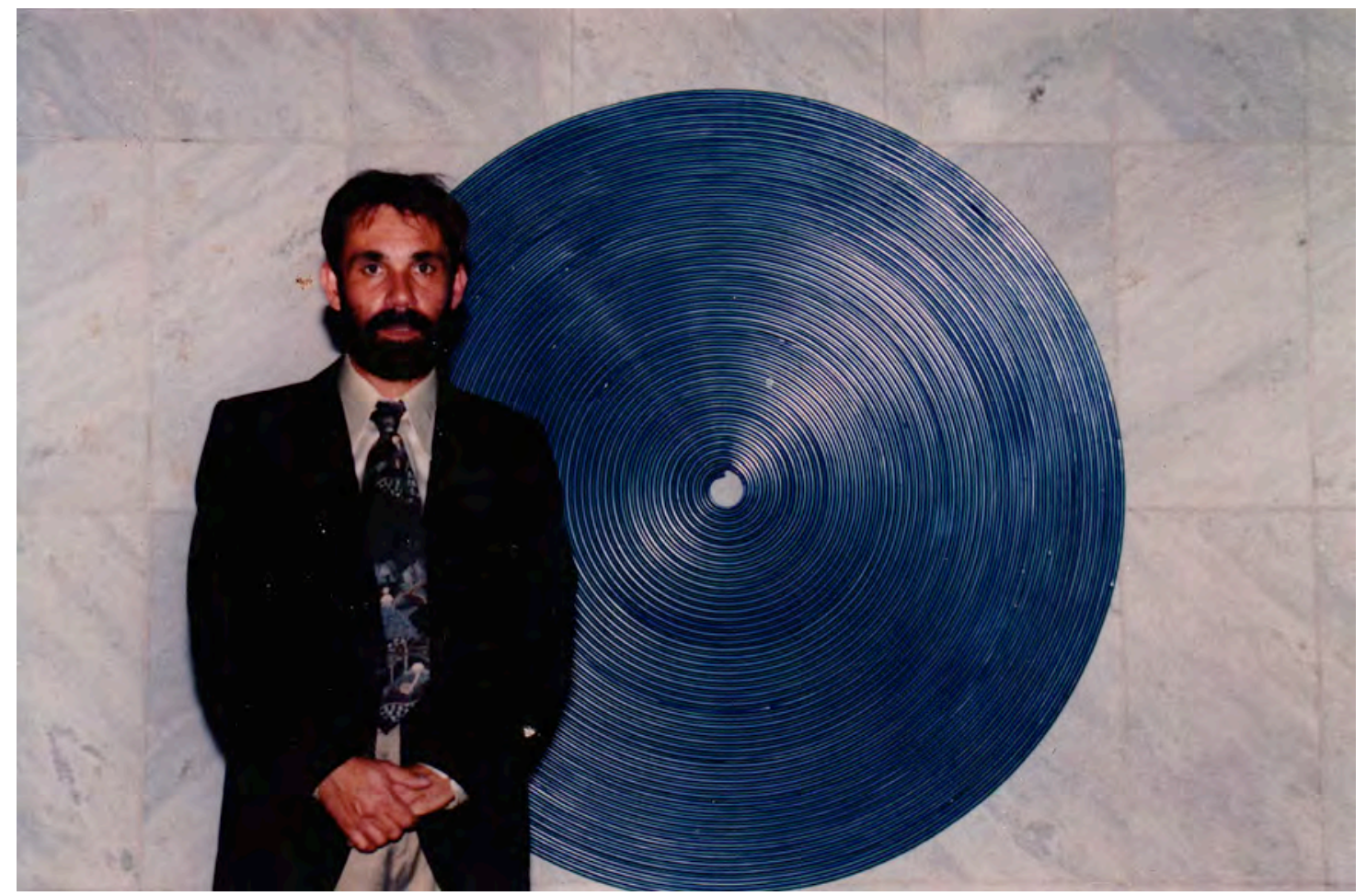

Figura 64 - Luiz Henrique Schwanke em frente a Mandala, 1989. 500 m de mangueira de plástico

Fonte: acervo da família Schwanke 


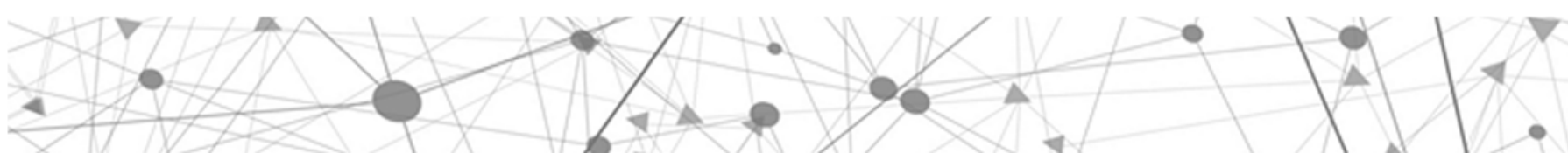

Ao mesmo tempo, de simples execução, na construção de uma forma simples, a peça traz rebuscamento, movimento e até exagero pela quantidade de mangueira, elementos presentes no barroco.

Também no fim dos anos 1980, Schwanke concebeu instalações fazendo uso do elemento luz, agora utilizado de maneira concreta. No total, o artista criou quatro projetos, dos quais três foram realizados em vida. Um deles é o Paralelepípedo de Luz, cuja origem, segundo sua amiga, a jornalista Néri Pedroso, está em uma instalação formada por dois refletores com espetos de churrasco, promovida em 1990, na Coletiva de Artistas de Joinville, no Museu de Arte de Joinville ${ }^{117}$ (figura 65).

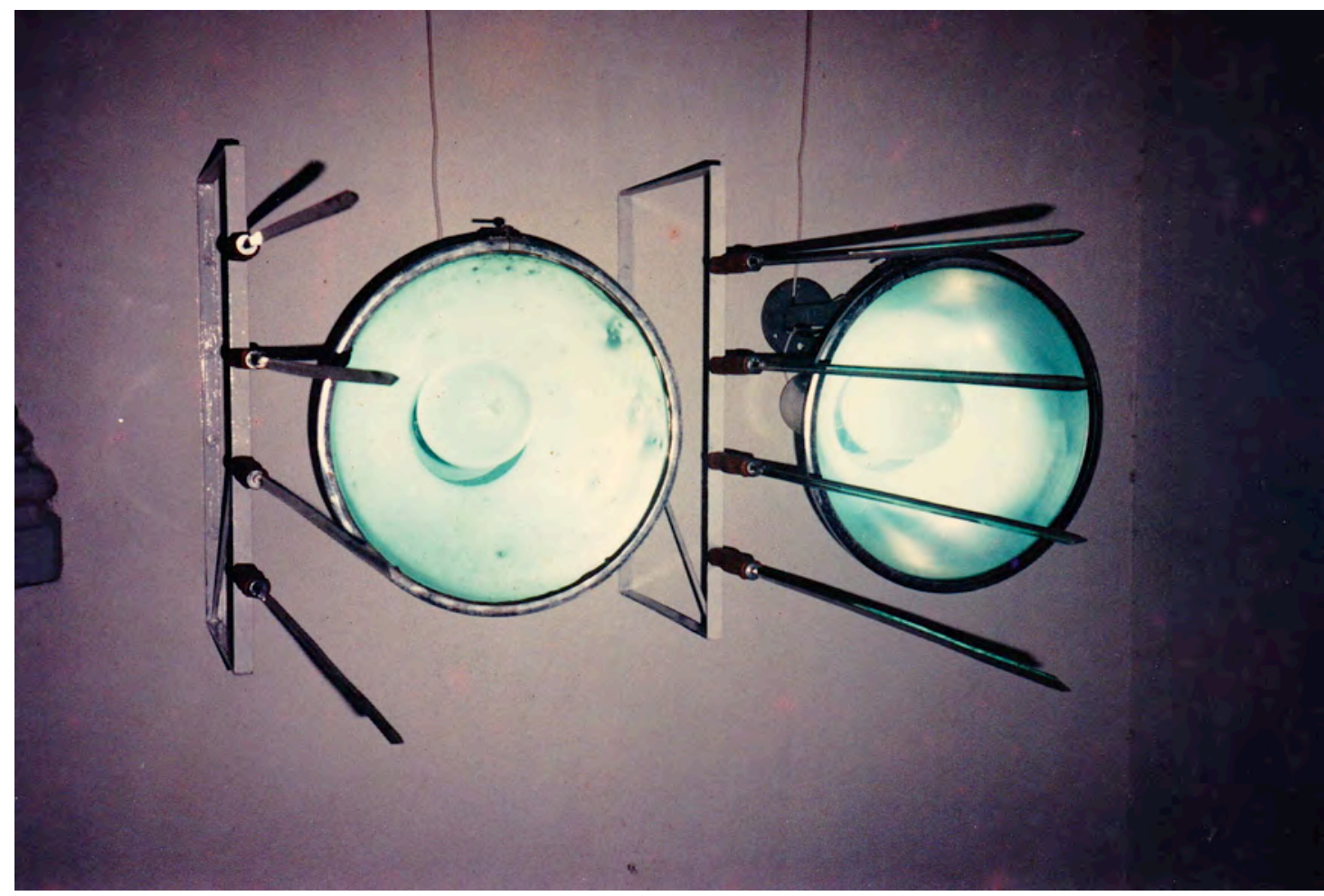

Figura 65 - Sem título, Luiz Henrique Schwanke, 1990. Refletores e espetos de churrasco. Coletiva de Artistas de Joinville. Museu de Arte de Joinville, Santa Catarina Fonte: arquivo do artista

\footnotetext{
${ }^{117}$ Em relação à origem do trabalho Paralelepípedo de Luz, em uma conversa pessoal, continuada via e-mail, Néri Pedroso relata: "A origem está nos dois refletores expostos na Coletiva em 1990 no MAJ [Museu de Arte de Joinville]. Aqui em casa há um trabalho na sala composto de dois espetos, um dentro do outro. Ganhei dele enquanto estava no processo de criação. 0 trabalho dá uma noção da fatura da obra apresentada no Panorama do Volume. Ele era muito preocupado sobretudo com a segurança. 0 biombo e 0 alerta (um recado, uma plaquinha), que retira de si a responsabilidade por algum dano ocular, são criados em função disso. Considero esse trabalho, por seus resultados formais, o mais potente de todos".
} 
A princípio, Paralelepípedo de Luz (figura 66) era composto apenas por uma parede de luz, na qual estavam instalados 20 refletores de 300 watts cada intercalados por espetos de churrasco e sustentados por uma estrutura de ferro. Ao ligar os refletores, uma grande quantidade de luz era projetada, de forma a tomar conta do ambiente e interferir diretamente, e até agressivamente, no olhar do espectador, já que não é possível contemplar diretamente toda aquela luminosidade. Schwanke (s.d.) (anexo 3) diz:

A luz intercalada com o espeto de churrasco provoca a alteração do sentido de espaço pelo ofuscamento - perda da noção de distância, gerando insegurança. A noção de proximidade/distância da obra se altera, como em algumas obras da pop art, em que o corpo do espectador se movimenta para acompanhar o ritmo das formas no quadro. [...] E os raios de luz dos refletores são como espadas disparadas em todas as direções. Mas maiores, muito maiores, que talvez Bachelar que não gostava de luz mudasse de opinião.

Preocupado em prejudicar a visão de alguém, Schwanke consultou alguns oftalmologistas que o alertaram que de fato isso poderia acontecer. Foi então que, segundo Néri Pedroso, se optou por acrescentar à instalação uma plaquinha de alerta em relação ao perigo e três paredes de tecido, quase brancas, de modo que a luz ficasse aprisionada, formando um grande volume, o qual apelidou de Paralelepípedo de Luz (figura 66). Assim, o espectador poderia escolher entre ultrapassar as paredes para experenciar aquela quantidade de luz, ou apenas contemplar, do lado de fora, a luz que fugia através dos tecidos. 


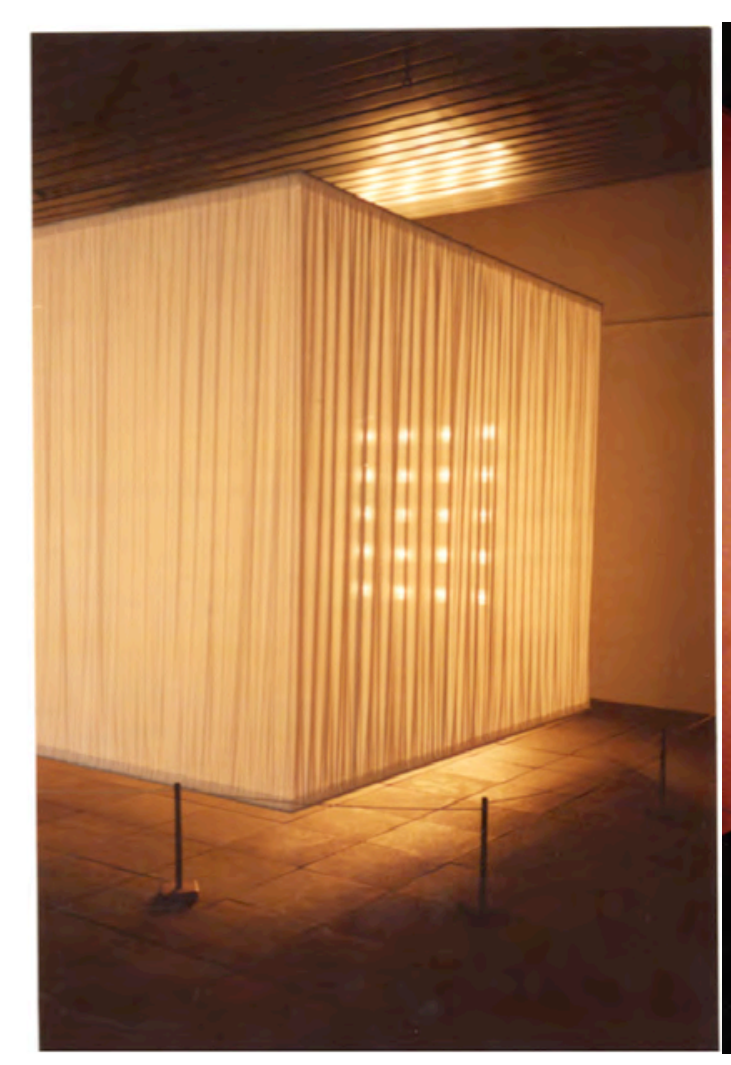

A

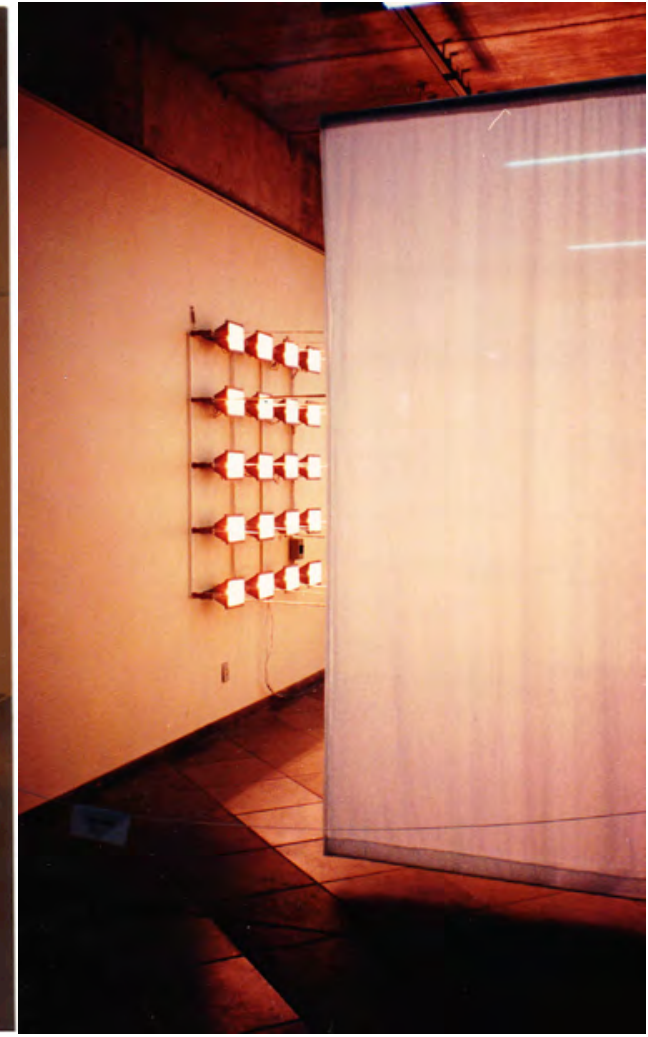

B

Figura 66 - Paralelepípedo de Luz, Luiz Henrique Schwanke, 1990. Vinte spots de luz de 300 watts, 20 espetos, $33 \mathrm{~m}$ de cortina de algodão. $5 \mathrm{~m} \times 3 \mathrm{~m} \times 5 \mathrm{~m}$. Panorama Catarinense do Volume

Fonte: arquivo do artista. Acervo da família Schwanke

A vivência direta da luz produzida no trabalho gera medo e insegurança, tanto pela cegueira momentânea como pelos espetos de churrasco, que aqui fazem o papel do dedo. Ao relatar a sua trajetória, Schwanke (s.d.) escreve:

Da parede de luzes, sem os espetos, cheguei ao cubo de luz, talvez próximo do concretismo latino-americano (imagem viva, caliente, sensual). Me lembro da primeira vez que vi o Cubocor, de Aloísio Carvão, para mim obra fundamental da arte brasileira, tanto quanto Macunaíma, de Andrade, ou o Tropicalismo, de Oiticica (anexo 3).

Por meio de uma conversa com o concretismo latino-americano, na discussão do trabalho Cubocor (1960), de Aluísio Carvão, conforme relatado pelo artista, Schwanke deu forma à instalação Cubo de Luz ou Antinomia, em 1991, projeto realizado apenas uma vez, na 21. ienal Internacional de São Paulo (figura 67). Trata-se de um cubo de $3 \mathrm{~m}^{2}$ integrado por 45 lâmpadas de 2 mil watts de multivapores metálicos, todas voltadas para a parte interior, na projeção de 90 mil 
watts de luz. Como declarou em uma reportagem realizada pela TV Record, “persegui o ideal utópico de fazer a maior concentração de luz de mundo, dentro desse cubo" (À LUZ DE..., 2008).

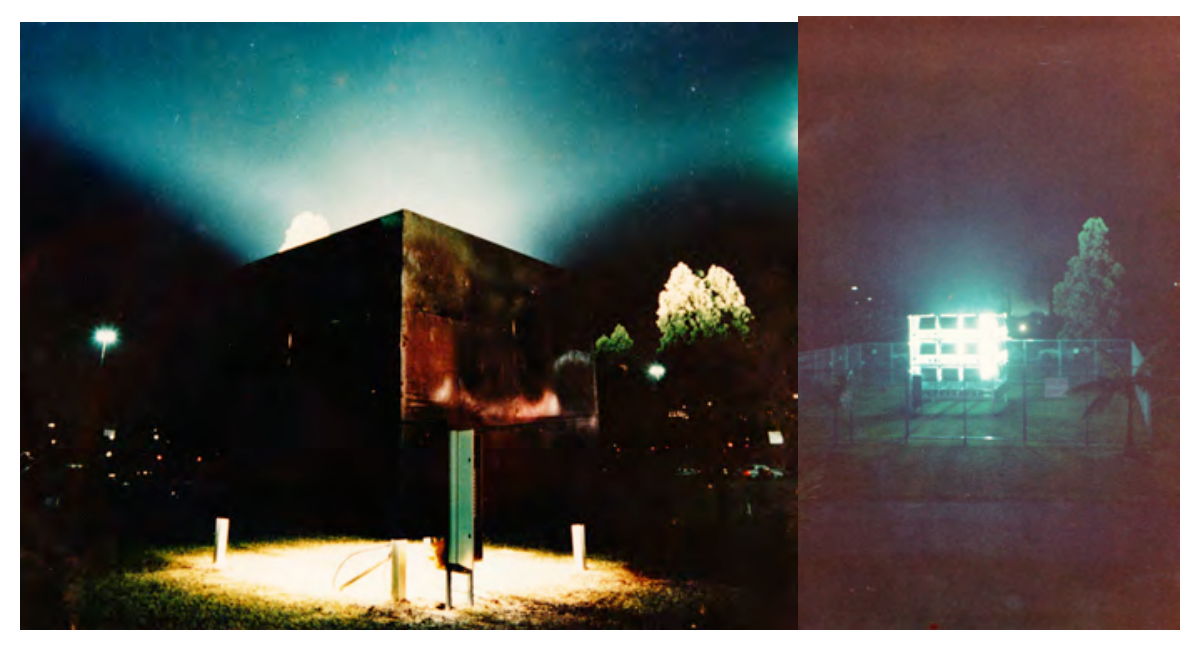

A

B

Figura 67 - Cubo de Luz ou Antinomia, Luiz Henrique Schwanke, 1991. Estrutura metálica, 45 lâmpadas de multivapor metálico. $3 \mathrm{~m}^{2}$. 21. a Bienal Internacional de São Paulo Fonte: arquivo do artista

Portanto, Schwanke construiu uma escultura feita de luz. Ao trabalhar a forma do cubo como uma estrutura aparente, tendo a paisagem como suporte e parte integrante, o artista estabelece um diálogo também com o minimalismo e, assim como Dan Flavin e Donald Judd, utiliza o objeto por si mesmo; o material fala diretamente ao espectador. Entretanto, diferentemente da obra de Flavin, a de Schwanke provoca instabilidade, como escreve o próprio artista:

Trinta anos atrás Flavin pegou lâmpadas para realizar obra. Sinto em Flavin que suas instalações me situam numa plenitude paradisíaca, como se estivesse em outra dimensão, em calma e segurança (isso independe de um juízo estético). É como se um sentimento de perda da realidade tomasse conta do meu ânimo. Vejo então que minha seriação de luzes busca o contrário: a provocação, a insegurança (SCHWANKE, s.d.) (anexo 3).

Já no Cubocor, de Carvão, é a cor pigmento que grita aos olhos do espectador, enquanto em Schwanke a força é a da cor luz. Carvão dá concretude e fisicalidade à cor vermelha, o que acaba por provocar a sua retração. Schwanke coloca o espectador em contato direto com o elemento luz, ao tentar contemplá-la, 
vivenciando o seu extremo oposto, que é a escuridão. Assim, o Cubo de Luz ou Antinomia faz um paradoxo, pois se configura na imaterialidade, uma vez que é feito de luz, então visível, porém incontemplável, já que não se pode contemplar aquela grande quantidade de luz, equivalente à utilizada por dois estádios de futebol. Assim, tendo o elemento luz como ponto de partida, por meio da discussão e exploração da relação claro/escuro em seus desenhos, Schwanke possibilita ao espectador a experiência real dessa antinomia, na construção de um trabalho que fala diretamente aos sentidos. Trata-se exclusivamente da vivência da luz, a qual quase se torna matéria e, consequentemente, o seu extremo oposto.

Tendo a Antiguidade Clássica como ponto de partida ainda na infância, os trabalhos produzidos por Schwanke discutem e comentam, ao longo de sua trajetória, o desdobramento dos princípios clássicos por meio do Renascimento, do Barroco, do Modernismo, chegando ao Pós-Modernismo, sempre na discussão da luz, do gesto e da exaltação da história da arte. É como se fizesse uso de sua produção para atualizar as discussões clássicas, aproximando sensivelmente 0 público da arte.

Ironicamente, e em diálogo com a contraposição, muito presente em sua obra, antes de tirar a própria vida, a mensagem que ficou na secretária eletrônica, gravada de sua voz, foi um fragmento apropriado de Ezra Pound: "0 medo de que os clássicos retornassem e tivessem ampla circulação perturba o meu sono".

\subsection{Exposição A casa tomada (de Julio Cortázar) por desenhos que não deram certo. Desenhos de 1978/80. Apogeu do claro-escuro pós-Caravaggio}

Conforme pode ser constatado pelo breve estudo realizado acerca da trajetória de Schwanke, a luz, o gesto e a apropriação da história da arte são elementos importantes em sua produção. Entre as exposições realizadas em vida, uma das mais significativas em sua trajetória foi $A$ casa tomada (de Julio Cortázar) por desenhos que não deram certo. Desenhos de 1978/80. Apogeu do claro-escuro pós-Caravaggio. Nessa exposição, os elementos citados estão fortemente presentes e acabam por evidenciar, ainda no início de seu percurso artístico, a complexidade e o refinamento de seu pensamento artístico, assim como o seu profundo conhecimento pela história da arte, na revelação de um artista maduro e erudito. Por esse motivo, essa exposição foi escolhida para ser remontada, 


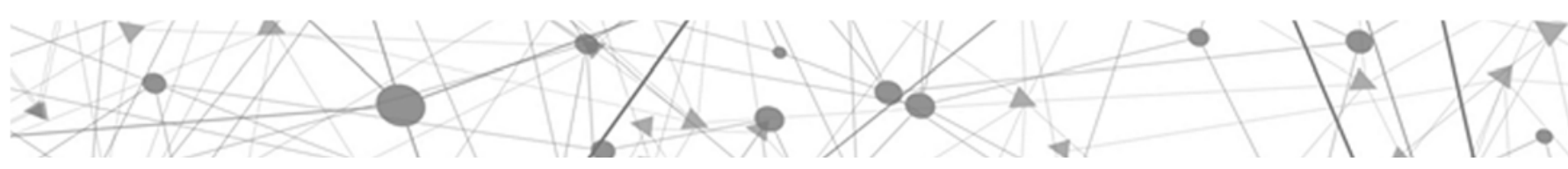

entretanto em uma versão virtual digital, com base na exploração das especificidades do ambiente virtual em rede, tendo como base a curadoria educativa, já discutida no capítulo 2 desta tese.

Essa exposição é resultado de um prêmio recebido no 36 . $^{\circ}$ Salão Paranaense de 1979 e foi promovida na Galeria Sérgio Milliet, do Museu Nacional de Belas Artes, do Rio de Janeiro, em 1980, a qual na época era gerenciada pela Fundação Nacional de Artes (Funarte). Como sugerido pelo título, a exposição é composta de três diferentes partes: a primeira é a instalação $A$ casa tomada (de Julio Cortázar) por desenhos que não deram certo; a segunda, pelo conjunto de Desenhos de 1979/80; e a terceira, por sua vez, pelo trabalho Apogeu do claro-escuro pós-Caravaggio.

\subsubsection{A casa tomada (de Julio Cortázar) por desenhos que não deram certo}

A casa tomada (de Julio Cortázar) por desenhos que não deram certo consiste numa instalação composta por $500 \mathrm{~m} \times 2 \mathrm{~m}$ de papel em branco amassado, de forma a ocupar boa parte da galeria (figura 68).

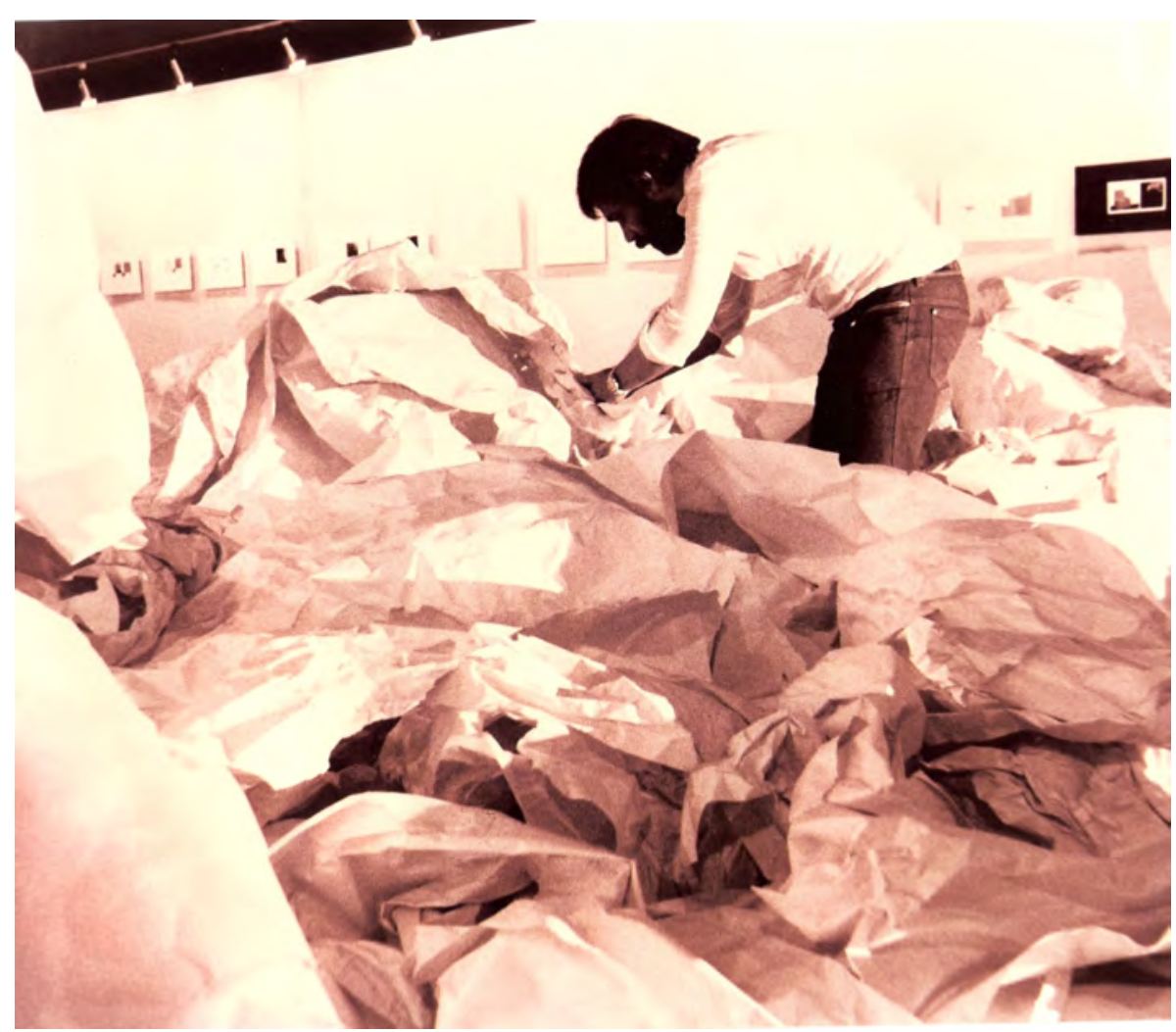

Figura 68 - Vista do processo de montagem de $A$ casa tomada (de Julio Cortázar) por desenhos que não deram certo, 1980. Museu Nacional de Belas Artes, Rio de Janeiro Fonte: foto de Antonio Jaques da Silva. Acervo da família Schwanke

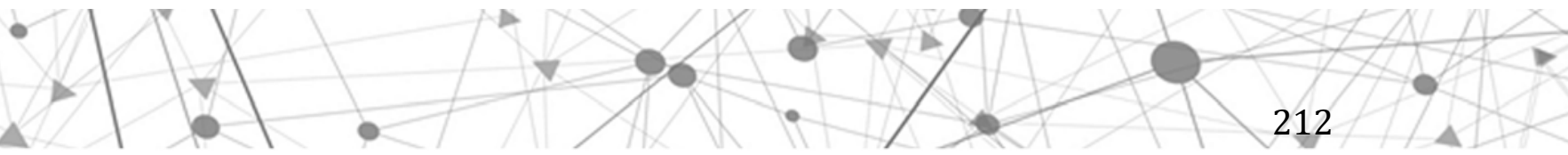


Um casal de amigos do artista, Antonio Jaques da Silva e Vera Lucia de Oliveira da Silva, em depoimento escrito com base em conversas que tiveram com Schwanke sobre essa exposição (anexo 6), relata que ele contou que, durante a execução dos desenhos que compuseram a segunda parte da mostra (Desenhos de 1978/80), se viu em meio a diversos papéis amassados e jogados no chão. Eram os desenhos desprezados, aqueles que não deram certo. Conforme escrevem seus amigos:

\begin{abstract}
Falou-nos, então, de um dia em que ele, sucessivamente, desenhava e desprezava o desenho, amassando o papel e jogando o trabalho fora - porque não gostava do resultado: eram desenhos que não davam certo, para ele, naquele dia. Quando deu por si, a sala estava tomada por papel amassado, cercando-o por todos os lados. Ele foi, então, atravessado por uma ideia: $A$ casa de Bernarda Alba, tomada por desenhos que não deram certo. Pareceu-lhe uma instalação interessante (SILVA; OLIVEIRA, 2016) (anexo 6).
\end{abstract}

Assim sendo, a princípio, a ideia inicial para a instalação estava relacionada com a peça de teatro $A$ Casa de Bernarda Alba, de Lorca, a cuja montagem realizada pelo Grupo Momento de Teatro Schwanke assistira em 1975, no Teatro Guaíra. Pode-se constatar então que, embora a instalação e o conjunto de desenhos sejam trabalhos distintos, eles foram concebidos com base nas mesmas fontes, na discussão de questões que se cruzam, já que na série de desenhos que executava naquele momento substituía personagens retratadas em pinturas por artistas de diferentes períodos, por poltronas e cadeiras, cuja inspiração, segundo seu amigo Paulo Schroeder, estava na montagem daquela peça a que assistiram juntos.

Mais para frente, narram Jaques e Vera, Schwanke substituiu Lorca pelo realismo fantástico do conto $A$ casa tomada, de Cortázar. 0 conto trata da história de um casal de irmãos que herda a casa dos pais. Aos poucos, uma coisa vai tomando conta da casa, cômodo por cômodo, de forma que os irmãos não têm outra alternativa senão sair da casa, agora toda tomada, deixando para trás tudo aquilo que tinham. Assim, eles acabam por trancar a porta, jogar as chaves no bueiro e irem embora.

A instalação feita por Schwanke chegava a atrapalhar o espaço de circulação do público, que já não tinha muito espaço de recuo para observar os trabalhos, de forma a estabelecer com ele uma relação de contemplação mais intimista. 


\subsubsection{Desenhos de 1978/80}

Como já tratado anteriormente, ao ter contato mais profundo com a história da arte, Schwanke interessou-se muito pelo elemento luz, tendo como ponto de partida especialmente a obra de Caravaggio. 0 artista barroco destaca-se tanto pelo tratamento dado às suas composições pelo contraste de luz e sombra como pelo acabamento naturalista dado às figuras religiosas, como se o acontecimento religioso fosse "um acontecimento contemporâneo entre gente humilde" (JANSON, 1992, p. 500).

Entre os 30 trabalhos que compuseram a exposição, Schwanke atualiza a discussão de Caravaggio, fazendo uso de um desenho hiper-realista, muitas vezes confundido com foto, na substituição das figuras religiosas e da burguesia retratada por peças comuns de mobiliário, copiadas de catálogos publicitários. Ressalta-se mais uma vez que, desses 30 desenhos, apenas 26 hoje são conhecidos e integram as seguintes séries: De uma conversa com Paulo sobre Mondrian, São Sebastião, Os Revisitamentos e Os Dedos - a última integra o conjunto Um Pouco de Paranismo.

De uma conversa com Paulo sobre Mondrian é uma série composta por três trabalhos, todos resultado da discussão que Schwanke estabeleceu com seu amigo Paulo sobre a produção de Mondrian. Os dois trabalhos de Mondrian que são apropriados, copiados e discutidos por Schwanke foram produzidos pelo artista holandês no período entre 1920 e 1940, quando fez uso exclusivamente de linhas retas (verticais e horizontais), na construção de grades, empregando as cores primárias, o branco (luz) como predominante e com frequência o negro (não luz) (ARGAN, 1992). São eles Composição Losango com Vermelho, Cinza, Azul, Amarelo e Preto (figura 69), de 1924, e Composição em Vermelho, Azul e Amarelo (figura 70), de 1930. 


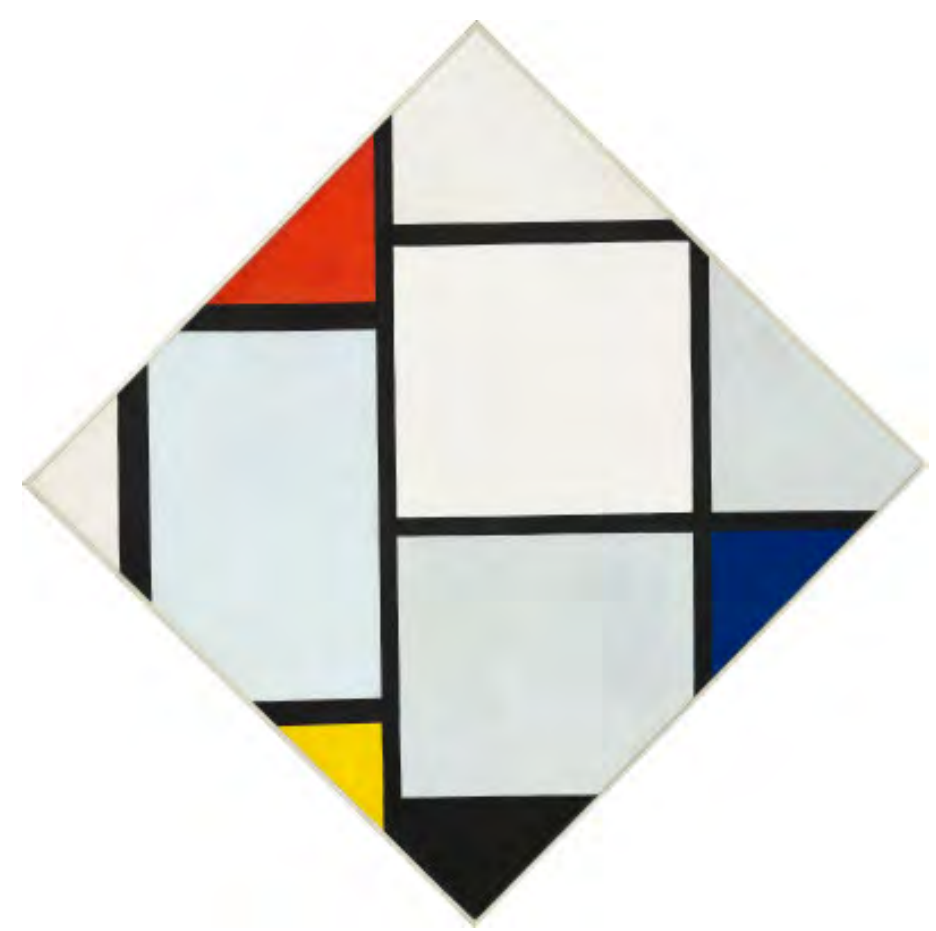

Figura 69 - Composição Losango com Vermelho, Cinza, Azul, Amarelo e Preto, Piet Mondrian, de 1924. Óleo sobre tela. $142,8 \mathrm{~cm} \times 142,3 \mathrm{~cm}$. Galeria Nacional de Arte, Londres, Inglaterra

Fonte: disponivel em <http://www.nga.gov/content/ngaweb/Collection/art-objectpage.52614.html>. Acesso em: 18 jul. 2016

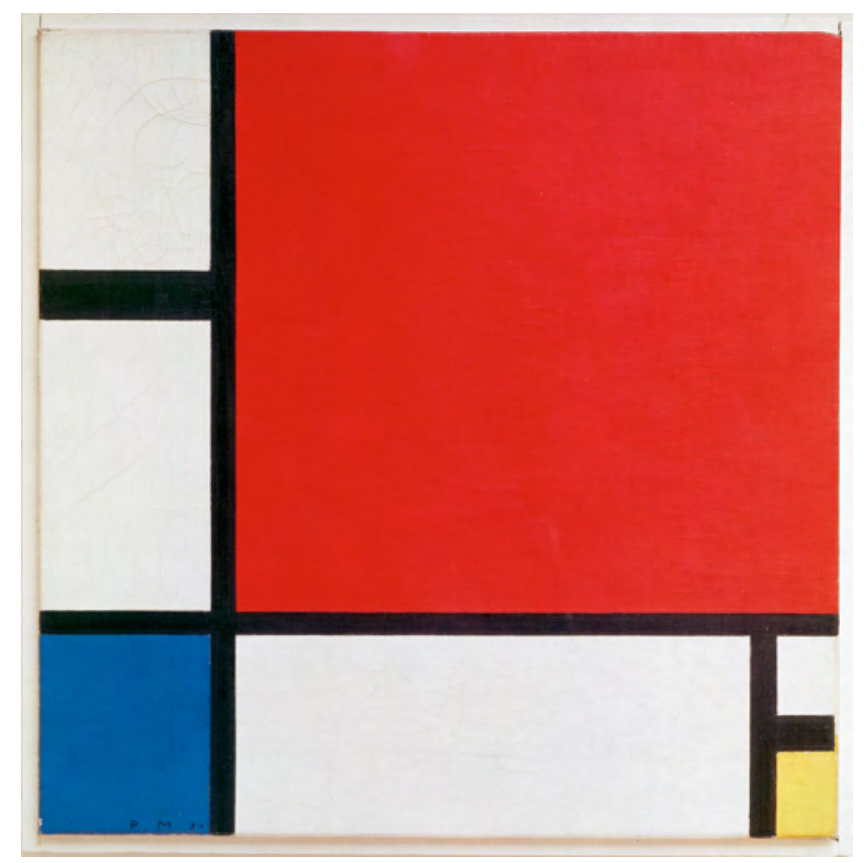

Figura 70 - Composição em Vermelho, Azul e Amarelo, Piet Mondrian, 1930. Óleo sobre tela. $46 \mathrm{~cm} \times 46 \mathrm{~cm}$. Acervo do Museu das Belas Artes, Zurique, Suiça

Fonte: disponivel em <http://www.kunsthaus.ch/en/the-collection/painting-andsculptures/modern-art/mondrian-and-constructivism/?redirect_url=title\%3DPerspectives >. Acesso em: 18 jul. 2016

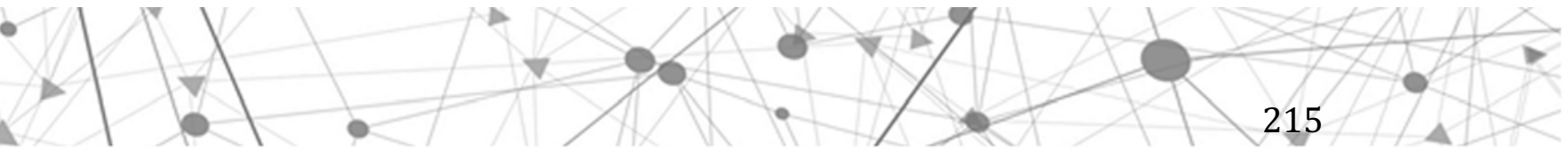



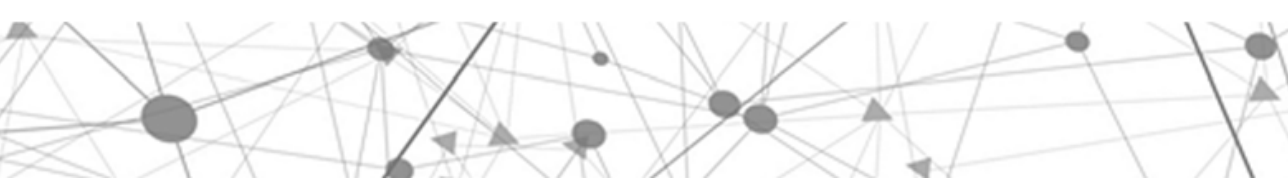

Percebe-se que Schwanke conhecia profundamente a produção de Mondrian e que a escolha de trabalhos desse período, muito provavelmente, se deve à forma como Mondrian faz uso não apenas das cores, mas também da luz e de seu contrário, a não luz. Isso se dá pelo fato de que nas composições do artista holandês produzidas nesse período são exploradas variações de quantidades de luz, reduzidas a qualidades diferentes de cor. Afirma Argan (1992, p. 412):

Mondrian propõe transformar a superfície (empírica) em plano (entidade matemática). Subdividindo a superfície por meio das coordenadas verticais e horizontais, resolve numa "proporção" métrica tudo o que, na natureza, apresenta-se como altura e largura. Resta o que se apresenta na terceira dimensão: e são as infinitas sensações variáveis segundo a cor local, a distância e a luz.

Nos desenhos de Schwanke que compõem essa série (figuras 71, 72 e 73), é utilizada a mesma proporção de cor e, consequentemente, de luz da pintura apropriada de Mondrian, contudo pela inserção de decalques figurativos.

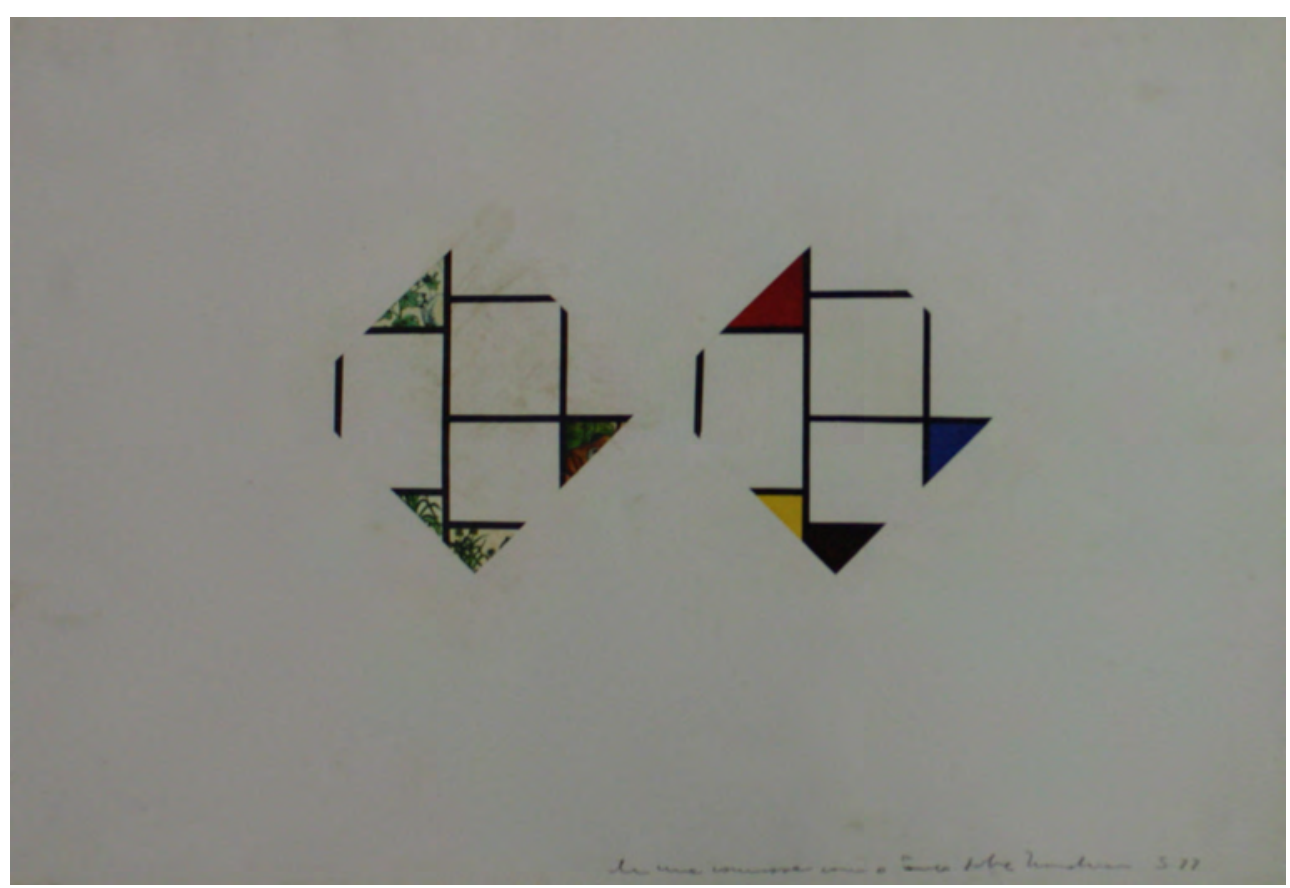

Figura 71 - De uma conversa com Paulo sobre Mondrian, Luiz Henrique Schwanke, 1977. Ecoline, letraset e decalcomania sobre papel encerado. $63 \mathrm{~cm} \times 46,5 \mathrm{~cm}$. Peça 1 Fonte: foto de Giovanna Fiamoncini. Acervo da família Schwanke 

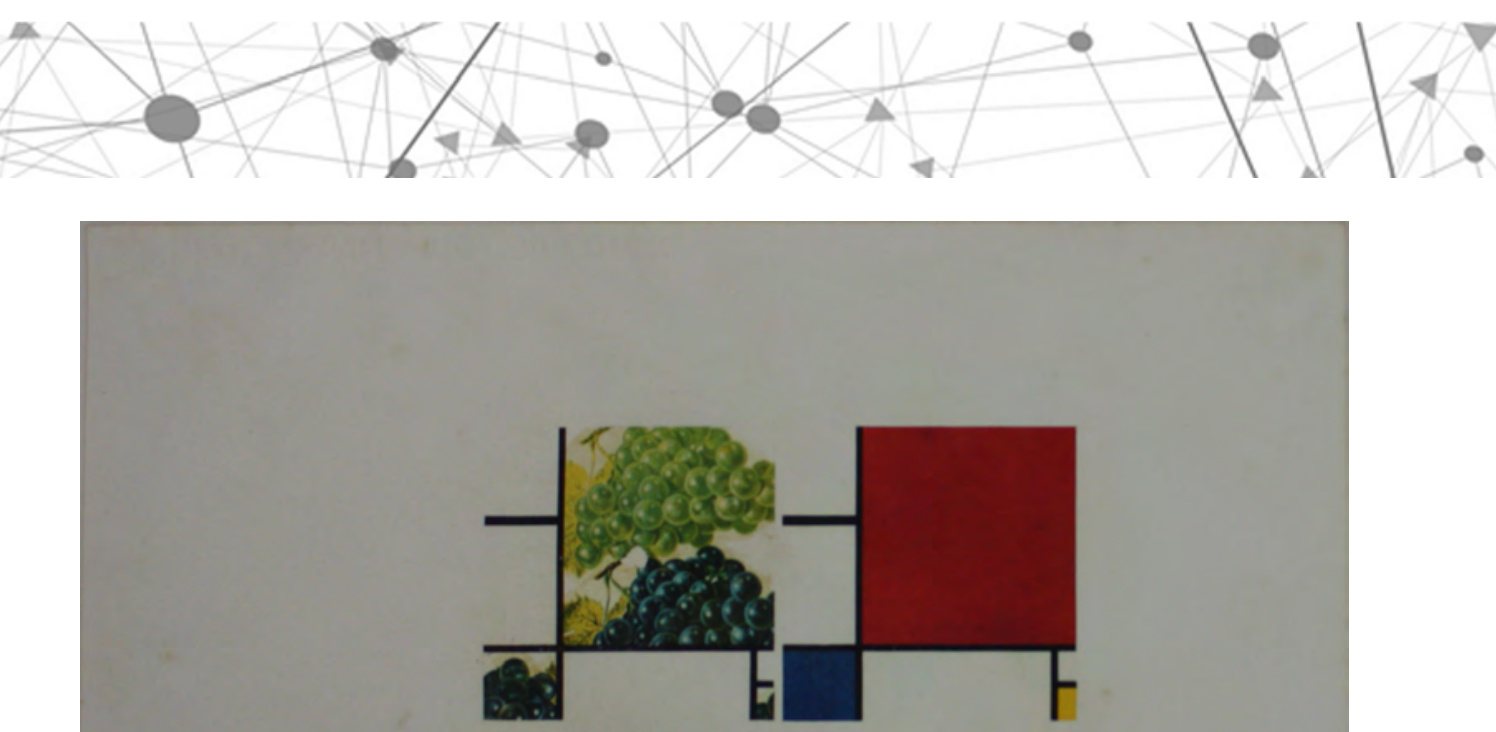

Figura 72 - De uma conversa com Paulo sobre Mondrian, Luiz Henrique Schwanke, 1977. Ecoline, letraset e decalcomania sobre papel encerado. $63 \mathrm{~cm} \times 46,5 \mathrm{~cm}$. Peça 2 Fonte: foto de Giovanna Fiamoncini. Acervo da família Schwanke

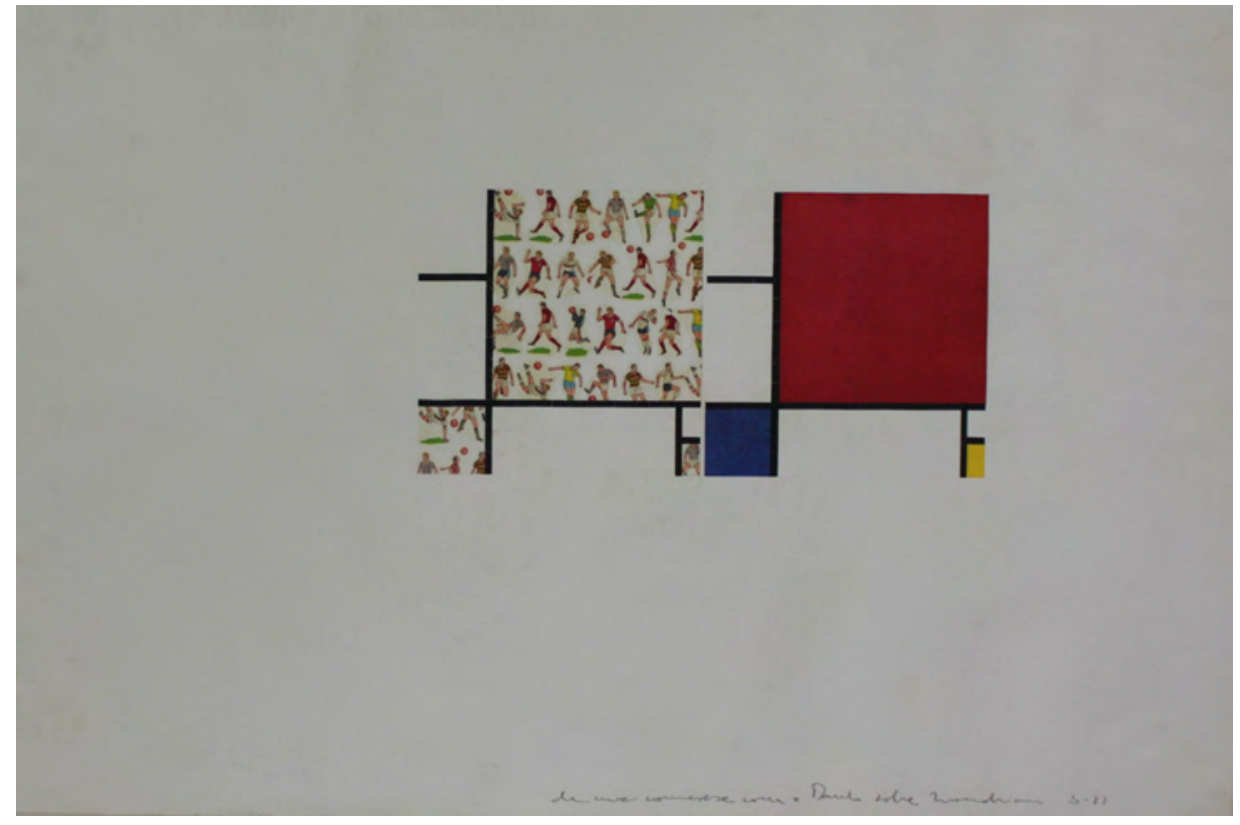

Figura 73 - De uma conversa com Paulo sobre Mondrian, Luiz Henrique Schwanke, 1977. Ecoline, letraset e decalcomania sobre papel encerado. $63 \mathrm{~cm} \times 46,5 \mathrm{~cm}$. Peça 3 Fonte: foto de Giovanna Fiamoncini. Acervo da família Schwanke

É como se Schwanke desdobrasse a natureza sintetizada nas composições do pintor holandês, estabelecendo uma relação entre o neoplasticismo de Mondrian e a pop art de Wahrol. 
Já a série São Sebastião, composta por seis desenhos, foi desenvolvida com base na pintura São Sebastião (figura 74), de Antonello da Messina. Conforme afirma Frederico de Moraes (1980), "ao fragmentar a imagem de São Sebastião, de Messina, em seis pequenos detalhes, Schwanke, por sua vez, desmistifica a religiosidade implícita na iconografia do santo, aproximando-a do universo da publicidade ou dos ídolos da cultura de massa". Assim, cada um dos desenhos traz a representação de uma parte do corpo do santo, de uma discussão atualizada, por meio da representação de imagens contemporâneas.

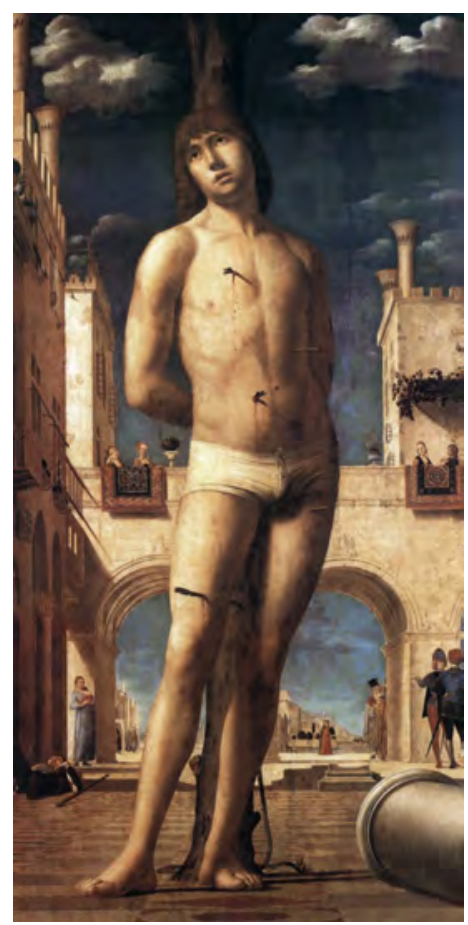

Figura 74 - São Sebastião, Antonello da Messina, 1476-77. Óleo sobre tela transferida de painel. $171 \mathrm{~cm} \times 86 \mathrm{~cm}$. Acervo: Gemäldegalerie, Dresden, Alemanha

Fonte: disponivel em: <http://www.wga.hu/index1.html>. Acesso em: 18 set. 2016

Entre os desenhos dessa série, está São Sebastião, de Antonello de Messina (retrato de Peter Jubel)" (figura 75), cuja figura do modelo alemão Peter Jubel, que substitui o santo em Schwanke, foi apropriada e copiada de uma campanha publicitária. 


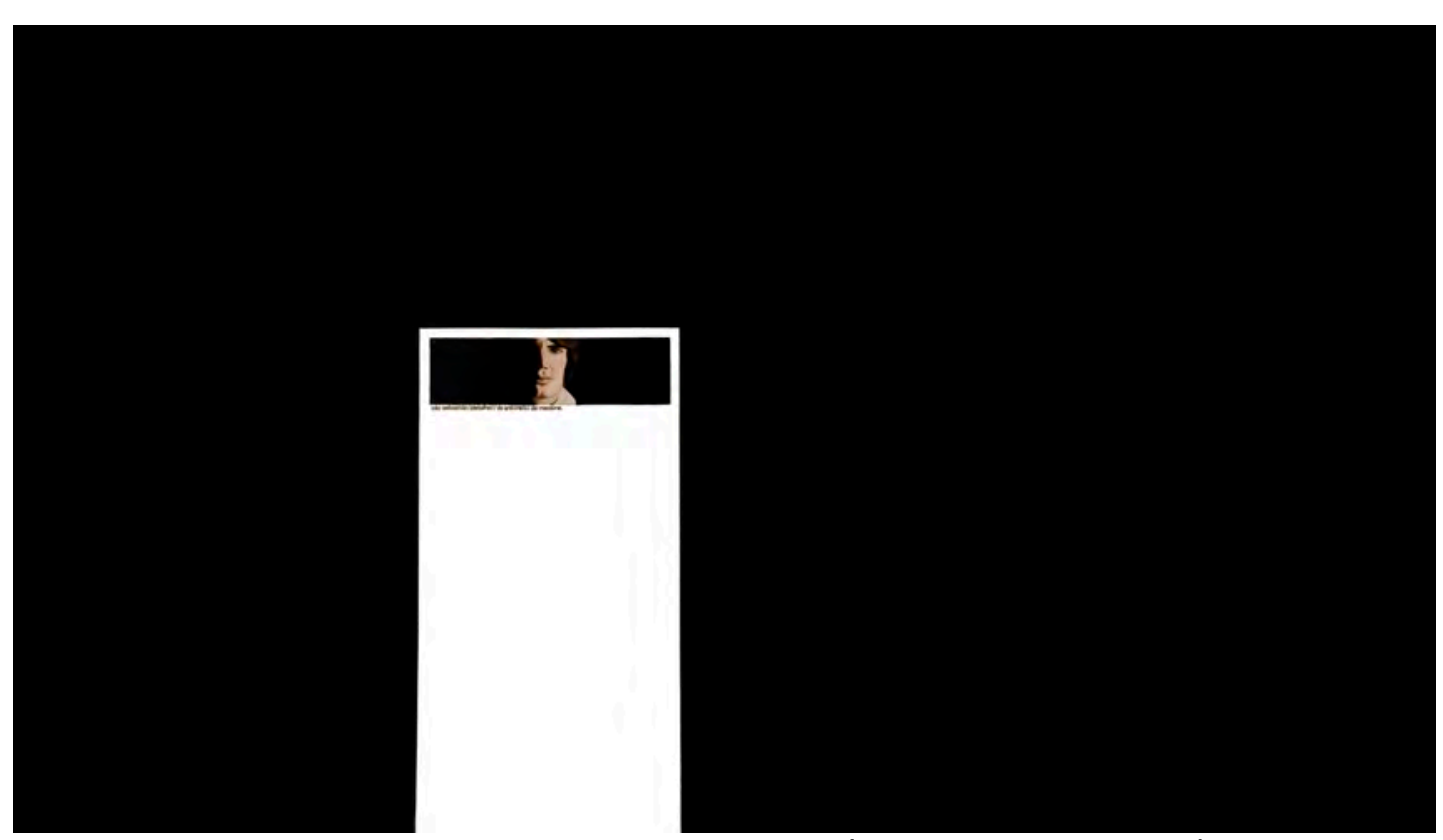

Figura 75 - São Sebastião, de Antonello de Messina (retrato de Peter Jubel), Luiz Henrique Schwanke, sem data. Grafite e aquarela sobre papel e tela. $35,1 \mathrm{~cm} \times 61,3 \mathrm{~cm}$ Fonte: foto de Peninha Machado. Acervo da família Schwanke

Antonello da Messina foi um artista do Renascimento que se destacou pelas conquistas da definição das formas por meio do uso da luz, o que pode ser observado na obra apropriada por Schwanke (figura 75), cujo tratamento de luz e sombra contribui para a definição do volume do corpo. Na pintura de Messina, a figura do santo, representada em uma composição vertical, encontra-se iluminada, enquanto o céu, que serve de fundo para a cabeça, é escurecido. Schwanke segue a lógica do jogo luz e sombra para realizar o seu desenho, em cujo fundo, preto, entra em contraste com a forma vertical branca que existe na mesma posição em que está o corpo de São Sebastião, que em Messina está iluminado.

A série de desenhos Cadeiras, por sua vez, já discutida na parte inicial deste texto, consiste na apropriação de pinturas do Renascimento, do neoclássico, do Barroco e do impressionismo, na substituição das personagens por cadeiras e poltronas e, em algumas situações, pela figura de um dedo. São conhecidos nove desenhos que compõem essa série, entre os quais, além dos já tratados anteriormente, está o Asinus in Tegulis, a Vênus Triunfante Paulina Bonaparte, de Canova" (figura 76). 


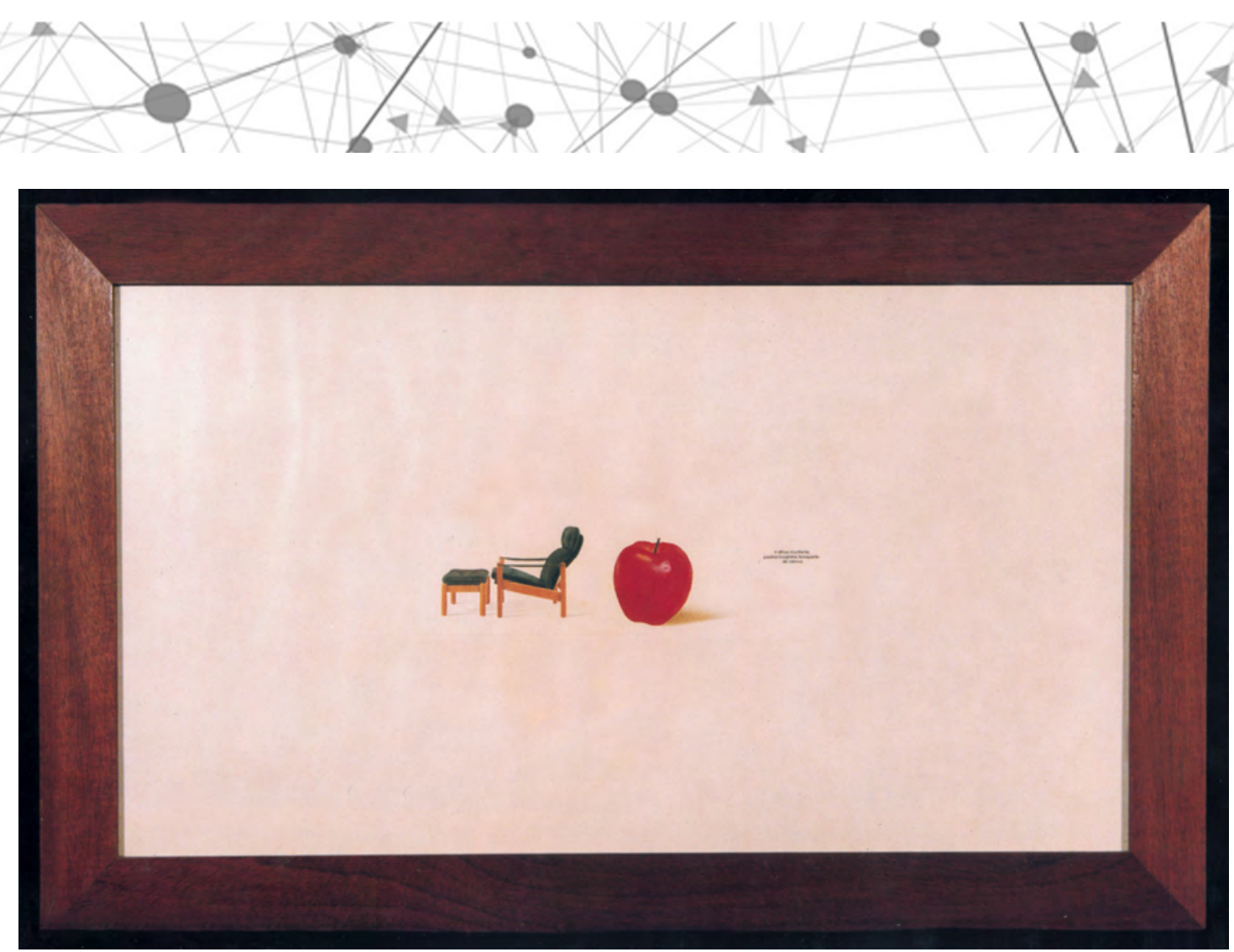

Figura 76 - Asinus in tegulis, a Vênus Triunfante Paulina Bonaparte, de Canova, Luiz Henrique Schwanke, 1979. Ecoline, lápis de cor e letraset sobre papel. $35 \mathrm{~cm} \times 62 \mathrm{~cm}$ Fonte: foto de Rui Arsego. Acervo da família Schwanke

Esse desenho foi feito com base na obra Paulina Borghese como Vênus Victrix" (figura 78), do escultor neoclássico Antoine Canova. Na escultura de Canova, Paulina aparece representada por Vênus. Muito provavelmente, a escolha de Schwanke por esse trabalho deve-se tanto pelo fato de ser uma produção neoclássica, marcada pelo resgate dos elementos da Antiguidade Clássica, nesse caso da mitologia, como também pelo gesto realizado pela personagem retratada, que segura uma pequena maçã com a mão esquerda. 


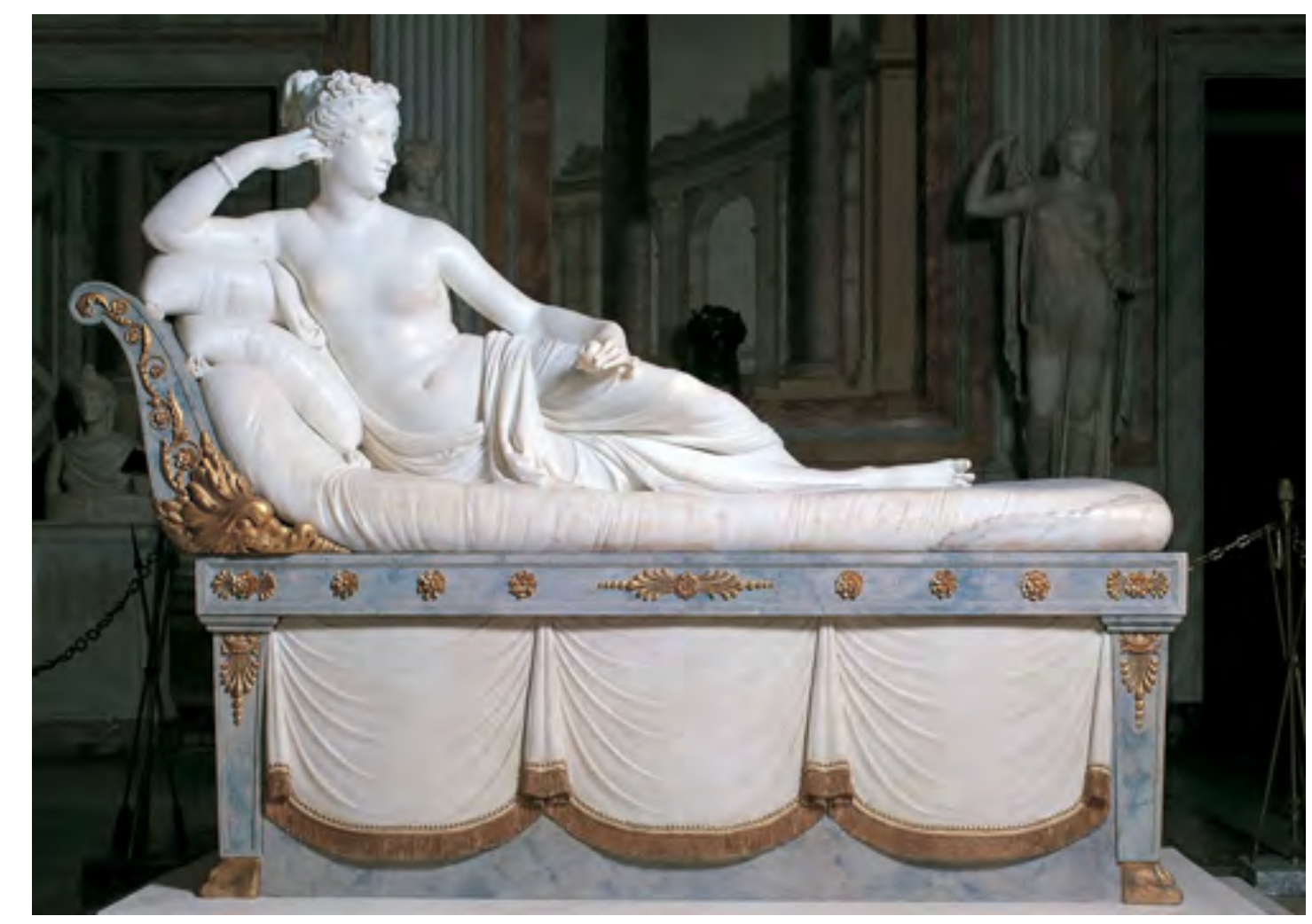

Figura 77 - Paulina Borghese como Vênus Victrix, Antoine Canova, 1800. Mármore. Acervo da Galleria Borghese, Roma, Itália

Fonte: disponível em: <http://www.galleriaborghese.it/paolina.html>. Acesso em: 19 jul. 2016

Sabe-se que o nome Paulina Bonaparte se refere à irmã de Napoleão Bonaparte. Casada com Camilo Borghese, cunhado de Napoleão, a mulher era dotada de má reputação por trair frequentemente o seu marido.

Enquanto Canova exalta Paulina por sua beleza, Schwanke ressalta a verdade sobre o seu comportamento pecaminoso. Isso se dá pela substituição de Paulina por uma chaise-longue desenhada e copiada de um catálogo de publicidade, proporcionalmente muito menor do que a figura da maçã, fruta que delicadamente segura. A maçã é um fruto que possui inúmeros significados, entre eles 0 conhecimento, a ciência, a árvore da vida e a beleza (CHEVALIER; GHEERBRANT, 2002). Contudo, em Schwanke, ela parece representar o pecado original, como referência ao gesto de traição de Paulina. Tal fato é reforçado pela frase "asinus in tegulis", que do latim significa asno no telhado, como se a situação não pudesse ser ignorada por quem a observa. Assim, o detalhe em Canova passa a ser evidência em Schwanke. Nota-se que no desenho de Schwanke há uma linha pontilhada que liga a maçã ao braço direito do móvel, invertendo, portanto, a mão utilizada para a 
realização do gesto, tal como fez na Série Sinistra Heliográfica, já discutida anteriormente.

Já a série de três desenhos Um Pouco de Paranismo faz referência ao estado em que viveu por 15 anos, quando residia na cidade de Curitiba. Em Um pouco de Paranismo / Pinheiro (figura 77), por exemplo, faz alusão à devastação sofrida pelas florestas do Paraná, nas quais foram plantados pinheiros em substituição da mata nativa (LAMAS, 1999). Em lugar de retratar o pinheiro, Schwanke faz um desenho de uma caixa de palito de fósforos, o pinheiro da Fiat Lux, cuja fábrica que produz o artigo está localizada na cidade de Curitiba e cujo nome se remete diretamente à matéria-prima natural, explorada para a sua produção. Além de, ironicamente, esse mesmo palito de fósforos, ao produzir fogo, gerar luz, ele também pode devastar florestas inteiras.

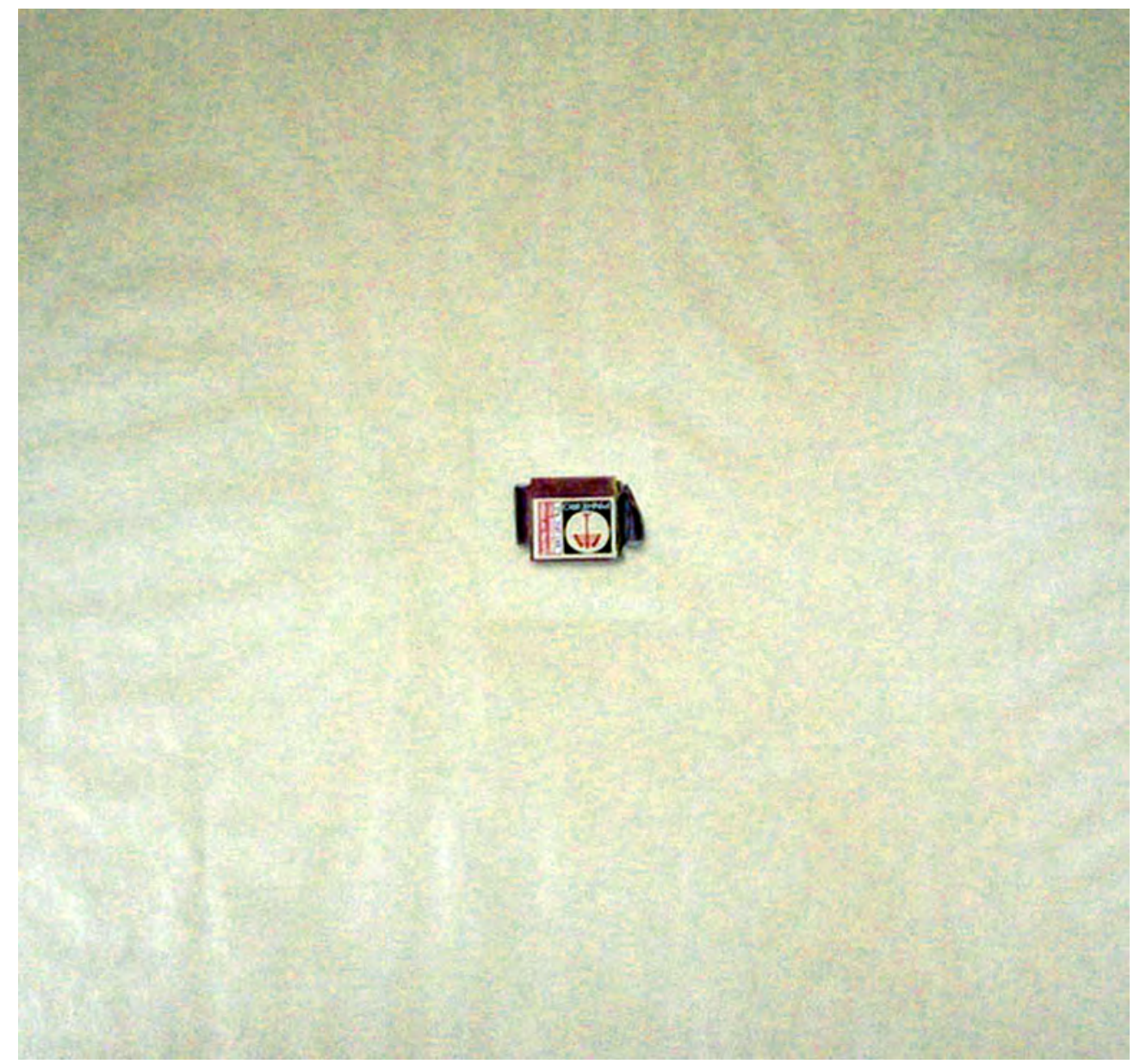

Figura 78 - Um pouco de Paranismo / Pinheiro, Luiz Henrique Schwanke, 1979. Ecoline e lápis de cor sobre papel encerado. $72,5 \mathrm{~cm} \times 77 \mathrm{~cm}$

Fonte: foto de Giovanna Fiamoncini. Acervo da família Schwanke

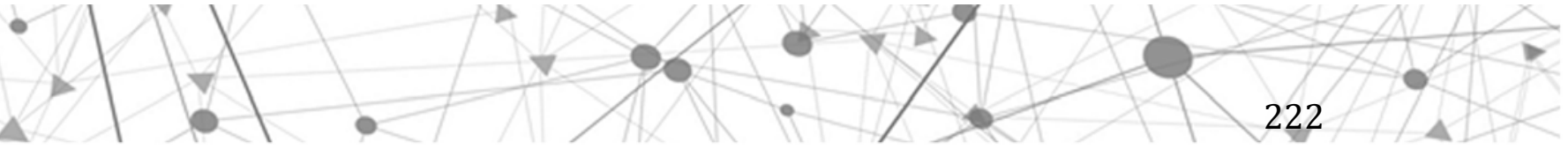


Também integra essa série um desenho que possui título duplo, e um de cada vez é destacado conforme disposição na parede. Trata-se da representação de um fragmento de uma mão esquerda, por meio do qual são exaltados o dedão e 0 intervalo da mão entre ele e o indicador. Quando o dedo está voltado para cima, o título que pode ser lido, centralizado na parte inferior, é "Um Pouco de Paranismo / Pico do Marumbi" (figura 79). Schwanke estabelece uma relação formal entre esse fragmento do corpo e o desenho do pico (figura 80).

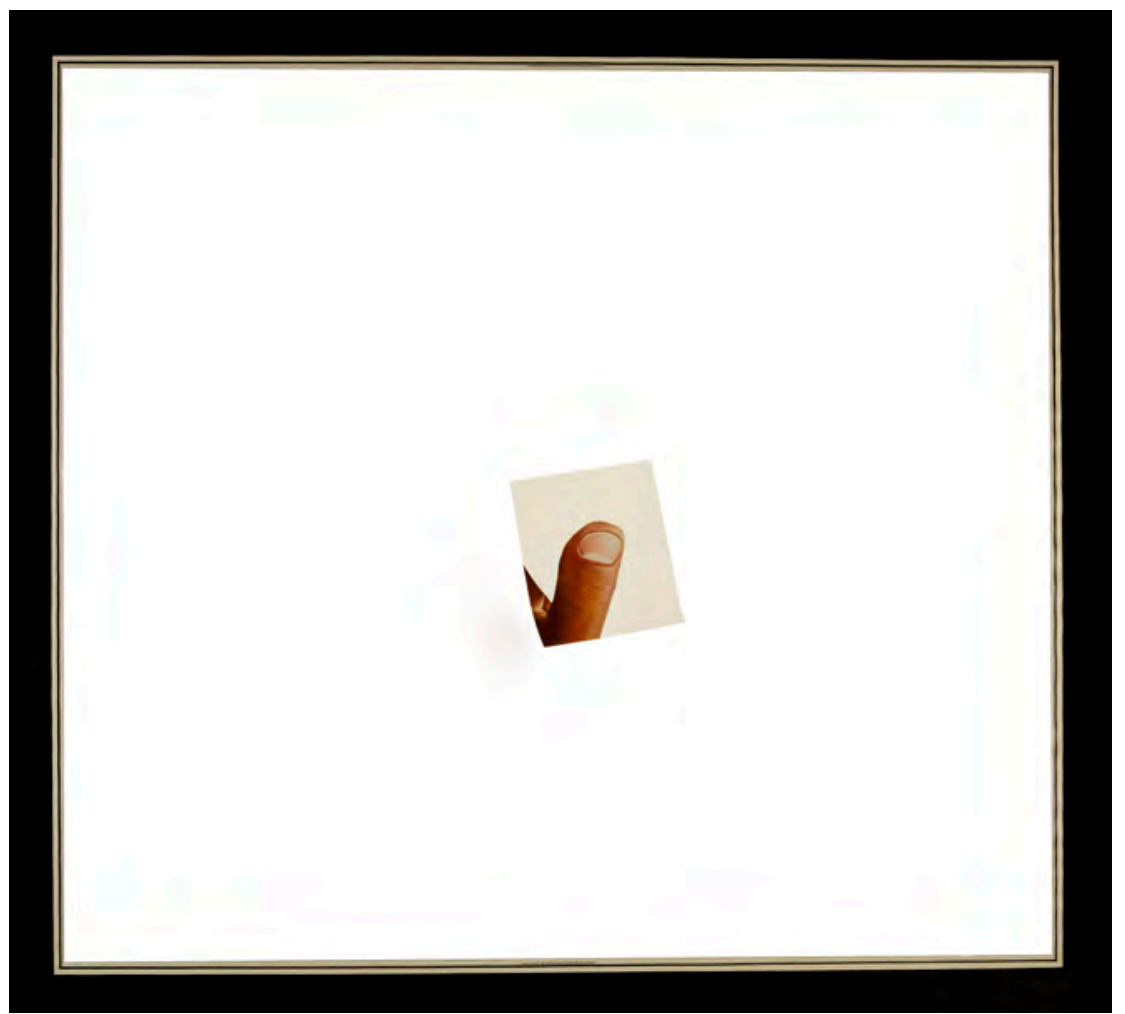

Figura 79 - Um Pouco do Paranismo / Pico do Marumbi, Luiz Henrique Schwanke, 1979. Lápis de cor e nanquim sobre papel. $73,2 \mathrm{~cm} \times 78,4 \mathrm{~cm}$ Fonte: foto de Peninha Machado. Acervo da família Schwanke 

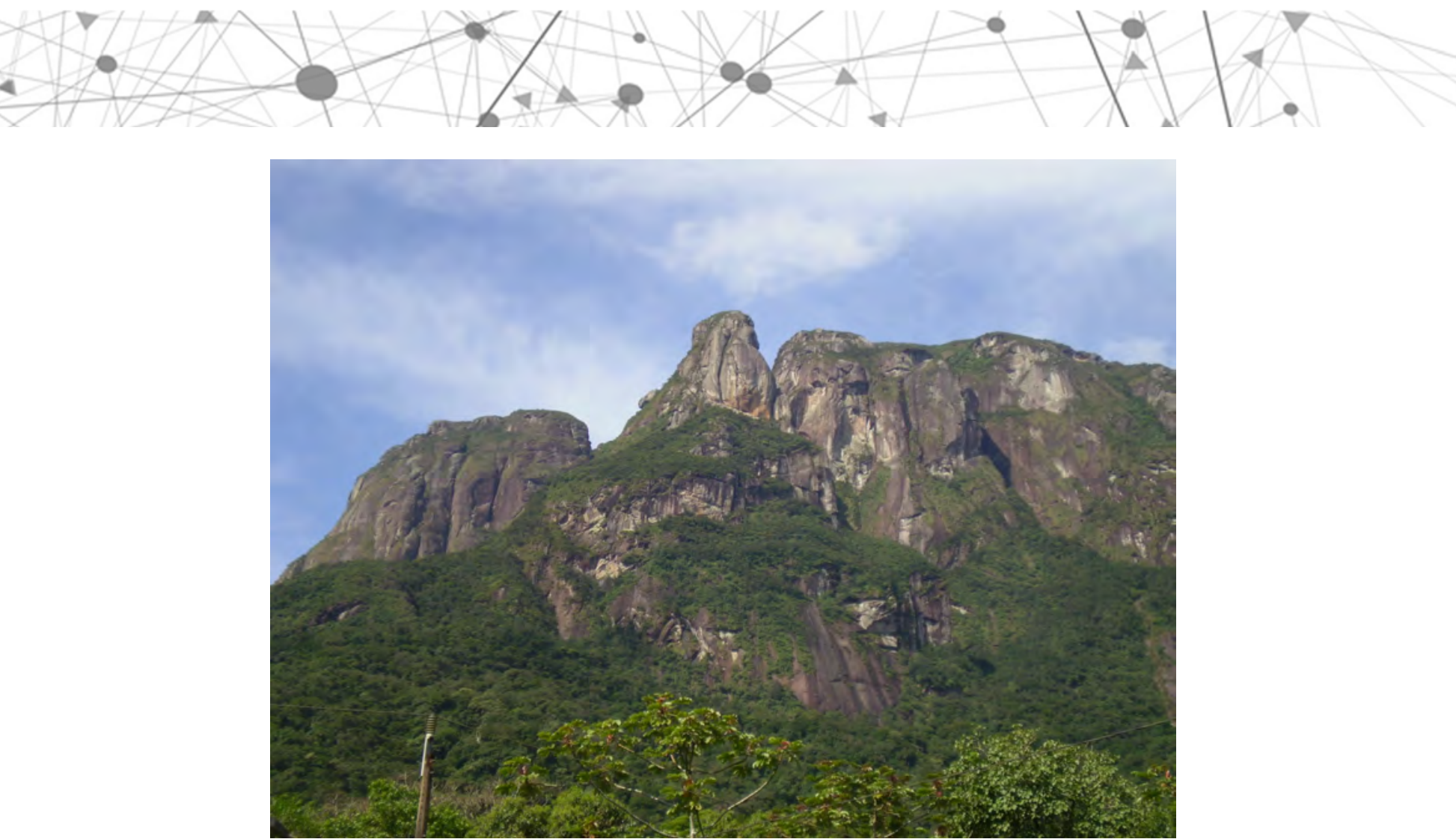

Figura 80 - Pico do Marumbi, Morretes, Paraná

Fonte: disponivel em: http://www.mochileiros.com/upload/galeria/fotos/20100516225125.JPG com acesso em 20 de julho de 2016

0 Pico do Marumbi fica localizado no Parque Estadual Pico do Marumbi, que engloba as regiões de Morretes, Piraquara e Quatro Barras, no estado do Paraná. 0 parque sobressai como uma unidade de conservação brasileira de proteção à natureza.

Quando o desenho do dedo está apontando para baixo, o título que pode ser lido na parte inferior central é Um Pouco de Paranismo / Cataratas do Iguaçu (figura 81). 


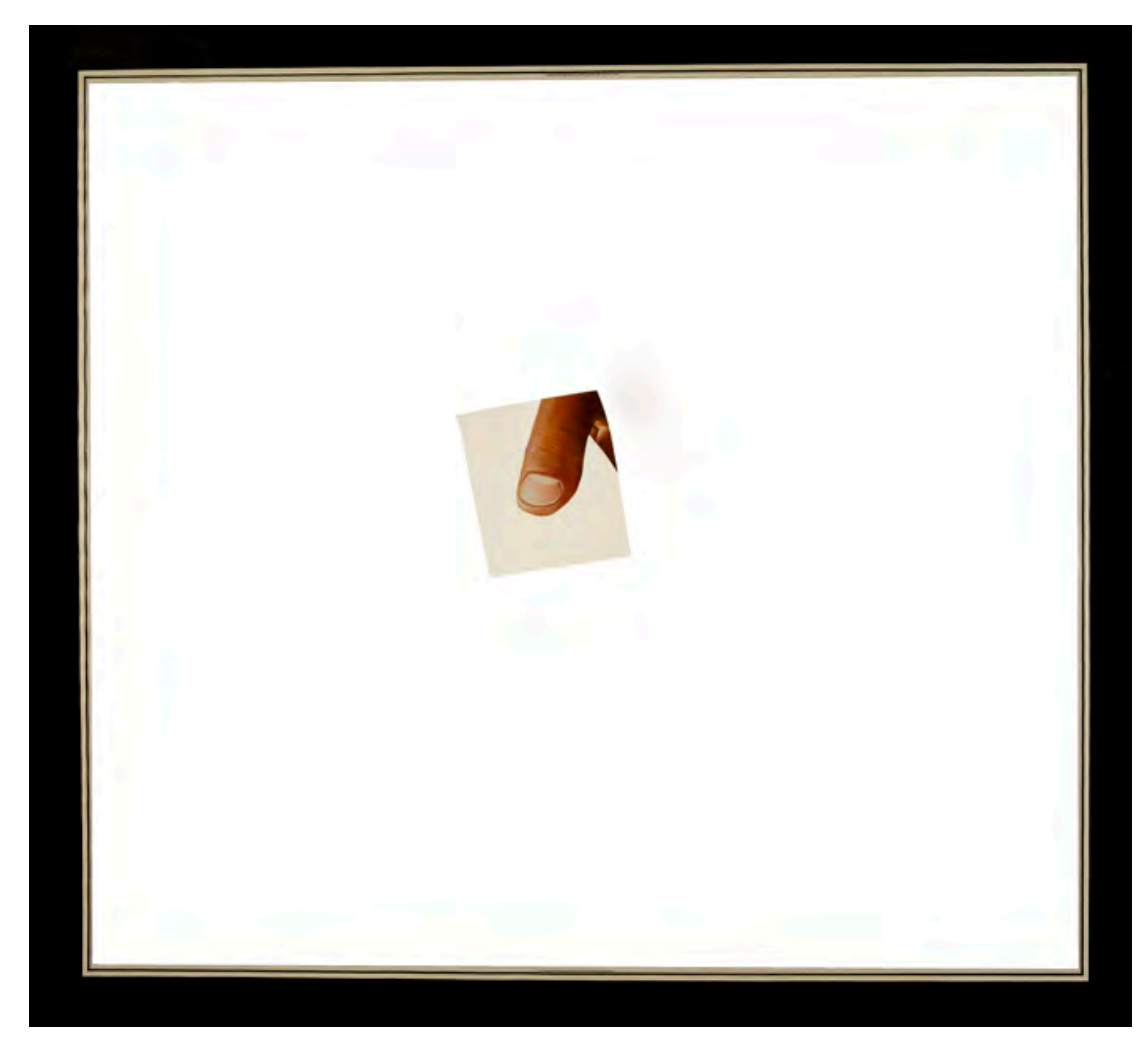

Figura 81 - Um Pouco do Paranismo / Cataratas do Iguaçu, Luiz Henrique Schwanke, 1979. Lápis de cor e nanquim sobre papel. $73,2 \mathrm{~cm} \times 78,4 \mathrm{~cm}$

Fonte: foto de Peninha Machado. Acervo da família Schwanke

As Cataratas do Iguaçu compreendem um conjunto formado por 275 quedas-d'água no Rio Iguaçu, localizadas entre o Parque Nacional do Iguaçu, no Paraná, e o Parque Nacional Iguazú, em Misiónes, na Argentina, na fronteira entre os dois países. Ambos os parques são considerados patrimônio natural da humanidade. Assim, esse trabalho exalta um conteúdo que é o extremo oposto daquele discutido em Um Pouco de Paranismo / Pinheiros (figura 78), marcando, uma vez mais, o contraponto na produção do artista.

\subsubsection{Apogeu do claro-escuro pós-Caravaggio}

Apogeu do claro-escuro pós-Caravaggio nasceu diretamente do interesse de Schwanke pela luz, e foi a primeira vez em que esse elemento foi por ele utilizado de forma concreta:

0 caso claro-escuro virou uma obsessão. Qualquer coisa era forma, via em tudo a forma da sombra tornando o volume uma forma. Comecei a disparar flashes e fotografar os ângulos da casa. As sombras nos contornos das portas e móveis da antiga casa de 

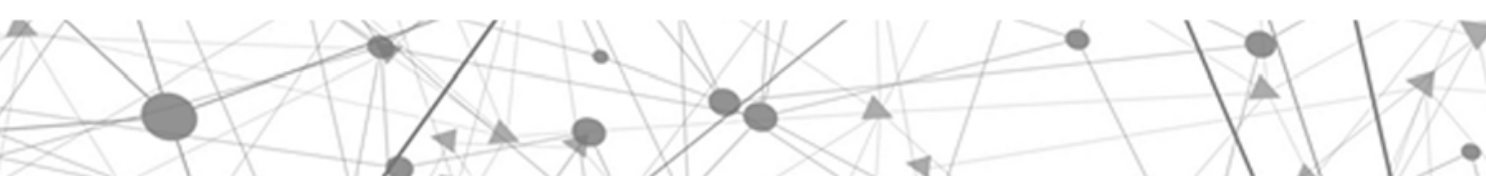

Curitiba se tornavam grossos traços pretos horizontais e verticais, como os de Mondrian (não buscava com isso uma justificação do neoplasticismo na natureza ou cotidiano, mas lembrava Mondrian devido à forma que a sombra de esquadrias de portas tomava na foto (SCHWANKE, s.d.).

Embora o interesse de Schwanke pela luz tenha seu ponto de partida na obra de Caravaggio, sua pesquisa alçou voos de maneira a relacionar elementos do cotidiano, mediante um olhar sensível e a discussão da luz, e trabalhos de diferentes artistas, a exemplo de Mondrian, cuja influência aparece em sua produção em diferentes momentos. Com base em seus escritos, percebe-se que 0 artista atualizava as discussões acerca da luz, as quais encontrava na história da arte, em situações vividas e em coisas que via e notava em seu entorno. Vera e Jaques falam sobre o momento em que surgiu a ideia para o Apogeu do claro-escuro pós-Caravaggio (figura 82):

Uma noite, vínhamos de carro, não sei de onde, e passamos pela rua onde hoje está o Shopping Mueller, em Curitiba. Naquele então, a quadra inteira estava ocupada pelas ruínas da antiga Fundição Mueller, já desativada e, para nossa tristeza, demolida. Era um belo prédio e sua demolição fora melancólica, para nós. Não para ele, que via ali o cenário ideal para uma instalação luminosa. Declarou em voz alta seu desejo de fazer funcionar, bem no centro da quadra, escondido em meio ao entulho, um dispositivo capaz de emitir raios luminosos, intensos e fugazes como relâmpagos, que assombrassem os eventuais passantes (SILVA; OLIVEIRA, 2016) (anexo 6).

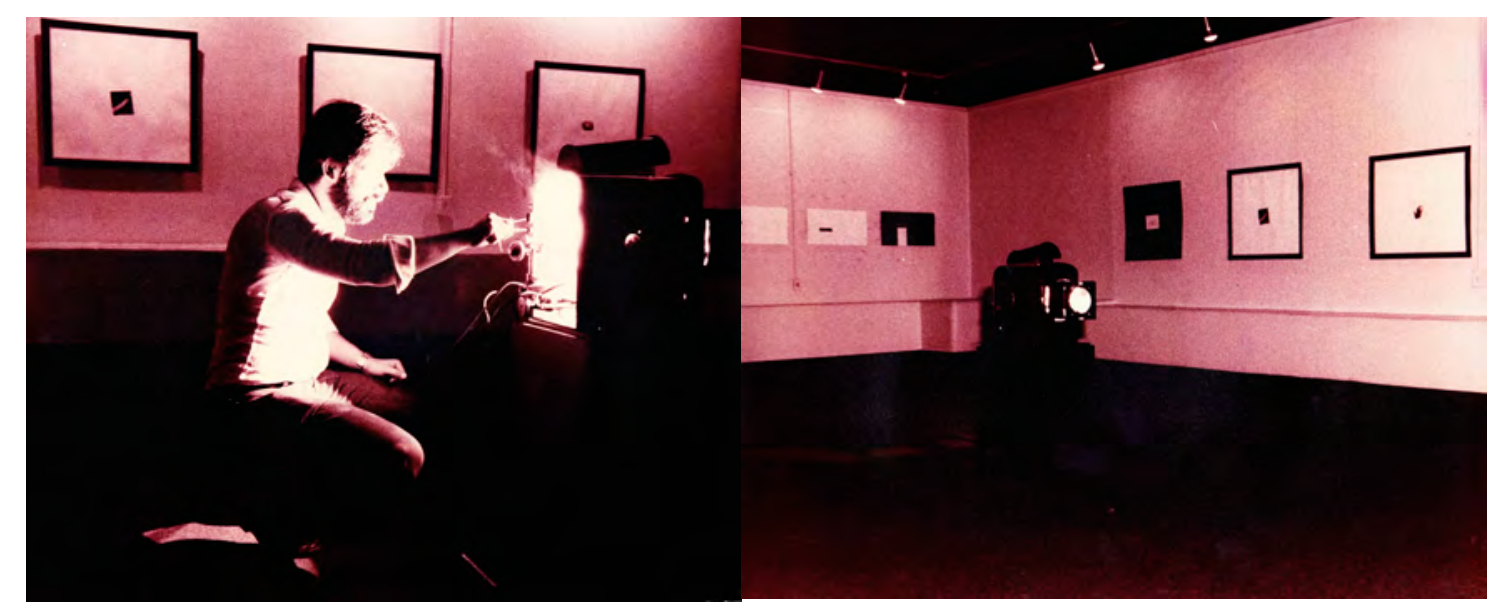

Figura 82 - O apogeu do claro-escuro pós-Caravaggio, Luiz Henrique Schwanke, 1980. Galeria Sérgio Milliet, Museu Nacional de Belas Artes, Rio de Janeiro Fonte: foto de Antônio Jaques da Silva. Acervo desconhecido 


\subsection{O Museu de Arte Contemporânea Luiz Henrique Schwanke}

O MAC Luiz Henrique Schwanke foi criado oficialmente pelo poder público municipal, por conta de manifestação por parte da classe artística e cultural da cidade de Joinville, pelo Decreto n. ${ }^{0}$ 10.632, assinado no dia 11 de julho de 2002. Ainda em 2002, foi criada uma comissão por meio do Decreto municipal n.․․ 10.804/2002, formada por diferentes profissionais e por representantes da família do artista, para que fossem definidos os critérios de implementação do museu. Definiu-se por essa comissão que o MAC Luiz Henrique Schwanke atuaria enquanto entidade de preservação e divulgação da obra de Schwanke, bem como constituiria um acervo formado por trabalhos de arte contemporânea de artistas nacionais e estrangeiros produzidos a partir de 2000, mantendo-o e divulgando-0.

No ano de 2003, com o objetivo de promover a implantação e a manutenção do museu, foi então estabelecido o Instituto Luiz Henrique Schwanke, o ILHS, contando com 208 associados fundadores. Desde 2005, conforme consta do site do MAC Schwanke ${ }^{118}$, o ILHS é qualificado enquanto Utilidade Pública Municipal e Estadual. No ato de criação do instituto, o governador do Estado de Santa Catarina e o prefeito da cidade de Joinville concederam ao MAC a desativada fábrica da Cervejaria Antarctica, já adquirida pelo poder público, localizada no centro da cidade. Com o consentimento da Câmara de Vereadores, a Prefeitura de Joinville concedeu ao ILHS a permissão de uso do espaço mediante a Lei municipal n. ${ }^{0} \mathbf{5} 476$. Com a submissão e aprovação de projetos a diferentes editais, municipais, estaduais e federais, o ILHS desenvolveu os diversos projetos necessários à construção do museu. Contudo, embora o projeto arquitetônico esteja pronto, por problemas estruturais da administração pública o instituto estuda novas possibilidades para a construção de sua sede em um novo local.

Independentemente de uma sede física, o Mac Schwanke vem atuando como museu desde a assinatura de seu decreto de criação, tendo desenvolvido inúmeros projetos, por intermédio de editais de incentivo, que muito contribuem para 0 desenvolvimento artístico e cultural de Joinville e região. São publicações, exposições, seminários, palestras e workshops com enfoques variados (educativo, patrimonial, artístico), voltados para diferentes públicos (iniciados ou não), na

\footnotetext{
${ }^{118}$ Mais informações em: <http://www.schwanke.org.br/plataformaeducativa/>.
} 
discussão e problematização tanto acerca da obra de Schwanke e da arte nacional como de aspectos que abrangem a arte contemporânea mundial. Via ILHS, já proferiram falas em Joinville inúmeros artísticas, teóricos e críticos de arte, tais como Agnaldo Farias, Angélica de Moraes, Fernando Cocchiarale, Teixeira Coelho, Ricardo Resende, Nuno Ramos e Valquíria Prates. Em 2013, por meio do Projeto Arte Conceitual: Realidade e Consistência?, o ILHS trouxe para Joinville o artista Joseph Kosuth, que, além de ter se reunido com artistas e profissionais da região, realizou uma palestra para 500 pessoas.

Segundo afirma Deloche (2002, p. 79-80), “assim como as salas de concerto de teatro, os museus são lugares autênticos, para o desenvolvimento de ações vivas". Entretanto, conforme já discutido no capítulo 1 e pode ser constatado pelas ações do MAC Schwanke, um museu não precisa de sede física para existir. São necessários a um museu para ser museu um acervo, o qual é estudado, pesquisado e colocado em exercício por meio de exposições, e programas que visem promover a formação de público, de artistas e de profissionais no âmbito das artes e ao acesso ao conhecimento e à produção artística e cultural. Por conseguinte, é possível ver o MAC Schwanke como um museu vivo e que muito contribui tanto para o estudo, a pesquisa e a difusão da obra de Schwanke como também com o desenvolvimento do contexto artístico e cultural do estado de Santa Catarina.

\subsection{0 website do MAC Schwanke e o MAC Schwanke Virtual}

0 website do MAC Schwanke foi criado e desenvolvido em 2014 pela Diretoria Cultural do ILHS, por meio da realização de um projeto denominado Plataforma Educativa, financiado pelo mecenato municipal. 0 objetivo do projeto era criar um lugar de existência para o museu, já que, conforme citado anteriormente, embora atue e cumpra a sua função de museu, ele não possui ainda uma sede física.

Assim, o ambiente virtual foi projetado tanto como um meio de divulgar 0 museu, suas ações e a produção de Schwanke como também como uma forma de colocar a produção do artista em exercício, mediante a realização de exposições no espaço denominado de MAC Virtual localizado no website. Logo, concordando com Deloche (2004), o MAC Virtual é encarado como uma ferramenta de atuação do museu, nesse caso como uma maneira de suprir, em potência, a ausência de um 
espaço físico próprio, não se resumindo ele mesmo em um museu, muito embora se configure em um museu virtual. Ressalta-se, mais uma vez, que as exposições a serem promovidas nesse espaço serão projetadas especificamente para o referido espaço, ou seja, existirão apenas em potência. Considerando que essas experiências serão exclusivas do cibermeio e pensadas especialmente para esse ambiente, mesmo tratando-se de um espaço vinculado ao museu físico, pode ser chamado de museu virtual, já que não existe equivalente a ele no mundo físico (SCHEINER, 2009).

0 website foi construído pela empresa Sirius $A B$ Agência Criativa, que trabalhou de modo muito próximo e dialogado com a equipe do museu. A ideia era a disponibilização ao visitante de uma plataforma limpa, objetiva e de fácil navegação, na qual fossem exploradas as possibilidades oferecidas pelo ambiente virtual em rede. Por conseguinte, o espaço é estruturado em cinco eixos: Instituto Schwanke, Luiz Henrique Schwanke, MAC Schwanke, MAC Schwanke Virtual e Blog.

Ao clicar em Instituto Schwanke, o visitante terá a opção de ler um breve texto de "Apresentação", por meio do qual entenderá o que é a entidade, e, se quiser se aprofundar e conhecer as ações desenvolvidas, pode acessar o "Currículo do Instituto", disponível pelo hiperlink localizado ao final do texto de apresentação. Este último pode ser salvo em PDF. Também o usuário pode optar por "Associe-se", cujo link disponibiliza uma ficha cadastral para quem se interessar. Por fim, pode ter acesso aos nomes dos projetos, tanto os já desenvolvidos como aqueles que ainda estão em desenvolvimento.

Em Luiz Henrique Schwanke, o visitante pode conhecer o artista e a sua produção, o que se dá mediante cinco opções de acesso. A primeira delas é um breve texto de "Apresentação" sobre o artista, o qual faz um apanhado geral de sua vida e obra. A segunda consiste no acesso a "Biografia", por meio da qual o visitante conhecerá o artista e a sua formação. A terceira opção é "Imagens do artista", formada por fotos de Schwanke em diferentes momentos ao longo de sua vida, o que permitirá com que a imagem da pessoa Schwanke também seja conhecida. Já ao clicar em "Trajetória Artística", é disponibilizado o currículo completo de Schwanke, com também as exposições póstumas. Esse currículo pode ser salvo em PDF. Por último, em "Acervos Nacionais", tem-se acesso a obras do artista que 
integram diferentes coleções institucionais, com o clique aos links de vários museus.

Para conhecer o museu, basta clicar em MAC Schwanke. Nesse link há informações tanto a respeito do museu e das etapas de implantação como também acerca do perfil do acervo, em processo de formação.

Já o espaço MAC Schwanke Virtual é destinado à realização de exposições para o espaço projetadas, não necessariamente da produção de Schwanke, e para a disponibilização de imagens digitalizadas de trabalhos do artista, pela formação de um banco de imagens.

Conforme já citado, a ideia é que as exposições não ocorram pela lógica dos espaços físicos, porém que explorem as especificidades do ambiente virtual, a exemplo da remontagem de $A$ casa tomada (de Julio Cortázar) por desenhos que não deram certo. Desenhos de 1979/80. Apogeu do claro-escuro pós-Caravaggio, feita no contexto desta tese. Observa-se ainda que a intenção é continuar a realizar exposições nesse espaço, mesmo quando o museu obtiver a sua sede física, já que pode funcionar como uma ferramenta rica para colocar o acervo constantemente em discussão e em exercício por intermédio de diferentes experiências. 0 banco de imagem vai crescer à medida que as exposições forem acontecendo, já que se acredita que não adianta disponibilizar imagens de inúmeros trabalhos descontextualizados de um artista que ainda está sendo estudado. Assim, conforme os trabalhos forem sendo pesquisados e discutidos por meio das exposições, eles serão disponibilizados.

Por meio do link Blog, o visitante será conduzido diretamente ao blog, em que poderá acompanhar o desenvolvimento de todas as ações do instituto. 0 website também possui links para as redes sociais e um botão "Fale conosco", caso o visitante queira se comunicar com o ILHS. Na exploração das possibilidades oferecidas pelo ambiente virtual, que não apresenta barreiras geográficas, é disponibilizado o botão "Procura-se", ferramenta pensada com o objetivo de localizar trabalhos de Schwanke em acervos particulares.

Assim, por meio de seu website, pensado como um dos espaços de manifestação do museu (SCHEINER, 2008), o MAC Schwanke poderá entrar na casa e na vida do visitante, que tanto vai exercitar o acervo virtualmente, sem sair de casa, como conhecerá as ações e, por conseguinte, poderá participar dos projetos e 
programas desenvolvidos presencialmente pela instituição. Ressalta-se que, conforme já tratado no capítulo 2, das 133 instituições que possuem sede física e mantêm um website, apenas sete realizam exposições virtuais (apêndice 1). Destas, quatro fazem uso do ambiente virtual para colocar o seu acervo em exercício, contudo sem explorar na proposta curatorial as possibilidades oferecidas pelo ambiente virtual em rede.

Por meio desta tese, defende-se a ideia de que a exposição virtual possa ser projetada como um programa educativo do museu, o que está sendo feito pela curadoria educativa, conforme visto no capítulo 2. 


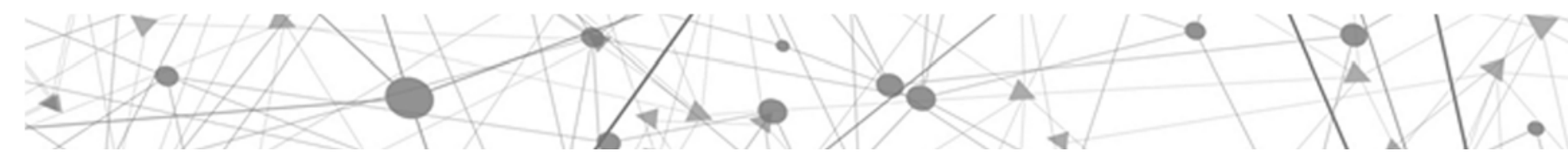

\section{CAPÍTULO 4}

\section{EXPOSIÇÃO VIRTUAL DIGITAL NO MAC SCHWANKE VIRTUAL, POR MEIO DA CURADORIA EDUCATIVA}




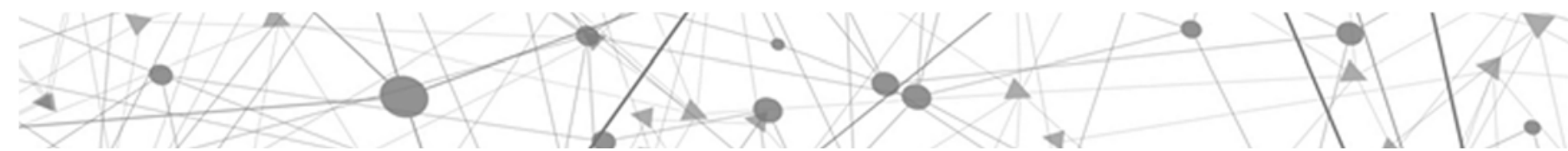

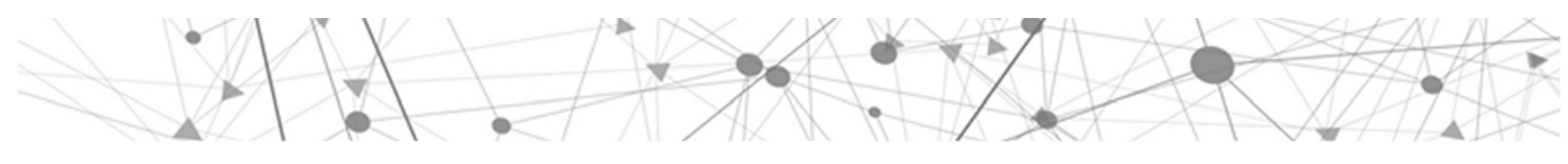




\subsection{0 desenho da exposição}

0 MAC Schwanke Virtual, localizado no website do MAC Luiz Henrique Schwanke, conforme já tratado em capítulos anteriores, consiste em um museu virtual digital. Ele é virtual por explorar o ciberespaço e por ser suporte para permitir a existência dele, imaterial por natureza, cujo conteúdo abrigado existe enquanto potência (LÉVY, 1995), e também por fazer uso desse espaço para suprir a ausência de espaço físico (DELOCHE, 2004). E é digital pelo fato de lidar com imagens de trabalhos físicos fruto do processo de digitalização para, assim, concretizar um dos principais papéis relacionais (BOURRIAUD, 2009) do museu, que é a realização de exposições, tendo em vista que o museu ainda não possui espaço físico para colocar o seu acervo em exercício.

Contudo, cabe observar, mais uma vez, que o que está sendo defendido nesta tese é que as exposições virtuais devem acontecer independentemente de 0 museu possuir sede física. Acredita-se ainda que, além de divulgar a sua coleção e de disponibilizar informações sobre os programas e as ações desenvolvidos, 0 museu pode e deve explorar as especificidades do ambiente virtual em rede para realizar, entre outras ações, exposições pensadas especificamente para esse espaço, com base em suas especificidades e, desse modo, colocar o seu acervo permanentemente em exercício, sem ter o tempo nem a distância como empecilhos. Pensa-se que as exposições promovidas nesse espaço podem ser encaradas enquanto um programa educativo do museu, não no sentido de oferecer exercícios de arte/educação pensados para estudantes e professores, mas como um meio de promover a produção de arte tal qual um instrumento de ação cultural (JACOB; BRENSON; OLSON, 1995), sendo projetada para todos os tipos de público.

Nesse sentido, a exposição que está sendo realizada no contexto desta tese foi estruturada por intermédio da curadoria educativa, que, conforme já tratado no capítulo 2, é entendida como um programa que visa provocar qualquer tipo de público a exercitar a coleção e a construir conhecimento com base nela. Assim, o propósito educativo já faz parte da concepção da mostra, não estando localizado em ações de arte/educação que em geral são oferecidas paralelamente e somente 
para as escolas, para os professores, para os pesquisadores e para o público interessado nessas atividades.

A exposição virtual construída aqui, já trabalhada no capítulo 3, constitui a remontagem da mostra $A$ Casa Tomada (de Julio Cortázar) por Desenhos que não Deram Certo). Desenhos de 1978/80. O Apogeu do Claro-escuro Pós-Caravaggio, originalmente realizada por Schwanke em 1980, na Galeria Sérgio Milliet, no Museu Nacional de Belas Artes, do Rio de Janeiro, como fruto de um prêmio recebido no Salão Paranaense de 1979. Composta por três partes, originalmente a primeira (seguindo a lógica do título), formada por $500 \mathrm{~m}$ de papel amassado, ficava no centro do espaço, de maneira a ocupar boa parte da galeria. Já a segunda consiste no conjunto de desenhos produzido no período entre 1978 e 1980 e que ficava disposto nas paredes do espaço. A terceira, por sua vez, configura-se na luz produzida pelo sistema de arco voltaico abrigado em um antigo projetor de cinema, situado também na parte central do espaço, direcionada para o papel amassado e influenciando diretamente a forma de visualizar os desenhos.

Partiu-se da lógica oferecida pelo título da exposição, aliada à disponibilização de documentação e de informações que envolvem o artista, a exposição e os trabalhos, e não à tentativa de reprodução do espaço físico. Essa remontagem foi desenhada especialmente para o MAC Schwanke Virtual. Portanto, ao acessar a página da mostra, o visitante vai visualizar em destaque o desenho geral da versão virtual da exposição, a qual poderá ser explorada pelo uso do mouse.

Compreendida como duração de uma experiência, e não como um espaço a ser percorrido (BOURRIAUD, 2009), a exposição, tal qual a original, promovida no espaço físico, está estruturada tendo em vista diferentes momentos, complementares, os quais serão vivenciados por escolhas particulares. Assim, não há ordem obrigatória para a visita. Pode-se optar por vivenciar, logo de início, a reprodução digital dos trabalhos que integram a mostra, ou por, primeiramente, conhecer as duas versões físicas anteriores: a original, em 1980, montada pelo próprio artista em parceria com o crítico de arte João Henrique do Amaral; ou a remontagem realizada em 1999, com curadoria da crítica de arte e professora Nadja de Carvalho Lamas, na Sala Especial do Salão Nacional Victor Meirelles, em Florianópolis (SC). 
Conforme já citado anteriormente, a exposição objetiva explorar as possibilidades oferecidas pelo ambiente virtual em rede, na disponibilização de ferramentas participativas. Assim sendo, é oferecida ao visitante a possibilidade de organizar a sua própria mostra, tanto mediante a imagem das obras de Schwanke que compõem a exposição, como também por outras imagens por ele selecionadas de acervos de diferentes instituições.

Como dito antes, essa exposição está fundamentada na curadoria educativa, ou seja, foi desenhada com o propósito de promover a construção de conhecimento em arte pela vivência e pelo estudo da produção de Schwanke, tendo por foco qualquer tipo de público. Nessa perspectiva, não foram pensadas ferramentas específicas para estudantes e professores, nem um espaço exclusivo para arte/educação, contudo são disponibilizadas na mostra informações e proposições práticas que poderão ser utilizadas pelo professor para pensar e construir aulas com base no exercício da exposição, o que poderá ser acessado em PDF.

De acordo com o que será especificado em seguida, integram a exposição, além da ferramenta Organize a sua Exposição, anteriormente referenciada, outras ferramentas participativas, além da natureza hipermidiática desse ambiente, na construção de uma mostra dinâmica que oferece inúmeras informações, documentos, depoimentos em formatos diversos, que contribuirão para 0 conhecimento e o aprofundamento da produção de Luiz Henrique Schwanke.

Nesse sentido, pode-se afirmar que a exposição fornece camadas distintas de aprofundamento, uma vez que o visitante pode ser restringir a visualizar as imagens dos trabalhos, ou escolher por aprofundar o seu olhar e o seu conhecimento por meio da leitura das análises. Pode também ir mais a fundo assistindo aos vídeos e escutando os áudios, lendo os excertos de críticos, de estudiosos e de amigos de Schwanke, ou ainda ler os escritos do artista, os textos e as entrevistas na íntegra. Observa-se ainda que a mostra contempla visitantes com perfis diferentes, já que oferece arquivos de imagens, de vídeos e de textos. Para a construção dela, foram tomadas como referência exposições e sites de museus e instituições culturais, analisados nos capítulos 1 e 2, tanto no que tange à estrutura como também em relação às ferramentas.

Conforme já dito no capítulo 1, durante o processo de investigação e de construção da tabela resultado do mapeamento, foram identificadas sete 
experiências de museus que possuem sede física e que fazem uso do ambiente virtual em rede para realizar exposições, ou seja, que se equiparam nesses aspectos com o MAC Schwanke Virtual. Como observado na tabela 3, todas elas fazem uso desse espaço como um meio de divulgar os seus programas e as suas ações. Seis delas disponibilizam o acervo digitalizado para consulta online e quatro oferecem visita em três dimensões às suas dependências físicas. Ou seja, essas instituições usam esse espaço como um meio de tornar a sua coleção e as suas dependências físicas conhecidas.

\begin{tabular}{|c|c|c|c|c|c|c|c|}
\hline $\begin{array}{l}\text { Instituiç } \\
\text { ão }\end{array}$ & $\begin{array}{l}\text { Disponibiliza } \\
\text { ção de } \\
\text { informações } \\
\text { gerais sobre } \\
\text { seus } \\
\text { programas e } \\
\text { ações }\end{array}$ & $\begin{array}{c}\text { Disponibiliza } \\
\text { ção de } \\
\text { acervo } \\
\text { digitalizado } \\
\text { para } \\
\text { consulta } \\
\text { online }\end{array}$ & $\begin{array}{l}\text { Disponibiliza } \\
\text { ção de visita } \\
\text { em três } \\
\text { dimensões à } \\
\text { sua sede } \\
\text { física }\end{array}$ & $\begin{array}{l}\text { Disponibiliza } \\
\text { ção de } \\
\text { endereços } \\
\text { eletrônicos } \\
\text { de outras } \\
\text { instituições }\end{array}$ & $\begin{array}{l}\text { Disponibiliza } \\
\text { ção de } \\
\text { ferramentas } \\
\text { participativa } \\
\text { s }\end{array}$ & $\begin{array}{l}\text { Disponibiliza } \\
\text { ção de } \\
\text { espaço de } \\
\text { troca com o } \\
\text { visitante }\end{array}$ & $\begin{array}{c}\text { Exposições } \\
\text { independen } \\
\text { tes do } \\
\text { espaço } \\
\text { físico }\end{array}$ \\
\hline $\begin{array}{c}\text { Carnam } \\
\text { ah } \\
\text { Museum }\end{array}$ & ज̧ुo & onic & & & & & $x$ \\
\hline $\begin{array}{c}\text { Palácio } \\
\text { de } \\
\text { Versalh } \\
\text { es } \\
\end{array}$ & $x$ & $x$ & $x$ & & & & $x$ \\
\hline $\begin{array}{c}\text { Instituto } \\
\text { Itaú } \\
\text { Cultural }\end{array}$ & $x$ & & $x$ & & & & \\
\hline $\begin{array}{c}\text { Museu } \\
\text { Casa de } \\
\text { Portinari }\end{array}$ & $x$ & $x$ & $x$ & & & & \\
\hline $\begin{array}{l}\text { Galeria } \\
\text { Nacional } \\
\text { do } \\
\text { Canadá }\end{array}$ & $x$ & $x$ & & & $x$ & & $x$ \\
\hline $\begin{array}{c}\text { The } \\
\text { Frick } \\
\text { Collectio } \\
n\end{array}$ & $x$ & $x$ & $x$ & & $x$ & & \\
\hline $\begin{array}{c}\text { Museu } \\
\text { de Arte } \\
\text { Modern } \\
\text { a Grand- } \\
\text { Duc }\end{array}$ & $x$ & $x$ & & & $x$ & & $x$ \\
\hline TOTAL & 7 & 6 & 4 & 0 & 3 & 0 & 4 \\
\hline
\end{tabular}

Tabela 3 - Comparação entre instituições culturais e museológicas com sede física e que fazem uso do ambiente virtual em rede para realizar exposições Fonte: Primária

É interessante observar que nenhuma delas faz uso da estrutura do ambiente virtual em rede para estabelecer conexões com outras instituições da mesma natureza, nem mesmo disponibiliza endereços eletrônicos para ampliar a rede de pesquisa dos visitantes. Nesse aspecto, o MAC Schwanke pode ser encarado como uma instituição que oferece um diferencial, já que em seu website disponibiliza espaço de troca com o visitante, como, por exemplo, por meio da 
ferramenta Procura-se, pela qual quem tiver uma obra do artista pode manifestarse (figura 83).

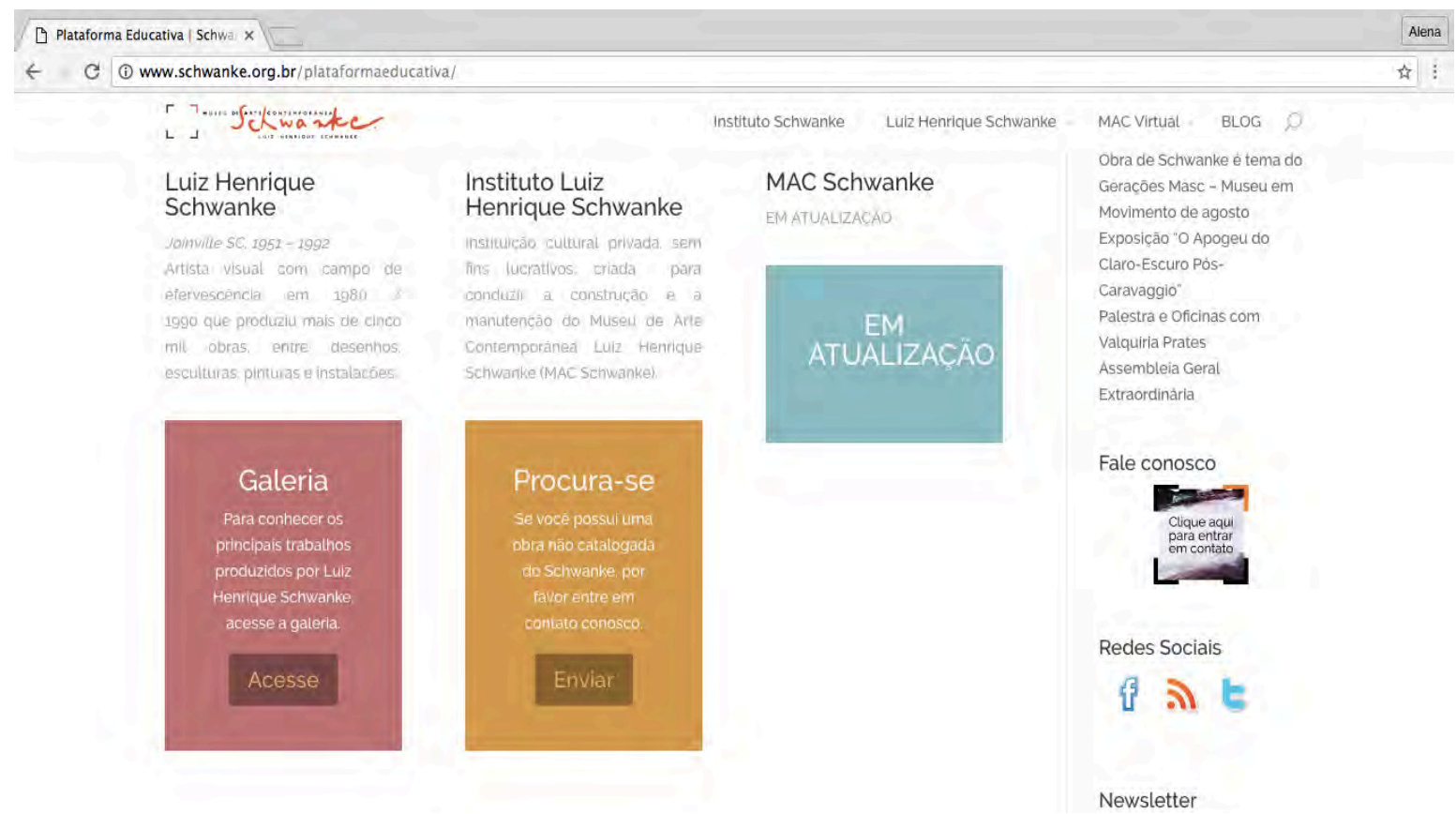

Figura 83 - Captura de imagem da página principal do website do Mac Schwanke Virtual Fonte: disponível em: <http://www.schwanke.org.br/plataformaeducativa/>. Acesso em: 15 set. 2016

0 MAC Schwanke Virtual também disponibiliza links de outras instituições que possuem obras de Schwanke em seu acervo (figura 84). 

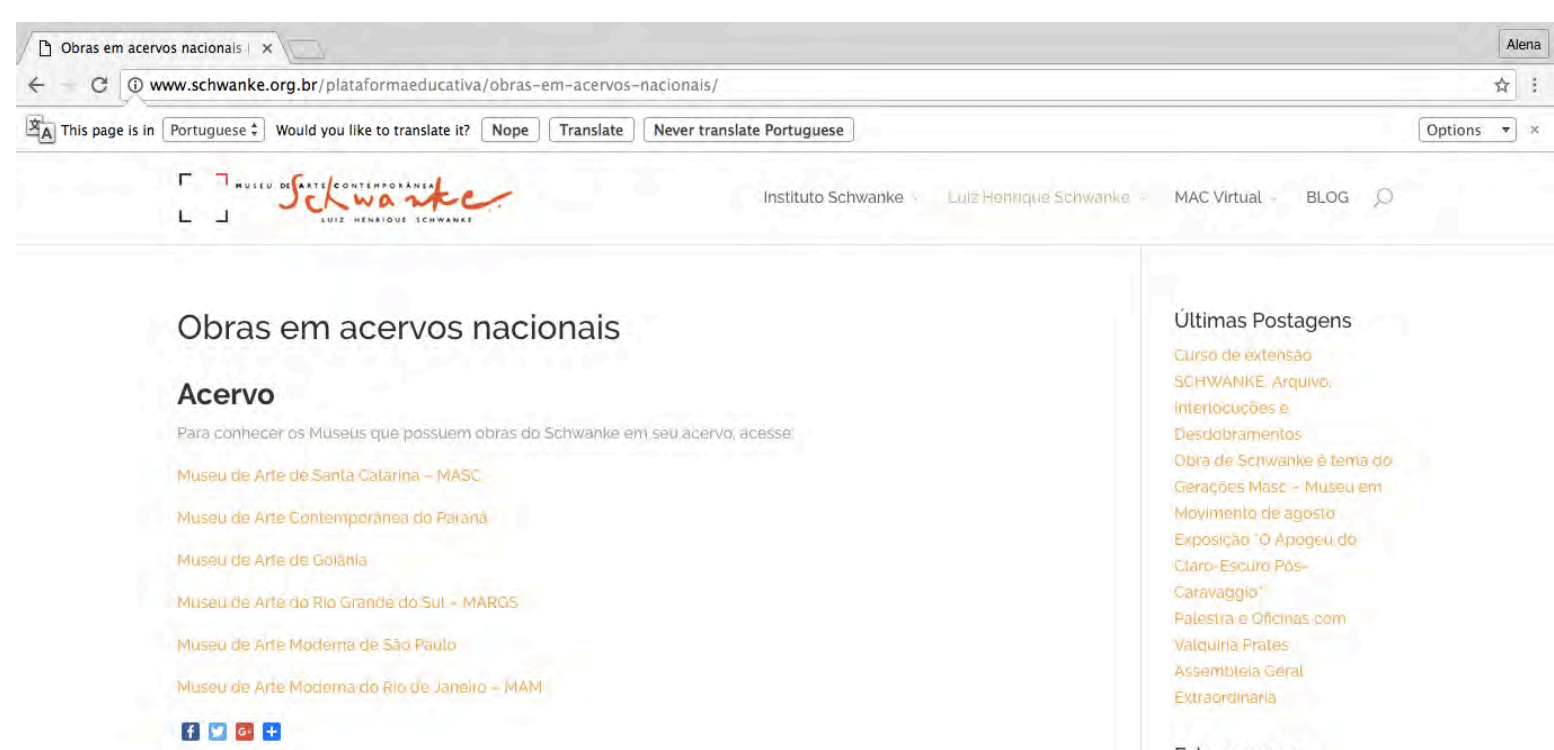

Fale conosco

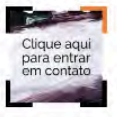

Figura 84 - Captura de imagem da página do website do Mac Schwanke Virtual mostrando Obras em Acervos Nacionais, item em que há links para websites de outras instituições com obras de Schwanke em seu acervo

Fonte: disponivel em: <http://www.schwanke.org.br/plataformaeducativa/obras-em-acervosnacionais/>. Acesso em: 15 set. 2016

Conforme tabela 3, das sete instituições com sede física e que disponibilizam exposições virtuais, seja em seu website, seja em seu museu virtual localizado em seu website, como é o caso do Carnamah Museum e do Museu de Arte Moderna Grand-Duc, apenas quatro têm exposições virtuais pensadas especificamente para o ambiente virtual em rede, isto é, exposições que foram construídas independentemente da realidade física. São elas: Carnamah Museum, Museu Casa de Portinari, Galeria Nacional do Canadá e Museu de Arte Moderna Grand-Duc. Dessas quatro, apenas o Museu de Arte Moderna Grand-Duc não promove exposições com seu acervo físico, restringindo-se a expor a sua produção, que já nasceu digital. Sendo assim, foram analisadas as exposições virtuais das três instituições que trabalham com seu acervo físico digitalizado (tabela 4), já que possuem a mesma natureza da exposição construída e disponibilizada no MAC Schwanke Virtual. 


\begin{tabular}{|l|c|c|c|c|c|c|}
\hline $\begin{array}{l}\text { Museus e } \\
\text { instituições }\end{array}$ & $\begin{array}{l}\text { Exposições } \\
\text { virtuais }\end{array}$ & $\begin{array}{l}\text { Acervo } \\
\text { físico } \\
\text { posto } \\
\text { em } \\
\text { exercício }\end{array}$ & $\begin{array}{l}\text { Hipermídia } \\
\text { está } \\
\text { presente }\end{array}$ & $\begin{array}{l}\text { Exploração } \\
\text { da } \\
\text { estrutura } \\
\text { não linear }\end{array}$ & $\begin{array}{l}\text { Ferramentas } \\
\text { participativas }\end{array}$ & $\begin{array}{l}\text { Oferta de } \\
\text { diferentes } \\
\text { camadas de } \\
\text { aprofundamento }\end{array}$ \\
\hline $\begin{array}{l}\text { Carnamah } \\
\text { Museum }\end{array}$ & 12 & $\mathrm{X}$ & & $\mathrm{X}$ & $\begin{array}{l}\text { Espaço de } \\
\text { troca com } \\
\text { o visitante }\end{array}$ \\
\hline $\begin{array}{l}\text { Museu Casa } \\
\text { de Portinari }\end{array}$ & 3 & $\mathrm{X}$ & $\mathrm{X}$ & $\mathrm{X}$ & \\
\hline $\begin{array}{l}\text { Galeria } \\
\text { Nacional do } \\
\text { Canadá }\end{array}$ & 16 & $\mathrm{X}$ & $\mathrm{X}$ & $\mathrm{X}$ & & \\
\hline
\end{tabular}

Tabela 4 - Análise geral das exposições virtuais de acervos físicos digitalizados Fonte: Primária

De acordo com a tabela 4, o Carnamah Museum oferece 12 exposições, cada uma com um tema, que apresentam objetos do acervo. Contudo, a exemplo da mostra já analisada no capítulo 1, 0 Carnaval na Paleta de Portinari, as exposições não tiram partido do ambiente no qual estão inseridas, disponibilizando apenas imagens aliadas a textos. Ou seja, não foge muito da lógica das exposições realizadas em espaços físicos.

0 Museu Casa de Portinari disponibiliza três exposições virtuais pensadas exclusivamente no espaço virtual, entretanto apenas uma coloca o acervo em exercício, o Carnaval na Paleta de Portinari. Conforme foi constatado, embora a mostra faça uso da estrutura não linear do ambiente virtual em rede, não explora a natureza hipermídia nem ferramentas próprias desse ambiente, que muito poderiam contribuir para a construção de conhecimento e aprofundamento da produção do artista. Outra exposição, intitulada Novos Talentos, apresenta os trabalhos fruto de um projeto, e a Futebol e Arte aborda a importância do futebol para a cidade de Brodowski, mas não apresenta nem problematiza um recorte do acervo; apenas disponibiliza jogos online.

A Galeria Nacional do Canadá, por sua vez, apresenta 16 exposições virtuais, nomeadas de Online Showcases, entre individuais, coletivas e mostras temáticas, envolvendo diferentes produções, de criadores diversos. Todas elas fazem uso da natureza hipermidiática do ambiente virtual em rede, porém não oferecem espaço de troca com o visitante, nem camadas distintas de aprofundamento.

Conforme poderá ser constatado, a exposição virtual construída no contexto desta tese, além de fazer uso da natureza hipermidiática e de explorar as especificidades da internet, oferece ferramentas participativas para que o visitante 
vivencie e se aprofunde na produção do artista, tendo a possibilidade de dar retorno em relação à sua experiência, bem como problematizar a produção do artista. Nesse sentido, o espaço de exposição acaba configurando-se não somente em um espaço de construção de conhecimento, mas também em um espaço de troca.

\subsubsection{A remontagem virtual}

0 ponto de partida para o desenho da remontagem na versão virtual, conforme já citado, foi a exploração das possibilidades do ambiente virtual em rede, sem tomar como referência, porém, a estrutura do espaço físico. Assim sendo, ao acessar o site da exposição, o visitante vai deparar com a visualização geral dela, por meio da qual poderá optar por explorar qualquer uma das partes que a compõem. Como observado no esquema, especificado na figura 85 , são elas: 0 texto de introdução; Montagem de 1980; Montagem de 1999, Schwanke; Desenhe sua Própria Exposição; Para o Professor; Casa Tomada por Desenhos que não Deram Certo; Desenhos de 1978/80; 0 Apogeu do Claro-escuro Pós-Caravaggio.

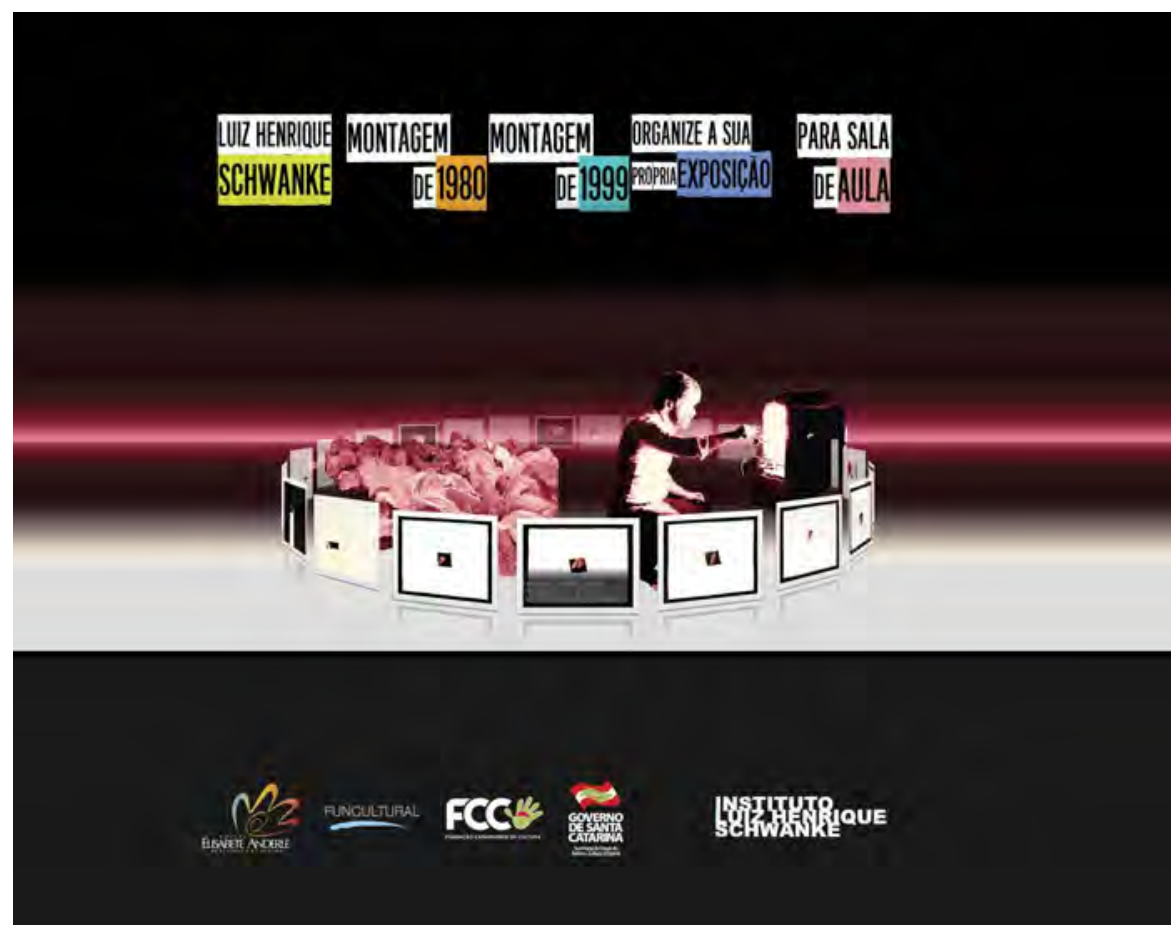

Figura 85 - Esquema do desenho geral da exposição virtual Fonte: Primária 
Considerando que deve estar em primeiro plano em uma mostra o trabalho do artista, e assim como na figura 85, a reprodução digital das obras está localizada de forma centralizada na página, de maneira a chamar a atenção do visitante, que pode visualizar todos os trabalhos ao mesmo tempo, embora em tamanho reduzido. Para o desenvolvimento deste texto, optou-se por tratar da exposição virtual pela ordem sugerida pelo título dado por Schwanke.

Portanto, ao acessar, por exemplo, o trabalho A Casa Tomada (de Julio Cortázar) por Desenhos que não Deram Certo, o visitante será direcionado para a página da exposição formada por esse trabalho (figura 86).

\section{a casa tomada (de julio cortázar) por desenhos que não deram certo}

Link para depoimento escrito de Jaques e Vera na íntegra
Video fruto da remontagem
Texto da Curadoria
Link para o conto

"A casa tomada" de Julio Cortázar
Arquivo de áudio

com depoimento de Paulo Schroder
Excerto depoimento escrito Jaques e Vera
Link para arquivo de áudio com depoimento de Paulo Schroede
Link para vídeo fruto da remontagem do trabalho

Figura 86 - Infográfico com o desenho da curadoria para a página do trabalho $A$ Casa Tomada (de Julio Cortázar) por Desenhos que não Deram Certo Fonte: Primária

Logo de início, poderá ser visualizado um texto da curadoria, curto e objetivo, sobre a instalação, pensado para diferentes tipos de visitante, com links para documentos acerca do trabalho, os quais contribuem para o aprofundamento da leitura. Poderá ser acessado, por exemplo, um documento de áudio no qual um amigo de Schwanke, Paulo Schroeder, fala do momento em que cadeiras apareceram como objeto na produção do artista. Ou então, se o visitante tiver interesse, poderá ler o depoimento de Jaques e Vera, casal de amigos de Schwanke, no qual relatam quando o artista teve a ideia para o título desse trabalho. Poderá também ser acessado o conto de Cortázar, Casa tomada, que serviu de base para Schwanke montar esse trabalho.

Conforme consta no capítulo 2, A Casa Tomada (de Julio Cortázar) por Desenhos que não Deram Certo consiste numa instalação formada por $500 \mathrm{~m}$ de 
papel em branco, amassados, que ocupava boa parte do espaço da galeria. Por ser uma instalação que explora a tridimensionalidade, optou-se por remontá-la fisicamente, para então realizar uma filmagem e, assim, oferecer ao visitante mais recursos para se aproximar do trabalho (figura 87).

Por conseguinte, em março de 2016, na Galeria Municipal de Arte Victor Kursancew, localizada na Casa da Cultura Fausto Rocha Junior, em Joinville, foi remontada fisicamente a instalação, com visitação aberta ao público por um mês.

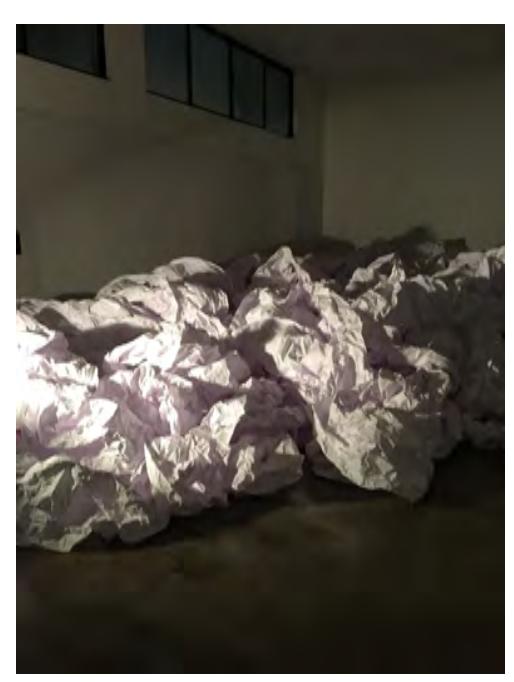

Figura 87 - Remontagem da instalação A Casa Tomada (de Julio Cortázar) por Desenhos que não Deram Certo, 2016, $500 \mathrm{~m}$ de papel em branco amassado. Galeria Municipal de Arte Victor Kursancew, Casa da Cultura Fausto Rocha Junior, Joinville, Santa Catarina Fonte: Primária

A filmagem foi realizada pela simulação do percurso ao redor do trabalho realizado pelo público durante a visita. Sabe-se que a vivência do trabalho diante do original físico não pode ser substituída, contudo, na impossibilidade dessa experiência, ferramentas como tal podem funcionar como um documento de registro, como um meio de tornar o trabalho conhecido e também para despertar 0 interesse no visitante em ter contato com o original assim que tiver a possibilidade. Ressalta-se aqui que a ideia com a disponibilização desse vídeo não era reproduzir 0 espaço físico, mas sim proporcionar ao visitante a proximidade do trabalho, tendo em vista a sua natureza tridimensional.

Desenhos de 1978/80, que, tal qual a ordem do título, consiste na segunda parte da exposição (figura 88), é contemplado por 30 trabalhos produzidos por Schwanke de 1978 a 1980 e que, conforme já tratado no capítulo 3, são fruto dos 


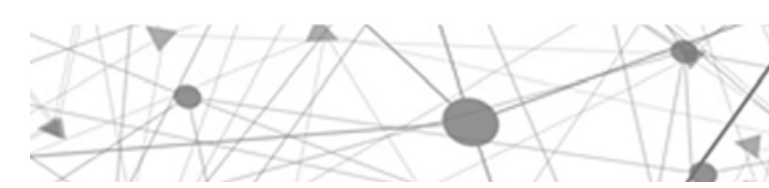

gestos de apropriação da história da arte, da discussão do gesto e da exploração do elemento luz.

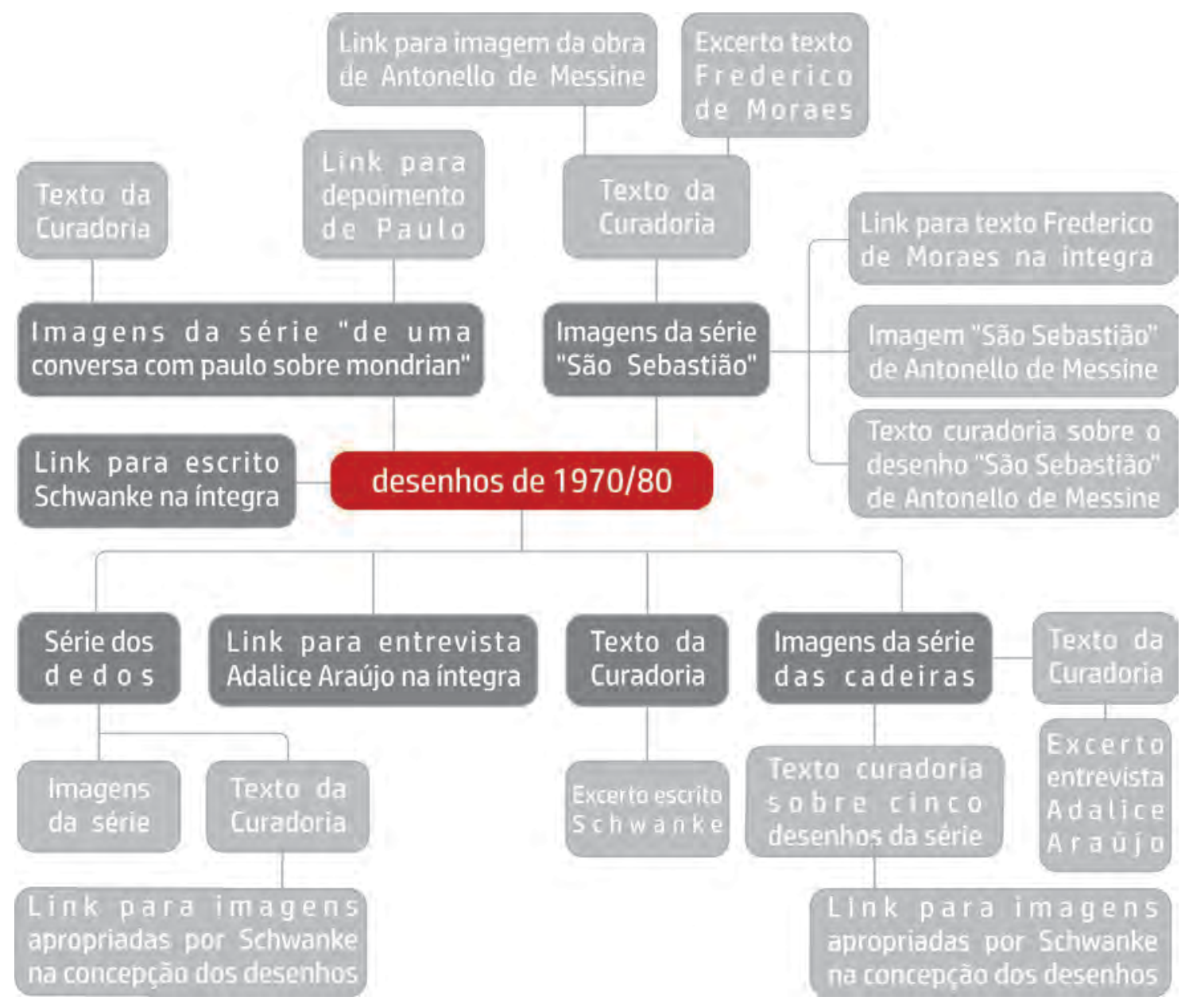

Figura 88 - Infográfico do desenho da curadoria para a página Desenhos de 1978/80 Fonte: Primária

Por conseguinte, com base no texto da curadoria, mas também de forma separada dele, é disponibilizado por meio de link o texto escrito por Schwanke em que relata, de maneira geral, o impacto que sofreu ao ter contato com o elemento luz, o que se deu por conta do estudo da história da arte. 0 texto do joinvilense também pontua alguns artistas que para ele foram importantes no que diz respeito ao estudo da luz e dos quais se apropriou para a realização dos desenhos que integraram a exposição. Disponibilizar esse texto é uma maneira de aproximar o visitante do artista e de seu pensamento. Observa-se aqui que o visitante, dependendo de seu perfil e do grau de interesse despertado pela produção do artista, pode ou não ler o texto disponibilizado, já que, conforme citado, a exposição oferece diferentes camadas de aprofundamento para diversos tipos de visitante.

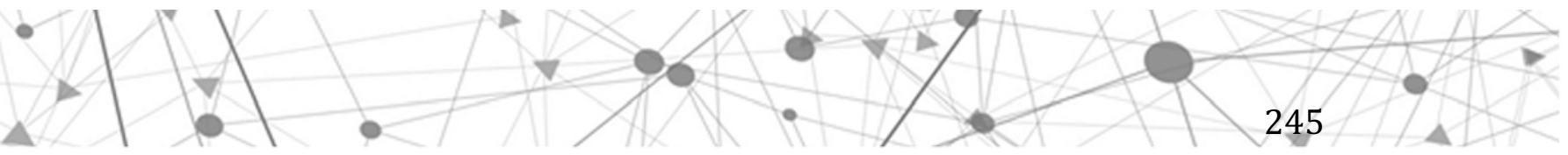


Assim como tratado no capítulo 3, esse conjunto de desenhos é formado por quatro diferentes seriações. A série De uma Conversa com Paulo sobre Mondrian é composta por três desenhos, e todos podem ser visualizados na exposição virtual. Caso o visitante queira mais informações além da visualização das imagens, foi feito como parte da exposição um pequeno texto acerca dessa série apresentando possíveis relações a ser estabelecidas entre os desenhos de Schwanke e as pinturas de Mondrian. Também acompanha esses desenhos uma gravação de áudio com depoimento de Paulo, amigo de Schwanke, citado no título dessa série.

A série São Sebastião, por sua vez, contém seis desenhos, porém tem-se apenas a imagem de quatro. Vê-se aqui que as imagens ausentes, por serem desconhecidas por parte da curadoria, estão representadas na exposição por um retângulo em branco. Acompanham as imagens dessa série um pequeno texto explicativo e uma citação de Frederico Morais, excerto extraído de uma reportagem de jornal, a qual pode ser acessada na íntegra pelo link, e no qual o crítico analisa a série. Além da disponibilização da imagem de Antonello de Messina por Schwanke, apropriada para a realização dessa série, foi desenvolvida uma breve leitura analítica do desenho São Sebastião de Antonello de Messina, Retrato de Peter Jubel.

Já as cadeiras são trabalhadas por Schwanke em uma série que, até o momento, se acredita ser composta por nove desenhos, e todos podem ser visualizados nessa exposição virtual. Assim como acontece com as demais, as imagens dessa série também são acompanhadas por um texto analítico. Para que o visitante conheça o pensamento de Schwanke acerca do objeto cadeira, foi disponibilizado um fragmento de uma entrevista realizada por Adalice Araújo, por meio da qual o artista fala dessa peça de mobiliário. Caso o visitante tenha interesse, pelo link pode ter acesso à entrevista completa. Ainda aqui, é disponibilizado um texto analítico a respeito de cinco dos nove desenhos da série, $\mathrm{e}$ todos eles acompanham link para a imagem da obra por Schwanke apropriada para a concepção dos desenhos.

A série dos dedos, por sua vez, acredita-se até o momento que seja composta por oito trabalhos, e todos podem ser visualizados na exposição virtual digital. Tal qual ocorre com as demais seriações, essa também acompanha um texto analítico, além da leitura de um dos trabalhos que a compõem. Segue também link 
para imagens das referências utilizadas por Schwanke no processo de criação desses trabalhos.

Já O Apogeu do Claro-escuro Pós-Caravaggio (figura 89) compõe, segundo a lógica do título dado por Schwanke, a terceira parte da exposição. Como já tratado no capítulo anterior, esse trabalho consiste na luz produzida por um sistema de arco voltaico, abrigado no interior de um antigo projetor de cinema. É o primeiro trabalho em que Schwanke fez uso da luz propriamente dita, produzida por eletricidade, gesto que se repetiria quase dez anos mais tarde. 0 texto analítico sobre esse trabalho acompanha fragmento de texto escrito por Schwanke no qual relata como o elemento luz surgiu em sua produção, possibilitando ao visitante estabelecer uma relação mais próxima com o trabalho com base na fala do próprio artista. Também é disponibilizada uma citação de Vera, amiga de Schwanke, na qual conta o momento, do qual participou, em que o artista teve a ideia que mais tarde originou esse trabalho.

0 visitante também poderá ter contato com o relato de Schwanke, por meio de mais uma citação, na qual conta como resolveu a realização desse trabalho, citando até mesmo a participação de Jaques. Para completar o conjunto de informações, também poderá ser lido um relato de Jaques sobre como conseguiu produzir o arco voltaico para a exposição do amigo. Ressalta-se que todos os documentos poderão ser lidos na íntegra, caso o visitante tenha interesse em se aprofundar ainda mais.

Como um complemento do olhar e do conhecimento sobre a produção de Schwanke, mas também para a constatação da importância do elemento luz na obra do artista, tendo em vista que, conforme já dito, esse trabalho é o primeiro em que ela aparece, disponibiliza-se um link para o documentário À luz de Schwanke, produzido pela Contraponto, empresa de Florianópolis.

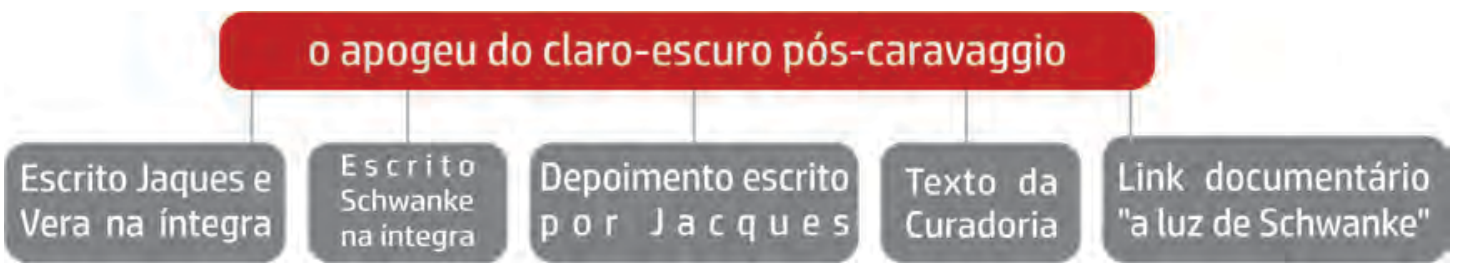

Figura 89 - Infográfico com o desenho da curadoria para a página de 0 Apogeu do Claroescuro Pós-Caravaggio

Fonte: Primária 
Conforme percebido pelo escrito e ressaltado pelos infográficos, a remontagem virtual realizada explora a natureza rizomática e hipermidiática do ciberespaço. Por meio dela, é oferecida ao visitante a exploração de diferentes camadas de aprofundamento, por meio de textos, áudios, vídeos ou imagens, exploradas segundo o seu interesse. Nada impede que o visitante se restrinja à visualização das imagens, contudo o objetivo é que ele seja incentivado a explorar um pouco mais, no desenvolvimento do olhar de procura.

\subsubsection{Montagem de 1980}

Essa parte da exposição foi concebida no processo de curadoria como uma forma de disponibilizar ao visitante informações sobre a montagem original realizada por Schwanke (figura 90).

Logo de início, pode ser lido um texto introdutório, curto, no qual constam informações básicas acerca da mostra. Por links no texto de introdução, mas que também são disponibilizados à parte, o visitante poderá ter contato com diferentes mídias que funcionam como ferramentas de aprofundamento e ampliação do olhar em relação aos trabalhos, que nesse momento podem já ter sido explorados, ou não.

Aqui, é disponibilizado um arquivo de vídeo no qual o crítico de arte João Henrique do Amaral, autor do texto do catálogo da mostra de 1980 , relata 0 processo de montagem da exposição. Também consta um relato escrito pelo amigo de Schwanke, o engenheiro eletricista Antônio Jaques da Silva, que o ajudou a produzir o arco voltaico que resultou no trabalho 0 Apogeu do Claro-escuro PósCaravaggio. Nesse relato, Jaques descreve minuciosamente o processo de produção da luz. Constam também dessa parte da exposição virtual inúmeras fotos, também realizadas por Jaques, único registro que até o momento se tem da mostra original, as quais serviram de base para a remontagem de Nadja de Carvalho Lamas em 1999, assim como para a remontagem de A Casa Tomada (de Julio Cortázar) por Desenhos que não Deram Certo e O Apogeu do Claro-escuro Pós-Caravaggio, feita para captar as imagens para o vídeo disponível na remontagem virtual.

Com o intuito de salientar a importância que essa exposição teve para a produção de Schwanke, são disponibilizados também um vídeo no qual a crítica de 
arte e pesquisadora de Schwanke Nadja de Carvalho Lamas fala dessa mostra e reportagens de jornais e revistas, excertos críticos e o catálogo original em PDF. Ainda nesse espaço, são disponibilizadas ferramentas participativas. Uma delas por meio do botão Estive nessa Exposição, pelo qual pessoas que tiveram a oportunidade de visitá-la podem deixar o seu relato, o que contribuirá tanto para enriquecer a exposição virtual como também para complementar a documentação que se tem sobre a mostra original. Outra, pelo botão Eu Tenho um Trabalho que fez Parte dessa Exposição", poderão ser localizados trabalhos que não são conhecidos pelo MAC Luiz Henrique Schwanke ou que têm a sua localização desconhecida.

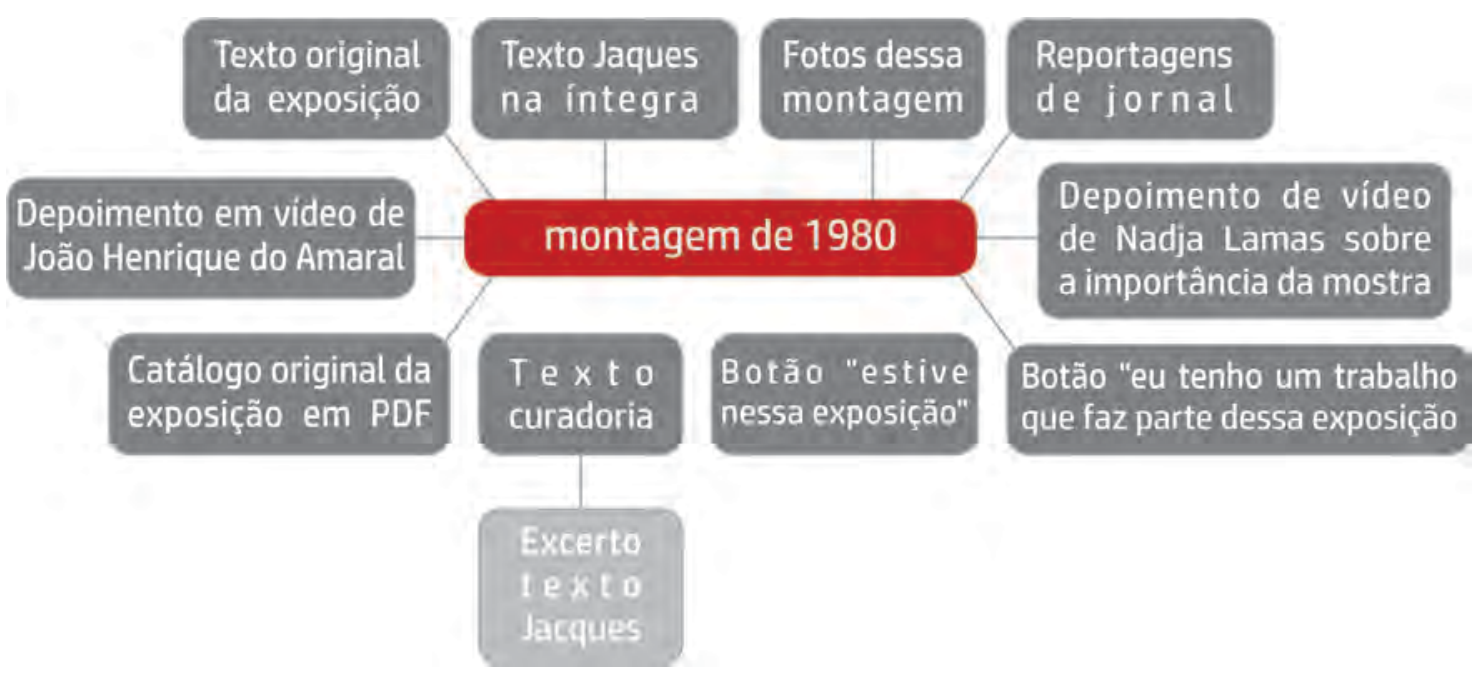

Figura 90 - Infográfico do desenho da curadoria para a página Montagem de 1980 Fonte: Primária

\subsubsection{A montagem de 1999}

Essa remontagem foi realizada por Nadja de Carvalho Lamas, na Sala Especial do Salão Nacional Victor Meirelles, em 1999, na cidade de Florianópolis. $\mathrm{Na}$ ocasião, Lamas trabalhou com o apoio de Maria Regina Schwanke Schroeder, irmã do artista, e conseguiu localizar em acervos institucionais e particulares 26 dos 30 desenhos originais, e todos eles foram emprestados para integrar a exposição. Além das fotos dessa remontagem, são disponibilizados ao visitante o catálogo em PDF e um vídeo no qual a curadora fala do processo de realização da exposição. Também é disponibilizado nessa parte da exposição o botão Estive nessa Exposição (figura 91). 


\section{Botão "estive Texto original $T$ e $x \mathrm{t}$ o Reportagens Fotos dessa nessa exposição" da curadoria curadoria de jornal montagem}

Figura 91 - Infográfico do desenho da curadoria para a página de Montagem de 1999 Fonte: Primária

\subsubsection{Organize a sua própria mostra}

No processo de concepção da exposição, foi levado em consideração o fato de o MAC Schwanke Virtual não possuir público, já que é imaterial, mas visitantes, os quais vão exercitar a exposição individualmente. Por meio de um constante processo de recriação, cada um dos visitantes é dotado de potencial para alterar a exposição (SCHEINER, 2008), o que se dará à medida que ela for exercitada.

Nesse sentido, as ferramentas disponibilizadas foram escolhidas no incentivo desse processo. Além das diferentes mídias que podem ser acessadas no processo de exploração da mostra tendo em vista o interesse do visitante e os botões para sua participação, é oferecida como ferramenta pensada como parte da experiência que é a exposição a possibilidade de cada um montar a sua própria mostra.

Para tal, podem ser selecionadas tanto imagens dos trabalhos de Schwanke que integram a mostra como também de outros artistas, disponíveis em sites, a fim de colocar-se em diálogo com a produção do artista joinvilense. As imagens podem ser selecionadas do arquivo pessoal do visitante, de alguma página da internet, ou do acervo online de museus, por uma lista de links. Também é oferecido um espaço para que se dê um título à mostra e se escreva um texto explicativo.

Após ser aprovada pelo ILHS, a exposição criada pelo visitante ficará disponível como parte integrante da exposição virtual durante um mês e poderá ser disponibilizada nas redes sociais. Esse processo de aprovação ou não será realizado no sentido de preservar a obra do artista, assim como o MAC Luiz Henrique Schwanke, levando em conta que esse espaço poderá ser utilizado também por pessoas de má-fé que tenham outras finalidades que não envolvam aquilo que 0 exercício propõe. 
É interessante observar, mais uma vez, que apenas seis instituições que possuem o seu ambiente virtual em rede oferecem essa possibilidade ao visitante, por meio da qual ele estabelece relação pessoal com a coleção (figura 95).

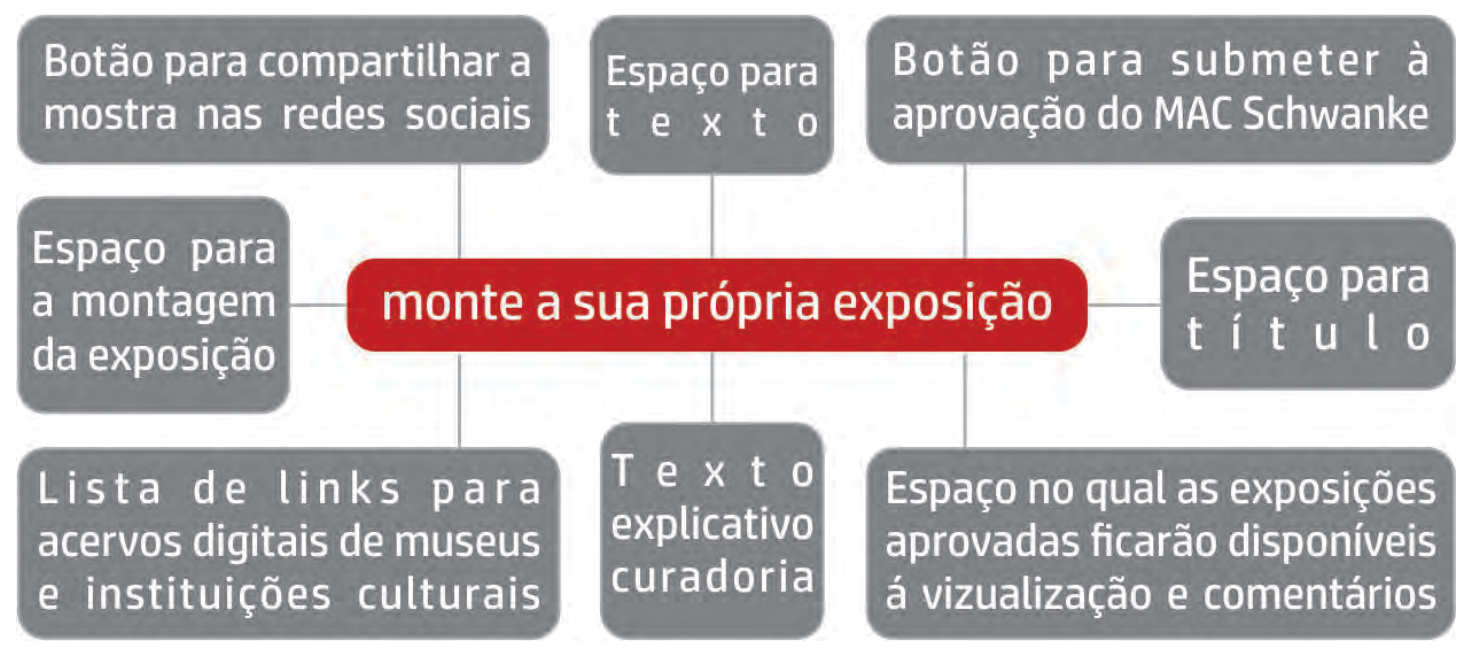

Figura 92 - Infográfico do desenho da curadoria para a página Monte sua Própria Exposição Fonte: Primária

\subsubsection{Para o professor}

Como já tratado em momentos anteriores, essa exposição foi desenhada com base na curadoria educativa, ou seja, foi pensada como um instrumento de ação cultural, não havendo necessidade de se fazer um espaço específico de arte/educação para disponibilizar atividades com esse fim. Contudo optou-se por construir um material pensado especificamente para o professor como um incentivo para que coloque essa exposição em exercício na escola, ou que a insira naquele contexto como uma ferramenta no processo de ensino/aprendizagem, de forma a incentivar os estudantes a visitar a exposição também de casa. A ideia que fundamenta a concepção desse material não é oferecer fórmulas, mas possibilidades que podem ser apropriadas pelo professor e adaptadas tendo em vista a realidade da escola e da turma.

Conforme pôde ser observado, a exposição virtual construída não possui equivalente na realidade física e explora ferramentas e a estrutura rizomática e não linear do ambiente virtual em rede. Com base na curadoria educativa, a mostra atinge diferentes perfis de visitante, na disponibilização de inúmeras camadas de 
aprofundamento, por meio de informações disponibilizadas em mídias de naturezas diversas.

Assim, com essa mostra, observa-se que não faz sentido a dissociação entre pensamento curatorial e proposta educativa, entendendo a última de maneira ampliada, já que está no âmago da proposta curatorial e tem por foco todo e qualquer visitante, visando articular a arte, o indivíduo e a sociedade. Essa exposição, bilíngue (português e inglês), consiste em um dos programas do MAC Luiz Henrique Schwanke, que, por meio de seu exercício no ciberespaço, torna a produção desse artista ativa, de forma constante, além de existir a possibilidade de levá-la a qualquer lugar do planeta que tenha um computador, ou outro dispositivo de natureza microeletrônica, conectado à internet.

Ao se comparar a exposição desenhada no contexto desta tese com as exposições virtuais realizadas pelas três instituições com sede física, mas que também exploram o ambiente virtual em rede como um meio de colocar seu acervo em exercício na construção de exposições independentes de espaço físico, poderão ser percebidos os avanços conquistados por meio da curadoria educativa (tabela 5).

\begin{tabular}{|c|c|c|c|c|c|c|}
\hline $\begin{array}{l}\text { Museus e } \\
\text { Instituições }\end{array}$ & $\begin{array}{l}\text { Disponibilização } \\
\text { do acervo físico } \\
\text { em exercício }\end{array}$ & $\begin{array}{l}\text { Trabalho com } \\
\text { hipermídia }\end{array}$ & $\begin{array}{c}\text { Exploração } \\
\text { da estrutura } \\
\text { não linear }\end{array}$ & $\begin{array}{l}\text { Ferramentas } \\
\text { participativas }\end{array}$ & $\begin{array}{c}\text { Oferta de } \\
\text { diferentes } \\
\text { camadas de } \\
\text { aprofundamento }\end{array}$ & $\begin{array}{l}\text { Espaço de } \\
\text { troca com o } \\
\text { visitante }\end{array}$ \\
\hline $\begin{array}{l}\text { Carnamah } \\
\text { Museum }\end{array}$ & $x$ & & & & & \\
\hline $\begin{array}{c}\text { Museu Casa de } \\
\text { Portinari }\end{array}$ & $x$ & & $x$ & $x$ & & \\
\hline $\begin{array}{c}\text { Galeria } \\
\text { Nacional do } \\
\text { Canadá }\end{array}$ & $x$ & $x$ & $x$ & & & \\
\hline $\begin{array}{c}\text { MAC } \\
\text { Schwanke } \\
\text { Virtual }\end{array}$ & $x$ & $x$ & $x$ & $x$ & $x$ & $x$ \\
\hline
\end{tabular}

Tabela 5 - Análise geral das exposições virtuais de acervos físicos digitalizados em comparação com a mostra do MAC Schwanke Virtual por meio da curadoria educativa Fonte: Primária

Segundo a tabela 5 , ao se ter por objetivo não apenas mostrar, mas problematizar, provocar o aprofundamento do olhar e exercitar a arte como um instrumento de ação cultural, a curadoria educativa promove a articulação entre a arte, 0 indivíduo e a sociedade. A arte é colocada em discussão na exposição virtual por meio da reprodução digitalizada do acervo físico. 0 indivíduo visitante tem a oportunidade de escolher o grau de aprofundamento em relação à produção em discussão e de optar pelas mídias e ferramentas que melhor se enquadram com o 
seu perfil. Por meio das ferramentas participativas, pode fazer parte da mostra e posicionar-se perante o museu e a sociedade sobre o que pensa e sobre o que construiu com base na vivência da arte em questão. Assim, a exposição construída destaca-se em comparação às analisadas principalmente por oferecer diferentes graus de aprofundamento e atividades de natureza participativa, o que não aparece em nenhuma das exposições averiguadas. 


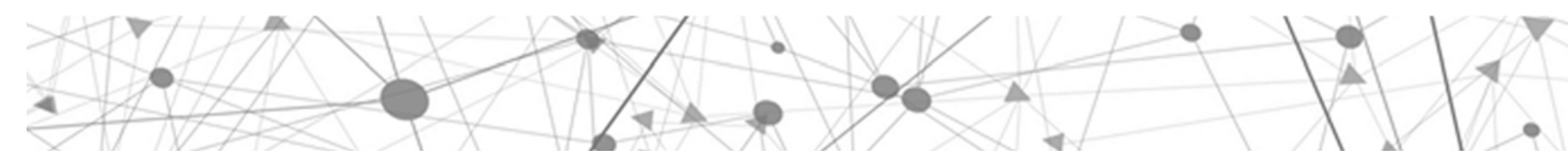

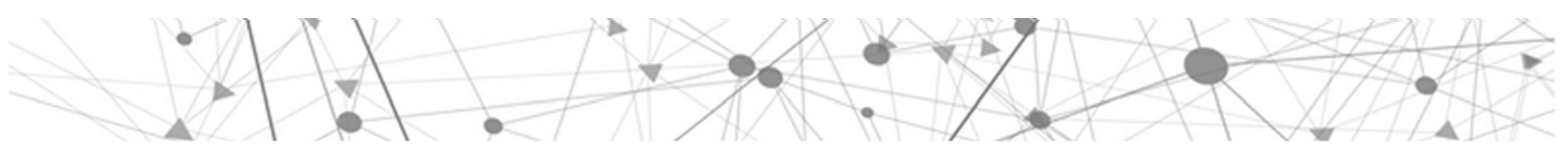


"Museums can become mausoleums of historical culture reserved for the pleasure of a global elite or they can respond to the challenge and become cultural connectors for a society which no longer knows how to communicate. In other words, museums can remain [...] museum pieces, or they can reinvent themselves as communication protocols for a new humankind" ${ }^{119}$ (CASTELLS, 2009, p. 434).

Com base no que foi tratado ao longo desta tese, pode-se afirmar que o MAC Schwanke Virtual é um museu virtual pelo fato de ele, apesar de estar vinculado a um acervo físico, não possuir equivalente na realidade física (SCHEINER, 2004), já que explora as especificidades no ambiente virtual em rede. Assim, o espaço virtual de exposição do museu foi então explorado enquanto espaço de presentificação (SCHEINER, 2008) dos trabalhos de Schwanke, em articulação com as ideias do visitante construídas por meio da vivência da mostra. Portanto, o museu atua, por meio de seu exercício no ciberespaço, enquanto um fenômeno cultural, e a exposição existirá apenas no momento da vivência.

Ressalta-se, uma vez mais, que, das 135 instituições mapeadas (apêndice 1), 95 disponibilizam consulta ao seu acervo online, enquanto apenas 40 oferecem propostas participativas que de alguma forma exercitam essa coleção. Delas, somente 22 disponibilizam exposições virtuais.

Sendo o foco deste estudo as instituições físicas que exercitam o ambiente virtual em rede também para realizar exposições de seu acervo físico digitalizado, foram analisadas exposições das quatro que atendem a esses critérios. São elas: 0 Carnamah Historical Society \& Museum, o Palácio de Versalhes, a Galeria Nacional do Canadá e o Museu Casa de Portinari. Tal fato evidencia tanto a insipiência da exploração do ambiente virtual em rede por parte dos museus e das instituições culturais e museológicas, assim como a relevância da pesquisa e da exposição virtual produzida no contexto desta tese, já que, além de divulgar e difundir a produção de Luiz Henrique Schwanke, a exposição exercita as possibilidades de envolver o visitante com o museu, envolvimento esse que não apenas implica

\footnotetext{
119 "Os museus podem se tornar mausoléus da cultura histórica reservados para o prazer de uma elite global ou eles podem responder ao desafio de se tornarem conectores culturais para uma sociedade que não sabe mais se comunicar. Em outras palavras, os museus podem continuar 'peças de museu' ou eles podem se reinventar como protocolos de comunicação para uma nova humanidade" (livre tradução).
} 
apresentar a obra do artista, ou tornar o museu conhecido e oferecer atividades participativas, mas também por entrar na vida do visitante.

A exposição construída aqui oferece, em uma primeira camada, imagens dos trabalhos do artista, disponíveis à experiência estética e ao exercício da imaginação, contudo diferencia-se das demais por também disponibilizar ao visitante, fora poder expressar seu ponto de vista e ele próprio exercitar a produção do artista organizando a sua própria exposição, mais camadas de aprofundamento, na exploração da estrutura não linear do ciberespaço, o que se dá pela disponibilização de diferentes mídias, as quais veiculam informações, documentos e depoimentos do próprio artista e também de historiadores, de críticos e de curadores. Logo, 0 visitante pode optar por ficar na experiência do imaginar, ou aprofundar o seu olhar e os seus conhecimentos acerca da fatura do artista e do contexto que a envolveu. Dessa forma, a exposição atinge vários tipos de público, desde 0 iniciante até 0 pesquisador e o iniciado.

Ressalta-se ainda que o MAC Schwanke Virtual optou por não inserir no ambiente virtual em rede imagens de todo o seu acervo, tendo em vista que disponibilizar não significa tornar acessível. A proposta do museu defendida na presente tese é realizar exposições, a exemplo da que foi agora construída, pensadas especificamente para esse ambiente, com base em propostas curatoriais que provoquem o visitante a pensar e a construir conhecimento mediante aquela produção, ou seja, que exercite o acervo, que dele tome posse enquanto patrimônio, que também é seu, e, assim, o valorize. Isso sim pode ser compreendido como acessibilidade.

Assim, com a realização dessa exposição virtual, de natureza digital, podese afirmar que o museu virtual, disponibilizado no contexto do ciberespaço, incentiva não somente a experiência estética, como também a construção de conhecimento pelo exercício de seu acervo, no cumprimento de um papel tão importante no que tange à experiência estética e à valorização do patrimônio artístico e cultural quanto o de um museu físico.

Ao mesmo tempo em que o MAC Schwanke Virtual torna conhecida a produção artística de Luiz Henrique Schwanke, preservando dessa maneira a sua memória, o que aqui se dá por meio da disponibilização de uma exposição virtual, 
ele a mantém viva, ativa e permanentemente em contato com o visitante que a exercita.

Por conseguinte, conclui-se que o museu virtual, por meio da realização de exposições, nesse caso fundamentada na curadoria educativa, promove a dinamização entre arte, indivíduo e sociedade, funcionando como um relevante programa relacional oferecido pelo museu. 


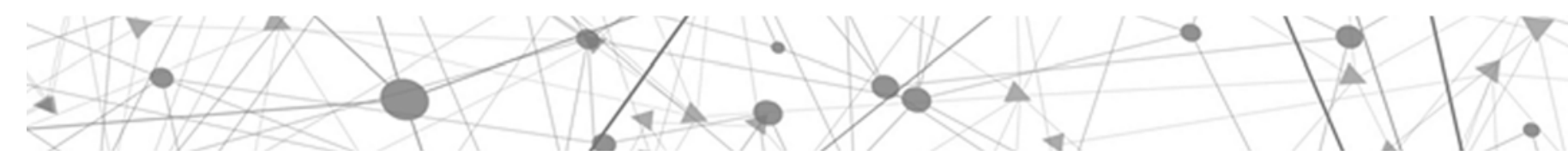

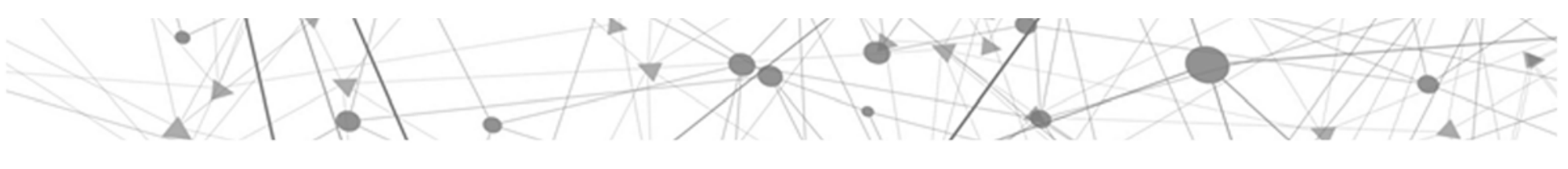




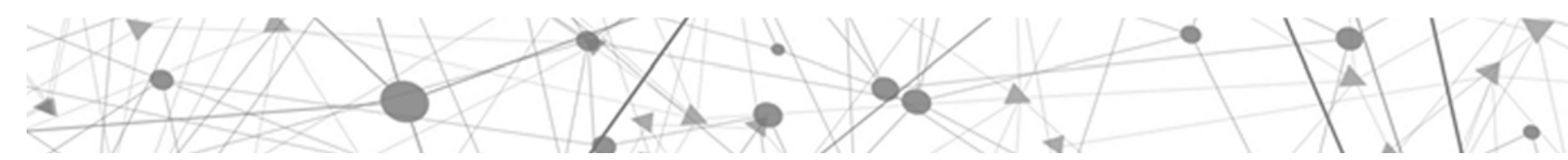

\section{REFERÊNCIAS}

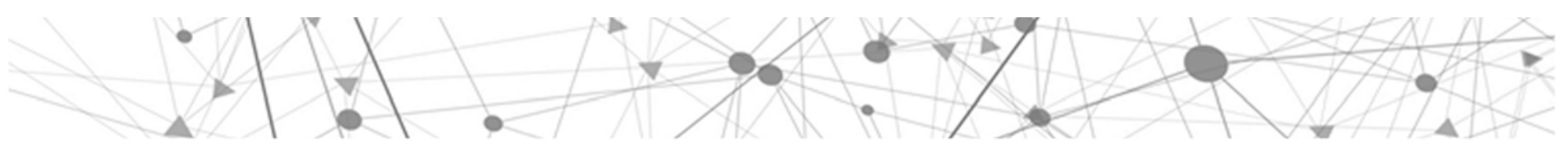




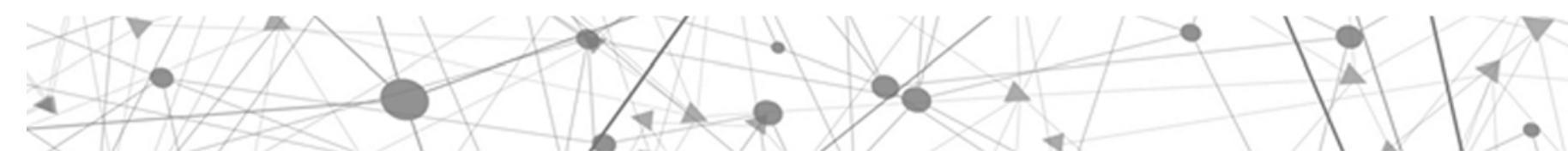

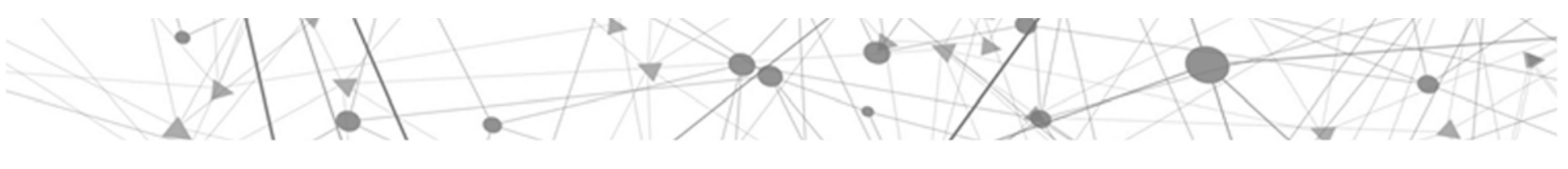


À LUZ DE Schwanke. Direção: Ivi Brasil e Maurício Venturi. Produção: Maurício Venturi. Florianópolis: Contraponto, 2008 [produção]. 1 documentário (17 min). Disponível em: https://vimeo.com/9762194. Acesso em: 16 set. 2016.

AGAMBEN, Giorgio. 0 que é o contemporâneo e outros ensaios. Chapecó: Argos, 2009.

ALTSHULER, Bruce. Salon to biennial: exhibitions that made history. 1963-1959. Estados Unidos: Phaidon Press, 2008. v. 1.

ARAÚJO, Adalice. Adalice Araújo: entrevista. [1986]. Entrevista concedida a Alena Rizi Marmo Jahn.

ARGAN, Giulio Carlo. Arte moderna. São Paulo: Companhia das Letras, 1992.

Letras, 2004.

Imagem e persuasão: ensaios sobre o barroco. São Paulo: Companhia das

ASCOTT, Roy. The museum of the third kind. InterCommunication, n. 15, 1996. Disponível em: <http://www.ntticc.or.jp/pub/ic_mag/ic015/ascott/ascott_e.html>. Acesso em: 10 jun. 2013.

BARBOSA, Ana Mae. Educação em museus: termos que revelam preconceitos. Caderno de Textos Diálogos entre Arte e Público, n. 1, p. 28-32, 2008.

BASBAUM, Ricardo (Org.). Arte contemporânea brasileira: texturas, dicções, ficções, estratégias. Rio de Janeiro: Contra Capa, 2001.

BÍBLIA SAGRADA. Rio de Janeiro: Barsa. Encyclopaédia Britannica Publishers, 1977.

BINI, Fernando A. F. A crítica de arte e a curadoria. In: GONÇALVES, Lisbeth Rebolo; FABRIS, Annateresa (Orgs.). Os lugares da crítica de arte. São Paulo: $A B C A$, Imprensa Social, 2005. p. 97-107.

BLOM, Philipp. Ter e manter: uma história íntima de colecionadores e coleções. Rio de Janeiro: Record, 2003.

BOURRIAUD, Nicolas. Estética relacional. São Paulo: Martins Fontes, 2009.

BRASIL. Presidência da República. Casa Civil. Subchefia para Assuntos Jurídicos. Lei n.- 11.904, de 14 de janeiro de 2009. Institui o Estatuto dos Museus e dá outras providências. Brasília, $2009 . \quad$ Disponível em: http://www.planalto.gov.br/ccivil_03/_Ato2007-2010/2009/Lei/L11904.htm>. Acesso em: 16 set. 2015.

BROWN, Milton. The Armory Show: un évenement médiatique. In: HEGEWISCH, Katharina; KLUSER, Bernd. L'art de L'Exposition L'. França: Editions Du Regard, 1998. p. 91-105. 
CAMNITZER, Luis; PÉREZ-BARREIRO, Gabriel (Orgs.). Arte para a educação: educação para a arte. Porto Alegre: Fundação Bienal do Mercosul, 2009. Disponível em:

<http://www.fundacaobienal.art.br/novo/arquivos/publicacao/pdf/Livro_Arte_Edu cacao.pdf>. Acesso em: 10 jun. 2016.

CASTELLS, Manuel. A sociedade em rede. São Paulo: Paz e Terra, 2000.

Terra, 1999.

Fim de milênio: a era da informação, sociedade e cultura. São Paulo: Paz e

. Museums in the information era: cultural connectors of time and space. In: PARRY, Ross. Museum in a digital age. Londres, 2009. p. 427-434.

CAUQUELIN, Anne. Arte contemporânea: uma introdução. São Paulo: Martins Fontes, 2005.

- Frequentar os incorporais: contribuição a uma teoria da arte contemporânea. São Paulo: Martins Fontes, 2008.

CHAGAS, Mário S. Os Museus na moldura da crise. Musas, Rio de Janeiro, v. 5, p. 102-121, 2011.

et al. Museus e público jovem: percepções e receptividades. Museologia e

Patrimônio, v. 3, p. 41-48, 2010.

CHEVALIER, Jean; GHEERBRANT, Aliain. Dicionário de símbolos: mitos, sonhos, costumes, gestos, formas, figuras, cores, números. Rio de Janeiro: José Olympio, 2002.

CHIARELLI, Tadeu. As funções do curador, o Museu de Arte Moderna de São Paulo e o Grupo de Estudos de Curadoria do MAM. In: CHAIMOVICH, Felipe (Org.). Grupo de estudos de curadoria. São Paulo: Museu de Arte Moderna de São Paulo, 2008. p. 13-19.

CINTRÃO, Rejane. As montagens de exposições de arte: dos Salões de Paris ao MoMA. 2010. p. 15-41.

CIPINIUK, Albert. A face pintada em pano de linho: moldura simbólica da identidade brasileira. São Paulo: Loyola, 2003.

CORTÁZAR, Julio. Bestiário. São Paulo: Círculo do Livro, 1951.

CROW, Thomas. Painters and public life in eighteenth-century Paris. Londres: Yale University Press/New Haven \& London, 1985.

CURY, Marília Xavier. Exposição, montagem e avaliação. São Paulo: Annablume, 2005. 
DELOCHE, Bernard. El museo virtual. Espanha: Ediciones Trea, 2002.

- El museo virtual: hacia una ética de las nuevas imágenes. Espanha: Ediciones Trea, 2004.

. ¿Es el museo virtuel un competidor real para el museo institucional? MusA, Andaluzia, n. 5, p. 16-21, jun. 2005. Disponível em: <http://www.juntadeandalucia.es/cultura/museos/media/docs/PORTAL_musa_n5. pdf>. Acesso em: 14 set. 2016.

DEMPSEY, Amy. Estilos, escolas e movimentos: guia enciclopédico da arte moderna. São Paulo: Cosac Naify, 2003.

DÉOTTE, Jean-Louis. Os imateriais de Lyotard (1985): um programa figural. Pós: Belo Horizonte, Belo Horizonte, v. 5, n. 9, p. 189-201, maio 2015. Disponível em: <http://www.eba.ufmg.br/revistapos/index.php/pos/article/view/264/153>. Acesso em: 1.ํo jun. 2016.

DESVALLÉES, André; MAIRESSE, François (Orgs.). Conceitos-chave de museologia. São Paulo: Icom, 2013. Disponível em: <http://icom.museum/fileadmin/user_upload/pdf/Key_Concepts_of_Museology/C onceitos-ChavedeMuseologia_pt.pdf>. Acesso em: 8 set. 2016.

DEWEY, John. Arte como experiência. São Paulo: Martins Fontes, 2010.

DIONÍSIO, Gustavo Henrique. Museu de Imagens do Inconsciente: considerações sobre sua história. Psicologia: Ciência e Profissão, Brasília, v. 21, n. 3, p. 30-35, set. 2001. Disponível em: <http://www.scielo.br/scielo.php?script=sci_arttext\&pid=S141498932001000300005\&lng=en\&nrm=iso>. Acesso em: $11 \mathrm{dez} .2015$.

FARIAS, Agnaldo (Coord.). Bienal 50 anos: 1951-2001. São Paulo: Fundação Bienal de São Paulo, 2001.

FREIRE, Paulo. Pedagogia da autonomia: saberes necessários à prática educativa. São Paulo: Paz e Terra, 2009.

GANT, María Luísa Bellido. Arte, museos y nuevas tecnologias. Espanha: Ediciones Trea, 2001.

GONÇALVES, Lisbethe Rebollo. Entre cenografias: o museu e a exposição de arte no século XXI. São Paulo: Edusp, 2004.

GREGOROVÁ, Anna. During the recent years of my work with the Slovak National Museum. In: MUSEOLOGICAL WORKING PAPERS MUSEOLOGY. Science or just practical museum work? Estocolmo: Icom, 1980. n. 1. p. 19-21.

HESÍODO. Teogonia: a origem dos deuses. Tradução de Jaa Torrano. São Paulo: Iluminuras, 1991. 
HUHTAMO, Erkki. On the origins of the virtual museum. In: NOBEL SYMPOSIUM: Virtual Museums and Public Understanding of Science and Culture, Estocolmo, maio 2002. $\quad 2002 . \quad$ Dnais..., em: <https://www.nobelprize.org/nobel_organizations/nobelfoundation/symposia/inte rdisciplinary/ns120/lectures/huhtamo.pdf>. Acesso em: 11 set. 2016.

. On the origins of the virtual museum. In: PARRY, Ross. Museum in a digital age. Londres/Nova York: Routledge, 2010. p. 121-135.

INTERNATIONAL COUNCIL OF MUSEUMS (Icom). Museum definition. 2010. Disponível em: <http://icom.museum/the-vision/museum-definition/>. Acesso em: 1. dez. 2015.

JACOB, Mary Jane; BAAS, Jacquelynn. Learning mind: experience into art. Commencement, School of the Art Institute of Chicago. Berkeley/Los Angeles/Londres: University of California Press, 2007.

JACOB, Mary Jane; BRENSON, Michael; OLSON, Eva M. (Eds.). Culture in action: a public art program of sculpture Chicago. Seattle: Bay Press, 1995.

JANET CARDIFF'S audio walks. [40] Notes: Investigations into Contemporary Art, 2011. Disponível em: <https://fortynotes.wordpress.com/2011/03/03/janetcardiffs-audio-walks/>. Acesso em: 10 jun. 2016.

JANSON, H. W. História da arte. São Paulo: Martins Fontes, 1992.

LACOMBE, Marcelo S. Masset. 1924: uma exposição de arte e arte decorativa alemã no Brasil. Baleia da Rede, v. 1, n. 6, dez. 2009. Disponível em: <http://www.marilia.unesp.br/Home/RevistasEletronicas/BaleianaRede/Edicao06/ 5c_exposicao_alema.pdf>. Acesso em: 20 maio 2016.

LAMAS, Nadja de Carvalho. Revendo a casa tomada..., tão atual como em 80. In: CATÁLOGO DA SALA ESPECIAL LUIZ HENRIQUE SCHWANKE. 6. Salão Nacional Victor Meirelles. 1999. p. 9-21.

LÉVY, Pierre. As tecnologias da inteligência: o futuro do pensamento na era da informática. São Paulo: 34, 1995.

. Cibercultura. São Paulo: 34, 1999.

Filosofia world: o mercado, o ciberespaço, a consciência. Portugal: Instituto Piaget, 2001.

0 que é virtual? São Paulo: 34, 2011.

LYOTARD, Jean-François. Les Immatériaux. 1985. In: GREENBERG, Reesa; FERGUSON, W. Bruce; NAIRNE, Sandy. Thinking about exhibitions. Londres/Nova York: Routledge, 2006. p. 159-173. 
LOUREIRO, Maria Lucia de Niemeyer Matheus. Webmuseus de arte: aparatos informacionais no ciberespaço. Ciência da Informação, Brasília, v. 33, dez. 2004. Disponível em: <http://www.scielo.br/pdf/ci/v33n2/a10v33n2.pdf>. Acesso em: 25 abr. 2016.

LYNTON, Norbert. Expressionismo. In: STANGOS, Nikos (Org.). Conceitos de arte moderna. Rio de Janeiro: Zahar, 2000. p. 24-37.

MACHADO, Ana Maria Alves. Cultura, ciência e política: olhares sobre a história da criação dos museus no Brasil. In: FIGUEIREDO, Betânia Gonçalves; VIDAL, Diana Gonçalves (Orgs.). Museus dos gabinetes de curiosidades à museologia moderna. Belo Horizonte: Fino Traço, 2013.

MALRAUX, André. Le musée imaginaire. Lisboa: Edições 70, 2011.

MARQUESINI, Zilah. Zilah Marquesini: entrevista [1992]. Entrevista do arquivo do Instituto Luiz Henrique Schwanke.

MARM0, Alena Rizi. Perseguindo vestígios: os perfis de Schwanke, catalogação em acervos institucionais. Dissertação (Mestrado)-Universidade Federal do Rio Grande do Sul, Porto Alegre, 2005.

MARTINS, Mirian Celeste (Coord.). Curadoria educativa: inventando conversas. Reflexão e Ação, Santa Cruz do Sul, v. 14, n. 1, p. 9-27, jan./jun. 2006. Disponível em: $\quad<$ http://fvcb.com.br/site/wp-content/uploads/2012/05/Canal-doEducador_Texto_Curadoria-Educativa.pdf>. Acesso em: 14 set. 2016.

MATHIAS, Paul. La ciudad de internet. Barcelona: Ediciones Bellatera, 1998.

MENEZES, Ulpiano Bezerra de. Museu virtual é o museu do futuro? Musas, ano 2, n. 2, 2006.

MENSCH, Peter Van. 0 objeto de estudo da museologia. Tradução de Débora Bolsanello e Vânia Dolores Estevam de Oliveira. Rio de Janeiro: Unirio/UGF, 1994. v. 1. (Pretextos museológicos, 1 ).

. Notas sobre os arredores: patrimônio e novas tecnologias. Musas, Rio de Janeiro, n. 4, 2009.

; POUW, Piet J. M.; SCHOUTEN, Frans F. J. Metodologia da museologia e treinamento profissional. Cadernos Museológicos, Rio de Janeiro, n. 3, p. 57-65, out. 1990.

; SUMINAS, Andrius; GUDINAVICIUS, Arunas. Lithuanian user perceptions of museum websites. Museologica Brunensia, 2015. Disponível em: <http://www.kf.vu.lt/dokumentai/Mokslas/Moksliniai_straipsniai/Mensh_Suminas_ Gudinavicius_Lithuanian_user_perceptions_of_museum_websites2.pdf>. Acesso em: 14 set. 2016. 
MORAIS, Frederico de. De Duchamp a Schwanke, a arte falando da arte. 0 Globo, Rio de Janeiro, 12 nov. 1980.

MUSEU DE ARTE MODERNA GRAND-DUC JEAN. About this Site. Disponível em: $<$ http://archive.mudam.lu/?mode=article\&langue=en\&menu=11002>. Acesso em: 29 abr. 2016.

MUSEU DO LOUVRE. Collections and departaments: Departament of Egyptian Antiquities. 2010. Disponível em: <http://www.louvre.fr/en/departments/egyptianantiquities>. Acesso em: 15 maio 2016.

OBRIST, Hans Ulrich. A brief history of curating. Canadá: JRP Ringier, 2011.

. Ways of curating. Estados Unidos: Farrar Straus \& Giro, 2014.

O'DOHERT, Brian. No interior do cubo branco: a ideologia do espaço da arte. São Paulo: Martins Fontes, 2002.

O'NEILL, Paul; WILSON, Mick (Orgs.). Curating and the educational turn. Londres: Open Editions; Amsterdã: De Appel, 2010.

PABLO HELGUeRA. Fórum Permanente, v. 1, n. 1, 2012. Disponível em: $<$ http://www.forumpermanente.org/revista/edicao-0/entrevistas/pablohelguera>. Acesso em: 11 jun. 2016.

PEREIRA, José Ramón Alonso. Introdução à história da arquitetura: das origens ao século XXI. Porto Alegre: Bookman, 2010.

POULOT, Dominique. Museu e museologia. Belo Horizonte: Autêntica, 2013.

QUÉAU, Philippe. 0 tempo do virtual. In: PARENTE, André (Org.). Imagem-Máquina: era das tecnologias do virtual. Rio de Janeiro: 34, 1999. p. 91-99.

RAMOS, Alexandre Dias (Org.). Sobre o ofício do curador. Porto Alegre: Zouk, 2010.

RATTEMEYER, Christian (Org). Exhibiting the new art. Op Losse Schoeven adn When Atitudes Become Form, 1969 (Exhibition Histories). Londres: Afterall Books, 2010.

RAYWARD, W. Boyd; TWIDALE, Michael B. From docent to cyberdocent: education and guidance in the virtual museum. Archives and Museum Informatics, n. 13, p. 23-53, $1999 . \quad$ Disponível em: <http://people.ischool.illinois.edu/ wrayward/CyberdocentPaper.htm>. Acesso em: 1.ago. 2013.

RITH-MAGNI, Isabel. Mediação artística: entre o norte e o sul. Humboldt, 2011. Disponível em: <http://www.goethe.de/wis/bib/prj/hmb/the/156/pt8622827.htm>. Acesso em: 15 jul. 2016.

RUGG, Judith; SEDGWICK, Michele. Issues in curating contemporary art and performance. Chicago: Intellect Books, Chicago University, 2007. 
RÚSSIO, Waldiza Guarnieri. Conceito de cultura e a interrelação com o patrimônio cultural e a preservação. Cadernos Museológicos, Rio de Janeiro, n. 3, p. 7-12, out. 1990.

RUSSO, Angelina; WATKINS, Jerry. Digital cultural communication: audience and remediation. In: KENDERDINE, Sarah; CAMERON, Fiona. Theorizing digital cultural heritage: a critical discourse. Londres: MIT Press, 2007. p. 149-164.

SANTAELLA, Lúcia. Culturas e arte do pós-humano: da cultura das mídias à cibercultura. São Paulo: Paulus, 2003.

Paulus, 2004.

Navegar no ciberespaço: o perfil cognitivo do leitor imersivo. São Paulo:

SCHEINER, Tereza. Apolo e Dionísio no templo dos museus - museu: gênese, ideia e representações na cultura ocidental. Dissertação (Mestrado)-Escola de Comunicação Social, Universidade Federal do Rio de Janeiro, Rio de Janeiro, 1998.

. Características das exposições segundo modelo conceitual de museu. In: . Museologia e comunicação. Texto n. 2. 2009. (Apostila).

. Imagens do não-lugar: comunicação e os novos patrimônios. Tese (Doutorado)-Escola de Comunicação, Universidade Federal do Rio de Janeiro, Rio de Janeiro, 2004.

- Museu, museologia e a "relação específica": considerações sobre os fundamentos teóricos do campo museal. Ciência da Informação, Brasília, v.42, n.3, p. 358-378, set./dez. 2013.

. 0 museu, a palavra, o retrato e o mito. Revista Eletrônica do Programa de Pós-Graduação em Museologia e Patrimônio, Rio de Janeiro, v. 1, n. 1, jul./dez. 2008. em: <http://revistamuseologiaepatrimonio.mast.br/index.php/ppgpmus/article/view/6 /19>. Acesso em: 28 fev. 2016.

SCHROEDER, Regina Schwanke. Regina Schwanke Schroeder: entrevista [2016]. Entrevista concedida a Alena Rizi Marmo Jahn.

SCHWANKE, Luiz Henrique. Luiz Henrique Schwanke: carta pessoal [1985]. Carta escrita a Harry Laus.

. Luiz Henrique Schwanke: escritos pessoais [1986]. Arquivo pessoal.

. Luiz Henrique Schwanke: escritos pessoais [1992]. Arquivo pessoal.

. Luiz Henrique Schwanke: escritos pessoais [s.d.]. Arquivo pessoal.

SCHWEIBENZ, Werner. The "virtual museum": new perspectives for museums to present objects and information using the internet as a knowledge base and 
communication system. In: INTERNATIONALEN SYMPOSIUMS FÜR INFORMATIONSWISSENSCHAFT, 6., 1998. Proceedings... Praga, nov. 1998. p. 185200. Disponível em: <http://www.informationswissenschaft.org/wpcontent/uploads/isi/isi1998/14_isi-98-dv-schweibenz-saarbruecken.pdf>. Acesso em: 14 set. 2016.

2004. Virtual museums: the development of virtual museums. Icom News, n. 3, <http://icom.museum/fileadmin/user_upload/pdf/ICOM_News/20043/ENG/p3_2004-3.pdf>. Acesso em: 7 mar. 2014.

SILVA, Antônio Jaques; OLIVEIRA, Vera Lúcia de. Apogeu do claro-escuro... e A casa tomada... Notas da pré-história. Curitiba, 13 jul. 2016.

SOLA, Tonislav. Contribuições para uma possível definição de museologia. Cadernos Museológicos, Rio de Janeiro, n. 3, p. 73-77, out. 1990.

TEATHER, L. A museum is a museum... or is it? Exploring museology and the web. Museums and the Web 98. Conference proceedings... Petesburgo: Archives and Museum Informatics, $1998 . \quad$ Disponível em: <http://www.archimuse.com/mw98/papers/teather/teather_paper.html>. Acesso em: 11 fev. 2010.

THE TEMPORARY MUSEUM OF PERMANENT CHANGE. Permanent Collection: Temporary Street Collection. Salt Lake City, 2015. Disponível em: <http://www.museumofchange.org/collection/streetcollection.php>. Acesso em: 1. abr. 2016.

TOMKINS, Calvin. Duchamp. São Paulo: Cosac Naify, 2013.

VERGARA, Luiz Guilherme. Curadorias educativas. In: ANPAP, Rio de Janeiro, 1996. Anais..., 1996. Disponível em: <http://www.arte.unb.br/anpap/vergara.htm>. Acesso em: 14 set. 2016.

WORCMAN, Karen. The Museum of the Person. Icom News, v. 57, n. 3, 2004. Disponível em: <http://icom.museum/fileadmin/user_upload/pdf/ICOM_News/20043/ENG/p4b_2004-3.pdf>. Acesso em: 31 mar. 2016. 


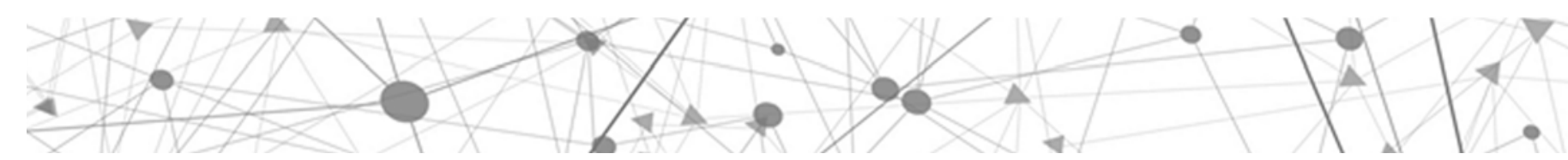

\section{APÊNDICES}

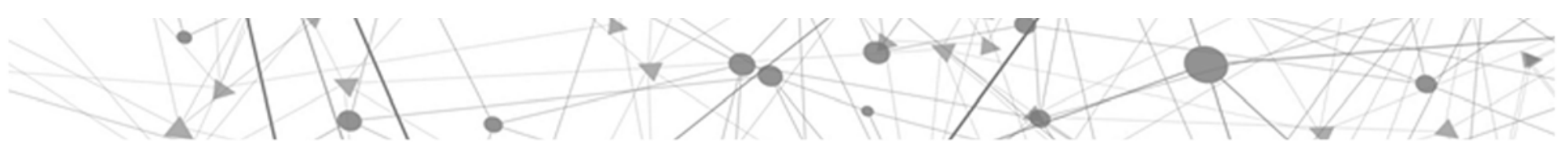




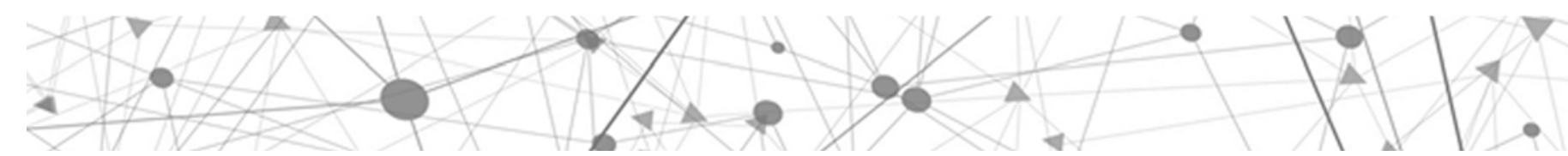

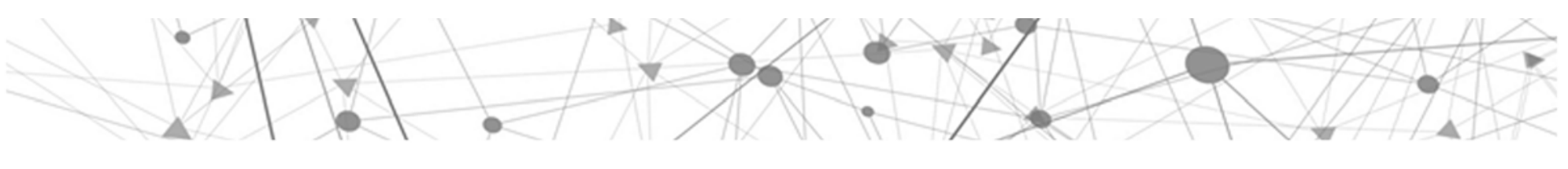




\section{APÊNDICE 01}

\begin{tabular}{|c|c|c|c|c|c|c|c|c|c|c|c|c|c|}
\hline 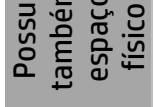 & $x$ & $x$ & $x$ & $x$ & $x$ & & $x$ & $x$ & $x$ & $x$ & $x$ & $x$ & $x$ \\
\hline 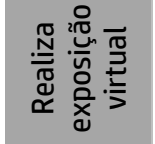 & & & & & & $x$ & & & & & $x$ & $x$ & \\
\hline 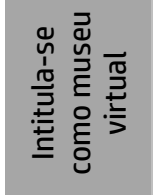 & & & & & & 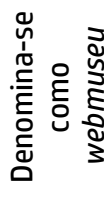 & & & & & 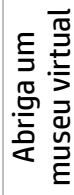 & & \\
\hline 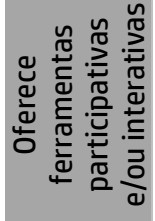 & & $x$ & & & & $x$ & & $x$ & & & & & \\
\hline 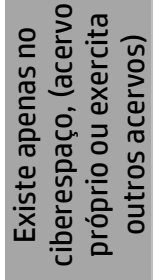 & & & & & & $x$ & & & & & & & \\
\hline 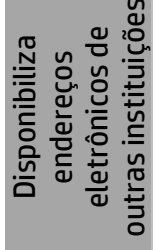 & & & & & & & & & & & & & \\
\hline 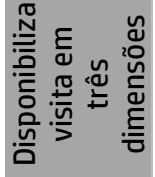 & & & & & $x$ & & & & & & & $x$ & \\
\hline 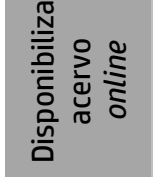 & $x$ & $x$ & $x$ & $x$ & $x$ & & $x$ & $x$ & $x$ & & $x$ & $x$ & \\
\hline 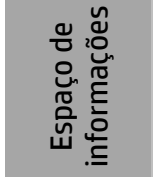 & $x$ & $x$ & $x$ & $x$ & $x$ & & $x$ & $x$ & $x$ & $x$ & $x$ & $x$ & $>$ \\
\hline $\begin{array}{l}\overrightarrow{\bar{v}} \\
\bar{y}_{\Sigma}\end{array}$ & 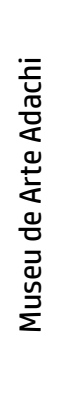 & 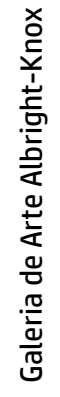 & 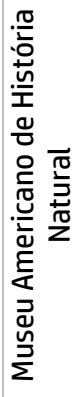 & 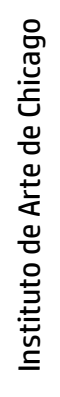 & 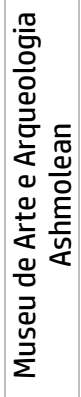 & 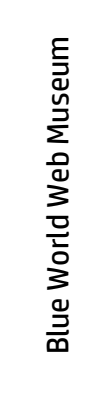 & 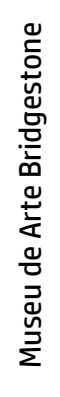 & 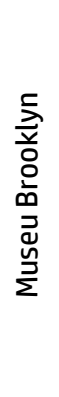 & 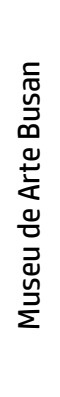 & 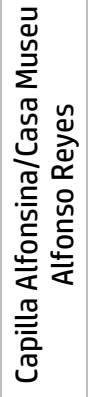 & 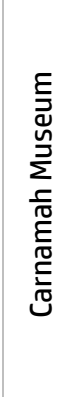 & 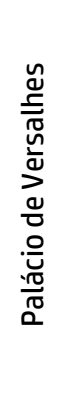 & 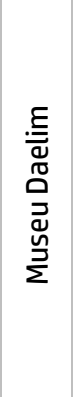 \\
\hline$z$ & $r$ & $\sim$ & $m$ & $\nabla$ & in & 6 & $r$ & $\infty$ & $\sigma$ & 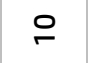 & $\mp$ & $\simeq$ & - \\
\hline
\end{tabular}




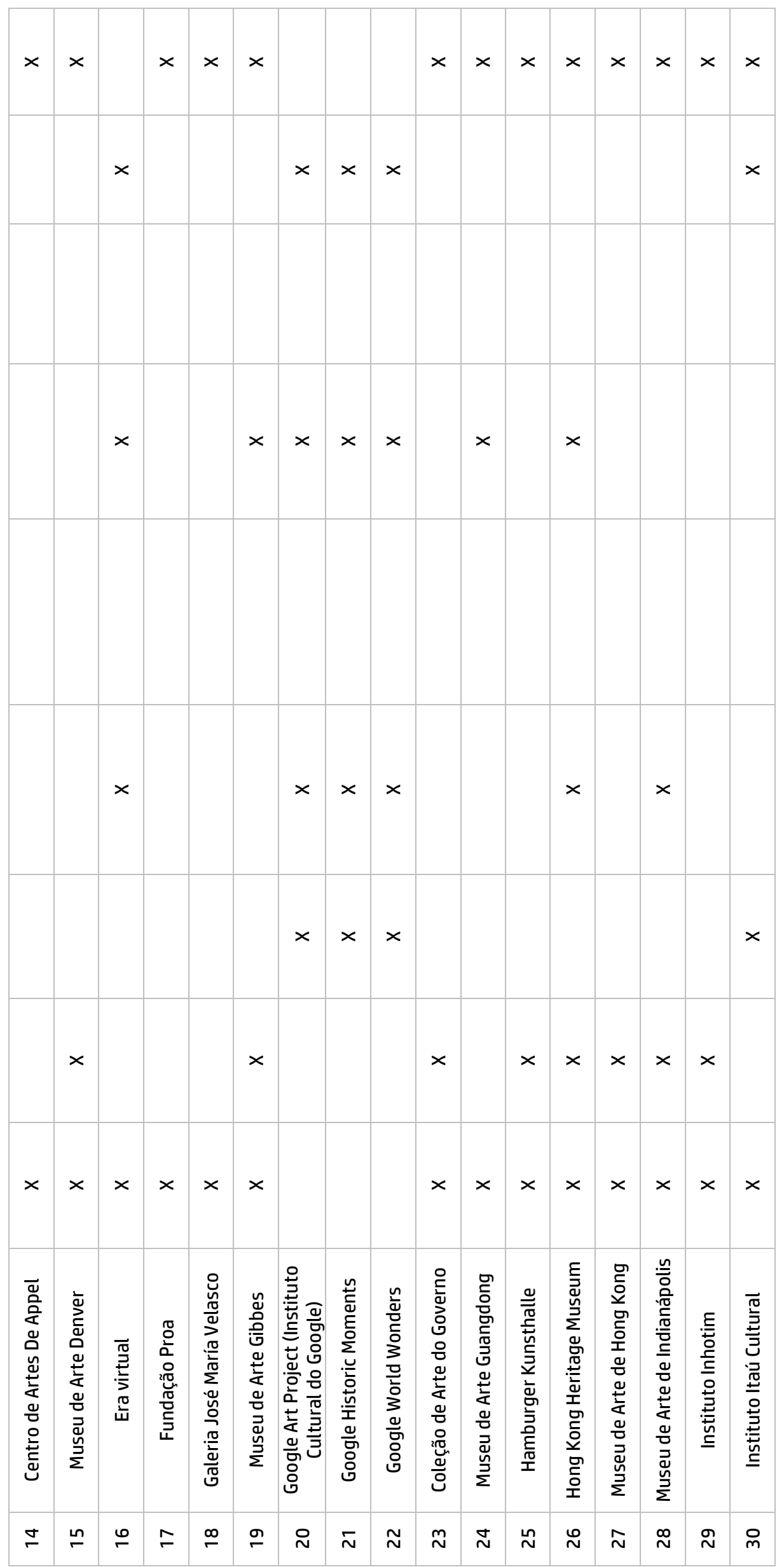




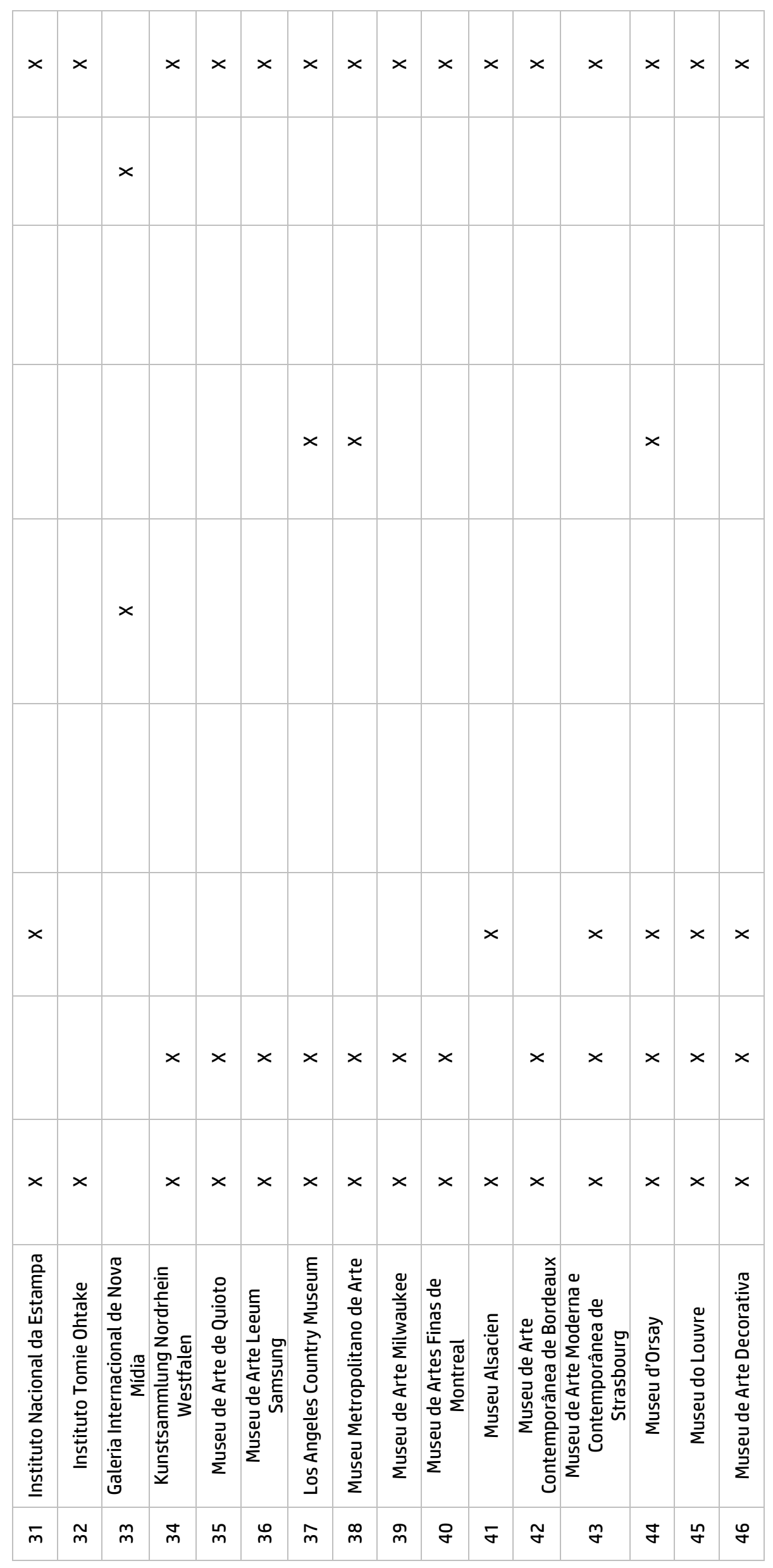




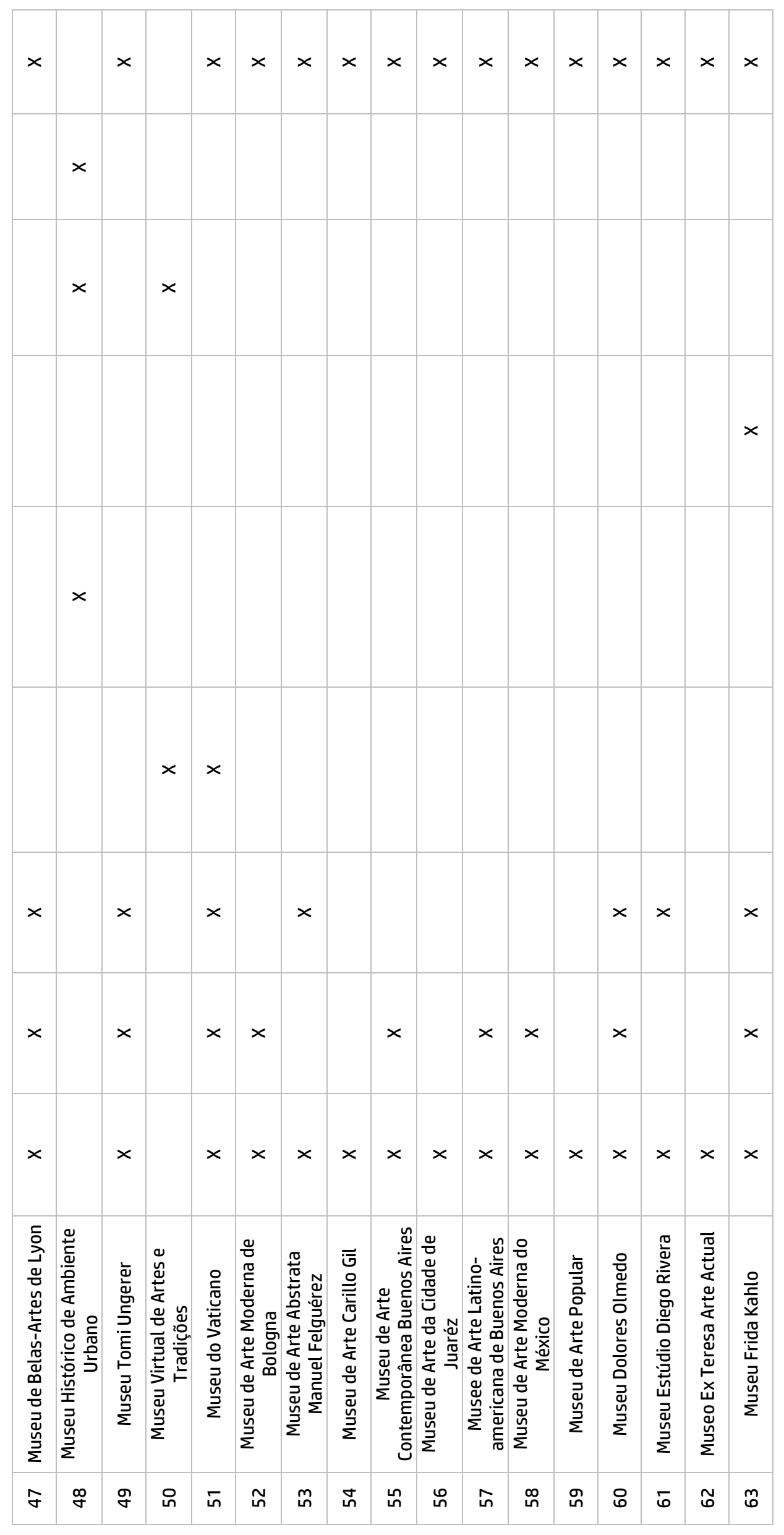




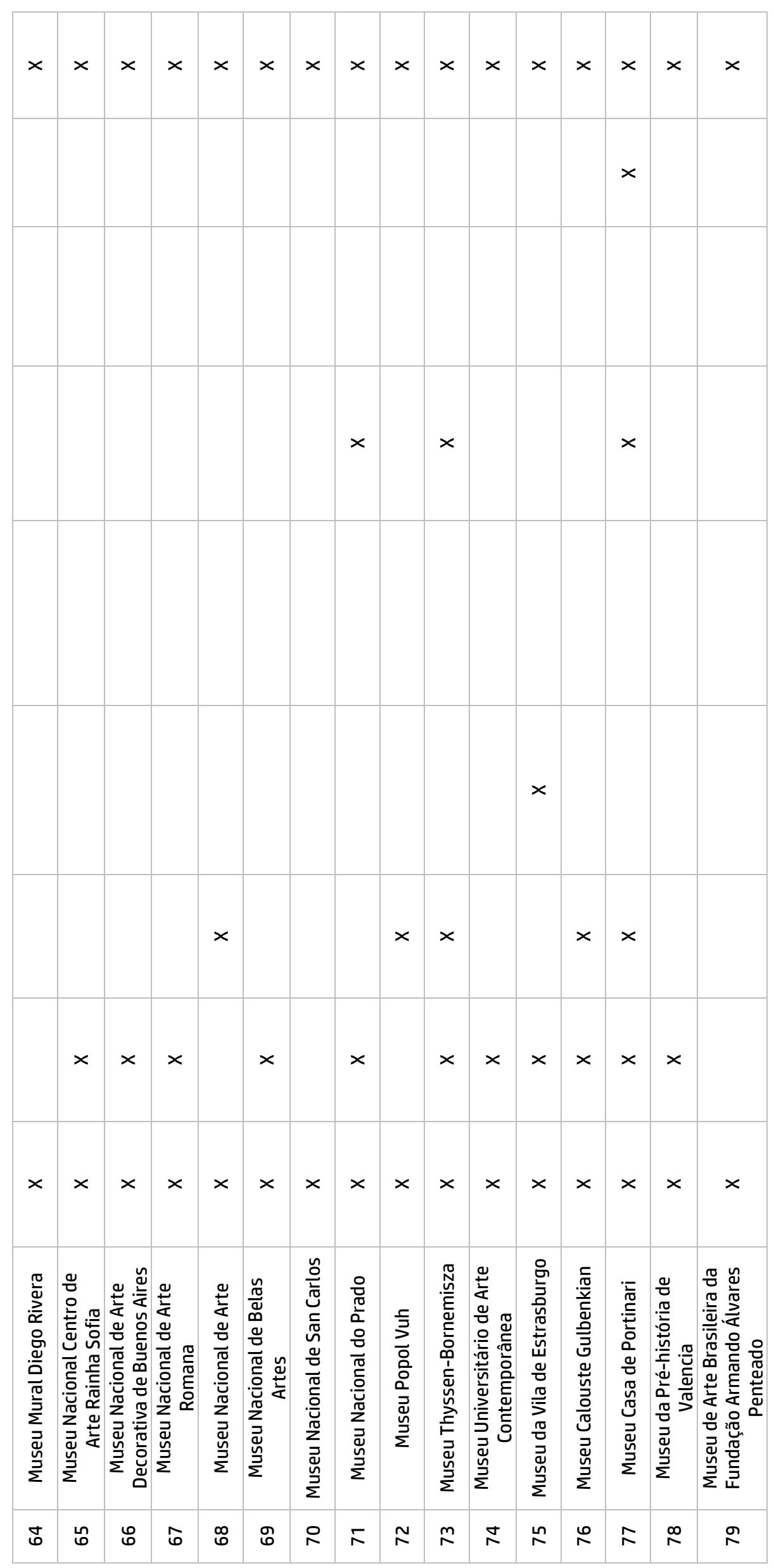




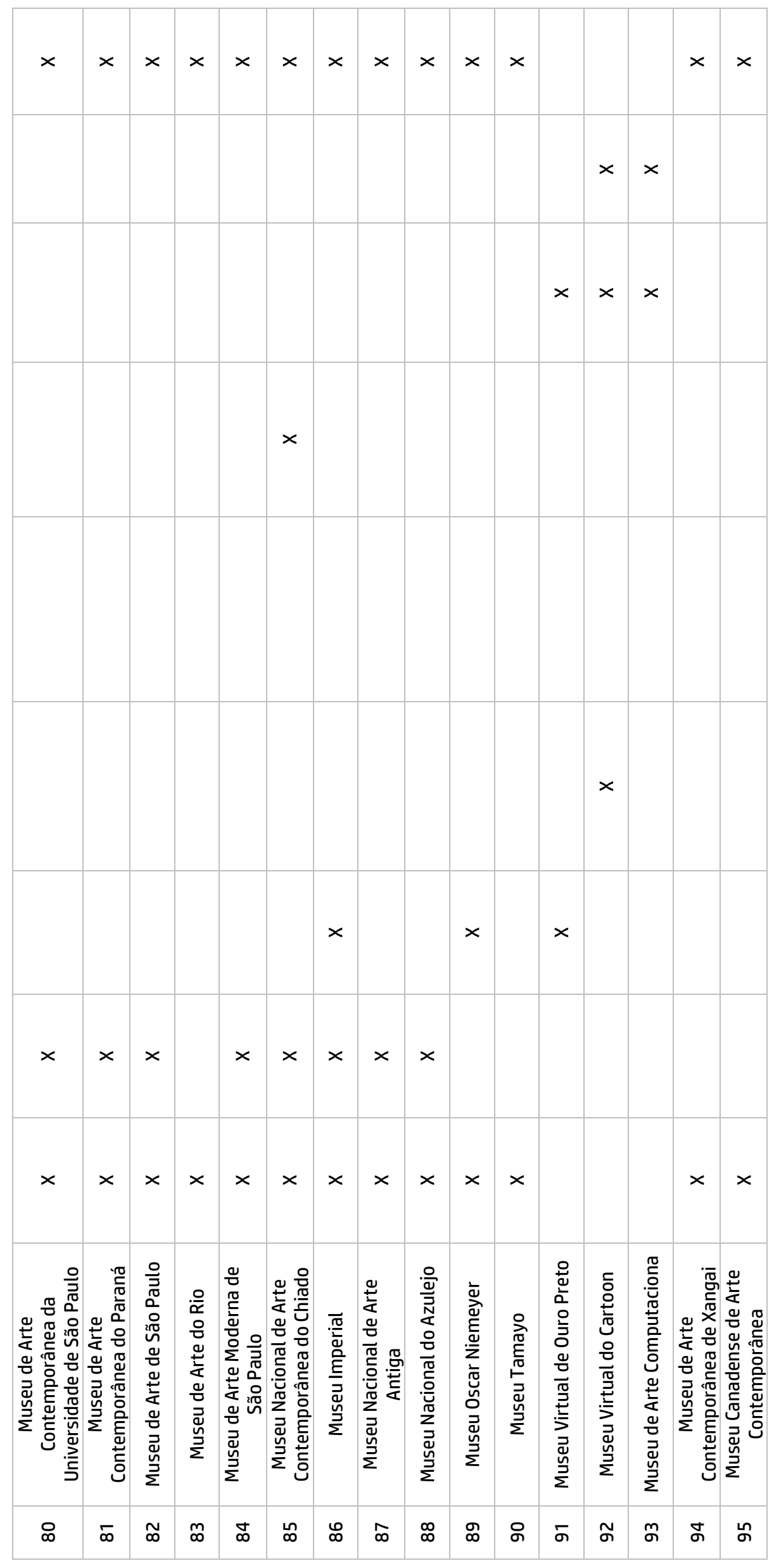




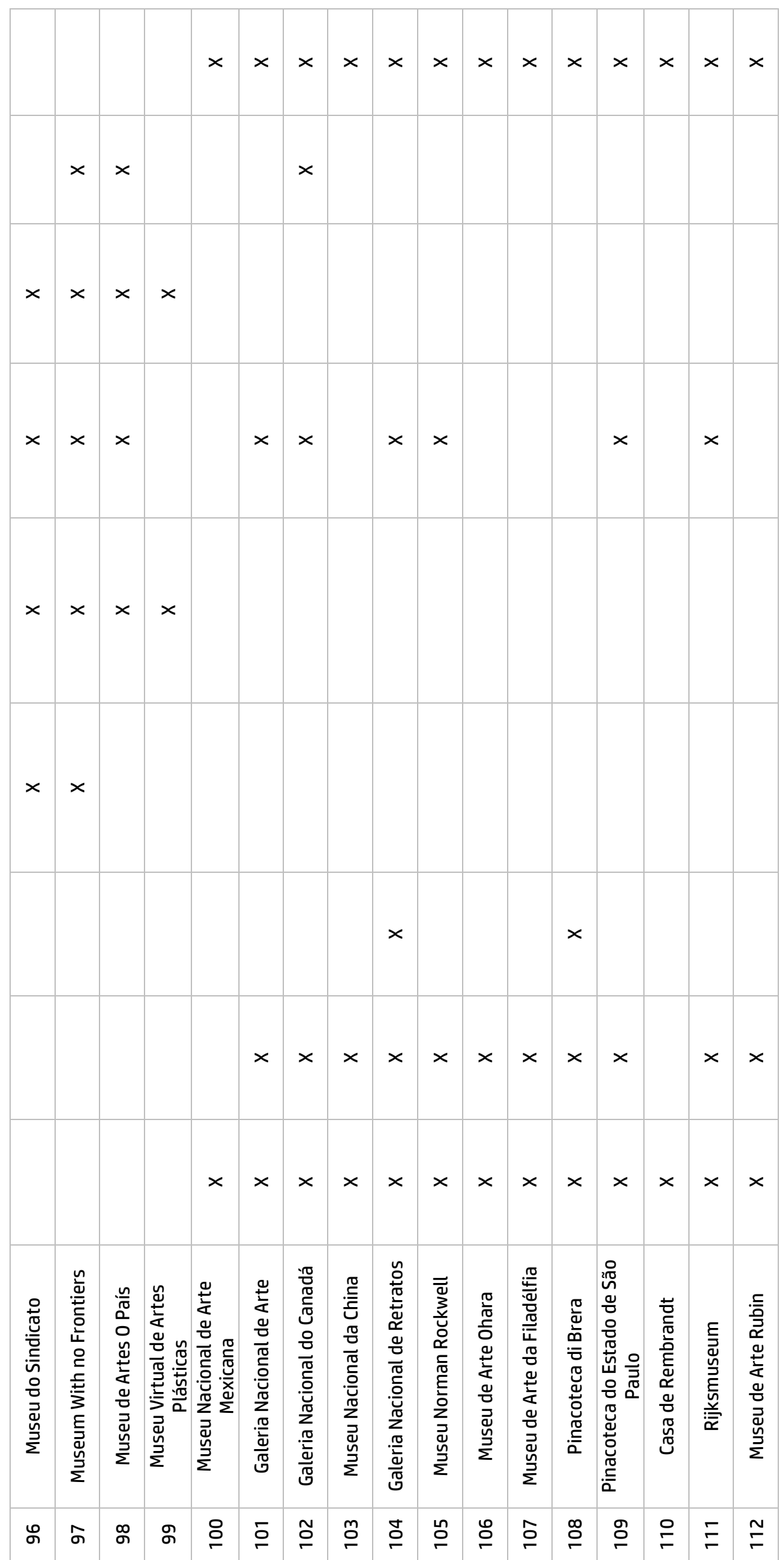




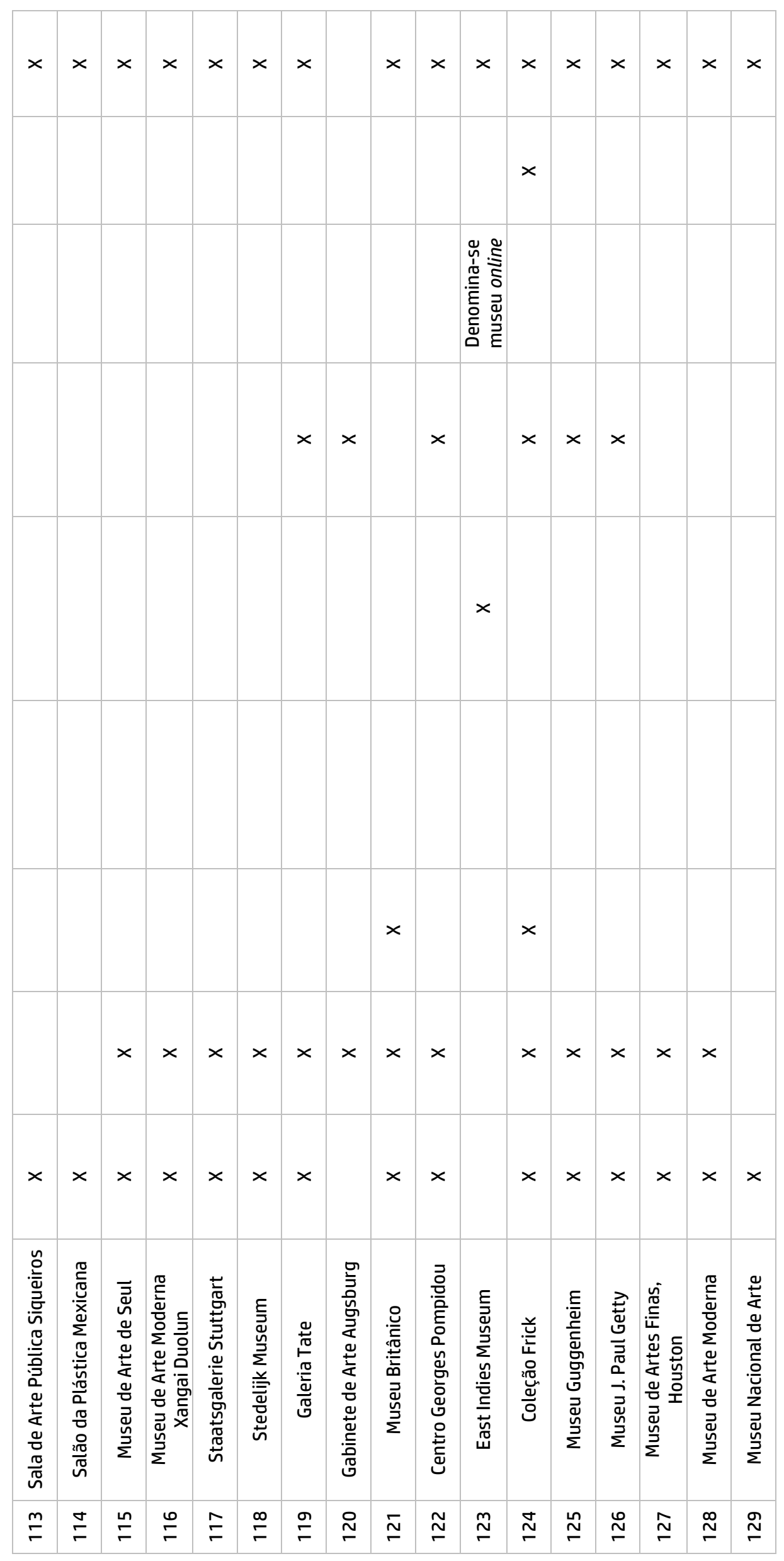




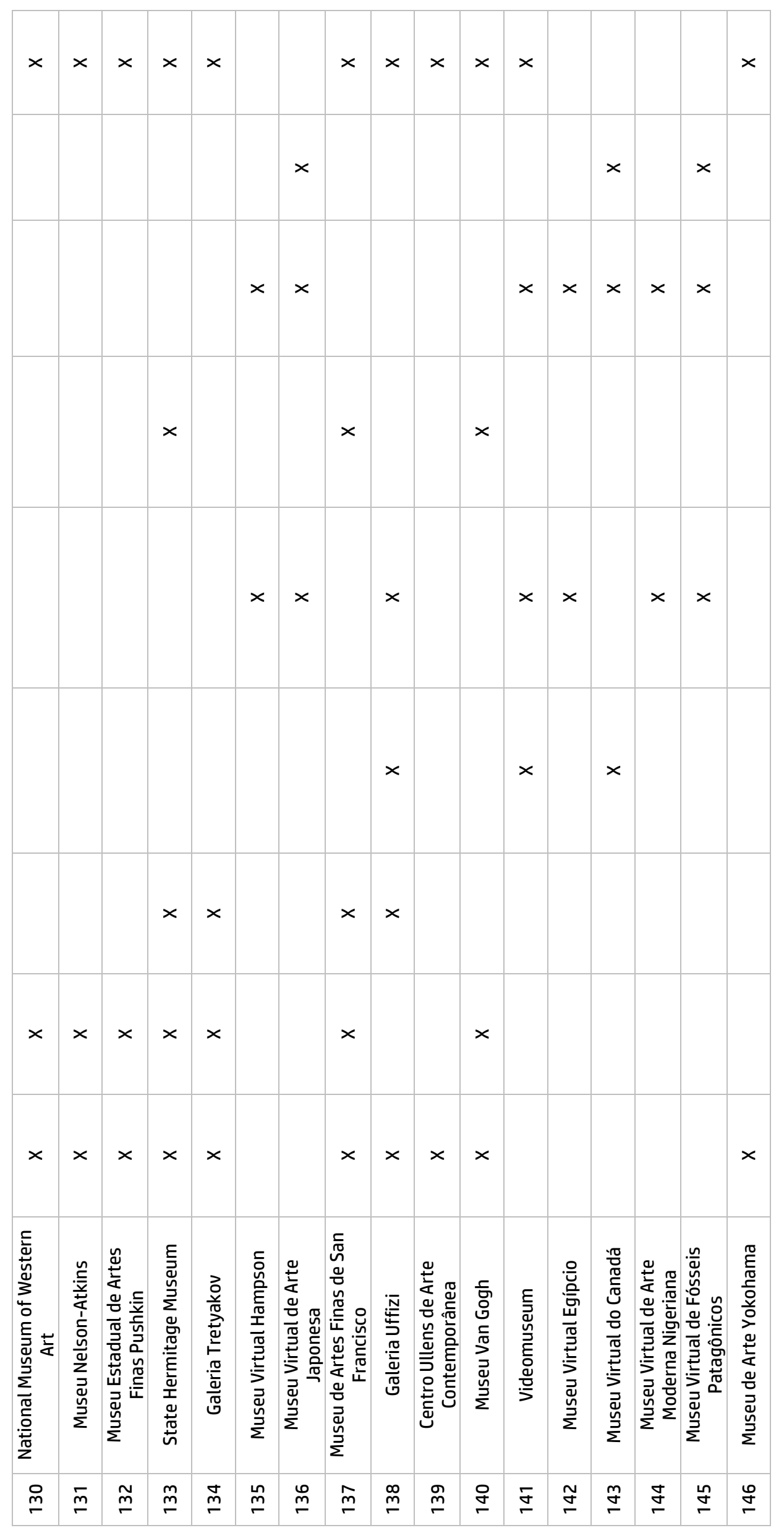




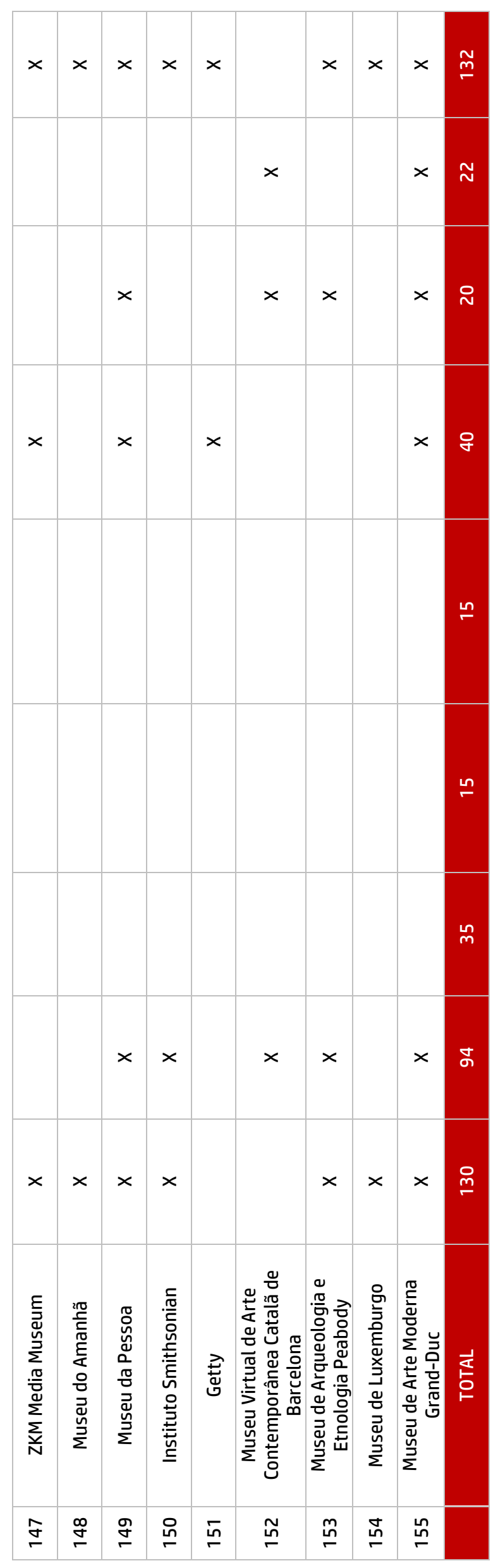




\section{APÊNDICE 02}

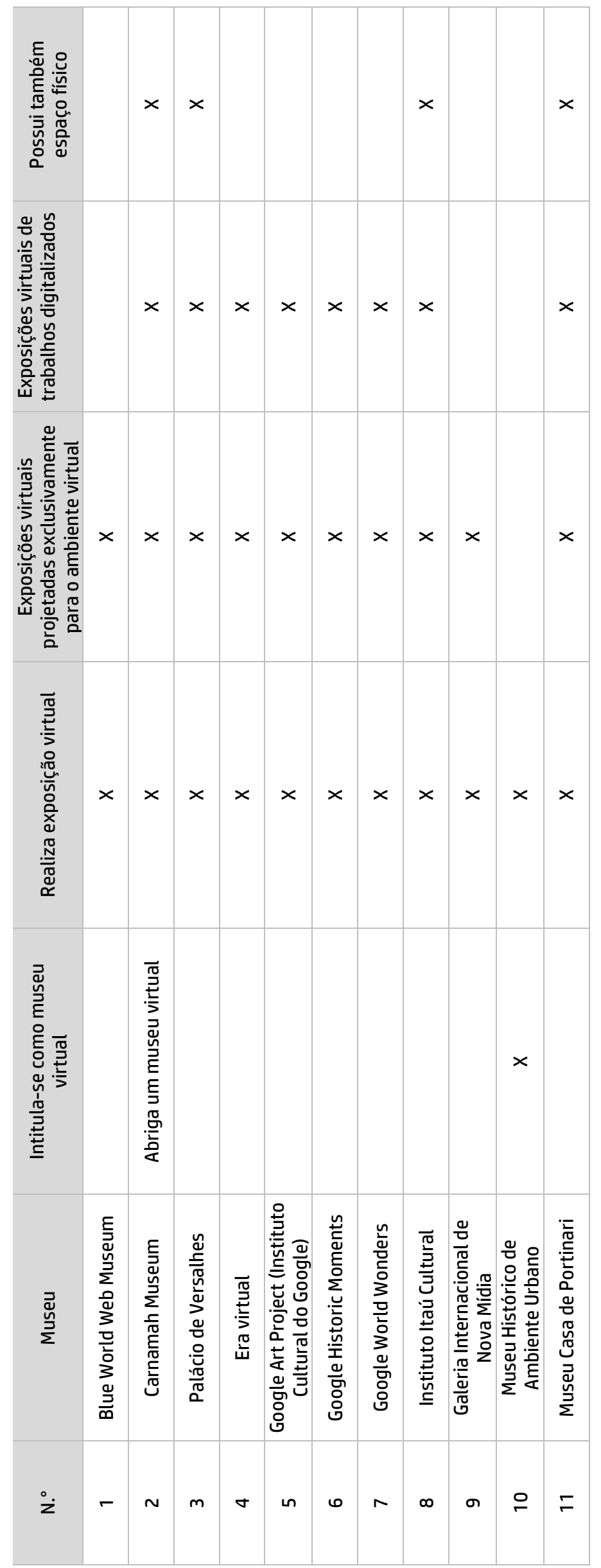




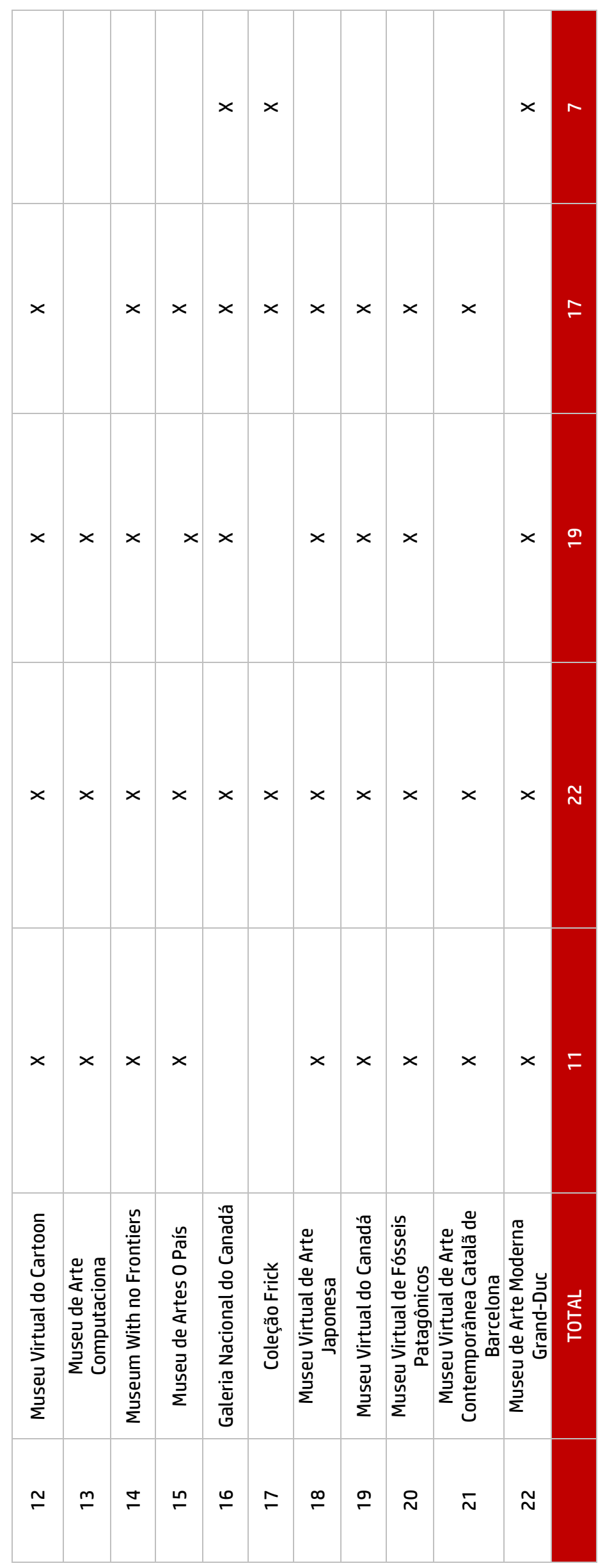




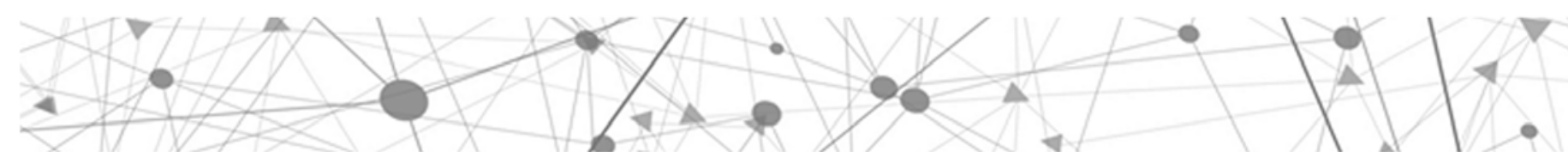

\section{ANEXOS}

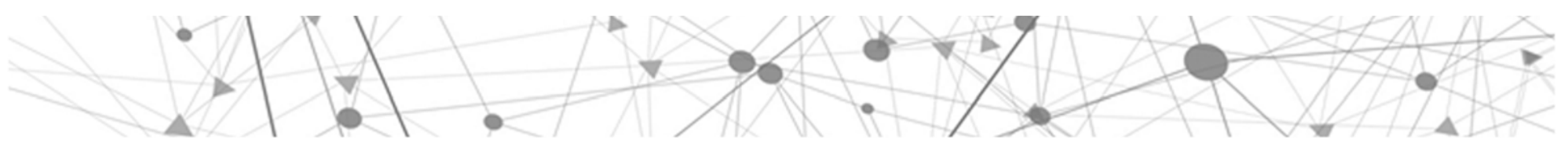




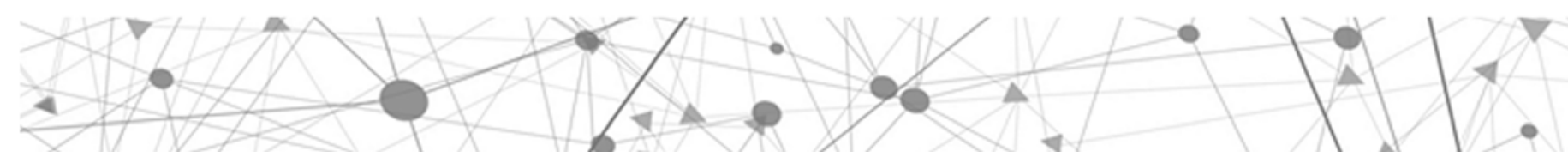

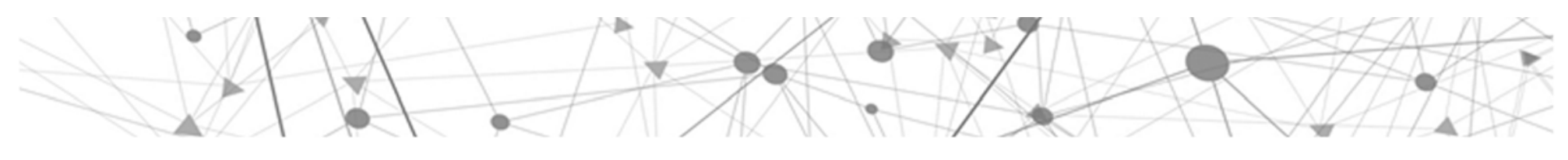




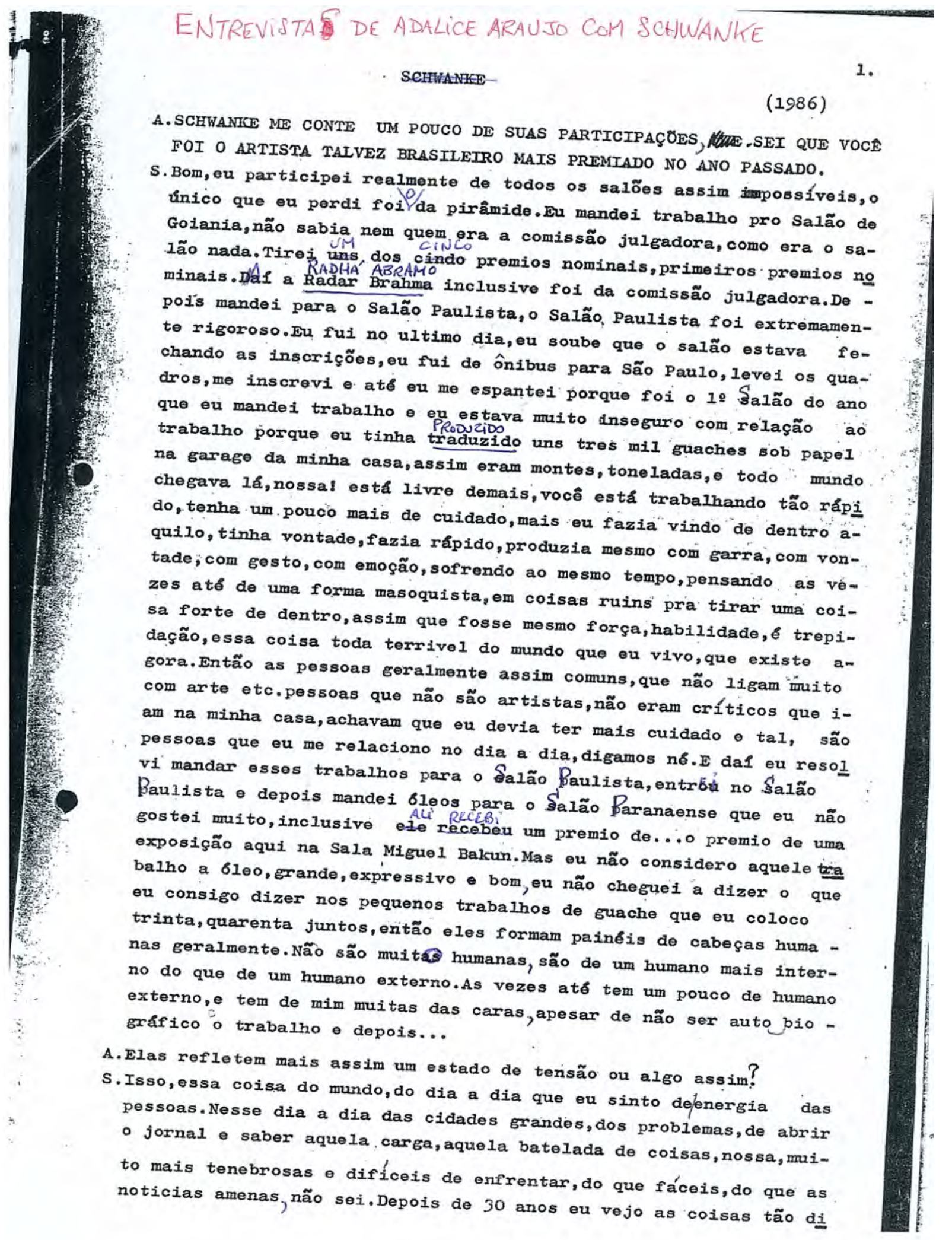


ficeis diante de mim, as coisas todas do mundo que 6...

A.Não tem mais aquela, talvez...

S.Não sou mais criança, infelizmente.

A.'Aquela névoa colorida que pende por um lado.

S.Eu não sou maiss criança, para ○ Salão Alacional $\odot$, Porto Alegre, foram aceitos também esses guaches sobl"papel e mandei pro salão de Minas Gerais, \& um Salão dí fícil.Recebi carta também do premio de 30 milhões,foi aquisição dos tref́s trabalhos e fui premiado em Recife, tambóm foram dois traba Thos adquiridos. Olivio Tavares de Araujo foi da comissão de Recife - bom outras pessoas, o olivio que eu me lembro agora.o olivio do Salão Paranaense, aqui tambßm. Eu tenho pensado, reflotido um pouco a respeito a respeito das coisas que en fiz assim dos ultimos tempos, porque foi muita coisa realmente.E esse ano depois do Salão farana ense, das coisas que eu soube que aconteceram dentro do julgamento, etc.acusações que eu fui primitivo etc.como um lado muito negativo da minha obra,inclusive eu pedi agora pro 0livio para fazer a próxima apresentação da exposição minha, $\theta$ elo disse que quería ver to das,toda a minha trajetória.Quer dizer ele vai querer ver todos, os trabalhos que eu fiz.Eu já peguei e mandei pra ele,tudo, os oleides fotos, catálogos que foram escritos, jâ que quer Thinformaça que tenha.Refleti um momento, sei lá um monte de coisas que eu vivia naquela época, que eu...

A. Como você falou...quando te conheci você era assim meio adolescente, portanto eu acho que ora normal fazer aquele...

S.Eu tinha eu acho que 19 anos e me disseram assim em Joinville, eu tenho um monte de trabalihos, eu vou fazer uma exposição, quero fazer uma exposição.Eu já tinha tirado quando era criança um premio na Fołha de São Paulo de dosenho,inclusive ou botava isso no meu curri culum o agora não ponho mais.Tirei também o Io premio de desenho infantil em Florianfpolis e depois surgiu um movimento em Joinville com Antonio Mir, fldari e etc.Todo mando expunha todo ano na Exposi cão das flores, eu disse eu'vou fazer, então fiz um monte de trabalhos de diversas linhas o o pessoel disse assim. Ah! você podia camirihar para esse estilo primitivo.Nunca tinha ouvidg falar em estilo, não sabia que as pessoas deviam pintar no mesmo estilo, não tinha visto uma exposição, nada.Passei a pintar e desenvolvi um estilo primitivo assim que me foi sugerido.Dal eu via coisas primtivas, trabalhei encima daquilo, afinal ficou uma coisa rococb, decorativa e me davam dinheiro grande. Eu fazia um toatro assim de ultra vanguarda parale10 e tal, $\theta$ depois víque não aguentava mais, que não dava mais para continuar pintando aquilo.

A.Um ator por sinal excelente que você 6 .

S.E.Fiz cenários de teatro e tudo mais, eu resolvi ficar com a pintura talvez até como ator ou tivesse tido um campo mais fácil não sei... 

A. Realmente você estava numa encruzilhada eram duas formas assim mui
to fortes de expressão.

S.De expressão.E, e a pintura não era forte naquela época, eu tinha muito envolvimento com pintura, gostava muito de ver pintura, lidar com pintura.Mas o teatro virou uma carga assim emocional negativa para mim.

A.Aquela força que eu $v i$ você desempenhando, não me lembro bem, sei que era uma tragédia grega.

S.Foi Eletra de Sbfocles,foi Marat-Sade,foi Maria Bueno. A. Acho que você está manifestando agora no desenho, aquela força que
você tinha.

S.E.Porque eu não tenho mais preocupação de estilo,preocupação de vencer na vida, expor na galeria melhor do Brasil, não tenho assim compromissos com, simplesmente não quero dizer com nada.

A.Com o circultto comercial.

S.Com o circuito comercial eu não quero ter preocupação com isso, me pedem as methores galerias do pals quando viram agora os meus tra quando eu expus no vauêิ produza trabalho em 6leo.Já no ano de 84

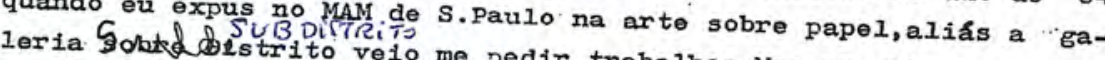
mais vendem telas $\theta$ rélir trabalhos.Nas as galerias que onistas, onistas, 0 pessoal da Casa 7, Leonilson, Daniel Senise etc.Mais pedin sobre papel sobre tela, 6leo sobre tela não, ou gosto mais de trabalhar as, $\hat{f}$ mais rápido, ño mais ranhuras com guache, mais transparenciho grande ou gosto de tem problemas tão grandes de secagem. 0 tamanihos menores que eu posso , mas quando ele 6 composto pelos trabatas, de pé, viro, trabalho,eto tem essa maneabilidade grandes já a gente não eu consigo um resultado brande quanto eu tenho com as pequenas, to. $\mathrm{E}$ como pintura também paciência, está af as bonita, são bonitos os trabalhos. E jâ há bastante temun isendo isso. Bakun o que você vai expor?

néis, cada um com 32 expor 640 desenhos que vão ser coupostos 20 pai chamar papel, são pinturas não são desenhos, às vezes eu me engano do nil sobre papel; alguns guache papel, guache sobre papel,alguns vi as vezes tem ate 1 f 32 desenhos,eles tem junto. Então vão ser 20 painếis cada um com Pêrios dos esses trabalhos que os bquisitivos nãoestão partic premiados o ano passado, of claro que lles não vão ter moldura, suporte o moldura quando va ter suporte porque eu mando com o suporte o moldura quando faço exposição em ఏ̧ẫo, devido a transpor 

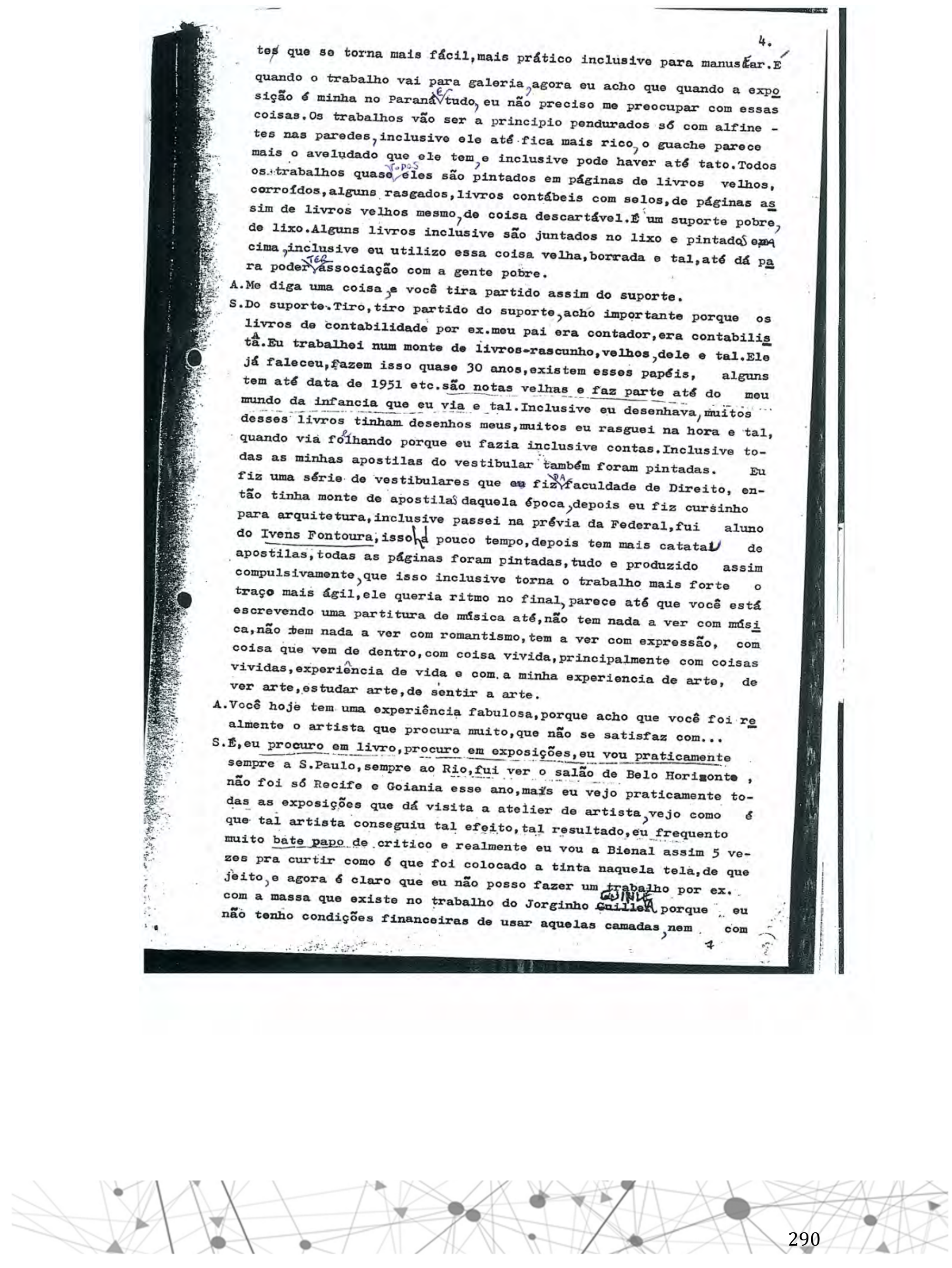
tinta nacional fazer os meus trabalhos com massas grossas e grandes do tintas que ou acho que um dia talvez ou possa o va utilizar, como os recursos do Iberê Camargo que eu v1 Numa exposição agora no MASP dele, que inclusive tem diverses artistas jovens que cercam a exposi ção dele, que foram alunos que trabalharam com ele.Eu gosto daquilo mais eu não tenho condições de lidar com essa massa devido ao preço dela, principalmente com tintas e materiais estrangeiros etc.Mal's deñtro do meu padrão de materiais, eu procuro fazer o máximo possiyel de trabalhar bastante.

A.Como ó que você vê hoje essa tua trajetória,essa mudança que deu na quele trabalho super meticuloso.

S.Pois 6 eu fiz um trabalho conceitual lá em finaís da década de 70 a té om principios ell 80 já estava praticamente deixando coisa assim, porque eu j̣á não aguentava mais eu fazia poltronas, cadeiras, dava tftulos de obras clássicas como a Madona da Serpente e fui super poe miado com esse trabalho também tive uns 4 premios do Salão paranaen se, participei do Şalão nacional, tive uma critica, quer dizer tive 6timas criticas de Adalice Araujo, tive uma 6tima critica do Frederico Morais no Rio, na minha exposição láñ Sergio Milfot

A.Mas o Frederico Mtorais, puxa, diz que depois de Marcel Ducbom/e só o Schwanke.Acho que foi o maior elogio que ele disse para um artista vivo brasileiro!

S.Pois é le me conhece até hoje quando eu vou Rio, você ô do Paran̊̊, você o - tal a at́́ a pouco tempo ou tinha que eu fui ver uma exposição lá de paris no MAM do Rio, Elle estava chegando, eles não me deixaram entrar porque eu não tinha convite e Eravata, daf ele me puxou para dentro lá no MAM do Rio e tal.Mas o Frederico \& boa pessoa, eu gosto dele não s6 porque ele es creveu bem, mas porque ele $\delta$ um critico muito sório.

A.Acho ele, é uma pessoa muito inteligente, muito séria,muito 1úcida, muito honesta no que ele faz, um bom profissional.

S.ț pena que ele não me julgou no Talão porque ele foi o 10 votado If em Minas, mas ele estava na Europa dal foi o 29 que entrou, o bom você fala do trabalho que fol feito om $78,79,80$, bom ou era super intelectual, estava lendo na época todos os filbsofos, eu estudei bas tante filosofia não foi sర pintura, lia muito filosofia,psiquiatria, psicologia muito, convivia com muitos psiquiatras o...

A.Acho que para chegar Afm amadurecimento que teu trabalho chegou tem que ser um madurecimento global, não 6 s $\delta$ você chegar asssim sem mais nem menos.

S.Sabe o que que éu acho muito ruim em termos brasileiros é que o artista jovem, participa de salão, tudo bem, eu acho otimo.Agora o salão quase que me vicia, quase que me deixa assim, inclusive as pessoas to das diziam pra mim maíg você ja vai mudar de trabalho agora, você es tá sendo premiado, aceitho em todos os salões que você está mandando trabalho etc.quando eu estava fazendo os trabalhos de linha concei- 
tual, já ostá mudando do novo você tom qua ter um trabaliso je tînth Maf́s ou nossa!tinha na boca 30 anos mais ou menos eu as=s ez 프-

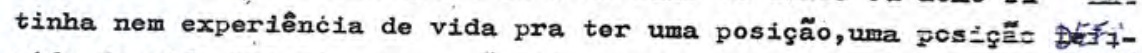
nida de vida pra mim mesmo, não tinha nem me escolhido, nem me sind sint do ainda no mundo.como of que eu vou me situar numa linha de wreja 1ho?Já ter definido uma linha do trabalho? Intão eu não era nem adx:to ainda, já tinha que ter um compromisso inclusive para as pessoas reconhecerem o meu trabalho quando olo estivesse numa galeria para não,prá ter aquele tipo de compromisso mesmo.

A.Agora ou acho assim esse pensamento assim terrivel para o artista, dal a pessoa se inibe de mudar, porque a vida é uma mudança constante.

S.É.Sei lá quando que eu vou mudar novamente.Agora estou muito mais adulto acho.Mais, ou pelo menos com muito mais anos, eu terno 35 anos eu acho, então sei lá muito mais experiência, muito mais carga de,já estou com uma vivência para produzir alguma coisa assim que eu estou sentindo no momento o naquela época eu estava sentindo aquilo ne, sentindo com força com garra maís de uma outra forma. Inclusive eu era muito solitário no sotă da minha casa aqui em Curi tiba, uma casa cheia de árvores do lado e tal, neio lúgubre na frente do cemitério municipal e tal, escura. mailo frio,essa cidade ó extremamente fria, eu gosto de levantar aqui meio-dia.Nos outros lu gares ou levanto cedo. Na praia assim eu no verão levanto às $7 \mathrm{hs}$. da manhã.Se eu estou em Curitiba eu levanto no minimo 9 hs.quando me chamam, porque é frio eu fico na cama se 6 quente dou um pulo já saio para ir trabalhar, desenhar. Ás vezes eu pinto até meia noite, u ma hora da manhã e ainda vou deitar com um livro de arte na mão. A.No momento você está exclusivamente pintando Schwanke?

S.Exclusivamente pintando já hâ muitos anos.Já em 1981 eu nunca mais já Eraças a Deus,é 81 , de lá para cá nunca maís botei o pé numa agen cia de publicidade, nunca mais fiz uma arte final, programação visual, nada, porque era uma coisa que eu não aguentava mais ver publi cidade, trabalhei uns 3 anos eu acho em publicidade. Inclusive a publicidade naquela época foi até boa,porque ou aprendi muitas técní cas que eu não tinha porque eu não fiz Escola de Belas Artes e a publicidade me onsinou a ver um monte de técnicas,inclusive dá para ver naqueles trabalhos daquela época que eu tinha e que eu lida va um pouco com programação visual e tal porque o trabalho tinha assim um cuidado enorme de estética visual e de acabamento inclusí ve, tudo sobre todos esses aspectos, e agora Eu considero muito sincero e muito meu todo o trabalho conceitual a série do São Sebasti ão, a série das cadeiras, era inclusive, gosto muito do trabalho foi assim uma fase assim que eu fiz muito poucos trabalios porque eles eram, eu levava um mês ou mais fazendo um trabalho trabalhando todo - dia com lápis de cor, as margens eram recortadas com durex. Inclu sive foi o Zimmermann que me ensinou a usar o durex sobre papel. 

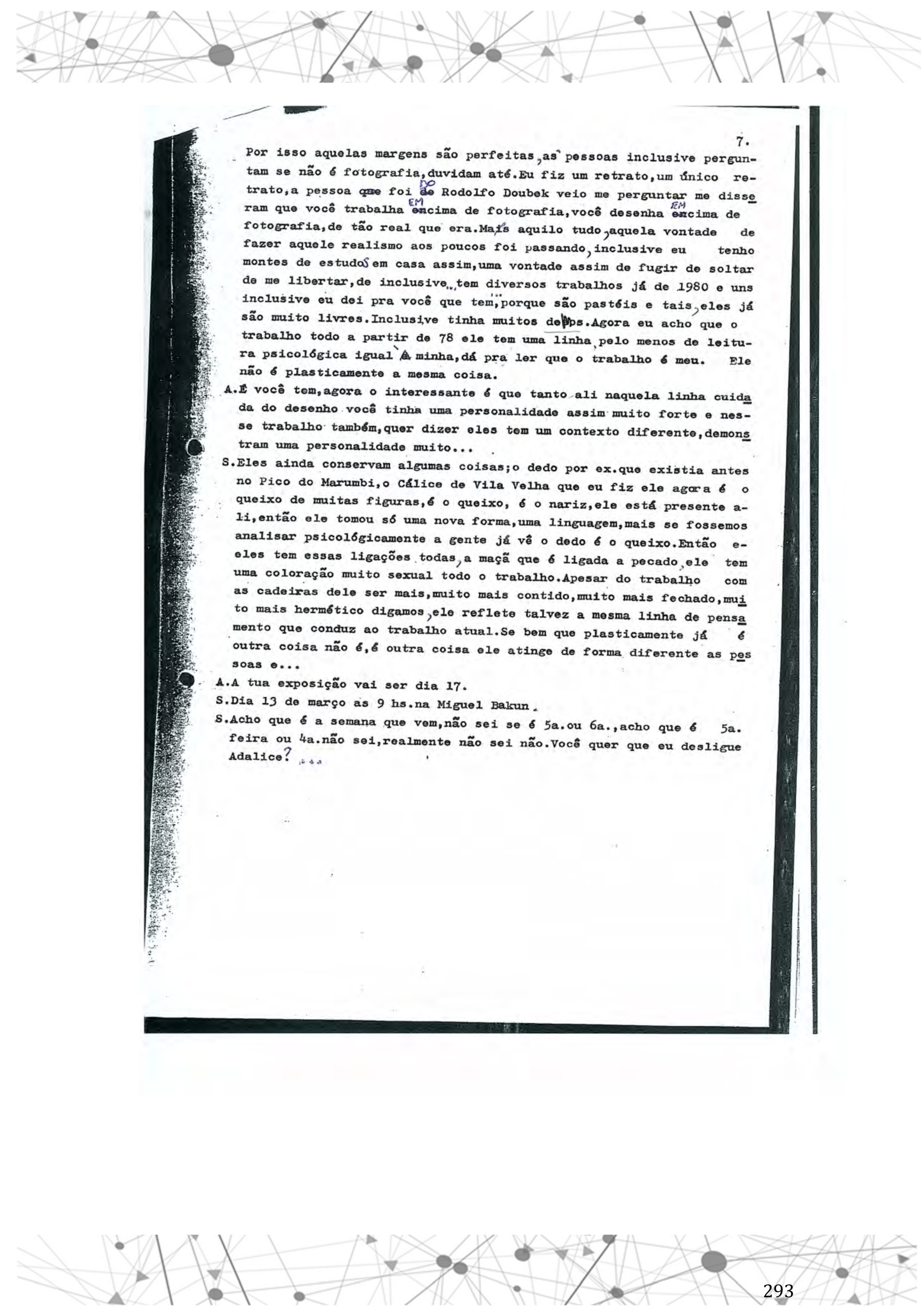

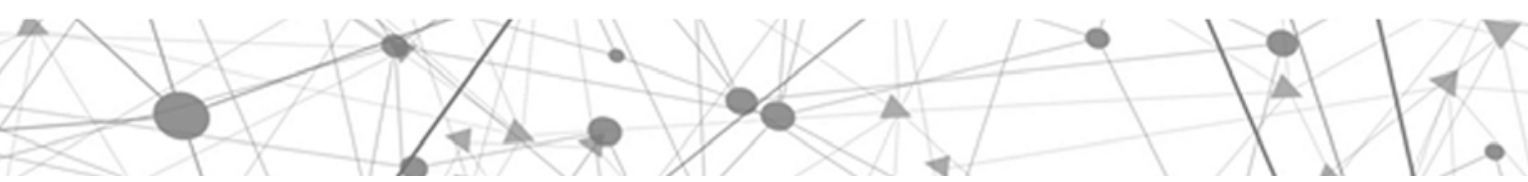

2etrevista. Luis Hearique Schwarise

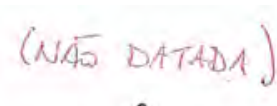

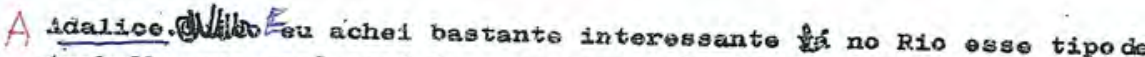
trabalho, que você está fazendo. Agora fry zendo no momentor

Luis-Qne ou saiba não, é uma técnica muito direta, eyłacho que deveria tex um caminho unisto largo, muito vasto, que oußajiba não tem ninguóm razondo.

A Adalise. 0 Goeldi razia muito não?

I Ixis. E o Goeldi, fazia, ele tinha una séxie de alunos que diminuiz muito, porquwe acontece como dissa a gravura"xilo;" não 6 a gravura da parede, ela tem carecterísticas muito fortes, então não tem merce do , ถão tendo mercado nẽo tem guiajo os artistas fazem só para deixar parado, $\theta$ os artistas não fazem por ser o material de gravuxa muito caro $_{3}$ e requer ruito tempo no trabelho.

A Adalice, como ó que você vè a função da cor na exavura?

$\int$ Iuis, Bem a cos é txu problema que deve ser unito bem estudado, porque senão dá problema na gravuxa. Bove ser estudada, como a maxgen de os pessura da paredis, que não tem mais função algumg, a margem da gravtra

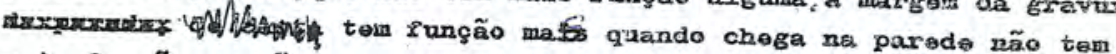
mais funçẽo, então se continua conservando a margem á mesma colsa a coxja gsavura de parede tem a cor em runção da parede, quar dizez,

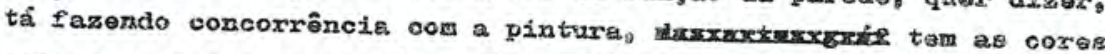
.................. des artes gréricas. quer dizer aquela cor que respeita o papelaque é usado, a cor que zespeita vamos dizer a tama who das letra, o cinza, por exemplo, o proto,as letras influenciam uruito o trabalho.

A Adajzce, qual á o processo que vocô está usando?

$S$ tuis Aquarela o o licápis preto.

A Adelice Sơ?

S Lais \$6.

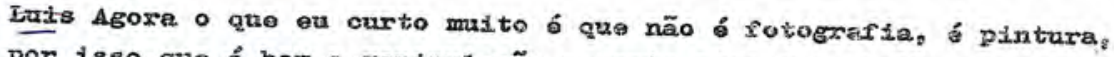
por isso que to bom a manipulação, a gante pode, o trabalho chame mui to a ḋtencão quario você está amejanclo ele, e prinoipeiment'o cowo eu tinha as idé́ías que eu tioha no começo,

A Adalico. Yocé PARTe da fotograria.

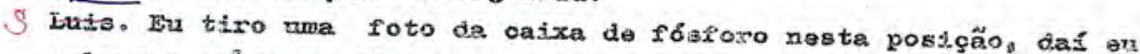
coloco a críle de fósforo na mithe frente o comego o dasenho. Agora saib o que á Adalice, a pintura 86 fón pintada gr clma da fotoerafia ela se ziga mais ao inpxesso, of $_{6}$ quadros de artiśtes que eu vi.

Adalice, Porque você faz quostão díaso, säo caracțrisitcas?

$S$ Linis. Cow praticamente parecendio, praticamente sendo igual, por isso não está vinculado ainda,tá vinculedo prixcipalmento a parecer um impresso, devido a esta abrangência do mmpresso devido a meio e au prepiro foj.har uma revista ................... ou consigo sei lá ter idélas em cima da roviste, talvas mais de quo ................... por exemplo a sério de São Sobastiäo, eu tirøi de aninetos de revistas ffiz questão daquelas coisas parscerom praticamento igrais,inclusive, 


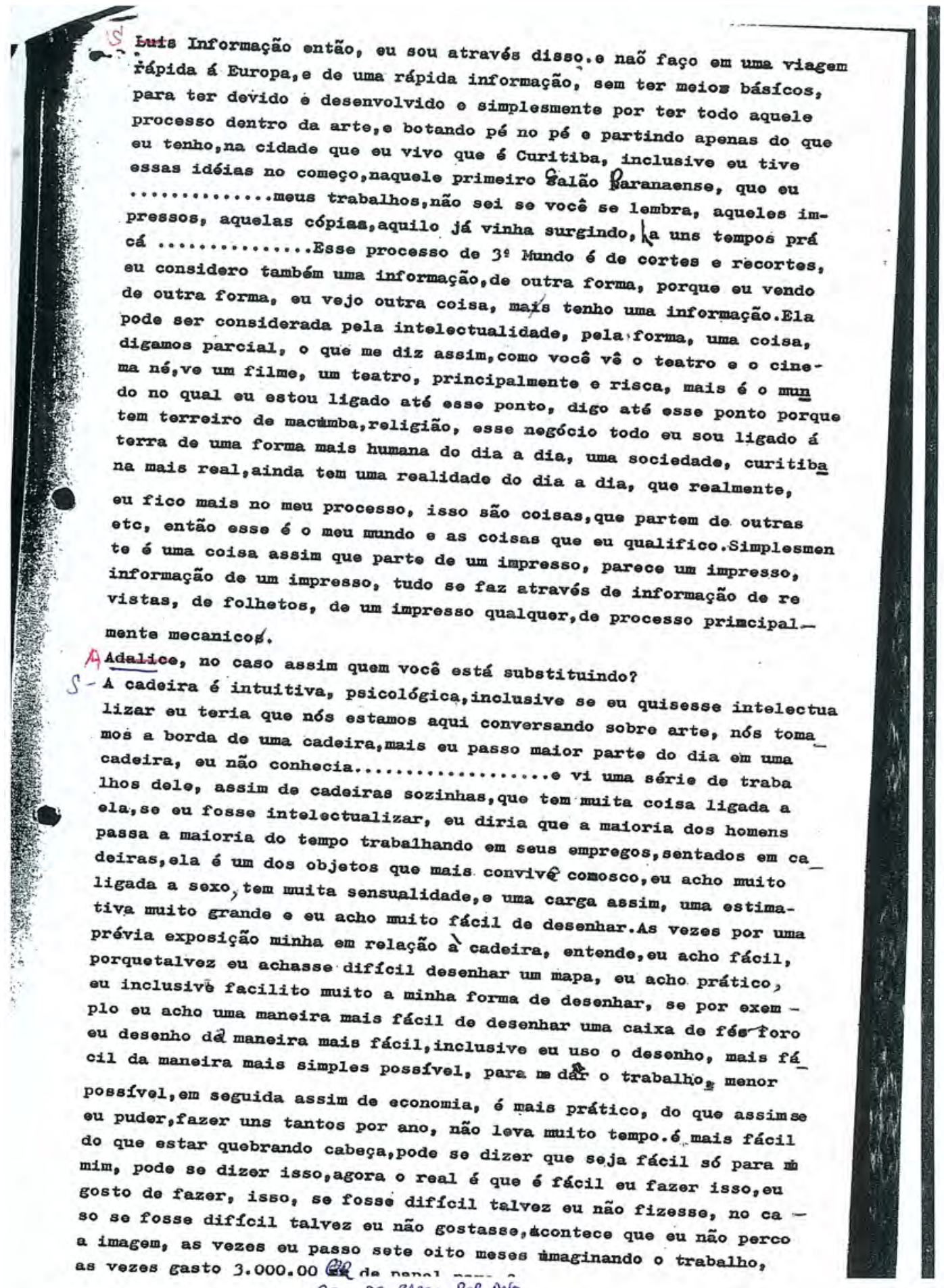
as vezes gasto $3.000 .00 \mathbb{C P}_{\text {da nan }}$.... CR D/ PAPEL POR ANONO 

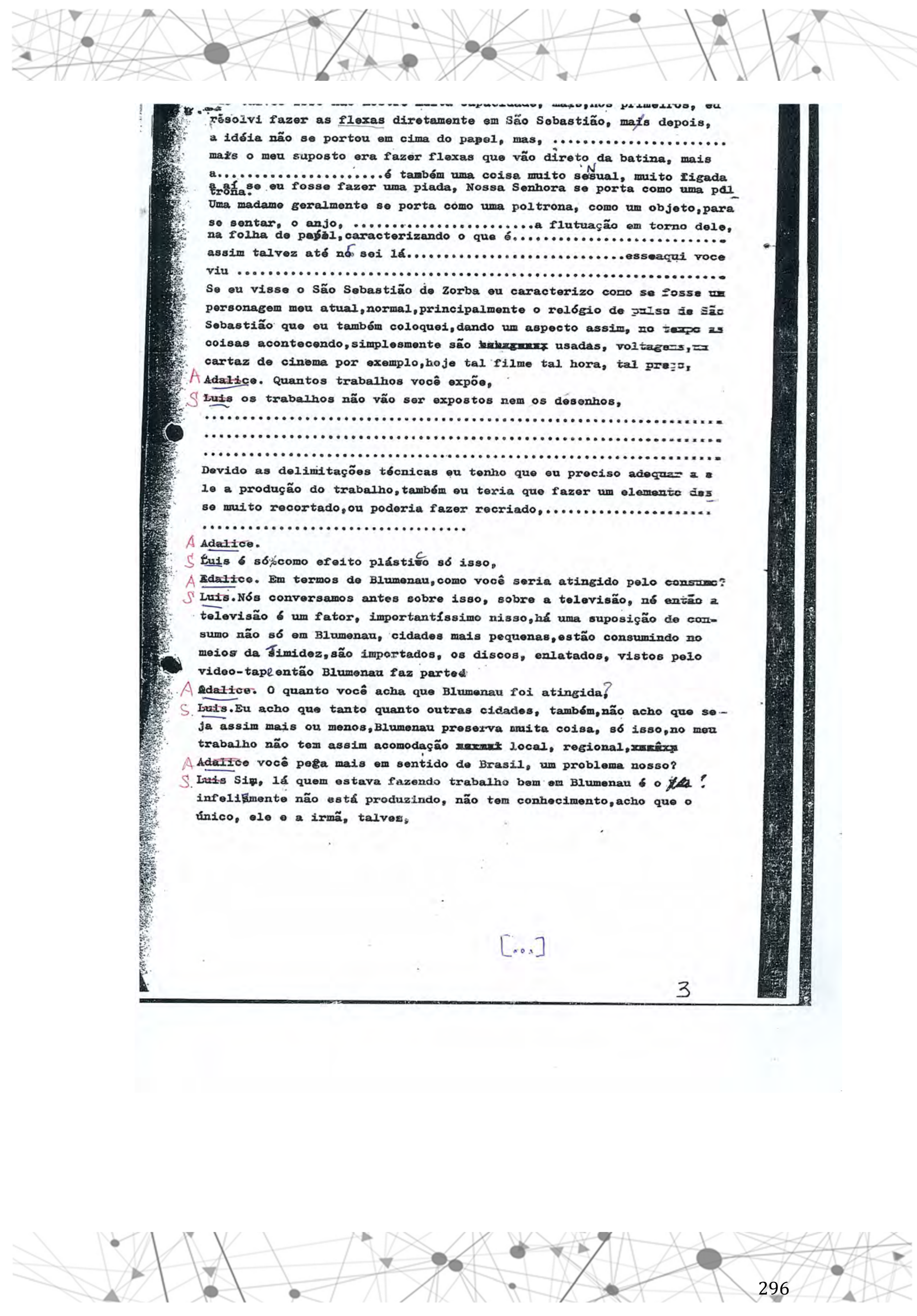


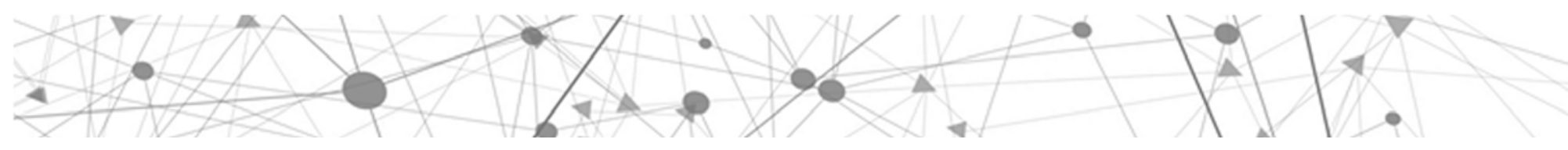

ANEXO 02
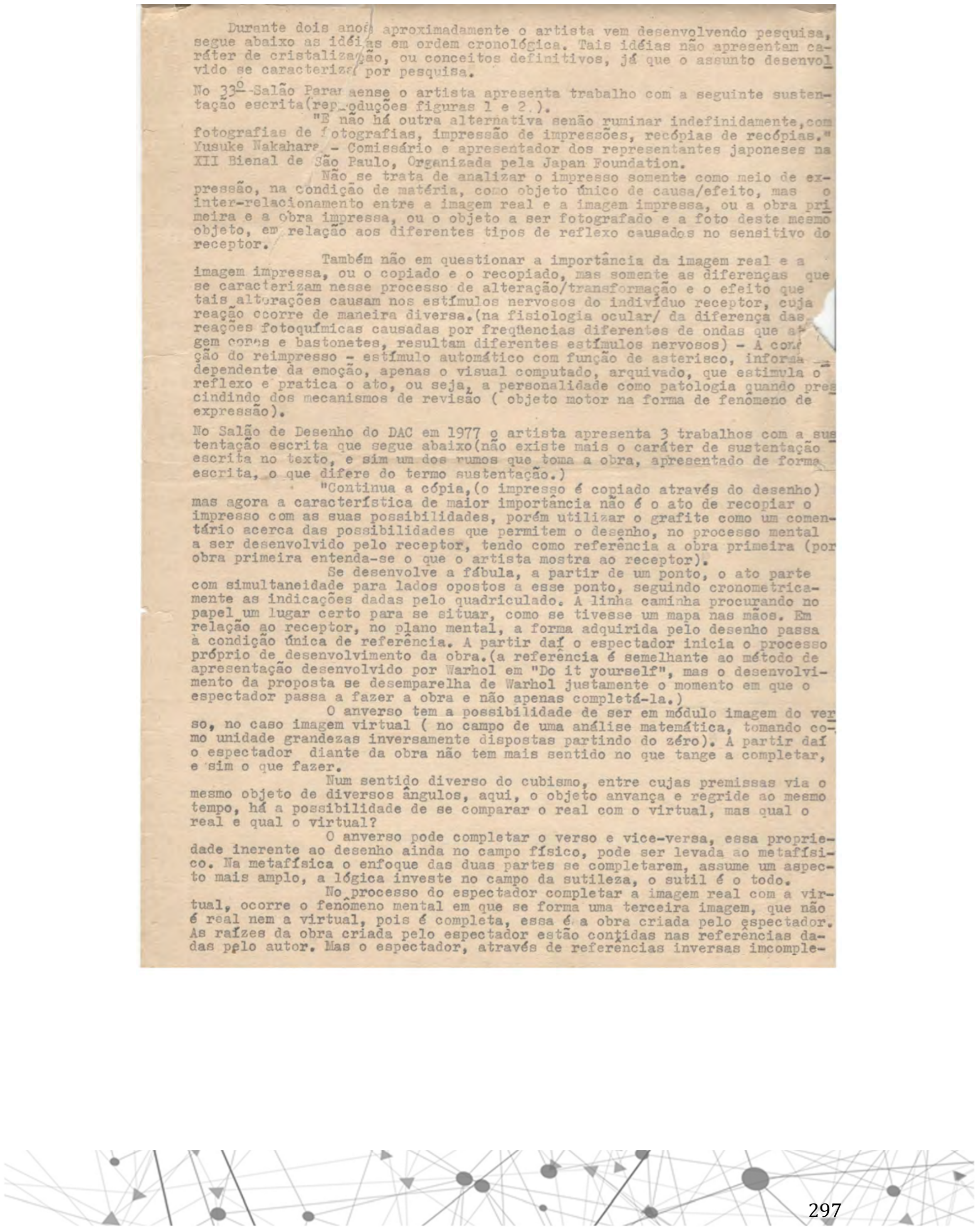


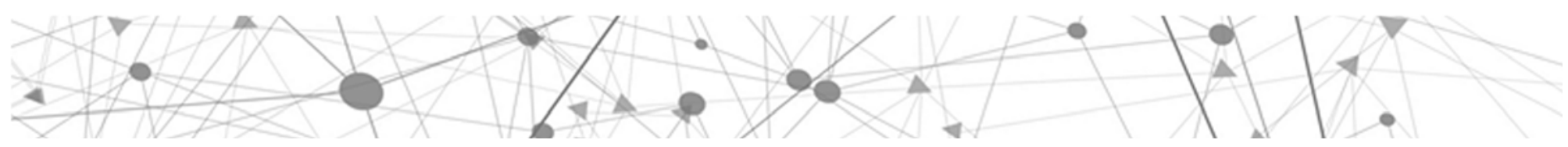

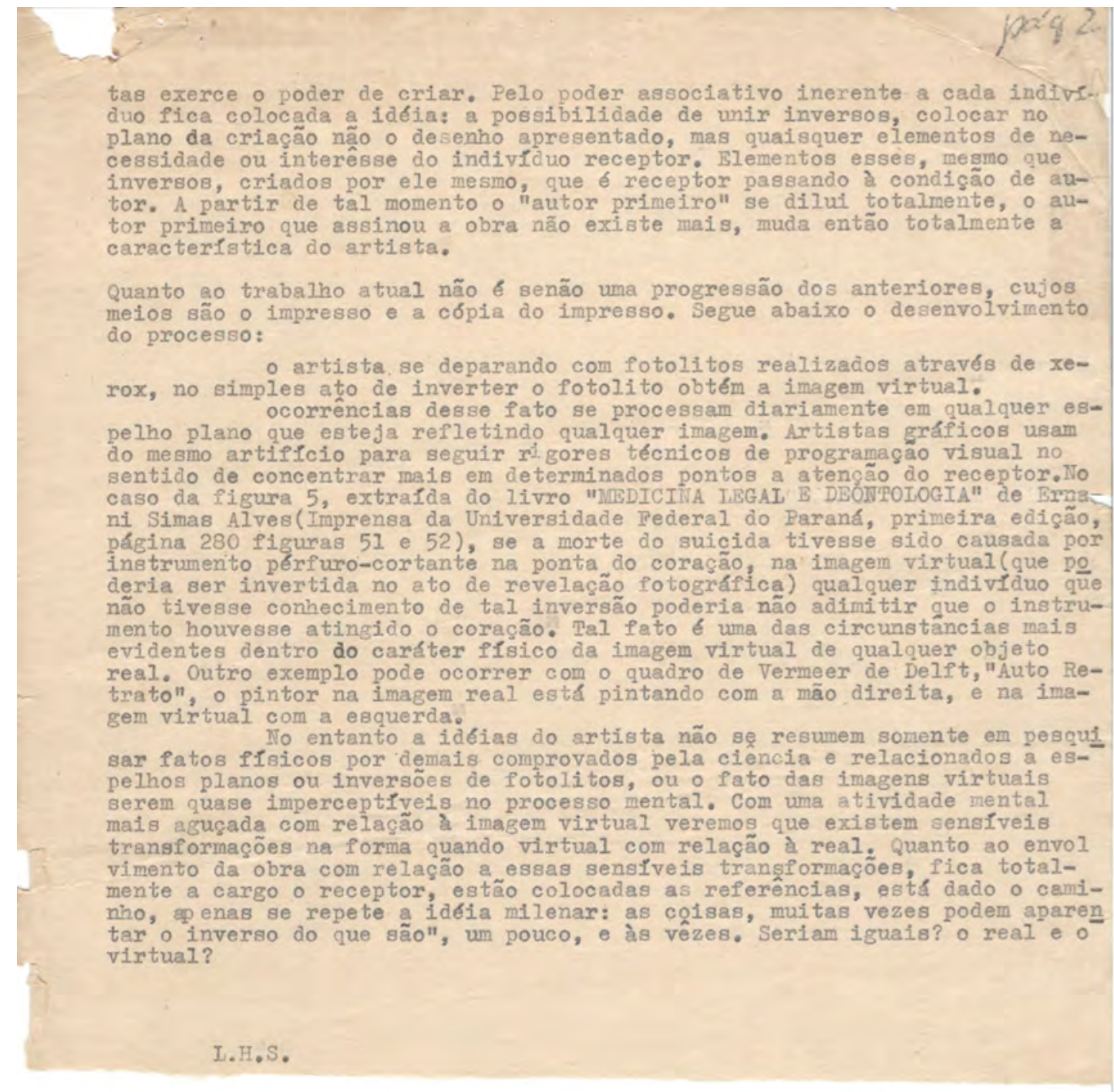

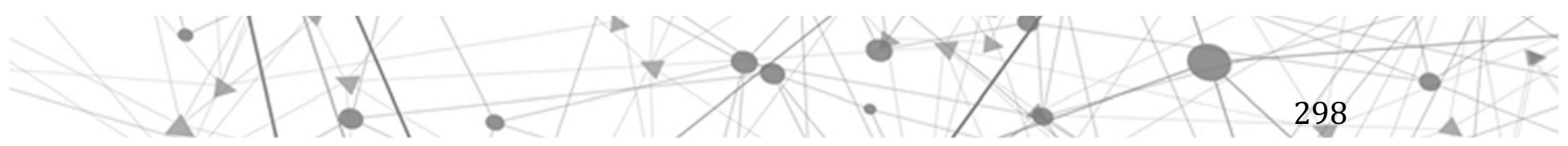




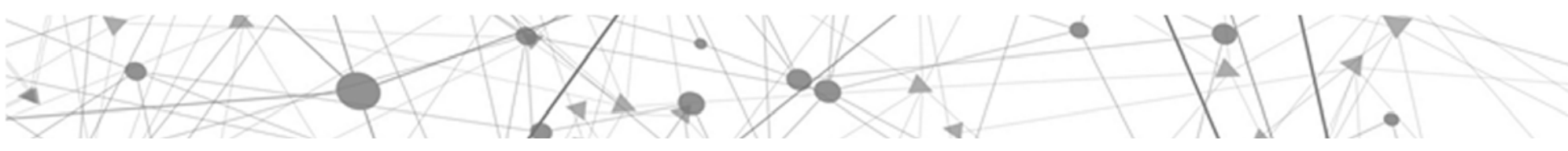

ANEXO 03
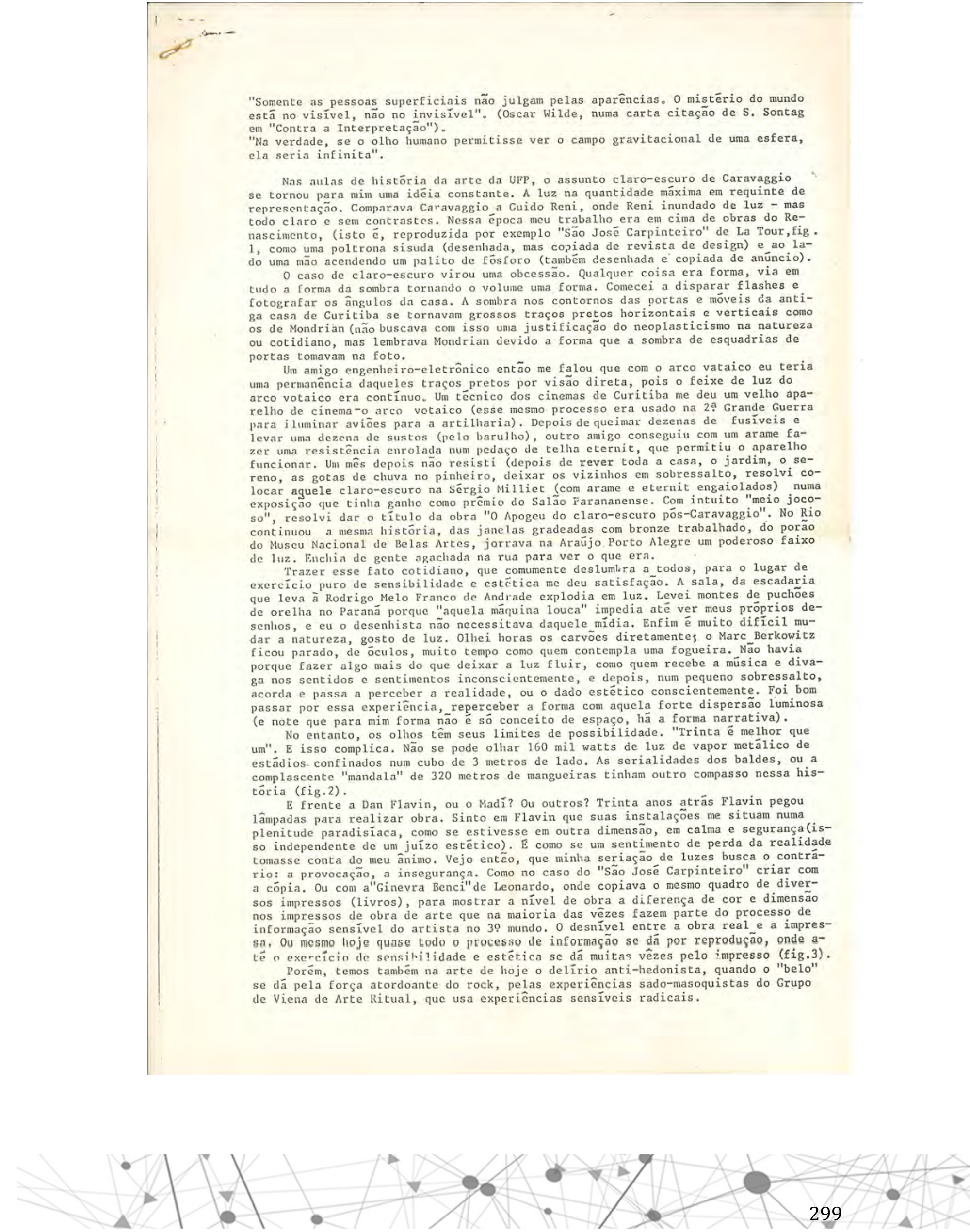

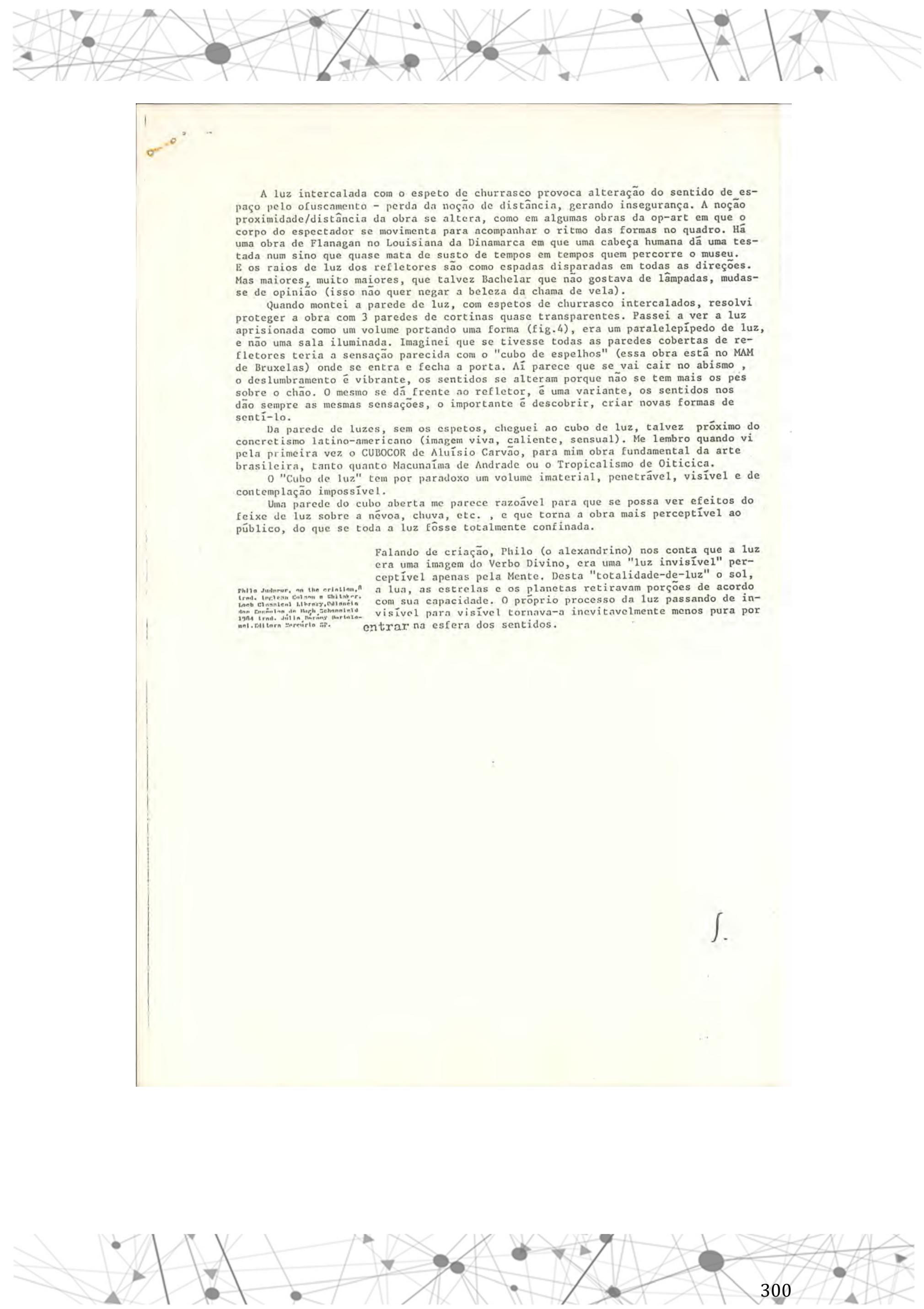

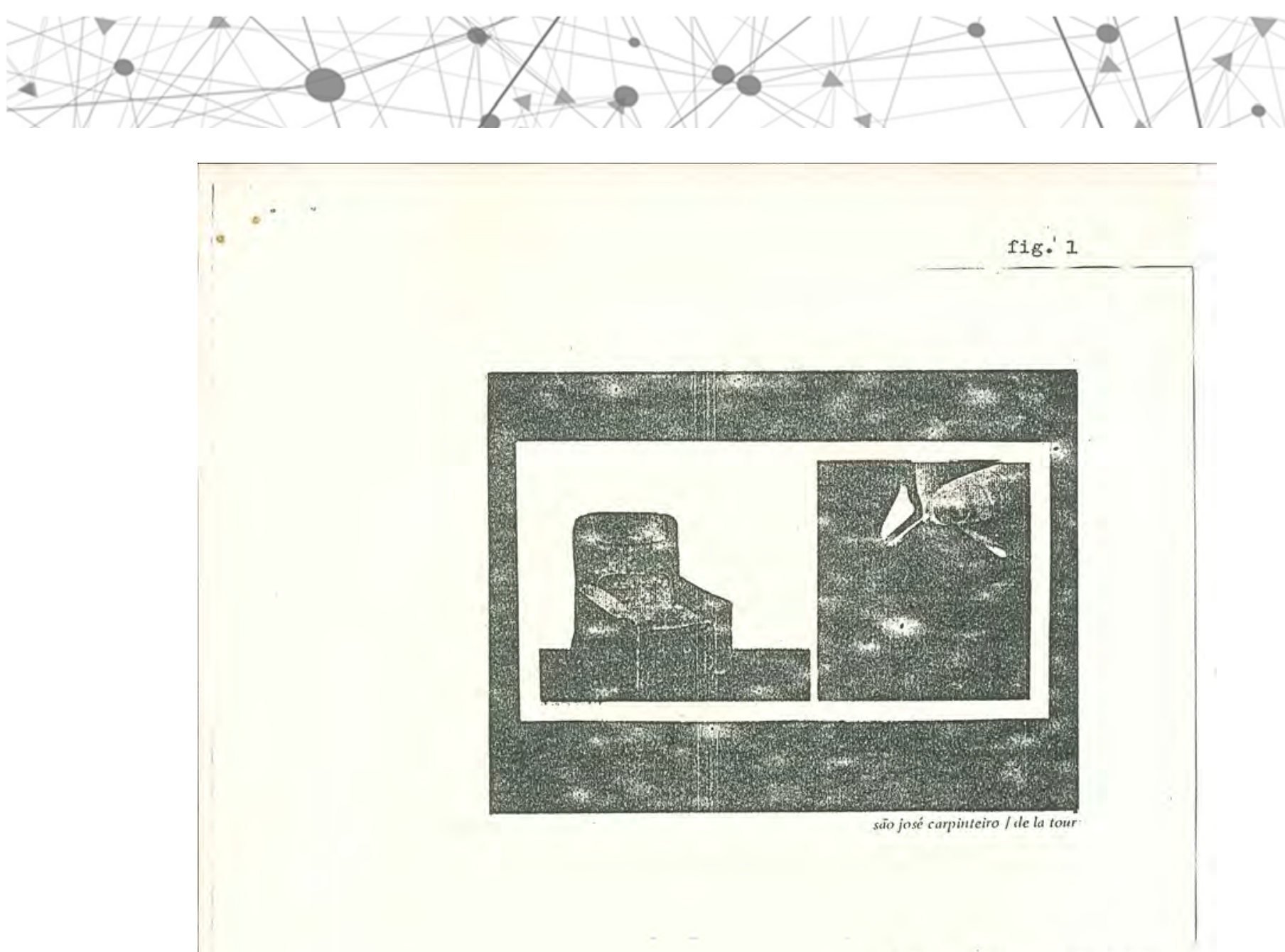

lápis de cor o aquarela s/ papel.

$70 \times 45 \mathrm{~cm}$.

1980

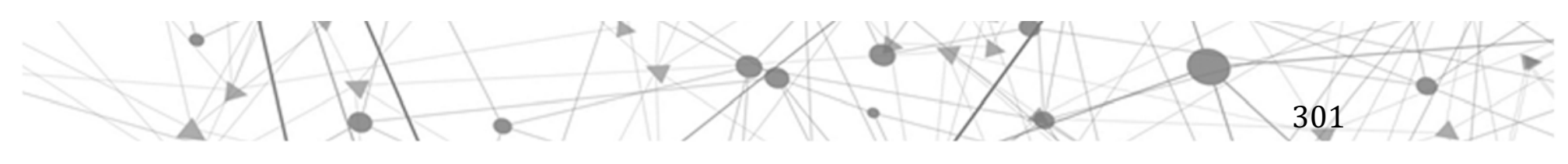



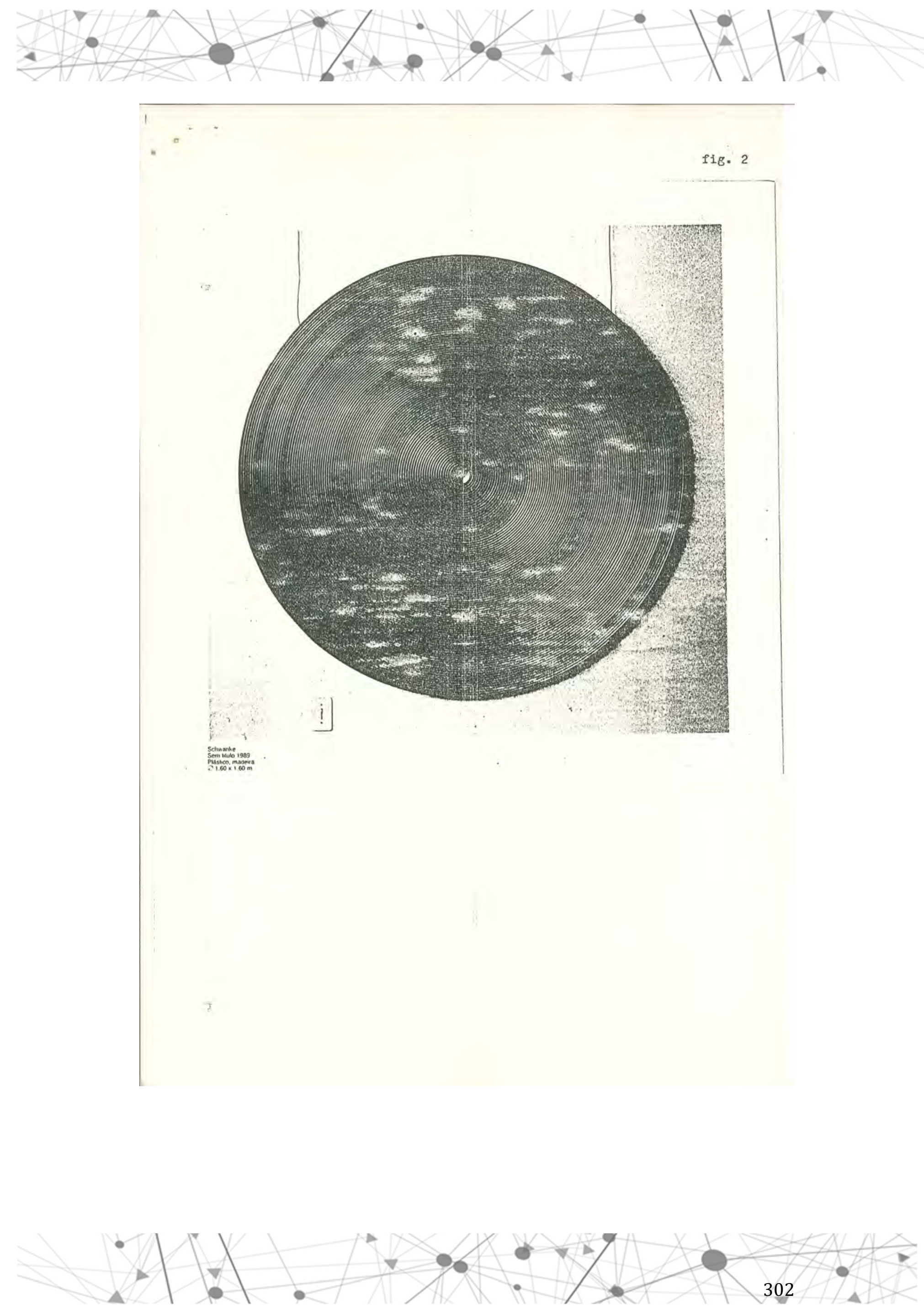

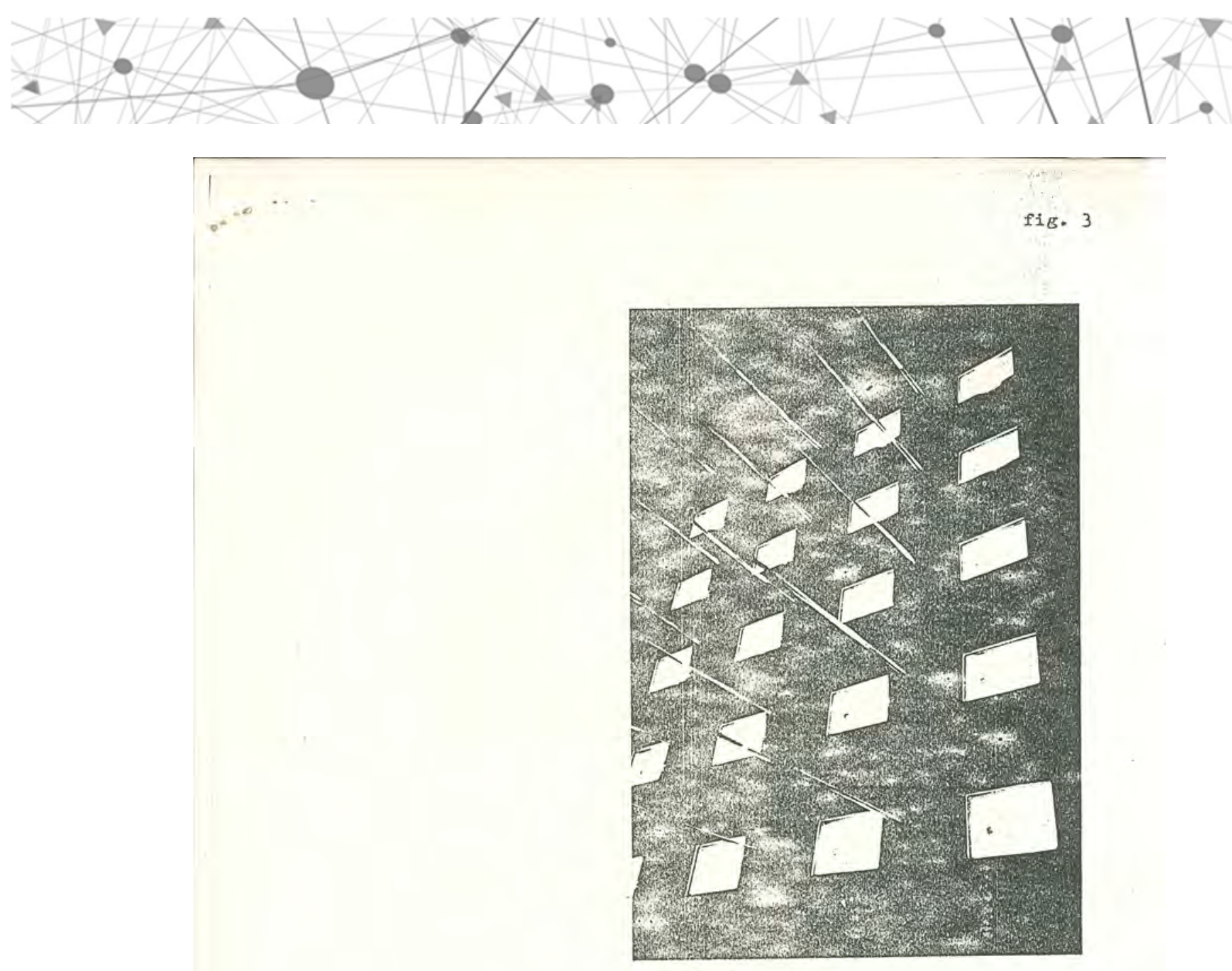

Som títuzo

$5 \mathrm{~m} \times 5 \times 3 \mathrm{~m}$

refletores de 300 wats, espetos de churrasco.

1990. 

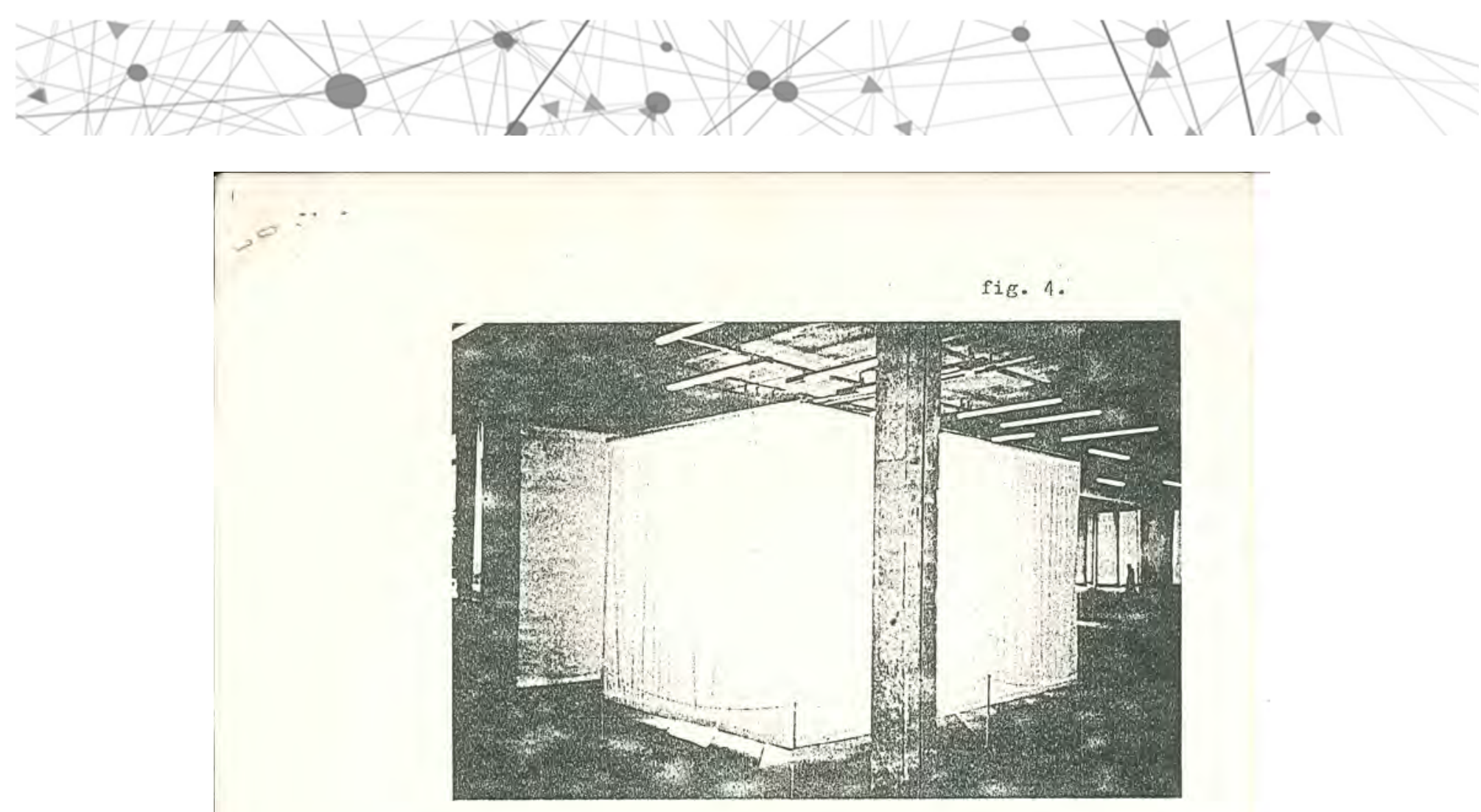

Som título

$5 \times 5 \times 3 \mathrm{~m}$

nano, refletores, espetos de churrisco.

1990
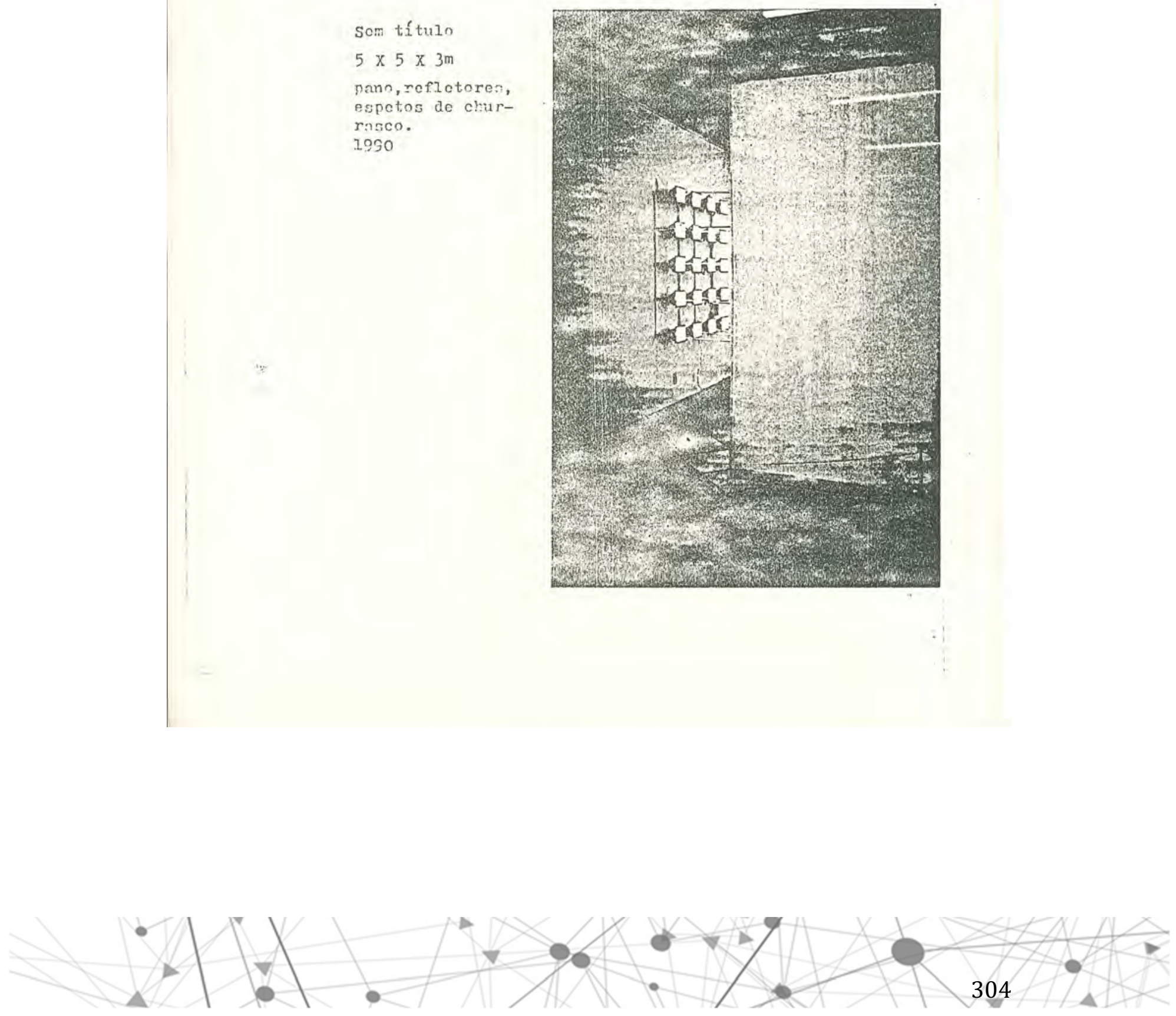


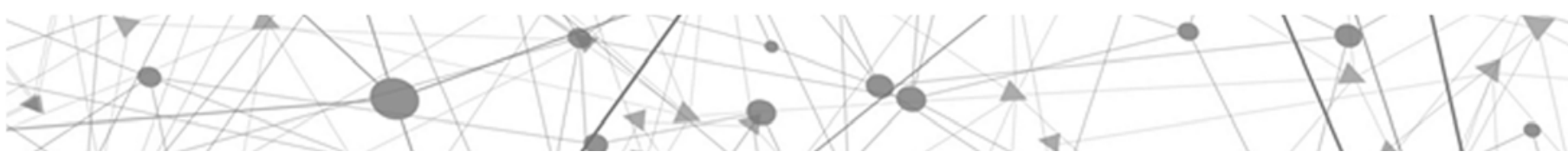

ANEXO 04

Anexo D, Carca a Harry Laus

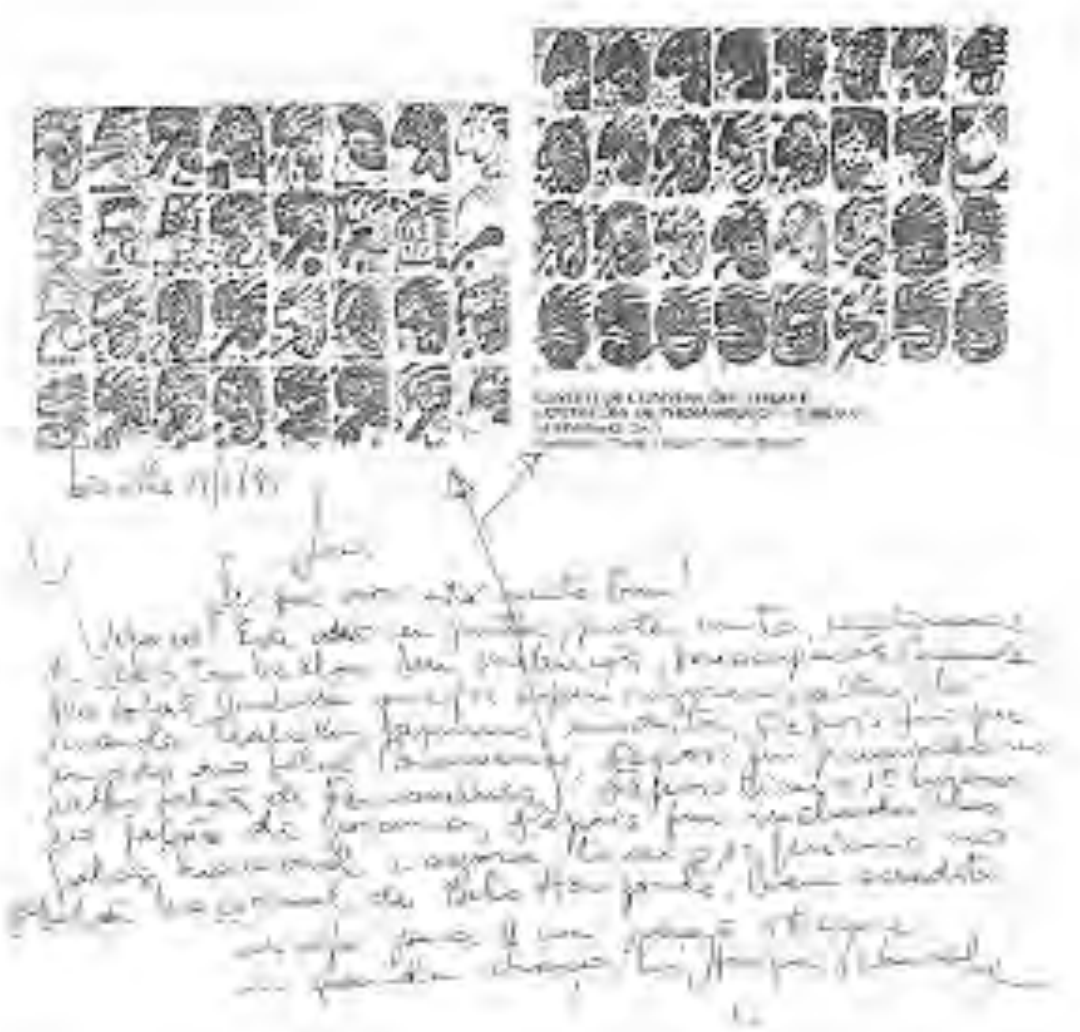




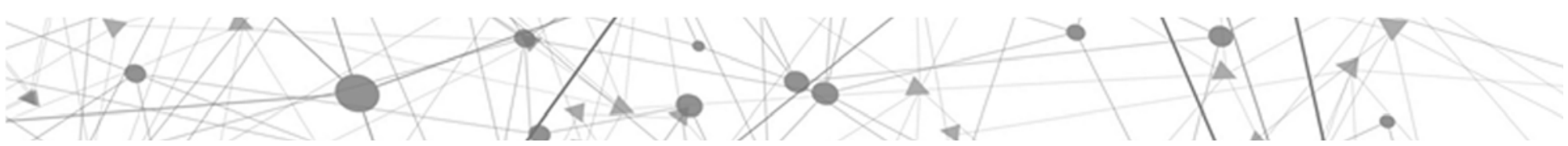

ANEXO 05

LUIZ HENRIOUE SCHWANKE - Entrevista concedida a Zilah Marchezini - março/1992.

Zillah - Schwanke como é que você situa sua obra dentro de uma visão mundial histórica e sociológica da arte?

Schwanke - ...busca um comentário sobre diversas escolas de arte, quer dizer, ele sempre teve uma tendência a ser um comentário de obras de arte, de escolas de arte, isto desde 1978 , venho produzindo. O artigo do Frederico, no Globo, em 1980 ele já comenta e naquela época essas coisas eram mais evidentes, esses comentários acerca da História da Arte, agora ele está menos evidente, mas ele ainda existe. $\mathrm{E}$, o que mesmo que você disse Zilah?...Mas enfim, o trabalho atual ele tem uma ligação grande com o barroco, ele é, ele entra dentro dos princípios do Barroco, quer dizer, principalmente nos trabalhos das mangueiras, né, é claro que envolve todo o trabalho das escolas minimalistas de serialismo. Mas os artistas serialistas eles geralmente tendem a uma simplicidade distante do barroco, pôr exemplo, o Carl André(?), ... como é o nome do artista que lida com as luzes, dos Estados Unidos, é o ..., bom daqui a pouco vem o nome dele. Enfim, agora o meu trabalho tende ... um momento... pốr que um círculo, mas a medida que as pessoas se aproximam, ele tem $500 \mathrm{~ms}$, de mangueira enrolada, né, então ele tem um rebuscamento barroco muito grande, e, eu acho que existe na arte, na supercontemporânea, no mundo, hoje, uma tendência, não é exclusiva, pois as tendências são múltiplas e são várias, né, e existe a tendência de alguns artistas trabalharem com esse mundo do barroco que... um dos artistas que tem alguma coisa dessas características é o Jass Cool(?), ele faz trabalhos sobre figuras prateadas, apropriadas, estátuas antigas, ele dá banho de prata, então a coisa vai meio pôr aí. Agora, o meu trabalho também, ele sempre teve um super dados de ironia, né, ele tem uma ironia muito grande, a medida que o trabalho do Malevitch ele buscava uma..., uma..., uma coisa mais distanciada, mais em torno do sério, não que o meu não tem um pressuposto sério, ele tem um pressuposto sério, mas ele tem aquela veia brasileira de ver as coisas, quer dizer, de quem vivência o Brasil, né. Uma coisa de..., mais brejeira no modo de ser, tanto que você..., o espaço branco no trabalho, ele é um simples forro, ele tem um forro de casa apropriado, então, quer dizer a medida que é um forro, ele é um trabalho pop. Ele é pop no material apropriado, no material que ele é usado, é a construção desse pop, quer dizer, o ajuntamento desse material pop ele remete ao novo realismo, agora... 


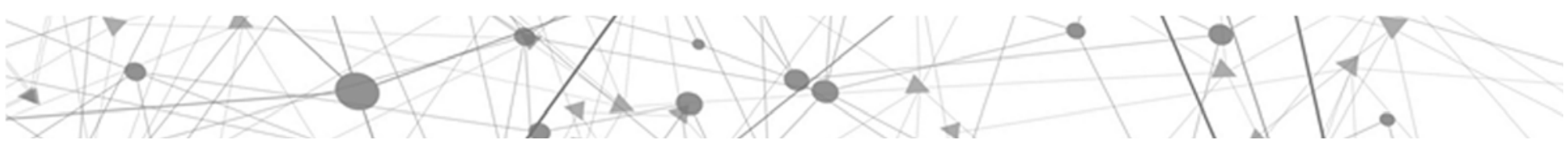

Zilah - É intencional?

Schwanke - As coisas não são totalmente intencionais, você vê, eu não, não é que se..., ele é intencional, mas vocễ veja só, é uma coisa do olhar, é relativa ao olhar. Você olha o material dai você concebe, mas você, pốr exemplo, não teoriza antes para executar depois, dai, escolhe o material e tal, você não tem teoricamente um caminho pré-determinado, o material é que se mostra. Se mostra como existe para o meu olhar e dai, a partir do olhar é concebido, digamos o nascimento da obra, então...

Zilah - Existe então um relacionamento de você, um interrelacionamento de você com o material?

Schwanke - Sim, não sei se é um inter-relacionamento, ele seria, o material, se mostra ao meu olhar, né. Daí eu consigo conceber a obra, com alguns materiais. Então, ele deriva da superfície, da cor e do ajuntamento que se pode fazer das coisas, o trabalho ele tem uma frieza, um distanciamento muito grande, ele é uma coisa muito fria, né. Mas, ao mesmo tempo ele é muito irônico né, ele tem um dado de iromia grande. $\mathrm{O}$ Arlindo $\mathrm{Da}$.?, a uns anos atrás, quando eu fiz esta exposição no Rịo, que eu fazia os personagens da História da Arte transformados em cadeiras e poltronas, ela fala umas coisas interessantes, essa carta é de $1980 \ldots$ O João Henrique fez a apresentação daquela exposição, na época, ele diz que o

5) João Henrique fala em humor e sem (incompreensivel), e o Arlindo diz assim "é verdade que é muito mais irreverência, um pouco de cinismo, também ficaria muito bom dizer, é mais irreverência do que humor, mas me agrada muito esta impunidade, ou seria um descaramento, como diria alguns, em se tratar as coisas da arte?" Quer dizer, o Arlindo acha que até poderia ser um descaramento tratando o. assunto da arte, ele diz que se identifica com esta minha conduta. Quanto ao erotismo, ele diz assim "Quanto ao erotismo" três pontos diz ele "...engraçado é que seu trabalho é aparentemente frio, quase seco, mas no fundo, no fundo mesmo, é uma coisa de uma envolvência estranha, mais abafamento do que calor, tensão que extravasamento, corda estirada. Duas fixações básicas, para mim que sou espectador, o cheiro do couro das poltronas, talvez esse cheiro de couro abafe o cheiro quente que sai das peles do gato quando chove "ele se refere como a umas das reminicências infantis da familia dele que...

Zillah - Ele fala como receptor, é interessante ..

Schwanke - ... da familia dele, que tinha criação de gato, essas coisas né. E eu fiz, também, uma série ligada ao São Sebastião, então ele diz assim, ele disse que está estudando (o (incompreensivel) de Santa Teresa D’Ávila e o São João de la Cruz, e ele fala que o amor é, sabe como é, o 


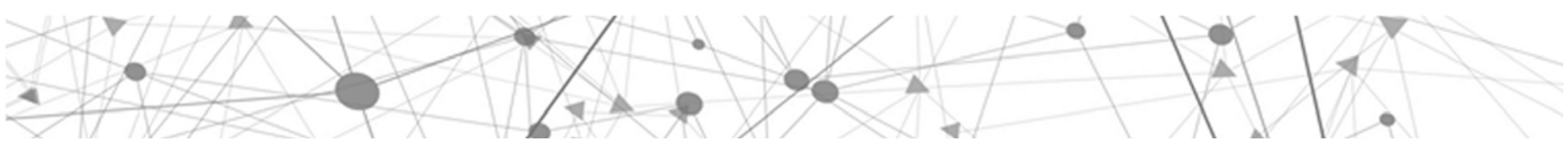

amor místico é uma poetização do amor profano, que justamente São Sebastião e Santa Teresa eram dois dos meus favoritos, os primeiros. O São Sebastião e Santa Teresa eram levemente perversos; admirar o corpo nu manchado de algumas gotas de sangue, e Teresa, de Bernimi, sempre me lembrava a Santa em êxtase, , não me deixa a menor cúvida sobre os estigmas à Santa Teresa, que acaba de receber. Então, essas posições do Arlindo, elas tem uma coisa de, ela situa bem, não é mais muito humor, é mais irreverência o trabalho, né! Ele é quase uma, uma contraposição ao "branco sobre o branco" de Malevitche, né. B́ um novo modo de você dessacralizar aquilo. Tornar aquilo uma coisa vista com outros olhos, outros materiais, você digamos é, você despe o santo, né. Você mostra o que tem atras do manto.

Zilah - Seria a tua linguagem?

Schwanke - É que ele tem alguma coisa que vai bastante sobre isto, né. O trabalho, acho que é uma linguagem, isso é um exercício de uma linguagem brasileira, o exercício do caráter brasileiro na arte, que tem uma série de exemplos, né, Macunaíma tem essa forma de ser, a própria Tarsila colocou no exercício da linguagem, que os artistas que se exerceram realmente, como uma coisa, quer dizer o Glauber Rocha, no cinema, que abordavam essa, e isso não quer dizer que não seja uma abordagem critica. Ela não é, digamos, uma energia, um favorecimento a esse carater brasileiro, não é, ela é inclusive crítica, ela mostra a realidade como ela é, do nosso modo de ser e viver...

Zillah - Até na escolha do material você confirma essa sua colocação irônica da situação. Schwanke e aquele contorno verde e azul, como você colocou?

Schwanke - Ele tem, ele reforça aquela coisa de relevar a moldura né, de que ele releva o sentido de moldura, ele decora o espaço em redor para justamente levar você a uma concentração no espaço interno, então, ele faz. as vezes da moldura par situar o espaço branco emoldurado é uma coisa também..., uma coisa de mostrar aqui eu tenho um vazio, aqui ele está definido ...

Zilah - Um vazio cheio de coisas...

Schwanke - É

Zilah - Schwanke aquelas linhas paralelas tem um significado também, para você?

Schwanke - Bom, elas são uma..., primeiro o material ele me impõe limitações e condições de ser. É claro que eu poderia ter, neste trabalho, ter colocado linhas verticais, mas não elas foram horizontais por uma 


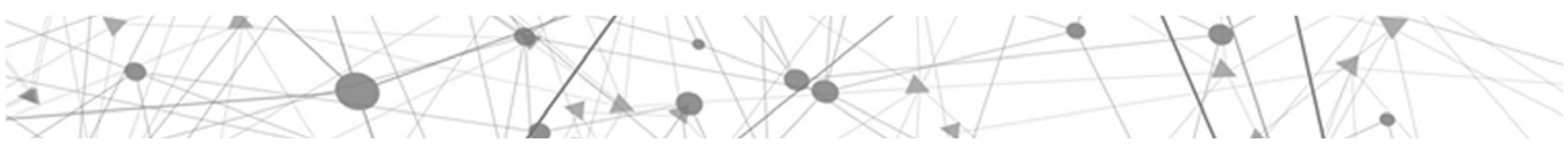

questão estética, é racional, por que o trabalho ficaria mais bonito, neste caso, horizontais. O problema da superficie, da textura do material, quer dizer, ele é acetinado. O plástico é um coisa muito, apesar de todo mundo. achar que é vulgar, eu acho ele muito bonito, né, acho que ele tem...

Zillah - ... a textura dele, né...

Schwanke - ... é a textura dele é belissima, ele é um material vulgar, você encontra, hoje na sociedade de consumo, em todo canto, todos os dias, nas coisas mais chulas possíveis...

Zillah - Você conseguiu através do plástico uma cor uniforme, não é?

Schwanke - Assim, é, e depois tem ainda aquela coisa de ainda é..., de aparentar, ele só aparenta né, é muito mais, menos rápido você fazer um trabalho desse que uma pintura. Uma pintura de hoje, de confeç̧ão, de criação, de execução, né. É claro que tem pintores que podem levar três anos, estou falando numa média para fazer uma quadro. Por que as coisas são muito rápidas né, você não vai de navio prá Europa, vai de avião, então, tudo tem que correr num rítmo mais rápido, mas ágil no século, né, par acompanhar o rítmo da vida, né. Então a..., é.. apesar de... Agora, para as pessoas ele parece uma coisa extremamente simples de execução, isto também revela uma coisa do caráter da obra. Apesar de não ser um trabalho minimalista, ele exige assim um cuidado tremendo no deslocamento, por que qualquer arranhamento, qualquer deformação, qualquer ângulo que esteja torto ele aparece muito mais, né. Agora, o sentido da moldura é para colocar o espectador em concentração no espaço, naquele espaço branco, vá ele em busca do..., daquela nova ordem, é...material, né. E, também, tem um texto meu, que eu acho que ele é um pouco série às vezes, você está entre..., você tem um, você tem uma antinomia (risos). E com relação a superfície, porque o cubismo era uma escola que levava a mostrar a superficie de um objeto de diversos ângulos, então, no fundo essa busca, hoje, do branco, da luz, do espaço é... maior, eu..., o importante seria levar os caminhos da arte para uma introspecção maior a nivel mental, do que você simplesmente é..., você simplesmente é..., ficar num..., podendo ser é ... enganado pela vista. No fundo, hoje, para mim em toda superfície, todo o rebuscamento que não leve a um processo mental de arte, ele tende a ser superficial. Superficial relativo não só a essa coisa assim de fachada, mas um..., a superficie é aquela coisa que detém o olhar. Eu acho que o olhar é aquele que entra, aquele que vai além das superficies, que se coloca num plano que você não precisaria mais dos olhos e do corpo, seria um plano de artes de pura 


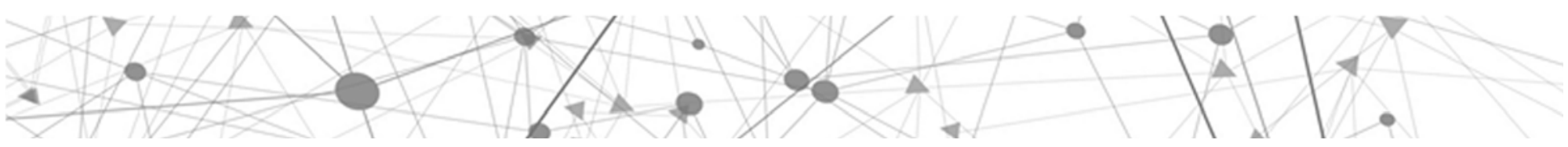

mentalização, quer dizer, um purismo que te levasse a nem precisar mais dos olhos, simplesmente vivenciar a mente.

Zillah - Schwanke, dentro desta sua filosofia, como você conseguiu trabalhar justamente com operários nesta tua obra?

Schwanke - Não é uma..

Zilah - ... o relacionamento dentro de toda essa filosofia...

Schwanke - Primeiro que é uma coisa muito complicada por que você esta lidando com seres humanos, e você..., e todos os seres humanos gostam de contribuir, então existe um ..., mas existe uma coisa de que eu não posso colocar na cabeça das pessoas assim, vinte anos de leitura da História da Arte, né. Todas as pessoas que lidam com técnica, com marcenarias, estas coisas, elas tem esses materiais, elas querem produzir e querem influir. Então, você é..., é muito complicado, as pessoas... outras coisas para você fazer, inclusive, descobertas que já foram feitas, que já foram usadas, que já foram utilizadas, dai, mas eu sempre fui muito paciente. Ai, eu ia lá, pegava um livro mostrava, mas isto aqui já foi feito, já foi criado, isto aqui, não insista, e papapá... Então é uma relação bem delicada, bem difficil, e, tem todo um processo, o pó né, do plástico serrado, é uma coisa que você usa máscara, você tem o cheiro da cola , que é coisa fortíssima. Tem uma série de cuidados que você tem que ter na execução, né...

Zilah - Schwanke, você colaborou bastante com uma visão nava de arte, para esses operários?

Schwanke - Ah sim, por que todomundo ia na oficina e queria criar uma obra, e fazia desenho e pedia para executar e se deixasse a fábrica (riso) virava oficina e ninguém mais fazia nada. $\mathrm{E}$ você tem uma relação com os donos da fábrica, com o Presidente, tal, que tem que manter, para não causar (riso) o transtorno na fábrica..

Zilah - De repente a fábrica ficou escola de arte?

Schwanke - Você tem que nesse caso, em último caso, você vai pra Profiplast, né, por que o profiplástico foi criado lá dentro, nos outros lugares eu só pegava material e o marceneiro geralmente que executava a obra, que aliás é complicadissimo, né, de executar, o trabalho digamos, nos galões eles tem toda uma estrutura. Se você tirar uma radiografia, tem parafusos de 2 metros, e tem vários, e os furos tem todos que ser tirados em um esquadro para estarem todos no mesmo lugar. $\mathrm{O}$ trabalho muito, não aparenta, mas é..

Zilah - A tecnologia no seu trabalho ela tem que ser perfeita? 
Schwanke - É, geralmente, entra a opinião de engenheiro. OS engenheiros que fazem os cálculos, vê, ninguém imagina que um trabalho pode pesar $150 \mathrm{kl}$., digamos no caso das maletas elas pesam em torno de $150 \mathrm{kl}$, e não é muito grande, tem $1.80 \times 1,20$, por aí.

Zilah - Você entra com a inspiração e a tecnologia de uma trabalho em equipe. O seu trabalho é em equipe. Schwanke, como é que você responderia para um adolescente sobre aquela tua obra do Museu, que diz "ó, mas isto ai também eu fazia?"

Schwanke - É, Colombo também colocou o ovo em pé e pronto, acabou né, é esta a história, e inclusive, quando eu tinha um. Esta pergunta sempre foi feita para um..., desde que comecei a fazer arte com uma linguagem contemporânea, todas as pessoas sempre disseram isto, a questão é que, o primeiro que pode fazer né, pode fazer e não é muito aconselhável, sobre o aspecto financeiro, né, que vai sofrer muito, a vida. toda, e quem quiser fazer dinheiro, realmente não faça isto. Por que as pessoas estão sempre prontas a consumir uma coisa que já está mais hierarquizada na sociedade, mas é a questão da descoberta né. Não adianta, você fazer uma coisa, uma segunda vez, a nivel de criatividade, é aquela história, já está feito, eu também faço, mas a questão é que já está feito, não tem mais por que você fazer, não tem mais porque eu escrever um livro de James Joice, quer dizer é uma tolice, um absurdo.

Zilah - Especificamente naquela obra do Museu, você conseguiu atingir todo o que você, todas as linguagens que você quis colocar. $\mathrm{O}$ artista Schwanke venceu o material, ou o material venceu o artista Schwanke?

Schwanke - Eu acho que desses trabalhos todos de plástico, quer dizer, os mais felizes são os que, inclusive, criaram mais empatia com o público, o que é perigoso. Nem sempre é o que o público tenta mais empatia ou que o artista, que o público tem não só empatia, mas que discute, ouve, fala, tal é o..., ou tenderias ser o melhor ou o pior, né. Mas,enfim, as coisas proliferam assim, através do 'que o povo fala, quer dizer, da empatia que tem a maioria. Mas eu acho que os trabalhos, esses de plástico, melhores são os círculos, não.., e esse trabalho do Museu eu ainda não depurei internamente, eu ainda preciso dar uma esquecida, dar um tempo, pra voltar de novo, par ver se ele, se realmente ele se sustenta, né. Realmente, esta..., por que esta exposição me assustou um pouco. Eu estava com o trabalho todo da Bienal junto, e é..., foi uma exposição feita dentro da fábrica, primeira experiência que eu tive fazendo, exatamente, executando dentro da fábrica mesmo as coisas, e então, não, eu podia mudar pouco. Quando você faz o trabalho olhando um catálogo, olhando os materiais,

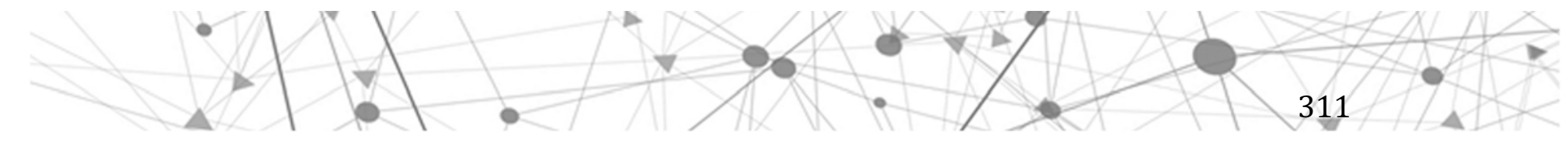




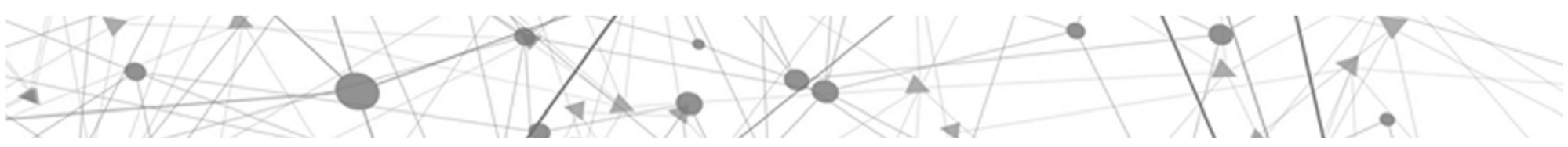

você tem que levar, isso limita muito. Você faz um pedido, numa fábrica tem que ser assim, você não pode estar pedindo hoje tantos, 200 metros de perfil, 300 do outro, daqui a pouco você corta tudo, se isso o dá certo. Você tem que apresentar o projeto, e você executa o projeto, daí é..., as vezes metade do projeto não fica bom, você quer mudar e quando você quer mudar, você leva de novo à diretoria, porque tem que ...,enfim, uma empresa tem almoxarifado, as coisas tem que ter uma burocracia, tem uma documentação e tal. O tempo também é determinado para os executores fazerem, não podem ficar a vida toda a sua disposição, e então, é uma coisa meio tensa, que ainda ..., essa coisa profissional, a esse respeito eu ainda não absorvi totalmente, é uma coisa assim, é eu acho, quer dizer em casa, quando você está fazendo uma pintura, você pode mudar, 200 vezes e tal, no processo de criação dentro de umá fábrica já é uma coisa assim que tem certas limitações.

Zilah - É um desafio.

Schwanke - É, e eu não sei se devido a estas coisas todas, eu não sei se as obras estão todas com a mesma validade, enfim, isso o tempo vai mostrando, né, espero que, mas é..., quer dizer sempre que eu sinto condições, agora com mais calma, sem exposição marcada, fazer um trabalho mais calmo e assim depurar mais, né, com mais, quer dizer..., produzir uma obra num mês, outra noutro, então fica mais tranqüilo para você pensar também.

Zilah - Eu agradeço e vou deixar um livro para o público, por que eu quero que o público também dê a sua impressão sobre a sua obra, e, assim você também vai saber como está sendo recebida pelo público. As indagações do público, por que ela realmente é uma obra que nos indaga muito, pois justamente por que ela não pretende nos dizer nada. A gente tem que dizer tudo a ela, então, a linguagem dela, por ser muito clara, ela passa a ser muito complicada.

Schwanke - É porque você fica assim sem o teu tapete, por que não tem um desenho, não tem um..

Zillah - Ela não te cobra nada, também...

Schwanke - Geralmente as pessoas tem uma história longa, imensa pra passar pra você, ela primeiro de cara já elimina esta coisa, né...

Zilah - É mas talvez você consiga fazer toda essa coisa que você quer que a gente aprende, vase a superficie através de divagações, de pensamento, talvez e consiga chegar lá. Muito Obrigado. 
ANEXO 06

\section{Apogeu do claro-escuro... e A casa tomada... Notas da pré-história}

Alguns privilégios a gente acaba sempre tendo na vida. Entre eles, acariciamos o de ter testemunhado algo da imaginação criadora de um grande artista - Luiz Henrique Schwanke.

Luiz entrou na nossa vida ali pela dobradiça das décadas de 70 e 80 , pelas mãos de um amigo comum. Uma simpatia mútua permitiu que mantivéssemos contato durante o tempo em que eles viveram em Curitiba. Depois, perdemos contato, mas conservamos o poder de reanimar lembranças alegres dos tempos em que convivíamos com alguma assiduidade. Queremos falar de algumas de tais lembranças.

Uma noite, vínhamos de carro, não sei de onde, e passamos pela rua onde hoje está o Shopping Mueller, em Curitiba. Naquele então, a quadra inteira estava ocupada pelas ruínas da antiga Fundição Mueller, já desativada e, para nossa tristeza, demolida. Era um belo prédio e sua demolição fora melancólica, para nós. Não para ele, que via ali o cenário ideal para uma instalação luminosa.

Declarou em voz alta seu desejo de fazer funcionar, bem no centro da quadra, escondido em meio ao entulho, um dispositivo capaz de emitir raios luminosos, intensos e fugazes como relâmpagos, que assombrassem os eventuais passantes. Meu marido lhe disse que, àquele tempo, um arco voltaico intermitente seria o dispositivo capaz de produzir tais efeitos. Luiz ficou muito interessado e Jaques nos contou que tal dispositivo tinha sido aplicado, na segunda guerra mundial, em holofotes usados para iluminar o céu e revelar aviões inimigos. Para fins bem mais pacíficos, embora também emocionantes, eram os geradores da luz nos projetores de cinema contemporâneos.

A partir dali eles não pararam mais de falar no assunto, conversa que culminou com a instalação "Apogeu do claro-escuro pós Caravaggio". Esta instalação ele a levou a público, junto com outros trabalhos, numa exposição realizada na sala Milliet do Museu de Belas Artes do Rio de Janeiro. As luzes do arco voltaico, que eram produzidas com um antigo projetor de cinema, vazavam pelas janelas da sala que, no nível da rua, ficavam rentes ao chão, produzindo lá o efeito que ele pretendera obter em Curitiba - e que aqui permaneceu inédito.

Naquela mesma exposição, no Rio - uma individual com que Schwanke havia sido premiado num Salão Paranaense - ele mostrava dois outros trabalhos: uma coleção de quadros - "Desenhos de 1978-80" - e a instalação "A casa (de Julio Cortázar) tomada por desenhos que não deram certo". De algum modo acho que também testemunhei a pré-história de $\boldsymbol{A}$ casa tomada... pois, numa tarde, em sua antiga casa no bairro São Francisco, tirei do lixo, debaixo de sua bancada de trabalho, um desenho seu, num pedacinho de papel. Vejam a seguir do que se trata: 


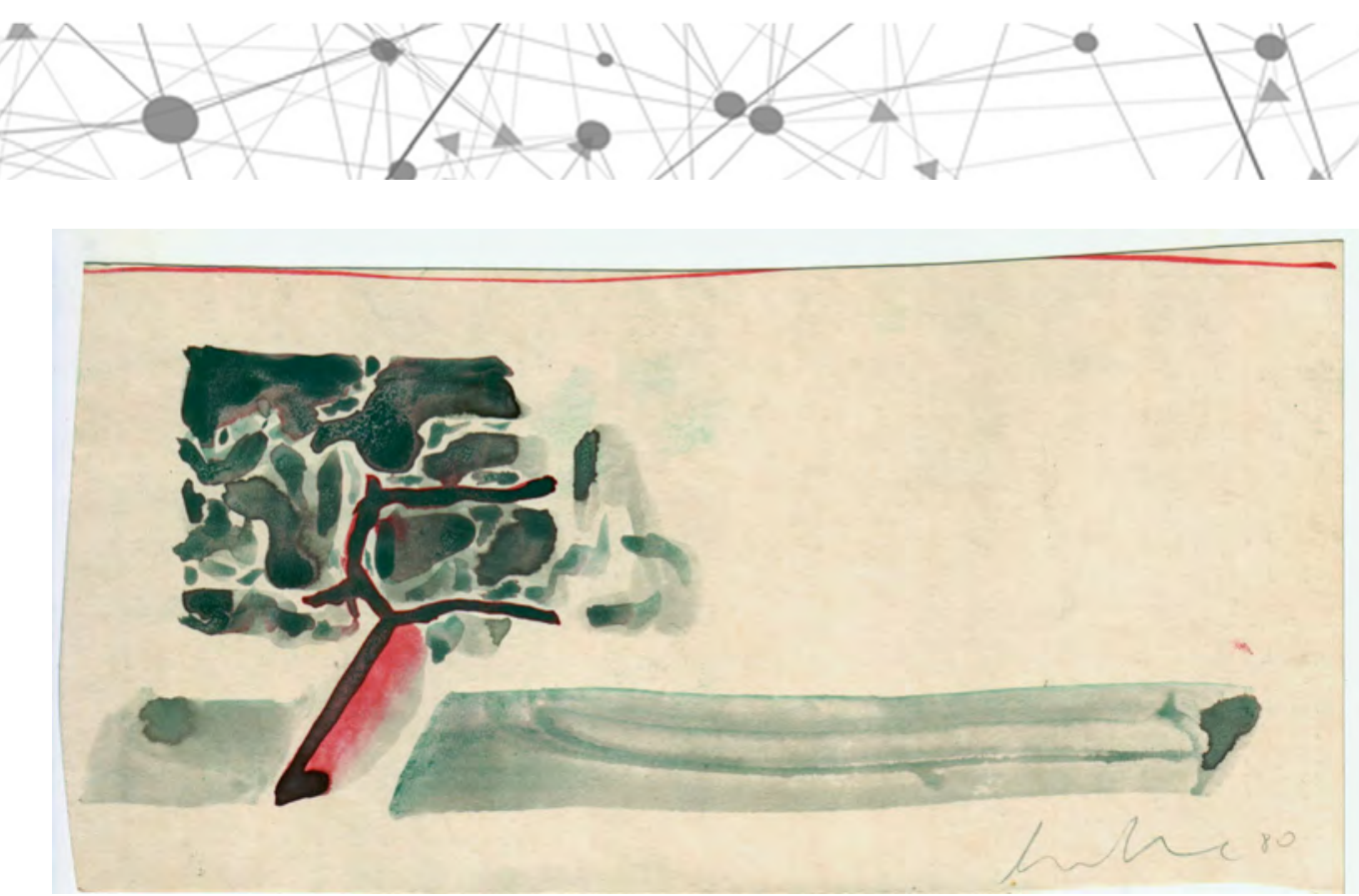

Eu the disse: Como é que você joga fora uma coisinha tão linda? Ele riu e disse que era um simples exercício para testar um pincel. Perguntei se podia ficar com o desenho e, concordando ele, se poderia assiná-lo. Ele me atendeu o pedido, divertindo-se, e falou: se você soubesse a quantidade de coisas assim - e nem sempre tão singelas - que eu jogo fora...

Falou-nos, então, de um dia em que ele, sucessivamente, desenhava e desprezava o desenho, amassando o papel e jogando o trabalho fora - porque não gostava do resultado: eram desenhos que não davam certo, para ele, naquele dia. Quando deu por si, a sala estava tomada por papel amassado, cercando-o por todos os lados. Ele foi, então, atravessado por uma idéia: $A$ casa de Bernarda Alba, tomada por desenhos que não deram certo. Pareceu-lhe uma instalação interessante.

Ele acabou migrando da casa de García Lorca para a de Julio Cortázar, quando concretizou esta idéia na Milliet. Não conversamos sobre isso, mas compreendo que, como no conto de Cortázar, a ocupação da casa é o elemento central da trama, esta referência mostrou-se mais adequada à experiência da sala tomada naquele dia em que, por alguma improvável dificuldade técnica, ou por uma possível ambição desmedida, os desenhos "não davam certo".

Também na exposição da Milliet, a instalação "A casa tomada..." era a idéia central, impactante, a peça que ocupava lugar no espaço (literal e metaforicamente). Embora ele tenha comentado que a luz do arco produzia um jogo de claro e escuro nas dobraduras do papel, absorvendo a "Casa tomada..." para dentro do conceito do "Apogeu...", também é verdade que "A casa tomada..." era a instalação "forte" da exposição: tinha concretude e permanência, enquanto que o "Apogeu..." só era visto quando 0 arco era ligado, o que era intermitente, pois não se podia mantê-lo em funcionamento o tempo todo.

Finalizando, deixamos o registro de que, para Schwanke, tudo - inclusive ruínas e dejetos inservíveis - era matéria prima para o exercício de sua incansável e sempre florescente imaginação criadora.

Gostaríamos, também, de deixar um retrato falado de sua bela figura: austero, porém simpático; ensimesmado, porém com um o-tempo-todo-iminente sorriso de criança; elegante no seu despojamento; hospitaleiro e capaz de preparar o melhor café solúvel espumante de nossas vidas.

Curitiba, 13 de Julho de 2016

Antonio Jaques da Silva \& Vera Lúcia de Oliveira e Silva,

amigos de um homem memorável.

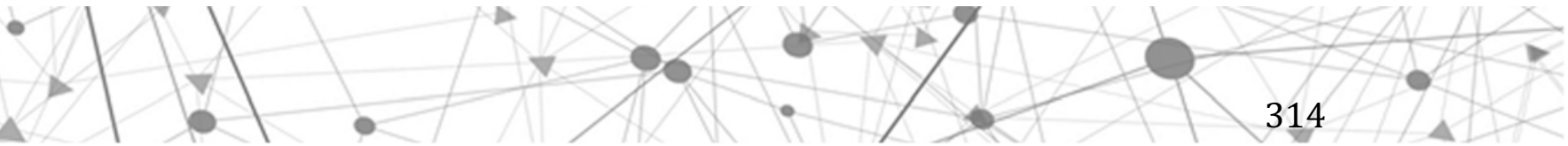

